\section{Cambios en la estructura económica social y conflictos sociales en el noroeste del Chubut 1990-2005}

\section{Tesis presentada para la obtención del grado de Doctor en Historia}

\section{Director: Iñigo Carrera, Nicolás}

\begin{abstract}
Este documento está disponible para su consulta y descarga en Memoria Académica, el repositorio institucional de la Facultad de Humanidades y Ciencias de la Educación de la Universidad Nacional de La Plata, que procura la reunión, el registro, la difusión y la preservación de la producción científico-académica édita e inédita de los miembros de su comunidad académica. Para más información, visite el sitio

www.memoria.fahce.unlp.edu.ar
\end{abstract}

Esta iniciativa está a cargo de BIBHUMA, la Biblioteca de la Facultad, que lleva adelante las tareas de gestión y coordinación para la concreción de los objetivos planteados. Para más información, visite el sitio www.bibhuma.fahce.unlp.edu.ar

\section{Cita sugerida \\ Pérez Alvarez, G. (2010) Cambios en la estructura económica social y conflictos sociales en el noroeste del Chubut 1990-2005 [en línea]. Tesis doctoral. Universidad Nacional de La Plata. Facultad de Humanidades y Ciencias de la Educación. Disponible en: http:// www.memoria.fahce.un/p.edu.ar/tesis/te.369/te.369.pdf}

\section{Licenciamiento}

Esta obra está bajo una licencia Atribución-No comercial-Sin obras derivadas 2.5 Argentina de Creative Commons.

Para ver una copia breve de esta licencia, visite http://creativecommons.org/licenses/by-nc-nd/2.5/ar/.

Para ver la licencia completa en código legal, visite http://creativecommons.org/licenses/by-nc-nd/2.5/ar/legalcode. 
Doctorado en Historia

Facultad de Humanidades y Ciencias de la Educación Universidad Nacional de La Plata

Tesis para optar al grado de Doctor en Historia:

\section{Cambios en la estructura económica social y conflictos sociales en el noreste del Chubut 1990 - 2005}

Lic. Gonzalo Pérez Álvarez

Director:

Prof. Nicolás Iñigo Carrera

Codirector:

Dr. Aníbal Viguera 


\section{Índice:}

1. ¿Qué pretendemos investigar? El planteo del sistema de problemas - (3)

1.1. El problema - (3)

1.2. Una síntesis del proceso histórico - (13)

1.3. El desarrollo de una estructura económica social - (19)

1.4. Hipótesis de trabajo - (31)

1.5. Síntesis de los problemas, objetivos e hipótesis de esta investigación - (43)

2. ¿Desde dónde partimos? La metodología y el estado de la cuestión - (46)

2.1. Instrumental teórico metodológico utilizado en esta investigación - (46)

2.1.a. Fuentes - (65)

2.2. Otros trabajos sobre el abordaje teórico del movimiento de la sociedad - (76)

2.2.a. Sobre el movimiento de la sociedad argentina - (105)

2.2.b. Sobre el movimiento de la sociedad en Patagonia - (145)

3. El movimiento de la sociedad: los conflictos sociales en el noreste del Chubut 1990 - 2005 - (170)

3.1. Cómo estudiar un proceso en un espacio y tiempo delimitados - (170)

3.2. Periodización del proceso: los hitos y los ciclos - (180)

3.3. La rebelión en el NE del Chubut: 1990 - 1993 - (197)

3.4. La rebelión en el NE del Chubut: 1994 - 1996 - (221)

3.5. La rebelión en el NE del Chubut: 1997 - 1999 - (237)

3.6. La rebelión en el NE del Chubut: 2000 - 2002 - (256)

3.7. La rebelión en el NE del Chubut: 2002 - 2005 - (282)

4. Afinando la mirada - (305)

4.1 Los trabajadores textiles - (306)

4.2 Los trabajadores pesqueros - (330)

4.3 Los trabajadores metalúrgicos - (352)

4.4 Los trabajadores desocupados - (377)

4.5 Acerca de bases, dirigencias, estrategias y proyectos políticos - (396)

5. El movimiento de la sociedad: Los cambios en la estructura económica social en el NE del Chubut - (414)

5.1. Un breve estado de la cuestión y algunos debates - (414)

5.2. Un repaso descriptivo - (428)

5.3. Las transformaciones económico-sociales - (451)

5.4. Una mirada desde la División Social del Trabajo - (471)

6. Hacia un intento de síntesis - (484)

7. Bibliografía - (511) 


\section{1. ¿Qué pretendemos investigar? Planteo del sistema de problemas, contexto histórico y social e hipótesis}

\subsection{El problema}

Como el título de la tesis lo plantea pretendemos investigar el proceso de cambios que se producen en lo que llamamos la "estructura económica social" del noreste del Chubut entre 1990 y 2005 y, junto a ello, hacer observables las características principales del proceso de rebelión ${ }^{1}$ que se desarrolla en la región durante esos años.

Una primera mirada podría suponer que el trabajo parte del intento de observar como se "relacionan" estos dos procesos que aparentemente suceden en espacios distintos de la sociedad. Así en general se ha tendido a pensar estas transformaciones como dos caminos separados, donde unos investigadores analizan el proceso económico y otros el proceso de luchas, buscando luego las relaciones o mediaciones entre ambos fenómenos, como si no fueran parte de un mismo movimiento de la sociedad $^{2}$.

La cuestión es que la investigación sobre el movimiento de la sociedad necesita de un proceso de análisis, o sea de separación de las partes que conforman esa totalidad que en primer término se nos presenta nebulosa, indeterminada. Desde allí es posible avanzar en el conocimiento, yendo de lo general indiferenciado a las determinaciones más simples, para volver luego a la totalidad pero ya no como algo indiferenciado sino como la expresión unitaria de las múltiples determinaciones particulares. El problema es cuando la tarea de análisis no se encadena con la imprescindible búsqueda de la síntesis. Como lo plantea Marx el camino de la ciencia es avanzar hacia la reconstrucción del todo concreto determinado desde las determinaciones más simples (Marx, 1997).

Por ello se comete un grave error cuando este recorte de la realidad, que es una necesidad objetiva del proceso investigativo, se transforma por una operación mental en un supuesto "reflejo" de la realidad y se deja de lado la necesidad de desarrollar

\footnotetext{
1 Tomamos el concepto de rebelión de Engels (1974). Las formas de la rebelión van desde las más elementales acciones que no conducen a cambios en la sociedad sino que buscan garantizar la sobrevivencia, aunque contengan elementos de rebeldía (como pueden ser algunas formas del delito), hasta las formas más sistemáticas y conscientes, en una escala que llega hasta las batallas decisivas por otra forma de sociedad, como la insurrección consciente.

${ }^{2}$ Creemos que esta ha sido la tendencia hegemónica en la producción académica de los últimos años en Argentina, pese a lo cual se han desarrollado otras líneas de investigación que rompen con esta falsa división y buscan abordar a la sociedad como totalidad. Ya desarrollaremos mejor este punto en el estado de la cuestión.
} 
procesos de explicación totalizantes. Así el plano de lo "económico" se divide del plano de lo "social", los cambios en lo "estructural" se analizan aislados de los cambios en lo "político" o del enfrentamiento entre las distintas fuerzas sociales.

Se cae en miradas donde lo que se piensa como "estructura económica" actúa como una especie de escenario por donde se mueven (más o menos condicionados, determinados o totalmente libres de las características y los límites que imponga ese escenario) los sujetos sociales, cual "actores" que representan una obra en una escenografía que no conocen y no pueden modificar. Ya veremos en el estado de la cuestión como este tipo de terminología teatral es utilizada entre aquellos que no entienden a la sociedad como una totalidad en movimiento, y las lecturas a las que ese tipo de abordajes llevan cuando se aplican a algunos casos particulares, como las protestas en la Argentina de los últimos veinte años.

Consideramos que no es inocente que en la producción académica actual se haya casi descartado el concepto de totalidad y la misma búsqueda de explicaciones holísticas de los procesos sociales. Atilio Borón muestra que se construyen “...visiones fragmentadoras y reificadoras de las relaciones sociales, características del pensamiento burgués tanto en su versión convencional como en sus corrientes "científicas", como la sociología, la economía, la ciencia política y el disperso campo de las ciencias sociales en general. (...) Conclusión: nadie entiende nada y las ciencias sociales hoy se enfrentan, en su absurdo aislamiento, a una crisis terminal" (en Boron, Amadeo y González, 2006).

En el mismo sentido Nicolás Iñigo Carrera muestra que los criterios en historia para considerar a un trabajo dentro de las reglas de la academia "bienpensante" suelen enfrentar al concepto de totalidad “...no se debe intentar conocer la totalidad, no se debe vincular distintos campos de relaciones sociales (por ejemplo relaciones productivas con relaciones políticas), no se debe intentar conocer qué intereses se expresan en los hechos analizados, etc." (2000b).

Nosotros, buscando retomar la tradición del socialismo científico, consideramos a la sociedad como una totalidad en movimiento. Partimos de la lógica dialéctica ${ }^{3}$ que entiende a lo que llamamos "estructura económica" como parte de una totalidad en

\footnotetext{
${ }^{3}$ Lenin realiza una magnífica síntesis de algunos componentes centrales de la lógica dialéctica en "Una vez más acerca de los sindicatos, el momento actual y los errores de los camaradas Trotski y Bujarin": "La lógica dialéctica exige que vayamos más lejos. Para conocer de verdad el objeto hay que abarcar y estudiar todos sus aspectos, todos sus vínculos y "mediaciones". Jamás lo conseguiremos por completo, pero la exigencia de la multilateralidad nos prevendrá contra los errores y el anquilosamiento. Eso, en primer lugar. En segundo lugar, la lógica dialéctica requiere que el objeto sea tomado en su desarrollo, en su "automovimiento" (como dice Hegel a veces), en su cambio (...). En tercer lugar toda la práctica del género humano debe entrar en "la definición" completa del objeto como criterio de la verdad y como determinante práctico del vínculo del objeto con lo que necesita el hombre. En cuarto lugar, la lógica dialéctica enseña que "la verdad abstracta no existe, la verdad es siempre concreta", como le gustaba decir, después de Hegel, al difunto Plejanov..." (Lenin, 1981a, Tomo 3: 556).
} 
movimiento, de la cual también son parte constituyente los distintos conflictos sociales. Consideramos, en definitiva, que la estructura de una sociedad esta en constante movimiento y, por ello, lo que debemos investigar es ese movimiento de la sociedad en su conjunto.

No se trata solamente de encontrar (y menos aún de "construir", donde la tarea sería un a posteriori puesto desde afuera por el investigador) las relaciones entre los cambios estructurales en lo económico y en lo social y los distintos conflictos sociales que se hacen observables sobre esa "superficie", sino de entender y conceptualizar en términos científicos cómo se mueve esa sociedad, de qué son expresión cada uno de sus conflictos, qué expresan los distintos sectores que se movilizan, qué expresan los cambios estructurales, etc.

En ese sentido tomamos como modelo de aplicación metodológico a las indicaciones del trabajo: "Análisis de las situaciones. Relaciones de fuerzas", de Antonio Gramsci (Gramsci, 1997: 51 a 62), donde plantea la necesidad de analizar a la sociedad en su totalidad como una disposición de fuerzas sociales que se manifiestan en diversos ámbitos de la vida de los hombres, pero que en verdad hacen a una única realidad. Allí está sintetizado, de manera magistral, el problema clave que en este tipo de abordajes se le plantea al investigador: la distinta naturaleza con que se presentan los hechos observables por el investigador para los hombres que realizan la historia.

Gramsci específica que en esa relación de fuerzas hay diversos momentos, grados o niveles. El primero de ellos es la relación de fuerzas sociales objetiva. Es el ámbito de la sociedad que se refiere a las relaciones necesarias e independientes de la voluntad de los hombres que viven bajo ellas, las relaciones que los hombres contraen en la producción de su existencia y que se corresponden con un determinado grado de desarrollo de las fuerzas productivas materiales de la sociedad. Sobre ese grado de desarrollo se conforman los grupos sociales (como parte de esa realidad objetiva), cada uno de los cuales tiene una función y ocupa una posición en el proceso productivo.

Como dice Gramsci este ámbito de la realidad es una "realidad rebelde", ya que no se puede modificar el número de fábricas, el de sus empleados, el número de ciudades, la cantidad de población urbana y rural, etc. Por esto es un ámbito de la realidad, un momento de las relaciones de fuerzas, que suele escaparse a la observación de los hombres, que se hace "invisible", y que por ello debemos descubrir de los velos que lo encubren para acceder a su conocimiento.

Es en el seno de este ámbito de la realidad donde se desarrollan los procesos de expropiación y explotación que producen y reproducen una sociedad como la capitalista. Por eso el interés manifiesto de la clase dominante de encubrir este ámbito 
de la realidad e impedir de esa manera un conocimiento totalizador, el cual permitiría, por ejemplo, hacer observable al conjunto de la sociedad quienes son los expropiados y quienes los expropiadores.

Ese encubrimiento impide ver que esta realidad (hoy objetiva e independiente de la voluntad de los hombres) fue también desarrollada por las luchas de los hombres que nos antecedieron en el tiempo a partir de una realidad también objetiva e independiente de su voluntad, ante la cual también se encontraron como algo "dado" por las generaciones pasadas. Dice Inés Izaguirre “... lo que se le aparece como natural y como objetivo es eso que existe, pero en rigor esto es una realidad que puede ser modificada. Esta noción de que puede ser modificada tarda mucho en desarrollarla el ser humano. Lo otro, lo que existe, tiene la fuerza de lo que se impone, en las representaciones, en la cultura, en las significaciones". (Astarita-GiarraccaIzaguirre-Pérez, 2003: 16). La naturalización de lo hoy existente, de la actual dominación de clase y del actual sistema económico, es una operación ideológica fundamental en todo sistema de dominación.

Pero en el capitalismo esto toma un cariz aún mayor. Como demuestra Marilena Chaui: "Hay un residuo de naturaleza que las formas precapitalistas nunca consiguen negar enteramente y transformar en historia. Por el contrario, la forma capitalista es la única que es histórica de punta a punta, no subsistiendo nada de natural en ella. Es por eso que en el modo de producción capitalista la ideología tiene una fuerza inmensa, pues su función es introducir lo natural en la historia, naturalizar lo que es histórico." (Chaui, en Boron, Amadeo y González, 2006).

Retomando a la misma autora, Sabrina González sintetiza que "La forma capitalista es la única en la que no queda residuo alguno de lo natural, explica Chaui, y en consecuencia la ideología propia de este modo de producción detenta una potencia singular e inédita en tanto su función es nada menos que naturalizar aquello que es histórico" (S. González, en Boron, Amadeo y González, 2006).

Donde ya nada hay de natural, donde en verdad todo es social porque todo ha pasado por las manos y las mentes de los hombres, la búsqueda de naturalizar lo existente (y por lo tanto de hacerlo no cuestionable y mostrarlo como imposible de ser modificado) cumple un rol central para legitimar el sistema e impugnar los proyectos de transformación social. Contra esa forma de mirar la realidad (propia del materialismo vulgar y de la lógica formal) debatía Marx en la tercera tesis sobre Feuerbach: "La teoría materialista de que los hombres son producto de las circunstancias y de la educación, y de que por tanto, los hombres modificados son producto de circunstancias distintas y de una educación modificada, olvida que son los hombres, precisamente, los que hacen que cambien las circunstancias y que el propio 
educador necesita ser educado. Conduce, pues, forzosamente, a la división de la sociedad en dos partes, una de las cuales está por encima de la sociedad" (Marx y Engels, 1985: 666).

O sea que la actual disposición de fuerzas objetivas es, en definitiva, la resultante de los procesos de luchas sociales que se dieron a lo largo de siglos, procesos que se desarrollaron en marcos condicionados también por las resultantes de los procesos anteriores. Por eso lo que entendemos como realidad objetiva o como estructura económica social, debe comprenderse como parte de las relaciones de fuerzas sociales y no como la superficie sobre la cual se desarrolla la lucha entre las fuerzas sociales que solamente quedarían reducidas, desde esa visión, al ámbito que Gramsci denomina "de las relaciones de fuerzas políticas".

Este momento de las relaciones de fuerzas políticas hace al grado de homogeneidad, autoconciencia y organización que han alcanzado, a través del proceso de luchas y en el marco de las relaciones de fuerzas objetivas, los diferentes grupos sociales. Este es el ámbito que se suele hacer visible ante los hombres de manera más evidente, el que hace a las protestas, los enfrentamientos, las organizaciones que se desarrollan, las que caen, los ataques y contra ataques, etc. Dentro de este momento Gramsci divide diversos niveles que va tomando la conciencia política colectiva: el primero y más elemental es el económico corporativo, el segundo es el de la toma de conciencia de la solidaridad de intereses entre todo el grupo social, pero aún en el plano meramente económico, y el tercero es el de la superación de los intereses corporativos y la toma de conciencia política (Gramsci, 1997: 57, este tema será más desarrollado cuando lo apliquemos para conceptualizar los niveles de conciencia que expresan las luchas en Chubut).

Estos niveles de la conciencia política colectiva no se presentan en forma evidente ante el observador, sino que deben ser comprendidos a partir de la investigación de los procesos de luchas que van desarrollando los grupos sociales. Y a su vez estos niveles de conciencia no pueden ser comprendidos sin relacionarlos con el ámbito de las relaciones de fuerzas objetivas, ya que la conciencia de los grupos sociales hace a qué grado de comprensión llegan a desarrollar de su situación objetiva y de las acciones que realizan para intentar mejorar o mantener esa situación como expropiados o expropiadores.

Si la conciencia de cada grupo social apunta a defender sus intereses como grupo más restringido, o a mejorar su posición como grupo social más vasto o a trastocar de fondo las actuales relaciones de fuerzas objetivas, es algo que solamente puede ser explicado a partir de las relaciones de fuerzas entendidas como totalidad. 
Esto es así ya que los grupos sociales se plantean sus metas de acuerdo a la situación objetiva que les esta planteada.

Así como la libertad, en términos del socialismo científico, es la conciencia de la necesidad, así también los grupos y las sociedades no se plantean metas para cuya solución no existan ya (o estén en vías de aparición y desarrollo, por más embrionario que ese desarrollo sea) las condiciones necesarias para hacerlas posible. $Y$, como parte de la misma situación, ninguna sociedad desaparece o es reemplazada por otra forma social si antes no desarrolló en su interior todas las formas de vida que podían dar a luz sus actuales relaciones sociales. Como decía Marx en el bastardeado (por las deficientes lecturas que de él se hicieron) prologo a la Contribución a la Crítica de la Economía Política "...la humanidad se propone siempre únicamente los objetivos que puede alcanzar" (Marx, 2008: 98).

No podemos analizar por ello los objetivos, las metas y la estrategia de los grupos sociales que se conforman en clases a través de la lucha, si no entendemos el marco global de movimiento de la sociedad. El intento de comprender los fenómenos del ámbito de las fuerzas políticas aislado del ámbito de las fuerzas sociales objetivas, cercena la realidad e impide comprender un proceso social en su totalidad. Lo encubierto, lo que no se presenta de manera evidente ante la mirada del observador o del participante, no puede ser entendido globalmente más que a través de un abordaje teórico que ponga en juego este complejo entramado dialéctico. Nada más alejado entonces de la visión artificial de un marxismo que simplemente explicaría la realidad con el expediente de "la estructura y la superestructura", y de clases sociales que se moverían como autómatas determinadas por una estructura todopoderosa.

Por ello, repetimos, nuestro objeto de investigación es el movimiento de la sociedad en su conjunto. Como lo plantea en forma muy clara el Programa de Investigación sobre el Movimiento de la Sociedad Argentina (PIMSA) ${ }^{4}$, "Su objeto es el movimiento de la sociedad en tanto tomamos como punto de partida el hecho de que toda la historia de la naturaleza, de la sociedad humana y del pensamiento es movimiento, cambio constante, transformación, desarrollo. El movimiento de la sociedad involucra los movimientos de la vida material (fuerza de producción), del estado social (modo de cooperación) y de la conciencia."(PIMSA, 1997)

Desde nuestro enfoque la investigación que deberíamos intentar desarrollar sobre la sociedad mundial y sobre la sociedad argentina es, justamente, explicar cómo se mueve la sociedad en su conjunto. Así entenderemos a las diversas partes de la

\footnotetext{
${ }^{4}$ Programa de investigación que tiene entre sus principales referentes a Nicolás Iñigo Carrera, María Celia Cotarelo, Jorge Podestá, Fabián Fernández, entre otros. Se entronca con la tradición del CICSO (Centro de Investigación en Ciencias Sociales), del que fueron parte algunos de sus investigadores.
} 
sociedad como fracciones de esa totalidad en movimiento, que se investigarán por separado como método (aquí la estructura económica social, allí las protestas sociales, alguna protesta en particular, una organización política, un ciclo de rebelión, etc.), pero que sólo pueden tener una explicación totalizadora si las intrincamos en una perspectiva holística del proceso.

No fue otra cosa lo que intentó realizar Carlos Marx sobre la sociedad capitalista de su época para el que era su núcleo central, Inglaterra, en "El Capital". Obviamente un estudio de semejante magnitud está muy lejos de nuestras capacidades, por eso realizamos un recorte de la realidad que nos permita hacer posible el abordaje de una fracción más reducida de información, considerando que, a pesar de lo recortado del acercamiento, igual nos permitirá avanzar en la comprensión del movimiento de la sociedad. Claro está que la obra de aquellos que fueron desarrollando conocimiento científico acerca de la sociedad capitalista, de su movimiento, de las relaciones entre sus distintas estructuras y niveles, de los factores de determinación e interrelación, nos sirven como base para esta investigación, y nos hacen posible abordar un problema como el que pretendemos responder.

Partimos de una base de conocimiento acumulado a lo largo de varios siglos en que la capacidad de comprensión del hombre sobre la realidad fue avanzando en profundidad, dando este proceso un salto cualitativo con la producción de Carlos Marx y Federico Engels. A lo largo de su obra ellos lograron mostrar cómo se desarrolla una sociedad particular en sus múltiples determinaciones (en el proceso económico, en la protesta económica corporativa, en la lucha política, en la lucha teórica, etc.).

Es importante entender que en ninguna investigación partimos de la nada y que especialmente esta investigación no pretende inventar un nuevo corpus teórico, sino utilizar el desarrollo científico que a lo largo de muchos esfuerzos ha desarrollado la humanidad, para intentar avanzar en la comprensión de nuestra sociedad.

Como decíamos, dentro del problema general planteado de buscar comprender el movimiento de la sociedad, realizamos un abordaje de la realidad desde la utilización de un conocimiento acumulado y desde un recorte de esa realidad. Ese recorte lo realizamos a dos niveles.

En primer lugar en términos espaciales: tomamos como base para nuestro estudio una región que denominamos el noreste de Chubut. Así recortamos de la provincia del Chubut, ubicada en la parte central de la patagonia argentina, al área que tuvo el mayor crecimiento vinculado a los programas de polos de desarrollo durante las décadas del sesenta, del setenta y parte de la década del ochenta. La misma está delimitada por los actuales departamentos de Rawson y Biedma, de acuerdo a la 
división administrativa que toma la provincia tras su formación como tal en 1957 (hasta ese momento Chubut era territorio nacional).

En segundo lugar realizamos un recorte en términos temporales: abordamos como objeto de estudio al movimiento de la sociedad en esa región durante el período que va de 1989-1990 hasta el 2005. Consideramos que tomar este período nos permite observar el proceso de cambios que se generan con la realización de la hegemonía del capital financiero ${ }^{5}$ y el proceso de protestas, luchas y conflictos sociales que estos cambios desarrollan en la sociedad. En este sentido tomamos las indicaciones de Donaire y Lascano (2002), Iñigo Carrera y Cotarelo (2004), Bonnet (2007, 2002), Piva (2007), Astarita $(2007)^{6}$, Boron y Thwaites Rey (2004) ${ }^{7}$, Thwaites Rey (2001) y otros, que ven a la hiperinflación de 1989-1990 como un hito a partir del cual se realiza la hegemonía del capital financiero en nuestro país.

En este sentido pensamos en la posibilidad de marcar el cierre en el 2001, tras la insurrección espontánea de diciembre (Iñigo Carrera y Cotarelo, 2003a), o a mediados del 2002, tras el desarrollo de un proceso de importantes conflictos sociales en marzo y abril de ese año. Otro tipo de abordaje, centrado en lo institucional, podía plantear un cierre a fines del 2003, cuando se produce la derrota electoral de la UCR tras doce años de gobierno en la provincia.

Nuestra decisión de estudiar el período hasta el 2005 parte de considerar como muy relevante el comprender cómo continua el proceso después del 2002. En esos años se produce una fuerte recuperación de la economía nacional, con gran impulso para la región (suba del precio del petróleo, de los productos de origen pesquero y de las exportaciones en general, gracias a la ventaja competitiva que genera la devaluación del peso), lo cual también genera el interés de poder precisar de qué se trata esta "recuperación", si estamos ante un movimiento orgánico o coyuntural de la economía, etc. El período también nos permitirá profundizar en el debate de las relaciones de fuerzas políticas, al hacer observable el período en que la burguesía logra recuperar la representación institucional como representación legítima de la sociedad y consigue poner freno a la protesta social.

Consideramos por esto que el período seleccionado abarca dos ciclos en términos del movimiento de la sociedad. A modo de hipótesis consideramos que el

\footnotetext{
${ }^{5}$ En el sentido que le da Lenin (1981a) de fusión del capital bancario con el capital industrial en condiciones monopólicas.

6 "... desemboca en la hiperinflación, bajo la cual se hace imposible el funcionamiento del mercado. La sociedad de conjunto, puesta en esta situación pide "orden", y esto legitima la reversión brusca hacia la moneda dura -mediante la Convertibilidad- y el disciplinamiento a través del mercado" (Astarita, 2007: 14). 7 “...el proceso hiperinflacionario de los ochenta constituye el otro componente del terror, en este caso económico, que se inoculó en una sociedad lacerada por el horror de la represión. Sobre estos efectos se fue construyendo una base de legitimación para un proyecto neoliberal que logró, por unos años, resolver las disputas entre los sectores dominantes y generar la ilusión entre los subalternos de que se avanzaría al capitalismo del "primer mundo". (Boron y Thwaites Rey, 2004: 117).
} 
primero de los ciclos comienza en 1975-1976 y se cierra en 2001-2002, teniendo como hitos de su comienzo al proceso conocido como "rodrigazo" y al golpe militar de 1976, y como hito de su cierre a las jornadas de diciembre de 2001. Este primer ciclo está caracterizado por el avance del proyecto del capital financiero que toma la ofensiva en un período claramente contrarrevolucionario, donde la alianza social que gobierna impulsa y desarrolla este proyecto, logrando imponerlo como un programa hegemónico en la sociedad.

Durante los noventa se desarrolla un ciclo de rebelión que acumula fuerza social y experiencias, las cuales se sintetizan en los hechos de diciembre de 2001 y la continuidad de movilización social durante el 2002. Estos hechos marcan lo que creemos se plantea como el cierre de la ofensiva hegemónica del proyecto del capital financiero. A partir de allí la alianza social que había ocupado el gobierno se fractura y es posible que estemos ante un cambio de período que ya no tomaría las características de una fase contrarrevolucionaria. Este segundo ciclo se abre en 2003 y abarca entonces la parte final del período seleccionado. Las hipótesis que construyamos sobre este segmento del período tendrán un carácter más provisorio ya que es un proceso que aún esta en curso, siendo su continuidad las que nos permitirá llegar a lecturas más precisas.

Es en este marco en el cual nos planteamos el sistema de problemas que ordenará nuestro trabajo. El problema central que pretendemos contestarnos a través de esta investigación podríamos expresarlo de la siguiente manera:

¿Cómo se manifiesta el movimiento de la sociedad en su conjunto, analizado en un caso particular que es el noreste del Chubut, desde la imposición de la hegemonía del capital financiero en 1989-1990 hasta el año 2005? Este es el problema mayor, el cual seguramente no podremos contestar en forma completa, pero que nos orienta como horizonte de hacia donde debe avanzar nuestra investigación.

A partir de la sistematización de un sistema de problemas podemos pensar desde ese problema general un problema parcial que sería el que sí pretendemos lograr responder:

¿Qué cambios se producen en esta estructura económica social caracterizada hasta 1980 como de capitalismo de estado ${ }^{8}$ en enclaves (Iñigo Carrera, Podestá, Cotarelo, 1999) a partir de la imposición de la hegemonía del capital financiero y qué propuestas expresan en relación a este proceso los distintos conflictos sociales que se desarrollan entre 1989 y el 2005 en la región? Desde este problema se encadenan hacia atrás una serie de problemas de carácter menos general, cuya respuesta parcial

\footnotetext{
${ }^{8}$ Considerando que lo que define al capitalismo de estado en un país capitalista es la regulación de la actividad económica por los grupos más concentrados de la economía mediante políticas de gobierno.
} 
nos permitirá acercarnos a dar una respuesta lo más aproximada posible al interrogante central que planteamos para nuestra investigación.

1. En lo metodológico:

¿Es posible observar este tipo de procesos en una unidad delimitada en el espacio y en el tiempo como la que hemos seleccionado? ¿Cómo estudiar este proceso en esa unidad delimitada en el espacio y en el tiempo sin perder la articulación de este movimiento de la sociedad regional con el proceso nacional y mundial? ¿Cómo hacer observable lo particular, no como pretendida "excepcionalidad", sino como expresión local de lo general, donde se combinan y entrelazan de formas diversas las relaciones de fuerzas nacionales e internacionales?

2. En el ámbito de la estructura económica social:

¿Cuáles son los cambios que se producen en la estructura económica social del NE del Chubut a partir de la hegemonía del capital financiero? ¿Hay una excepcionalidad del proceso de desarrollo capitalista en la Patagonia o este proceso se da en el marco del desarrollo desigual y combinado de la formación económica social que constituyen las distintas estructuras económico sociales de Argentina? ¿El cambio de la estructura económica social avanza en el sentido de una "desindustrialización", donde perdería importancia la clase obrera y donde las ganancias empresarias ya no provendrían de la explotación del trabajo de los obreros?

¿Hay un proceso de "desaparición del Estado", que lleva a que el Estado deje de ser el articulador y regulador de la economía, o es que el Estado produce una nueva articulación y una nueva regulación de la economía en función de los intereses de una nueva alianza de clases que concentra el poder en la actual fase de dominio del capital financiero? ¿Cuál es la nueva articulación que se construye y cómo se articula a su vez con el proceso de cambios en la estructura económica social a nivel nacional?

3. En el ámbito de las relaciones de fuerzas políticas:

¿Cómo se relaciona el proceso de protestas y luchas en el NE del Chubut con el proceso de protestas y luchas a nivel nacional? ¿Cómo se constituyen en parte del proceso nacional de acumulación de experiencia en las formas de organización de la protesta y en las formas de lucha, los sujetos sociales que desarrollan estas protestas en la región? ¿Quiénes son los sujetos que desarrollan este proceso a nivel regional? ¿Hay durante los años estudiados una perdida de la centralidad del movimiento obrero y de sus formas tradicionales de protesta y de organización?

¿Qué expresan, en términos de intereses de clase o de fracciones de ella y en términos de niveles de conciencia, las distintas formas de protesta y de organización que se van desarrollando? ¿Se manifiestan en el proceso de rebelión en el NE del 
Chubut las distintas estrategias que es posible observar en el ciclo a nivel nacional? ¿Si es así, cuales son las particularidades que aquí se presentan? ¿Cómo se desarrollan los procesos de unidad y alianza de la clase obrera en la región y cómo se articulan con el proceso nacional?

Obviamente sólo es posible construir este sistema de problemas a partir de tomar como contestados previamente por otras investigaciones una serie de problemas mayores que hacen a los procesos más generales a nivel nacional y mundial. En este sentido sería necesario para explicitar cada punto desarrollar en particular el marco teórico del que partimos, algo que plantearemos más adelante.

\subsection{Una síntesis del proceso histórico previo}

Consideramos que en nuestro país se impone desde el golpe militar de 1976 una nueva fase del capitalismo que denominamos como de dominio del capital financiero. Podemos ubicar el inicio de esta fase en 1975 en lo que se llamó el "rodrigazo", un hecho fundamental en el cual se intentaron sentar las bases políticas y económicas para romper con el proyecto del capital industrial.

Para Cotarelo y Fernández estas jornadas son un acontecimiento bisagra en la historia de las luchas sociales en la Argentina “...ya que en ellas se pone de manifiesto la crisis de la fuerza del capital industrial (la fuerza de la reacción), a la vez que se encuentran presentes los elementos que tienden a su superación (tanto desde el campo del pueblo como desde el campo del régimen)". (Cotarelo y Fernández, 1998: 104).

En ese acontecimiento el gobierno constitucional se muestra incapaz de imponer estos cambios a la clase obrera y hasta tiene serios problemas para imponer el plan sobre los otros sectores de la burguesía. Esta es la razón fundamental para que en los próximos meses se agudice el proceso de guerra directa ${ }^{9}$ contra aquellos que se oponían a la instauración de esta nueva fase del capitalismo. Desde ese momento el capital financiero ocupará con sus cuadros distintos espacios claves en la estructura política, aumentando su poder y desarrollando en forma sistemática la lucha por imponer su hegemonía, con un poder económico y político fuertemente concentrado en un pequeño sector de la población.

El hecho de que en diversos momentos del proceso histórico recurrieran centralmente a sus cuadros militares o a sus cuadros "políticos"10, obedece a

\footnotetext{
${ }^{9}$ Que ya estaba puesta en marcha desde hacía unos años por parte de la fuerza social que defendía el dominio del capital industrial y luego sería impulsada por la fuerza que propugnaba la transformación de la sociedad en el sentido del dominio del capital financiero.

${ }^{10}$ En verdad todo cuadro es político, incluidos los militares; usamos el término "cuadro político" por ser el que se usa comúnmente para designar a los profesionales de la actividad política electoral.
} 
decisiones tácticas en el camino estratégico de imponer a sus intereses particulares como si fueran los intereses del conjunto social.

Por estas razones caracterizamos que en lo fundamental desde 1976 la Argentina está bajo un mismo gobierno, que es el de la gran burguesía financiera. Durante los siguientes años se van produciendo una serie de transformaciones que "son expresión de la construcción, consolidación y realización de la hegemonía del capital financiero en nuestro país" (Donaire y Lascano, 2002: 77), algunas realizadas durante la dictadura cívico-militar y otras por los gobiernos constitucionales, que continuaron las características fundamentales de su programa económico. Donaire y Lascano resumen de la siguiente manera el proceso:

"El verdadero punto de inflexión se produce a mediados de la década del '70 y se expresa bajo la forma de la guerra. La fuerza social dirigida por el capital financiero se enfrenta por un lado, a aquella comandada por el capital industrial (que expresa la forma de organización de la sociedad argentina hasta ese momento) y por otro, a la fuerza social popular conducida por distintas organizaciones revolucionarias (que expresan una nueva forma de organización social superadora del capitalismo). (...) El aniquilamiento y desarticulación de la fuerza social revolucionaria, la subordinación del capital industrial y una mayor centralización y concentración del capital financiero fueron el resultado final de este enfrentamiento."(Donaire y Lascano, 2002: 77).

Este proyecto de la fuerza social que impulsa la realización del dominio del capital financiero incluyó, como partes fundamentales y que se dieron a veces en forma paralela y otras en forma progresiva, los siguientes puntos:

a) La destrucción por medio de la fuerza militar de las organizaciones políticas revolucionarias que luchaban por un cambio de sistema social en nuestro país en el sentido de apuntar a una forma de organización social distinta al capitalismo (que genéricamente se denominaba "socialismo") y la subordinación de los sectores que llevaban adelante y defendían el proyecto del capital industrial.

b) El desarrollo de las fuerzas productivas que garantizarán la reproducción ampliada del régimen capitalista.

c) La profunda concentración y centralización de las riquezas y la propiedad, la pauperización de una parte importante de la pequeña burguesía y del proletariado y la proletarización de crecientes masas de población, incrementándose además la proporción de población sobrante para el capital.

d) Como punto imprescindible se instaura desde la situación de guerra un estado de terror social, a través de las torturas, las masacres, las persecuciones, el exilio, etc. Se busca destruir o subordinar toda forma de organización social que se oponga a su proyecto, proponiendo una sociedad basada en el individualismo, en 
la cual el vecino puede ser un asesino, un delator o un infiltrado; pero, sobre todo, siempre es un enemigo en potencia. O sea una forma de estructurar la sociedad que haga posible la hegemonía del capitalismo, donde el otro es siempre una competencia y no alguien con quién se puede avanzar en común.

e) Desde ese marco de terror social se impone un discurso ideológico que muestra a este sistema social, y a este modelo económico y político, como los únicos posibles en el marco del "nuevo orden mundial". Esto se realiza especialmente en la década del noventa, con el fuerte impacto que produjo la caída del muro de Berlín y con las dos presidencias de Carlos Menem como símbolo central de la supuesta imposibilidad de construir un mundo distinto. Siempre está presente la violencia, las persecuciones y el terror de Estado, como última instancia de esas trincheras intermedias.

f) Se va construyendo, a través de diversos mecanismos, un consenso social hacia el proyecto del capital financiero. Este proceso tiene varios momentos y está presente aún durante el gobierno militar. La construcción de consenso es clave durante los años de gobierno constitucional y aún más tras el proceso hiperinflacionario. Las reformas impulsadas por la fuerza social que impulsa los intereses del capital financiero son apoyadas por la mayoría de la sociedad durante varios años.

Dentro de este proyecto global la dictadura tuvo el papel de impulsarlo en el plano de la guerra, en el ámbito de las relaciones de fuerzas militares. Así la gran burguesía eliminó a través de sus cuadros militares a casi toda una generación de cuadros políticos populares que se oponían a esa política, y que luchaban por la construcción de una sociedad diferente. A su vez se logró imponer el terrorismo de Estado al conjunto de la sociedad ${ }^{11}$. La imposición del terror a luchar por un cambio revolucionario fue parte del proyecto: los que quedaron vivos debían ser muertos en vida, debían ser muestras andantes de lo que les pasaría a todos aquellos que osaran buscar un cambio en el mundo ${ }^{12}$.

\footnotetext{
11 "Las dictaduras militares latinoamericanas duraron relativamente pocos años, pero la aplicación de los métodos del terrorismo de estado dejaron huellas profundas en las sociedades. [...] El terror de estado son asesinatos, desapariciones, acallamiento de la disidencia, cancelación de espacios sociales autónomos, vigilancia permanente de la ciudadanía o, como en el panóptico benthamiano, creación del sentimiento de la vigilancia sin tregua; es, en fin, siembra de una cultura de la delación de modo tal que cada ciudadano se vuelva un policía. El terror logra de esta manera su objetivo: el de la parálisis de la acción y del pensamiento."(Fernández Picolo, 2002: 75-76)

12 "El terror aterra, y en eso consiste su insidia: se resiste a ser pensado, a que tomemos conciencia de su existencia. No podemos pensarlo como método político que hizo posible la sumisión colectiva al neoliberalismo: que hizo posible nuestra actual miseria." (Rozitchner, 1996: 4). En un sentido semejante Jacoby (1986) plantea "...hasta en la actualidad se mantiene la ignorancia acerca de los procesos específicos por medio de los cuales ciertas situaciones de "terror" destruyen núcleos de convicción racional y logra, por ejemplo, el abandono de una teoría por otra, de menor nivel de consistencia, incluso en personas alejadas del peligro inmediato" (66).
} 
En ese programa de imposición de las nuevas características que necesitaba el capitalismo era clave lograr lo que llamamos el disciplinamiento del movimiento obrero. Vimos desarrollados antes algunos de los ejes centrales que se siguieron para lograr este cometido (sin dudas el fundamental fue el exterminio físico de aquellos cuadros políticos que personificaban y sintetizaban lo más avanzado de la clase obrera en su proceso de lucha, lo que Gramsci denomina "la fuerza de élite").

Como ya planteamos también jugó un papel clave un hecho que marca profundamente el momento de inicio de nuestra investigación: la hiperinflación de 1989. Este hecho se constituye en un hito en ese proceso de disciplinamiento de la clase obrera y en la forzada redistribución de ingresos a favor de la clase dominante. Como lo marcan distintos autores creemos que es a partir de este hecho cuando se realiza la hegemonía del capital financiero en nuestro país. Se conforma además una nueva dirección social, estructurada por el capital financiero, que tuvo su etapa de apogeo y consolidación durante la década de gobierno de Carlos Menem (1989-1999).

Podríamos decir que casi la totalidad del período a estudiar es, o fue considerado en su momento, como de "crisis". Así se ha hablado de crisis nacional, crisis económica, crisis política, crisis de las economías regionales, etc. Si bien sería necesario un trabajo en sí mismo para abordar en profundidad el tratamiento de este concepto tan vulgarizado, diremos aquí que para nosotros la crisis no es algo extraño o rupturista con respecto al sistema, sino que el sistema capitalista vive y se reproduce en una constante situación de crisis latente.

El capitalismo se asienta en una situación objetiva que plantea la posibilidad de la crisis, dada por la separación de la producción y la circulación, hecho que hace posible la no realización de las mercancías ya producidas. Como anclaje estructural de esta posibilidad permanente de crisis está la contradicción fundamental del sistema entre la producción social y la acumulación privada, y la problemática estructural de la tendencia a la baja de la tasa de ganancia: “... la causa de toda crisis se asienta siempre en la "contradicción entre la tendencia a la ampliación ilimitada de la producción y la necesidad de un consumo limitado a consecuencia de la situación proletaria de las masas del pueblo". (Podestá y Tarditi, 1998: 16, citando a Marx, Carlos, EI Capital tomo III, Cap. LI).

Las crisis siempre se desarrollan durante plazos más o menos largos y en verdad lo que vulgarmente se observa como el "estallido de la crisis" (cuando se hace explicita en términos de quiebras de empresas, desocupación, crisis política, agudización de los enfrentamientos sociales, etc.), son las formas en que se expresa y se intenta resolver esa crisis, y no la crisis en sí misma. En este punto seguimos las 
indicaciones metodológicas de Podestá y Tarditi (1998), fundamentadas a su vez en el aporte de Gramsci (especialmente contenidos en Gramsci, 1997).

El neoliberalismo, como proyecto ideológico de la gran burguesía financiera, es una expresión de la crisis capitalista que se desarrolla a nivel mundial desde los años treinta. Crisis que parte de la caída en la tasa de ganancia que se produce a nivel mundial, y en los serios problemas del capitalismo para sostener su reproducción ampliada. Es esa crisis la que los sectores más concentrados de la economía intentan resolver mediante el aumento de la desocupación, la concentración económica en manos de los grandes capitales y la centralización financiera. Estos procesos no son la crisis, sino la manera en que el capitalismo intenta resolverla, generando las condiciones para recuperar los niveles de ganancia que aseguren la continuidad de su reproducción ampliada.

Es claro que una de las manifestaciones sociales más evidentes de la crisis capitalista es el aumento de la desocupación que se produce durante la década del noventa en todo el país. Sin embargo, volvemos a decirlo, la desocupación no es la crisis, sino una de las formas en que esta se expresa y, a su vez, uno de los caminos centrales para intentar resolverla. “...El aparente desorden que se produce con la desocupación no es otra cosa que una manifestación del nuevo orden, el nuevo estado de equilibrio que caracterizará esta fase del desarrollo capitalista en la sociedad argentina." (Podestá, 1999: 7).

El capital financiero, utilizando su posición de hegemonía, exige nuevas condiciones para comprar la fuerza de trabajo argentina, pretendiendo una fuerte baja de su costo. Para ello conforma una masa de superpoblación que acrecienta la oferta de fuerza de trabajo y lleva a la baja los salarios. Se destaca el dato de que el aumento de la desocupación va en paralelo a un aumento de la sobreocupación (Piva, 2005). Esto muestra que la desocupación es la forma en que se resuelve parte de la crisis de acumulación del capitalismo en Argentina, ya que posibilita la sobreexplotación de los obreros ocupados y una recuperación de las tasas de ganancia gracias al crecimiento de la plusvalía absoluta.

Para Podestá la gran expansión cuantitativa de la desocupación indica una transformación de orden cualitativo en el orden social vigente, en la estructura económica social de la sociedad. Es el resultado más patente del disciplinamiento de la clase obrera, traducido para los trabajadores en un profundo retroceso de sus condiciones de vida. 
En términos generales se trata de la imposición, en un país dependiente de capitalismo ya desarrollado ${ }^{13}$, de un crecimiento del capitalismo predominantemente en profundidad ${ }^{14}$ bajo la hegemonía del capital financiero. Se impone un modelo concentrador de las riquezas y la propiedad que desaloja de sus territorios sociales a una parte importante de la masa trabajadora y explotada. Este proceso se realiza en el marco de un período contrarrevolucionario a nivel nacional y mundial, que modifica sustancialmente las relaciones de fuerzas objetivas y las relaciones de fuerzas políticas en términos desfavorables para la masa trabajadora y explotada ( $y$ en especial para la clase obrera).

En términos de las relaciones de fuerzas objetivas el capitalismo en Argentina se desarrolla predominantemente en profundidad, generando una masa cada vez mayor de población sobrante para sus necesidades actuales, y agravando su parasitismo (indicador del mayor peso del capital financiero sobre la estructura global). En este sentido son significativos algunos resultados de los trabajos de Donaire, Rosati y Cavalleri sobre las transformaciones a nivel nacional (Cavalleri, Donaire y Rosati, 2005; Donaire y Rosati, 2007a; Donaire y Rosati, 2007b; Donaire y Rosati, en prensa).

En términos de la división social del trabajo demuestran que para el 2001 hay una clara disminución del peso relativo de la población inserta en las ramas relacionadas con la producción de la riqueza social. La población industrial y comercial cae en términos absolutos y relativos entre 1991 y 2001 y dentro de ella aumenta significativamente la proporción de la población agrupada en la circulación por sobre la agrupada en la producción.

Contra la tesis que se ha intentado imponer, a modo de una verdadera guerra sicológica, de que estamos ante una disminución o una desaparición del proletariado, el análisis de la distribución de los grupos sociales fundamentales que estos autores realizan nos muestra que la población expropiada total o parcialmente de sus condiciones de vida y trabajo ha aumentado en términos cuantitativos en forma permanente, y ha mantenido sus valores relativos desde 1960 hasta la actualidad. Esto demuestra que el capitalismo mantiene su condición básica de expropiar de sus condiciones de existencia a sectores cada vez más importantes de la población.

\footnotetext{
${ }^{13}$ En el sentido de que están ampliamente difundidas y son claramente hegemónicas las relaciones sociales propias del capitalismo.

14 "En el desarrollo del capitalismo existen siempre dos direcciones de expansión, una de las cuales prima sobre la otra según los momentos: una expansión en extensión constituida por la difusión de la esfera de dominio de las relaciones sociales capitalistas a nuevos territorios sociales, en que las relaciones sociales preexistentes van siendo descompuestas mientras se van constituyendo las relaciones propias del capital, y otra dirección, en profundidad, constituida por un mayor crecimiento de la agricultura y la industria capitalistas en un territorio social dado, donde las relaciones capitalistas ya eran dominantes." (Iñigo Carrera y Podestá, 1997b: 2)
} 
Obviamente esto no implica negar la existencia de cambios cualitativos en la composición del proletariado, cambios que justamente son demostrativos del proceso global que atraviesa el capitalismo como sistema social. El cambio fundamental es el relacionado con el crecimiento de la población sobrante respecto a las necesidades actuales del capital: tomando solamente su forma abierta, la población desocupada, pasa de agrupar un 2,5\% en 1980 a un 18,3\% en 2001 (llegando a un $34,6 \%$ sumándole los subocupados, frente a un $8,3 \%$ que entregaba esta suma en 1980 , Donaire, Rosati, 2007a).

Otro dato clave que arrojan estos trabajos es la fuerte reducción de la gran burguesía, que desde 1980 es inferior al 1\% de la población económicamente activa, evidencia clara de la concentración y centralización de la propiedad. Su caída en términos relativos se ve afirmada por su descenso abrupto en términos absolutos, pasando de 182.781 en 1960 a 71.466 en 2001 (Donaire, Rosati, 2007a).

Pero el dato fundamental que muestra el movimiento del capitalismo es el aumento de la población no productiva, que pasa de agrupar el 28\% en 1960 al 52\% en 2001 (Cavalleri, Donaire, Rosati, 2005). Esto es expresión de un cambio cualitativo en el capitalismo en Argentina, indicador de que el sistema está en un grado de descomposición avanzado, ya que en este marco la pauperización de la sociedad crece más rápidamente que el desarrollo de la riqueza.

\subsection{El desarrollo de una estructura económica social}

Tomamos como espacio de la investigación al noreste de la provincia del Chubut, más particularmente al territorio geográfico delimitado por los actuales departamentos de Biedma y Rawson, en los cuales se ubican las ciudades de Trelew, Rawson y Puerto Madryn. La provincia del Chubut se crea en 1955, recortando una porción de 224.686 km cuadrados en la parte central de la Patagonia Argentina, entre los paralelos $42^{\circ}$ y $46^{\circ}$ de latitud sur, limitando al norte con la provincia de Río Negro, al sur con la de Santa Cruz, al este con el océano Atlántico y al oeste con la cordillera de los Andes.

Hasta mediados del siglo XIX la zona era únicamente habitada por tribus de pueblos originarios, especialmente tehuelches que se irían uniendo luego con los mapuches ante la avanzada en paralelo del ejército argentino y chileno sobre las tierras del sur hacia 1870-1880.

En 1865 llegaron a lo que hoy es Puerto Madryn inmigrantes provenientes de Gales, que escapaban de las malas condiciones de vida y la persecución religiosa en su país natal. Se instalaron en la zona y comenzaron a desarrollar tareas agrícolas y comerciales. Esta corriente de colonización se centra en el actual área noreste de la 
provincia cercana a la costa (donde fundan las poblaciones de Rawson, Puerto Madryn, Trelew, Gaiman, Dolavon) y posteriormente avanzan hacia el área cordillerana, donde fundaron las ciudades de Esquel y Trevelin.

Tras la guerra por la conquista de Pampa y Patagonia (Vezub, 2003), producida por la necesidad de aumentar la extensión de las tierras en producción a partir de la incorporación del país al mercado internacional capitalista con el rol de agroexportador, comienza a instalarse el Estado argentino en la región. Con ello también empieza la llegada de inmigrantes de distintos orígenes (Luque, Martínez, Avalos, Auzoberría, 2000). En lo económico se pasa a una expoliación acelerada de los recursos para la acumulación individual de capitales, en el marco de un proceso de acumulación originaria.

A principios del siglo $\mathrm{XX}$ el gobierno nacional declaró libres a los puertos patagónicos, pudiendo comerciar sin impuestos con los demás países del mundo. Esta medida puede ser considerada el primer antecedente de las posteriores leyes de promoción para la región (Irusta y Rodríguez, 1993). También en los primeros años del siglo pasado se comenzaría a poblar, por otras corrientes migratorias, lo que luego sería la zona sur del Chubut, especialmente a partir del hallazgo de petróleo en lo que hoy es Comodoro Rivadavia.

Teniendo la actual zona noreste de la provincia como principales actividades a la producción agrícola (especialmente en el valle inferior del Río Chubut, que bordea a Trelew, Rawson, Gaiman y Dolavon), la ganadería ovina (en la Península Valdés y también en la meseta y la cordillera de la provincia, desde que las ovejas fueron desplazadas del área central del país por la mayor rentabilidad del ganado vacuno) y la explotación de las salinas (en la Península Valdés), es que Trelew comenzará a funcionar como centro comercial de la región, a partir de su condición de centro geográfico de articulación de estos productos (López, Susana, 1997; Ibarra y Hernández, 2005).

Así se empiezan a desarrollar los primeros comerciantes (de distintos orígenes migratorios) que a través de sus almacenes de ramos generales y de sus redes de distribución de productos, controlan la economía de la región (Hernández, Carlos, 1999).

La concentración y centralización de la propiedad y la riqueza, como en todo proceso de avance del capitalismo, se hace cada vez más profunda, y esto da como resultado la formación de grandes casas comerciales, como la de los MenéndezBehety (su actividad comercial se origina en Punta Arenas y Santa Cruz, pero domina luego gran parte de la Patagonia, siendo los fundadores de la actual cadena de supermercados "La Anónima") y de una estructura de tenencia de la tierra basada en 
el latifundio y el sobrepastoreo (se sobrecarga una tierra poco productiva con demasiadas ovejas por hectárea).

Ya para 1940 la producción de las salinas se había abandonado ante su nula rentabilidad y la agrícola (especialmente el trigo que hasta allí lograba importantes rendimientos por su muy buena calidad) se comenzará a hacer menos redituable ante la baja de los costos del transporte, que dificultaba la competencia con los productos del norte, de menor costo de producción por las diferencias de clima y suelo. La creación del Dique Florentino Ameghino (inaugurado en 1963, fundamentalmente para el control de las periódicas inundaciones del Valle), sin los estudios adecuados sobre sus efectos, produjo la salinización de las tierras de muchas chacras del Valle. Esto termino de afianzar la caída de esa producción agrícola, que desde allí no logra superar sus carencias, limitándose al intento de sobrevivir.

Otras producciones de la región, como su fábrica de cerveza (Draguicevich, 2000), los molinos harineros o la producción tambera, tampoco pudieron competir con las grandes empresas nacionales e internacionales. La mayoría de ellas son vendidas (y compradas por empresas nacionales que inmediatamente las cierran y ocupan su mercado con los productos fabricados en el norte del país) o directamente caen en la quiebra. Así la producción ganadera ovina para lana será la actividad primordial (y casi única) en la región hasta la llegada de los programas desarrollistas y la instalación del modelo de "polos de desarrollo".

Como síntesis tenemos que desde 1865, y especialmente luego de 1880 , para nosotros la región comprendida por el actual noreste de Chubut, tiene una estructura económica social concreta con las características principales del predominio del capitalismo de economía privada, con un importante peso de la actividad agropecuaria y gran parte de la población agrupada alrededor de dicha actividad (tomamos esta conceptualización de Iñigo Carrera, Podestá y Cotarelo, 1999).

A partir de allí, y desde mediados de los años cincuenta, comienza a darse la transición desde ese tipo de estructura a una estructura económica social que denominaremos de "capitalismo de estado en enclaves", siguiendo al citado trabajo de Iñigo Carrera, Podestá y Cotarelo. En esa investigación los autores revisan las características fundamentales de las distintas estructuras económicas sociales concretas que forman la Argentina.

La estructura económica social concreta de capitalismo de estado en enclaves se caracteriza por la limitación de la actividad productiva a pocas ramas y la "creación" de ciudades a partir de una sola empresa o de proyectos financiados y orientados por el Estado. Hay un alto grado de desarrollo de la división del trabajo social y, por lo tanto, de desarrollo de las fuerzas productivas. El peso del sector asalariado es muy 
fuerte, con una profunda inserción de las relaciones sociales capitalistas y un predominio de la población productiva. En ellas el elemento capitalista fundamental es personificado por el Estado, que es el principal impulsor de las políticas seguidas en la región, y las relaciones industriales predominan sobre las relaciones mercantiles.

Las actividades productivas que se realizan tienen una débil o nula articulación con las demás ramas productivas de la estructura y, por ello, un escaso efecto multiplicador sobre el conjunto de las actividades económicas. La base de su desarrollo y de su conformación esta fijada casi exclusivamente por estímulos externos a la región, ya sea a partir de aportes del Estado (polos de desarrollo en el caso de la región que estudiamos aquí, centros mineros como en Sierra Grande o Río Turbio) o de la exportación del producto sin casi agregado de valor (pesca, extracción de petróleo, etc.).

Estos enclaves tienen una gran fragilidad por su especialización extrema en determinadas producciones y por la dependencia de esos factores externos; cualquier cambio en ellos llevará a la caída de los proyectos. Justamente es en esta estructura económica social donde se han producido mayores modificaciones desde la década del noventa, a partir de la hegemonía del capital financiero y de las modificaciones a las políticas nacionales que esté desarrolló. Cuáles son esos cambios y qué tipo de estructura económica social se ha constituido en la región, es lo que debemos investigar más profundamente.

Como tendencia general vemos que la formación económica social que constituye la Argentina como totalidad se mueve hacia una mayor homogeneización de las distintas estructuras económicas sociales concretas que la conforman (Iñigo Carrera, Podestá, 1985), marcada por la dominación más directa que desarrolla el capital financiero ${ }^{15}$. En ese sentido nuestra hipótesis es que el proceso que realiza la estructura económica social de la región que investigamos avanza en el mismo sentido que marcamos cuando analizábamos la situación general de Argentina, y que el proceso previo de crecimiento capitalista en el marco del proyecto de polos de desarrollo no era algo excepcional.

Lo que podría pensarse como motivaciones más "puramente" políticas (las que hacen al plano de lo ideológico, o a las disputas entre diversos actores de la política) si bien tienen incidencia, no son determinantes, y deben ser comprendidas como parte del proceso que realizaba esta estructura económica social, en el marco de las particularidades de la inserción de la región patagónica en el capitalismo argentino.

\footnotetext{
${ }^{15}$ Se debate aquí con la posición defendida por Eduardo Basualdo y otros autores, quienes sostienen que el dominio del capital financiero ha traído una "generalizada reducción del grado de integración nacional" (Basualdo, 2000: 43).
} 
Por eso lo fundamental a resaltar es que esas decisiones políticas se corresponden con las necesidades del desarrollo capitalista en Argentina y en esta región en particular, o sea que en esas políticas se manifiestan y pueden observarse las características del desarrollo capitalista en esa fase.

Podemos marcar el inicio del programa "desarrollista" en el decreto-ley 10.991/56 de la llamada "revolución libertadora", bajo el gobierno del general Aramburu. Ese decreto exime de impuestos a las importaciones al sur del paralelo 42 como forma de "propender al desarrollo de la Patagonia"16. En ese momento se comienzan a instalar las primeras empresas textiles en la ciudad de Trelew, que luego darán origen al parque industrial textil.

La elección de Trelew como centro de inversión por ser una de las ciudades más cercanas al límite del paralelo 42, muestra la expectativa de conseguir ganancias a corto plazo y no de invertir para "propender al desarrollo de la Patagonia". La gran extensión patagónica queda sumida en la misma situación de antes, con la enorme mayoría de su territorio despoblado y teniendo como única actividad a la producción de lana ovina o la extracción de materias primas sin elaboración.

Nuevas y continuas leyes de promoción industrial se promulgan entre el año 1958 y 1973, en general durante gobiernos militares y sin participación de la población local. A partir de esos años el aporte estatal se va haciendo más importante, con inversiones directas en infraestructura (caminos, viviendas, redes de agua, teléfono, gas, energía eléctrica, etc.), créditos estatales a tasas muy bajas para empresas privadas (muchos de los cuales nunca se devolvieron), otorgamiento de múltiples privilegios a esas mismas empresas, etc.

En los primeros años de la década del sesenta las franquicias de importación van siendo reemplazadas por la exención de impuestos. Se dio impulso, por sucesivas leyes, a la producción de fibras textiles sintéticas, proyecto que impedía la articulación y hacia competitivas a estas industrias con la producción tradicional de la zona: la lana de oveja.

En 1971 se crea el Parque Industrial de Trelew. Todas las tareas de infraestructura fueron aportadas por el Estado, realizando un nuevo subsidio a los empresarios privados. Chubut pasó a tener una importante contribución a la producción industrial nacional y el noreste de la provincia pasó a producir en 1975 más del $70 \%$ de la producción provincial contra alrededor del $36,56 \%$ en 1970 . A su vez la industria textil representaba el $65 \%$ de la producción industrial de la provincia (Gatica, 1998).

\footnotetext{
${ }^{16}$ Texto del decreto - ley de la dictadura que había derrocado en 1955 al gobierno constitucional de Juan Domingo Perón.
} 
También en 1971 Lanusse adjudica el proyecto de una empresa nacional de aluminio, que se instalaría en la por entonces pequeña localidad de Puerto Madryn, a ALUAR (Aluminio Argentino S.A.). Al igual que en el caso del parque industrial en Trelew, la inversión fundamental fue aportada por el Estado, realizando una enorme transferencia de fondos públicos a una empresa privada. ALUAR logró grandes privilegios como: exención total del impuesto a las ganancias durante los primeros cuatro años y pagos reducidos hasta el décimo; exención por un decenio del impuesto de sellos; exenciones en IVA y capitales; franquicias para la importación de equipos y arancel cero para importar materias primas e insumos. La empresa estatal Agua y Energía Eléctrica construyó la central de Futaleufú (en la cordillera de la provincia, a unos 600 kilómetros de Puerto Madryn) y el sistema de transmisión transpatagónico hasta Puerto Madryn, directamente para proveer de energía eléctrica a ALUAR. Se realizó un puerto de aguas profundas, también para que esta empresa pudiera descargar la materia prima que traía del exterior ${ }^{17}$.

La investigación realizada por Eduardo Basualdo y Daniel Azpiazu (1981) sobre la promoción industrial en la $\operatorname{Argentina}^{18}$, demuestra que en las siguientes décadas se ha sostenido este sistema de subsidios del Estado nacional a algunas empresas: " $A$ este respecto FIEL afirma "por cada austral invertido por el sector privado el Estado contribuye con la misma suma a través de menores impuestos. De esta forma, en los hechos, los contribuyentes aportan la totalidad de los fondos invertidos". Esto significa que la totalidad de los recursos invertidos al amparo de los regímenes de promoción industrial provendrían del estado sin que los empresarios ("propietarios" de las nuevas plantas fabriles) aporten capital propio alguno" (18).

La idea de generar "polos de desarrollo" se planteaba desde lo teórico como la creación de centros industriales, desde donde el "progreso" logrado se irradiaría hacia el interior de la región, y al resto del país. En verdad esto nunca sucedió y el crecimiento quedó circunscrito a los territorios donde se instalaron estas industrias. De hecho estos proyectos no sólo fracasaron en cancelar la desigualdad ya existente en la distribución de la población y los factores relacionados con el nivel de vida de los distintos pueblos y ciudades, sino que la agravaron y consolidaron ${ }^{19}$.

La Patagonia fue el centro primordial de ensayo de esa política, siendo las Fuerzas Armadas las principales impulsoras. Es muy claro esto para ALUAR, proyecto

\footnotetext{
${ }^{17}$ Ver, para un mayor desarrollo de esta temática, el avance de investigación de Caprano, Palacios y López (2004) Aluar ¿privado o estatal?, Departamento de Historia, sede Trelew.

18 Basualdo, Eduardo y Daniel Azpiazu (1981) Cara y contracara de los grupos económicos. Estado y promoción industrial en la Argentina, Ed. Cántaro, Bs. As. Sus resultados son comparables con nuestro trabajo, aunque se centre en promociones industriales posteriores a las que aquí trabajamos.

${ }^{19}$ Esto puede observarse en Pérez Álvarez, G. (2007c) Calidad de Vida y desigualdad en Chubut, Trabajo final del seminario de Postgrado "Geografía y bienestar. Argentina, S XXI", dictado por el Dr. Guillermo Velásquez.
} 
directamente nacido en la Fuerza Área Argentina, pero también aparece el papel de estas instituciones del Estado en los otros casos. Estos proyectos tenían una incidencia clave de la Doctrina de Seguridad Nacional. Por un lado ello se reflejaba en el discurso de la necesidad de poblar la Patagonia, como región estratégica por su riqueza en recursos naturales y por ser la hipótesis de conflicto, especialmente con Chile y en segundo término con Inglaterra.

Otro elemento importante para comprender los fundamentos de la idea de generar polos de desarrollo industrial por fuera de las ciudades tradicionales (Buenos Aires, Rosario, Córdoba), tiene relación con la importancia que se le asignaba desde el poder a la posibilidad de descentralizar a los obreros. Se buscaba dividir al movimiento obrero para impedir sus grandes concentraciones y así debilitar a los sindicatos y otras organizaciones de los trabajadores.

Para comprender la relevancia de este punto debemos tener en cuenta que este proyecto se da en el marco de años de gran conflictividad social en todo el país y especialmente en las regiones de mayor concentración fabril. La lucha de la clase obrera y otros sectores del pueblo durante los años que siguieron al derrocamiento del peronismo, desarrolló una acumulación de fuerza social que puso en jaque al sistema durante las insurrecciones populares de 1969, de las cuales se recuerdan especialmente el Cordobazo y los dos Rosariazos.

Retomando teorías elaboradas en los EEUU, se proyectaba dividir a la clase obrera, generando nuevas ciudades industriales, sin tradición de organización obrera y con dirigencias sindicales cercanas al poder político y económico. Así se consideraba que sería posible descomprimir la situación social y tener un control más estricto sobre la clase obrera. Es claro que este origen del proyecto impacta en las características de las formas de lucha, organización y conciencia que desarrolla la clase obrera de la región, en especial en los obreros insertos en las ramas de la actividad económica que son impulsadas por el Estado.

A partir del desarrollo industrial y la generación de gran cantidad de puestos de trabajo (tanto en la industria, como en las actividades satélites y en las diferentes instancias del Estado provincial en formación) se produjo una masiva llegada de migrantes a la zona (especialmente en términos de la escasa población que hasta allí habitaba en estos centros urbanos). Muchos de estos migrantes se movilizan desde el interior de la provincia en busca de una mejor situación económica. Antiguos habitantes de la zona rural, muchos descendientes de los pueblos originarios de la región, deben abandonar sus tierras ante la imposibilidad de trabajarlas por la falta de capital, el avance de los grandes latifundios y también por el aumento demográfico que 
impide seguir viviendo en las pequeñas porciones de tierra que se les había permitido conservar.

La economía lanar se encuentra desde los cincuenta en un largo ciclo de estancamiento y posterior declinación (tanto para la provincia como para el país, cuya incidencia en la producción mundial de lana se redujo al 50\% entre 1960 y 1990, pasando de tener el $7 \%$ del stock ovino en 1945 , a menos del $2 \%$ en la actualidad) que no encuentra perspectivas de modificarse para mejor. Ese proceso se aceleró en los ochenta con un desplome del $20 \%$ en la existencia de cabezas ovinas en Chubut. Procesos como el de la desertificación (pérdida de la cobertura vegetal del suelo por el sobrepastoreo ovino) y la consecuencia de graves caídas de la productividad aceleran el despoblamiento de una vasta región del país. El mayor problema es que en este caso no se produce un reemplazo de la producción ovina por otra más rentable (como en la región pampeana al inicio del siglo XX) sino que estamos ante un fuerte proceso de descapitalización y decadencia de la economía agropecuaria. (Beinstein, 1993).

El siguiente cuadro de Irusta y Rodríguez (1993) muestra la correlación directa entre el despoblamiento del interior provincial, la migración hacia las ciudades de la costa (Trelew, Rawson, Puerto Madryn y Comodoro Rivadavia) y la concentración del producto bruto geográfico en la zona urbanizada:

Cuadro N9: Distribución porcentual de la población por zonas según Censos Nacionales.

P.B.G.: Concentración porcentual ${ }^{20}$.

\begin{tabular}{|l|c|c|c|c|c|c|c|c|c|}
\hline & \multicolumn{4}{|c|}{ CENSOS - POBLACIÓN } & \multicolumn{4}{c|}{ P.B.G. } \\
\hline ZONAS & $\mathbf{1 9 6 0}$ & $\mathbf{1 9 7 0}$ & $\mathbf{1 9 8 0}$ & $\mathbf{1 9 9 1}$ & $\mathbf{1 9 6 0}$ & $\mathbf{1 9 7 0}$ & $\mathbf{1 9 8 0}$ & $\mathbf{1 9 9 1}$ \\
\hline Cordillera & 28.8 & 24.3 & 18.4 & 16.3 & & 15.4 & 12.0 & 10.9 & 7.4 \\
\hline Central & 10.2 & 8.2 & 5.4 & 3.7 & 5.5 & 3.5 & 3.6 & 2.5 \\
\hline Costa & 62.0 & 67.5 & 76.2 & 80.0 & & 79.1 & 82.5 & 85.5 & 90.0 \\
\hline
\end{tabular}

Fuente: Irusta y Rodríguez, 1993.

La mayoría de estas familias se instalan en los barrios pobres de Trelew, Puerto Madryn y Comodoro Rivadavia, y comienzan una compleja transición a la vida urbana, que se complicará aún más ante la pérdida de sus trabajos, cosa que muchos sufren a los pocos años de instalarse en la ciudad.

\footnotetext{
${ }^{20}$ El trabajo de Irusta y Rodríguez fue realizado en 1993 y por esta razón el cuadro no cuenta con los datos de 2001. Asimismo el cuadro original no comprendía la presentación de los números absolutos (que permitirían una mejor comprensión del proceso que la sola referencia a porcentajes) y dado que no contabamos con información precisa acerca del proceso de construcción de los datos y de las fuentes para la distribución en zonas, no hemos podido subsanar estas limitaciones. De todas maneras consideramos que las mismas no descartan el valor demostrativo del cuadro acerca del agudo proceso de concentración poblacional y del PBG en la zona de la costa.
} 
También llegaron migrantes del norte del país ante la apertura de fuentes de trabajo bien remuneradas. La mayoría ocupa puestos en las fábricas que se abrían, y los migrantes que tenían algún tipo de especialización cubrirán los cargos medios y superiores, ya sea en las empresas privadas o en el aparato estatal. En esos años la población en las ciudades de la región aumenta de forma vertiginosa, modificando totalmente la vida de esa sociedad y agrupando a una gran cantidad de migrantes provenientes de distintas partes del país y de países limítrofes (en especial de Chile).

Vemos como en el departamento Rawson la población se duplica entre 1960 y 1970 y vuelve a duplicarse entre 1970 y 1980. Por su parte en Biedma la población, que se mantiene casi sin cambios entre 1945 y 1970, explota entre 1970 y 1980, triplicando la cantidad original, y vuelve a aumentar a más del doble para 1991. Es claro que este nivel de crecimiento está relacionado con las industrias que se instalaban en la región a partir del impulso y la planificación generada por el Estado. La fuerte caída del aumento poblacional entre 1991 y 2001 es un primer indicador del proceso de crisis y cambio que atravesó la estructura económica que se había conformado en las décadas anteriores.

Cuadro N2: Población Total Chubut y Deptos Rawson y Biedma.

\begin{tabular}{|r|r|r|r|r|r|}
\hline \multicolumn{5}{|c|}{ Población Total Chubut, Deptos Rawson y Biedma } \\
\hline \multicolumn{2}{|c|}{ Chubut } & \multicolumn{2}{c|}{ Rawson } & \multicolumn{2}{c|}{ Biedma } \\
\hline Año & Pobl. Total & Año & Pobl. Total & Año & Pobl. Total \\
\hline 1895 & $\mathbf{3 7 4 8}$ & & & & \\
\hline 1914 & $\mathbf{2 3 0 6 5}$ & & & & \\
\hline 1947 & $\mathbf{9 2 4 5 6}$ & 1947 & $\mathbf{9 6 0 5}$ & 1947 & $\mathbf{4 5 5 4}$ \\
\hline 1960 & $\mathbf{1 4 2 4 1 2}$ & 1960 & $\mathbf{1 7 1 5 5}$ & 1960 & $\mathbf{6 1 8 9}$ \\
\hline 1970 & $\mathbf{1 8 9 7 3 5}$ & 1970 & $\mathbf{3 4 2 8 8}$ & 1970 & $\mathbf{6 9 4 5}$ \\
\hline 1980 & $\mathbf{2 3 6 1 1 6}$ & 1980 & $\mathbf{6 7 9 9 1}$ & 1980 & $\mathbf{2 1 6 8 9}$ \\
\hline 1991 & $\mathbf{3 5 7 1 8 9}$ & 1991 & $\mathbf{1 0 0 2 4 3}$ & 1991 & $\mathbf{4 5 4 9 4}$ \\
\hline 2001 & $\mathbf{4 1 3 2 3 7}$ & 2001 & $\mathbf{1 1 5 8 2 9}$ & 2001 & $\mathbf{5 8 6 7 7}$ \\
\hline \multicolumn{7}{|c|}{ Fuente: censos nacionales $1895-2001}$. \\
\end{tabular}

Sin dudas la región que investigamos es transformada durante estos años por las políticas que se ponen en marcha desde el Estado nacional. La nueva situación generó una gran expansión de las actividades económicas, aunque sin lograr diversificarse ni integrarse con las otras ramas de la estructura; o sea sin perder su característica de enclave. Trelew decía ser "la ciudad más progresista del sur 
argentino $^{, 21}$ y Puerto Madryn pasaba, de ser un pequeño pueblo que languidecía cerca de la desaparición (especialmente tras el cierre del ferrocarril patagónico en 1961), a transformarse en una ciudad moderna y dinámica.

La industria textil sintética instalada en Trelew, en tanto contó con las ventajas de la promoción industrial, generó un parque de fábricas modernas, y con miles de puestos laborales directos y bien remunerados, ya que la mano de obra especializada era escasa y su costo no tenía una incidencia clave en la estructura de costos. Tal como dice Horacio Ibarra (Ibarra, 1997) "El alto salario fabril representaba el efecto de derrame del subsidio estatal, porque el beneficio surgía de la exención impositiva (IVA compra + IVA venta $=18$ a 20\% de la facturación), más reintegros por promoción de exportaciones, más reembolsos por exportación por puertos patagónicos, en el caso de ventas externas." Aunque obviamente la realidad es que ese derrame iba fundamentalmente a manos de los empresarios y no de los trabajadores.

Chubut pasó ser un importante centro industrial a nivel nacional y Trelew era uno de los mayores polos de producción textil en todo el país. En ese marco se produce una situación de pleno empleo con inauguración frecuente de ampliaciones y nuevas fábricas.

La estabilidad laboral, las buenas condiciones de trabajo y los salarios altos aparecían como seguros. La capacidad de negociación de los sindicatos era alta, sus organizaciones eran poderosas (especialmente las vinculadas a las ramas promocionadas, sobre todo textiles y metalúrgicos) y solían obtener buenas condiciones de trabajo en las negociaciones paritarias sin necesidad de tomar medidas de acción directa. Incluso durante la segunda mitad de los años ochenta pudieron sostener una resistencia exitosa ante los intentos de la patronal de imponer los criterios internacionales en uso para los trabajadores textiles: todavía en 1986-87, cuando cada operario atendía en Brasil 12 telares y en Corea 18, en el Parque Industrial de Trelew la $\mathrm{AOT}^{22}$ aceptaba un máximo de 6 telares por operario.

En Puerto Madryn ALUAR instala una industria de características únicas en el país. Su monopolio en la producción de aluminio primario en Argentina y la situación oligopólica a nivel internacional, sumado a los subsidios que sigue recibiendo del Estado nacional, le asegura una gran rentabilidad que no sufre mayores sobresaltos a lo largo de los años. Una mínima parte de esa rentabilidad genera un importante crecimiento en Puerto Madryn, con la asignación de salarios por encima del convenio para sus trabajadores durante los primeros años. Además el Estado construye un acueducto que soluciona el permanente problema de la falta de agua para la ciudad

\footnotetext{
${ }^{21}$ Slogan de la principal radio de Trelew durante los años setenta y ochenta.

${ }^{22}$ Asociación Obrera Textil.
} 
(alejada unos $70 \mathrm{~km}$ de la única fuente de agua dulce en la región, el Río Chubut), barrios de viviendas sociales, escuelas, un hospital, etc.

Ante este proceso también el Estado provincial debe aumentar su personal para cubrir las distintas necesidades que el crecimiento poblacional iba generando. Así Rawson recibe parte de los beneficios, ya que la gran mayoría de estos nuevos empleos se concentran en la capital de la provincia y en Trelew. También se instalan en Rawson algunas fábricas textiles (especialmente una importante tintorería) y empieza a cobrar impulso la producción pesquera, con la instalación de plantas de procesamiento en tierra.

O sea estamos ante un período, marcado especialmente por las décadas de 1960 y 1970, en que la región que investigamos vive una profunda transformación de su estructura económica y social. Se conforma en esas décadas la génesis y el desarrollo de un nuevo tipo de estructura económica, que, como ya lo decíamos, tiene las características generales de un "capitalismo de estado en enclaves".

Esta estructura da sus primeras señales de crisis al iniciarse la década del ochenta. Ese mismo año comienzan a expresarse varios sectores a nivel nacional que se oponen a la continuidad del modelo de polos de desarrollo. Son la expresión del avance de la fuerza social que apoya el proyecto del capital financiero, a quienes no les cerraba este tipo de proyectos propios de la fase de hegemonía del capital industrial. Los cambios políticos orientaban la economía del país hacia una mayor apertura al exterior y un impulso a la desgravación de los aranceles de importación. Esto se suma a la recesión económica, que ya se hacía sentir, y ese nuevo marco comienza a generar problemas en el parque industrial. Varias empresas reducen su personal, cortan turnos y bajan su producción. Algunas cancelan nuevas inversiones.

Ante esto se producen varios reclamos al gobierno (todavía en manos de las fuerzas armadas) desde los partidos políticos locales y los distintos medios de comunicación, donde se plantea la necesidad de que el Estado continué aportando al desarrollo de la Patagonia. Se perfilaba un futuro complejo para el antiguo modelo que había hecho crecer estas ciudades.

Pese a estos problemas para 1980 la industria ocupa el primer puesto como generadora de empleo provincial (ocupando el 14\% de la PEA). En 1984 la industria textil (con centro en Trelew) aportaba cerca del 50\% del valor agregado industrial provincial (tejido de fibras sintéticas, hilado textil, fibras artificiales y sintéticas; Beinstein, 1993). Ese año de 1984 sería el límite temporal en el cual aún la mayoría de las industrias continuaban produciendo al tope de sus posibilidades y reinvirtiendo en tecnología. 
Los cuestionamientos al modelo de promoción industrial se iban haciendo más fuertes y complicaban la previsión de las empresas ya instaladas. En 1985 ya encontramos la primera caída en la producción industrial (cuando llegaba al 30\% del PBG provincial, su máximo de participación histórica). Aquí encontramos un paralelo muy importante con la investigación que sobre la vecina provincia de Santa Cruz realizan Luque, Martínez, Avalos y Auzoberría (2007, 2003, 2000), en la cual también se marca a 1985 como un año de inflexión para Santa Cruz.

A partir de 1986-1987 los cuadros políticos del capital financiero logran imponer su política con respecto a este tema y se recortan definitivamente varios beneficios para la región. Es en esos años cuando se interrumpió el otorgamiento de promoción a nuevos emprendimientos.

Este cambio de política llevó al freno de la reinversión en las plantas existentes. El avance posterior en la desregulación de las tarifas de servicios, que afectaron la estructura de costos, y la apertura comercial que de hecho subsidió a la importación a precios de dumping (por la sobre valuación del peso), llevaron al cierre progresivo de las plantas textiles. Como consecuencia inmediata se generó una drástica reducción de los requerimientos del sector industrial a las actividades de servicios vinculadas, mientras que el achicamiento de la capacidad adquisitiva global en la región impactó también en el comercio.

A esto se sumó la problemática del Estado provincial que desde 1988, al igual que otras provincias como Santa Cruz, Jujuy, Tucumán o Santa Fe, comienza a recibir menor porcentaje de coparticipación y ve progresivamente congelados sus recursos. La compleja situación se agrava con la caída de las regalías de YPF y la negativa de la empresa estatal de adelantar regalías para solventar los gastos más urgentes de la provincia. La hiperinflación del año siguiente termina de dibujar el marco de presión que el capital financiero imponía a las provincias para que estas encaren las medidas de ajuste fiscal que se exigían desde los organismos de crédito internacionales (FMI y Banco Mundial).

Este es el contexto en el que se insertan el proceso de transformación económica social y el de protestas, luchas y conflictos sociales que pretendemos investigar. Nuestra hipótesis en torno a este cambio de la política del Estado nacional para la región (que como planteamos comienza a expresarse a principios de 1980) es que expresa el agotamiento de la posibilidad de desarrollo predominantemente en extensión del capitalismo en la Patagonia, el cual ahora debe impulsar su desarrollo predominantemente en profundidad.

En ese sentido la región avanzaría hacia una mayor homogeneización con el proceso del resto del país $y$, justamente, esa necesidad de una mayor 
homogeneización en su desarrollo es lo que explica la aparente "excepcionalidad" del proyecto de desarrollo industrial subsidiado de los años sesenta y setenta.

La estructura económica social que habíamos visto crecer y desarrollarse en los años sesenta y setenta, entra en crisis en los ochenta, configurándose en esa década los elementos fundamentales que darían nacimiento a una nueva estructura económica social, que se consolidaría en los años noventa y termina de presentarse como tal en los primeros años del nuevo siglo.

\subsection{Hipótesis de trabajo}

El problema que guía nuestra investigación es comprender cuáles son los cambios que se producen en esta estructura económica social caracterizada hasta 1980 como de capitalismo de estado en enclaves a partir de la imposición de la hegemonía del capital financiero y qué propuestas expresan en relación a este proceso los distintos conflictos sociales que se desarrollan entre 1989 y el 2005 en la región que estudiamos.

La intención es poder relacionar los distintos ámbitos de la sociedad en que los hombres desarrollan su vida y su actividad. Así buscamos comprender el proceso global, para lo cual deberemos poder encontrar las articulaciones que en general permanecen ocultas a la mirada del "sentido común"23 y que conectan estos distintos ámbitos.

En el marco de este problema general de la investigación, consideramos que los cambios que se producen en esta estructura económica social son parte del proceso global que vive Argentina como país. En este sentido tomamos los trabajos de Cavalleri, Donaire y Rosati (2005, 2007b) como indicadores globales del sentido que ha tomado el desarrollo global del capitalismo en Argentina. A partir de allí nuestra hipótesis es que la estructura económica social de la región ha vivido cambios profundos, que en términos generales han modificado la relación de fuerzas beneficiando a los sectores más concentrados de la gran burguesía. Para nosotros en el período que estudiamos se expresan claramente en la región los tres procesos que Iñigo Carrera y Podestá (1985) plantean que recorren a la sociedad argentina y que ellos demuestran cómo se presentan a nivel país en 1980: la centralización y concentración de la propiedad y la riqueza, la proletarización y pauperización ${ }^{24}$ de

\footnotetext{
${ }^{23}$ En el sentido que le da Gramsci, de ser la manifestación más directa e inconsciente de la hegemonía burguesa.

24 "La pauperización implica entonces un cambio respecto a la capa dentro de una misma clase social a la que pertenece una parte de la población, desde las más acomodadas a las más pobres. La proletarización implica un cambio de clase social, desde la clase propietaria hacia la proletaria." (Donaire, 2009: 13).
} 
crecientes masas de población y el paralelo incremento de la productividad del trabajo y de la riqueza que éste genera.

Ese marco global muestra el proceso de cambio de un período a otro en el desarrollo del capitalismo, proceso que a nivel nacional comienza a manifestarse en la década del cincuenta y que se hace claramente visible desde mediados de la década del setenta, cuando se acelera el proceso de construcción del dominio y después de la hegemonía del capital financiero.

En el caso que estudiamos consideramos que este proceso se manifiesta más claramente recién después de 1980, y con mayor profundidad a partir de 1991, ya que en los años anteriores el capitalismo aún podía desarrollarse en extensión en esta estructura económica social concreta. La transformación fundamental es el cambio de la hegemonía del capital industrial al capital financiero, expresión a su vez de que el capitalismo ya había encontrado los límites de su desarrollo predominantemente en extensión y necesitaba ahora desarrollarse predominantemente en profundidad. Se trataba de acrecentar los niveles de explotación de los territorios sociales ya dominados por el capitalismo, al ya no ser posible incorporar nuevos territorios a esa dominación.

Las protestas y luchas que se desarrollan durante el período expresan distintas posturas y propuestas, las cuales sólo podemos entender en forma completa si las enmarcamos en el proceso de cambio que se está dando en la estructura económica social. La hipótesis específica para la clase obrera es que durante estos conflictos no se logra construir una propuesta alternativa a la que impulsaba el capital financiero y que en su gran mayoría desarrollan una estrategia global que busca resistir los aspectos más regresivos del cambio social que estaban viviendo, intentando insertarse en las mejores condiciones posibles en ese nuevo marco social.

Decíamos que del problema central, como en todo sistema de problemas, se encadenan hacia atrás una serie de problemas menores, cuya respuesta sucesiva hará posible la respuesta del problema mayor. Planteábamos allí que un problema que podía plantearse era el metodológico, en especial en torno a si es posible observar procesos de este tipo en una unidad delimitada en el espacio y en el tiempo como la que hemos seleccionado para esta investigación.

Obviamente nuestra hipótesis es que esta tarea es posible y que el abordaje del estudio de este tipo de procesos en su desarrollo en determinadas regiones particulares del territorio que conforma la Argentina, permite avanzar en el sentido de comprender el movimiento del conjunto de la sociedad argentina. Es también obvio decir que toda investigación implica un recorte de la realidad y que lo que se debe 
discutir no es el hecho del recorte en sí mismo, sino las características de cada recorte.

Nuestra hipótesis es que la región que seleccionamos constituye una unidad económica social articulada por una historia en común, por un mismo proyecto político y social que conformó este territorio social ${ }^{25}$ como una región con características propias y diferenciadas de otras, como podrían ser la región noroeste o la región sur de la provincia. En este sentido otra hipótesis es que estas tres regiones tienen articulaciones económicas y sociales más significativas con las ciudades y pueblos más cercanos de las provincias vecinas, que entre sí en el marco de la misma provincia.

La región que recortamos ha sido constituida por una historia común, diferenciable de las otras regiones, y por ello el entramado de relaciones sociales que la constituye y reconstituye día a día tiene características propias que la hace plausible de ser investigada como unidad (una unidad que, como toda unidad desde nuestra perspectiva, es en verdad una síntesis de múltiples contradicciones).

Es claro que esto no significa que sea posible estudiar estos procesos sociales en la región sin relacionarlos y articularlos con lo que sucede, al menos, a nivel nacional. Si bien el proceso social es cada vez más un mismo proceso interrelacionado a nivel mundial, la posibilidad objetiva de abordar su estudio implica la necesidad de selecciones. Nuestras referencias en ese camino será observar como se articulan estos procesos en cuatro dimensiones sucesivas: la estructura económica social común en la cual la región esta inserta en el marco del país, la articulación con el proceso a nivel nacional, la articulación a nivel Latinoamericano y la articulación a nivel del proceso mundial. Por la posibilidad objetiva de nuestra investigación creemos que las articulaciones a nivel latinoamericano y mundial no podrán ser abordadas de forma significativa, más allá de algunas referencias parciales.

Partimos entonces de plantear que los procesos particulares deben entenderse en el marco del proceso general, del cual son parte y expresión. Por eso deben ser estudiados y profundizados en esta línea de pensar lo particular como expresiones de lo general, pero donde a su vez lo general es constituido dialécticamente a partir de las múltiples particularidades, constituyéndose en una expresión unitaria de lo múltiple (Marx, 1997).

Como plantea Gramsci, el análisis de las relaciones de fuerzas se complica aún más por las diferentes secciones territoriales dentro de cada país, en cuyo seno se

${ }^{25}$ Entendemos a un territorio social como al entretejido de relaciones sociales que, a través de generaciones, los hombres van creando, destruyendo y reproduciendo en relación con otros hombres y con su medio. 
combinan las distintas fuerzas nacionales e internacionales, conformando "...estructuras diferentes y relaciones de fuerzas también diferentes en todos los grados" (1997: 59). Lo mismo destaca Lenin ${ }^{26}$ cuando llama la atención sobre la necesidad de estudiar las articulaciones de una realidad tan heterogénea como era la Rusia de 1918, donde en cada región se "entrelazaban" de modo diverso los distintos tipos de economía social. Es este enfoque el que retoman Iñigo Carrera, Podestá y Cotarelo en su trabajo sobre las estructuras económicas sociales concretas en Argentina.

Desde este punto de vista la cuestión de las relaciones entre lo regional y lo nacional e internacional no puede entenderse como una contradicción excluyente. Sería un grave error que, como respuesta a los que ven en cada hecho una excepción y una refutación de las leyes generales (donde lo local no se entendería en ninguna instancia por lo general), se opusiera un reflejo mecánico que planteara que todo lo local se entiende solamente por lo general. Es por ello clave la reflexión metodológica de Gramsci y Lenin, donde lo regional no es entendido como algo aparte de las relaciones de fuerzas en una sociedad ni tampoco como una mera situación local de esas relaciones, sino como un ámbito en que las relaciones de fuerza de la sociedad se combinan con las relaciones de fuerza locales, que tienen sus particularidades y desde las cuales inciden a su vez en lo general.

Para nosotros las miradas que pretenden hacer de cada estudio de un proceso particular el origen de conclusiones acerca de situaciones "excepcionales", suelen encubrir la falta de profundidad de la investigación. Se debe buscar cómo esa pretendida "excepcionalidad" de un proceso particular es siempre una expresión del proceso general (en todo caso una expresión contradictoria o alternativa, pero no aislada 0 al margen de la tendencia general). Lo que debe buscarse es que la explicación de lo particular se articule con la explicación de lo general, como forma de construir explicaciones holísticas de los procesos sociales. Así creemos que no es posible pensar la articulación de una fuerza social en una región de una provincia o en una provincia del país, y tampoco pensar los cambios en una estructura económica social sin articularlos con los cambios que ocurren a nivel de la formación económica social de Argentina. Lo que sí es posible es aportar a esa síntesis que debe ser todo estudio general, desde el análisis de sus expresiones particulares.

El siguiente campo de problemas que se nos presenta, al descomponer el problema general en sus problemas parciales, es el de la estructura económica social. Allí nos preguntamos cuáles son los cambios que se producen en la estructura

\footnotetext{
${ }^{26}$ Entre otros trabajos en "Acerca del infantilismo "izquierdista" y el espíritu pequeñoburgués" (1981, T.2, pp. 712-736).
} 
económica social del NE del Chubut a partir de la hegemonía del capital financiero. Como ya lo marcábamos nuestra hipótesis es que estos cambios avanzan en el mismo sentido que el conjunto del país, con el desarrollo de tres grandes procesos sociales: centralización y concentración de la riqueza y la propiedad, proletarización y pauperización de importantes masas de la población (con el desarrollo de una miseria consolidada) y el incremento de la productividad global en función del gran capital concentrado.

A su vez otra hipótesis es que el desarrollo de la región durante los últimos cincuenta años (o sea incluyendo al período del desarrollo industrial y a la actual transformación) no tuvo características de excepcionalidad, sino que la estructura económica social concreta de la región avanza hacia una mayor homogeneización con el resto de la Argentina. En nuestra hipótesis el objetivo del modelo de "polos de desarrollo" fue incorporar la región patagónica al desarrollo capitalista argentino, haciéndole realizar un rápido pasaje por la fase del capital industrial para luego pasar al desarrollo del capitalismo en profundidad, en consonancia con el proceso nacional de realización hegemónica del capital financiero.

La región patagónica aún mantenía condiciones para desarrollar el capitalismo predominantemente en extensión durante las décadas del sesenta, setenta y parte de los ochenta, y ese fue el objetivo que persiguió y realizó el modelo de polos de desarrollo. Una vez que se alcanzó el límite de un desarrollo predominantemente en extensión comenzó en la región el mismo proceso que ya se había puesto en marcha años antes para el nivel nacional: el desarrollo del capitalismo predominantemente en profundidad.

Otro problema hace a sí el período analizado tiene como contenido central el de la des industrialización de la economía ${ }^{27}$. En ese marco además perdería centralidad la clase obrera y el peso fundamental de las ganancias empresarias ya no provendría de la explotación de la fuerza de trabajo. Esta afirmación, que se ha ido consolidando como lectura del sentido común a nivel país, es aún más presente para nuestra región, donde el cierre de fábricas y la pérdida de puestos de trabajo industriales es un hecho evidente.

Pese a esto nuestra hipótesis es contraria a esta corriente mayoritaria: para nosotros no estamos ante un proceso de des industrialización sino, justamente a la inversa, ante un avance del dominio del régimen de gran industria que supera al régimen basado en la manufactura y se instala como definitivamente dominante en el

\footnotetext{
27 Esta visión ha sido difundida por los trabajos de Basualdo (2002 y otros) y Azpiazu, Basualdo y Khavisse (2004) y por distintos integrantes del grupo Fénix. Entre otros está siendo discutida por Grigera (2007), Donaire y Rosati (2007), Sartelli (2007) e Iñigo Carrera y Podestá (1997).
} 
territorio de Argentina (tomamos esta hipótesis general de Podestá, 1999). Junto con este proceso se desarrolla el aumento de la explotación del proletariado, tanto en intensidad como en extensión.

Para observar si hubo o no des industrialización no debemos quedarnos en los simples datos de cantidad de fábricas y puestos de trabajo. Como parte del proceso de concentración de la economía y de aumento de la productividad, menos obreros agrupados en menos fábricas con mejores niveles de maquinización han aumentado los niveles de producción globales. Estos datos, que no son fáciles de observar durante la década del noventa (cuando se generan las condiciones para realizar esta transformación), sí se presentan más claramente en los datos que recogemos para el año 2005, y creemos que se corrobora para la continuidad del proceso (lo que implicaría que este fenómeno expresaría un movimiento orgánico y no coyuntural).

A su vez en esta perspectiva sigue siendo clave el análisis de la clase obrera, de cuya explotación se continúa extrayendo la ganancia empresaria. Esto se relaciona directamente con varios de los problemas planteados en el campo del análisis de las relaciones de fuerzas políticas.

Un último problema que hemos formulado en el campo de las relaciones de fuerzas objetivas hace al papel del Estado en la conformación de esta nueva estructura económica social. Hay un planteo muy extendido, especialmente entre muchos críticos del neoliberalismo, que caracteriza a este periodo como una fase en que el Estado nación ha perdido peso, llegando muchas veces a hablar de la "desaparición" del Estado. Según esta perspectiva, que como decíamos apunta a ser crítica del discurso neoliberal, la posibilidad de disputar el poder a estos grupos más concentrados de la economía pasaría por recuperar el papel del Estado como planificador y regulador de la economía.

Para nosotros este planteo toma como verdad lo que dicen los defensores de la hegemonía del capital financiero, sin atender a lo que concretamente hacen. Llamativamente durante varios años, tanto desde los cultores del neoliberalismo como desde sus mayores "críticos", se repetía constantemente, sin casi analizarla, esta afirmación de que el Estado-nación había perdido peso en el conjunto de la vida de las sociedades (tanto a nivel económico como político). Esto era destacado como positivo por los neoliberales y como negativo por sus críticos.

En verdad consideramos que en varias investigaciones a nivel nacional (Azpiazu, Basualdo y Khavisse, 2004; Iñigo Carrera y Podestá, 1997, Piva, 2007; Bonnet, 2007, 2002; entre otros trabajos) está ya claramente demostrado que ha sido el mismo Estado el que impuso las condiciones políticas, económicas y jurídicas que posibilitaron la realización hegemónica del capital financiero. 
Es el Estado el que siguió realizando la regulación de la economía y fue desde allí que se instrumentaron las distintas políticas que hicieron posible las privatizaciones, las leyes de flexibilización laboral, la mayor sumisión nacional al dominio de los monopolios internacionales, la financierización de la economía, la concentración y centralización de la economía, etc ${ }^{28}$.

Pero aunque consideramos que esta discusión esta resuelta a nivel nacional observamos que sigue siendo un problema a discutir en nuestra región, y más en general en la estructura económica social concreta de capitalismo de estado en enclaves. Es allí donde esa apariencia de la pérdida de peso del Estado se hace más significativa y se presenta como parte del sentido común, de lo que se hace directamente visible para la mayoría de la sociedad.

Lo que aparece ante la sociedad es que el Estado deja de financiar la instalación de industrias textiles, que el Estado deja de controlar la pesca de buques extranjeros, que el Estado deja de manejar las grandes empresas extractoras de hidrocarburos, que el Estado deja de explotar la mina de Sierra Grande. También discutiendo con esta mirada, nuestra hipótesis sobre este grupo de problemas es que en la región estudiada (al igual que a nivel nacional) el Estado sigue siendo el que regula y articula a la economía, pero que ahora esa regulación y esa articulación se hacen en el sentido de los intereses de otra alianza de clases que es la que ocupa el poder político a partir de la imposición del capital financiero sobre el capital industrial.

Justamente la pretendida "desregulación" de la economía no es más que el nombre de fantasía que se le puso a una brutal regulación de toda la sociedad de acuerdo a los intereses de los sectores más concentrados de la economía mundial. Para nosotros no sólo no deja de haber un capitalismo de estado, sino que esta característica esta aún más acentuada que antes.

El Estado, manteniendo su función de defender los intereses de la clase dominante, pasa a realizar otra planificación y otra regulación de la economía, en función de los intereses de la fracción del capital que ahora ocupa los puestos claves del poder. Esto se muestra en la finalización de las políticas de promoción industrial y en la privatización de aquellas empresas donde funcionaba como capitalista directo.

La economía de la región pasa a estar directamente en manos del capital financiero transnacional que controla los enclaves de gran capital (extracción y

\footnotetext{
${ }^{28}$ Así por ejemplo sostienen Azpiazu y Basualdo que las distintas políticas económicas generadas desde el Estado fueron reforzando la concentración y centralización económica: “... las modalidades y especificidades que adoptó el desarrollo del programa privatizador no han hecho más que fortalecer el poder relativo de los mismos agentes económicos que crecieron y se consolidaron al amparo de la promoción industrial, de la estatización de la deuda externa privada, de las compras de bienes y servicios del sector público, del mantenimiento de reservas de mercado en medio de procesos de apertura, etc" (Azpiazu y Basualdo, 2004: 62).
} 
depredación de recursos naturales como la pesca y la energía). Los enclaves generados por el papel del Estado como planificador en el sentido de los intereses del capital industrial (polos de desarrollo, promociones industriales) son en gran medida abandonados, ya que no resultan rentables para las grandes empresas privadas.

Para la región que investigamos esa decisión implicó el final de las políticas de promoción industrial que se realizaban en el marco del proyecto de polos de desarrollo. Políticas que garantizaban la continuidad de las fábricas textiles en Trelew, Rawson y Puerto Madryn y sin las cuales no podían competir con la producción del área central del país, y menos aún con las importaciones de Brasil o del sudeste asiático. También las plantas pesqueras en tierra atravesaron una profunda crisis que llevó a continuos cierres, despidos y suspensiones, y a una mayor explotación del personal que seguía ocupado.

Nuestra hipótesis es que desde mediados de la década del ochenta y más claramente durante los noventa, se desarrolló un nuevo modelo de articulación del capitalismo de estado con el capitalismo de economía privada, modelo que parte de las necesidades de un capitalismo que en la región ya había encontrado sus límites de desarrollo predominantemente en extensión a principios de los ochenta y que necesita ahora desarrollarse en profundidad.

Quizás el hecho más visible de este proceso es la política de privatizaciones y el abandono del impulso al proyecto de polos de desarrollo. Es importante ante esto destacar, a riesgo de ser reiterativos, que estos procesos no implican la modificación de la caracterización de esta región como un capitalismo de estado, ya que se mantiene lo fundamental de este tipo de estructura económica social: que la producción es planeada y organizada por parte del Estado (y por ello a favor de los grupos que controlan y dirigen ese Estado). Si bien el capitalismo de estado es por definición de capital monopólico, en estos años se desarrolla una profundización del dominio de los monopolios privados sobre los recursos naturales y la explotación del trabajo asalariado en la región.

Por eso las políticas impulsadas por el Estado son diferentes y van unicámente en beneficio de las grandes empresas privadas de capital concentrado, que son las que subsisten y crecen en este nuevo marco. Las empresas que no son de capital concentrado dejan de recibir apoyo estatal, realizándose un fuerte proceso de concentración de la propiedad y de la riqueza que se expresa en el cierre de la mayoría de las pequeñas y medianas empresas, la venta a capitales extranjeros de otras y la caída de la producción de las que quedaron en pie.

Como parte del mismo proceso Argentina ha sufrido una profundización de su dependencia económica y política, lo cual se expresa en una mayor presencia en la 
dirección de las políticas del Estado por parte de los organismos financieros internacionales y los representantes de grandes empresas de los países dominantes. Las empresas estatales dejan de apropiarse del trabajo asalariado y esta apropiación se concentra en las empresas de capital privado ${ }^{29}$.

El siguiente grupo de problemas hace al campo de las relaciones de fuerzas políticas. En este campo es evidente que no es posible analizar el proceso que se desarrolla en lo regional sin tener en cuenta su articulación con el proceso de rebelión que se desarrolla a nivel nacional. Partimos de considerar que el proceso que estudiamos en la región no puede ser comprendido sin abordarlo como parte de un proceso general que se desarrolla a nivel nacional, y del cual las expresiones que se dan en nuestra región son manifestaciones particulares.

Por ello el primer problema que nos planteamos es comprender cómo se relaciona el proceso de rebelión en el NE del Chubut con el proceso a nivel nacional. Nuestra hipótesis es que esta relación existe, que el ciclo de rebelión ${ }^{30}$ tiene un carácter nacional y que por ello lo que debemos ir demostrando en cada momento del ciclo son las particularidades con las cuales se expresa esa relación.

El segundo problema está directamente relacionado, y se basa en buscar hacer observable cómo los sujetos sociales que desarrollan las protestas en el NE del Chubut se constituyen en parte del proceso nacional de acumulación de experiencias en las formas de organización y de lucha. Partimos de un resultado de la investigación desarrollada por Paula Klachko (2006), en la cual logra demostrar que, durante el ciclo de rebelión que se desarrolla en Argentina en los años noventa, se realiza a nivel nacional un proceso de acumulación de experiencias que puede hacer posible la conformación de una fuerza social con un potencial cuestionador del orden social vigente, o de algunos aspectos parciales del mismo.

Nuestra hipótesis es que los sujetos sociales que desarrollan las protestas y luchas en la región que estudiamos son parte del mismo proceso nacional. Consideramos que en esta región también se desarrolla ese proceso de acumulación de experiencias, y que dicho proceso no puede ser comprendido desde lo regional sino como parte de un proceso nacional.

Otro problema hace a cuáles son los sujetos que participan de las protestas en la región. El problema fundamental aquí es hacer observable si es correcto el planteo

\footnotetext{
${ }^{29}$ Es posible que algunos de estos procesos se hayan modificado en cierta medida después del 2003, con la asunción del gobierno de Kirchner en el nuevo marco de relaciones de fuerza que habían dejado las jornadas de diciembre de 2001. Intentaremos reflexionar sobre el grado de estos posibles cambios hacia el final de este trabajo.

${ }_{30}$ Tomamos el concepto de ciclo en el sentido que le da Iñigo Carrera (2000). Para Iñigo Carrera un ciclo es un conjunto de hechos de rebelión que corresponden a un mismo proceso histórico y en el cual se articulan distintos puntos de la escala de formas de lucha.
} 
que durante varios años ha sido mayoritario en las investigaciones desde las distintas ciencias sociales sobre la conflictividad social contemporánea en nuestro país. Se afirma en muchas investigaciones que el movimiento obrero y sus formas tradicionales de lucha han perdido peso y que fueron reemplazados, como sujeto fundamental del conflicto social, por los "nuevos movimientos sociales", donde se utilizan "nuevos métodos de protesta" y "nuevas formas organizativas" (Farinetti, 1999; Seoane, 2002; Schuster, Pérez y otros, 2006; entre otros).

Nuestra hipótesis es que en la región, durante el período que analizamos, se mantiene la centralidad del movimiento obrero y de lo que se suelen denominar sus "métodos tradicionales" de lucha y organización. Construimos esta hipótesis desde los resultados de investigaciones nacionales desarrollados por el PIMSA (Iñigo carrera y Cotarelo, 2004, entre otros), por nuestros propios resultados parciales (Pérez Álvarez, 2010b, 2009g, 2007a y otros) y hasta por investigadores que partiendo de una lectura de la realidad distinta y una hipótesis contrapuesta a la que planteamos han llegado en sus últimas investigaciones a datos muy semejantes (Schuster, Perez y otros 2006).

De hecho muchas de las formas de rebelión consideradas "no tradicionales" (como el corte de ruta, los escraches o las ocupaciones), son instrumentos que tienen una larga tradición entre los sectores oprimidos, y siempre han sido utilizados de diversas maneras en sus protestas. En ese mismo sentido no consideramos a los llamados "desocupados" como parte de un grupo social diferente al proletariado, ya que en su gran mayoría son proletarios que las actuales condiciones del capitalismo han desplazado de la posibilidad de reproducir su existencia a través de la venta de su fuerza de trabajo.

Por ello otra hipótesis a hacer observable es que los movimientos de trabajadores desocupados que se organizaron durante la década del noventa y los primeros años del nuevo siglo, expresan la organización de un sector del proletariado, y no una "nueva forma de organización" o un "nuevo sujeto social". Al contrario, lo que presentan es la fortaleza de las tradiciones previas de la clase obrera argentina y de la histórica importancia de su organización sindical.

El último grupo de problemas que nos hemos planteado hace a los niveles de conciencia que se expresan en el proceso de protestas y luchas sociales que se dan en la región estudiada, comparando y buscando sus articulaciones con el proceso que se desarrolla a nivel nacional. En este sentido tomamos las indicaciones metodológicas ya brevemente reseñadas de Gramsci (1997).

Dentro de este grupo de problemas nos interesa poder hacer observable qué expresan, en términos de intereses de clase (o de fracciones de ella) y en términos de 
niveles de conciencia, las distintas formas de protesta y de organización que se van desarrollando en el período analizado.

Desde aquí surgen otros problemas, como si se expresan en el ciclo de rebelión en el NE del Chubut las distintas estrategias que es posible observar en el ciclo a nivel nacional. $\mathrm{Y}$, si esto es así, cuáles son las particularidades que aquí encontramos con respecto al proceso general.

Nosotros pensamos que es posible hacer observable, en el conjunto de los enfrentamientos sociales que se van desarrollando, distintos objetivos entre los sujetos que participan en estos hechos. La demarcación de las formas de acción, de los niveles de conciencia que expresan, de los tipos de organización, de la relación entre lo conciente y lo espontáneo y entre lo institucional y la acción por fuera de lo institucional, nos posibilita encontrar un sentido general del proceso de lucha. A ese sentido general lo denominamos estrategia (Iñigo Carrera, 2000). Obviamente en todo proceso habrá más de una estrategia y hasta múltiples variables dentro de una misma estrategia general. Pero justamente lo que buscaremos demostrar es que es posible encontrar, entre esos múltiples hechos y tendencias parciales, una tendencia central que explica la globalidad del proceso.

En nuestra hipótesis hay una estrategia central en las luchas de la clase obrera durante estos años. Es una estrategia que se desarrolla a nivel nacional y que se expresa en la región. Creemos que esa tendencia central hace al interés corporativo de la clase social, y por ello a la estrategia de buscar vender su fuerza de trabajo en las mejores condiciones posibles dentro del actual sistema vigente, expresando así la conciencia de su situación como vendedores de fuerza de trabajo y no de su condición de expropiados de sus condiciones materiales de existencia.

Esa misma estrategia se desarrolla en nuestra región, aunque con algunas particularidades que no modifican lo central del proceso. Creemos que estas particularidades se presentan en especial alrededor del tipo de grupo social que constituye a la clase obrera de la región, un grupo con poca experiencia y tradición como clase, con elementos muy heterogéneos, con poca experiencia de trabajo fabril y hasta de vida urbana. Por ello se presentan características de menor enfrentamiento que en otras regiones. Otro elemento que contribuye a esto es el tipo de estructura económica social que se desarrolla, una estructura fuertemente subsidiada y donde opera en gran medida el discurso de que si hay conflictos sociales el Estado podría quitar estos subsidios.

Un problema que se nos presenta aquí es cómo se relaciona esta estrategia general con la situación de un capitalismo en descomposición que ya no puede integrar a la totalidad del proletariado a la producción social, y que por ello lo repele de 
sus antiguos territorios sociales. En este sentido es posible que una estrategia de este tipo en esta fase del capitalismo lleve necesariamente a la clase a llegar a niveles de enfrentamiento más importantes, y a ir presentando elementos cada vez mayores de una estrategia alternativa: la de buscar realizar sus intereses como expropiados, a través de la transformación de la actual forma de organización social.

Retomamos aquí lo planteado anteriormente sobre cuáles fueron algunos de los mecanismos que llevaron a que las formas de rebelión en la región no llegaran a los niveles de confrontación que tomaron en otras partes del país. Esto, según nuestra hipótesis, lleva a que podamos encontrar en la región menores elementos de esa estrategia alternativa que se va presentando, en principio de forma difusa pero cada vez con mayor claridad, en distintos hitos nacionales a lo largo de los noventa y que tiene su máxima expresión nacional, hasta el momento, en la insurrección espontánea de diciembre de 2001.

Esta hipótesis está directamente relacionada con nuestro último problema que hace a cómo se desarrollan los procesos de unidad y alianza de la clase obrera en la región, y cómo estos se articulan con el proceso nacional. Este problema es central para comprender cómo la clase obrera va desarrollando sus luchas, si lo hace unida o dividida como clase y si lo hace en alianza o aislamiento con otros grupos sociales.

Nuestra hipótesis es que los períodos de unidad y división entre la clase en la región siguen en gran medida los procesos que se dan a nivel nacional, reflejándose esto en una profunda coincidencia de la periodización que podremos realizar del ciclo de rebelión a nivel local con la periodización que para el ciclo nacional se construye desde el PIMSA (Iñigo Carrera y Cotarelo, 2004, entre otros trabajos).

Creemos en cambio que los procesos de alianza y aislamiento siguen una dinámica más propia de la región. Esto se debe a que durante un período inicial la burguesía y pequeña burguesía acomodada con intereses en la región ${ }^{31}$, que realizaban sus ganancias en el marco del anterior dominio del capital industrial, buscan resistir el proceso de cambio, y desarrollan una alianza con algunas fracciones de la clase obrera que se subordinan a su dirección.

Sin embargo esto luego se modifica, con la subordinación de estas fracciones de la burguesía al dominio del capital financiero, rompiendo así la alianza con la clase

\footnotetext{
${ }^{31}$ Hablamos siempre de "burguesía con intereses en la región" y no de "burguesía regional". Este último concepto plantearía la unidad de intereses entre esa burguesía y el resto de la población de la región, cuando en verdad en la mayoría de los casos se trata de empresarios con inversiones diversificadas en varias ramas económicas y varias regiones del país, y que en su gran mayoría no viven en la provincia en forma estable. En un sentido similar Claudio Katz (2006) propone hablar, para Argentina, de burguesía local y ya no de "burguesía nacional". También Eduardo Basualdo destaca la necesidad de repensar algunos conceptos clásicos a partir de las profundas transformaciones que se han producido en la sociedad y en las formas de organización de la estructura económica social: "...volviendo insuficientes algunos instrumentos analíticos, y obsoletos otros. Tal es el caso de la distinción entre empresas nacionales y extranjeras" (Basualdo, 2000: 104).
} 
obrera. A partir de allí constituyen otra alianza, que ocupa el gobierno del Estado provincial, en la cual estos sectores que encabezaban el anterior modelo son dirigidos ahora por la fuerza social que impulsa la transformación de la estructura económica social en función de los intereses del capital financiero.

1.5. Síntesis de los objetivos, problemas e hipótesis de esta investigación

Intentando ordenar los diversos elementos volcados, cerramos este primer capítulo con una síntesis de los objetivos, problemas e hipótesis:

- Objetivo general: avanzar en el conocimiento sobre cómo se desarrolla el movimiento de la sociedad argentina en su conjunto, analizado desde un caso particular que es el noreste del Chubut en el período que va desde la imposición de la hegemonía del capital financiero en 1989-1990 hasta el año 2005. Buscaremos entender y conceptualizar cómo se mueve esa sociedad, de qué son expresión cada uno de sus conflictos, qué expresan los distintos sectores que se movilizan, qué expresan los cambios estructurales, etc.

- Problema general: analizar cuáles son los cambios que se producen en esta estructura económica social, caracterizada hasta 1980 como de capitalismo de Estado en enclaves, a partir de la imposición de la hegemonía del capital financiero, y qué propuestas expresan en relación a este proceso los distintos conflictos sociales que se desarrollan entre 1989 y el 2005 en la región que estudiamos.

- Problema específico: explicar cómo se expresan los procesos nacionales en lo regional, tanto a nivel de la estructura económica social como, especialmente, a nivel de las luchas sociales. De esta manera podremos aportar a la complejización del análisis de lo general y avanzar en el conocimiento de lo regional. Nos interesa específicamente observar como las protestas y luchas de la clase obrera en nuestra región contribuyen, o no, al proceso nacional de acumulación de experiencias y a la posibilidad de articular una fuerza social que pudiera plantear una alternativa distinta al actual régimen social (siguiendo en este sentido la hipótesis y el problema específico de Klachko, 2006).

Síntesis de las principales hipótesis:

1 - la estructura económica social de la región ha vivido cambios profundos que en términos generales han modificado la relación de fuerzas beneficiando a los sectores más concentrados de la gran burguesía financiera. Se produce el cambio de 
un período a otro en el desarrollo del capitalismo, proceso que en el caso de Patagonia se presenta más claramente después de 1980 y con mayor profundidad a partir de 1991. El cambio fundamental es el paso de la hegemonía del capital industrial al capital financiero, expresión a su vez de que el capitalismo había encontrado los límites de su desarrollo predominantemente en extensión y necesitaba ahora desarrollarse predominantemente en profundidad.

2 - el desarrollo de la región avanza hacia una mayor homogeneización con el resto de la Argentina. El objetivo del modelo de "polos de desarrollo" fue incorporar la región patagónica al desarrollo capitalista argentino, pasando por la fase del capital industrial y el desarrollo predominantemente en extensión para llegar al desarrollo del capitalismo predominantemente en profundidad. La región patagónica aún mantenía condiciones para desarrollar el capitalismo predominantemente en extensión durante las décadas del sesenta y setenta y ese fue el objetivo que persiguió y realizó el modelo de polos de desarrollo. Una vez que se alcanzó el límite del desarrollo predominantemente en extensión comenzó en la región el mismo proceso que ya se había puesto en marcha a nivel nacional.

3 - durante la década del noventa se desarrolló un nuevo modelo de articulación del capitalismo de Estado con el capitalismo de economía privada. El Estado realiza una planificación a favor de las grandes empresas de capital concentrado que son las que crecen en la fase de dominio del capital financiero. Se configura un nuevo tipo de estructura económica social que ya no se organiza como un capitalismo de Estado en enclaves, sino que toma la forma de un capitalismo de Estado en enclave de grandes empresas privadas. No estamos ante un proceso de des industrialización, sino ante un avance del dominio del régimen de gran industria, que supera a la manufactura y se instala como definitivamente dominante en el territorio de Argentina. Junto con este proceso se desarrolla el aumento de la explotación del proletariado, tanto en intensidad como en extensión, y la profundización de la dependencia política y económica de Argentina.

4 - la hipótesis específica para la clase obrera es que durante el desarrollo de los diversos conflictos no logra construir una propuesta alternativa a la que impulsaba el capital financiero, y que en la gran mayoría de los hechos relevados se expresa una estrategia global que busca resistir los aspectos más regresivos del cambio social que estaban viviendo, intentando insertarse en las mejores condiciones posibles en el nuevo marco social. 
5 - los sujetos que desarrollan el ciclo de rebelión en la región son parte de un ciclo nacional. Debemos mostrar, en cada momento del ciclo, las particularidades con las que se expresa esa relación entre lo regional y lo nacional. En la región se desarrolla el proceso de acumulación de experiencias y se mantiene la centralidad del movimiento obrero y de sus "métodos tradicionales" de lucha y organización. Los movimientos de trabajadores desocupados expresan la organización de un sector del proletariado y no una "nueva forma de organización" o un "nuevo sujeto social". Muestran la fortaleza de las tradiciones de la clase obrera argentina y la histórica importancia de su organización a nivel corporativo.

6 - hay una estrategia central en las luchas de la clase obrera durante estos años, que se desarrolla a nivel nacional y se expresa en la región. Su tendencia central hace al interés corporativo de la clase, y por ello la estrategia mayoritaria es la de buscar vender su fuerza de trabajo en las mejores condiciones posibles dentro del actual sistema vigente. Esa estrategia se desarrolla en nuestra región con algunas particularidades que llevan a menores niveles de confrontación que en otras regiones del país, y por ello a la menor presencia de elementos de una posible estrategia alternativa.

7 - los procesos de unidad y división de la clase obrera en la región confluyen en gran medida con el ciclo que se desarrolla a nivel nacional. En cambio consideramos que los procesos de alianza y aislamiento siguen una dinámica más propia. Durante un período inicial la burguesía con intereses en la región busca resistir el proceso de cambio y desarrolla una alianza con fracciones de la clase obrera que se subordinan a su dirección. Esto luego se modifica con la subordinación de estos sectores burgueses al dominio del capital financiero, rompiendo la alianza con la clase obrera y constituyendo otra alianza que ocupa el gobierno del Estado provincial, en la cual son dirigidos por la fuerza social que impulsa los intereses del capital financiero. 


\section{2. ¿Desde dónde partimos? La metodología y el estado de la} cuestión:

\subsection{Instrumental teórico metodológico utilizado en esta investigación}

En términos generales tomamos como punto de partida a los resultados de investigación logrados por el desarrollo del socialismo científico (en especial las obras de Carlos Marx, Federico Engels, Vladimir Lenin, León Trotsky y Antonio Gramsci) y por los resultados obtenidos por el CICSO y el PIMSA al nivel del estudio del movimiento de la sociedad argentina. Sumamos también aportes de las investigaciones y desarrollos conceptuales realizados por otros investigadores, en especial los de la llamada historia social inglesa (Hobsbawm, E. P. Thompson, Rudé y Samuel), elementos teóricos de Atilio Boron y Eduardo Grünner, de los investigadores del Programa de Investigación sobre Cambio Social del Instituto Gino Germani ${ }^{32}$, los debates que generan Alberto Bonnet, Adrián Piva y Ernesto Villanueva, las investigaciones de Svampa y Federico Schuster, las reflexiones de Adolfo Gilly, entre muchos otros.

Esto no significa no tomar aportes, indicaciones y avances de otras múltiples expresiones teóricas, sino apoyarse en un corpus teórico consolidado, que será justamente el que otorgue coherencia y consistencia sistémica a los distintos elementos que necesariamente se van sumando en el marco de cualquier tarea de investigación.

Si bien a lo largo de la tesis iremos desarrollando los conceptos e indicaciones metodológicas que aplicamos (ya lo hemos hecho con varios elementos en el primer capítulo), aquí expondremos brevemente algunos lineamientos centrales de nuestra perspectiva.

Partimos de considerar que los procesos sociales pueden ser explicados y que la posibilidad de lograr una mejor comprensión de los mismos parte del instrumental teórico que se aplica y de la capacidad y seriedad del investigador. En contra de las tendencias que plantean que no hay una verdad objetiva en los hechos sociales, y que estos tienen tantas explicaciones como discursos pueden construirse, nosotros consideramos que el conocimiento científico, en su acumulación, va alcanzando grados de aproximación a la verdad sobre los hechos que investiga y que, por eso mismo, siempre hay algún conocimiento que está más próximo a la verdad. Por lo tanto, si es que existen distintas interpretaciones sobre un hecho, habrá entre ellas

\footnotetext{
${ }^{32}$ Entre otros los trabajos de Inés Izaguirre (2006, 2002, 1994a, 1994b) y Agustín Santella (2009, 2008 y 2006).
} 
algunas con mayor o menor grado de aproximación a lo que realmente sucede o sucedió, lo que deberá ser demostrado científicamente.

Consideramos que hay una relación fundamental entre el enfoque teórico y la seriedad en la investigación concreta en términos metodológicos. Un enfoque teórico que fragmenta la realidad, que invisibiliza u oculta (conciente o inconscientemente) aspectos fundamentales acerca de cómo se mueve la sociedad, impide de hecho, por más seria y sistemática que sea la investigación, develar en profundidad la realidad que pretende comprenderse. Pero a su vez la aplicación de un enfoque teórico que permita hacer observable ${ }^{33}$ lo que se nos mantiene oculto o que aún no ha sido precisado no alcanza por sí sólo para avanzar en el conocimiento de la realidad; se necesita, además, un riguroso trabajo "gris y cotidiano" de investigación para obtener datos y precisiones.

Y esa investigación debe hacerse desde una mirada que apunte a ser holística, a abordar la totalidad del proceso de cambio social. Contrariamente a lo que sostienen muchos teóricos, el enfoque holístico lejos está de desconocer las particularidades o de subsumir bajo una "totalidad totalitaria" a las múltiples formas sociales y de resistencia que no pueden reducirse a la lucha de clases o al condicionamiento económico. No nos detendremos demasiado aquí. La mejor forma de desmontar este discurso es releer las obras clásicas del marxismo, y ver allí cómo se articulaban y se tenían en cuenta, en tanto profundas y poderosas fuerzas históricas, a las ideas, los sentimientos, las creencias religiosas, etc. Lo clave es que el marxismo nunca renunció a conocer y explicar las causas últimas de los procesos sociales, y en esas causas siempre cumplen un papel preponderante las relaciones económicas.

La realidad es que el enfoque marxista no solamente no subsume lo particular, sino que le da su real significación, lo recupera como parte central de la historia. Al explicar a la parte imbricada en el todo, se rompe con las lecturas que, ellas sí, subsumen lo particular al campo de lo "excepcional", lo anecdótico o lo regional. Para nosotros no hay forma de conocer la parte sin conocer el todo, y tampoco de conocer el todo sin conocer sus partes y su interrelación en esa totalidad concreta. Rechazar la posibilidad de conocer los procesos globales es rechazar también la posibilidad de conocer sus partes, ya que aún lo supuestamente excepcional (su nombre mismo así lo indica) lo es en relación con determinadas tendencias sociales a nivel global.

\footnotetext{
${ }^{33}$ Desde nuestra perspectiva el conocimiento acerca de un proceso social se desarrolla a partir de hacer observable algo que permanecía oculto, que ha pasado desapercibido, por falta de investigación o por la acción conciente $o$ inconciente de determinados sujetos sociales. Consideramos que existe una diferencia entre lo que sucede y lo que creemos saber acerca de lo que sucede, distancia que debe ser reducida a través de hacer observable lo que realmente pasó y del entrelazamiento del conjunto de relaciones sociales que imbrica ese hecho en el proceso social entendido en su totalidad.
} 
Nos dice Iñigo Carrera que "...se reafirma la renuncia a conocer el todo. Lo que implica de hecho, como ya dijimos, la renuncia a conocer las partes, en la medida en que las partes sólo adquieren significación si se conoce el lugar que ocupan en el todo" (2000b: 32).

En la misma línea Atilio Boron enfrenta ese ocultamiento de la totalidad y explica cómo encontrar esa relación entre las partes y el todo: "De lo que se trata, en cambio, es de hallar los términos exactos de la relación de los elementos múltiples y diversos que constituyen la totalidad social entre sí y con el todo del cual forman parte. Sólo de este modo será posible reconstruir, en el pensamiento, la totalidad concreta que existe en la realidad" (Boron, en Boron, Amadeo y González, 2006: 50).

Necesitamos un abordaje científico que rompa con las falsas barreras disciplinarias de la historia, la sociología, la ciencia política, la antropología o la economía, y que construya una verdadera ciencia social. Rechazando la búsqueda de una supuesta teoría política "marxista", Boron cita a Antonio Gramsci: "En función de tales planteamientos, redoblamos la apuesta del filósofo italiano al sostener que no sólo no hay sino que no puede haber una teoría "política" marxista. ¿Por qué? Porque para el marxismo ningún aspecto o dimensión de la realidad social puede teorizarse al margen -o con independencia- de la totalidad en la cual dicho aspecto se constituye. Como lo recordaba reiteradamente Antonio Gramsci, las separaciones precedentes sólo pueden tener una función "analítica," ser recortes conceptuales que permitan delimitar campos de reflexión a ser explorados de un modo sistemático y riguroso, pero que de ninguna manera pueden ser pensados -en realidad, reificados- como realidades autónomas e independientes. Se convierte "una distinción metodológica" como la que separa la economía de la política, advierte Gramsci, "en una distinción orgánica y presentada como tal (Gramsci, 1999: 41)" (Boron, en Boron, Amadeo y González, 2006: 186).

A contramano de las teorías que han sido más difundidas en los últimos años, consideramos que la lucha de clases sigue siendo determinante en el movimiento de la sociedad, y por eso todo estudio que intente generar explicaciones sobre los procesos sociales debe analizar al conflicto social de clases como un elemento explicativo fundamental.

La propuesta metodológica de estudiar la realidad como una disposición de fuerzas plantea la necesidad de una mirada holística, dialéctica y que comprenda el permanente movimiento de la sociedad, una mirada que supera en su capacidad de interpretar la realidad a otras teorías que fragmentan el conocimiento.

Pero la lucha de clases no solamente aparece cuando estudiamos la realidad, sino que es parte de nuestro mismo estudio, del enfoque que adoptamos, de los temas 
y, sobre todo, de los problemas que nos planteamos. La praxis transformadora que nos propuso Marx en sus tesis se nos replantea día a día en nuestra tarea como cientistas sociales. $Y$ esto implica que es imposible desvincular nuestra tarea en tanto científicos de nuestra práctica en tanto sujetos históricos que viven en una sociedad injusta.

El marxismo sigue siendo la herramienta central para comprender y analizar la realidad. Atilio Boron (2000) nos muestra como, en un mundo dominado por el discurso posmoderno, el marxismo se sigue levantando como el corpus teórico que ha tenido mayor capacidad para explicar el movimiento de la sociedad y prever sus tendencias fundamentales de desarrollo.

Hoy vemos como las previsiones del Manifiesto Comunista se han ratificado casi totalmente. La demostración de que la lucha de clases es la base en torno a la cual se organiza la sociedad, la centralización y concentración de la producción y de la riqueza, el rol del Estado como asegurador del dominio de la burguesía y, sobre todo, el dominio y la expansión que el capitalismo realizó sobre todo el mundo y sobre todos los espacios de la vida de los hombres: "La consolidación de los monopolios, el aumento de la polarización social (no solo en los capitalismos de periferia sino también en los centros metropolitanos), la universalización del fenómeno de la pobreza, la degradación del trabajo humano y del medio ambiente, el resurgimiento del racismo y la creciente desigualdad internacional que abre un abismo entre los países industrializados y las naciones que componen el $80 \%$ de la población mundial son otras tantas pruebas, irrebatibles y contundentes, que atestiguan la vigencia de los diagnósticos y pronósticos fundamentales formulados por Marx y Engels en los lejanos días de febrero de 1848."(Boron, 2000: 16-17).

La capacidad de comprender la realidad que permite este marco teórico está vinculada a su compromiso político: el de luchar para transformar la sociedad. La comprensión del modo de funcionamiento y de las bases de reproducción del capitalismo realizados por Marx en "El Capital", la comprensión de Engels de que estaba surgiendo una nueva fase del capitalismo en 1880-1890, el estudio de esta nueva fase por parte de Lenin en 1916, son sólo algunos ejemplos del potencial explicativo, y socialmente disruptivo, de esta perspectiva.

Ahora bien ¿cómo cambia esa sociedad? ¿Cómo se transforma y cuál es el sujeto clave a observar? Para nosotros la lucha de clases $^{34}$ sigue siendo lo

\footnotetext{
${ }^{34}$ Como plantea Aníbal Viguera: "La noción de "lucha de clases" remite necesariamente a una matriz teórica definida y no tiene sentido pensarla fuera de los presupuestos básicos de la tradición marxista. Aplicada a las sociedades contemporáneas esta matriz implica partir de una visión totalizadora de la realidad social en la que la condición capitalista de la misma es un elemento central e ineludible en el análisis, y que conlleva una dinámica atravesada por definición por el conflicto..." (2009: 7).
} 
determinante para comprender el movimiento de la sociedad, y por eso todo estudio que intente generar explicaciones holísticas sobre los procesos sociales debe tomarla como un elemento fundamental en los análisis que realice.

Partimos de la concepción de que las clases se desarrollan y conforman como tales en la lucha, en el conflicto, y por ello para estudiar las correlaciones de fuerza se hace necesaria una revisión exhaustiva de cada conflicto social, para hacer observables los cambios y continuidades y las modificaciones en esas relaciones de fuerzas entre las clases o las capas de cada clase.

Nuestra perspectiva hace hincapié en la investigación de la clase obrera, pero desde la concepción de que es imposible estudiarla sin comprender también la dinámica del resto de las clases en acción y, especialmente, de la otra clase central del sistema capitalista, la burguesía.

A nivel estructural la sociedad capitalista se divide en grupos sociales fundamentales, entre los cuales se establece una diferencia central según sean propietarios de sus condiciones materiales de existencia o estén expropiados de ellas. Esa división entre propietarios y no propietarios no explica, sin embargo, la complejidad del proceso. Porque la estructura social es transformación y en términos generales el cambio en la sociedad capitalista hace que sectores cada vez más numerosos de quienes eran propietarios, pasen a ser no propietarios (lo que se denomina proceso de proletarización), aunque también se producen, en menor medida, procesos en el sentido inverso.

Son procesos de largo plazo, que implican cambios profundos en las relaciones sociales y que generan diversas situaciones, dificultando la tarea de delimitar la posición en la actividad productiva de determinados conjuntos de personas, debiendo ser analizado no solamente la necesidad que tienen de vender su fuerza de trabajo para poder subsistir sino también la posición que históricamente han ocupado las familias de las que provienen (el reclutamiento).

Pero además de su posición, para observar cómo se dividen los grupos sociales fundamentales debemos estudiar su función en la actividad productiva, específicamente para delimitar a quienes cumplen funciones de dirección, organización, planificación y control del proceso productivo. El cruce de ambas situaciones nos delimitan cuatro grupos sociales fundamentales en el capitalismo desarrollado: gran burguesía, pequeña burguesía acomodada, pequeña burguesía pobre y proletariado y semiproletariado ${ }^{35}$.

\footnotetext{
35 Seguimos aquí, en términos generales, algunos aspectos de lo desarrollado en DT № 24: Taller "Estructura Social de la Argentina", en PIMSA Documentos y Comunicaciones 2000, pp. 59 a 76.
} 
Cada una de las situaciones es posible de ser medida y cuantificada en base a cuáles son las necesidades de vender su fuerza de trabajo que tiene determinado conjunto humano, en qué medida explotan fuerza de trabajo ajena, en qué medida usan su propia fuerza de trabajo al ser propietarios también de algún medio de producción, etc. Específicamente esto es clave realizarlo para las clases intermedias (pequeña burguesía acomodada y pequeña burguesía pobre), en cuyos casos es central observar si están en procesos de proletarización. Son claros ejemplos de este tipo de trabajo los desarrollados por Ricardo Donaire (entre otros 2009, 2004, 2002, 2001).

Pero aquí estamos todavía solamente al nivel del grupo social: de grupos de individuos que viven bajo condiciones materiales de existencia comunes o semejantes, y que por lo tanto comparten también modos de vivir, costumbres, intereses. Pero pese a todo esto no podemos aún, desde nuestra perspectiva, pensar a estos agrupamientos como clases.

Solamente podemos hablar de clases cuando estos grupos sociales toman conciencia de sus intereses contrapuestos con los de otros grupos sociales, y se organizan para luchar por ellos. Es en la lucha cuando las clases se constituyen como sujetos históricos, como productores del cambio, de la transformación social. Así las clases van adquiriendo conciencia de sus intereses comunes y van desarrollando organizaciones que buscan defender sus intereses y luchar contra aquellos que pretenden perjudicarlos. En el enfrentamiento esos grupos sociales toman algún nivel de conciencia acerca de sus intereses comunes y de la oposición de esos intereses con los de otro grupo social.

Por lo expuesto consideramos importante la indicación de E. P. Thompson ${ }^{36}$, quién propone que el concepto de lucha de clases es más sólido y explicativo que el de clase, ya que este último puede caer en una visión estática de la realidad, coartando su característica de ser un proceso diacrónico ${ }^{37}$. Sólo así podremos observar cómo se configuran los grados o niveles de conciencia que los trabajadores van desarrollando sobre sus intereses, observando el enfrentamiento y superando el vaciamiento de “...la noción de lucha de clases, de la que se escamoteó cada vez más la lucha y quedó la reificación de las “clases”(Marín, 1984b: 48).

\footnotetext{
${ }^{36}$ Especialmente en Thompson, E. P. "Algunas observaciones sobre clase y "falsa conciencia”, en Historia Social № 10, primavera-verano 1991, pp. 27-32.

${ }^{37}$ En el mismo sentido plantea Inés Izaguirre que “...las clases se constituyen permanentemente en sus luchas, en sus confrontaciones, o como diría Marx, se hacen clases para sí. De allí que la teoría se llame de la lucha de clases, no de las clases, y que los análisis clásicos del marxismo siempre refieran a procesos concretos de lucha." (2002: 2). Aún más clara quizás es esta síntesis en Izaguirre y Aristizabal (2002): "Marx no concibe las clases como algo con existencia previa a las relaciones de clase. $O$ sea que en su teoría primero es el movimiento -la lucha- y luego la constitución de las clases." (pág. 13).
} 
La sociedad cambia entonces a partir de la lucha y esa transformación se expresa en los enfrentamientos, allí se hace observable. En el capitalismo el sujeto fundamental de ese cambio es la clase obrera, quién es la única clase puramente capitalista, la que surge y se constituye como tal en este sistema, la que sufre con mayor rigor las injusticias del mismo y la que se constituye en el sujeto más dinámico de la conflictividad social. Al ser la clase oprimida es ella la que protagoniza centralmente los intentos de cambiar la situación, aunque esto no inhibe que muchas veces sea la gran burguesía la que toma la ofensiva de generar cambios en las relaciones de fuerzas sociales, condenando a la clase obrera a una acción defensiva, de pura resistencia.

Es fundamental partir de que la clase obrera es conformada por el capital, del cual la burguesía es personificación. Asimismo cada fracción del proletariado es producida por la fracción específica del capital que desarrolla esa actividad en el marco de la división social del trabajo. Es conformada desde un proceso objetivo: la burguesía, en tanto personificación del capital, desarrolla la clase obrera que necesita para asegurar su reproducción como clase dominante, y luego va intentando modificar aspectos parciales de sus características de acuerdo a los cambios que se producen. Pero a su vez, las clases y sus diversas fracciones se conforman mutuamente en el proceso de lucha de clases. Como nos dice Marx $^{38}$, la clase obrera se conforma como tal en el proceso de lucha contra la otra clase fundamental del capitalismo.

Esto lleva a que esa lucha se exprese también a un nivel teórico y político, ocultando desde la burguesía la importancia de las luchas obreras. Se invisibiliza su accionar, generando una visión que busca mostrar a la "armonía" como la situación normal del sistema, situación que solamente entraría en desequilibrios coyunturales por acciones de grupos que buscan afectar el orden ${ }^{39}$.

Contra esta visión nosotros consideramos que la sociedad vive y progresa a través del conflicto, y que este es el elemento central de toda sociedad. A la vez entendemos que el ocultamiento que se realiza de las acciones de la clase (en especial de aquellas que afirman su autonomía), nos obliga como investigadores a un importante esfuerzo para poder encontrar los ejes centrales, y para develar la verdadera explicación de los procesos sociales.

\footnotetext{
${ }^{38}$ En Miseria de la Filosofía (1985, Editorial Cartago, Bs. As.), explicita que “...esta masa es ya una clase con respecto al capital, pero aún no es una clase para sí. En la lucha, de la que no hemos señalado más que algunas fases, esta masa se une, se constituye como clase para sí" (pág. 136)

39 "Se han hecho no pocos estudios para mostrar las diferentes fases históricas recorridas por la burguesía, desde la comunidad urbana autónoma hasta su constitución como clase. Pero cuando se trata de darse cuenta exacta de las huelgas, de las coaliciones y de otras formas en las que los proletarios realizan su organización como clase, unos son presa de verdadero espanto y otros hacen alarde de un desdén trascendental." (Marx, 1985: 136-137).
} 
Seguimos en este sentido a Antonio Gramsci. En "Apuntes sobre la historia de las clases subalternas. Criterios metódicos ${ }^{, 40}$, nos alerta sobre las dificultades para investigar la actividad de los trabajadores y la formación de sus organizaciones. Si bien en el desarrollo de los procesos de conflicto social hay una clara tendencia a la unificación de estos grupos sociales (aunque sea a niveles provisorios), dicha intención es atacada por los grupos dirigentes y, casi siempre, derrotada. Por eso para Gramsci "todo indicio de iniciativa autónoma de los grupos subalternos tiene que ser de inestimable valor para el historiador integral". Al igual que para la investigación de la formación de un partido político, para Gramsci estudiar la conformación y el desarrollo de la clase obrera o hasta de una fracción obrera demanda "...escribir la historia general de un país desde un punto de vista monográfico, para subrayar un aspecto característico" (Gramsci, 1997: 99).

Así se hace necesaria una investigación de este tipo para poder conocer el proceso de génesis, formación y desarrollo de la clase obrera, proceso que está constituido por una sucesión de enfrentamientos sociales ${ }^{41}$. Es el ordenamiento de esos enfrentamientos el que nos permite observar cuáles son las estrategias que desarrolla la clase obrera en cada período, que pueden intentar penetrar el sistema institucional vigente buscando generar mejores condiciones para la venta de la fuerza de trabajo o apuntar a transformar de raíz el actual sistema social. Ambas estrategias parten de distintos niveles de conciencia, que a su vez se estructuran en programas políticos, uno de los cuales hace a los intereses de la clase en tanto vendedores de fuerza de trabajo y el otro a sus intereses en tanto expropiados de sus condiciones materiales de existencia.

Es fundamental, para comprender las estrategias, desarrollar una descripción minuciosa y precisa de los diversos enfrentamientos. Desde allí se construirán los datos que hacen posible desarrollar conocimiento científico acerca de los procesos sociales.

\footnotetext{
${ }^{40}$ En http://www.gramsci.org.ar. En este apartado Gramsci plantea un brillante programa de investigación: "Hay que estudiar, por tanto: 1) la formación objetiva de los grupos sociales subalternos, por el desarrollo y las transformaciones que se producen en el mundo de la producción económica, su difusión cuantitativa y su origen a partir de grupos sociales preexistentes, de los que conservan durante algún tiempo la mentalidad, la ideología y los fines; 2) su adhesión activa o pasiva a las formaciones políticas dominantes, los intentos de influir en los programas de estas formaciones para imponer reivindicaciones propias, y las consecuencias que tengan esos intentos en la determinación de procesos de descomposición, renovación o neo-formación; 3) el nacimiento de partidos nuevos de los grupos dominantes para mantener el consentimiento y el control de los grupos subalternos; 4) las formaciones propias de los grupos subalternos para reivindicaciones de carácter reducido y parcial; 5) las nuevas formaciones que afirmen la autonomía de los grupos subalternos, pero dentro de los viejos marcos; 6) las formaciones que afirmen la autonomía integral, etc."

${ }_{41}$ Seguimos aquí a Nicolás Iñigo Carrera, en especial "El concepto de clase obrera”, publicado en la Revista de Estudios Sociales y Marítimos №1 (2008), pp. 101 a 120 e "Instrumentos teórico metodológicos para la investigación de la historia de la clase obrera", en la misma revista, pp. 7 a 12.
} 
La rebelión de los trabajadores toma diversas formas que para nosotros se ordenan en una escala que va desde formas del delito común individual (que no constituyen lucha) hasta las grandes batallas del conjunto de la clase por la construcción de otra sociedad (expresadas en la insurrección conciente o la guerra civil revolucionaria). Las protestas o luchas ${ }^{42}$ toman así distintas formas, que también pueden ser adoptadas por otras clases ${ }^{43}$, pero que no se dan en el vacío ni se "eligen" a voluntad, sino que se entroncan y parten de un determinado proceso de lucha de clases, en el cual ellas se insertan.

En el desarrollo del proceso de rebelión la lucha en determinados momentos deviene política ${ }^{44}$ y allí el proceso pasa a incluir en el enfrentamiento a otras clases o fracciones. La lucha se desarrolla entre fuerzas sociales, es decir entre distintas alianzas de clases o fracciones de clases que levantan un programa común ${ }^{45}$. Según cuál interés sea el predominante en el programa podremos analizar cuál es la clase que hegemoniza esa fuerza social y que le imprime centralmente su estrategia.

Una alianza de clases se establece cuando se produce una confluencia objetiva de intereses, la cuál se hace observable a partir de las acciones que los sujetos desarrollan en el marco de los enfrentamientos sociales, más allá de lo que pueda expresarse en términos de voluntad. Como en toda investigación las alianzas deben estudiarse por lo que se hace y no por lo que los sujetos que intervienen dicen que hacen ${ }^{46}$. En este caso esto es aún más importante ya que las alianzas muchas

\footnotetext{
42 Consideramos que se puede hablar de lucha cuando es posible encontrar en el encadenamiento de enfrentamientos sociales una estrategia por parte de la clase.

${ }^{43}$ Excepto la huelga, que en términos estrictos solamente puede ser desarrollada como forma de lucha por la clase obrera.

${ }^{44}$ Por ejemplo ante una huelga general, donde el conjunto de los obreros se unen contra el conjunto de los capitalistas y se encuentran con el poder del Estado como un poder contrario a sus intereses. Esto nada dice sobre la conciencia de la situación que tenga la clase y la estrategia que se plantee para superarla, pero sí expresa un momento en que se supera la fragmentación de la organización a nivel económico profesional, llegando al menos a la defensa de los intereses comunes como grupo social.

45 "Si partimos del modelo de la lucha de clases, tenemos la premisa de que las clases se enfrentan por medio de fuerzas sociales. Y una fuerza social es siempre la expresión de una alianza de clases. La lucha de clases, en nuestra imagen, es confrontaciones, encuentros, combates entre fuerzas sociales, fuerzas que son la territorialidad de una alianza de clases, territorialidad en la que se manifiestan los grados de unidad de cada clase social. La constitución de las clases se da en la lucha misma entre ellas, pero la lucha de clases determina también y es determinada por los grados de unidad de cada clase social, y estos grados de unidad dependen del tipo de alianzas en que están involucradas esas clases sociales. Todo ello marca el grado de desarrollo de la lucha de clases en un momento determinado: constitución de la clase, expresión como fuerza social, alianzas de clase, grado de unidad de la clase." (Marín, 1995: 6263).

${ }^{46}$ Que lo central a evaluar sea lo que se hace y no lo que se dice que se hace, no implica que lo que se dice no tenga importancia y no deba ser valorado como un aporte importante a la comprensión global. Pero justamente ese aporte se puede valorar desde tener claro lo que objetivamente sucedió, más allá de lo que los sujetos intervinientes buscaban (o decían que buscaban) realizar. Allí es cuando podrá observarse quién pudo llevar adelante sus cometidos y quién no, quién fue consecuente en sus planteos y, básicamente, quién logró imponer en mayor medida su voluntad a la resultante global del proceso. Recuperamos aquí la reflexión de Spivak (2003) acerca del error que subyace a las visiones que pretenden que los oprimidos pueden hablar, actuar y conocer por sí mismos, sin formas de dominación que les impiden desarrollar su propia agencia.
} 
veces se dan en los hechos, más allá (y a veces hasta en contra) de la voluntad de los sujetos que las realizan.

Como plantea Marín: "Esto nos remite al tema leninista de los "intereses objetivos" que se refiere a lo que objetivamente un ser social es. Cuando Lenin analiza alianzas de clase, y utiliza este concepto, hace énfasis en lo que objetivamente sucede y tiende a suceder, no a partir de las visiones subjetivas de las clases $y$ de los individuos, a partir no de lo que desean ser, sino de lo que objetivamente son". (Marín, 1984b: 32).

Desde esta concepción, y tras el proceso de descripción de los enfrentamientos, se hace posible encontrar las formas de lucha que utiliza la clase en el período analizado, las alianzas que desarrolla, las estrategias que pone en juego, etc. Desde este conocimiento acumulado es posible avanzar en la periodización del proceso, determinando si estamos ante un período revolucionario o contrarrevolucionario, y qué fase del mismo recorremos, prestando especial atención a qué clase o fracción tiene la iniciativa y toma la ofensiva.

También desde aquí se puede avanzar en conocer cuáles son los grados de unidad o fractura de la clase y su capacidad para generar alianzas. Estas condiciones son claves para delimitar si el momento de la lucha de clases es ascendente o descendente y si la lucha de la clase toma una forma ofensiva o defensiva.

Desde allí construimos la noción de "ciclo", en el sentido de un conjunto de hechos de rebelión que, aunque están en distintos puntos de la escala de las formas de lucha, corresponden a un mismo proceso histórico. Desde otro enfoque teórico Sidney Tarrow llama ciclo de protesta a una fase de incremento del conflicto y la contienda a través del sistema social, que incluye: una rápida difusión de la acción colectiva de los sectores más movilizados a los menos movilizados; un cambio acelerado en las formas de la protesta; nuevos marcos de acción colectiva; una combinación de participación organizada y espontánea; y secuencias de acción intensificada entre quienes protestan y las autoridades, que puede terminar en reformas, represión, y, algunas veces, en revolución ${ }^{47}$.

\footnotetext{
${ }^{47}$ En Schuster, Federico; Naishtat, Francisco; Nardacchione, Gabriel y Pereyra, Sebastián (2005: 51). También Charles Tilly toma la definición de Tarrow acerca de que "...los movimientos sociales (abiertos desafíos a las autoridades públicas en nombre de sectores de la población agraviados) se producen muchas veces en oleadas (...). Durante esas oleadas, una serie de peticiones parecen inducir otras, las organizaciones que participan en el movimiento social compiten entre sí por conseguir el mayor apoyo posible y las exigencias son cada vez más radicales para luego ir perdiendo fuerza. Frecuentemente ese proceso sirve a los activistas para experimentar nuevas formas de organizarse, estructurar sus demandas, combatir a sus enemigos y mantener lo que ya poseen. Al finalizar el ciclo, algunos protagonistas nuevos han conseguido cuando menos una pequeña parcela de poder, otros miembros de la comunidad política han perdido poder, el marco de los asuntos públicos se ha alterado un tanto y los modos de lucha han cambiado al menos ligeramente", citado en Tilly (1995) capítulo "Conflicto, Revuelta y Revolución", en Las revoluciones europeas (1492-1992), pág. 10. Véase también de Tarrow (1991) "Ciclos de protesta", en Zona Abierta n56.
} 
Otro elemento clave para construir un conocimiento integrador es saber distinguir lo que Gramsci denomina "movimientos ocasionales, coyunturales y orgánicos". Nuestra mirada debe saber encontrar la relación entre el movimiento coyuntural y el orgánico, sin dejarnos deslumbrar por las luces del movimiento ocasional: “...es necesario distinguir los movimientos orgánicos (relativamente permanentes) de los movimientos que se pueden llamar "de coyuntura" (y se presentan como ocasionales, inmediatos, casi accidentales). Los fenómenos de coyuntura dependen también de movimientos orgánicos, pero su significado no es de gran importancia histórica; dan lugar a una crítica política mezquina, cotidiana, que se dirige a los pequeños grupos dirigentes y a las personalidades que tienen la responsabilidad inmediata del poder. Los fenómenos orgánicos dan lugar a la crítica histórico-social que se dirige a los grandes agrupamientos, más allá de las personas inmediatamente responsables y del personal dirigente. Al estudiar un período histórico aparece la gran importancia de esta distinción." (Gramsci, 1997: 53).

Es clave, entonces, no confundir los grandes procesos sociales, que determinan cambios en las correlaciones de fuerzas sociales, con las peleas coyunturales, "mezquinas", ocasionales. Y para no hacerlo el elemento central es saber relacionar el campo de las relaciones de fuerzas políticas con el de las relaciones de fuerzas objetivas (Gramsci, 1997). Hasta aquí hemos desarrollado centralmente cómo la clase obrera se constituye en sujeto, y en el capítulo 1 hemos expuesto cómo va desarrollando las diversas formas o niveles de conciencia. Allí también planteábamos que tomamos como aporte metodológico al "Análisis de las situaciones. Relaciones de fuerzas" de Antonio Gramsci, para pensar cómo se desarrolla la sociedad, en tanto una totalidad en constante movimiento.

Consideramos que todo conflicto forma parte de un movimiento social y este es, a su vez, expresión de los elementos de una determinada estructura económica social que entra en acción, configurando alineamientos políticos sociales que la cortan transversalmente y producen diversos territorios sociales. Esos territorios en su totalidad presentan los programas, los objetivos del movimiento de cada capa social en ese determinado momento, en ese conflicto, y son, por eso, la herramienta fundamental para comprender y explicar científicamente un hecho social.

Así se puede observar, en el transcurso de la investigación, y a partir de la recolección, análisis y sistematización de los datos, cuál es la disposición de fuerzas objetiva, cuál la posición, la fuerza social, las estrategias y las posibilidades de triunfo de cada grupo en el marco de la pelea (Balvé, 2005). Por esto no hay forma de comprender las protestas y sus objetivos sin conocer también qué sucede a nivel de la estructura económica social concreta, en la disposición de fuerzas objetiva. 
Esa disposición de fuerzas va mucho más allá del ámbito de la producción. Ya veremos como muchos críticos del marxismo le achacan un supuesto reduccionismo de su mirada al proceso productivo. A su vez muchos investigadores que analizan aspectos de la historia de los trabajadores, limitan su mirada a los procesos productivos, estudiando lo que ellos denominan "el mundo del trabajo".

Entonces si bien es claro que la clase obrera se constituye a través de la lucha, la condición previa para su conformación como clase con conciencia en sí y para sí, es la propia conformación del grupo social proletario, que en esa instancia es solamente una "clase para el capital" (Marx, 1985). Como decíamos es el capital el que reúne por primera vez a esa masa y la conforma como un conjunto humano con circunstancias e intereses comunes. Pero estas circunstancias comunes no se limitan al proceso de trabajo.

Marx comprende y explica que la producción es un proceso integral que involucra no solamente la actividad propiamente productiva, sino también la distribución, la circulación o cambio y el consumo de mercancías y de fuerza de trabajo (Marx, 1997). A su vez cada uno de estos aspectos se vincula con el resto y no es posible comprender un aspecto del proceso recortado de la totalidad. Por eso las miradas que pretenden abordar los procesos de conformación de conciencia de clase observando solamente a la clase durante el proceso de trabajo, o tomando como unidad a la fábrica, cercenan su actividad. Ya veremos que estos análisis no suelen encontrar conciencia ni lucha: es de hecho lo esperable, ya que observan solamente el ámbito en que la dictadura del capital es más fuerte, donde la clase es, fundamentalmente, clase para el capitalista. El mismo tipo de limitación encuentran aquellos que limitan su abordaje a la observación del consumo de los obreros.

A nivel estructural ya expresamos en el capítulo 1 a que nos referimos cuando hablamos de "crisis". La crisis del sistema capitalista tiene diversas características y niveles: hay una crisis radical del sistema capitalista que para nosotros marca que ya desde la imposición del capital financiero el sistema transita su fase de descomposición social ${ }^{48}$, lo cual implica su crisis fundamental. A su vez vemos grandes crisis económicas que se refieren al conjunto del movimiento del mercado mundial. Por último las crisis orgánicas, cíclicas, económicas, de coyuntura, estructurales, que se refieren a la estructura económica de una formación social determinada.

\footnotetext{
${ }^{48}$ Cuando hablamos de un capitalismo en descomposición estamos refiriéndonos a que es un sistema que solamente puede mantenerse sobre la destrucción de fuerzas productivas, la descomposición de las relaciones sociales y la destrucción de la naturaleza.
} 
Destacamos que una de las manifestaciones más evidentes de la crisis capitalista es el aumento de la desocupación. Por ello debemos referirnos a un tema que atraviesa parte de las polémicas de las ciencias sociales en las últimas décadas (a veces explícitamente, la mayoría de las veces no expresada claramente): ¿cuál es la adscripción de clase de los denominados "desocupados"?. De acuerdo a una definición clásica, propia de los tiempos en que el capitalismo aseguraba el casi pleno empleo de la clase obrera, los hombres y mujeres que no trabajaban durante largos periodos de tiempo, y que por esa razón vivían de recursos no provenientes directamente de su trabajo cotidiano (asistencia pública, limosna, robos, estafas, etc.), eran considerados como una sub-clase a la que se llamó "lumpen proletariado".

Para nosotros los actuales "desocupados" se diferencian de la figura de "lumpen proletariado" en que son individuos desplazados de la actividad laboral por un sistema que los utiliza como uno de sus factores de explotación para poder reproducir su dominación en la actual coyuntura de un capitalismo en crisis. Los llamados "desocupados" son una fracción de la clase trabajadora, cuyos intereses de clase son antagónicos a los expresados por la subsistencia del régimen capitalista de producción.

Consideramos que gran parte de esta discusión fue definida por la práctica de lucha social, en la cual los desocupados mostraron su capacidad de organización, el desarrollo de organizaciones propias que defienden sus intereses como grupo económico (retomando la tradición sindical de la clase obrera argentina) y, en ciertos casos, articulando sus luchas con otros sectores, desarrollando algunos rasgos de defensa y organización de sus intereses como grupo social.

Esta postura se opone a una visión de la conflictividad social muy presente en los estudios académicos sobre estos movimientos que suelen ser conceptualizados como "nuevos sujetos" o "actores", que cumplen un "rol" nuevo en la sociedad. Ponemos especialmente en cuestión la figura del "excluido", como un supuesto sujeto que actúa desde una pretendida exterioridad con respecto a la sociedad capitalista.

Desde el socialismo científico los desocupados no serán vistos nunca como una nueva clase. De hecho desde los escritos teóricos clásicos de Marx y Engels ya estaba presente la tendencia del capitalismo a generar una masa cada vez mayor de población sobrante para las necesidades del capital. $Y$ en sus textos históricos también aparecen repetidamente estos "...trabajadores sin pan, cuyas fábricas fueron cerradas, cuyos patrones no podían darles ningún trabajo, estaban en la calle, mendigaban solos o en grupos, asediaban la calle en grupos y reclamaban ayuda de los transeúntes; pero no pedían rogando, como hacen en general los postulantes, sino amenazando con su número, con sus gestos y sus palabras."(Engels, 1974: 100). 
O en "La ideología alemana": “...los obreros eliminados por la gran industria se ven empujados por ésta a una situación de vida aún peor que la de los obreros de la gran industria misma" (Marx y Engels, 1985: 70). Población sobrante que claramente es vista como parte de la clase obrera y no como algo externo a la misma. Y que por ello menos aún puede entenderse como algo externo a la sociedad (situación a la que hace referencia la utilización del concepto de "excluido").

Son indudablemente parte de la clase obrera ya que necesitan vender su fuerza de trabajo para poder sobrevivir. El hecho de que el capital no necesite comprarle esa fuerza de trabaja no elimina su condición proletaria, sino que la hace aún más patente. La conformación de lo que se denomina un "ejército de reserva" lleva a la baja del precio de la fuerza de trabajo y a la posibilidad de sobreexplotar a los trabajadores ocupados. Es una herramienta clave para disciplinar a la clase obrera. Por ello no hay "fallas o desajustes" de un sistema, sino una lógica implacable del mismo, que lleva a una mayor centralización del capital y a peores condiciones de vida para la mayoría.

También el crecimiento del lumpen proletariado es expresión del proceso objetivo, y hace a la situación actual de la clase obrera. La tendencia del capitalismo actual de generar una masa cada vez mayor de población sobrante (superpoblación relativa para las necesidades de reproducción del capital) lleva a que aparezcan conjuntos humanos que se vean arrojados a situaciones como la de la desocupación estructural, el empleo inestable, el crecimiento exponencial del trabajo improductivo, la generación de puestos de trabajo que en verdad son encubridores de población sobrante (ya veremos como esto se expresa en el trabajo estatal). Una parte de esa superpoblación encuentra como único medio de asegurar su reproducción el recurrir a actividades formalmente ilegales, en un sistema social donde importantes ramas de la actividad económica se desarrollan por fuera de la legalidad (drogas, prostitución, etc.).

Comprender a la sociedad como una relación de fuerzas sociales, y a la estructura económica social como relación de fuerzas objetiva, es un enfoque contrario al de la estratificación social. Esta teoría, en lugar de comprender a la sociedad como una totalidad en movimiento, en conflicto y cambio, la piensa como dividida en átomos, en individuos, que no tienen intereses contrapuestos. Por ello el conflicto es episódico y la estratificación en "equilibrio" es lo permanente, lo "normal".

Esta diferenciación es clave para terminar de asimilar nuestro enfoque sobre las clases sociales. Los grupos sociales fundamentales son relaciones sociales puestas en acción y la modificación de la situación de algún conjunto humano (por ejemplo un proceso de proletarización de alguna fracción de la pequeña burguesía) es 
un complejo proceso de construcción y destrucción de relaciones sociales. Para la teoría de la estratificación social estaríamos ante un simple cambio (caída o ascenso) entre estratos jerárquicos previamente determinados. Allí las clases sociales serían el resultado del agrupamiento de individuos con determinadas características comunes (en general el ingreso), pero sin contradicciones entre ellas. Para ellos no hay explotados y explotadores. Hay simplemente ricos y pobres, pero sin que aparezca una relación que muestre que la posibilidad de la riqueza de unos pocos reside justamente en la pobreza de muchos ${ }^{49}$.

Para nosotros los grupos sociales fundamentales se basan en relaciones sociales contradictorias, agrupadas alrededor de la contradicción central del capitalismo: capital - trabajo. Por ello no podemos comprender al proletariado sin entender como polo de esa contradicción a la burguesía y sin observar los procesos de cambio que en todo momento se van produciendo.

Así el proletariado y semiproletariado estará conformado por aquellos que están expropiados de sus condiciones materiales de existencia y que necesitan vender su fuerza de trabajo (ya sea en forma total o una parte importante de ella) para conseguir sus medios de vida.

La pequeña burguesía (o pequeños patrones) se constituye con sujetos que son propietarios de sus condiciones materiales de existencia, que no venden su fuerza de trabajo. Este grupo se encuentra en una permanente situación de diferenciación en dos grupos.

Por un lado, más cercana al proletariado, la pequeña burguesía pobre, que atraviesa constantes dificultades para mantener su posición y cuya principal fuente de subsistencia es su pequeña propiedad que se presenta como "independiente". En general explotan a muy pocos o ningún trabajador y no logran realizar acumulación de capital. Se encuentra constituida por quienes son sólo propietarios de sus propios medios de vida y trabajo y es un grupo al que nos podemos aproximar mediante las categorías de pequeños comerciantes, pequeños propietarios de medios de transporte, trabajadores independientes de oficio, etc. Una parte de este grupo se encuentra inmerso en procesos de proletarización y/o pauperización.

Por el otro, más cercana a la gran burguesía, se encuentra la pequeña burguesía acomodada. Está constituida por quienes, además de ser propietarios de

\footnotetext{
49 Es clara la explicación de María Celia Duek y Graciela Inda: “...la imagen de una línea gradual ascendente o la imagen alternativa pero no contradictoria de una pirámide, autorizan a pensar en términos de clases "altas", "medias" y "bajas", o bien "superiores", "medias" e "inferiores". Entonces, en la literatura de la estratificación social, las clases terminan siendo, muchas veces, simples categorías estadísticas: series de personas que tienen en común ciertas características mensurables, cierta posición social. (...) En contraste con la figura de la escala continua, la representación marxista de la estructura de clases es la de un sistema constituido por lugares antagónicos y contradictorios." (2009: 38)
} 
sus condiciones materiales de existencia, son propietarios de los medios de vida y trabajo de otros, y por quienes cumplen funciones de mando propias del capital, aunque sea bajo la forma del salario. También ubicamos en este grupo a quienes cumplen funciones como intelectuales de la burguesía, aunque ya veremos que una parte de ellos están inmersos en procesos de proletarización y/o pauperización.

Por último se encuentra a la gran burguesía, que constituye la cúpula de la clase dominante: los grandes industriales, los magnates financieros, los terratenientes, los altos funcionarios, los rentistas. Incluimos aquí a los altos funcionarios ya que, más allá de que se presentan como asalariados, cumplen la función de comandar el proceso productivo, ya sea como gerentes de empresas, cargos políticos de jerarquía, etc.

A su vez al interior de estos grupos sociales fundamentales, y en base a los criterios de estudiar su posición y función en el proceso productivo entendido como totalidad, podemos encontrar diversas capas y fracciones.

Las capas hacen fundamentalmente al nivel de ingresos y a las condiciones de vida, pudiendo así dividir en forma horizontal a un mismo grupo social entre capas más acomodadas y capas más empobrecidas. Las fracciones se basan en el proceso de división social del trabajo, que genera distintas actividades económicas y divide a los grupos sociales según la tarea en la que se ocupan. Son divisiones de tipo vertical, y en principio podemos plantear tres grandes fracciones: la agrícola, la industrial y comercial y la no productiva.

La población agrícola se distingue de la industrial y comercial en que se encuentra más ligada las determinaciones de la naturaleza, ya que está vinculada a las actividades de agricultura, ganadería y pesca. Debe quedar claro que no es lo mismo que población rural, que se refiere a la población que reside en el campo o en pequeños pueblos que no son considerados urbanos. Si bien la tendencia del sistema es a transformar la agricultura y demás actividades en ramas de la industria ${ }^{50}$, estas aún mantienen condiciones específicas que la diferencian, especialmente el mayor grado de dispersión de la población que realiza estas tareas (con lo que ello implica de mayor dificultad para generar conflictos colectivos, menor tasa de sindicalización, etc).

La población industrial y comercial se divide en dos fracciones fundamentales: aquella ligada a la industria y otra ligada al comercio. Así una estará básicamente ocupada en la esfera de la producción y la otra en la esfera de la circulación. El nivel de importancia que tenga la producción o la circulación comparativamente, también

50 “... la indicada separación de la industria transformativa de la extractiva, la separación de la manufactura de la agricultura, transforma la propia agricultura en industria, es decir, en rama de la economía que produce mercancías." (Lenin, 1981b: 22). 
nos estará hablando del proceso de desarrollo del capitalismo y del momento histórico por el que transita en un determinado territorio social. El capital desarrolla sus diversas burguesías, las cuales generan las fracciones del proletariado a las que explota. La burguesía, a su vez, tiene una cúpula dirigente que es la financiera, que está constituida por aquellos que expresan la fusión de los capitales industriales, comerciales y bancarios.

El elemento que distingue a la población no productiva de las otras fracciones es que la población agrupada en esta fracción recibe un ingreso sin participar en la actividad productiva. Esto es desde el punto de vista estrictamente económico, ya que una parte de ella cumple distintas funciones que aseguran la reproducción de las condiciones sociales y organizativas de la producción material ${ }^{51}$.

Dentro de ella se pueden distinguir tres grandes grupos:

- los que perciben un ingreso por estar insertos en actividades dirigidas a garantizar las condiciones de producción y reproducción del sistema social: administración pública, las llamadas profesiones ideológicas, el gobierno, el personal de las iglesias, los militares, etc.

los que perciben un ingreso por prestar servicios personales (los llamados "empleados domésticos".

los que recien ingresos sin trabajar, ya sea bajo la forma de rentas (jubilados y rentistas) o como caridad (mendigos, pobres "oficiales"). (Pimsa, 2000)

Todos estos elementos son partes, y a la vez expresiones, de la estructura económica social, que debe estudiarse como una disposición de fuerzas que se encuentran en posiciones contrapuestas, pero no necesariamente en enfrentamiento. Es cuando se produce el choque entre esas fuerzas el momento en que se genera el enfrentamiento, y con él se constituyen las clases, se desarrollan organizaciones, etc.

Lo importante es saber encontrar en esa disposición de fuerzas las diversas contradicciones (que obviamente no se limitan a la de capital-trabajo o burguesíaproletariado) y poder identificar allí cuáles son las contradicciones principales y las subordinadas en cada momento histórico.

Para estudiar las estructuras económico sociales concretas tomamos como indicación metodológica a los trabajos de Lenin sobre la estructura económica de

\footnotetext{
51 "El trabajo puede ser necesario y no ser productivo. Por consiguiente, todas las condiciones generales, colectivas de la producción - mientras tanto no pueda ocurrir su creación por el capital en cuanto tal, bajo sus condiciones - se cubren con una parte del rédito nacional, del erario publico, y los obreros no se presentan como trabajadores productivos, aunque aumenten la fuerza productiva del capital (MARX, 1997a: 23)". (Donaire, 2009: 30).
} 
Rusia ${ }^{52}$, dónde hace hincapié en que no se debe observar sólo lo propio del capitalismo, sino también los elementos de modos de producción anteriores y los que puedan existir de un modo de producción alternativo. Desde esa concepción plantea la existencia de cinco formas de estructura económica social: la patriarcal, la pequeña producción mercantil, el capitalismo de economía privada, el capitalismo de estado y el socialismo ${ }^{53}$.

En una sociedad específica los diferentes tipos de estructura económica social se combinan entre ellos y generan distintas formas concretas. Partimos de considerar a la Argentina como un país dependiente ${ }^{54}$ de capitalismo desarrollado, con una serie de estructuras económicas complejas que muestran un desarrollo desigual y combinado $^{55}$ de su economía. En el mismo no se encuentra desarrollado en forma importante el tipo de estructura patriarcal (economía campesina de auto subsistencia) ni el socialismo.

La consideración de Argentina como país dependiente tiene una larga tradición en los estudios sobre sus características estructurales, ubicándola como parte del conjunto de países que tienen una independencia formal en lo político, pero que dependen en forma estructural de los países imperialistas, quienes han desarrollado un complejo armado financiero, económico y diplomático que envuelve a estos países y profundiza sistemáticamente sus niveles de dependencia y pérdida de soberanía.

Para el estudio de las transformaciones económico - sociales en nuestra región partiremos de este instrumental teórico metodológico y del fundamental estudio sobre las estructuras económico sociales concretas en Argentina realizado por Nicolás Iñigo Carrera, Jorge Podestá y María Celia Cotarelo (1999). En dicho trabajo observan que el país presenta cinco grandes estructuras económicas sociales:

1- Capitalismo de economía privada de gran industria y pequeña producción, integrada por Capital Federal, Córdoba, Santa Fe y provincia de Buenos

\footnotetext{
52 Entre otros "La catástrofe que nos amenaza y cómo combatirla", "El impuesto en especie (la significación de la nueva política económica y sus condiciones)" y especialmente "El desarrollo del capitalismo en Rusia" (Lenin, 1981a y Lenin, 1981b).

53 Ver Lenin (1981a) Tomo 3: 604-605.

54 Incorporamos aquí la noción de "relaciones de fuerzas internacionales" que plantea Gramsci en el ya citado "Análisis de situación. Relaciones de fuerzas". Este criterio es aplicado para Argentina en Iñigo Carrera y Podestá (1985) Análisis de una relación de fuerzas sociales objetiva: caracterización de los grupos sociales fundamentales en la Argentina actual; Cuadernos de Cicso - serie estudios № 46, Bs. As. 55 "El factor más importante del progreso humano es el dominio del hombre sobre las fuerzas de producción. Todo avance histórico se produce por un crecimiento más rápido o más lento de las fuerzas productivas en este o aquel segmento de la sociedad, debido a las diferencias en las condiciones naturales y en las conexiones históricas. Estas disparidades dan un carácter de expansión o compresión a toda una época histórica e imparte distintas proporciones de crecimiento a los diferentes pueblos, a las diferentes ramas de la economía, a las diferentes clases, instituciones sociales y campos de cultura. Esta es la esencia de la ley del desarrollo desigual. Estas variaciones entre los múltiples factores de la historia dan la base para el surgimiento de un fenómeno excepcional, en el cual las características de una etapa más baja del desarrollo social se mezclan con las de otra superior." (Novack, 1974: 8 y 9).
} 
Aires. Lo característico es la gran industria con importante desarrollo de la división social del trabajo y de las fuerzas productivas.

2- $\quad$ Capitalismo de economía privada con peso del campo, que integra a Mendoza, Tucumán, Jujuy, Salta, Río Negro y San Juan. Tiene pocas ramas industriales, con un importante peso del proletariado y de la población agrícola.

3- $\quad$ Capitalismo de estado en enclaves, integrado por Santa Cruz, Tierra del Fuego, Chubut y Neuquén. Se caracteriza por una actividad productiva limitada a pocas ramas, lo que le da la característica de enclave. Las relaciones capitalistas están muy extendidas y el Estado personifica al elemento capitalista.

4- Pequeña producción mercantil, principalmente en el campo, integrada por Misiones, Formosa, Corrientes, Chaco, Santiago del Estero y La Pampa. Tiene un grado bajo de división del trabajo social y de las fuerzas productivas y un importante peso de la superpoblación relativa.

5- Pequeña producción mercantil, con superpoblación relativa, integrada por Entre Ríos, San Luís, La Rioja y Catamarca. Es fundamentalmente reservorio de fuerza de trabajo de las otras estructuras, con peso de la población no productiva y del proletariado.

Estas estructuras además pueden ser divididas en dos grandes territorios. Uno en el cual predomina la población productiva y donde hay un fuerte peso de las relaciones capitalistas. Aquí se inscribirían las tres primeras estructuras. El otro territorio esta integrada por las estructuras 4 y 5 , con predominio de la superpoblación relativa y relaciones capitalistas con menor desarrollo en extensión y profundidad.

Como dicen los autores: "Esto no significa que haya dos Argentinas o que una sea capitalista y otra no. Justamente al contrario ambos territorios forman una unidad inescindible" (Iñigo Carrera, Cotarelo, Podestá, 1999: 59). Uno de los objetivos de nuestro trabajo es observar e intentar conceptualizar las transformaciones que se produjeron en nuestra región desde esta caracterización de la economía argentina.

Un ejercicio que nos permitirá observar con mayor profundidad el proceso de cambios en la estructura económica social es la evaluación del cambio que se produce en la distribución de la población según la división social del trabajo. La división social del trabajo es un indicador del grado de desarrollo de las fuerzas productivas y del sentido que va tomando ese desarrollo. La metodología parte del trabajo de Vladimir Lenin, "El desarrollo del capitalismo en Rusia"56.

\footnotetext{
56 Lenin, Vladimir (1981b): "Ese aumento progresivo de la división social del trabajo es el elemento fundamental en el proceso de creación del mercado interior para el capitalismo (...) es la base para todo el proceso de desarrollo de la economía mercantil y del capitalismo." (Pág. 22-23)
} 
Para conocer la disposición de fuerzas de una sociedad y las contradicciones que se desarrollan en la producción de la vida material, debemos observar el grado de desarrollo de las fuerzas productivas materiales y los grupos sociales que sobre ellas se conforman. Ya hablamos acerca de los grupos sociales y como los clasificamos. En el caso del desarrollo de las fuerzas productivas el indicador que tomaremos es la división social del trabajo.

Tomamos en este sentido las indicaciones específicas de Iñigo Carrera y Podestá (1985) y las generales desarrolladas por Marx en sus principales obras. Él destaca que la división del trabajo indica hasta donde se han desarrollado las fuerzas productivas, ya que toda nueva fuerza productiva (que no sea un simple aumento cuantitativo de alguna ya existente) implica un aumento de la división del trabajo.

Esa división genera en primer lugar la división del trabajo industrial y comercial del agrícola, lo que se expresa en términos de la clásica contradicción entre campo y ciudad. A medida que el capitalismo se desarrolla y crecen las fuerzas productivas se avanza en la separación del trabajo comercial del industrial y en la especialización de cada rama productiva al interior de estos grandes conjuntos de actividades.

En este apartado buscamos exponer en líneas generales nuestro enfoque teórico-metodológico, el cual será complementado con distintos aportes al discutir otras importantes miradas sobre la sociedad y al aplicarlo en nuestra investigación concreta.

\section{1.a. Fuentes utilizadas y construidas}

Como fuentes para la construcción de nuestro trabajo hemos desarrollado un importante archivo documental que compendia las distintas noticias publicadas en los diarios de nuestra región sobre protestas, conflictos sociales y cambios económicos y políticos entre 1990 y 2005 . Este archivo en formato papel se encuentra a disposición, y ya ha sido utilizado por distintos investigadores interesados en abordar aspectos específicos del período.

Este archivo documental se compone de nueve biblioratos, con un total aproximado de 3393 fojas, dividido de la siguiente manera:

Bibliorato con 315 fojas de Enero 1990 a Junio 1991.

- $\quad$ Bibliorato con 369 fojas de Julio 1991 a Junio 1993.

- $\quad$ Bibliorato con 350 fojas de Julio 1993 a Septiembre 1995.

- $\quad$ Bibliorato con 395 fojas de Octubre 1995 a Agosto 1997.

- $\quad$ Bibliorato con 327 fojas de Septiembre 1997 a Junio 1999.

- $\quad$ Bibliorato con 415 fojas de Julio 1999 a Junio 2001.

- $\quad$ Bibliorato con 422 fojas de Julio 2001 a Mayo 2002. 
- $\quad$ Bibliorato con 404 fojas de Junio 2002 a Mayo 2004.

- $\quad$ Bibliorato con 396 fojas de Junio 2004 a Diciembre 2005.

Los diarios relevados fueron el Diario Jornada, el Diario El Chubut y el Diario de Madryn, abarcando los dos primeros, los dieciséis años en estudio, mientras el último solamente fue publicado en el último tramo del período que abordamos. La columna vertebral de la recopilación fue la sistematización de las noticias del Diario Jornada, ya que por la amabilidad de varios empleados del mismo y de su Director de Redacción hemos podido acceder en forma sistemática a su archivo, el más ordenado de la región hasta el día de la fecha.

En cambio fue mucho más complejo acercarnos al otro Diario que fue publicado durante todos estos años, El Chubut. En este caso se privilegió buscar fechas precisas en las cuales tuviéramos noticias de conflictos que no aparecían en el relato que construimos a partir del Diario Jornada, o para construir una información más compleja que involucrara el enfoque de ambos diarios en determinados conflictos que consideramos se constituyen como hitos en el proceso histórico de la región.

También para algunos conflictos particulares se ha registrado su publicación en diarios nacionales, relevando el diario Clarín, La Nación y Página/12 en fechas específicas. Otra fuente que aportó elementos valiosos fue la publicación de algunos conflictos en periódicos de organizaciones de izquierda. Especialmente por luchas salariales se han registrado publicaciones del Partido Comunista, el Movimiento Al Socialismo y el Partido Obrero.

Otra fuente consultada fueron los archivos laborales de los conflictos que se encuentran en la Subsecretaria de Trabajo de la Provincia del Chubut (recientemente transformada en Secretaría). Los expedientes de esta Subsecretaría podrían aportar datos de gran importancia para investigaciones de este tipo. Especialmente las diversas denuncias sobre condiciones de trabajo, higiene y seguridad nos podrían dar elementos para abordar una dimensión de la conflictividad laboral y del ámbito productivo que se nos hace muy complejo estudiar por la dificultad de acceder a fuentes de las empresas o a una observación directa de los procesos productivos.

Sin embargo la realidad es que este archivo es muy escaso y absolutamente desordenado y, por lo tanto, de casi imposible utilización para los investigadores. Hemos podido acceder a expedientes específicos de conflictos laborales en las metalúrgicas ALUAR y Quinto Cipoletta y en las textiles Modecraft y Supersil, gracias a la amabilidad de algunos empleados, pero no conseguimos poder desarrollar un relevamiento sistemático de la información que seguramente descansa en muchos de esos expedientes. 
En este sentido recuperamos varias reflexiones que realiza Julia Soul (2010 y 2009) acerca de la dificultad para desarrollar la agenda de investigación que propone John Womack (2007) con los recursos que los investigadores contamos en Argentina. Sabemos que este será quizás uno de los puntos en los cuáles no pudimos profundizar nuestro conocimiento, aunque buscamos subsanar estos problemas mediante la construcción de otras fuentes, como las orales, las escasas fuentes empresarias, los archivos personales de algunos militantes, etc.

A partir de estas fuentes hemos construido un registro sistematizado de 1669 hechos de rebelión. El hecho de rebelión es nuestra unidad de registro, definido como "todo hecho colectivo de protesta o de lucha, llevado a cabo por personificaciones de categorías económicas, sociales o políticas, dirigido contra alguna expresión del estado de cosas existente" (Cotarelo, 2009).

Otra fuente central para el desarrollo de nuestra investigación fue la sistematización y análisis de datos estadísticos, en su gran mayoría procedentes de la Dirección de Estadísticas y Censos de la Provincia del Chubut y del Instituto Nacional de Estadísticas y Censos (INDEC) a nivel nacional. En forma particular se ha elaborado una sistematización de los distintos censos que se han realizado en la región, desde 1895 hasta el presente.

El registro de datos censales se realizó específicamente sobre la provincia del Chubut en general y sobre la región Noreste (actuales departamentos de Rawson y Biedma) en particular. Se enumeran los censos relevados:

- Censos Nacionales: 1895 - 1914 - 1947 - 1960 - 1970 -1980 -1991 - 2001

- Censos Económicos: 1963 - 1994 - 2004/2005

- Censos Agropecuarios: 1937 - 1988 - $2002^{57}$

- EPH sobre conglomerado urbano Rawson-Trelew: se realizó en 1994 (en forma experimental) y desde Octubre de 2002 en adelante ya se integra al registro habitual de la EPH.

Hemos podido recuperar también datos estadísticos de los análisis de varios gremios (especialmente AOT, Setia, UOM y Stia) en lo que hace a puestos de trabajo y situación productiva de las empresas de sus sectores. Esta información en algunos casos fue relevada directamente desde su publicación en la prensa, y en otros casos hemos accedido a archivos parciales y no sistematizados de estos y otros sindicatos, o a los archivos personales de militantes sindicales.

Por último otros datos claves en términos estadísticos se han podido relevar desde archivos parciales de la Municipalidad de Trelew, en general de difícil acceso y

\footnotetext{
57 No hemos encontrado datos del Censo Industrial de 1935, el cual intentaremos registrar para la continuidad de nuestro proceso de investigación.
} 
poco orden en su sistematización. Muchos elementos fueron recuperados de relevamientos estadísticos realizados por otros investigadores en trabajos previos, como los de Gatica (2007, 2000 y otros), Ibarra y Hernández (2005), Ibarra (1997), Beinstein (1993), Irusta y Rodríguez (1993) y Laveglia (2004), entre otros.

También fueron importantes los aportes de trabajos realizados en clave técnica, por parte de los equipos científicos de planificación que fueron propulsores de algunos de los proyectos de polos de desarrollo o de organismos que analizaban los resultados de esos proyectos. Así hemos retomado los tres tomos en los cuáles Oscar Altimir (1970) analiza la economía del Chubut y propone líneas de desarrollo y proyectos específicos, en su obra "Análisis de la economía del Chubut y de sus perspectivas de desarrollo". Los documentos de la Unión Industrial Patagónica ("Algunos aspectos de los cambios demográficos en la Argentina; algunos comentarios sobre la política arancelaria y la situación industrial: el caso de los Textiles"), el análisis de Fernández Miranda (1975) sobre la "Situación industria textil en la provincia del Chubut", y el de Martha Pelosi y otros (1977) "El Parque Industrial de Trelew. Su importancia socioeconómica", parten de similar perspectiva.

Hemos accedido a expedientes judiciales, que especialmente nos aportaron datos y elementos de análisis acerca de los casos de cortes de ruta en Trelew y Puerto Madryn.

Ha sido central para el desarrollo de nuestra investigación el trabajar en la producción de fuentes que se encuentran en un cruce y debate permanente entre distintas perspectivas, como las de la historia oral, la historia desde abajo, la historia del pasado reciente y el análisis de las distintas memorias que se producen históricamente.

La necesidad de construir la historia de la rebelión social en la región durante el período que investigamos, nos obligó a partir casi desde cero, en una difícil tarea que por momentos llego a ser molecular. Las fuentes escritas, más controladas por los sectores ligados al poder económico y político, ocultaban aspectos centrales de esos conflictos y solamente hemos podido acceder a algunos de ellos a través de una historia a contrapelo, que permitiera hacer visible los elementos ocultados por las perspectivas tradicionales.

Por las características de lo que buscamos estudiar hubiera sido inconducente trabajar solamente con las fuentes históricas tradicionales. Nos hubiera llevado a lograr visibilizar únicamente una parte del proceso histórico. Las fuentes escritas y oficiales nos dicen muy poco sobre muchas formas de resistencia, necesariamente subterráneas y ocultas. $Y$ no nos hablan tampoco de los procesos de desarrollo de organizaciones, de los procesos de conformación de militantes obreros, de sus 
transformaciones, de sus debates. Es en base a estas otras fuentes desde las que se consiguió profundizar el conocimiento sobre las transformaciones económicas y los conflictos sociales que se produjeron en nuestra región en los últimos años.

En este camino ha sido central para nosotros el aporte que nos ha brindado la historia oral. Sabemos que más allá de lo que nos diga sobre los acontecimientos, la historia oral nos aporta, fundamentalmente, sobre el significado que tuvieron esos hechos para los sujetos concretos que los desarrollaron y padecieron; nos dice del impacto, la magnitud y el costo real que los hombres de carne y hueso pagaron por sus vivencias.

Aún las declaraciones formalmente equivocadas o contradictorias tienen un aspecto verídico, y puede que indagando el porqué de esa "equivocación" surjan elementos que sean mucho más importantes que los datos factuales. Se ha hecho común, entre críticos de la historia oral, el plantear las dificultades que existen para tratar las fuentes orales y poder determinar la validez de lo que nos aportan los sujetos que nos cuentan su historia. Los distintos estudios sobre las memorias y sobre lo clave que es comprender no sólo lo que se dice, sino cómo se lo dice y, sobre todo, lo que se calla, ha permitido avanzar en un tratamiento cada vez más rico de estas fuentes, claves para construir una historia que logre dar explicaciones holísticas.

En todo caso, y sin profundizar el tema, es obvio que estas críticas a la historia oral encubren una visión ingenua de las fuentes escritas, las cuales suelen ser valoradas como con un contenido de validez superior a las orales, sin que haya elementos para comprobar esa mirada del sentido común. Nos parece destacable en términos generales la formulación de Gayatri Spivak: "El trabajo de archivo, historiográfico, crítico-disciplinario e inevitablemente, intervencionista, involucrado aquí es ciertamente una tarea de "medir silencios" (2003: 326). Silencios que no solamente aparecen en las fuentes orales sino también en las escritas. El desafío que nos propone Spivak es a mantenernos siempre atentos y alertas para descubrir y valorar esos silencios, que nos dicen tanto como lo escrito y lo dicho, aunque sea mucho más complejo de procesar.

Buscamos continuar las líneas de debate planteadas por Alessandro Portelli (1989, 1987) y Luisa Passerini (1984), quién ha propuesto un camino muy interesante con su estudio sobre memoria de la clase obrera, "Turín obrero y fascismo". En esta línea también nos nutrimos con aportes clásicos de la historia social inglesa de Samuel (1984), Thompson (1978) y Rudé (1981).

En nuestras entrevistas retomamos aspectos de la propuesta metodológica de Daniel Bertaux (1989, "Los relatos de vida en el análisis social'), quién plantea la intención de reconstruir la historia de vida del entrevistado, como forma de conseguir 
reconstruir el proceso histórico integral que constituyó a ese sujeto. Se hace así objeto de estudio también a la memoria.

En este sentido repetimos que los silencios hablan, y muchas veces lo hacen de forma más ensordecedora que las palabras. La pregunta del clásico trabajo de Gayatri Chakravorty Spivak (2003) sobre la capacidad del subalterno/a para hablar, nos abre todo un abanico de necesidades de indagación, incluidos aspectos de la psicología de los entrevistados que, por nuestra formación profesional, muchas veces no hemos conseguido abordar en la medida en que quizás era necesario.

En dicho trabajo nos alerta tanto sobre la supuesta incapacidad para hablar de los subalternos (que en verdad casi siempre es incapacidad del investigador para escuchar) como de los supuestos que pretenden encontrar en las voces de los dominados todas las respuestas. Criticando a Foucault y Deleuze impugna la idea de que "...los sujetos oprimidos hablan, actúan y conocen por sí mismos", ya que esto "conduce hacia una política utópica y esencialista" (Spivak, 2003: 310).

Sabemos que el entrevistado ha seguido viviendo su propia historia, y por ello es factible que cambie la evaluación de lo sucedido, que lo interprete de diversas maneras, desarrollando un cambiante y continuo balance sobre su accionar en el pasado, de cara al presente en el que desarrolla su vida.

Es obvio que se debe partir de que la historia oral es subjetiva, ya que la memoria no registra una sucesión lineal de hechos y acontecimientos, sino que la memoria re-construye el pasado, y lo resignifica. Buscamos conjugar la no uniformidad de la experiencia humana con la exigencia de generalidad y explicación de la ciencia social. A su vez el entrevistado construye y reconstruye su relato en interacción constante con el entrevistador. Nuestra lectura sobre lo que nos dice y sobre lo que nos calla, no puede dejar de poner en el centro del análisis a nuestro papel en ese proceso de compleja interrelación que plantea la situación de entrevista, más aún cuando ésta toma la forma de una historia de vida.

Específicamente para la región el trabajo de recopilación y construcción de fuentes orales, partió de retomar aportes de las investigaciones de Pablo Pozzi (2008, 1998), de Pozzi y Alejandro Schneider (1994) y de Mónica Gatica (2007, 2000), entre otros. Desde estos trabajos, muchos de ellos realizados ante la oposición de un importante sector del mundo académico, se fue incorporando a la historia la memoria de mujeres y hombres, que vinieron a problematizar la historia tradicional, basada únicamente en los documentos escritos.

Hemos realizado diversas entrevistas a trabajadores, que creemos nos presentan un mapa bastante completo de las fracciones y capas claves de la clase obrera en la región noreste de la provincia del Chubut. En general casi todos tuvieron 
algún nivel de participación en los procesos de protestas y algunos de ellos integraron estructuras sindicales orgánicas. Consideramos que estas entrevistas nos presentan elementos que permiten sintetizar los diversos aportes que la historia oral nos suma a los ejes que pretendemos debatir.

El énfasis que se observa en las entrevistas de sujetos que fueron promotores de espacios de oposición sindical, de militancia en grupos de izquierda o de trabajadores y trabajadoras que han quedado desocupados, tiende a buscar construir la historia de actores que son los que centralmente fueron ocultados por la historia dominante y las fuentes tradicionales.

Esto no quiere decir que no prestamos atención a la importancia clave del papel de la dirigencia sindical no combativa, más cercana a una estrategia negociadora y de buena relación con los gobiernos y la patronal, o que no observemos que no hay posibilidad de comprender los cambios económicos y sociales sin atender también a la acción de los funcionarios de gobierno, los dirigentes de los partidos políticos tradicionales y los grandes empresarios. La cuestión es que el papel de esos sujetos sí suele aparecer en las fuentes tradicionales y lo hace, para nosotros, hasta en forma sobre representada, abonando a la perspectiva de la historiografía que sostiene que los cambios los generan los "grandes hombres" o los reemplazos y la rotación entre el personal gobernante o entre los empresarios que toman la dirección de los procesos productivos.

Por ello el proceso de construcción de fuentes orales lo centramos en buscar construir la información que nos falta, y en balancear los aportes que al proceso de transformaciones realizan los distintos sujetos que participan en el movimiento de la sociedad. Así hemos realizado extensas entrevistas a Juan A. ${ }^{58}$ y Miguel Z. ${ }^{59}$ sobre su experiencia en la fábrica textil Modecraft ${ }^{60}$, su historia de vida y su militancia sindical y política. Juan era militante del PJ, había ingresado a la planta poco tiempo antes de 1990 y luego fue uno de los organizadores de los movimientos de desocupados en la región, siendo hoy el máximo dirigente de la Coordinadora de Trabajadores Desocupados “Aníbal Verón”. Miguel era delegado de la planta, uno de los principales referentes de la oposición en la AOT (agrupados en la lista "Celeste y Blanca") y militante del Partido Intransigente (PI).

\footnotetext{
58 Juan A. entrevista realizada en el Comedor Universitario de Trelew, el día 9 de Junio de 2007.

${ }^{59}$ Miguel Z. entrevista realizada en el café Touring Club de Trelew, el día 15 de Junio de 2007.

${ }_{60}$ Modecraft es una empresa que produce medias de algodón y lycra, especialmente para mujeres, que tenía una planta en Trelew hasta mediados de los noventa. Hoy mantiene una fábrica en Buenos Aires, desde la cual realiza medias para varias de las principales marcas del país, pero ha vendido gran parte de su capital accionario. Era una de las fábricas más antiguas de la región, ya que se había instalado a fines de la década del sesenta, antes de la creación del parque industrial de Trelew.
} 
Entre los trabajadores metalúrgicos realizamos entrevistas a Héctor $\mathrm{G}^{61}$, Gerardo C. ${ }^{62}$, Fernando D. ${ }^{63}$ y Ricardo $B .^{64}$. Los cuatro fueron durante años trabajadores de ALUAR.

Héctor y Gerardo fueron integrantes de la lista opositora al oficialismo en la UOM, la "Rafael Uribe". Héctor fue "traído"65 por ALUAR a Puerto Madryn desde su apertura, era trabajador rural, no tenía ninguna experiencia política y no tuvo participación política más allá de la actividad sindical.

Gerardo viaja a Madryn en 1977, tenía un interesante conocimiento de la dinámica política y de la actividad sindical ya que había sido durante nueve años delegado sindical en una pequeña metalúrgica de Lanús y era simpatizante del PC. Fernando es trabajador de ALUAR y, si bien tiene interés en las cuestiones políticas, nunca tuvo una participación orgánica en un grupo político o en el sindicato. Es un cuadro técnico, llega a mediados de los ochenta desde La Plata y no trae experiencia de militancia previa. Ricardo trabaja desde hace más de quince años en ALUAR y no ha tenido militancia activa ni en el sindicato ni en ningún partido político.

Jaime $A{ }^{66}$ es un ex trabajador de YPF en Comodoro Rivadavia y actualmente es trabajador no docente en la Universidad Nacional de la Patagonia de la sede Trelew. En ambos trabajos fue dirigente sindical, en el caso de YPF en la oposición al gremio y hoy siendo parte de la conducción oficial. Además fue un importante referente de izquierda, en especial durante el auge del MAS (Movimiento al Socialismo).

De la actividad petrolera también hemos realizado entrevistas a Jorge $P{ }^{67}$, (dirigente sindical de la oposición a la conducción gremial de petroleros, al igual que Jaime fue durante años militante del MAS y actualmente ha logrado reinsertarse en la actividad petrolera), y a Daniel $\mathrm{R}^{68}$, quién fuera durante años un joven dirigente de los grupos de desocupados de Comodoro Rivadavia, militante de distintos grupos de

\footnotetext{
${ }^{61}$ Héctor G., entrevista realizada en la casa de Héctor en Puerto Madryn el día 9 de Mayo de 2008.

62 Gerardo C., entrevista realizada en la Universidad Nacional de la Patagonia, sede Puerto Madryn, el día 2 de Mayo de 2008.

63 Fernando D., entrevista realizada en la casa de Fernando en Puerto Madryn, el día 2 de Mayo de 2008.

Este nombre es de fantasía por tratarse de un obrero que trabaja actualmente en la planta de ALUAR.

${ }^{64}$ Ricardo B., entrevista realizada en cercanías de la planta de ALUAR, durante un piquete de huelga, el 14 de junio de 2007. También es nombre de fantasía porque el entrevistado es empleado de ALUAR.

${ }^{65}$ ALUAR seleccionó a la mayoría de su personal inicial entre trabajadores rurales.

66 Jaime A. entrevista realizada el día 7 de noviembre de 2006 por Susana López, Mónica Gatica y Gonzalo Pérez Álvarez, en la casa de uno de los entrevistadores. Esta entrevista fue trabajada en López, Susana; Gatica, Mónica y Pérez Álvarez, Gonzalo (2008) "Son errores que tuvimos que pasar para después en un futuro no volverlos a hacer" La experiencia de Jaime, un ex trabajador de YPF, en Pasquali, Laura (comp) Historia Social e Historia Oral. Experiencias en la Historia Reciente de Argentina y América Latina, Edic. Homo Sapiens, Rosario.

67 Jorge P., entrevista realizada el 20 de julio de 2008 en la casa del entrevistado.

${ }^{68}$ Daniel R., entrevista realizada el 21 de julio de 2008 en la casa del entrevistado.
} 
extracción trotskista y que desde el 2007 ha conseguido un trabajo estable como trabajador petrolero.

Alfonso I. $^{69}$ es un ex obrero de la pesca, filetero en distintas plantas de la Patagonia, es de origen chileno y en los últimos años de los noventa fue uno de los principales dirigentes de los grupos piqueteros en el noreste del Chubut. Nunca fue parte de un sindicato ni militante orgánico de algún partido.

También en la actividad pesquera fue entrevistado Antonio $\mathrm{C}^{70}$, quién especialmente se desempeñó como mecánico naval y fue durante varios años dirigente sindical del SAON ${ }^{71}$. Tuvo una activa participación en diversos procesos de agrupamiento sindical combativo, entre otros en el surgimiento del primer espacio de lo que luego fuera la CTA en Chubut.

René $\mathrm{P}^{72}$ fue trabajador textil durante muchos años, también de origen chileno. Luego de ser echado de las fábricas ingresó a trabajar como portero de escuela, donde hoy se desempeña. Integró el Partido Comunista y hoy es parte del Ateneo Elvio Ángel $\mathrm{Bel}^{73}$. Fue integrante de la oposición a la AOT y luego, ya como portero de escuela, integró la conducción de $\mathrm{ATE}^{74}$ aunque sin ocupar cargos exclusivos.

Hugo $0 .^{75}$ fue durante años trabajador textil en distintas fábricas del parque industrial. Quedó desocupado hacia fines de los noventa, participó luego en cortes de ruta y hasta organizó un grupo de desocupados en su barrio. Hoy plantea que se ha retirado de toda actividad social y es vendedor de lotería en la calle.

Celina $P{ }^{76}$ fue militante política y sindical durante años en el MAS, se desempeño varios años como docente y tuvo participación en diversos acontecimientos políticos en la región. Hoy también participa en la CTD "Aníbal Verón", organización en la cual se integró tras quedar desocupada a principios del 2002.

Otro entrevistado fue Oscar $\mathrm{J}^{77}$, quien fuera integrante del Partido Obrero a fines de los ochenta y principios de los noventa, cuando ese partido se organizó incipientemente en la región. Fue trabajador de la construcción y luego, al quedar desocupado durante años, se integró como cuadro con responsabilidades de dirección

\footnotetext{
${ }^{69}$ Alfonso I., entrevista realizada el 22 de abril del 2009 en el local del MIJD de Trelew.

${ }_{71}^{70}$ Antonio C., entrevista realizada el 30 de agosto de 2009 en la casa del entrevistado.

${ }^{71}$ Sindicato Argentino de Obreros Navales.

72 René P., entrevista realizada el 4 de Julio de 2009 en el ateneo Elvio Ángel Bel.

73 Lleva el nombre de quién fuera secretario general del PC en Trelew y apoderado de Mario Roberto Santucho cuando estuvo preso en el penal de Rawson. Fue secuestrado por la dictadura en noviembre de 1976 en Trelew y desde allí esta desaparecido.

${ }_{75}^{74}$ Asociación de Trabajadores del Estado.

${ }^{75}$ Hugo O., entrevista realizada el 15 de diciembre de 2009 en la casa del entrevistador.

${ }^{76}$ Celina P., entrevista realizada el 5 de Agosto de 2009 en la casa de la entrevistada.

77 Oscar J., entrevista realizada el 15 de septiembre de 2009 en el Comedor Universitario.
} 
en el MIJD. Hoy consiguió volver a trabajar en la construcción y participa de la oposición a la conducción gremial.

También desarrollamos entrevistas a trabajadores de Tierra del Fuego, en la búsqueda de poder comparar elementos de su historia con el proceso específico que nosotros abordamos aquí. Así fueron entrevistadas Feduca y Norma ${ }^{78}$, quienes fueron trabajadoras metalúrgicas durante el conflicto de 1994 en esa provincia. Hoy aún se encuentran trabajando en plantas de electrodomésticos. Alberto $C^{79}$ fue dirigente sindical en la misma fábrica en que trabajaban Norma y Feduca, enrolado en la oposición a la conducción de la UOM. Es militante del PCR (Partido Comunista Revolucionario) y hoy es parte de la conducción del Sutef (Sindicato Único de Trabajadores de la Educación de Tierra del Fuego). Entrevistamos allí a otros docentes que integraban el Sutef $^{80}$ y a los por entonces dirigentes de ATE, Nieto y Portel $^{81}$.

Pretendemos observar como se configuran distintas memorias sobre el proceso, memorias que se desarrollan especialmente a partir de la actividad política y sindical, del trabajo que realizan, de la lucha por mantener sus condiciones de vida y sus puestos de trabajo y en los momentos de desocupación que muchos de ellos han sufrido.

Especialmente intentamos profundizar nuestro conocimiento del período a partir de acercarnos a entender cómo se constituyen distintas memorias sobre los conflictos que se desarrollan, retomando elementos de trabajos de Josefina Cuesta Bustillo (2007: “La odisea de la memoria"; 1998: "Memoria e historia") que hemos trabajado en algunos artículos de nuestra autoría ${ }^{82}$.

Las fuentes construidas a partir de las entrevistas son analizadas y comparadas con la manera en que presenta el proceso general y los conflictos particulares desde los diarios de la zona, los expedientes laborales y otras fuentes escritas, observando diferencias, convergencias, contradicciones y disputas.

La historia oficial tiende a invisibilizar los conflictos, a presentar una historia supuestamente aséptica y sin enfrentamientos, en el camino de buscar construir una memoria que legitime un orden social injusto. Contra eso es una tarea central la de rescatar otras memorias, que nos permitan construir un conocimiento más completo

\footnotetext{
${ }^{78}$ Feduca y Norma, entrevistas realizadas el 12 de diciembre de 2006 en la casa de Feduca, en la ciudad de Ushuaia.

${ }^{79}$ Alberto C., entrevista realizada el 14 de diciembre del 2006 en el local del Sutef de Ushuaia.

${ }^{80}$ En una entrevista colectiva y sin la profundización del resto, también el 14 de diciembre de 2006 , en el local del Sutef.

${ }_{81}^{81}$ Nieto y Portel, entrevista realizada el 13 de diciembre en el local de ATE de la ciudad de Ushuaia.

82 Por ejemplo en Pérez Álvarez, Gonzalo (2009c) "Lucha y memoria obrera en el noreste del Chubut. Una aproximación desde la fábrica Modecraft 1990-1991" en Historia Antropología y Fuentes Orales, № 41, Barcelona, España. ISSN 1136-1700. pp. 25 a 48.
} 
sobre lo realmente ocurrido y nos den la posibilidad de discutir ese discurso legitimador al que hacíamos referencia.

Así, a través del trabajo de recuperar la memoria obrera, consideramos que logramos llegar a una comprensión más completa de los conflictos que pretendemos estudiar. Pudimos enmarcar el proceso general y los conflictos claves en un proceso social que muestra las principales características de la clase obrera de la región, de su experiencia y sus luchas.

Se destaca como primera gran diferencia la contraposición entre una memoria desde el poder y una memoria de los trabajadores. Desde la mirada de la dominación los conflictos casi siempre se presentan como desarrollados y motivados por cuestiones particulares y de coyuntura, que no tienen relación con el marco más amplio de cambio y conflicto social que se vive en toda la estructura económica social. Cada conflicto, además, termina en sí mismo, sin mostrarse la articulación con el resto: las relaciones, los debates, los aprendizajes; en definitiva, la posible acumulación de experiencias que contribuyen a la conformación de una fuerza social.

Es muy difícil que en las fuentes tradicionales aparezca la posibilidad de que los trabajadores logren articular algún programa de acción alternativo. Para nosotros se construye desde esos ámbitos una memoria de los sectores dominantes de nuestra región, que intenta mostrar el proceso de transformación de la estructura económica y social como algo que tuvo relación solamente con las decisiones a nivel nacional y en cuyo proceso los sujetos locales no tuvieron ninguna participación.

Según esta memoria los cambios económicos determinados por el gobierno nacional plantearon nuevas reglas de juego ante las cuales los empresarios y los trabajadores fueron igualmente víctimas del proceso, sin poder articular en ningún caso resistencias o caminos alternativos. Esta construcción de la memoria se articula con el comportamiento de la mayoría de las dirigencias sindicales, que planteaban la unidad de los intereses de empresarios y obreros.

Esa memoria que se construye desde el poder influye fuertemente en la gran mayoría de los trabajadores y construye permanentemente nuevos significados. Esa memoria del poder, que oculta la lucha de clases y los distintos intereses de patrones y obreros, refuerza la dominación de los primeros y evita que los trabajadores puedan articular un programa alternativo.

En cambio la memoria obrera nos muestra claramente la oposición de intereses entre los patrones y los obreros. Es así que para nuestros entrevistados siempre está presente esa contraposición de intereses, está presente algo que la memoria del poder intenta invisibilizar: el conflicto. 
En las memorias de los obreros el conflicto está siempre allí, y es un conflicto permanente que se produce día a día y a distintos niveles. En la memoria del poder el conflicto intenta ser ocultado, y cuando no se puede se lo presenta como algo coyuntural, episódico, culpa de las actitudes particulares de alguno de los sujetos. Se busca ocultar que el surgimiento del conflicto parte de la misma estructura económica social, y que por ello su explicación va mucho más allá de la mera situación coyuntural.

Pero también hay diferencias importantes entre las memorias de los obreros entrevistados, diferencias que hacen a sus distintas experiencias durante el proceso que recuerdan, y a las distintas posiciones estructurales que ellos ocupan y las funciones que realizan.

Esta diferencia es expresión de las fracturas dentro de la clase obrera de la región: entre otras las principales son la división entre trabajadores ocupados y desocupados y entre ocupados en empresas privadas y ocupados en el Estado. Como destaca Inés Izaguirre (entre otros en su trabajo de 1994: "Problemas metodológicos y construcción de observables en una investigación sobre luchas obreras'), es clave observar no solamente los enfrentamientos entre las clases, sino también las luchas al interior de cada clase ${ }^{83}$.

Pero aún más importantes son las coincidencias entre las memorias de los trabajadores. Vemos que la solidaridad, el compañerismo, el preocuparse por el otro, son valores altamente positivos para los obreros. $Y$ está muy claro que la única forma de mejorar sus condiciones de vida fue luchar, organizarse, trabajar. Encontramos así valores, experiencias y costumbres en común, que construyen una configuración de lecturas de la realidad que dan significado a sus vidas y a sus acciones como sujetos sociales.

\subsection{Otros trabajos sobre el abordaje teórico del movimiento de la sociedad}

Realizaremos en este apartado un abordaje sobre los principales enfoques acerca del proceso de cambio social en la Argentina actual. Ubicamos nuestra atención en aquellos enfoques con los cuales discutimos, buscando mostrar los elementos conceptuales desde los cuales parten este tipo de interpretaciones de la realidad.

Organizamos el trabajo realizando una breve presentación de los trabajos más representativos de los diversos enfoques sobre el funcionamiento de la sociedad

\footnotetext{
${ }^{83}$ Un trabajo muy interesante en esta perspectiva es el de Gabriela Scodeller (2009) "Conflictos gremiales en la historia reciente argentina: una mirada", en A Contra Corriente, Vol. 6, No. 3, pp. 108-136 www.ncsu.edu/project/acontracorriente, que se centra en reflejar los conflictos y las luchas al interior de la clase obrera.
} 
actual, mostrando como en la mayoría actúan las discusiones centrales sobre el rol del individuo en la historia y el tipo de sujeto social que consideran el protagonista de los hechos.

Discutimos con los enfoques que consideramos realizan algún nivel de aporte científico y con algunos que, si bien consideramos que no avanzan en este sentido, por su nivel de difusión social, o por ser sostenidos por teóricos de amplia trascendencia en el ámbito académico, ameritan ser discutidos, ya que sustentan mucha de la opinión que desde el "sentido común" se reproduce socialmente sobre estos temas.

Intentamos no tomar como puntos a discutir la ya descartada teoría de la acción-reacción mecánica, según la cual todo hecho de protesta social puede explicarse en forma automática por una acción que modificó alguna de las situaciones que constituían la vida previa de los sectores que se movilizan. Esto ha sido ya claramente desacreditado, mostrando que es necesario avanzar en explicaciones mucho más complejas de los fenómenos sociales. Creemos que la mayoría de las posturas que discutimos en este trabajo superan esta mirada (aunque muchas puedan, y hasta podamos, recaer en interpretaciones mecanicistas en algunos casos).

Para comenzar es necesario aclarar brevemente la centralidad de lo que nos interesa debatir con los autores que citaremos. Nosotros comprendemos al movimiento de la sociedad como un proceso total y por lo tanto lo conceptualizamos como un movimiento de la sociedad. En ese sentido no acordamos con la posibilidad de estudiar un hecho por fuera de su contexto o con que podamos referirnos a un determinado hecho social como un movimiento social por fuera del movimiento de la sociedad.

Entonces los problemas centrales a discutir son: ¿quién se mueve y cambia? ¿Es la sociedad, son los individuos o los movimientos sociales? Esta primera pregunta se sintetiza en el debate sobre qué debemos investigar.

El segundo eje es: ¿quién es el sujeto de los cambios? ¿Es un sujeto individual o colectivo? ¿El proceso parte de lo general (y puede estudiarse hacia lo individual, pero en un proceso de análisis de las partes que luego debe necesariamente converger en una síntesis) o parte de lo individual? Podríamos decir que este segundo problema se sintetiza en preguntarnos si la sociedad es una sumatoria de individuos o si el hecho de vivir en sociedad genera una transformación cualitativa que hace imposible la existencia de un individuo totalmente independiente de la sociedad, a lo Robinson Crusoe.

Y el tercero hace a cómo conocer la realidad: ¿nos regimos por lo que los sujetos dicen o por lo que hacen? ¿Los procesos se explican por sí mismos o 
solamente pueden ser explicados tras un proceso posterior de análisis científico? ¿Se trata solamente de "dar voz" a los participantes o de poder explicar el hecho que estudiamos en el marco del movimiento global de la sociedad? Allí entra Gramsci y su propuesta metodológica, que apunta a quebrar esa separación entre el análisis de relaciones de lo que denomina las fuerzas sociales objetivas y las fuerzas sociales políticas.

Los teóricos de la sociedad post lucha de clase:

Los enfoques que vamos a desarrollar y discutir parten de asumir como presupuestos (para nosotros erróneos según los datos empíricos) dos planteos que son comunes en muchos teóricos con posturas disímiles en otros ámbitos:

- la pérdida de centralidad de la clase obrera (por la supuesta caída del régimen asalariado como estructurante central del sistema capitalista) tanto en lo estructural como en su capacidad para plantear un cambio social.

- la supuesta desaparición o pérdida de poder del Estado (por lo cual no habría un centro sistémico).

Así las protestas ya no serían de la clase obrera en términos de resolver las problemáticas fundamentales de la explotación, sino de distintos sujetos (sean los excluidos, los marginales o la gente común) por ser incluidos. Esa inclusión genera algunos ajustes en el sistema, que debe ser reformado pero no transformado.

Muchos de estos teóricos parten de conceptos retomados de los trabajos de Marx que aceptan como válidos para la sociedad del siglo XIX o de las primeras décadas del siglo $X X$, pero que consideran ya no explican el conflicto actual ni la forma en que se organizan los sujetos para intentar modificar la realidad. Desde esa perspectiva común hay grandes diferencias. Intentaremos sintetizar los elementos centrales de algunos de estos autores en los temas que hacen a nuestra investigación. En especial buscaremos los elementos teóricos desde los cuales se construyen muchas de las investigaciones sobre el conflicto social en la Argentina actual.

Para Castel (1997) el individuo actual ha perdido sus soportes clásicos, en especial el Estado. Considera que se produce un cambio abrupto en lo que denomina la antigua "sociedad salarial", aunque el desarrollar conclusiones generales de su trabajo es complejo, ya que su investigación tiene como sujeto de análisis a la sociedad francesa y, en menor medida, a otros países de Europa occidental.

La sociedad salarial construía un individuo positivo, con un Estado fuerte donde lo individual pasaba a segundo plano. Todo estaba muy regulado, se generaba una identidad colectiva fuerte, con la sociabilidad construida alrededor del trabajo y con sindicatos fuertes. Es lo que denomina un modelo "fordista", donde las protecciones se 
universalizan al conjunto de los trabajadores. Para él esto comienza a romperse en los ochenta, generando un individualismo negativo a partir del dominio del capital financiero. Se hace un culto al individuo, al cual se le impone que todo está bajo su responsabilidad y quién ya no tiene como soportes ni al Estado, ni al trabajo.

Todo se fragmenta, en especial las demandas que se transforman en particulares y sin posibilidad de articularse entre sí. En la nueva sociedad hay dos grupos: los que se salvan por su capacidad y desde la independencia y los que sufren la individualidad como una cruz y nada pueden construir. Su panorama es negativo, destacando que es muy difícil modificar las consecuencias de esta nueva fase de la modernidad. Propone como solución recuperar el rol del Estado en tanto soporte, buscando formas de articular la necesidad de lo flexible con la necesidad de protección social. Propone formas de protección que partan desde lo individual y ya no desde lo colectivo, dado que es casi imposible recuperar los actores grupales de antes.

Consideramos que en Castel se presenta un problema en su concepción del Estado, que aparece como un aparato aséptico y neutral, como el único que garantiza la subsistencia de la vida en sociedad. El Estado no es visto como herramienta de dominación de la clase dominante, ni como capitalista ideal que articula los intereses de los diversos sectores de la burguesía. Creemos que la evidencia empírica muestra que ese punto de partida no es correcto. Para nosotros los cambios que él observa fueron en verdad ejecutados y planificados desde el Estado, dominado en esta fase del capitalismo por los cuadros del capital financiero. Además creemos que está demostrado que la relación salarial sigue siendo la forma fundamental en que se organiza la sociedad y la producción, y que las demandas sociales en lugar de caer se han generalizado.

Castel es un crítico de las características de este capitalismo en descomposición, pero su propuesta de resolución de las problemáticas sociales es regresar a las formas de dominio propias de la fase de hegemonía del capital industrial. Su esperanza es poder volver atrás en el desarrollo histórico.

Martuccelli (2007) analiza el proceso de "individuación" en Occidente, el cual pasó por una extraña dialéctica ya que el individuo se "liberó" de la comunidad pero pasó a ser dependiente de las protecciones del Estado. Retoma a Castel, volviendo a la tradición de Durkheim, quién veía a la relación entre el individuo y la sociedad como una "dependencia liberadora". Para Castel la propiedad privada fue el soporte fundante del individuo. El problema surgió cuando se vio que no todos llegaban a ser propietarios. Entonces allí los derechos sociales jugaron el papel de posesión: todos éramos igualmente propietarios de los mismos derechos. 
Castel ve como ese "Estado providencia" fue el soporte fundamental del individuo moderno. Es un soporte que debe permanecer lo menos visible posible porque la visibilidad de la asistencia externa (la asistencia social) se transforma en un estigma, ya que el modelo de individuo occidental es el de alguien totalmente dueño de sí mismo. Habla por ello del surgimiento de "nuevos sujetos", como los excluidos o desafiliados.

El cambio que para Castel es, fundamentalmente, la caída de la sociedad salarial, para Bauman (2000) es el fin de lo que llama "modernidad". Pero no coincide con caracterizar a la sociedad actual como "posmodernidad", sino que para él lo que se produce es un cambio del capitalismo. Del modelo fordista basado en el capital "pesado" y en trabajadores atados (que clásicamente se jubilaban en el mismo trabajo en que empezaron) se pasaría a un capital "liviano" con trabajadores flexibles que trabajan en el día a día. Esto se acrecienta en una carrera desbocada hacia adelante y en un mundo que ya no puede volver atrás, como para Bauman pretende Castel. Se conforman nuevas adicciones, en especial el consumo compulsivo, donde nada es durable y hay una insatisfacción permanente. Así no habría marcos ni autoridades y cada individuo está a cargo de su propia historia.

Bauman ve a este proceso como algo positivo, porque el trabajador ya no esta atado, sino que puede conformar libremente su individualidad. No ve lo que decía Marx: que el trabajador bajo el capitalismo es tan libre que es totalmente libre de morirse de hambre sin que a nadie le importe. Al no observar lo total no ve que la libertad no puede entenderse por fuera del marco general de la sociedad, donde esa supuesta flexibilidad se ha convertido en una condena para millones de hambrientos en el mundo entero.

La teoría de la reflexividad es una construcción especialmente de Giddens (1997) y Lash $(1997,1998)$, aunque creemos que muchos autores que mencionamos en este apartado comparten el punto de partida teórico. Sería un rasgo propio de lo que definen como la "modernidad tardía". Giddens considera que casi todas las actividades sociales y las relaciones materiales que se establecen con la naturaleza son revisadas continuamente por parte de los agentes a partir de las nuevas experiencias y las informaciones que reciben. Esto lo realiza el individuo pensado desde una sociedad postradicional, donde ya no se establece la relación entre individuo y sociedad desde los antiguos marcos de socialización, como la familia, la escuela, el trabajo o el barrio. El individuo debe buscar justificaciones propias a sus acciones, que ya no pueden sustentarse y legitimarse desde la tradición. Por eso, para él, hay una creciente reflexividad en cada individuo. 
Coinciden en el análisis de que estas nuevas formas de subjetivación tienen un carácter ambivalente, que otorga mayores posibilidades a los individuos pero que a la vez plantea riesgos de fragmentación y de enfrentamientos sociales. Para Giddens los riesgos son menores que las posibilidades que se abren, y por eso es optimista. Considera que se plantea una gran posibilidad de desarrollar nuevos estilos de vida, con una mayor autonomía de acción y la posibilidad de una planificación reflexiva. Esto lo critica en forma contundente Svampa (2001), quién ve como esta reflexividad no se presenta como algo real para países como Argentina, con constantes turbulencias sociales y donde la planificación es una tarea casi imposible, en especial para los grupos sociales oprimidos.

Para Giddens estamos ante una radicalización de la modernidad, donde lo experto sigue siendo el sostén de nuestra vida y lo que puede generar seguridad a la sociedad, pero el problema es que ha perdido credibilidad. Desde una perspectiva claramente institucional sostiene a la tecnocracia como el camino para generar, desde el conocimiento experto, un nuevo soporte social compatible con la reflexividad.

Por su parte Lash y Urry (1998) marcan que esa reflexividad es un recurso distribuido de manera muy desigual y que los únicos que pueden disfrutar ese individualismo son las "clases ganadoras", mientras los perdedores lo sufren como una condena. Critican a Giddens y a Beck (1998) por no ver esto. Una visión semejante sostiene Sennet (2000), para quién los trabajadores no tienen ninguna posibilidad de planificar en el marco del actual "capitalismo flexible".

En Lash la confrontación se da desde lo estético, con una gran importancia de lo simbólico. En ese ámbito se produce una fuerte democratización, ya que para él ahora hay continuos flujos de información y de signos, que hacen posible construir redes alternativas. Ve que este proceso es posible de realizar para la nueva clase media, siendo allí central el papel del turismo como un producto cargado de estética que permite producir reflexividad. Son esas "nuevas clases medias" que veremos aparecer como el eje del conflicto actual para varias interpretaciones de la protesta social. Demás esta decir que, si el conflicto es por los elementos simbólicos, el problema de la estructura económica y de la lucha de clases queda desplazado de la centralidad.

Beck (1998) también discute la teoría de la autoreflexibidad, observando la globalización más desde lo político que desde lo económico. Es más pesimista que Giddens, destacando los riesgos que esta nueva situación genera y acercándose allí al concepto de sociedad de riesgo que desarrolla Nicklaus Luhmann (1997). Destaca tres rasgos centrales: la caída del Estado-nación, la crisis de las economías nacionales y lo que denomina la "subpolitización", entendida como la emergencia de nuevos 
referentes políticos, nuevos actores con miradas distintas de las tradicionales, que se organizan en nuevos movimientos sociales.

Critica el globalismo como predominancia y triunfo del mercado y acuerda con el concepto de glocalización (lo toma de Bauman), según el cual los ganadores son globales y los perdedores son locales. Pero pese a estas críticas para él la salida es aceptar esta situación como la realidad, ya que es imposible volver atrás y sólo puede modificarse construyendo, desde la reflexividad, un "republicanismo cosmopolita". Luhmann destaca como ejemplo de este proyecto a los movimientos ecologistas, que para él generan el despertar de una nueva política basada en valores universales y no en la búsqueda de soluciones personales a corto plazo.

Comparte con Ortiz (1996) la seguridad sobre la supuesta desaparición del Estado-nación. Ortiz lleva más lejos la calificación de la globalización como un proceso donde lo económico no es lo clave, y por ello lo denomina "mundialización". Es un proceso que se da en lo cultural y en lo simbólico, desarrollando nuevos territorios desde donde se conforman nuevas identidades y articulaciones locales que entran en contradicción con las identidades nacionales. No hay para él una homogeneización cultural, sino que la mundialización genera una revalorización de lo local. Ve en ello una gran oportunidad, desde la puesta en valor, en términos económicos, de los elementos culturales locales. Así se transforma en uno de los impulsores de las teorías del desarrollo local

Robles (2000) piensa la modernidad reflexiva desde sociedades periféricas. Para él la división no es entre centro y periferia (menos aún entre dominados y dominantes) sino entre sociedades del capitalismo tardío y sociedades periféricas. Plantea que es posible la individualización como camino hacia la autoreflexibidad, pero cree que todavía es importante el soporte del Estado. Esto acentúa los riesgos en la periferia, por las reformas neoliberales y la caída del Estado benefactor. Trabaja desde los conceptos de excluidos e incluidos, y para él sólo es posible que se desarrolle reflexividad en contextos de exclusión desde la solidaridad grupal, porque sino se cae en la soledad y el aislamiento.

Autores como Freytes Frey (2000), Fressoli (2000) y Pecheny (2002) estudian diferentes aspectos de la vida en sociedad en las grandes ciudades. Trabajan desde el marco conceptual desarrollado por Simmel, quién ve que la conformación de las metrópolis genera un fuerte proceso de individuación. Los sujetos se aíslan cada vez más, pero a la vez esto genera dinámicas de autoafirmación y auto reconocimiento. Este proceso se acentúa por el aumento de la fetichización de las relaciones y de la alienación, que hace ver como elementos ajenos a aquellas cosas que el mismo hombre produce. 
Como parte del proceso de individuación (aunque más bien parecería de fragmentación) se da la ghettización de la ciudad, la conformación de las tribus urbanas, de los barrios cerrados. Allí juegan un rol central los secretos, como herramientas para diferenciar a los que pertenecen al grupo de los que están afuera. Esto lo trabaja especialmente Fressoli, con un interesante análisis del papel que juega el automóvil en esta individuación. Freytes toma el tema de la moda como elemento importante en el intento de diferenciarse y autoafirmarse.

Pecheny analiza desde Simmel la cuestión de la homosexualidad en el espacio público. Allí ve como constituyente al "secreto" y a las formas de comunicar ese secreto. Hay una ghettización de lo homosexual y una hipócrita diferenciación entre la esfera pública y privada, donde lo homosexual debe quedar en lo privado y se debe ser "discretos" en lo público. La reacción contra esto partiría siempre desde el análisis individual, tomando allí el concepto de estigma de Goffman, que lleva a algunos a tomar ese estigma como parte central de su identidad y a enorgullecerse del mismo. A esta situación de invisibilización de lo homosexual la pone en crisis la epidemia del SIDA (que obliga a hablar "de eso") y el surgimiento de movimientos por las minorías sexuales.

Todas estas investigaciones parten de la intención de recuperar lo individual, partiendo de elementos teóricos de Max Weber, pero discutiendo el mayor énfasis que este ponía en lo social. Ven que hay un abandono de la comunidad, de lo colectivo y tradicional. Y, siguiendo a Simmel, destacan como él que es el estudio de lo individual lo que explica mejor esta dinámica, por encima de los procesos objetivos y los cambios sociales.

Santiago (2002) investiga cómo se conforman los espacios de sociabilidad de los jóvenes que producen delitos violentos. Destaca, como dato central, que no hay grupos cerrados, con identidades fuertes, al modo de las "tribus urbanas", sino ámbitos permeables, de donde se puede salir y entrar sin grandes costos. Citando a Svampa, (2000) habla de "identidades en tránsito". Los jóvenes comparten distintos ámbitos donde conviven quienes delinquen y quienes no lo hacen. En ese marco ni la escuela ni el trabajo ni el barrio son ya lugares que aseguren la posibilidad de satisfacer sus expectativas. Entonces se les ofrece una "estructura de opciones" (concepto tomado de Przeworski, 1984, muy semejante al de estructura de oportunidades de Tarrow) donde el robo aparece como la posibilidad más eficiente de obtener lo que quieren para satisfacer sus necesidades. El delito no se les presenta como algo rupturista, sino como una estrategia más que puede ser compartida con la asistencia a la escuela 0 con tener un trabajo. 
Toma el concepto de estigma de Goffman. Esos estigmas llevan a que los jóvenes los tomen como propios y así es típico que jóvenes de barrios considerados violentos se comporten como tales. Todo aparece en tanto casos individuales, donde es poco el factor condicionante de los procesos estructurales y el delito no se ve como una forma de rebelión o como una manifestación del marco general de injusticia social, sino como una "elección" totalmente racional entre el menú de una estructura de opciones.

Sennet (2000) sostiene que la vida de los hombres esta centralmente organizada desde el tipo de relaciones que entablan en el trabajo. La nueva organización del trabajo (lo que llama el "trabajo flexible") lleva al trabajador a sufrir una crisis, ya que la realidad se le vuelve "ilegible". No puede comprender esa nueva situación ni procesarla en sus marcos interpretativos. Todo el trabajo está organizado por códigos que solamente entiende el especialista. Cada vez hay mayor distancia entre el proceso de trabajo y el trabajador. La relación es cada vez más débil, no hay identidades fuertes y se produce la desintegración social.

Para él la forma de superar este problema es articular esa producción "flexible" y los avances tecnológicos, con la necesidad de otro tipo de organización del trabajo que no lleve a esa "corrosión del carácter". El problema en Sennet es que parte de creer que estamos ante una desintegración de la sociedad de clases, cuando en realidad todos los procesos que él describe (en forma muy interesante y clara) son mejor explicados si los vemos como una acentuación de las tendencias clásicas del capitalismo ya indicadas por Marx.

Lo que él ve como un trabajo "flexible" (tomando el término que usaron los ideólogos del neoliberalismo) es la precarización del trabajo para poder acentuar los niveles de explotación. Lo que describe como corrosión del trabajo lo entendemos como una acentuación de la alienación, radicalizada por el avance de la maquinización (también un proceso clásico, donde la producción depende cada vez más del trabajo muerto cristalizado que del trabajo vivo, achicando así la tasa de ganancia). Lo que ve como una “... obsesión americana por el individualismo” (Senett, 2000: 66) no es más que la hegemonía del capitalismo (al igual que la falta de identificación como clase obrera que observa en los trabajadores que se definen como clase media). También se observa en los procesos que describe, la centralización y concentración del capital.

Por último marcamos que hay una confusión en Sennet, cuando critica al marxismo por su supuesta definición de que “... la conciencia de clase se basa en el proceso de trabajo" (2000: 67). Esto es un error grave ya que, como lo marcamos repetidamente, en varios trabajos Marx se encarga de definir que la conciencia de clase solamente se desarrolla en la lucha. Por eso es lógico que Sennet no encuentre 
conciencia cuando lo que va a mirar no es la lucha sino la organización del trabajo (que bajo el dominio del sistema capitalista es el ámbito donde por antonomasia domina la ideología y la forma de organización del capitalismo). El problema es su punto de partida.

La mirada de la acción colectiva:

Charles Tilly $(1995,2000)$ y Sydney Tarrow $(1991,1997,2003)$ representan globalmente una misma mirada, la que solemos denominar de la "acción colectiva" ${ }^{84}$. Aunque con algunas diferencias comparten lo central del enfoque. Ha sido el tipo de abordaje predominante en los estudios sobre la protesta social en la Argentina actual, con ciertas modificaciones al marco teórico por parte de algunos investigadores locales.

Lo que los autores buscan explicar es el porqué los individuos se suman entre sí para realizar una "acción colectiva". Su punto de partida parece ser entonces el individuo y no el colectivo social. Así Tarrow sintetiza la pregunta en buscar entender "por qué la gente se junta en banda" (1997: 10). La situación lógica desde este abordaje pareciera ser el individuo quieto, inmóvil. Un individuo que se activa y se moviliza en conjunto con otros por determinados factores que lo impulsan a ello.

Pero, al mismo tiempo, en la mayoría de sus trabajos hay una referencia constante a los cambios en la sociedad, al permanente proceso de movimiento que desarrolla el conjunto social. La diferencia en el enfoque es que su punto de partida teórico entiende que ese cambio lo generan los individuos que se unen, y no los colectivos sociales. Es una mirada que comprende a la sociedad como un conjunto de individuos y no como una totalidad, de la cual son parte fundamental las clases sociales, los sujetos colectivos.

Por eso la preocupación es explicar por qué se movilizan los sujetos (considerando al sujeto como el individuo, denominado generalmente la "gente común"), sin observar que al estar la sociedad en un movimiento constante los sujetos están en todo momento actuando y movilizándose, ya sea intentando transformar algún aspecto de la realidad o realizando su labor "normal", que también es una actividad y un movimiento. En ese movimiento "normal" los trabajadores están movilizados solamente para el capital, en su acción diaria como trabajadores que reproducen el sistema.

\footnotetext{
${ }^{84}$ Tilly sostiene que en el "...sentido acotado, se parece a lo que otros analistas llaman protesta, rebelión o disturbio" y "difiere de otras acciones colectivas en que es discontinua y contenciosa: no está construida sobre rutinas diarias y tiene implicancias para los intereses de personas distintas al grupo que actúa así como para los propios intereses compartidos de los actores. Cuando estas implicancias son negativas podemos hablar de conflicto; cuando son positivas podemos hablar de cooperación" (Tilly, 2000: 10).
} 
Desde este abordaje se entienden sus preocupaciones centrales y su forma de interpretar la protesta social. Al no ver un movimiento de la sociedad en su conjunto desvinculan en lo teórico el movimiento de las fuerzas sociales objetivas y el de las fuerzas sociales políticas. De esa manera lo que se piensa como "estructura económica" actúa como una especie de escenario por donde se mueven los sujetos sociales, cual "actores" que representan una obra. Es sintomático de esto como la terminología teatral es utilizada constantemente por estos autores. Para Tilly a lo sumo lo que se puede es improvisar pero sobre guiones ya escritos (es a lo que hace referencia el concepto de "performance").

Para ellos los individuos toman la decisión de sumarse a una acción colectiva a partir de una situación de oportunidades políticas. En Tarrow aparece una mayor preocupación por la interpretación de la movilización de los "líderes" en torno a esa oportunidad. Los líderes "movilizan" a otra "gente" para negociar con las elites dirigentes un nuevo marco de relaciones, que es básicamente asegurar la entrada de estos líderes al régimen actual. Esto se realiza a través de la institucionalización, donde los líderes pasan a integrarse al poder y su gente movilizada obtiene algún rédito por su participación. El hecho culmina entonces volviendo a la situación inicial de individuos fragmentados.

Es clara en Tarrow la visión según la cual el conflicto es utilizado en forma instrumental y conciente por los organizadores. Así habría un duelo de estrategia y contra estrategia entre los activistas de los movimientos y los que detentan el poder. El grueso de los que conforman el movimiento cumple un papel de acompañamiento pasivo. Esta mirada no es central en Tilly.

Pero lo que sí es común en ambos es la concepción fundamental de que los procesos parten de los individuos. Los sujetos individuales se movilizan por su interés, a partir de observar una oportunidad ante la cual tienen mayores posibilidades de obtener lo que les interesa. Esto es evidente en Tilly, quién se interesa más por los participantes por "abajo", que en Tarrow, quién mira más hacia "arriba" (coincidente con su punto de partida teórico más cercano al primer Touraine, que lo lleva a preocuparse por la formación de nuevas identidades y por su institucionalización en el marco de las normativas fijadas por el régimen de gobierno).

Para Tilly hay una estrategia ${ }^{85}$ de los actores, que divide entre: los que van a fondo para obtener la meta; los que esperan sin arriesgar nada a que se gane en la acción colectiva que desarrollan otros para luego sumarse y conseguir algo sin hacer nada; los oportunistas (que son los que maximizan las ganancias netas); y el promedio

\footnotetext{
85 Con un sentido muy distinto al que le da Iñigo Carrera (2000). En Tilly la intención es explicar individualmente porqué cada actor se suma a la acción.
} 
(aquel que busca realizar el menor esfuerzo posible para obtener lo que necesita). Acá es claro que no hay un sujeto colectivo en acción, son todos individuos: unos miserables, otros audaces, otros oportunistas. Cada uno aparece intentando conseguir el mayor beneficio posible mediante la menor inversión: es la lógica del mercado como ámbito de libre competencia aplicada al estudio de la protesta social.

Además el individuo es presentado como un estratega. Él es conciente de todo lo que hace, lo calcula, lo prepara. Como en Goffman (1997) la vida aparece cual un escenario, donde no hay estructura que los condicione, y en el que cada uno toma sus decisiones. Es un individuo que esta preparando y calculando cada paso. Como el individuo sabe lo que está haciendo, lo que importa para explicar el proceso es lo que él dice, por sobre lo que hace objetivamente. No se discute aquí la dificultad para que un sujeto pueda comprender en cada momento la globalidad de causas y consecuencias que operan tras cada acción que realiza. Para nosotros la explicación por lo que dice sólo es una parte del hecho, aún queda por develar la más importante: lo que realmente hacen esos sujetos más allá de lo que pretendían concientemente realizar.

Tilly y Tarrow tienen una preocupación permanente por lo "nuevo", por las rupturas. Esto, que es un rasgo muy positivo ya que permite ver el conflicto, cae en algunas ocasiones en una sobrevaloración del aspecto de novedad de algunos movimientos coyunturales, dándoles un carácter de movimientos orgánicos ${ }^{86}$. Esto es así porque si lo normal es el equilibrio, lo que debe estudiarse es el momento de la ruptura. Desde nuestra perspectiva esto es un error teórico con profundas ramificaciones.

El otro eje que suelen tomar sus investigaciones es la afirmación de la centralidad que en el capitalismo actual tendrían las demandas ciudadanas como factor clave del conflicto. Esto es retomado por otros teóricos y por muchos investigadores que lo aplican a la protesta contemporánea en Argentina.

Las acciones que realizan los actores sociales no tienen una escala. Nosotros, en cambio, partimos de la existencia de una escala de las formas de lucha, desde la comprensión de que no todos los hechos significan lo mismo, ni tienen la misma importancia, ni provocan los mismos cambios sociales (Klachko, 2006). Esa escala atraviesa desde las formas más elementales de lo espontáneo a las formas más complejas de lo sistemático, debiendo incluirse en el análisis al carácter del ciclo de luchas que se esté recorriendo durante el período.

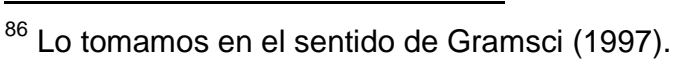


Para Tarrow y Tilly hay un repertorio de formas, del cuál se "elige" la medida adecuada a cada momento según la oportunidad política, y a continuación se la lleva a la práctica de un modo particular (lo que Tilly llama "performance"). Consideramos que esta concepción genera un problema en la investigación, ya que se complejiza mucho el poder periodizar y medir un ciclo de protestas. Tarrow denomina ciclo de protesta a un momento de aumento del conflicto.

Ese ciclo para Tarrow culmina con la conformación de un movimiento social o se agota en sí mismo. Si termina en un movimiento social (que debe tener un interés general y no un interés "particular") el ciclo se ha completado a través de la institucionalización: "Como señala Sidney Tarrow (1989), los movimientos sociales (abiertos desafíos a las autoridades públicas en nombre de sectores de la población agraviados) se producen muchas veces en oleadas (...). Durante esas oleadas, una serie de peticiones parecen inducir otras, las organizaciones que participan en el movimiento social compiten entre sí por conseguir el mayor apoyo posible y las exigencias son cada vez más radicales para luego ir perdiendo fuerza. Frecuentemente ese proceso sirve a los activistas para experimentar nuevas formas de organizarse, estructurar sus demandas, combatir a sus enemigos y mantener lo que ya poseen. Al finalizar el ciclo, algunos protagonistas nuevos han conseguido cuando menos una pequeña parcela de poder, otros miembros de la comunidad política han perdido poder, el marco de los asuntos públicos se ha alterado un tanto y los modos de lucha han cambiado al menos ligeramente". (Tilly, 1995, pág. 10)

Si bien tenemos diferencias con este enfoque hay también coincidencias. Muy importante es que, especialmente los que toman a Tilly como referencia, parten de los hechos como entrada a la investigación ${ }^{87}$. Los momentos de conflicto en la sociedad ponen en acción a todos los sectores y expresan en mayor o menor medida a la totalidad del proceso social. Esto es así, especialmente, cuando analizamos un período significativo de protestas sociales, o un hito del mismo.

Aquí hay cierta diferencia entre Tilly y Tarrow, ya que este último suele tomar como puerta de entrada de la investigación a los movimientos sociales ya constituidos, en ocasiones sin observar cuál es el proceso formativo de ellos y de qué movimiento objetivo de la sociedad son expresión (en este sentido consideramos que Tarrow está más cercano que Tilly a los teóricos de los nuevos movimientos sociales).

\footnotetext{
87 Debemos esta indicación a María Celia Cotarelo, en el seminario de postgrado "Los movimientos de rebelión social en el capitalismo. Instrumentos teórico-metodológicos para su análisis: de los "rebeldes primitivos" a los "nuevos movimientos sociales", dictado junto a Nicolás Iñigo Carrera durante el primer cuatrimestre del año 2008 en el Instituto de Estudios Históricos y Sociales, Universidad Nacional del Centro de la Provincia de Buenos Aires - Tandil.
} 
Algunas discusiones con los aportes de Bourdieu:

Bourdieu (1999, 2000, 2002, 2005) critica este tipo de abordajes desde algunos presupuestos cercanos a los nuestros. Hace hincapié en que las posturas que parten del criterio de la "acción racional" suponen un sujeto totalmente consciente de aquello que realiza, libre de toda imposición, que, por lo tanto, tiene la posibilidad de tomar la decisión que él quiera. Asimila estas miradas al enfoque del utilitarismo en lo filosófico, desarrollado especialmente por Jeremy Bentham y Stuart Mill ${ }^{88}$. Por ello dice que este tipo de abordaje reemplaza la necesidad de estudiar la realidad empírica que hace posible un determinado proceso social, por una supuesta explicación que parte de lo que nos dicen los individuos que actúan o, más repetidamente, por lo que el investigador supone como razón explicativa de la acción investigada.

Contra esto Bourdieu plantea la necesidad de incorporar la noción de habitus, entendido como un concepto que, según él, evita la confusión de Marx entre clases "teóricas” y clases "reales”, quién consideraría que: “(...) las clases teóricas son clases reales, grupos reales de individuos movidos por la conciencia de la identidad de su condición e intereses (...) nos lleva a creer que las clases teóricas son automáticamente clases reales -grupos conformados por individuos unidos por la conciencia y el conocimiento de su comunidad de condición y listos para movilizarse en busca de sus intereses comunes-". (Bourdieu, 2000: 111).

Creemos que esta suposición de Bourdieu parte de una errónea lectura de Marx, quién especifica que las clases se constituyen en la lucha, y que no diferencia entre clase "teórica" y "real". Para Marx no existe una supuesta clase "real", en el sentido de "lo que debe ser", sino que la clase es un estar siendo. De hecho en "Miseria de la Filosofía" (Marx, 1987) sostiene que sin lucha la clase obrera no es más que una clase con respecto al capital, un grupo de individuos puestos en una posición y una función similar en el proceso productivo. Posición y función que les plantean objetivos e intereses comunes, pero que por sí solas no generan una conciencia de esa "comunidad de condición". Esto significa no hay nada automático entre esa clase "en sí" y la conformación de ese grupo social como clase "para sí". La clase se conforma en la lucha, como un proceso social colectivo.

\footnotetext{
${ }^{88}$ La primera indicación a este respecto la registramos en el citado seminario de postgrado "Los movimientos de rebelión social en el capitalismo...", por parte de Nicolás Iñigo Carrera. Desarrolló en extenso esta mirada en el artículo "Algunos instrumentos para el analisis de las luchas populares en la llamada historia reciente": "Partir de conjuntos de individuos (gente) como constituyentes de los actores colectivos, y no de las clases sociales como constituyentes de los individuos, permite explicar su "confianza en Mill" (Tilly, 1978: 48), lo que se refleja en la observación de motivaciones individuales más que en las tendencias (leyes) que rigen el movimiento de la sociedad" (Iñigo Carrera, 2008b: 84). Gilly (2006) plantea una mirada semejante sobre estas perspectivas: "El protagonista de este visión de la historia es el "hombre económico" de Adam Smith, que vive en un mundo en el cual las "posibilidades" se han transformado en "oportunidades" y las "decisiones" en "opciones" (pág. 63).
} 
Para nosotros el problema central del enfoque de Bourdieu parte de la fragmentación que realiza de la totalidad al separarla en múltiples "campos", cada uno de los cuales constituye distintos habitus, que a su vez dependen de las proporciones definidas de cada tipo de capital que cada agente tiene al momento de actuar socialmente y de las trayectorias individuales de cada uno de ellos. Esta múltiple fragmentación de la realidad lleva a que se haga muy difícil poder incorporar la totalidad social en su abordaje, más allá de que Bourdieu en todo momento lo plantea como expectativa de sus investigaciones.

Consideramos que desde su abordaje los sujetos sociales quedan tan desarticulados entre sí que la posibilidad de explicar el movimiento de la sociedad se reduce a cada campo específico. Así se hace complejo pensar desde esta teoría cómo se articulan las distintas luchas, cómo se van construyendo sujetos colectivos, cómo se conforma una fuerza social. De hecho es difícil desde su teoría entender cómo se producen los cambios en la sociedad (entendida como totalidad y no como acumulación de campos y subcampos).

Coherente con esa visión Bourdieu reivindica el concepto de agente ${ }^{89 ~ “ . . . q u e ~}$ no es un sujeto, una conciencia, ni el mero ejecutante de un papel, un soporte de una estructura..." (Bourdieu y Wacquant, 2005: 189), desde una postura que para ellos rompe con la falsa antinomia entre lo individual y lo social. Para nosotros el análisis de Bourdieu no deja de hacer hincapié en la conformación de los individuos (aunque desde una visión más cercana a nuestro enfoque que autores como Touraine, ya que para Bourdieu es imposible comprender al individuo por fuera de lo social) o de grupos reducidos (dejando los fenómenos estudiados circunscriptos a determinados "campos" de la vida social).

Creemos que para Bourdieu el sujeto fundamental no deja de ser el individuo (el "agente"), aunque se trate de un individuo que internaliza un habitus social y que se conforma como tal en sociedad. La interpretación que realizan los estudios desarrollados desde su teoría sobre los procesos colectivos parten, en forma semejante que los de la acción colectiva, de buscar explicar porqué "las personas" son llevadas a actuar en conjunto, partiendo de una concepción distinta a quienes sostenemos que los sujetos sociales son sujetos colectivos, imposibles de comprender y explicar por fuera de la sociedad entendida como conjunto.

De lo que se trata para él es, tomando sus metáforas, de explicar porqué y cómo cada jugador se integra a un juego: "Podemos representarnos a los jugadores

\footnotetext{
${ }^{89} \mathrm{Sin}$ desarrollarlo en mayor medida, por no ser materia específica del trabajo, consideramos importante marcar que su concepción de agente se diferencia de Giddens y otros autores. En el caso de Bourdieu tiene más centralidad el papel de la estructura, coherente con la importancia que le da al concepto de reproducción.
} 
como si cada uno de ellos tuviera una pila de fichas de colores y cada color correspondiese a una especie dada de capital, de manera tal que su fuerza relativa en el juego, su posición en el espacio de juego como así también los movimientos que haga (...) dependerán tanto del número total de fichas como de la composición de pilas de fichas que conserve, esto es, del volumen y estructura de su capital. Dos individuos dotados de un capital general equivalente pueden diferir, en su posición y en sus posturas"(Bourdieu y Wacquant, 2005: 152.)

¿Cómo explicamos un proceso social desde esta concepción teórica? Creo que esta indicación metodológica plantea que no hay otra forma que partir desde lo individual.

Esto aparece en su interpretación del papel central que en los conflictos políticos tienen los intelectuales, quiénes producen políticamente desde afuera a las "clases reales", conformando instituciones objetivas (también presenta una preocupación central por la institucionalización de los procesos). A partir de esto es que la lucha y la acción política la reduce en gran medida al papel de algunos “...profesionales de la representación que, actuando como portavoces de los grupos a cuyo servicio colocan su competencia específica, se enfrentan unos a otros en un campo cerrado y relativamente autónomo, a saber, el campo de la política". (Bourdieu, 2000: 125 y 126).

Para nosotros Bourdieu cae en una posición que sobre valora el papel y la voluntad de algunos hombres destacados y ve a la acción colectiva como resultante de la acción individual de algunos dirigentes que despliegan un modo de coordinación, participación, decisión y acción. No ve a las luchas sociales como un proceso colectivo, que involucra a grupos sociales, los cuales no "realizan" su conciencia en un continuum, en forma claramente estratificada o de una vez y para siempre, sino que la desarrollan en ese mismo proceso de luchas.

Los dirigentes expresan esos niveles de conciencia de forma contradictoria, a veces en mayor y otras veces en menor medida, y cuando hablamos de un desarrollo de la conciencia no lo hacemos en el sentido de un supuesto ascenso permanente, sino de un proceso dialéctico, con avances y retrocesos, triunfos y derrotas parciales.

El enfoque de los nuevos movimientos sociales:

Enfocaremos aquí una breve reflexión acerca de los elementos centrales de esta concepción en algunos de sus principales teóricos. Claus Offe (1992) parte de considerar que el capital hoy esta en todas partes y se ha globalizado. Para él esto se presenta como un proceso novedoso y no como la realización de una tendencia 
histórica del capitalismo. De esto saca una conclusión (con la que coincidimos): que la opresión está en todas las partes del sistema; y otra (que nos separa): que no hay una centralidad de esa opresión.

Para él los conflictos son múltiples y necesariamente desarticulados, porque no hay un centro hacia el cual dirigir los reclamos. El conflicto actual no se expresa como lucha por el poder, porque no se necesita el poder para cambiar lo que se busca modificar. Tampoco son necesarias las organizaciones centralizadas. Holloway toma casi el mismo punto de partida para su análisis, incorporándole el análisis de la fetichización y la alienación que genera el capitalismo actual, pero la lectura estructural es coincidente con la que Offe desarrolla previamente.

Offe discute con los teóricos conservadores (como Huntington, 1975) que ven a los movimientos sociales como un factor desestabilizador, que erosiona la autoridad política y la capacidad de gobernar. La propuesta de los conservadores es deslindar lo político de lo no político (o sea determinar qué es discutible y qué no lo es en términos sociales). Es el proyecto del neoliberalismo, que busca imponer como "naturales" (o sea como "no políticos", o no sociales) a los nodos centrales de su dominación. Pero Offe no se opone a la totalidad del proyecto sino a la privatización de los conflictos y tensiones. En cambio coincide, desde su abordaje de los "nuevos movimientos sociales", con que las soluciones ya no pueden venir del "estatismo" o del reclamo a las autoridades burocráticas. Desde allí es que los nuevos movimientos sociales deben buscar politizar las instituciones de la sociedad civil, la cual sería jerarquizada en contra de la antigua centralidad del Estado.

Se rompe así con el "viejo paradigma" de la lucha de intereses (en los cuales para él es más simple llegar a acuerdos, ya que todo surge de la negociación) por un nuevo paradigma de lucha por valores, donde es más difícil acordar, ya que hacen a visiones del mundo imposibles de ser negociadas. En ese viejo paradigma los temas claves eran el crecimiento económico, la distribución y la seguridad. Para Offe se había llegado a un consenso social sobre la base del Estado de bienestar que aseguraba buenos niveles de vida para los trabajadores. Así plantea que para fines de los cincuenta se habían dejado atrás "temas" como el socialismo o la necesidad de una transformación social. Este enfoque deja de lado procesos como el imperialismo (no observa qué pasa en los países dominados) o el inocultable avance de grupos revolucionarios en los años sesenta a nivel mundial, por sólo citar algunos elementos que su mirada no toma en cuenta ${ }^{90}$.

\footnotetext{
90 Como correctamente plantean María Celia Duek y Graciela Inda: "Lo que es cuestionable de los enfoques actuales no es la atención prestada a los "nuevos sujetos" o nuevos agentes sino el hecho de
} 
En ese marco surge este paradigma de los nuevos movimientos sociales, para el cual Offe retoma a Melucci (1981) y Rachke (1980). Estos movimientos surgen en una situación intermedia entre lo público y lo privado, realizando una política "no institucional". No pretenden transformar la sociedad, sino que se acepten como válidos sus valores y formas de comprender la vida. Para él los movimientos más importantes son: el de los ecologistas, el pro derechos humanos, el feminista y el pacifista. El problema que Offe marca en estos nuevos movimientos sociales es que al referirse a valores que asumen como no negociables, pueden generar situaciones donde sea imposible llegar a acuerdos.

Para Offe el éxito de estos nuevos movimientos sociales estaría en lograr fluir, cambiar los códigos y llegar a los medios de comunicación. Desde allí se construye la identidad pero, coincidiendo con el primer Touraine, la identidad no surge del conflicto, sino de los símbolos, los valores y la construcción simbólica de un oponente. Offe sintetiza esto en lo que llama el desarrollo de un "marketing político".

Estos nuevos movimientos sociales siempre toman valores universales, que intentan involucrar a la totalidad de la sociedad, "convenciendo" a los otros de esos valores, que no son contrarios a los intereses estructurales de nadie. Offe no ve intereses contrapuestos o causas estructurales en los conflictos que plantean los movimientos sociales.

Además generan un gran cambio en su forma de actuar y en los sujetos que los integran. Offe no logra ver los lazos que este tipo de movimientos tienen con la historia de corrientes como el socialismo o el anarquismo. Su enfoque se basa, al igual que los teóricos de la acción colectiva, en explicar “... la manera por la que multitudes de individuos pasan a ser actores colectivos" (Offe, 1992: 178). Para estudiarlos propone superar la "barrera" entre las explicaciones psicologizantes (auto interpretaciones) y las "estructurales" (que para él son identificables con las causales). Hay que buscar una comprensión que observe tanto el papel de los sujetos como los cambios estructurales.

Las formes de protesta de los nuevos movimientos sociales son no convencionales, recurriendo a acciones que llamen la atención de los medios de comunicación. Se nutren de profesionales de la nueva clase media ${ }^{91}$, de sujetos marginales al mercado ${ }^{92}$ y de individuos de la "antigua" clase media (o sea todos menos la clase obrera, que para él sigue actuando como un grupo de interés anclado

que se los coloque como eje exclusivo del análisis social y político, expulsando totalmente la categoría de lucha de clases" (2009: 30).

${ }_{91}$ Toma este concepto de la nueva clase media como el sector con mayor potencial de transformación, de Giddens y Poulantzas, y lo de la base social de pequeños propietarios especialmente de Castel.

92 Desocupados, estudiantes, jóvenes y amas de casa. 
en el viejo paradigma). También incorpora de Castel el concepto de "marginales" o "excluidos". En estos movimientos sociales no es importante para identificarse la situación económica de los participantes, sino otros elementos como su género o su edad. Obviamente la clase obrera no es vista como un posible sujeto transformador, sino que se la observa como el sostén más importante del sistema.

Pero finalmente Offe destaca las debilidades de estos nuevos movimientos sociales. La falta de organización estable, les permite una incidencia muy fuerte, pero que se da en períodos breves de gran movilización. Luego, cuando esto desciende, quedan muy pocos: los activistas. La cuestión para poder sobrevivir es qué tipo de alianzas se teje con los elementos del "viejo paradigma", pensado en términos de derecha e izquierda.

Así para Offe se dibujan tres posibles alianzas: derecha e izquierda contra NMS, NMS y derecha y NMS e izquierda. Solamente esta última alianza tendría alguna posibilidad de avanzar en reformas exitosas, para que los valores de los NMS se incorporen socialmente. Esta alianza se basa en la nueva clase media, y es la única que puede quebrar el dominio de la vieja política. Para que esa alianza pueda darse los partidos socialdemócratas deben abandonar su política centrada en la clase obrera, moderar sus expectativas de transformación y sumar a la nueva clase media. El resultado es que el camino a seguir por los nuevos movimientos sociales es el de formar instituciones, incorporarse a los partidos políticos ya existentes y aislar a la clase obrera.

Klaus Eder (1998) se pregunta por la importancia que tienen los movimientos sociales, diferenciándolos de los partidos y los grupos de interés. Plantea una separación entre la teoría de los movimientos sociales europea (lo que llama el paradigma de la identidad) y la teoría de la motivación de recursos americana (o paradigma organizacional). En la discusión sobre el papel de los movimientos sociales en la sociedad moderna, postula como una postura radical a Touraine (la denomina respuesta "macro social"), quién sostiene que los movimientos sociales son un elemento central en la dinámica de la sociedad actual. Serían el sustituto de la antigua identidad de clase, construyendo una nueva identidad a través de la acción colectiva, en una situación donde las instituciones pasan a ser secundarias para la vida social. Contra esto Eder plantea que la clase todavía se muestra como un factor explicativo de los mismos movimientos sociales (destacando allí el tema del radicalismo de la clase media) y que las instituciones moldean la vida social mucho más que los movimientos sociales. En definitiva para él es a la inversa de Touraine: los movimientos sociales están más moldeados por la sociedad moderna que la sociedad por los movimientos sociales. 
Después reseña la "respuesta micro social". Y la pregunta allí es, justamente, ¿por qué las personas se suman en acciones colectivas tales como los movimientos sociales? Se enfrentan la explicación racionalista (o acción racional, insertada en una situación de elección) y la explicación interpretativa de la acción social (o acción razonable, en una situación de búsqueda de identidad, formulada desde la teoría de la acción comunicativa de Habermas, 1983). Para Eder en la primera el modelo de cooperación es el mercado (la búsqueda de la mejor situación individual) y en la otra el discurso, como forma de generar consensos que construyan identidades. Considera que estos enfoques han llegado a un acuerdo sobre la base de una mirada individualista, entendiendo que hay elecciones, pero que estas muchas veces se apartan de lo esperable en términos de la conveniencia o la racionalidad abstracta, cosa que se explica por la influencia de las identidades (normas, valores, lealtades).

Ese consenso fue sintetizado por Nidhardt y Rucht (1991) que hablan de estructura de oportunidades, profundizando el concepto planteado por Tarrow, quién veía ese contexto de oportunidad por fuera de los movimientos sociales (como condición previa para su realización) y no como parte de la misma realidad.

En esta discusión Eder propone una explicación institucionalista de los movimientos, tomando como "caso" a los movimientos ecologistas. En ellos es un factor clave el discurso público como forma de sustentar su postura, compitiendo con los "grupos de presión tradicionales", como los sindicatos, y tomando importancia la "reflexividad" (recuperando especialmente a Habermas y Giddens). A través de sus acciones los ecologistas instalan el medio ambientalismo como un discurso generalizado, pero esto, al presentarse como un bien común, invita a no comprometerse y a esperar que otros lo hagan por uno. Se vuelve a plantear aquí el viejo dilema del polizonte de Olson $(1965)^{93}$.

Por ello la movilización permanente se hace imposible y lleva al desgaste de los grupos. Lo que deben buscar los movimientos sociales es institucionalizarse, generando formas de "autoorganización" por fuera del Estado pero que sean reconocidas por él, para poder influir en sus políticas (es la propuesta de la necesidad de formar ONG's, sin problematizar la cuestión del control estatal sobre estas organizaciones). Esto lo toma desde una perspectiva neo institucionalista ${ }^{94}$ y construccionista $^{95}$. Porque para Eder lo que se esta creando (y es muy positivo) es un

\footnotetext{
${ }^{93}$ El que obtiene algo sin hacer nada a cambio, como aquel que viaja en un barco sin pagar el pasaje, ni trabajar. Es asimilable a la figura del "oportunista" que propone Tilly, cuando diferencia los diversos roles que toman los individuos en las acciones colectivas.

94 Donde todo movimiento es una institución, ya que configura un sistema de reglas compartido. Allí juega un papel central lo simbólico, ver Lash y Urry, 1998.

95 Destacando el papel central de los medios de comunicación en la conformación de los movimientos sociales. Ver Habermas, 1983 y Powell y Di Maggio, 1991.
} 
orden pos corporativo, donde todos los actores podrían ganar y las diferencias ya no serían de "suma cero". Desde esta base teórica creemos que puede pensarse la hipótesis de Schuster y su equipo (2006), que plantean que desde 1996 la protesta social en Argentina se ha descorporativizado.

Estas teorías van sustituyendo las interpretaciones individualistas del anterior consenso por una nueva base: el situacionismo (Knorr-Cetina, 1988). En este abordaje no habría posibilidad de explicaciones totalizadoras sino solamente parciales. Esto lo criticábamos como una consecuencia del enfoque de Bourdieu, pero allí la totalidad seguía puesta como horizonte: en el situacionismo directamente se destaca como algo bueno el no poder dar una explicación holística del proceso social.

En estos enfoques hay una "elección" de un movimiento a estudiar, al que se lo aborda por fuera de la totalidad (en este caso se "elige" a los ecologistas). Se descalifica a organizaciones como los sindicatos, llamándolos grupos de presión, pero no se demuestra porqué para entender al conflicto social actual es más importante investigar a los ecologistas que a los sindicatos. ¿Dónde se agrupan mayores sectores? ¿Quiénes inciden en los cambios sociales? ¿Quién juega un rol más activo en el conflicto social actual en Argentina y en el mundo? Creemos que el planteo de Eder está más cerca de construir una propuesta política que avance hacia la institucionalización de los movimientos sociales, que en aportar a la comprensión del proceso de movimiento de la sociedad.

Para Melucci (1994, 1999 y otros) no es posible afirmar con claridad qué tipo de sociedad es esta en la que vivimos (sí considera demostrado que ya no es industrial, y, por lo tanto, ya no sería "capitalista tradicional") y por eso se niega a conceptualizarla. Las características fundamentales son: el papel central de la información (que lleva a que las decisiones sean cada vez más reflexivas), la planetarización del sistema (todo hecho afecta a todo el sistema, no hay nada que no sea sistémico), la información vista como un recurso (en especial simbólico, lo cual demostraría que las demás necesidades básicas están satisfechas), y que la información no puede ser un recurso sino hay capacidad de procesarla. Por eso la capacidad de descifrar los códigos determina cada vez más las relaciones de poder.

Los problemas son muy variables y es difícil identificar actores y conflictos. Por eso cree que ha sido un error mucho de lo que se produjo sobre movimientos sociales (reconociendo que él fue parte de este "equívoco"), en especial la discusión sobre si realmente eran procesos novedosos o no ${ }^{96}$. Para Melucci esa discusión ya no importa: lo relevante es si somos capaces de comprenderlos, y para eso debemos revisar

\footnotetext{
${ }^{96}$ Destacando que lo que sí aparece como nuevo es su carácter distinto a los "tradicionales" movimientos de clase.
} 
nuestros viejos instrumentos, que son parte de la vieja sociedad, y construir otros para analizar lo que tienen de la nueva sociedad estos nuevos fenómenos.

Los movimientos sociales contemporáneos plantean cuestiones globales. Y la cuestión del peso de la información genera un proceso de individualización, ya que las redes necesitan terminales que lo interpreten y decodifiquen, y esas terminales necesariamente son individuos. Esto genera un proceso complejo de relación de estas "experiencias individuales" con el nivel colectivo. Un proceso que ya no puede explicarse desde la psicología freudiana, porque el individuo actual no tiene el problema de reprimir su libido sino de tener un exceso de liberación, un exceso de posibilidad de consumo en el mercado, donde las diferencias entre clases sociales ya no serían en términos materiales sino en términos del acceso desigual a los nuevos recursos de individuación. Cada uno puede pasar a ser su propio centro autónomo y por ello lo que ha perdido significado son los sujetos colectivos, entendidos como personajes que juegan un papel clave en la historia.

Su interpretación sobre los movimientos sociales en la actualidad parte de que ya no es necesario estudiar lo que llama "la estructura social" o "de clases", para comprenderlos. No se precisa analizar lo total, sino comprender cada hecho en su especificidad. Si bien plantea la necesidad de mantener una mirada sistémica esto es solamente para tratar de entender cómo repercute cada hecho en el resto del sistema, pero no para comprender el hecho que investigamos como parte de esa totalidad en movimiento.

Critica la perspectiva de la acción colectiva por su necesidad de pensar que las movilizaciones siempre son por recursos, y porque ven el proceso cuando ya está en movimiento. Compartimos su indicación de que el movimiento está en acción mucho antes de hacerse visible. Desde allí propone, como metodología, que debemos buscar esas "redes invisibles" que conforman el origen de todo movimiento social, rastreando “... los niveles intermedios entre los individuos y las movilizaciones organizadas" (1999: 26). Por eso lo importante es encontrar esos “... mecanismos que generan que los individuos se junten: las redes de reclutamiento y la motivación para la participación (Klandermans, 1986)" (Melucci: 379). Claramente, pese a lo interesante del primer planteo, su propuesta metodológica parte del individuo y no de lo social.

Critica a Touraine $(1973,1978,1984)$ por su necesidad de recurrir a una identidad colectiva que no define, y que le aparece como esencialista, y a Pizzorno $(1978,1983)$ quién define esta identidad desde la "tradición marxista" de la comunidad de intereses. Pero sí toma la idea de que los individuos se suman a procesos colectivos a partir de su capacidad diferencial para definir una identidad y participar en su proceso de construcción. Allí toma el modelo de Offe (1985) del reclutamiento de 
los activistas de los nuevos movimientos sociales: la nueva clase media, los estudiantes y amas de casa y los elementos independientes de la "vieja" clase media. El sector más movilizado es el proveniente del primer grupo, justamente el que tiene más recursos para construir una identidad y para institucionalizar el proceso, hecho que aparece como el objetivo central de todo el movimiento.

Nuestro enfoque está en discusión con el que plantea Melucci, cuyos resultados de investigación son complejos de comparar, ya que niega la necesidad de estudiar la totalidad. Además, enfrentando tanto a la teoría de la acción colectiva como a la del socialismo científico, plantea como un error epistemológico entender a los hechos colectivos como fenómenos a estudiar en su dinámica. Según él esto implica suponer que un hecho colectivo puede analizarse como un dato empírico en sí mismo, y eso lleva a subsumir los múltiples procesos individuales que llevaron a cada individuo a sumarse a ese hecho. Aquí no hay, como en Tilly, un abordaje desde la acción, desde el conflicto, sino desde las organizaciones, lo institucional y lo individual.

El hecho colectivo es fragmentado en los múltiples hechos individuales. Obviamente aquí no sería posible (ni se buscaría) encontrar una estrategia central en el proceso o un resultado general de lo que sucedió. A lo sumo habría una multitud de explicaciones individuales de lo que hizo o dejo de hacer cada uno en el marco de un acontecimiento determinado, pero nunca se podría llegar a una síntesis.

\section{E1 situacionismo:}

Las teorías que englobamos bajo el nombre de "situacionismo" coinciden en que los nuevos conflictos sociales de la actualidad no se plantean en términos de clase ni de la antinomia reforma-revolución. Para ellos, en el marco de un "capitalismo tardío" y un proceso de desindustrialización, los movimientos sociales buscan implantar una soberanía situacional que sólo puede ser entendida desde su especificidad singular. Las luchas no son comunicables entre sí, no pueden traducirse porque cada una parte de su "situación". Para ellos esto es una fortaleza para la lucha, porque lo múltiple se transforma en incontrolable. Pero para nosotros si se dificulta hasta la posibilidad de comunicación entre las luchas, es casi imposible que haya posibilidad de construir un proyecto colectivo alternativo al del capitalismo.

Para comprender estos procesos proponen estudiar cada movimiento en sí mismo, en su dinámica interna, sus formas de funcionamiento, etc. Esto es más importante que observar los conflictos en sí mismos, donde se expresan los otros sectores de la sociedad. No importa casi contra quién o cómo se lucha, sino comprender las especificidades de construcción de cada grupo. En este sentido hay varias coincidencias con el enfoque de Melucci y los nuevos movimientos sociales. 
Además en el situacionismo hay una coincidencia muy marcada entre lo que se investiga, lo que se considera que explica lo investigado, y el programa político que estos intelectuales consideran válido para construir un mundo más justo. Entre ellos los más destacados son John Holloway (2002), Michael Hardt y Toni Negri (2002). Para el estudio de la realidad argentina sus exponentes son el Colectivo Situaciones (2002a, 2002b), Raúl Zibechi (2003), Francisco Ferrara (2003) y Diego Sztulwark (2002), entre otros. Otros teóricos que aportan a comprender esta concepción son Alain Badiou (1999), Giorgio Agamben (1998), Paolo Virno y Silvayn Lazarius.

Desde su perspectiva el conflicto actual se caracteriza por esa múltiple singularidad y por la búsqueda de construir "soberanías situacionales". En esa línea es complejo pensar en la coordinación de estas multiplicidades que no buscan ir más allá de su territorio y su singularidad. De allí se deduce que su programa plantea que se debe romper con la visión leninista de la necesidad de tomar el poder. La tesis fundamental de todos estos autores es la de "Cambiar el mundo sin tomar el poder" (título, además, de uno de los más conocidos libros de John Holloway).

En general las investigaciones que se realizan desde este marco teórico no logran superar la narración de experiencias individuales o de pequeños grupos. Es complejo discutir esto con ellos, ya que lo que nosotros vemos como una falencia ellos lo destacan como una virtud: como el movimiento es fragmentado y allí, justamente, está su fortaleza y su pulsión de vida, el buscar en estos procesos generalizaciones y explicaciones totalizantes llevaría a ahogar esos impulsos, y a transformarlos en dinámicas que sólo pudieran ser explicadas en los términos clásicos del poder.

Su línea metodológica lleva a que cada investigador "elija" alguno de los movimientos que construyen sus experiencias desde estos lineamientos y se desarrolla una historia donde lo que importa es la dinámica interna de cada grupo por sobre los procesos sociales colectivos. Lógicamente desde esta perspectiva es fundamental lo que dicen las personas, sus testimonios. Se desdibuja la postura del investigador, y se lo mezcla con el testimonio del sujeto que realiza la acción, quién "explica" su intención y las razones y resultados de su actuación política actual y pasada.

Los cambios, para ellos, no surgen del proceso de luchas sino de las transformaciones internas en las organizaciones. $Y$ estos cambios aparecen como diseñados por los militantes, quienes aparentemente pueden construir sus organizaciones a partir de sus ideas, sin que las características de la base material y de los ciclos de enfrentamiento social los condicionen. Así destacan constantemente la necesidad de no confrontar, de no militarizarse, de no centralizar. Lo que debe 
buscarse es construir "asimetrías", rompiendo con las respuestas "simétricas", que terminan reproduciendo la lógica sistémica.

Parten de una concepción que consideramos voluntarista, donde pareciera que cada sujeto hace lo que quiere hacer, y no que muchas veces hace lo que puede, o hace cosas que ni siquiera sabe que esta haciendo. No se explica porqué lo que caracterizan como "viejas formas y organizaciones", siguen siendo los canales a través de los cuales se expresan la mayoría de los conflictos. Esta teoría, que postula la necesidad de no luchar por el poder sino de construir espacios de anti o contra poder, consolida la fragmentación de los movimientos. Partiendo de la realidad de que en el capitalismo las relaciones de opresión se extienden a todos los ámbitos de la sociedad (lectura que Marx y Engels postulan como tendencia del sistema en el Manifiesto Comunista), ellos sacan la errónea conclusión de que no hay un centro hacia el cual deba desarrollarse una política que busque transformar la sociedad.

Como el poder es múltiple y está repartido de forma dispersa, se lo debe enfrentar con formas semejantes: múltiples, dispersas y ancladas en las situaciones particulares (y no en búsquedas generales). Esta postura lleva a una importante dificultad para comprender la sociedad, ya que no se considera ni posible ni deseable el dar una explicación holística del proceso social.

Coincidimos con su postura de criticar la comprensión de las luchas actuales desde la lógica del excluido-incluido, aunque no lo hacen desde nuestra perspectiva (que considera que los supuestos "excluidos" no existen, sino que son parte del funcionamiento del capitalismo actual, y que por ello están "incluidos" en el sistema) sino desde la concepción de que no se debe buscar ser incluido, sino construir poderes alternativos desde la exclusión. Esto es posible porque cada situación debe entenderse como una totalidad concreta (o sea que puede explicarse desde su misma particularidad) sin necesidad de referirse a lo general (lo que denominan una totalidad abstracta).

Para Hardt y Negri las clases existen pero no son el sujeto del cambio social. Se oponen a la necesidad de la representación y de organizaciones estructuradas con instancias de conducción permanentes. Desde su perspectiva esto llevaría a una síntesis de lo múltiple, que sacaría fuerza a la lucha. Entonces el sujeto de las protestas es la "multitud", un conjunto indiferenciado de "personas" que se movilizan juntas, pero que no tienen una pertenencia o intereses comunes más allá del hecho en sí mismo. La herramienta central de lucha es el "éxodo", un escape hacia los márgenes del sistema, donde es posible construir espacios alternativos.

La propuesta del éxodo como forma clave de rebelión plantea que esto genera "un nuevo republicanismo" (como ya veíamos en Luhmann, 1997), compuesto de 
"deserción, éxodo y nomadismo", sin aclarar si se da de manera individual o colectiva, o si es un proceso material o que se realiza en el plano de lo ideal. Para nosotros igualan así los viajes de placer de los jóvenes europeos hijos de la burguesía que disfrutan del exotismo de los países dominados, con la inmigración desesperada de los pobres de los países oprimidos en búsqueda de trabajo, o tratando de escapar de la muerte por hambre, guerras o persecuciones. Es el problema de no incorporar en el análisis a las relaciones de fuerzas objetivas, que nos permiten comprender que un hecho que en el plano de lo aparente parece tener el mismo contenido, expresa situaciones de clase diametralmente opuestas. Esa visión les impide observar la evidente diferencia en la base material de estos fenómenos, y por ello el carácter totalmente distinto que cada hecho representa.

El individualismo metodológico:

Touraine $(1979,1991,1997,2006)$ tiene una amplia trayectoria como investigador que no puede ser encasillada. La discutible decisión de enmarcarlo dentro de la figura del "individualismo metodológico" la realizamos por sus últimos desarrollos teóricos, que han avanzando hacia una individualización extrema de los procesos sociales, y al abandono del abordaje social de los conflictos.

Sin embargo muy brevemente destacaremos también lo que podríamos denominar los planteos "clásicos" del "primer" Touraine, cuyos aportes al desarrollo de conocimiento por parte de las ciencias sociales son indiscutibles. De sus primeras investigaciones surgen conceptos como los de conciencia obrera, conciencia proletaria y conciencia orgullosa (1979 y otros) que, por ejemplo, retoman Svampa y Pereyra (2003: 135) para su trabajo sobre el movimiento piquetero.

Touraine veía en los movimientos sociales a las fuerzas que podían generar cambios en la sociedad moderna. De hecho fue de los primeros en acuñar el concepto de "nuevos movimientos sociales", en sus estudios sobre el mayo francés. Para 1991 conceptualiza a los movimientos sociales como conjuntos sociales que se movilizan generando acciones conflictivas para buscar la transformación de las relaciones de dominación social. Pero, esto es fundamental y lo emparenta con el primer grupo de teóricos que reseñamos en este trabajo, las diferencias ya no son en términos de disputa por los recursos materiales o por los intereses de clase, sino por los recursos culturales, el conocimiento, las reglas éticas, etc. Esto los diferencia de los "antiguos" movimientos de la clase obrera, que sólo habría sido el actor fundamental del conflicto durante el siglo XIX. 
Diferencia "movimiento social" de luchas ${ }^{97}$ y de las "conductas colectivas"98. Para él los países centrales han perdido su hegemonía mundial y se debe concebir a las clases solamente como actores, entendiendo a los conflictos como expresiones de coyunturas, y no como indicadores de contradicciones estructurales. Por eso destaca la necesidad de hablar de movimientos sociales, en oposición al concepto de clases sociales.

Únicamente el movimiento social tiene un potencial transformador. Pero ese potencial está limitado al ámbito cultural, en el que ejerce su actividad, y que es, para Touraine, el espacio central de la disputa.

Ya aparece en sus trabajos de la década del noventa su interpretación de las "fuerzas no sociales". Para él, por ejemplo, las luchas destruyen la referencia a una sociedad. Lo social se le empieza a deshacer entre los dedos.

En su trabajo más reciente (2006) observa tres etapas en los movimientos sociales: la de los derechos políticos, la de los derechos sociales y la de los derechos culturales, que sería la actual. Considera que la disputa por lo cultural pasa al plano individual, ya que se trata del individuo que lucha por ser "él mismo". Ya no se debe hablar de actor social sino de "sujeto personal", y en lugar de movimiento social propone hablar de movimiento cultural. Es un texto donde son planteadas como "fuerzas no sociales" el mercado, el Estado, la guerra y hasta la misma búsqueda del individuo por conseguir su libertad. $Y$ es que esa libertad ya no se construiría por una transformación social, sino por un camino "personal". La única lucha que ve es por los derechos humanos contra el gobierno, las corporaciones y los grupos políticos, que son analizados como "no sociales". Lo social se ha desconfigurado, ha caído, y estas luchas se dan por fuera de lo social.

El individualismo es considerado un proceso objetivo e inmodificable, y no una expresión subjetiva de la imposición hegemónica del capitalismo. Por eso la lucha que debe realizarse no es social sino cultural contra las fuerzas "... que impiden que seamos nosotros mismos" (Touraine, 2006: 131). Toma a Giddens y su concepción de la reflexividad, pero sumando más individualismo, ya que para él este sujeto personal se vuelve sobre sí mismo y debe convertirse en un "sujeto individual", en alguien que sólo dependa y sea soportado por él mismo “... abismados en lo más profundo de nosotros mismos para escapar de las ideologías de la tierra, del pueblo o de la comunidad"(2006: 133); ya que: “El sujeto es su propio fin"(2006: 140).

\footnotetext{
${ }^{97}$ Conflictos que buscan actuar como mecanismos de modificación de los sistemas de decisiones, pero que no harían referencia a la sociedad.

98 Entendidas como acciones conflictivas que pueden explicarse como un esfuerzo de defensa, reconstrucción o adaptación de un elemento enfermo del sistema social. Buscan reconstruir la sociedad tal como estaba cuando algún elemento aparece en peligro, y por eso deben analizarse por sí mismas en términos de integración o desintegración.
} 
Ese logro del sujeto personal solamente puede realizarse en el marco de la democracia representativa, y sin tomar partido por ninguna causa colectiva excepto por lo que denomina "los derechos del hombre". Consideramos que se trata de una teoría que no acepta ninguna posibilidad de que esta realidad pueda ser transformada.

Como todo parte del individuo y de su mente, no hay casi forma de estudiar esto; solamente queda lo que Touraine llama el "autoanálisis", donde el "actor" debe analizar su acción. Estamos mucho más lejos de esta mirada que de abordajes como el de Tilly o Tarrow, donde vemos una teoría construida para abordar la realidad. En cambio aquí se desarrolla una teoría que pretende "ordenar" a priori una realidad que ni siquiera aparece. Como todo es individual desecha y critica la noción de identidad, distanciándose así de su primer mirada y de un enfoque como el de Melucci y otros teóricos de los nuevos movimientos sociales.

Pierre Rosanvallón $(1992,1995)$ parte de presupuestos semejantes a Castel en el análisis de los cambios sociales que se habrían dado en lo objetivo. Como Castel ve en el "Estado benefactor" de los países de Europa Occidental al soporte que mantenía la cohesión de la sociedad. Esto se da hasta fines de los setenta y lo que él va a proponer es discutir cómo puede hacerse para que, en el marco de los cambios que se han producido, el Estado pueda seguir cumpliendo ese antiguo papel.

Considera que estamos ante un proceso de "individualización de lo social", que parte de una profundización de las características centrales de la modernidad. Este proceso es presentado como algo que se dio de manera casi abstracta, y no se lo relaciona con el aniquilamiento de los proyectos alternativos que se desarrolla en las décadas previas a la imposición hegemónica del capital financiero. Lo mismo le critica Celi (2008), quién analiza el trabajo de Rosanvallón sobre "La consagración del ciudadano..." (1992), cuando destaca que para el autor "En la explicación sobre el surgimiento del sufragio universal, la construcción y consolidación de nuevas ideas "vuela" en un "cielo" jurídico y político. Esta abstracción carece de bases materiales." (Celi, 2008: 167). Allí destaca que también en estos trabajos se invisibiliza la dinámica económica y social, no presentando las tensiones y los conflictos, y mostrando un proceso supuestamente lineal, evolutivo y sin saltos.

Desde esa interpretación general, para Rosanvallón el conflicto actual tomará un carácter centralmente individual de reclamos por la ciudadanía. Ya no se hablará de clase o pueblo, sino de actor o, mejor aún, de individuo o persona. La posibilidad de lograr mayores derechos individuales evita que cualquier conflicto pueda plantearse como necesaria la tarea de una transformación social, ya que el derecho ciudadano parte de la lógica liberal de pensar al individuo como encerrado en sí mismo, como una "monada". En cambio la clase social o el pueblo, cuando se mueven para luchar 
por sus intereses, necesariamente hacen referencia a una transformación más profunda, ya que siempre se refieren a procesos colectivos.

Cada persona debería preocuparse por sus derechos específicos, desvalorizando la participación colectiva como forma de garantizar una mejor vida en sociedad. La búsqueda de mayores derechos para cada uno se conseguirían a través de la acción de las personas, y no de colectivos sociales en lucha.

El trabajador está totalmente fragmentado y es parte de la sociedad civil. Por ello las luchas no pueden ya darse desde esa identidad, sino desde la del ciudadano, que representa al único espacio que queda de sociabilidad: la "comunidad". Pero como el ciudadano parte de la idea de individuo, los caminos hacia una posible resolución de los conflictos son necesariamente personales.

Así el Estado deberá generar programas para solucionar problemas particulares. El antiguo Estado "providencia" generaba marcos generales, adecuados para poblaciones estables y homogéneas. Sin embargo esta nueva sociedad plantea múltiples y fragmentados conflictos. Para él la desocupación es el ejemplo más claro de esto, considerando que la situación de cada desocupado debe tratarse en forma particular, analizando las trayectorias individuales de vida.

Creemos que esta es la base ideológica de la culpabilización de la desocupación, que ya veremos como afectó a la clase obrera argentina en los primeros años de la década del noventa. Al analizarlo como problemáticas individuales, se carga al desocupado con la supuesta falta de capacitación o de iniciativa personal. Las resoluciones serán particulares y no parece haber posibilidades de generar respuestas colectivas.

Son interesantes los paralelos de esta visión con la de Touraine. Se observa esto en su indicación metodológica para estudiar la realidad. Como se trata de procesos a nivel personal, coincide con Touraine en que "... para analizar lo social, hay que recurrir cada vez más a la historia individual antes que a la sociología" (Rosanvallón, 1995: 192).

La incapacidad de estos enfoques para comprender y explicar el movimiento de la sociedad o el conflicto actual en Argentina, se muestra en las conclusiones que Rosanvallón saca de este análisis cuando debate sobre la posibilidad de que los desocupados puedan organizarse. Su enfoque considera que esta sociedad es absolutamente fragmentada, y por eso Rosanvallón no habla de trabajadores desocupados, sino de "excluidos". Considera entonces que sería un "milagro sociológico" que esos excluidos puedan organizarse.

$\mathrm{Y}$ es que esto es correcto y coherente desde su perspectiva general. Si todas las situaciones son resultantes de procesos individuales sin causas estructurales, y por 
ello sin intereses comunes, no caben dudas de que no habría posibilidad de conformar movimientos colectivos. El problema es que esto no es así en esa "realidad rebelde" a la que denominamos relación de fuerzas sociales objetivas.

Para Rosanvallón es imposible que estos excluidos se movilicen y puedan generar formas de representación social: "No constituyen una fuerza social a la que podría movilizarse. No son los nuevos proletarios de la sociedad de la desocupación. No tienen un interés común propiamente dicho. (...) no constituyen una clase que pueda tener sus delegados o voceros. Es por eso que no hay sindicatos de desocupados y que todos los intentos de transformar, de una u otra manera, en fuerza colectiva organizada a los millones de desempleados siempre fracasaron." (1995: 195)

Como marcábamos en el primer capítulo, desde el socialismo científico los trabajadores desocupados son considerados parte de la clase obrera, expresión de la tendencia del capitalismo a generar población sobrante para las necesidades de comprar fuerza de trabajo que tiene el capital. Población sobrante que es parte de la clase obrera, y que por ello no puede entenderse como algo externo a la sociedad.

Consideramos que la explicación desde lo individual que proponen Rosanvallón y los últimos trabajos de Touraine, no consigue generar resultados de investigación que aporten a un conocimiento profundo de los procesos sociales. Pensar que "...la pobreza sigue inscripta fundamentalmente en una historia personal" (Rosanvallón, 1995: 142) elimina la posibilidad de comprender los procesos reales que hicieron posible, por ejemplo, el impresionante aumento de la pobreza en América Latina durante los años noventa. Suponer que la explicación de estos acontecimientos debe buscarse en la historia personal de cada individuo culpabiliza a la víctima, y nos quita la posibilidad de develar los verdaderos procesos que se desarrollaron para que esto sea posible.

\section{2.a. Sobre el movimiento de la sociedad argentina}

En este apartado realizaremos un abordaje sobre algunos de los principales enfoques acerca del movimiento de la sociedad en la Argentina actual. Organizamos la exposición realizando una breve presentación de trabajos representativos sobre la protesta en la Argentina actual, debatiendo y relacionando sus aportes con el marco teórico y metodológico del cual partimos. Como ya lo planteamos, nos afirmamos en una base de conocimiento acumulado que nos permite avanzar en el desarrollo de conocimiento acerca del movimiento de la sociedad en la región que estudiamos.

En este sentido marcaremos en este apartado sólo los nombres y unos pocos datos de los trabajos en que basamos muchas de nuestras hipótesis y resultados, ya que luego iremos volcando los elementos centrales de esas producciones, 
cruzándolos con nuestra propia investigación. En cambio realizaremos una exposición más desarrollada de investigaciones sobre el movimiento de la sociedad argentina que aportan al conocimiento científico, pero con las cuáles tenemos algunos ejes de debate.

Como referencias generales (que deben completarse con lo citado en la bibliografía) sobre el movimiento de la sociedad argentina de los últimos años, y a fin de ser utilizadas como base del análisis de las rupturas y continuidades que se presentan en los conflictos a estudiar, partimos de los resultados de investigación desarrollados por el PIMSA sobre el ciclo de rebelión en la Argentina actual.

Entre otros destacamos los trabajos de María Celia Cotarelo ("Conflicto social en Argentina entre 2002 y 2008"; "La rebelión en la América Latina actual. Un ejercicio cuantitativo"; "Movimiento sindical en Argentina 2004-2007: ¿anarquía sindical?"; "El motín de Santiago del Estero, Argentina, diciembre de 1993"; "La protesta en la Argentina de los 90"; "Crisis política en Argentina (2002)"; "Aproximación al análisis de los "sujetos" emergentes en la crisis de 2001-2002 en Argentina"), Nicolás Iñigo Carrera ("La huelga general como indicador de momentos de ascenso y descenso en la lucha de la clase obrera. Argentina 1984-2002"; "Fisonomía de las Huelgas generales de la década de 1990 (1992-1999)"; "De la revuelta del hambre a la insurrección espontánea”; “Las huelgas generales, Argentina 1983-2001: un ejercicio de periodización"), Nicolás Iñigo Carrera y María Celia Cotarelo ("La protesta social en los 90. Aproximación a una periodización"; "Los llamados 'cortes de ruta' Argentina 1993-1997"; "Luchas sociales en la Argentina actual (1993 - 2001)"; "La insurrección espontánea. Argentina Diciembre 2001..."; "Algunos rasgos de la rebelión en Argentina (1993 - 2001)"). Un trabajo clave para comprender las características del comienzo del período que estudiamos es el de Nicolás Iñigo Carrera, María Celia Cotarelo, Elizabeth Gómez y Federico Kindgard (“La revuelta. Argentina 1989/90”).

Estos artículos presentan, en su conjunto, una síntesis sobre las luchas sociales en la Argentina de los últimos años, las formas que adopta y los grupos que las llevan adelante. Cuentan con análisis cualitativos y cuantitativos que dan sólidas respuestas a algunos interrogantes claves sobre las luchas: su adscripción de clase, su supuesta "novedad", la naturaleza de las herramientas de lucha utilizadas, etc. Además permiten acercarnos a los conflictos con una visión diacrónica y totalizadora, presentando en forma clara el proceso de acumulación de los sectores populares, el papel de cada sector (ocupados, desocupados, pequeña burguesía, pobres, jubilados, estudiantes, etc.) y las respuestas que articula el poder.

Desde la misma perspectiva del PIMSA trabajos como los de Elizabeth Gómez y Fedérico Kindgard ("Los cortes de ruta en la provincia de Jujuy. Mayo/Junio de 
1997"), de Paula Klachko ("Cutral Có y Plaza Huincul. El primer corte de ruta (del 20 al 26 de Junio de 1996) Cronología e hipótesis" y "El proceso de lucha social en Corrientes, marzo a diciembre de 1999. Los "Autoconvocados") y del grupo "Contraviento" (que analizaremos en el siguiente apartado), nos aportaron a pensar cómo encarar estudios de procesos de conflicto social en regiones específicas del país sin perder ni la articulación con el proceso general ni las características particulares. En este sentido la síntesis que luego realiza Klachko de diversos procesos regionales en su tesis de doctorado ("La forma de organización emergente del ciclo de la rebelión popular de los '90 en Argentina'), abona el desarrollo de esta perspectiva epistemológica. Allí Klachko estudia distintos conflictos observando que la asamblea es la forma de organización que emerge del ciclo de rebelión.

Desde otras perspectivas, pero también referenciados en la teoría del materialismo histórico, rescatamos algunos trabajos que analizan procesos de conflicto social en escenarios regionales. De ellos tomamos elementos metodológicos y la capacidad para articular la mirada local con la perspectiva general.

Los artículos de distintos investigadores de la Universidad Nacional de Mar del Plata también aportaron a nuestra perspectiva. Entre otros los de Agustín Nieto ("Conflictividad obrera en la industria de la pesca, 1997-2008"; "Conflictividad obrera en el puerto de Mar del Plata: del anarquismo al peronismo..."; "El Argentinazo: entre lo consciente y lo espontáneo"; "Lucha de calles en el puerto de Mar del Plata. 28 y 29 de Junio de 2000"), Gustavo Contreras ("En río revuelto ganancia de Pescador. El gremio marítimo y el peronismo"; "El peronismo obrero. La estrategia laborista de la clase obrera durante el gobierno peronista. Un análisis de la huelga de los trabajadores frigoríficos de 1950') y Guillermo Colombo ('Los burócratas son ellos'. Una aproximación a la contienda gremial en el Sindicato de Obreros de la Industria del Pescado, Mar del Plata (1997-2007)"; "Cuando los trabajadores se vuelven 'vándalos'. Descripción y análisis de un 'estallido social' en el puerto de Mar del Plata (año 2000)"; "Conflicto social en el puerto de Mar del Plata. Los medios y sus fines. Una aproximación crítica en torno a la cobertura mediática de la protesta social"). Específicamente fueron claves para construir nuestro apartado sobre la dinámica de luchas en el sector pesquero.

Varios trabajos de Oscar Videla nos aportaron la necesidad de una mirada atenta a las características que toma el proceso general en coyunturas locales y a cómo se entrelazan los conflictos sociales con las disputas políticas al interior de esos espacios regionales, (citamos aquí a "Una mirada a las tradiciones y prácticas obreras en el sudeste santafesino de los treinta para reflexionar sobre las continuidades históricas y las interpretaciones de la historia del movimiento obrero" y "Algunas 
reflexiones sobre tradiciones obreras e interpretaciones de la historia del movimiento obrero a través del análisis de la historia local. Conflictos intersindicales, movimiento obrero y política en el sudeste santafesino en los treinta'). Si bien no se investiga allí el período que nosotros abordamos, sí nos sirvió para pensar las dinámicas locales.

Aunque tenemos algunas diferencias con su enfoque, también es interesante el aporte de Gloria Rodríguez ("Un "Rosario" de conflictos. La conflictividad social en clave local'), quién muestra como el aumento de la conflictividad social, que para la autora expresa las conmociones provocadas por la reestructuración capitalista en su búsqueda de recomponer sus tasas de ganancia (2001: 29), se manifiestan localmente en la ciudad de Rosario. Para ello sintetiza lo que considera tres importantes procesos que presentan “... "estilos" novedosos de protesta y organización..." (2001: 30): el supermercado recuperado Tigre, las Coordinadoras de Lucha en la Universidad Nacional de Rosario nacidas en la lucha contra el ajuste y en oposición al "burocratismo de los centros de estudiantes" y el movimiento piquetero local.

Si bien destaca el peso que aún conserva la organización sindical en el conflicto social, considera como fundamentales a estos nuevos fenómenos. Realiza un interesante planteo en torno a la supuesta novedad de estas experiencias, dejando claro que en verdad recuperan viejas experiencias y prácticas de la clase trabajadora y de los "sectores populares" (2001: 30) Hace hincapié en la fragmentación de las protestas, que obstaculiza los procesos de unidad, sosteniendo que algunas de las experiencias reseñadas en Rosario muestran un intento de avanzar en procesos de unificación de los sectores en lucha.

Es claro que tomamos elementos teóricos y metodológicos de la tradición del CICSO a lo largo de todo nuestro trabajo. En el caso de los procesos de conflicto social y cambios en la estructura económica social en la Argentina de los últimos años nos aportaron especialmente los trabajos de Beba y Beatriz Balvé ("Acerca de los movimientos sociales y la lucha de clases"; "El 69 Huelga política de masas"; "Algunas consideraciones acerca de la temática de los movimientos sociales") y la clásica investigación desarrollada por Beba Balvé y otros ("Lucha de calles, lucha de clases"). Expondremos en mayor profundidad estos aportes en otros apartados de la tesis

En una línea semejante ya destacamos los trabajos de Inés Izaguirre. Específicamente nos aportaron aspectos claves en su perspectiva metodológica ("Problemas metodológicos y construcción de observables en una investigación sobre luchas obreras"; "Las luchas obreras 1973-1976 Los alineamientos de la clase obrera durante el gobierno peronista. Nuevas consideraciones teórico-metodológicas para el estudio de los conflictos obreros", este último junto a Zulema Aristizábal) y reflexiones centrales acerca de la relación entre el marco teórico del cuál partimos y perspectivas 
como las de los nuevos movimientos sociales y la acción colectiva ("Movimientos sociales y lucha de clases. Sociogénesis de una sustitución conceptual en el discurso académico"; también el artículo de Fernando Stratta y Marcelo Barrera “¿Movimientos sin clases o clases sin movimiento?'). También buscaremos abordar algunas de las problemáticas que viene desarrollando en sus últimas contribuciones Agustín Santella, especialmente en lo que hace a repensar los ciclos de conflicto laboral y su relación con el marco general de fuerzas sociales ("Ciclos de protestas laborales sin situaciones revolucionarias, Argentina 1958-2002').

Retomamos aportes de los trabajos de Pablo Pozzi, Alejandro Schneider, Hernán Camarero y Laura Pasquali, entre otros historiadores que se nuclearon alrededor de la experiencia de "Taller. Revista de Sociedad, Cultura y Política". Si bien todos se han especializado en períodos anteriores de la historia de la clase obrera argentina, consideramos que varios de sus aportes metodológicos nos permiten abordar de forma más completa nuestro objeto de estudio. Por otro lado la continuidad establecida entre el libro de Schneider "Los compañeros. Trabajadores, izquierda y peronismo (1955-1973)"; el clásico de Pozzi "La oposición obrera a la dictadura (19761982)" y el de Pozzi y Schneider "Combatiendo el capital: Crisis y Recomposición de la clase obrera argentina (1985-1993)", nos presentan un mapa bastante completo acerca de la situación de la clase obrera argentina al momento de la imposición de la hegemonía del capital financiero. Discutiremos algunos elementos y retomaremos otros en los capítulos específicos.

Especialmente nos ha interesado tomar de estos historiadores su hincapié en las posibilidades que para la construcción de la historia reciente nos brinda el testimonio de los trabajadores a través de la historia oral. Como ya lo marcamos la construcción de fuentes orales es una parte importante de nuestro acervo de fuentes y en ese sentido los trabajos de estos autores y sus contribuciones teóricas nos aportaron a nuestra mirada (por citar sólo algunos de ellos "Hacia una alternativa intelectual" de Pozzi "Historia Social e Historia Oral. Experiencias en la Historia Reciente de Argentina y América Latina", compilado por Pasquali; "Eppur si muove. De la realidad a la conceptualización en el estudio de la clase obrera argentina" y "De la Revolución Libertadora al menemismo. Historia social y política argentina" de Camarero, Pozzi y Schneider).

Consideramos que hay aportes muy significativos en los trabajos del grupo de investigadores nucleados en la Universidad de Quilmes, con la coordinación de Alberto Bonnet. Entre otros los trabajos del mismo Bonnet ("La hegemonía menemista"; "Crisis e insurrección en Argentina 2001"; "Una aproximación a la metamorfosis en el modo de desenvolvimiento de la lucha de clases en la Argentina de los 90"; "Luchas sociales 
y neoconservadurismo: a propósito de La protesta social en la Argentina (1990-2004) de Guillermo Almeyra"), los de Adrián Piva ("Algunas hipótesis sobre la relación entre modo de acumulación y hegemonía débil en Argentina (1989-2001)"; "Notas sobre la noción marxista de clase"; "El desacople entre los ciclos del conflicto obrero y la acción de las cúpulas sindicales en Argentina (1989-2001)"; "Acumulación de capital, desempleo y sobreocupación en Argentina"). También tomamos aportes de Juan Grigera ("Debates en torno a la industrialización en Argentina hasta los años '70: una reconsideración a la luz de la 'desindustrialización'.'), que desarrollaremos más adelante, y de la importante síntesis acerca de las diversas formas de rebeldía que se desarrollan durante casi la totalidad del período que investigamos, aportada por Guillermo Almeyra en "La protesta social en la Argentina: 1990-2004"

Desde este grupo se plantean especialmente dos discusiones centrales con el enfoque de PIMSA que son relevantes para nuestra investigación: la discusión sobre el comienzo del ciclo (que el PIMSA plantea en 1993, tras el motín de Santiago del Estero, y estos investigadores observan en 1996, al igual que otros autores como los nucleados en el GEPSAC ${ }^{99}$ ) y sobre la validez de las huelgas generales como indicador de momentos de ascenso y descenso de la lucha obrera (en este sentido los artículos específicos de Nicolás Iñigo Carrera y Adrián Piva serán discutidos y analizados en base a nuestros datos ${ }^{100}$ ).

Además prestan una especial atención al problema de la hegemonía y de la relación entre modo de acumulación y características del proceso de lucha y organización obrera. El debate planteado por Bonnet sobre las características del "neoconservadurismo", y el acercamiento que realiza Adrián Piva acerca de cómo esto impacta en la conciencia de la clase obrera, nos aporta elementos claves para nuestro trabajo.

Recuperan, a su vez, algunos elementos de los teóricos del situacionismo, en especial de Holloway, aunque con críticas y debates. En este sentido se puede observar un quiebre en la producción de algunos de estos investigadores, quienes en el 2002 pensaban más directamente desde una perspectiva semejante a la del situacionismo. Así, hacia el final de este apartado, citaremos el trabajo del 2002 de Hernán Ouviña ("Las asambleas barriales: apuntes a modo de hipótesis de trabajo"), enmarcado en la crítica que realizamos a la perspectiva teórica del situacionismo.

\footnotetext{
${ }_{99}$ Grupo de Estudios Sobre Protesta Social y Acción Colectiva, investigadores del Instituto Gino Germani. 100 Piva, Adrián (2009) "El desacople entre los ciclos del conflicto obrero y la acción de las cúpulas sindicales en Argentina (1989 - 2001)" e Iñigo Carrera, Nicolás (2009) "La huelga general como indicador de momentos de ascenso y descenso en la lucha de la clase obrera. Argentina 1984 - 2002", ambos en Actas XII Jornadas Interescuelas Departamentos de Historia, Bariloche, Universidad Nacional de Comahue, publicada en CD ISBN 978-987-604-153-9.
} 
Este grupo realiza una síntesis y actualización de sus producciones en la compilación de Bonnet y Piva, "Argentina en pedazos. Luchas sociales y conflictos interburgueses en la crisis de la convertibilidad". El libro se encuentra divido en dos bloques de tres artículos cada uno. El primer bloque aborda específicamente procesos de luchas sociales enfocados desde la perspectiva de encontrar los ejes de la lucha entre las distintas clases, o alianzas de clases, en los enfrentamientos sociales.

En el segundo se abordan distintos momentos del conflicto interburgués, de la disputa entre fracciones de la clase dominante. Pero es clave comprender que para los autores, en una perspectiva que acompañamos, no hay un quiebre entre una mirada y la otra: se trata de poder encontrar un enfoque que dé cuenta de la totalidad de los conflictos que ordenan el desarrollo de la sociedad argentina en esos años, entendiéndolos como parte del mismo proceso de ascenso de la lucha de clases. Por razones de ordenamiento de la información tomaremos aquí los artículos del primer bloque y dejaremos los de Matías Eskenazi ("El espectro de la dolarización..."), Julián Kan ("Vuelta previa al 2001...") y Sebastián Salvia ("Estado y conflicto interburgués en Argentina...') para ser analizados en el capítulo 5, cuando abordemos el análisis de los cambios en las relaciones de fuerzas objetivas, en la estructura económica social.

El artículo de Ouviña ("La autonomía urbana en territorio argentino. Apuntes en torno a la experiencia de las asambleas barriales, los movimientos piqueteros y las empresas recuperadas") realiza una interesante reflexión acerca de la dinámica de estas tres experiencias de movilización social, rastreando en ellas la búsqueda de autonomía por parte de los sujetos que intervienen en las mismas. Si bien se recuperan centralmente planteos de los teóricos del autonomismo, hay aquí una mayor problematización que en el artículo del mismo autor realizado en el 2002.

La continuidad del proceso demostró la complejidad de la intención de construir nuevas formas de organización, y los errores de lo que el autor denomina "el autonomismo ingenuo". Sin embargo sigue presente la idea de que las organizaciones sindícales han perdido centralidad en el movimiento de la sociedad, así como la clase obrera ocupada (a la cual solamente aborda cuando toma el pequeño sector que desarrolla la experiencia de recuperación de fábricas). Creemos que aquí se mantiene una mirada que atiende centralmente a aquellos procesos que parecen presentar algo "novedoso" (un procedimiento propio del situacionismo), perdiendo de vista las fuertes continuidades y la presencia de sujetos tradicionales, como factores claves para comprender la rebelión social de la actualidad.

Es interesante que sus conclusiones apuntan a varios elementos que nosotros veremos presentes en cómo se desarrolla el proceso de rebelión en nuestra región y que también son destacados por el PIMSA en varios trabajos de ese grupo: la 
apelación a la acción directa, la dinámica asamblearia y el surgimiento de nuevas personificaciones sociales (lo que Ouviña conceptualiza como "transformación de la subjetividad'), entre otros.

Bonnet continúa aquí algunos de los debates centrales planteados en "La hegemonía menemista". En su artículo "Las relaciones con el estado en las luchas sociales recientes...", vuelve a destacar su fuerte apuesta a comprender el cambio en las formas de desarrollo de la lucha de clases, a partir de la hipótesis de que estamos ante una metamorfosis en el "modo de desenvolvimiento de la lucha de clases", un concepto que recupera “... las cuatro dimensiones tradicionalmente asociadas con las luchas sociales, a saber, sus sujetos, sus demandas y sus modos de organización y acción" (2009: 72).

En una mirada intermedia entre los enfoques que hablan de un desplazamiento de la "matriz sindical" (criticando a Schuster) y de los que no ven un cambio cualitativo en las características del proceso de lucha de clases en la Argentina reciente (básicamente criticando a los trabajos del PIMSA), Bonnet postula que hay modificaciones claves que hacen a una nueva síntesis entre modalidades sindicales y no sindicales, y que tienen su expresión más concreta en las nuevas formas de relacionarse con el Estado.

Para comprender esta realidad propone como operador teórico al concepto de "autonomía", asumiendo la complejidad del mismo pero sosteniendo que es operativo. La tarea de observar las diversas formas de relacionarse con el Estado capitalista que se generan, puede permitir avanzar en tipologías que nos sirvan de guía en el análisis de la dimensión política de las luchas sociales.

El artículo de Adrían Piva ("Vecinos, piqueteros y sindicatos disidentes. La dinámica del conflicto social entre 1989 y 2001') es una síntesis de sus desarrollos previos, articulados en un trabajo que avanza en la formulación de una interesante mirada sobre el proceso de rebelión social en la Argentina reciente. Si bien será abordado más adelante aportamos aquí que Piva observa el desarrollo del conflicto obrero desde 1989 a 2001, marcando dos etapas. La primera hasta 1995 se caracteriza por el aumento de los conflictos defensivos, marcando el pico de conflictividad en los años entre 1992 y 1994. La segunda etapa, desde 1996, presenta un descenso de los conflictos y el inicio de un período de baja conflictividad laboral que no es revertida ni siquiera por el 2001.

Este cambio se basa en los procesos de construcción de hegemonía en torno al programa neoconservador, basado en la amenaza hiperinflacionaria, la amenaza del desempleo y la fragmentación de la clase obrera. A su vez se reestructuró la relación de los sindicatos con el Estado, desarrollando un nuevo modelo sindical basado en el 
disciplinamiento de la base obrera y la conversión de los dirigente sindicales en empresarios.

Piva observa que el proceso de aumento de la conflictividad social se inicia alrededor de una serie de conflictos provinciales, donde se pone de manifiesto la debilidad de la hegemonía que se había construido. En base a la presencia de sectores medios urbanos, de trabajadores estatales y del desarrollo de ese nuevo sujeto que será el trabajador desocupado - piquetero, se consolidará el aumento del conflicto social y el quiebre de la hegemonía menemista. Sin embargo es clave aquí recuperar la polémica con Iñigo Carrera, en torno al papel del movimiento sindical organizado y las huelgas generales. Para Piva solamente el "sindicalismo combativo" tendrá algún papel en este proceso (la CTA, el MTA y la CCC) y las huelgas generales no serán un indicador clave del proceso (en especial no las que son convocadas por la CGT "oficial").

En cambio son para él los "sectores medios", los "vecinos" y los piqueteros y sindicatos disidentes los que cumplen un rol central. Destaca a los docentes como articuladores claves de esa fuerza social, ya que por su lugar en la sociedad funcionan como un puente entre esos sectores medios y los trabajadores. La clase obrera ocupada no logra superar su fragmentación y no es un factor clave de la rebelión, como expresión de una tendencia histórica a la baja de la conflictividad laboral. Ya volveremos más adelante a los trabajos de Piva y Bonnet, que nos generan aportes y debates claves para nuestra producción.

El clásico trabajo que coordinó en 1994 Ernesto Villanueva ("Conflicto obrero. Transición política, conflictividad obrera y comportamiento sindical en la Argentina 19841989'), es un insumo clave para acercarnos a la dinámica conflictual de la que emerge el período que investigamos. En este sentido varias lecturas de Bonnet y Piva recuperan elementos de este trabajo. En la misma línea se plantean trabajos como los de Marcelo Gómez ("Origen y desarrollo de los patrones de acción y organización colectiva desafiante de los movimientos de desocupados en la Argentina"; "La conflictividad laboral después del 19/12/01: cambios en la acción reivindicativa y nuevo marco político'), que desde la mirada de la lucha de clases buscan acercarse a un diálogo con la teoría de la acción colectiva y con los que enfocan el conflicto actual desde los nuevos movimientos sociales.

Una buena síntesis de esta intención de generar estos diálogos la muestra la compilación de Villanueva y Astor Massetti (Movimientos sociales y acción colectiva en la Argentina de hoy), donde publican trabajos los principales referentes de las distintas miradas teóricas que abordan la conflictividad social en Argentina. Allí tanto Villanueva como Gómez enfocan dos debates centrales para nuestro trabajo: que el ciclo de 
conflicto tiene un punto de inflexión en 1997 con la extensión a nivel nacional de los cortes de rutas y puebladas y que ese proceso de "cambio en las formas de acción colectiva" ya se presentaba en varios elementos a fines de la década del ochenta.

El enfoque de Massetti sobre los procesos de organización de los desocupados ("Piqueteros. Protesta social e identidad colectiva"), parte de las concepciones de "desafiliación" de Castel y de elementos teóricos de Beck y Goffman. Si bien su perspectiva hace hincapié en el problema de la representación y de la identidad colectiva de los desocupados (y no en pensarlos como parte del proceso de lucha de clases) la atención que presta a las dinámicas de toma de decisiones y a la vida interna de las organizaciones, nos ha planteado la necesidad de abordar esos elementos en nuestra investigación.

Sin embargo en esa compilación la intención de establecer el diálogo entre distintas miradas queda un tanto trunca. Cada artículo específica una mirada y los intentos de síntesis establecen una lectura que hace hincapié en las concepciones de Tilly y Tarrow, sin recuperar la complejidad que se pone en juego y las discusiones que emergen de las distintas perspectivas que se manifiestan en el volumen. En este sentido consideramos que el trabajo ya citado de Aníbal Viguera ("Movimientos sociales y lucha de clases'), plantea una lectura que permite avanzar hacia miradas más complejas sobre la posibilidad de articular algunos elementos de estos enfoques, pero también de las especificidades teóricas y epistemológicas de cada marco teórico.

También se expresa una perspectiva similar en los trabajos de Atilio Borón (entre otros "Movimientos sociales y luchas democráticas: algunas lecciones de la experiencia reciente en América Latina') y en varios artículos de los compilados por Gerardo Caetano en "Sujetos sociales y nuevas formas de protesta en la historia reciente de América Latina".

En una línea semejante encontramos aportes en los artículos de la compilación "La atmósfera incandescente. Escritos políticos sobre la Argentina movilizada", realizada por Osvaldo Battistini. Entre otros destacamos los de Paula Lenguita ("El poder del desempleo. Reflexiones críticas sobre la relevancia del movimiento piquetero"), Cecilia Cross, Paula Lenguita y Ariel Wilkins ("Piqueteros: de la exclusión a la revitalización del conflicto social. Apuntes para comprender la emergencia del movimiento piquetero como un nuevo sujeto político en los conflictos de trabajo") y el de Cecilia Cross y Juan Montes Cató ("Crisis de representación e identidades colectivas en los sectores populares. Acerca de las experiencias de las organizaciones piqueteras").

Se presenta allí una caracterización sobre las diferentes líneas de investigación acerca del movimiento piquetero, sosteniendo que estos movimientos siguen 
funcionando en torno a la contradicción capital-trabajo. Sin embargo se lo presenta como "un nuevo sujeto" o un "nuevo actor", quedando, como ellos mismos afirman, a mitad de camino entre los que ven un quiebre entre estos movimientos y las luchas de la clase obrera y aquellos que los entendemos como una de las formas de lucha que adopta un sector de la clase para defender sus intereses. Es claro el rechazo al uso de la categoría de "excluidos" para analizar la desocupación, ya que los desocupados son parte del proceso de reproducción del capital en esta fase y no algo externo a la misma.

En especial en el primero de los trabajos se muestra la necesidad del uso de la categoría de clase social para estudiar el tema, y la discusión sobre el aporte que estos movimientos hacen a la disputa del poder por parte de la clase obrera como una cuestión clave a investigar. Sin embargo no se plantea una mirada que permita observar la relación de la creciente conflictividad de los trabajadores desocupados con los demás sectores de la clase obrera o con el movimiento general de la sociedad. Desde esa perspectiva comparten la postura acerca de la supuesta perdida de centralidad del conflicto salarial y del papel de los sindicatos en la conflictividad actual.

Claudio Lozano ("Contexto económico y político en la protesta social de la Argentina contemporánea") presenta a la crisis del 2001 como una crisis del régimen implementado desde 1976 que fue profundizado por el menemismo. Hace allí particular énfasis en la "violencia de la moneda" de la hiperinflación y de la desocupación como proceso de disciplinamiento social (2001: 5). Marca el proceso de pauperización de la población y hace una breve síntesis del proceso que para él llevo a que la economía del país se convierta en "deuda - dependiente", acrecentando su extrema vulnerabilidad a los cambios externos.

Como respuestas a las medidas recesivas de la Alianza se profundizó el proceso de luchas, destacando una diferencia central con respecto a 1989, básicamente en torno a la carencia de una oposición dentro del sistema que esté legitimada socialmente. Esto se traduce en la llamada "crisis de representatividad" expresada en las elecciones de octubre (2001: 9). Entonces lo novedoso es que a diferencia de 1989 aquí se expresa la caída de la hegemonía de los sectores dominantes que controlan el país desde 1976, desarrollando así una hipótesis fuerte, que tiene puntos de coincidencia con lo propuesto por Bonnet y por Iñigo Carrera y Cotarelo, entre otros.

Ya veremos más adelante los importantes datos que aportan otros trabajos realizados desde la CTA, específicamente desde su Observatorio del Derecho Social. Trabajos de carácter cuantitativo sobre los convenios laborales y la negociación colectiva (como los realizados por Marcos Ambruso, Julia Campos, Luis Campos y 
Felipe Castello “La negociación colectiva 2003 - 2008: un estudio comparativo con el período 1991 - 1999, en particular sobre la regulación de jornada y organización del trabajo" y por Julia Campos y Jimena Frankel “Obstáculos y estrategias organizativas de los trabajadores en su lugar de trabajo: un análisis de casos. 2003-2009") permiten, especialmente al cruzarlos con la observación de los conflictos y del ciclo de rebelión en su conjunto, el extraer lecturas cualitativas de relevancia.

Desarrollaremos distintos trabajos de Schuster, ya que consideramos a la producción de este investigador y su equipo como un aporte clave al conocimiento y como aquella perspectiva que, desde una serie de hipótesis en gran medida opuestas a las nuestras, ha llegado a algunos resultados que convergen y pueden compararse con los que nosotros planteamos. Por eso seleccionamos aquí cuatro trabajos para presentarlos en forma cronológica, mostrando los elementos de cambio en su línea de análisis y los principales resultados del Grupo de Estudios Sobre Protesta Social y Acción Colectiva.

Partimos del artículo de Federico Schuster y Adrián Scribano ("Protesta social en la Argentina de 2001: entre la continuidad y la ruptura') en el que sintetizan gran parte de su línea interpretativa sobre la protesta social en la actualidad. Para ellos han aumentado y se diversificaron las organizaciones de protesta, dando lugar a la aparición de "... una gran diversidad de actores con demandas heterogéneas" (2001: 19). Denominan como "desafiliados" al nuevo actor social y político que se conforma a partir de los sectores más perjudicados por la Argentina neoliberal, retomando la concepción de Castel.

Esos desafiliados conformarán los movimientos piqueteros, intensificando sus protestas como consecuencia del aumento de la desigualdad social. La manifestación embrionaria de este grupo de desafiliados son los saqueos de 1989, donde ellos son por primera vez los protagonistas. Desde nuestra perspectiva esta lectura no recupera la tradición obrera en la que se enmarca el proceso de organización de los trabajadores desocupados en Argentina, pensando centralmente en los condicionantes económicos directos y de corto plazo. Con respecto a los saqueos observamos la falta de una conceptualización específica sobre este hecho, y la ausencia de su ubicación en el marco de un ciclo de protesta, lucha o rebelión.

Varias veces se usa el concepto de "redes", tanto para los conflictos como para las organizaciones que se conforman. Esto tiene que ver con la idea de la imposibilidad de acceder a organizaciones fuertes y estructuradas como los sindicatos o los partidos políticos (y también con la concepción de que ese tipo de organizaciones no son positivas). Para ellos esa forma de organización perdió centralidad, ya que la alta fragmentación y localización de los conflictos impide la posibilidad de construir “... 
sujetos unificados de acción de cierta permanencia en el tiempo y extensión en el espacio" (2001: 17). Esto aparece como un ataque directo al concepto explicativo de clase social.

El artículo que Schuster realiza con Sebastián Pereyra ("La protesta social en la Argentina democrática: balance y perspectiva de una forma de acción política') conceptualiza a la protesta como una acción pública contenciosa e intencional que adquiere visibilidad social y que está destinada a sostener una demanda centralmente frente al Estado. Protestar es entonces manifestar un reclamo en búsqueda de conseguir una solución. Desde alrededor de 1995 la protesta social se caracteriza por la desarticulación de su antigua matriz sindical y su progresiva fragmentación con una cada vez mayor complejización y multiplicación de los actores que participan en la misma.

Surgen de allí lo que califican de "nuevos sujetos" que encabezan "nuevos tipos de organización" desarrollando "novedosas acciones de protesta". El espacio público (la calle, la ruta, la fábrica) es ocupado y compartido por estas múltiples expresiones de lucha, que se van extendiendo a toda la geografía del país. Para ellos se debe priorizar el concepto de protesta, el estudio de cada hecho aislado o de cada ciclo de protestas de un sector determinado, como mecanismo que permitiría una explicación científica de la actual situación de la lucha social, por encima de otras concepciones como la de clase o movimientos sociales.

La protesta estaría caracterizada por la profunda derrota que el neoliberalismo impuso a los "sectores populares", llevando a su segmentación y a la dificultad, por ello, de estudiarlas como partes constituyentes de un mismo proceso, criticando allí la mirada de la lucha de clases. Creemos que este enfoque dificulta un abordaje que permita remitirse en cada estudio a los vínculos que une un determinado proceso con toda la historia anterior de luchas, que marque sus cambios y sus continuidades y que se involucre en la explicación de los procesos organizativos más amplios que tienen relación con los cambios en la disposición de fuerzas objetivas de cada grupo social.

En el artículo "Algunas reflexiones sobre la sociedad y la política en la Argentina contemporánea", Schuster define al santiagazo de 1993 como un "estallido", que generó una importante repercusión y fue uno de los primeros llamados de atención acerca de los efectos del neoliberalismo. Complejiza allí la discusión sobre si el ciclo comienza en 1996 (su perspectiva) o en 1993. Schuster destaca que en 1995 vuelve a ser elegido Carlos Juárez y toma ese hecho como eje para preguntarse acerca de cuál es la relación entre estos movimientos de la sociedad y los efectos políticos que los mismos producen. 
Marca un cambio entre los ochenta, cuando las protestas eran "clásicas" y organizadas centralmente por los sindicatos y los noventa. En esta segunda fase las acciones aparecen muy fragmentadas, sin “... ninguna capacidad de articulación” (2004: 48) y anclada en problemas locales. Recién para mediados de los noventa esas fuerzas fragmentadas empiezan a articularse, marcando en las asambleas piqueteras nacionales del 2000 y 2001 el hecho que demuestra ese proceso de unificación. Así, para Schuster, el ciclo de protestas comienza con los cortes de 1996 y 1997, y el anterior es otro ciclo que parece agotarse en sí mismo.

A partir de allí considera que diciembre de 2001 marca el fin de un movimiento social y el nacimiento de otro, donde los elementos claves son el movimiento piquetero, las asambleas barriales y las fábricas recuperadas. Pero sigue viendo allí una diferencia entre esas expresiones populares y cómo se expresa la sociedad en lo electoral. Para entender esto Schuster marca que debe observarse como clave a la dictadura militar, considerada como un proceso que barrió toda una generación de cuadros populares y marcando que esa experiencia de construir una política propia recién se estaría recuperando desde la práctica asamblearia (coincidiendo en algún punto con la conclusión que posteriormente desarrolla Klachko). Retoma entonces allí a Melucci, planteando que en Argentina está en marcha un "laboratorio de vida", donde se configuran nuevas experiencias y nuevas formas de encarar las relaciones entre los sujetos.

En este texto de Schuster se observa su visión de que el movimiento social logra peso cuando consigue institucionalizarse (por eso no comprende al santiagazo como parte del ciclo) y por ello se lamenta de que el movimiento del 2001 y 2002 “... todavía no tiene la construcción política capaz de expresarse en una opción electoral, en una opción de gobierno" (2004: 52). Desde esa perspectiva solamente es posible pensar una opción dentro del sistema representativo burgués, dejando de lado la posibilidad de una transformación revolucionaria que quiebre con el sistema. Creemos que esta visión, que en algún punto naturaliza la dominación del sistema, genera además una dificultad para observar la importancia de procesos de lucha que ni buscan ni quieren la institucionalización en los términos en que lo propone Schuster. Muchos conflictos sociales no son suficientemente valorados en sus efectos políticos, al considerar que estos efectos sólo pueden observarse en el marco de las relaciones de fuerzas políticas del sistema representativo burgués, quedando por fuera las relaciones de fuerzas políticas en términos más amplios y las relaciones de fuerzas objetivas.

El último trabajo a cargo de Schuster y demás integrantes del GEPSAC ("Transformaciones de la protesta social en Argentina 1989-2003") presenta los 
resultados de su base de datos sobre las protestas sociales desde 1989 hasta el 2003. Sin dudas se trata de un avance significativo hacia la posibilidad de conocer la realidad y poder comparar las diversas líneas interpretativas. A diferencia de otras miradas en este caso hay un interés manifiesto por cuantificar los datos para hacer posible la comparación y la medición. Buscan indagar las transformaciones de la protesta social en Argentina, superando los enfoques que se quedan en el estudio de algunas organizaciones específicas o de situaciones conflictivas particulares pero que no intentan una mirada de conjunto. Se diferencian de la noción de Melucci y los nuevos movimientos sociales, cuyo enfoque no entra por el conflicto y la acción, sino por la organización, que para nosotros suele ser un resultado y no una causa del conflicto social.

Para ello confeccionaron un mapa de protestas lo más exhaustivo posible. Relevan, como otros intentos similares, al de la OSAL, el del PIMSA, y como proyectos más acotados, al del Grupo de Estudios Rurales del Instituto Gino Germani (dirigido por Norma Giarracca) y a los investigadores coordinados por Ernesto Villanueva en la Universidad Nacional de Quilmes. Definen una acción de protesta como “... un evento de carácter contencioso producido por un actor social colectivo que implica movilización de recursos" (2006: 6). De esta manera siguen las nociones de Tilly y Tarrow, haciendo énfasis en las nociones de racionalidad, organización y recursos como elementos explicativos fundamentales. Para nosotros desatienden los aspectos estructurales del conflicto y la realidad de que los sujetos muchas veces no actúan por criterios que puedan ser comprendidos desde una lógica racional.

Su hipótesis inicial es que la matriz corporativa del conflicto (que haría referencia a la noción de "interés") había perdido poder en relación a la matriz cívica (que haría referencia a la noción de regeneración del espacio público). Pero en el marco de la investigación ven que es necesario darle mayor centralidad al análisis de las transformaciones que llaman socio políticas (lo que nosotros denominaríamos cambios en la estructura económica social, pero que en su caso queda limitado al campo de las relaciones de fuerzas políticas), que para ellos llevan a la caída del poder de los "antiguos" sujetos de la protesta (especialmente los sindicatos), al mayor poderío de los capitales transnacionales y a un proceso de surgimiento de nuevas formas de protesta con nuevos sujetos.

En un principio del período estas formas serían fragmentadas, con alta localización, sin continuidad entre sí y con múltiples actores. Toman como dimensiones centrales del análisis a la demanda, el formato predominante y el tipo de organización. 
Desde el concepto de ciclo de protesta de Tarrow marcan dos momentos para el período analizado: "El primero comienza en el cuarto trimestre de 1993, alcanza su punto más alto un año más tarde y luego desciende sistemáticamente hasta el tercer trimestre de 1996. El segundo comienza en el cuarto trimestre de 1996, llega a su punto más alto en el segundo trimestre de 1997 y luego comienza a declinar hasta alcanzar su punto más bajo en el cuatro trimestre de 1999." (2006: 30).

El problema de este concepto de ciclo, que no observa unidad y alianza sino solamente aumento o descenso del número de protestas, se marca cuando vemos que ellos no identifican un ciclo entre fines de 1999 y fines de 2002 ya que durante todo ese período, según los números de protestas, cambia el sentido de la fase de un trimestre a otro. Además no aparece la conexión entre el primer y el segundo ciclo. Cada ciclo parece comenzar de cero, no aplicando así tampoco el concepto de acumulación ni de que hay medidas de lucha que generan efectos más importantes que otras (lo que denominamos una "escala" en las formas de rebelión).

Su periodización para comparar impacto político toma los mandatos institucionales de los presidentes. Marcamos aquí un nuevo problema, que ya observamos en el trabajo anterior: los autores suponen que el análisis de la protesta social debe centrarse en la forma en que las acciones se inscriben en la política nacional, pero pensando esa política como los efectos en el entramado institucional reconocido por el Estado.

Una diferencia metodológica importante hace al modo de medición de las protestas. Ellos entran por protesta, donde un paro nacional es una sola medida, sin atender a los múltiples hechos que se pueden articular a su interior (por ejemplo en los paros de los noventa, que articulaban cortes de rutas, ollas populares, movilizaciones, etc). De esta manera para nosotros se pierde gran parte de la información que se debería relevar y no logran observar este carácter cualitativamente distinto que tienen las huelgas de articular las distintas formas de rebelión social que hasta allí se daban de manera dispersa. En un sentido parecido discutimos con medir por conflicto, como citamos cuando tratábamos a Piva y Bonnet

Pese a las diferencias ya destacamos la importancia de este trabajo y la seriedad de la investigación que realizan. Esto se muestra en sus resultados, que en cierta medida sostienen nuestra postura en la discusión acerca de la importancia clave que mantiene la investigación de la clase obrera y de sus organizaciones y métodos históricos. Es que si bien los resultados de PIMSA a nivel nacional, y los nuestros a nivel local, marcan esta realidad, siempre pareciera sospechoso que un grupo de investigadores encuentre aquello que hipotetizaba en primer término. 
En este caso la seriedad de la investigación de Schuster se demuestra en que sus resultados presentan que los sindicatos son el sujeto que más protesta, superando de forma importante a las organizaciones que denomina "civiles". También la demanda más importante es la salarial, la segunda es por reclamos económicos y la tercera por seguridad social, siendo centrales en estos casos los reclamos de trabajadores ocupados. En los formatos el más usado es la manifestación, luego la huelga y en tercer término el corte de ruta (además observa que esta forma no sólo es usada por trabajadores desocupados sino también por ocupados y otros sectores sociales).

Entre las organizaciones "civiles" solamente encuentra un aumento en la participación de la personificación social de "vecinos", aunque para nosotros muchas de las protestas que se agregan aquí son realizadas por la personificación de "pobres, sin techo, sin vivienda", que clásicamente generan una parte importante de los reclamos en América Latina. También los estudiantes son un sujeto clásico de la protesta social, y no creemos que debiera ser comprendido como un nuevo actor.

Pero si bien aparecen estos datos los autores destacan que observan una tendencia de caída permanente en el porcentaje de protestas convocadas por los sindicatos, y en las modalidades "tradicionales" de protesta, generándose un progresivo aumento de las demandas ciudadanas en contra, por ejemplo, de la "clásica" demanda salarial. No desconocen que todavía son centrales las formas de protesta "clásicas" (que tantos otros investigadores se habían apresurado en tirar por la ventana), pero sí reafirman que estamos en un proceso de lento declive y cambio del repertorio, que si bien hoy es observable como tendencia no debemos apresurarnos a convertirlo en una verdad a priori ni en una ley inmodificable. Las formas "tradicionales" representaron el $82 \%$ de las protestas, en tanto que las nuevas constituyeron el 16\%. Sin embargo señalan que en 2001 cuatro de cada diez protestas utilizaron formatos nuevos, lo que marcaría también una tendencia de cambio. $Y$ destacan como una de las transformaciones más interesantes del período la tendencia al aumento de los cortes de ruta en paralelo a la caída de las huelgas.

Hay dos transformaciones claves en este proceso: la heterogeneización de las demandas y su tipo de orientación. Registran un proceso de fragmentación, por lo heterogéneo, y otro de unificación, ya que mientras en el primer período económico se trata de demandas "micro", en el último encuentran demandas de tipo "macro", vinculadas con el cuestionamiento e impugnación al "modelo". Como conclusión ven, desde 1996 en adelante, un “... proceso que podríamos denominar de descorporativización de la protesta” (2006: 64). Desde allí discuten el concepto de Castel de la desafiliación, que es central en los análisis sobre este período y que estos autores habían tomado en trabajos anteriores. Para ellos no aparece en Argentina esa 
desafiliación que generaría una crisis de la ciudadanía industrial y, como consecuencia, un proceso de individuación, riesgo y desmovilización. Al contrario destacan que en los noventa hay una fuerte resistencia, importantes procesos de movilización y constantes protestas de muchos sectores que, según estas teorías, se veían condenados a la pasividad absoluta.

Finalizan entonces discutiendo con su misma hipótesis inicial “... de la oposición entre matriz ciudadana y matriz corporativa, en la medida que la resultante del proceso no parece ser tanto el tradicional modelo liberal de libertad negativa en términos de protección de los derechos individuales, sino más bien lo que B. Manin llama una "democracia de lo público": una combinación entre formas deliberativas y participativas novedosas con vínculos políticos plebiscitarios." (2006: 66)

Utilizando conceptos muy distintos y partiendo de importantes diferencias metodológicas, un trabajo con este nivel de profundidad llega a muchos resultados que contribuyen a nuestra indagación en Chubut. En definitiva lo que estarían observando es la permanencia de las formas y los sujetos clásicos como factores centrales de la protesta actual y que, a través de distintas acciones, se fue configurando una experiencia y una acumulación de fuerza que hizo posible resistir en forma más decidida el avance del proceso neoliberal. Así surgieron formas organizativas, en especial la asamblea, como método central para poder garantizar las acciones que combatieran la hegemonía del capital financiero

Desde una perspectiva epistémica y metodológica similar a los autores recientemente reseñados se inscriben dos trabajos muy interesantes. Tanto el artículo de Germán Pérez ("Modelo para armar: complejidad y perspectivas de la protesta social en la Argentina reciente"), como la sintética visión de conjunto que muestra Sebastián Pereyra en su libro "¿La lucha es una sola? La movilización social entre la democratización y el neoliberalismo", desarrollan lecturas generales sobre el proceso de conflictos sociales en los últimos años, especificando su mirada desde la concepción de la acción colectiva y el marco general analizado más profundamente en relación a los artículos de Schuster y otros.

Con elementos en común con Schuster, los trabajos de Adrián Scribano ("Acciones colectivas, movimientos y protesta social: preguntas y desafíos"; "Fantasmas y fantasías sociales: notas para un homenaje a T. W. Adorno desde Argentina"; "Geometría del Conflicto: Estudios sobre Acción Colectiva y Conflicto Social"; "Itinerarios de la Protesta y del Conflicto Social") prestan especial atención a lo que denomina "cambios en la estructura y sentido de las acciones colectivas", postulando que hay cuatro elementos centrales: "a) el corte de ruta como técnica, b) la 
derecho-humanización de los formatos de protesta, c) los estallidos de bronca y d) la represión selectiva a la protesta social" (Scribano, 2009: 102)

Aparecen entre sus conclusiones tres rasgos que son destacados por diversos autores, entre ellos por la perspectiva del PIMSA: la importancia que adquiere la forma de protesta consistente en cortar las vías de comunicación, "la modalidad asamblearia para la toma de decisiones y la creación de la múltiple y compleja identidad piquetera" (2009: 103).

El autor hace un llamado a la importancia de articular el estudio de las acciones colectivas con una "sociología de las emociones", una perspectiva que para él lograría complejizar el abordaje que se ciñe a las conexiones de las acciones colectivas con el sistema político. Critica así pensar a los movimientos sociales solamente desde la pregunta sobre su posible institucionalización, sin abordar las múltiples complejidades que esto plantea y las rupturas que generan los procesos de ingreso al sistema institucional, especialmente en los efectos de disrupción radical que estas acciones tenían en su origen.

Si bien Scribano parte de la lectura que busca encontrar un sujeto que dé explicaciones más allá del concepto de "clase social" (al cual considera restringido, debiendo sumársele las implicancias de las identidades étnicas, de género y de edad), en sus últimos trabajos postula un cambio más cercano a nuestra perspectiva, desde la hipótesis de que “... las organizaciones de clase serán posiblemente las que recuperen la capacidad de interpelación a las masas de expropiados y destituidos generados por la depredación capitalista" (2009: 111).

También desde la perspectiva de la acción colectiva se inscriben los trabajos del grupo de investigadores dirigidos por Norma Giarraca (entre otros su compilación "La protesta social en Argentina" y su artículo "Argentina 1991-2001: Una década de protesta que finaliza en un comienzo. La mirada desde el país interior') que se centran en el estudio de protestas rurales, especialmente en la parte central y norte del país. Para ellas las protestas que se desarrollan son básicamente defensivas, buscando la preservación de las posiciones ante el avance de las políticas neoliberales que amenazaban con expropiarlos. En pocas ocasiones estas protestas lograron avanzar en la búsqueda de nuevos derechos o en la intención de lograr nuevos espacios políticos o ciudadanos. Giarraca llama aquí la atención sobre la necesidad de no confundir lo que ella ve como "nuevas formas de protesta" y una "nueva matriz ciudadana" con el tipo de demandas que se efectúan en estas protestas, la mayoría de los cuales aún se inscriben en los reclamos tradicionales.

Javier Auyero ("Evita como perfomance. Mediación y resolución de problemas entre los pobres urbanos del Gran Buenos Aires"; "El juez, la reina y el policía. 
Etnografía, narrativa y los sentidos de la protesta"; "La protesta: retratos de la beligerancia popular en la Argentina democrática') parte fundamentalmente de los trabajos teóricos de Tilly y Tarrow para sus estudios sobre las acciones colectivas. Además incorpora elementos de Goffman y Bourdieu, especialmente para sus trabajos sobre clientelismo político. Toma como operadores metodológicos centrales a los conceptos de "repertorio" y "performance".

En el trabajo del 2002 ("La protesta...") realiza un aporte importante al conocimiento, con una interesante síntesis del proceso de luchas en los años noventa y hasta diciembre del 2001. Destaca la generalización de los cortes de rutas, a los que ve como nuevas formas de lucha que desarrollan nuevas formas organizativas (citando a Marinetti, 1999, aunque Auyero matiza este carácter de "novedad", mostrando la articulación, por ejemplo, de los cortes con las huelgas). También marca hitos en el proceso, en especial destaca el santiagazo, lo que define como "pueblada" de Cutral Có en 1996 y la plaza del aguante en Corrientes. Es un valioso trabajo realizado desde el marco de Tilly que, como decíamos, nos permite comparar y discutir con los resultados que desde otro enfoque podemos obtener al estudiar estos hechos.

El concepto de repertorio plantea para él una opción a las explicaciones tradicionales y "mecanicistas" (o vulgares) de la protesta social. Se estudia así la emergencia de las formas de protesta en su relación con los procesos políticos que cada sector procesa de acuerdo a su cultura de acción colectiva y a sus hábitos de lucha. Este enfoque rompe con las lecturas simplistas de suponer que determinadas luchas son expresión directa de tal o cual situación social (la pobreza o el desempleo como las generadoras, sin más mediación, de los cortes de ruta o de la formación del movimiento piquetero) y esto implica un avance en relación a las explicaciones vulgares sobre el conflicto social. Pero también consideramos que obtura una visión de conjunto del proceso de lucha, por centrarse en los análisis particulares de cada sector desvinculados de la totalidad histórica y de la estructura económica social de la cual esos conflictos son expresión.

Desde el uso de ese marco conceptual considera que no hay una escala en las medidas de lucha, ni tampoco distintos sujetos que participan en el proceso. El sujeto es la "gente común", que actúa desde su marco cultural y desde la estructura de oportunidades que se les ofrece en cada momento histórico. No hay problematización de cómo se conforma una fuerza social o cómo se acumulan experiencias a lo largo del ciclo.

Es fundamental en esta línea interpretativa el planteo de que lo clave para explicar científicamente la protesta social es comprender aquello que los 
manifestantes "... creen que son, lo que creen que están haciendo y con qué fines creen que lo hacen..." (Auyero, 2002: 81) por sobre la investigación de lo que esos sujetos objetivamente están realizando con su praxis social en términos históricos (qué intereses están defendiendo, qué estrategia desarrollan, qué significación tiene el hecho en torno a la a la génesis, formación y desarrollo de la clase social o de una fracción de ella, etc.).

Cuando analiza los hechos ocurridos en Santiago del Estero en diciembre de 1993 (el proceso conocido como "santiagazo") lo hace desde la búsqueda de reconstruir las memorias de la protesta a través de entrevistas etnográficas. En esta investigación destaca que sus entrevistados marcan como central el carácter "espontáneo" del hecho y la ausencia de activistas o de preparación consciente. Nosotros creemos que estos testimonios son elementos importantes para la investigación pero que la misma debe sumar más datos. El quedarse en este nivel lo lleva a que, pese a que lo crítica como expresión de una lectura vulgar, él no plantea una opción a la conceptualización del hecho como "estallido social" o "explosión" y de hecho así lo denomina en su trabajo (aunque lo pone entre comillas, marcando su disconformidad).

Desde su perspectiva, coincidente con el resto de las investigaciones que parten de los modelos de Tilly y Tarrow, los conflictos de la década del noventa son fragmentados, diversificados y dispersos en sus acciones, demandas y actores. Se considera a las luchas como expresión de demandas ciudadanas y de inclusión, demandas que se darían en el marco de la desaparición del Estado y de la caída de las relaciones tradicionales (recuperando aquí en gran medida el desarrollo conceptual de Castel).

Así trabaja desde la lógica del excluido y el incluido, aspecto que no permite abordar el proceso como una totalidad en movimiento. Un elemento particular del enfoque de Auyero es la importancia que atribuye a la relación "clientelar" en la formación de las acciones colectivas. Para nosotros por momentos reproduce una mirada casi utilitarista acerca del cómo se construyen estos procesos. En general los conflictos suceden cuando esa relación clientelar sufre algún corte, especialmente cuando el patrón no da lo que el cliente espera; o sea cuando se rompe el "contrato".

Su forma de intentar explicar las acciones parte de una "tarea etnográfica" en la cual lo clave es entender el comportamiento de cada individuo, y especialmente de algunos individuos determinados. Así en el trabajo "Evita como performance..." el sujeto político central son aquellas mujeres que realizan su "actuación" (cuyas posibilidades de acción no son ilimitadas porque parten de un habitus que las determina, pero dentro del cual "diseñan" su estrategia política) mientras el sujeto 
colectivo (que en este caso serían "los pobres") no responde como colectivo sino como individuos que se movilizan de acuerdo a sus "estrategias de sobrevivencia" (Hintze, 1989).

La posición estructural de la situación debe ser tomada como factor explicativo, pero no es lo central ya que no explica el tipo de relaciones (redes) que se constituyen. Para él explica mucho más la performance, entendida como "la actividad llevada a cabo por actores "en una ocasión dada que sirve para influir de alguna manera en los otros participantes"'” (en Auyero, 1997: 183, citando a Goffman, 1959: 16). Como ya lo marcamos su indicación metodológica es que para comprender las características de un proceso colectivo, nos explica más lo que una persona dice y cómo lo dice, que lo que podamos estudiar sobre cómo se mueve estructuralmente una sociedad.

De la abundante producción de Maristella Svampa tomamos para este apartado centralmente lo elaborado en: "Cambio de época. Movimientos sociales y poder político"; "La sociedad excluyente. La Argentina bajo el signo del neoliberalismo; "Identidades astilladas. De la patria metalúrgica al heavy metal"; "El análisis de la dinámica asamblearia"; "Organizaciones de trabajadores desocupados. El modelo General Mosconi"; "Los que ganaron. La vida en los countries y barrios privados" y "Entre la ruta y el barrio. La experiencia de las organizaciones piqueteras". Especialmente importante para nuestra investigación ha sido el trabajo realizado con Sebastián Pereyra ("Entre la ruta...", 2003) que construye una síntesis con gran base erudita del proceso de conformación de los movimientos de trabajadores desocupados. Más allá de las diferencias teóricas y de la discusión sobre las conclusiones que desarrollan, al igual que en el caso de Schuster, Auyero y otros, las investigaciones de Svampa generan un innegable aporte al conocimiento de la realidad.

Para ella la sociedad actual vive los efectos de la implementación del modelo económico neoliberal a partir de la dictadura militar iniciada en 1976 y, especialmente, con el gobierno de Carlos Menem durante los años noventa y su profundo programa de reestructuración del Estado y la economía del país. Con estos programas de gobierno se configura un proceso que denomina de "descolectivización", a través del quiebre de las antiguas identidades que daban solidez y creaban los marcos de socialización de los individuos. Sociedades nacidas y formadas en medios basados en una "cultura del trabajo", en torno a grandes empresas estatales o privadas. Ese modelo desarrollado a lo largo de generaciones, que se estructuraban a partir de su relación con el mercado laboral, se quiebra con la expansión de la desocupación y la precarización masiva que sufre toda la clase obrera argentina. 
Su metodología parte de la investigación empírica, en base a trabajo de archivo y entrevistas. Su opción teórica muestra un abordaje desde una lectura sociológica cercana a Weber que hace hincapié en la mirada sincrónica del fenómeno y en la conformación de tipos ideales. Retoma a Norbert Elías y su postura acerca de la necesidad de un estudio que mantenga una convivencia ordenada entre el distanciamiento y el compromiso. En el trabajo sobre los countries hay una clara influencia de Simmel, mientras en "Identidades astilladas..." recupera elementos de Senett y aportes de Touraine. Su marco general es el de Tilly y Tarrow. Todos autores que no ven a la lucha de clases como la constituyente central del conflicto social en la actualidad.

Una de las hipótesis de "Entre la ruta..." es la de que el movimiento piquetero nace de dos vertientes distintas que se sintetizan en la concreción de esta nueva identidad que seria la del "piquetero". El primer afluente es el que nace de "las grandes puebladas y piquetes del interior" y se enmarca para ellos en una perspectiva de ruptura, de quiebre con las prácticas sociales anteriores. Allí estudian los hechos de Cutral Có y Plaza Huincul y de Tartagal y Mosconi, encontrando fuertes coincidencias. Las dos experiencias nacen de la desestructuración de YPF, la principal empresa del Estado, y se constituyen en torno a la demanda de trabajo genuino, con la presencia explosiva de múltiples sectores sociales.

El segundo aporte marcaría una línea de continuidad y se manifiesta en el trabajo territorial en el conurbano bonaerense ligado a las reivindicaciones barriales y la búsqueda de satisfacer las necesidades básicas. Estas organizaciones territoriales nacerán en íntima relación de una disputa cuerpo a cuerpo con el peronismo, y su mismo crecimiento tendrá que ver con el pasaje de muchos antiguos militantes de ese partido político.

Para los autores se constituye un nuevo "actor social", que va generando una novedosa "configuración identitaria" que será la del "piquetero". Esa identidad lograría romper con el "estigma" de ser un desocupado, o sea un sujeto caracterizado por su pasividad, reemplazándolo por un sujeto caracterizado por su actividad.

En este caso la nueva identidad surgiría ante la crisis y el debilitamiento de la identidad peronista, planteando como clave la fractura del modelo de "clientelismo afectivo" (repetimos aquí las críticas al concepto de relación clientelar que planteamos hacia Auyero).

Es destacable que los autores observan que estas prácticas sociales ponen un freno a muchas políticas del poder. Los movimientos intentan recomponer un tejido social fragmentado por el neoliberalismo y sus prácticas de descolectivización. Sin embargo se carece de una pregunta más profunda acerca de su importancia y su 
papel concreto en la actual lucha de clases, acerca de cuál es su aporte y cuáles sus limitaciones en la posibilidad de construir un proyecto alternativo de sociedad.

Un análisis muy interesante es el de los múltiples sujetos que entran en juego en las organizaciones piqueteras. Los antiguos trabajadores desplazados del mercado laboral parecen ser los impulsores de la organización, que suele reproducir formas y métodos de la organización sindical, tradiciones de las cuales ellos se sienten parte. Por otro lado se suma un sector muy importante de jóvenes hijos de trabajadores, que nunca han podido insertarse en el mercado y cuya conciencia social no pasa por la adscripción al mercado o por la relación con el trabajo sino, más concretamente, por el enfrentamiento cotidiano con las fuerzas represivas. Estos jóvenes serán los que tomaran la vanguardia de los grupos en la organización y el trabajo diario, y los que lideran la confrontación.

El tercer componente son las mujeres. Entre ellas algunas son antiguas trabajadoras que se encuentran en un proceso semejante al de los hombres desempleados; pero el proceso de transformación más significativo es el de aquellas que eran amas de casa, y que ahora toman un papel activo en las luchas. Ellas son centrales en el trabajo territorial y generan quiebres en la ideología machista de las clases populares de nuestro país. Si bien el cambio no es absoluto, se provocan modificaciones que reinscriben las relaciones de género a partir de las luchas que se desarrollan, y en las cuales las mujeres cada vez tienen posiciones más relevantes.

Como en otros autores se presta mayor atención a lo que los sujetos dicen que a lo que hacen. Por eso muchas veces se queda en una excelente descripción del proceso, sin afanarse consecuentemente en preguntarse los porqués. Las explicaciones surgen del discurso de los participantes, sin discutir que esos discursos son también parte del problema a explicar y no la explicación en sí misma.

Svampa matiza mucho más que otros autores la aparición de un nuevo "repertorio" y la supuesta caída del "actor corporativo sindical". Atenta no solamente a las rupturas sino también a las continuidades, observa que en los MTD se expresa la tradición previa del movimiento obrero y que hay articulaciones durante los noventa entre sindicatos, partidos políticos y movimientos de trabajadores desocupados. Sin embargo no observa cómo esta articulación se realiza centralmente en el momento del enfrentamiento y especialmente alrededor de las huelgas generales como hechos a nivel nacional.

En este sentido consideramos relevante al trabajo de Verónica Maceira y Ricardo Spaltenberg ("Una aproximación al movimiento de desocupados en el marco de las transformaciones de la clase obrera en Argentina"), donde observan las continuidades entre la lucha de los desocupados y las de los trabajadores ocupados, 
entendiendo que lo que se produce es una transformación en la estructura productiva que modifica la realidad de la lucha de clases. Analizan allí cómo la pérdida del trabajo opera en estos individuos, formados en torno a su relación laboral, culpabilizándolos y generando una fuerte dificultad para construir respuestas colectivas. Sin embargo es la tradición obrera la que permite la construcción de las organizaciones de desocupados, que constituyen una nueva herramienta de lucha de la clase ante la pérdida de poder de sus herramientas más tradicionales.

Volviendo a Svampa, consideramos que su enfoque micro sociológico y una mirada que capta mucho más lo sincrónico que lo diacrónico, le permite observar elementos que se escapan a una mirada macro, pero a su vez la lleva por momentos a quitarle centralidad a los procesos de proletarización y pauperización que viene sufriendo el proletariado y la pequeña burguesía pobre y acomodada durante el neoliberalismo. Es clave en Svampa la mirada de que todos estos conflictos se dan en el marco de disputas por la ciudadanía. Svampa suele trabajar con las figuras del que está "adentro" y el que está "afuera". Por ello es importante estudiar los countries y los barrios privados, como expresión concreta en lo espacial de lo que para ella se da en toda la sociedad. La sociedad no parece pensada como una totalidad, sino como un escenario altamente fragmentado, donde se quiebran las antiguas identidades y las luchas se dan por recuperar una identidad y volver a sentirse contenido al estar nuevamente integrado. Una mirada que entiende a estos conflictos desde el prisma de la ciudadanía tenderá a verlos desde lo individual, ya que los derechos del ciudadano son, por definición, los derechos del individuo de la sociedad liberal.

Esto se expresa también en su rechazo a incorporar el motín de Santiago del Estero como parte del ciclo de luchas. Como en otros autores (Seoane, Schuster, etc) el ciclo comienza en 1996 o 1997, con los cortes de rutas que dan nacimiento al movimiento piquetero. El santiagazo es una "acción evanescente" que muere en sí misma, sin articularse con la continuidad de hechos. Al observar el conflicto en términos de ciudadanía no se logra encontrar sentido a un hecho como el santiagazo, que expresa el momento inicial de la acumulación de una fuerza social, pero donde no hay elementos de una política positiva (en el sentido de Gramsci, que la diferencia de una "política negativa", donde hay rechazo pero no propuesta de una solución alternativa) que se pueda encaminar hacia su institucionalización sino un repudio generalizado con expresión clara del odio al sistema que los oprime.

Marina Farinetti ("El estallido. Formas de la protesta"; "Violencia y risa contra la política en el Santiagueñazo. Indagación sobre el significado de una rebelión popular"; "¿Qué queda del "movimiento obrero"? Las formas del reclamo laboral en la nueva democracia argentina') aborda la investigación de las luchas en la Argentina desde 
1983. Para la autora se produce la aparición de nuevas formas de protesta después del gobierno de Alfonsín que desplazan las tradicionales huelgas y movilizaciones. Ellas van a ser especialmente los cortes de ruta y los "estallidos". Entiende por protestas a "...las manifestaciones colectivas de carácter público, directo y discontinuo que expresan desacuerdo y reclaman soluciones frente a un cierto estado de cosas. Una protesta es de carácter público toda vez que hace visible ante la población civil y/o las autoridades políticas un reclamo o una situación percibida como un problema social por los protagonistas"(1999: 1-2).

Esta visión, como decíamos, para nosotros tiende a fragmentar el estudio de los conflictos. Desarrolla una síntesis de lo que considera las explicaciones más utilizadas de la protesta social, dividiéndolas en la dicotomía individualismo-holismo. Observa entonces dos conjuntos “...según propongan explicaciones centradas en el nivel de los individuos o en el nivel de las estructuras o totalidades: a saber, (1) enfoques individualistas y (2) enfoques holistas. Entre los primeros, consideré: los enfoques psicologistas tradicionales y los enfoques utilitaristas. Entre los segundos, el enfoque sistémico clásico y el enfoque de los nuevos movimientos sociales"(1999: 4).

Sin embargo no acepta ninguno de estos ya que considera que todos tienen puntos vulnerables, por lo cual intenta un nuevo marco, tomando aportes de cada uno. Es significativo que no considera al análisis materialista histórico como un posible aporte al conocimiento de las protestas, algo relacionado con el hecho de considerar como demostrado que la clase social no es un factor que explique la conflictividad social en la actualidad.

Toma los conceptos de "repertorio de acción colectiva" y "estructura de oportunidades políticas", desarrollados por Tilly y Tarrow, y el de "economía moral" de Thompson, pero desvinculando este aporte de la concepción thompsoniana de lucha de clases. Para ella deben estudiarse, sobre todo, los factores políticos que se producen alrededor de la protesta, ya que son los que condicionan sus formas. Los cambios económicos sólo impactan a través de la mediación de la arena política. Por ello considera que el gran cambio es la caída del dominio del peronismo sobre la protesta social y sus características, relacionando esto con la pérdida de poder de los sindicatos. En ese marco el "repertorio clásico" será el del sindicalismo peronista y las "nuevas formas" las que se desaten tras su caída.

Su trabajo sobre el santiagazo (2000) lo presenta como un hecho que se agota en sí mismo. Por eso, si bien polemiza con las lecturas de la prensa, no logra llegar a una conceptualización propia del hecho, utilizando el concepto de "estallido" (aunque también habla de "revuelta"). Si bien en el trabajo de 1999 (“¿Qué queda...”) marca que después de 1993 crecen las protestas en general y especialmente lo que 
denomina "nuevas formas de protesta", no ve al santiagazo como parte de esto, sino como un punto previo sin conexión con los hechos posteriores.

En este artículo toma como fuente fundamental para pensar el problema a una novela ("La guerra del fin del mundo" de Vargas Llosa). Busca desde allí analizar la forma y el sentido de lo que describe como una protesta, recuperando elementos de Thompson y Darnton en relación a la importancia de la cultura y las costumbres en este tipo de hechos.

Farinetti critica el concepto de "turba" y en contra postula el de "muchedumbre". Realiza una individualización de los participantes que quiebra con el carácter colectivo de este tipo de hechos. Para ella los participantes son: los cabecillas, la segunda línea, los vecinos, los observadores entusiastas presenciales y los observadores entusiastas no presenciales (ya que incorpora como sujetos de la protesta a los que la miran por la televisión o la escuchan por la radio “...asintiendo y alentando con su espíritu” (2000: 86).

Es una enumeración semejante a la que veíamos en Tilly, con gran preocupación por los líderes como en Tarrow. Ve que en el santiagazo no hay líderes claros, y por eso la protesta no se institucionaliza y se pierde, a excepción del grupo que forma el movimiento "16 de diciembre" que luego se presenta a elecciones.

Considera que la movilización surge por la deuda salarial y la corrupción, en un contexto de oportunidades políticas y de pocos riesgos debido a la pasividad de la policía y la caída de legitimidad de los gobernantes. Desde esa lectura se toma a los testimoniantes como los que nos pueden dar el sentido de la protesta. Observa que lógicamente hay distintas lecturas, pero que la mayoritaria es la del infiltrado, la que busca explicar el hecho por "una mano oculta" externa a Santiago del Estero. De esta manera se lograría sacar el conflicto de Santiago y sería posible restaurar las heridas. Se le quitaría el carácter disruptivo a la protesta y se le dejaría solamente su carácter de "carnaval".

Por eso la explicación final se encuentra cuando analiza lo que denomina la relación clientelar. Ya veíamos esto presente en Auyero. La interpretación mayoritaria de los entrevistados muestra, para ella, que esta relación era la fundamental. La figura del infiltrado es una forma de lavar culpas y asegurar que tras el estallido todo vuelva a la normalidad previa. El cliente reacciona ante la falta de cumplimiento del contrato por parte del patrón, que rompería esa "economía moral", según el uso que la autora realiza de este concepto de Thompson. La protesta responde a la lógica del mercado. El cliente muestra su bronca pero sin ninguna posibilidad ni intención de querer suplantar al patrón, de querer transformar la sociedad. Solamente busca mostrarle que debe cumplir con el contrato. 
En definitiva el santiagazo fue simplemente una búsqueda de restaurar las condiciones previas de dominación, un hecho que se agota en sí mismo. Al haberse roto el contrato, los "clientes" se levantan contra el patrón, quién se da cuenta y vuelve a generar la relación (evidenciado por la victoria electoral del viejo caudillo Carlos Juárez en 1995). Tras el paso del carnaval todo vuelve a ser como antes. Así uno de los procesos que a nivel continental es considerado por varios autores como el inicio de la resistencia contra el neoliberalismo (junto al alzamiento del EZLN en México ${ }^{101}$ ) es aquí reducido a un día de carnaval, donde el pueblo, tras las risas, vuelve cansado a dormir la resaca. No hay ninguna mirada de cómo impacta esto a nivel nacional. En todo el análisis casi no se amplia el marco más allá de lo que pasa en Santiago y así tampoco se analiza el proceso de cambios en las fuerzas sociales objetivas.

Según sus datos entre 1984 y 1994 los resultados fundamentales a nivel país son: la disminución de la cantidad de protestas laborales, el desplazamiento relativo del conflicto laboral desde el área industrial hacia el sector público y, desde 1988, el traspaso de los conflictos al nivel provincial. Describe entonces ejemplos de estas nuevas formas de protesta, marcando que para ella el ciclo (en términos de Tarrow) comienza con los cortes de ruta en Cutral Có y Plaza Huincul. Allí destaca la aparición de estructuras organizadas que desarrollan el hecho y formulan reclamos específicos y puntuales, en oposición a un discurso más centrado en lo "moral" que era lo propio de los "estallidos".

Su conclusión es que se produce un cambio en el repertorio del reclamo, algo observable en el lenguaje (ya no de clase sino de lo moral en el estallido o de derechos insatisfechos en el corte de ruta), en una interpelación más dirigida al Estado provincial que al nacional, la progresiva des institucionalización, el carácter más espontáneo y puntual de los reclamos y el carácter "antipolítico" de los mismos. Lo que ha variado entonces es ese repertorio en el marco de un cambio en la oportunidad política, y con ello el cambio de rol del sindicalismo y su pérdida de poder en relación con las reformas neoliberales.

En Farinetti no se observa el proceso de más largo plazo, desarrollando una visión pensada desde la estructura política, sin acceder al proceso real de luchas, a la derrota sufrida durante la dictadura y al cómo estas luchas reseñadas son parte de su proceso de recomposición en el marco de la lucha contra el dominio del capital financiero. Tampoco se incorpora el análisis de los cambios en la estructura económica social, y cuando se hace referencia a la "estructura" se deja este análisis

\footnotetext{
101 Además de los autores argentinos que postulan dicha mirada, y que trabajamos en esta tesis, es interesante que James Petras destaca lo mismo en (1999) "América Latina. De la globalización a la revolución", Homo Sapiens, Rosario y en Petras, J. y Veltmeyer (comp. 2004) Las privatizaciones y la desnacionalización de América latina, Prometeo, Bs. As.
} 
sólo en el marco de las relaciones de fuerzas políticas, sin observar nunca las relaciones de fuerzas objetivas. Se fragmenta de esta manera un conocimiento más completo de los procesos sociales, debilidad que para nosotros se hace evidente en su análisis específico del santiagazo.

El enfoque de José Seoane ("Movimientos Sociales y conflicto en América Latina”; "Crisis de régimen y protesta social en Argentina") tiene fuertes similitudes con los de otros autores ya reseñados. Se propone describir y analizar el proceso constitutivo y la significación de la rebelión social que desemboca en el 19 y 20 de diciembre. Este hecho significaría la destrucción de la hegemonía construida en torno al modelo neoliberal, cuya aplicación tuvo un brutal efecto de transformación de la estructura de la sociedad, de sus clases y de las fracciones de cada clase.

El proceso de rebelión parte del crecimiento de la protesta social que para él pone de manifiesto el final del período de derrota, retroceso y cooptación de las organizaciones sindicales y de los movimientos populares en los primeros años del noventa. Esa protesta se expresa a través de “... nuevas prácticas colectivas, de nuevos movimientos asociados a nuevas formas de organización, de lucha y de inscripciones programáticas e identitarias"(2002: 102).

Destaca casi únicamente las líneas de ruptura y lo novedoso, no observando las continuidades y la persistencia de formas históricas de protesta. Las estadísticas realizadas por distintos equipos acerca de conflictos, hechos de rebelión o protestas, nos muestran que la mayoría se siguen realizando desde las organizaciones tradicionales y con sus formatos históricos. Así tampoco se presenta como una realidad demostrada su planteo de que las protestas actuales ya no se dan desde el tipo de organizaciones tradicionales sino desde redes.

Para el autor el ciclo de protestas "claramente" se abre en 1996, cae entre el '97 y el '99 por las expectativas electorales y recrudece desde el 2000, abarcando a diversos sectores sociales. Deja afuera del ciclo al santiagazo y plantea que esto se intensifica en el 2001. Como decíamos el ciclo para el autor marca el quiebre del disciplinamiento social realizado por la dictadura y reafirmado por el "terror económico" de la hiperinflación y el desempleo de masas. Además destaca el fuerte cuestionamiento a las relaciones de representación, expresado de forma manifiesta en las elecciones de octubre del 2001 con el gran aumento del voto nulo y en blanco. En este sentido logra una mirada diacrónica del proceso, integrando diversos elementos que presentan características del proceso de rebelión en distintos ámbitos de la sociedad.

Esa resistencia social abre entonces, al igual que otros movimientos en América Latina (el indígena en Bolivia y Ecuador, el zapatismo en México, etc.) la 
posibilidad de un cambio hacia una "... democratización radical de la vida social" (2002: 109) ante la fragilidad de la salida del sistema, por lo cual este momento se diferencia cualitativamente de la salida a la crisis de 1989. Observa que entre lo nuevo que aparece están las formas asamblearias y el surgimiento de organizaciones de tipo más horizontal, como expresión del cuestionamiento a las formas de representación política instituidas por la democracia burguesa.

Sus trabajos junto a Emilio Taddei y Clara Algranati ("Las resistencias mundiales. De Seattle a Porto Alegre"; "Protesta social, ajuste y democracia: la encrucijada latinoamericana"; "Neoliberalismo, crisis y resistencias sociales en América Latina: las configuraciones de la protesta') presentan un interesante mapa de los conflictos en América Latina desde el 2000 al 2004. Muestran allí lo que ven como un nuevo ciclo de protestas, que expresa el avance contra el neoliberalismo y sus dramáticas consecuencias sociales. Mantienen la perspectiva general de que la mayoría de las acciones son desarrolladas por nuevos sujetos colectivos que centralmente plantearían demandas democráticas (planteando allí como antecedente al levantamiento de Chiapas en 1994, al que observan como una reivindicación democrática basada en la identidad indígena, cuya línea impactaría en los demás movimientos que van surgiendo en América Latina).

A su vez, en algo que nos parece un exceso en la comparación, ponen a este proceso como parte del movimiento anti globalización, una especie de frente mundial antineoliberal. Si bien no será un motivo de nuestra investigación creemos que la protesta en los países dominados toma un carácter muy distinto a la que se desarrolla en los países dominantes. La falta de centralidad que para estos autores tiene el Estado nación actual, les impide observar las marcadas diferencias en el contenido político de cada tipo de hecho.

A partir de la caída de lo que llaman el régimen fordista, cae para ellos el peso de los sindicatos como sujetos privilegiados del conflicto. Surgen nuevos movimientos sociales de base territorial, con fuerte identidad étnica o cultural, o con una carencia específica. Hay un fuerte peso de los movimientos sociales de origen rural, en especial en México, Bolivia y Ecuador. También destacan el peso del MST en Brasil y los mapuches en Chile. En Argentina se forman los MTD, con fuerte peso y base barrial. Luego destacan que, de todas maneras, los trabajadores ocupados siguen teniendo un papel importante, con alrededor de un tercio de las protestas, pero que el peso central pasa a los trabajadores del sector público, que realizan el $75 \%$ de estos hechos.

Ven que ante la segunda generación de reformas neoliberales la fragmentación inicial de la resistencia ya no existe y se conforman espacios amplios, muchas veces bajo las formas de multisectoriales, que toman medidas de lucha con importantes 
elementos de confrontación. Esto marca una diferencia con la primera fase de reformas, a las cuales en general sólo las habían resistido los trabajadores de cada sector afectado en forma aislada, siendo casi siempre derrotados. Ahora es cada vez más difícil para los gobiernos avanzar con sus proyectos.

Es fundamental para ellos el cambio en el repertorio de protestas. Por eso marcan como un hecho central la profundización del tipo de medidas "En relación con ello, y respecto de los "repertorios de la protesta", es importante destacar una tendencia a una mayor radicalidad en las formas de lucha, que se pone de manifiesto en la duración temporal de las acciones de protesta (acciones prolongadas o por tiempo indeterminado)" (2006: 240).

Destacan también la conformación de espacios de coordinación internacional como el Foro Social Mundial, que presentaría un "nuevo internacionalismo" (2006: 244). Nuevamente para nosotros hay una sobre valoración de los parecidos entre algunos procesos, sin observar las diferencias de estos movimientos de la sociedad.

Como consecuencias generales marcan un proceso de reapropiación de los territorios que caracteriza a estas prácticas colectivas, un cuestionamiento de la democracia representativa y la búsqueda de organizaciones horizontales y amplias. La respuesta desde el poder es el neoliberalismo de guerra (González Casanova, 2002; Taddei, 2002) no solamente a través de ataques evidentes, sino por todo un aparato de militarización progresiva, criminalización de la protesta social y avances particulares con tratados de libre comercio.

Contra eso surgen protestas que llevan a "levantamientos populares" (no hay mayor conceptualización de las formas de protesta, ni se aplica una escala) que llegan hasta a derrocar gobiernos y a la formación de mayorías electorales opositoras al programa neoliberal.

Vemos que Seoane, ya sea sólo o en colaboración con Emilio Taddei y Clara Algranati, presenta trabajos serios con un profundo relevamiento y una problematización que aporta al conocimiento, mostrando el avance en los niveles de confrontación (aunque no vea la escala de luchas en nuestros términos) y lo que nosotros marcamos como la formación de una fuerza social que empieza a plantearse la posibilidad de una alternativa distinta para la sociedad.

Lamentablemente su concepción de que la clase obrera como tal ya no juega un papel central en el proceso de luchas lo lleva a sobrevalorar los elementos de cambio y a no observar los fuertes rasgos de continuidad que se expresan en las protestas actuales en Argentina y que marcan que estas son parte y resultado de la rica historia de luchas de nuestra clase obrera. Se destacan como procesos novedosos a formas históricas de la masa obrera y explotada y a conflictos que 
siempre estuvieron presentes en América Latina (por ejemplo el rural, que atraviesa la historia de los países dominados y que se presenta como un elemento que demostraría la novedad del tipo de movimientos que surgen después de los noventa).

Son interesantes las reflexiones de Raúl Fradkin en "Cosecharas tu siembra. Notas sobre la rebelión popular argentina de diciembre de 2001". Allí Fradkin problematiza algunas de las visiones hegemónicas sobre el proceso de rebelión que desemboca en diciembre de 2001. Especialmente es importante la polémica sobre la concepción vulgar del saqueo como forma de lucha "salvaje, vandálica", y la del cacerolazo como forma "civilizada y ordenada" y la propuesta de conceptualizar y discutir científicamente estos hechos.

Así como profundiza estas ideas en oposición al pensamiento dominante, consideramos que cae en algunos de los tópicos que de tanto repetirse se han hecho carne en la mayoría de las investigaciones sobre estos procesos: la no participación de las organizaciones sindicales en el proceso y "... la drástica reducción de las filas y de la incidencia política del movimiento obrero" (2002: 64). Varias veces recurre a la conceptualización de "incluidos y excluidos" que impide el abordaje de clase, necesario para comprender la naturaleza del proceso a estudiar.

Su metodología de trabajo nos sirvió como indicador para intentar en nuestra investigación desarrollar ese cruce que realiza entre las informaciones de los medios de comunicación y lo que ocurría en la realidad. Muestra como los grandes medios de comunicación operan en tanto instrumentos de la clase dominante, por ejemplo en el ensalzamiento de todo aquello que fuera supuestamente "espontáneo" y la crítica de todo lo que apareciera como "organizado".

Los trabajos que se sostienen en el situacionismo suelen partir más desde una postura de interpretación y debate político que de una intención de buscar producir conocimiento científico. En algunos casos esto se lleva al extremo de plantear que no se busca producir ciencia, ya que se la considera como una de las formas que toma la razón instrumentalizada del poder. Sin embargo debemos marcar que hay importantes diferencias dentro de esas posiciones. Raúl Zibechi y el Colectivo Situaciones, por ejemplo, se sitúan en el horizontalismo a ultranza y en la concepción de que no se debe buscar medir, conceptualizar, ni buscar explicaciones holísticas de los procesos sociales. En cambio otros autores, como Ana Dinerstein o Miguel Mazzeo, consideran necesario una organización popular estructurada y en esa línea entienden la importancia de encontrar tendencias generales y entender los procesos de cambios en las relaciones de fuerzas.

Así Dinerstein ("El poder de lo irrealizado en Argentina y el potencial subversivo de la mundialización" y "¿Que se vayan todos! Crisis, insurrección y la reinvención de 
lo político en Argentina") plantea su oposición a pensar las luchas de los noventa en clave de que los sujetos buscaban su "inclusión" en la sociedad. Sostiene que estas luchas muestran como los procesos de desarrollo del capitalismo impactan en la vida y en la subjetividad de esos supuestos "excluidos", que son parte de la dinámica actual del capitalismo. La contradicción que se acrecienta entre trabajo concreto y trabajo abstracto se hace evidente en esos sujetos, a los que el capital vuelve sobrantes y que sólo pueden encontrar en la acción colectiva la posibilidad de volver a convertirse en sujetos activos.

Destaca el desarrollo de nuevas organizaciones (comisiones multisectoriales, de desocupados, coordinadoras de piqueteros, fogoneros, vecinales o similares) pero mostrando el papel de los sindicatos y la participación de gran parte de la comunidad. Para ella los cambios del capitalismo generan una gran debilidad en las organizaciones tradicionales de la clase obrera y la necesidad de que surjan nuevas formas, pero esto no inhibe que las organizaciones tradicionales no puedan recomponerse y adecuarse a las necesidades actuales de la lucha (poniéndose aquí en una postura más cauta que la de muchos investigadores que dieron por desaparecidos a los sindicatos y partidos como sujetos claves del conflicto social).

Discutimos con la autora la igualación que sostiene entre las luchas de los piqueteros y las de los grupos "antiglobalización" europeos o norteamericanos. De acuerdo a su tesis lo que se desarrolla no es una lucha por el poder entre clases sociales, sino una búsqueda de "nuevas subjetividades" que de la misma manera se desarrollaría en Seattle, en Chiapas o en Mosconi. Para nosotros aparece aquí una carencia en el abordaje sobre la realidad concreta de Argentina y acerca de las diversas formas que toma el enfrentamiento contra el sistema de acuerdo a las características de cada estructura económica social.

El trabajo de Miguel Mazzeo ("Piqueteros. Notas para una tipología") analiza en forma minuciosa a las diversas organizaciones piqueteras, buscando comprender sus concepciones políticas generales, lo que podríamos denominar sus programas. Y las divide en tres grandes bloques que nosotros llamaríamos reformistas (para él estructuradas en el eje sociedad (o pueblo) - partidos o movimientos políticos representación - poder del estado), revolucionarias (para él en el eje clase obrera (o pueblo) - vanguardia - revolución) y los que escapan a esos ejes tradicionales, a los que plantea como corrientes "autónomas".

El autor demuestra un profundo conocimiento de estas organizaciones y de sus dinámicas políticas y hay una intención de relacionar sus actividades con el desarrollo capitalista y los cambios en las relaciones de fuerzas sociales. Para nosotros su limitación se centra en que en lugar de investigar lo que hacen esas organizaciones en 
su relación con la dinámica general de conflicto social, Mazzeo supone que cada corriente hace lo que dice, centrando su análisis en el discurso político y las formas organizativas, en lugar de hacerlo en el enfrentamiento social. Como suele ser propio de esta corriente, Mazzeo centra su estudio en las organizaciones con las que comparte su postura ideológica, en su caso los MTD, que para él se encuentran en una posición intermedia entre el "horizontalismo" y la "organización estructurada".

En Raúl Zibechi ("Genealogía de la Revuelta. Argentina: la sociedad en movimiento") es quizás donde más se expresan las posturas extremas de esta corriente intelectual. Para nosotros hay una grave falencia en esta perspectiva, que se ahonda en este autor, y es que se busca aquello que sustenta su postura política sin observar la totalidad del proceso. Se realiza un recorte de la realidad desde una visión apriorística y sólo se ve lo que se quiere ver. Zibechi constantemente desarrolla reflexiones acerca de cómo entiende que debería ser el proceso social y cómo se debe desarrollar la lucha por otra sociedad y luego busca ejemplos que lo "demostrarían". Esto es claro cuando se plantea que el elemento más distintivo de los últimos años es el surgimiento y expansión de nuevas organizaciones basadas en lazos horizontales y en una perspectiva "autónoma". Para sustentar esta postura se citan algunos ejemplos, pero se deja afuera del estudio a todas las organizaciones que siguen tomando otros modelos de construcción.

En esa perspectiva es lógico que toda su producción se base en criticar la mirada del socialismo científico. Pero, coherente con su postura de ver lo que quiere ver, no discute realmente con el socialismo sino con las interpretaciones que él realiza sobre lo que el socialismo científico expresaría. También hay errores en varias lecturas de procesos históricos, que llevan a justificar su línea teórica para la actualidad. Zibechi afirma que el cordobazo no fue una lucha planificada (2003: 32), sino que se trató de una experiencia "autoafirmante" de los obreros. Lo pone así como parte de esos nuevos movimientos sociales entre cuyas características estaría el concentrar grandes masas para "evitar riesgos" (en una postura muy similar a los de la acción colectiva, como si la acción surgiera del cálculo, 2003: 35). De más esta decir que suponer que en esas acciones no hubo riesgos es una lectura al menos discutible.

El prologo del libro es de John Holloway, quién plantea que a partir del 2001 surge un nuevo movimiento en Argentina que se propone cambiar el mundo sin tomar el poder. Califica a los hechos de diciembre de 2001 como "la gran explosión de diciembre de 2001", cayendo en una conceptualización vulgar semejante a la de "estallido". No observa así al 2001 como resultado de una acumulación, de años de lucha de las masas explotadas de Argentina y América Latina. 
Luego Zibechi lo deja más claro, rechazando el concepto de acumulación. Toma el concepto de repertorio de Tilly y Tarrow, dejando de lado la idea de que hay una escala en las formas de rebelión. Es constante la utilización de un lenguaje teatral, que para nosotros es sintomático de una forma de comprender el mundo,. Así considera que los grandes cambios se miden por las modificaciones en las formas que toma la protesta, proceso que comenzaría en la década del ochenta, cuando los "viejos métodos" de la clase obrera dejan de resultar "atractivos". Entran "nuevos actores" al escenario de las luchas. Estos nuevos actores serían especialmente las mujeres y los jóvenes, quienes buscan nuevas formas de acción. No hay una problematización acerca de la histórica presencia de las mujeres y los jóvenes en la totalidad de los hechos de rebelión, al menos durante todo el siglo XX.

Así surgen nuevos grupos que romperían con la lógica simétrica del poder y con la idea de acumulación. Los sujetos que integran estos grupos aparecen como los sujetos del cambio, diseñando desde su voluntad, conciente y con independencia de las condiciones objetivas, su forma de dar la lucha. Ellos organizan sus grupos sin importar a quién enfrentan y aparecen como conscientes de todo lo que están haciendo. Como no hay escalas no hay formas de rebelión más o menos contundentes. Cualquier acción puede modificar el mundo, y esto es especialmente posible desde los márgenes del sistema, por lo cual la desafiliación aparece como algo positivo que permite realizar este proceso.

Para la mirada de Zibechi todo es ruptura y cambio, sin observar las líneas de continuidad en los procesos históricos. Si bien comienza sosteniendo la necesidad de estudiar los procesos desde los conflictos, en verdad su estudio termina haciendo historias de las organizaciones. Así se seleccionan algunos grupos para ser estudiados: Zibechi toma a agrupaciones estudiantiles como La Mariátegui y el Mate (de las facultades de Filosofía y Letras y de Ciencias Sociales de la UBA), a grupos de jóvenes surgidos del trabajo junto a las Madres de Plaza de Mayo, a la radio La Tribu, a las Comunidades Eclesiales de Base de Quilmes, entre otros. Se estudia lo particular sin observar cómo esas expresiones particulares y localizadas se articulan en el proceso general.

No queda claro porque el investigador determina que algo pasa ser viejo. Se construye un modelo que se aplica, determinando qué es nuevo y qué es viejo, pero sin medir ni comparar. Así casi no presta atención a las huelgas de los noventa desde la muy discutible afirmación de que "Huelga y clase obrera dejaron de identificarse" (2003: 24).

Para Zibechi aparecen nuevas formas que son las más dinámicas y que son experiencias de autoafirmación: el movimiento homosexual, los piquetes, el 
movimiento de derechos humanos, las murgas, los escraches. Dentro de los ocupados solamente destaca aquellos procesos que irían más allá de los intereses sectoriales, tomando como ejemplos a la lucha de Aerolíneas y la Carpa Docente.

Zibechi toma como sujeto del proceso a los "sectores populares", una definición que fue propuesta en Argentina por Luís Alberto Romero, entre otros trabajos en su libro junto a Leandro Gutiérrez "Sectores populares, cultura y política". También comparte con dichos autores la definición de que tras la dictadura los militantes buscaron "refugios". Por eso plantea la necesidad de estudiar la "infrapolítica", lo que sería la fase organizativa de los nuevos movimientos. Consideramos interesante esta formulación, semejante a la indicación de Gramsci de la necesidad de estudios "moleculares" para comprender los procesos de construcción de las organizaciones. Aparecen aquí elementos comunes con la propuesta de Melucci.

Por último marcamos las coincidencias, en torno al período ve a 1989 como un momento de quiebre, donde se termina de imponer el neoliberalismo y a su vez se genera el piso desde donde comenzará el proceso de los noventa. Observa que recién se comienza a recomponer después de 1993, tras el santiagazo, en lo que plantea una importante coincidencia con nuestra periodización. Sin embargo luego centra su mirada en las organizaciones, en lugar de seguir observando el proceso de lucha. $Y$ allí es muy fragmentario, ya que sólo observa una pequeña parte de la totalidad (básicamente la Capital Federal y una parte del Conurbano).

Igual destaca la importancia de los cortes de rutas en 1996 y 1997 y de los cambios en las huelgas de los noventa, observando que en estas se articulan los distintos hechos de protesta. Pero esta evidencia, en lugar de mostrarle que la huelga sigue siendo importante, lo lleva a decir que perdió peso en relación a los cortes de rutas y otras formas de protesta que se dan en esos días. Es que Zibechi es coherente en todas estas lecturas con su caracterización de que no hay hechos superiores e inferiores, y por eso no puede haber articulaciones ni hechos que se sintetizan o se subsumen en otros. Esto es claro para el 2001, donde para él no hay síntesis sino multiplicidad. Así no ve justamente lo clave de cada hecho. En el caso de diciembre del 2001 lo cualitativamente diferente es que en ocho días (del 13 al 20) se sintetizaron en un hecho superior todas las formas de rebelión que se habían dado en forma dispersa a lo largo del ciclo (como lo plantean Iñigo Carrera y Cotarelo en "La insurrección espontánea...").

La producción del Colectivo Situaciones ("19 y 20. Apuntes para el nuevo protagonismo social"; "La hipótesis 891. Más allá de los piquetes") esta dirigida claramente al debate político y al intento de propagandizar su línea acerca de la necesidad de "cambiar el mundo sin tomar el poder", no planteándose como tarea de 
sus trabajos el contribuir a desarrollar conocimiento científico sobre los hechos que analizan. De hecho rechazan en varias partes el mismo criterio de ciencia. En verdad quizás sería más lógico tomar estos trabajos como fuentes (o sea como expresión de una de las corrientes políticas del movimiento social en Argentina) que como producción científica, pero lo hacemos en este plano porque creemos que parte de sus posturas han incidido en sectores importantes de la producción académica.

En sus trabajos no hay mediciones ni intentos de comparar. Como en toda su corriente no hay escala de luchas ni hechos superiores, ya sea en los niveles de conciencia que expresan o en la capacidad para generar cambios en la sociedad. Observan que se desarrolla un "ciclo de insurrecciones y puebladas desde 1993" (2002b: 121), sin conceptualizar las diferencias entre hechos de rebelión cualitativamente diferentes. Tampoco queda claro a qué se refieren con cada término, ni con el concepto de ciclo. Este aparece más como una sucesión de hechos que como una acumulación, ya que se manifiestan expresamente en contra de este concepto.

Sin embargo al mismo tiempo se destaca que el movimiento piquetero es expresión de la tradición sindical de la clase obrera argentina y de las experiencias que se van desarrollando en este proceso de insurrecciones y puebladas. Allí es central la aparición de los cortes de ruta como punto clave de este aumento de la conflictividad social. Plantean una hipótesis que consideramos muy rica en sus perspectivas: el pensar que la conformación de los movimientos de trabajadores desocupados retomarían las experiencias de la primera fase del movimiento sindical en Argentina, antes de que este consolidará una perspectiva limitada a lo corporativoprofesional.

Pero si bien se marcan estos lazos entre la historia del movimiento obrero y el piquetero, cuando se trata el período no se da la menor importancia a los hechos de lucha de los trabajadores ocupados. Ni siquiera se nombra a las huelgas y menos aún se discute su carácter de articuladoras de los distintos hechos durante los años noventa. Para ellos los trabajadores ocupados hoy no son un sujeto importante de la lucha y los sindicatos son organizaciones antiguas que ya no cumplen un papel disruptivo.

Afirman que la identidad se construye en la lucha. Pero pareciera ser un proceso individual y no colectivo, ya que lo que se produce es un "acto subjetivador", una autoafirmación de las personas que intervienen en el hecho. Allí desarrollan una interesante taxonomía, diferenciando entre las personificaciones sociales del desocupado, el excluido y el piquetero. El desocupado es un sujeto pasivo, una víctima, que quiere volver a trabajar. El excluido alguien que solamente reclama ser 
incluido y no transformar nada. Ambas identidades compartirían la necesidad de mantener este sistema.

En cambio "el piquetero" pretende transformar la sociedad del trabajo enajenado, del individualismo y la competencia. El problema es que no aparece una demostración de que esto sea así. Coherente con su postura metodológica pretenden demostrar esto desde el testimonio de algunos militantes, en lugar de observar cuál es el ciclo de enfrentamientos sociales, cuáles son las metas, qué organizaciones lo dirigen, cuáles son las potencialidades del movimiento, etc. No hay así investigación de los hechos sino una identificación política con algunos de los sujetos que los realizan.

El 19 y 20 de diciembre es calificado como una expresión de la clase media y es conceptualizado como "una fiesta". No observan la articulación con los saqueos ni los elementos de confrontación, de lucha y combate en las calles, con muertos y heridos. Lo ven como un hecho que se produce fundamentalmente en Buenos Aires y no hay claridad en que es parte de un ciclo o la resultante de años de acumulación. En definitiva el 19 y 20 es, al igual que los cortes de ruta o que una asamblea en el barrio, una experiencia de autoafirmación, que solamente sería más importante que estas otras experiencias por su carácter masivo.

El sujeto es la multitud. Pero esa multitud no es un sujeto colectivo sino la unión situacional (o sea a partir de múltiples particularidades) de miles de personas que se conforman como una multitud durante el hecho y luego se dispersan. Se destaca allí la importancia de lo fragmentado como algo positivo, comprendiéndolo como un logro y no como una carencia. Ya que todo parte de procesos singulares (situacionales) no hay posibilidad de síntesis, pero sobre todo no se busca esa síntesis, ya que esto sería quitarle fuerza al hecho cuya potencia parte de ser múltiple. O sea no hay intención de encontrar explicaciones holísticas de los procesos.

Es interesante que para explicar cómo cada persona se suma a la multitud hablan de decisión y no de elección, criticando la visión de la acción racional de un sujeto que calcula su participación según la estructura de oportunidad. Por ello prefieren plantear que lo que se realiza cuando se decide pasar a la acción es una decisión, que parte de un proceso de autoafirmación del individuo. Lo que aparece es una explicación más vinculada a procesos individuales que a procesos colectivos condicionados por las relaciones de fuerzas sociales.

En Ferrara ("Más allá del corte de rutas. La lucha por una nueva subjetividad") vemos elementos típicos de esta perspectiva. El autor plantea que quiere realizar un estudio sobre la subjetivación en situaciones de miseria (tomando como marcos teóricos a los desarrollados por Alain Badiou y Agamben) y no sobre el proceso de 
protestas sociales. Su propuesta es que todo el proceso de luchas actuales constituye ese proceso de subjetivación, marcando como punto más alto al desarrollo del MTD Solano. Para él esto comienza con los cortes de ruta de Cutral Có y Plaza Huincul, que expresan el posfordismo. Cae la huelga como método de lucha central y surgen estos cortes de rutas (a los que luego define como formas de dispersión, recuperando a Hardt y Negri). De allí se dividen dos corrientes: entre los que quieren volver al sistema para ser "incluidos" y los que ya no quieren regresar y prefieren construir desde los márgenes. Esta división no tendría nada que ver con el proceso de luchas o con las condiciones materiales, sino con decisiones de los que realizan los hechos. $\mathrm{Y}$, como para él es el punto más interesante de desarrollo, lo que hace es analizar al MTD Solano, dejando casi fuera de su abordaje lo que no coincide con su postura.

En definitiva para nosotros otra vez hay una teoría que se "constata" en la realidad y no una realidad que es analizada desde un determinado marco teórico. Para Ferrara las viejas teorías no pueden comprender los "fenómenos novedosos" como el cacerolazo y los piquetes. Por eso afirma que marcos teóricos como el que nosotros planteamos son un "obstáculo epistemológico", según la concepción de Bachelard.

Diego Sztulwark ("Doce hipótesis sobre el contrapoder elaboradas desde la Argentina convulsionada') desarrolla una reflexión más de tipo ensayístico que una investigación concreta del proceso. Sin embargo nos sirve para reseñar algunas características de este tipo de abordaje teórico. Habla en primer término del 19 y 20 de diciembre como un "fenómeno insurreccional" (2002: 47), que sucedió sobre todo en Buenos Aires. Vemos aquí que no observa el proceso en su totalidad ni su articulación con los saqueos. Si bien primero habla de insurrección (y allí coincidiría con nuestra mirada) luego muestra que no le da importancia a comprender la escala de luchas ya que habla del mismo hecho como una "revuelta" (52), mezclando así la forma más elemental de rebelión social (que no es todavía siquiera lucha) con una de las formas más sistemáticas de la misma

Como ya lo marcamos esta postura de no incorporar los saqueos al hecho que culmina en el 19 y 20 de diciembre es sintomático de una mirada que elimina la confrontación, y que prefiere quedarse con esa imagen idílica de una "multitud" caminando durante la noche del 19 de diciembre por la Capital Federal. Los saqueos desesperados en el Conurbano y en el interior del país, son más difíciles de ver, y quizás más complejos de explicar, para esta teoría.

Para él estamos ante un “...fracaso del neoliberalismo" (2002: 48), un “...fracaso de la política” (49) y una caída del Estado que "...deja de regular los flujos de capital, bienes, dinero e información". Como ya lo marcamos todos estos planteos son claramente discutibles desde un estudio más profundo de la realidad. 
Tomamos por último el artículo de Ouviña del 2002, ya citado anteriormente. Sabemos que no es un trabajo que refleje la producción integral de este autor, pero sí consideramos que es una buena demostración de las limitaciones a los que lleva un enfoque como el que estamos criticando cuando intenta estudiar un proceso concreto de la realidad. Desde esta perspectiva en general tenemos trabajos de características ensayísticas que recurren a "ejemplos" de la realidad, pero sin pretender investigarla. En cambio este trabajo es un intento de comprender la especificidad de las asambleas barriales que, luego de diciembre del 2001, habían surgido en muchos barrios de Capital Federal, Conurbano bonaerense y varias ciudades del interior.

La falta de organización, la fragmentación y las dificultades para articularse no se destacan como signos de debilidad sino como fortalezas de este proceso de asambleas. Como en los autores anteriores el único riesgo que aparece son los militantes de las organizaciones de izquierda, a los que se considera incapaces de comprender el proceso y como posibles destructores del mismo. Obviamente desde esta perspectiva, que no asume al proceso como una totalidad, se piensa, por ejemplo, al militante como algo externo al movimiento y no como una parte del mismo que expresa determinados elementos (sean estos negativos o positivos según la consideración de cada grupo).

Su perspectiva teórica lo lleva a analizar las asambleas casi por fuera del proceso global de movilizaciones sociales, buscando su importancia no en las luchas o en el conflicto, sino en su funcionamiento interno. $Y$ desde allí se cae en lecturas que hoy aparecen como un claro error en términos de análisis científico.

Para el autor las asambleas muestran una nueva forma de organización que expresa "un punto de no retorno" a la lógica capitalista (2002: 63). Los conflictos ya no pasarían por el ámbito laboral ni por los trabajadores ocupados. Ahora el vecindario se transforma en la nueva matriz organizativa a partir de la reestructuración capitalista que hace más difícil la organización en el ámbito laboral (67). Afirma que "Las asambleas condensan, además, una nueva forma de (anti) poder popular, pero no pretenden la toma del poder del Estado" (66). Esto no se demuestra ni con datos u observación del proceso de enfrentamientos. Como no se observa el proceso de luchas, el papel de las asambleas en el marco global, sus metas o su programa, lo que queda es el análisis del investigador o el testimonio de algunos participantes.

La sobre valoración de lo novedoso, la falta de visión de la totalidad, lleva a errores de apreciación. Las asambleas que el autor destaca como un punto de no retorno en su mayoría se disolvieron a los pocos meses. Es muy posible que al menos una parte de los sujetos que las integraron hayan vivido sí un antes y un después de esta experiencia práctica y hoy estén abonando otros procesos de movilización social. 
Pero quizás ya no lo hacen desde estas formas organizativas, sino desde aquellas que, apresuradamente, muchos ya daban por muertas.

\section{2.b. Sobre el movimiento de la sociedad en Patagonia}

La producción sobre conflictos sociales recientes en la Patagonia argentina es escasa y, además, muchas veces es de difícil acceso, dados los serios problemas que suelen tener los investigadores de nuestra región para publicar y difundir sus trabajos.

Especialmente se han producido gran cantidad de trabajos sobre la fuerte conflictividad en la provincia de Neuquén, concentrados en los hechos de Cutral Có y Plaza Huincul (indicados desde distintas perspectivas como uno de los afluentes claves para comprender el surgimiento del movimiento piquetero a nivel nacional) y en la experiencia de la fábrica recuperada Zanón.

Sin embargo la mayoría de esas investigaciones no logran enfocar su atención en las especificidades de la región, en el desarrollo particular de la clase obrera y en su ubicación, a la vez, como parte del proceso general. Las distintas perspectivas suelen encontrar en estos conflictos o solamente "particularidades" o únicamente "casos" de un proceso nacional, sin poder hacer observable lo particular como expresión de lo general (ya discutimos en alguna medida estas cuestiones en el primer capítulo y volveremos a enfocarnos directamente en este tema en el primer apartado del tercer capítulo de esta tesis).

A su vez la delimitación de la conflictividad en Patagonia ofrece serias dificultades por la enorme extensión de la región y las escasas relaciones que se entablan entre las diversas provincias, mucho más conectadas con la región central del país que entre sí (no solamente por razones de infraestructura, rutas terrestres y aéreas, circulación de camiones, sino especialmente por razones ideológicas donde el papel de los medios de comunicación nacionales concentrados en Buenos Aires es clave). Por esto, si bien habría diversas claves que nos permitirían encontrar paralelos entre las diversas protestas que se relevan en Patagonia, en el proceso concreto desarrollado en el período que estudiamos la conexión entre los conflictos en la región noreste de Chubut y los del resto de Patagonia es sumamente escasa, relacionándose además con ellos en forma muy similar a la mirada que se mantiene con respecto al resto de la conflictividad nacional.

Partiendo de estas consideraciones, que obviamente relativizan la importancia de pensar un apartado dirigido centralmente a pensar los trabajos producidos sobre los conflictos y el movimiento de la sociedad en la Patagonia, abordamos esta tarea para debatir sobre algunos trabajos en forma específica y porque consideramos que este apartado expone claramente la necesidad de nuestro trabajo en el contexto 
general de producciones sobre las diversas provincias que integran lo que conocemos como Patagonia argentina.

Comenzamos por destacar el aporte de un importante grupo de investigadores de la Universidad Nacional del Comahue, que desarrollan sus trabajos desde la perspectiva metodológica inspirada centralmente en Charles Tilly y Sidney Tarrow.

Hay en ellos una preocupación permanente por cruzar el análisis de la conflictividad social con las diversas instancias del poder político, el tipo de gobiernos provinciales que se establece, las relaciones con el gobierno nacional y con la sociedad civil de la región, y las disputas interburguesas que se entablan. Esta, en verdad, es una preocupación que atraviesa a casi toda la producción historiográfica neuquina desde diversas perspectivas ideológicas, muy afirmada en la historia de esa provincia y en las características de su partido-movimiento-estado provincial (Favaro, luorno, Cao, 2006: 99), el Movimiento Popular Neuquino, cuyas disputas internas parecen abarcar gran parte de la dinámica de la conflictividad social.

Los trabajos de Orietta Favaro ("Una puesta en cuestión sobre el tema de los movimientos sociales. Problemas, tendencias y desafíos", "Neuquén. La sociedad y el conflicto. ¿Viejos actores y nuevas prácticas sociales?”, entre muchos otros) son quizás una de las mejores síntesis de estas preocupaciones.

Como un trabajo central para esta parte del capítulo fue tomado la síntesis que realizan de las protestas en Patagonia, Orietta Favaro y Graciela luorno ("La Patagonia protesta", del 2006). En este artículo las autoras avanzan en un sintético estado de la cuestión, buscando en las transformaciones estructurales producidas por el neoliberalismo la explicación fundamental del fuerte caudal de protestas y desarrollando un importante esfuerzo de reflexión y recopilación de muchos de los trabajos producidos hasta esa fecha.

Este trabajo se complementa, y continúa, un artículo anterior realizado por las mismas autoras junto a Mario Arias Bucciarelli en 1997 ("La conflictividad social en Neuquén: el movimiento cutralquense y los nuevos sujetos sociales'), donde, en una fecha tan próxima a los conflictos analizados, ya hacen observable el surgimiento de nuevos sujetos sociales y de las prácticas asamblearias. Estas serán luego conclusiones comunes a muchos investigadores que estudiaron estos y otros conflictos que atravesaron al país en los últimos años.

Por último también Orietta Favaro y Graciela luorno, esta vez junto a Horacio Cao, desarrollan un trabajo de síntesis en la compilación de Gerardo Caetano del año 2006. El artículo ("Política y protesta social en las provincias argentinas") logra presentar una visión de conjunto de diversos conflictos, que en una primera mirada podrían ser calificados de "locales" o de "casos", donde las particularidades podrían 
esconder el proceso general. Sin embargo los autores logran mostrar como en los procesos desarrollados en Neuquén, Río Negro y San Juan aparece el delineado de un proceso general de cambio social, que hace a una mirada integral y que involucra no solamente cambios en las formas de protesta y organización social, sino fundamentalmente una profunda reestructuración de la relación de fuerzas objetivas en la estructura económica social. Ese cambio se expresa en las formas de relaciones de los poderes políticos provinciales con el Estado nacional, en la pérdida de poderío de los Estados provinciales y su incapacidad cada vez mayor de preservar grados de autonomía (lo que los lleva a perder capacidad de control sobre los conflictos), y hasta el recurso al conflicto visible y aparentemente incontrolable como una estrategia de esos Estados provinciales empobrecidos y debilitados, para hacerse escuchar en el contexto nacional.

Para nosotros este es un trabajo orientador de nuestra perspectiva de investigación, aún cuando sus presupuestos epistemológicos sean en alguna medida contrarios a los nuestros, y muchos de sus resultados serán discutidos. Así para ellos estamos ante una descomposición del Estado, ante una aguda des industrialización, ante la aparición de nuevas organizaciones sociales que desarrollan nuevas formas de protesta y que desplazan a las organizaciones y formas tradicionales (reproduciendo la difundida idea de la pérdida de importancia de los sindicatos y las huelgas en el conflicto social actual).

Parten de la definición de acción colectiva, más concretamente de la desarrollada por Norma Giarracca y otros, que delimitan como "acción colectiva de protesta”. Para ellos lo central son las “...luchas de los sin: sin trabajo, sin casa, sin tierra, sin papeles, etc" (2006: 96). Estas luchas son políticas, personales, sociales y culturales y son descriptas como fragmentadas, diversificadas y dispersas en sus acciones, demandas y actores. Se considera que centralmente son expresión de demandas ciudadanas, o de "matriz ciudadana", y de inclusión, y por ello modifican su repertorio con respecto a las anteriores luchas de matriz sindical. Es central para estas nuevas formas de protesta el papel de los medios de comunicación, como mecanismo para dar visibilidad a sus reclamos, necesidad que también es uno de los elementos propios de la aparición del corte de ruta como medida más difundida.

No enfocaremos aquí discusiones que ya desarrollamos más profundamente en otros apartados. Sí nos interesa hacer hincapié en la importancia de la caracterización que realizan en este artículo sobre las características históricas de Neuquén y Río Negro. Si bien la historia del desarrollo de Neuquén y de su recurrente conflictividad (lo que autores como Aiziczon y Petruccelli llaman una "cultura de la protesta") puede observarse en varios trabajos, hay aquí una síntesis que muestra 
como el crecimiento y desarrollo de los setenta y los ochenta, es frenado en los noventa por el despliegue del proyecto neoliberal, presentando los profundos quiebres que produce esto en una sociedad acostumbrada a años de mejoría de los niveles de vida.

Especialmente relevante se nos hace la sección del trabajo que hace referencia a Río Negro. Además de reseñar los pocos trabajos sobre las luchas en Río Negro en los noventa, y de aportar una interesante mirada de conjunto sobre esta cuestión, problematiza aspectos claves del desarrollo histórico de esa provincia. Recuperamos en nuestra producción la idea de una provincia que no ha logrado integrarse y que funciona con la lógica de regiones autónomas que no tienen casi conexión entre sí. Vemos que esta realidad, que los autores hacen observable en Río Negro entre la región del Alto Valle, la línea sur, las ciudades de San Antonio y aún más de Sierra Grande, etc; es algo que se hace evidente en la provincia de Chubut, especialmente entre sus tres grandes conglomerados: la región noreste, la noroeste y la sureste, mientras la gran extensión de la provincia se encuentra casi despoblada y sin posibilidades reales de integración o desarrollo.

En una línea semejante encontramos los interesantes trabajos de Fernando Aiziczon. Su perspectiva recupera centralmente la teoría de la acción colectiva, pero retomando a su vez algunos elementos del materialismo histórico, algo que también se hace presente en los trabajos de Favaro e luorno. Hemos recuperado especialmente su interés por situar la emergencia de la experiencia de la fábrica recuperada Zanón (su tema central de investigación, ver el trabajo junto a Orietta Favaro "Al filo de la cornisa - La resistencia obrera en la fábrica Zanón", y su artículo "El clasismo revisitado. La impronta del trotskismo en la politización del sindicato ceramista: Zanón Bajo Control Obrero, Neuquén 1998-2006") y de los procesos de conflicto social en los noventa ("Sindicatos y conflictividad social. ATEN durante la primer década de los '90") en una perspectiva de más larga duración, rastreando la formación de tradiciones obreras, de una cultura propia de los sectores subalternos, y la construcción de procesos de politización que desafían a los poderes hegemónicos.

Un muy buen ejemplo es el interesante artículo "Construyendo tradiciones en tiempos de transición: activistas en las luchas de los obreros de la construcción de Neuquén a fines de los años '80', donde a partir de la observación del sepelio de un militante político clave en las huelgas de la construcción, logra revisar la conformación de una tradición obrera en la provincia de Neuquén, que incide claramente en el desarrollo de las protestas de los noventa.

Hay, además, una fuerte preocupación en este grupo de investigadores por construir una selección de fuentes que supere a las tradicionales, y que permita hacer 
observables los procesos que las fuentes más controladas por el poder suelen invisibilizar. El interés por la construcción de fuentes orales y el desarrollo de metodologías de "historia oral", se hace presente en casi todos estos trabajos, así como la búsqueda de otros repositorios no tradicionales, como los archivos de militantes, los periódicos y panfletos partidarios, las minutas internas, etc.

Enrique Mases y el grupo de investigadores que se nuclean alrededor del GEHISO (Grupo de Estudios de Historia Social) constituyen otro aporte clave al momento de pensar la historia de los trabajadores en la Patagonia. De hecho es desde este espacio que surgen las jornadas de historia de los trabajadores en las que hemos podido arribar a una mirada bastante integral del conjunto de investigaciones sobre la clase obrera que se desarrollan en la región.

Los trabajos de este grupo en su gran mayoría se refieren a períodos previos al que estudiamos, y por eso no los abordaremos en forma particular. Sí destacamos en ellos una perspectiva que apunta a una mirada holística del proceso social, y a vincular y entender la historia de Patagonia en el marco de la historia nacional, de la cual es parte constitutiva y a su vez expresión.

Especialmente relevante es el trabajo de compilación que realizan Enrique Mases y Lisandro Galucci ("Historia de los trabajadores en la Patagonia"), donde encontramos diversos artículos que complejizan el enfoque sobre la clase obrera en nuestra región. Los dos trabajos más conceptuales realizados por Mases, uno junto a Norma García ("De la perspectiva desde abajo a la perspectiva desde afuera: ¿una nueva mirada para el análisis de la protesta social?') y el otro junto a Lisandro Galucci ( 'La historiografía sobre los trabajadores en la Patagonia. Un estudio preliminar") brindan una mirada de conjunto y discuten perspectivas teóricas generales.

Hay centralmente una discusión con lo que denominan "perspectiva desde abajo", donde involucran a los investigadores que trabajan desde el enfoque de "mundo del trabajo" y desde la conceptualización de "sectores populares" (entre otros los trabajos clásicos de Mirta Lobato y Juan Suriano, "La protesta social en la Argentina" y de Luís Alberto Romero y Leandro Gutiérrez "Sectores populares, cultura y política"). El enfoque de Mases y García comparte con ellos los aspectos fundamentales del marco teórico y metodológico, pero les marca que esa mirada ya no puede encontrar los puntos claves para explicar una conflictividad social que, para los autores, estaría marcada por la aparición de un nuevo actor social, el desocupado, el surgimiento de nuevas modalidades organizativas y de nuevos repertorios de protesta y la pérdida de importancia del trabajador ocupado y de sus métodos históricos de lucha y organización.

En esa línea, que ya hemos discutido en sus trazos principales, plantean la 
necesidad de una "perspectiva desde afuera", que tome como clave la categoría de "excluido y exclusión" para entender a esos sujetos que se estructuran en términos de organización e identidad por fuera de los marcos tradicionales y del mundo del trabajo. Si bien es claro que este enfoque discute aún más fuertemente con una perspectiva como la nuestra, sí recuperamos de su trabajo el hincapié en la necesidad de atender a nuevas y más complejas fuentes históricas, donde el historiador juega un papel clave en su construcción e interpretación.

Son destacables los artículos que apuntan a visibilizar distintos sujetos trabajadores que suelen quedar ocultos en la perspectiva más tradicional. Así aparecen investigaciones sobre el trabajo de las mujeres, entre ellos el de Glenda Miralles ("El sindicato, el galpón y la casa: las mujeres en el Sindicato de la Fruta (1953-1996)") y los de Verónica Trpin ("Sindicalismo rural en el Alto Valle de Río Negro. La presencia de las mujeres en UATRE').

Esta misma autora aborda además otra complejidad clave en la construcción de la clase obrera patagónica y es la de su aporte inmigratorio. En "Migrantes chilenos que trabajan en las chacras: la etnicidad ante una nueva ruralidad", plantea una problemática sumamente rica que retoma muchos trabajos sobre el tema. Específicamente la importante producción de Joaquín Perren ("Hacer la América en la Patagonia. Los migrantes bajo la lupa de la comparación (Neuquén: 1980-1991)'), consigue imbricar su abordaje de la inmigración con una mirada de conjunto del proceso social, que comprende la dinámica general y la complejidad de los procesos económicos, políticos y sociales, incluida la fuerte conflictividad social que se genera en Neuquén.

El trabajo que hemos realizado junto a Joaquín Perren ("Las "nuevas" provincias como problema historiográfico. Una primera aproximación a los casos patagónicos") y sus anteriores producciones en el mismo sentido ("Un desarrollismo genérico en la Patagonia. Pragmatismo y dependencia financiera en la economía neuquina (1960-1991)") apuntan a desarrollar una línea de investigación que ponga en primer plano la incorporación de estos amplios territorios al Estado nacional.

Consideramos que en los últimos años los territorios nacionales lograron consolidarse como un objeto de estudio con peso propio e interesantes avances empíricos. Las que denominamos como "nuevas provincias", en cambio, no han recibido una atención semejante. Avanzar en esta senda de indagación permitirá profundizar el conocimiento acerca de la incorporación de esas nuevas provincias al Estado nacional, la construcción de su economía y las articulaciones que los procesos sociales toman en estas regiones, en relación y comparación con lo que sucede en las provincias centrales de nuestro país. 
En estas "nuevas provincias", que incluye a los antiguos territorios nacionales de Chaco y Patagonia, observamos una serie de características singulares (importante peso del Estado en sus economías, explosivo comportamiento demográfico y emergencia de conflictos sociales de enorme trascendencia) cuyo análisis en profundidad facilitaría el transito hacia una historia argentina contemporánea más compleja, que rompa con la visión "pampeano céntrica" que aún atraviesa a muchas de sus producciones.

Nuestra intención se inscribe en el marco de un esfuerzo sostenido de distintos investigadores que vienen abordando estas temáticas en los últimos años, hecho que se ha registrado en libros, artículos y ponencias y se ha expresado en las últimas Jornadas Interescuelas de Historia realizadas en la ciudad de Bariloche.

Un buen ejemplo de esta perspectiva es el libro "Silencio Hospital. Una historia de la salud pública en Neuquén", realizado por Demetrio Taranda, Joaquín Perren, Enrique Mases, Lisandro Galucci y Fernando Casullo. En su intención de estudiar el sistema de salud pública en Neuquén construyen una mirada sobre la historia del país y, especialmente, desarrollan una historia de la construcción del Estado neuquino. Si bien hay un mayor acercamiento en términos fácticos al tema del sistema de salud, el libro puede leerse como una historia sobre el desarrollo y construcción del Estado neuquino, y, así, es también una historia del Movimiento Popular Neuquino, de su compleja composición, del tipo de relación que establece con el poder central, las relaciones con las dictaduras, la conformación de un partido-estado, etc.

La investigación discute el mito del sistema de salud pública en Neuquén, un mito construido desde el MPN, que sostiene la excelencia de este sistema, su naturaleza democratizante e inclusiva y la posibilidad que aseguraría de atención de primera calidad a todos los habitantes de la provincia.

Con una sólida base empírica se demuestra que este sistema de salud tiene su origen en 1970, en un contexto autoritario signado por la dictadura de Onganía, y en el marco del nombramiento de Felipe Sapag como interventor del gobierno neuquino. El desarrollo de este sistema de salud tuvo como un componente fundamental (al igual que el resto de los proyectos desarrollistas que se impulsan hacia Patagonia) la temática de la seguridad nacional. La única posibilidad de garantizar la soberanía nacional era poblar la región y para esto era imprescindible dotarla de servicios. Esto se reforzó para el caso de Neuquén, ante la constante hipótesis de conflicto armado con Chile, algo que se potenció, justamente, en la década del setenta.

El otro elemento que el libro se ocupa de develar es el de la supuesta naturaleza absolutamente pública del sistema de salud neuquino. Se muestra que desde su origen este sistema tenía una matriz compartida con el sector privado, sector 
que se aseguraba una parte importante de los ingresos y el subsidio permanente de parte del Estado para un negocio privado.

Así la investigación aporta en una mirada de largo plazo que consideramos clave. En general la mirada del sentido común tiende a pensar, para todo el país y aún más para el caso de Patagonia, que a partir de 1989-1990 se produce un gran quiebre en términos históricos, fracturando un proyecto de desarrollo basado en el Estado y comenzando a consolidar otro que plantearía una "desaparición del Estado" y que dejaría la región a merced de las grandes compañías privadas.

Distintas investigaciones ${ }^{102}$ vienen demostrando que para Patagonia hay muchos más elementos de continuidad que de quiebre absoluto. Esto no quiere decir que 1989-1990 no sea un hito en el proceso histórico: es plantear que ese hito fue posible porque se inscribía en tendencias socio-económicas de largo plazo. Las políticas impulsadas por el Estado en las décadas previas tenían en su misma matriz la lógica de impulsar los negocios privados, y de hecho la gran mayoría de los proyectos de promoción se constituyeron en gigantescas transferencias de recursos del sector público al capital privado.

Los Estados no dejaron de regular la economía en la región. Siguieron realizándolo, pero ahora abandonando los antiguos proyectos de promoción y dejando en manos del capital privado la gestión directa de los ámbitos que eran rentables en términos económicos. Los autores demuestran como este proceso general se desarrolla en el sistema de salud neuquino. Desde principios de la década del ochenta la salud pública comienza su crisis y este proceso sufre un notable avance hacia 1987, con Gustavo Vaca Narvaja al frente del sistema de salud, a cuya gestión se le presta una especial atención ya que es vista como el momento en que el cambio de ciclo se acelera.

Los cambios en curso se vuelven transformaciones cualitativas. Del antiguo sistema de salud con dos subsistemas, uno público y otro privado financiados ambos por fondos estatales, uno de ellos, el público, va entrando en su agonía mientras el subsistema privado vive una etapa de florecimiento y esplendor. Como en toda la región el capital privado comienza a controlar en forma directa los fondos de los cuales hasta allí era beneficiario indirecto. El subsistema público es cada vez más

\footnotetext{
102 Por citar sólo algunas, Beinstein, Jorge (1993) Dinámica global de la economía patagónica, LUDEPASME/INTA-GTZ; Luque, Martínez, Avalos, Auzoberría (2003) Nueva articulación del capitalismo de estado en Santa Cruz: sus efectos en los grupos sociales, las alianzas políticas y la ideología. Los años noventa, Informe Final SECyT, UNPA; Ibarra, H. y Hernández, C. (2005) Estado, Economía y Sociedad. Trelew y su hinterland: 1989-1999, Informe de Investigación, UNPSJB, Chubut. Pérez Álvarez, Gonzalo (2007b) "Cambios en la estructura económica social en el noreste de Chubut durante los años noventa", en Actas $\mathrm{XI}{ }^{\circ}$ Jornadas Interescuelas.
} 
desfinanciado, pero esto no equivale a una retirada o desaparición del Estado, sino a una política planificada desde la dirección de ese Estado a favor de la salud privada.

La exclusión del servicio de salud de amplios sectores de la sociedad y el surgimiento de conflictos sociales, se inscriben en el contexto de las transformaciones neoliberales y la resistencia que distintos sujetos realizaron contra este proceso. E "feroz" ajuste de 1993 y la descripción del conflicto sindical (donde se refleja la interna del MPN y los conflictos intrasindicales) aportan a la comprensión de este complejo proceso. Esa resistencia si bien no pudo frenar lo más importante del proceso de transformación, sí logró impedir algunos de los proyectos en curso desde el poder.

Así ese antiguo sistema de salud queda definitivamente fragmentado en dos subsistemas: uno público, que pierde la capacidad de garantizar la cobertura de salud a la población, desfinanciado, sin tareas de prevención y que pone en riesgo la vida de los habitantes de la provincia. Por el otro lado se constituye un gran negocio, con un subsistema privado que considera a la salud como un negocio y que busca en cada caso maximizar sus ganancias, sin importar si esto redunda en el bienestar del paciente en cuestión y menos aún si eso redunda en un mejoramiento sanitario de la población. Totalmente en el olvido quedaron las tareas de prevención, la educación para la salud y la búsqueda de garantizar una cobertura integral a toda la población.

Distintos trabajos aportan acerca de la construcción de los movimientos de desocupados en Neuquén, abordando especialmente la relación de estos trabajadores sin empleo con los trabajadores ocupados, y con trabajadores que luchaban por recuperar sus puestos de trabajo a través de la toma de fábricas y la puesta en producción bajo control obrero. El interés de varios investigadores está directamente influenciado por el desarrollo de la conflictividad en Neuquén, que demostró la interrelación entre estas diversas fracciones de la clase obrera, que en otros enfoques y otras regiones tendieron a verse como fragmentos absolutamente aislados y sin conexión entre sí.

Los trabajos dirigidos por Demetrio Taranda ("Movimiento de los Trabajadores Desocupados (MTD): de la emergencia a la cotidianeidad. Un estudio de caso en la zona oeste de Neuquén capital"; "Procesos de constitución de movimientos piqueteros en la provincia de Neuquén", en un grupo integrado además por Ana Matus y Guillermo Maqueda), el de Walter Fernández Albouy y Gustavo Vicini ("Disciplinamiento de la mano de obra y Estrategia obrera: La experiencia de los trabajadores ceramistas de la Fábrica Zanon y los trabajadores desocupados del M.T.D. Neuquén, 2000-2003"), José Luís Bonifacio ("La organización de los trabajadores desocupados en Neuquén Capital durante los años noventa...') y 
especialmente la muy buena investigación de Ariel Petrucceli ("Docentes y piqueteros. De la huelga de Aten a la pueblada de Cutral Co").

Este último trabajo toma como interés específico observar las articulaciones entre desocupados y ocupados, y lo aborda desde el instrumental teórico del materialismo histórico, permitiendo encontrar una explicación de largo plazo a la conflictividad social en el Neuquén de los noventa. Así lo que para muchos autores aparecía como un "estallido", como una expresión espontánea y sin organización, es recuperado como parte de la larga y rica historia de tradición obrera neuquina. Se demuestra la presencia de distintas experiencias entre esos trabajadores, y de diferentes proyectos, algo que se manifiesta a partir del estudio de los diversos enfrentamientos sociales.

Ya hemos destacado en el apartado anterior a los trabajos de Paula Klachko. Aquí citamos sus producciones directamente vinculadas al estudio del conflicto social en la provincia de Neuquén ("La conflictividad social en la Argentina de los '90: el caso de las localidades petroleras de Cutral Có y Plaza Huincul (1996-1997)", "Cutral Có y Plaza Huincul El primer corte de ruta (del 20 al 26 de Junio de 1996) Cronología e hipótesis"), las cuáles aportan un enfoque que nosotros consideramos de gran complejidad e interés, ya que enmarca el estudio de estos enfrentamientos sociales en el marco de las preguntas sobre el desarrollo de alianzas sociales, la constitución de fuerzas sociales y el desarrollo de nuevas formas organizativas que intentan abonar a cambios en las relaciones de fuerzas. Ya que esta mirada, y en gran medida esas preguntas-problemas, son las que intentamos dirijan nuestra indagación, no desarrollaremos en extenso el contenido de estos artículos.

Desde un enfoque más restringido al ámbito de las fuerzas objetivas se encuentran los interesantes trabajos de Ernesto Bilder y Adriana Giuliani (por citar solamente los últimos trabajos a los que accedimos de una rica y extensa producción, ver "La Economía Política de la Provincia de Neuquén (1983-2008)", "Petróleo y gas en la política neuquina'), donde hacen hincapié en la matriz productiva poco diversificada y con características de enclave de la economía neuquina. Complejiza algunos de estos aportes el artículo de Joaquín Perren "Érase una vez en la Patagonia - Luces y sombras de la economía neuquina (1958-1991)".

En el caso de Neuquén se encuentra además la muy buena investigación de conjunto compilada por Susana Bandieri, Orietta Favaro y Marta Morinelli ("Historia del Neuquén'), un trabajo clásico de una colección que tuvo distintas historias "provinciales". En su gran mayoría estas producciones estuvieron vinculadas a perspectivas tradicionales y poco científicas de la historiografía, pero en este caso sí 
se aporta una mirada científica, consiguiendo realizar una interesante síntesis acerca de los distintos trabajos existentes hasta esa fecha (1993).

Son muy escasos los trabajos que hemos podido recopilar acerca de la conflictividad social en la provincia de Río Negro en los años recientes. Ya hemos citado el aporte de Graciela luorno en el libro compilado por Gerardo Caetano (2006). La misma autora, también junto a Orietta Favaro, aporta al debate sobre el desarrollo de nuevas formas organizativas en el artículo publicado en la compilación de Laura Pasquali (2008), en el cual desarrollan la experiencia de dos cooperativas de trabajadores ("Nuevas formas organizativas en la Argentina de los últimos años. El caso de las cooperativas Ados y Fricader (Neuquén y Río Negro), 1990-2006'). En este caso el grueso de la conflictividad analizada se encuentra en la región norte de Río Negro, más específicamente en la ciudad de General Roca.

Desde el enfoque del CICSO, y atendiendo centralmente a los procesos de conflictividad en la región norte de esa provincia, encontramos el artículo de Beatriz Balvé y Claudia Guerrero ("De lucha política a guerra social abierta. El alto Valle de Río Negro 2001 y 1969'). Allí, desde las preguntas clásicas de esta vertiente, las autoras buscan conectar el enfrentamiento social desarrollado en 1969 en Cipolletti, con el ciclo de enfrentamientos del 2001. Realizan una periodización de ambos procesos, mostrando las principales líneas de continuidad y ruptura, haciendo hincapié en estas últimas. Específicamente buscan hacer observables los efectos de un ciclo contrarrevolucionario que ha aislado a la clase obrera, tanto en relación a los conflictos de 1969 como a aquellos desarrollados a principios de los noventa.

Para esto presentan una síntesis de algunos conflictos sociales que consideran claves en el sector frutícola, mostrando el movimiento de las diversas fracciones y clases: desocupados, trabajadores, pequeños y medianos productores y grandes monopolistas. Se hace evidente el desarrollo de una alta conflictividad en la región durante los años previos al 2001 y en ese mismo momento: paros, cortes de ruta, movilizaciones, saqueos y el enfrentamiento social abierto con las fuerzas represivas por parte de los desposeídos, en el momento más álgido del enfrentamiento. Ya intentaremos debatir con esta perspectiva la premisa de que al tratarse de un período contrarrevolucionario no hay posibilidad de construcción de fuerza social. Hay además una reflexión acerca del quiebre entre la forma organizativa de sindicato y la de asamblea en determinados momentos del enfrentamiento, que podría llevar a romper la matriz corporativa del conflicto.

Encontramos también pocas producciones sobre el sur de Río Negro, muy vinculado a la región que nosotros estudiamos, y en especial acerca del importante ciclo de surgimiento y posterior crisis del pueblo de Sierra Grande alrededor de la 
explotación minera. En ese marco se desarrollan fuertes conflictos que ameritan investigaciones específicas, algunas de las cuales hoy están en desarrollo, cubriendo así un vacío historiográfico.

Hemos accedido al artículo de divulgación de Alejandra Díaz y Nadine Carreño ( "La Sierra y su mina de hierro"), que presenta una historia fáctica del proceso de desarrollo de Sierra Grande y de algunos de los principales conflictos que allí se desarrollan. Nuevamente citamos aquí la producción de Orietta Favaro y Graciela luorno, quiénes en "La Patagonia protesta" presentan una mirada general de la realidad de Sierra Grande y de su conflictividad, pensada en clave de comparación con otros procesos como Cutral Có y Plaza Huincul.

El artículo de Graciela Hopstein ("Piqueteros: Dilemas e potencialidades de um movimiento que emergiu a pesar do estado e a margen do mercado"), aborda algo que es destacado por muchos autores, y es plantear al corte de ruta en Sierra Grande durante 1991 como un punto de inicio del tipo de conflictividad social que inaugura las puebladas que darán surgimiento a la personificación del piquetero. Consideramos que esto es más complejo, el corte de ruta es una modalidad histórica en varias pequeñas ciudades ubicadas a la vera de rutas nacionales y el conflicto de 1991 está más vinculado al ciclo anterior que al posterior en términos del desarrollo de la lucha de clases.

Destacamos los importantes avances de investigación de Mauricio Fernández Picolo y Leticia Salgado, ambos desde la carrera de historia de la sede Trelew de la UNPSJB. Encontramos una síntesis del proceso histórico del crecimiento de Sierra Grande, vinculado al avance desarrollista sobre Patagonia y a la lógica de la doctrina de la seguridad nacional. Estas ciudades directamente creadas por el Estado nacional, que opera como personificación del desarrollo capitalista, sufren un duro golpe ante la realización hegemónica del dominio del capital financiero.

En ese sentido ambos avances recuperan algunos conflictos centrales, en especial los de 1975 y 1991. Sobre la conflictividad en 1975 se expone la represión sufrida en este conflicto, que se ubica entre el rodrigazo y el golpe militar de 1976. Allí se hace presente la modalidad del corte de ruta, al igual que en 1991 y en otros conflictos desarrollados en Sierra Grande. El ataque a aquellos activistas obreros que demandaban mejoras en las condiciones de trabajo, y su característica de economía de enclave, emparentan este proceso con el de nuestra región, aún al nivel del sentido común popular, como ya lo veremos en capítulos posteriores.

La investigación en Santa Cruz aporta elementos de importancia para nuestro trabajo. Al igual que lo ocurrido en Sierra Grande (que impacta en el noreste de Chubut por su cercanía) hay una clara sincronía en la periodización, en los procesos 
de crecimiento y crisis de los proyectos desarrollistas, en las transformaciones de la estructura económica social, en las privatizaciones de grandes empresas estatales, en el abandono de otros proyectos orientados por el Estado y hasta en las características de la conflictividad social que se genera.

En este sentido son un insumo central para todas las instancias de nuestra investigación, y nos sirvieron de guía orientadora en varios momentos de la misma, los resultados de los trabajos realizados por el grupo "Contraviento", de la Universidad Nacional de la Patagonia Austral sede Río Gallegos, integrado por Elida Luque, Susana Martínez, Miguel Auzoberría y Hugo Huenul y que fuera dirigido en gran parte de su recorrido por Nicolás Iñigo Carrera.

Para no repetir elementos que serán retomados en capítulos posteriores aquí solamente nombraremos algunos de sus principales trabajos: "Los conflictos sociales producidos en las primeras décadas del siglo XX en Santa Cruz. La constitución de un territorio social"; "Los 70' y la crisis política en Santa Cruz"; "Yacimientos Carboníferos Fiscales y el paternalismo como estrategia empresarial"; "De la génesis a la crisis de una estructura económica (Santa Cruz entre 1940 y los 90)"; "La situación de los trabajadores desocupados del petróleo en la zona norte de la provincia de Santa Cruz"; "Conflictos sociales en la provincia de Santa Cruz. Los años noventa"; "Nueva articulación del capitalismo de estado en Santa Cruz: sus efectos en los grupos sociales, las alianzas políticas y la ideología. Los años noventa".

Como vemos hay aquí un verdadero programa de investigación que aborda gran parte de la historia de Santa Cruz, desde la concepción de buscar comprender el movimiento de la sociedad como un todo. Su anclaje en el marco conceptual propuesto en términos generales por los trabajos del PIMSA permite además que la comparación con nuestros datos y resultados sea mucho más directa y precisa, tanto al nivel de los resultados económicos como, fundamentalmente, en la elaboración conceptual.

Su recorrido histórico aborda desde la conformación de las primeras organizaciones obreras a principios del siglo XX (dialogando y debatiendo con el clásico trabajo de Osvaldo Bayer "Los vengadores de la Patagonia trágica"103). En el abordaje del grupo "Contraviento" se pone en dialogo los procesos desarrollados al nivel de las relaciones de fuerzas políticas con la dinámica de cambio y transformación a nivel de la relación de fuerzas objetivas. Su observación del proceso de construcción de un territorio social en la provincia de Santa Cruz, de la incorporación de este territorio al desarrollo capitalista, de la génesis y crisis de una estructura económica social

\footnotetext{
103 Una tarea que también nosotros nos hemos planteado abordar y cuyos primeros resultados están presentes en el artículo Gatica, Mónica y Pérez Álvarez, Gonzalo (2009) "El surgimiento del movimiento obrero en el noreste del Chubut", en Actas III Jornadas de Historia Social: Los trabajadores y el mundo del trabajo en la Patagonia, Comodoro Rivadavia, publicada en CD ISBN 978-950-763-090-3.
} 
caracterizada como un "capitalismo de estado en enclaves" y de las profundas transformaciones ocurridas durante los noventa y los primeros años del 2000, y la nueva articulación que esto genera, ha producido un cúmulo de aportes que creemos transforma a esta producción en uno de los afluentes claves para una historiografía renovada de la Patagonia y de Argentina.

Los trabajos de Aixa Bona y Juan Vilaboa (la compilación "Las formas de la política en la Patagonia. El primer peronismo en los territorios nacionales", y sus artículos "La transición política de los territorios nacionales y la caída del peronismo: el caso de Santa Cruz" y "Trabajadores y peronismo en Santa Cruz", entre otros) se centran en un intento de comprender la dimensión política del proceso durante los años cuarenta, cincuenta y sesenta en Santa Cruz, especialmente debatiendo acerca del significado y la proyección que toma el peronismo en estos territorios alejados del área central del país. Es una producción significativa que, aunque no aborda el período que a nosotros nos interesa directamente, sí toma algunos ejes que consideramos relevantes en torno a comprender cómo se manifiestan en estas regiones los fenómenos políticos nacionales, las relaciones entre gobiernos locales y nacionales, la configuración de nuevos liderazgos y la inclusión de la Patagonia en el marco de un proyecto desarrollista que allí comenzaba a despuntar con mayor fuerza.

Ya directamente vinculados a la zona sureste de nuestra provincia se encuentran los trabajos que toman como área de investigación a los efectos de la privatización de YPF en el norte de Santa Cruz, y a la conflictividad social que se desarrolla en los años recientes. Ya citamos el trabajo del grupo Contraviento, y encontramos también la investigación de Edda Crespo ("Cien años no es nada... Patrimonio, imaginarios urbanos y políticas sociales de conmemoración. Caleta Olivia 1995-1999") y los artículos de María Rosa Cicciari ("Prácticas sociales organizativas y desarrollo local en una comunidad petrolera. Estudio de caso: los ex agentes de YPF de Caleta Olivia" y "Trayectorias laborales en espacios sociales urbanos afectados por el proceso de reestructuración productiva. Estudio de caso: Comodoro Rivadavia en los años '90') y de la misma autora junto a Mariano Prado y Julio César Romero "Cambios en las oportunidades de empleo y nuevos emprendimientos en el complejo petrolero de Santa Cruz Norte (1993-1995)".

También en las compilaciones realizadas por Agustín Salvia encontramos el trabajo de D'Amelio, Galaretto y Prado ("El lado oscuro de la reestructuración. Empleo, desempleo y precariedad laboral en Caleta Olivia, 1993-1995') y el del mismo Salvia ("Crisis y reestructuración de complejos mineros: estudio de dos sistemas regionales patagónicos"). 
Anteriores en el período histórico destacamos diversos trabajos de Susana Torres, Adrián Duplatt y Graciela Ciselli (entre otros "Género, migración y mercado laboral en el sureste del Chubut"; "Pioneras astrenses"; "Km 5 Barrios patagónicos con memoria petrolera y ferroviaria"; "Historia de un ferrocarril patagónico").

Como trabajos de síntesis que aportaron a una mirada de conjunto del proceso encontramos diversas producciones. Ya citamos en extenso a algunas de Orietta Favaro y otros investigadores. Destacamos aquí nuevamente las compilaciones realizadas por Agustín Salvia ("La Patagonia de los noventa: sectores que ganan, sociedades que pierden") y por Salvia y Marta Panaia ("La Patagonia privatizada. Crisis, cambios estructurales en el sistema regional patagónico y sus impactos en los mercados de trabajo'). Desde un enfoque más económico, y vinculado específicamente a observar las transformaciones en el mercado laboral, en los procesos productivos y en las articulaciones del Estado con las empresas privadas, encontramos elementos que aportan a nuestra investigación. Especialmente relevantes son los artículos de síntesis que desarrolla Salvia.

En una perspectiva semejante, pero que busca centralmente observar las relaciones entre las llamadas "economías regionales" y el Estado nacional, encontramos los clásicos trabajos de Alejandro Rofman ("Las economías regionales a fines del siglo $X X$ ") y del mismo autor junto a Luís Alberto Romero ("Sistema socioeconómico y estructura regional en la Argentina"). Para nosotros hay aquí una fragmentación del objeto de estudio, a partir de considerar que la formación económica social de Argentina se estructura a partir de distintas piezas que se vinculan como en un rompecabezas que se conformaría a posteriori. No se comprende que estamos ante una totalidad social, que funciona en forma articulada y donde cada una de las estructuras económicas sociales concretas que se desarrollan, y de los territorios sociales que se conforman, se hacen en directa relación y complementariedad con el resto. Ya intentaremos volver sobre esta discusión en capítulos posteriores.

Especialmente relevante es el trabajo de Jorge Beinstein ("Dinámica global de la economía patagónica"), que muestra pormenorizadamente el desarrollo de cada sector de la economía patagónica hasta el año 1993, dejando claros los primeros efectos del neoliberalismo sobre la región. Retomar esa investigación completando al menos para el área delimitada por el presente trabajo sus principales líneas de trabajo será un aporte que intentaremos desarrollar en los capítulos posteriores. La investigación de Beinstein tiene un claro perfil técnico y de prospectiva económica, pero al estar desarrollado con metodología científica y con un marco teórico que toma a la lucha de clases y al conflicto como operadores metodológicos, aborda una mirada histórica de los procesos que permite que sus datos y resultados sean un aporte sustancial para cualquier historiador 
que quiera trabajar la historia de Patagonia en los últimos años, especialmente para los que consideramos que no hay posibilidad de comprender las transformaciones sociales y políticas sin comprender también los cambios económicos.

También desde una perspectiva más de medición cuantitativa, otro trabajo que intenta sintetizar un abordaje de conjunto para la Patagonia, es el desarrollado por Elba Kloster ("Región Patagónica"). En el marco del proyecto dirigido por Guillermo Velásquez, que busca construir observables científicos acerca de la calidad de vida y los procesos de cambio social (ver su compilación "Geografía, calidad de vida y fragmentación en la Argentina de los noventa"), Kloster presenta un mapa de la Patagonia dividida a nivel de los departamentos censales, permitiéndole realizar interpretaciones acerca de los niveles de desigualdad existentes en las provincias.

El enfoque metodológico de Velásquez, y los resultados aportados por Kloster, nos permitieron hacer observables en términos cuantitativos las enormes diferencias sociales que se viven en nuestra provincia, donde la casi totalidad de los servicios, infraestructura y puestos de trabajo están concentrados en el área costera, mientras la meseta parece cada vez más destinada al olvido o a los negocios de las grandes compañías transnacionales ${ }^{104}$.

Los trabajos desarrollados desde la Facultad de Ciencias Económicas de la Universidad Nacional de la Patagonia realizan descripciones de algunas situaciones estructurales y buscan postular soluciones administrativas a las problemáticas planteadas. Desde un enfoque más vinculado a la especialización contable que a la ciencia económica, estos estudios aportan algunos datos y resultados interesantes para una investigación como la nuestra, aunque, para nosotros, no logran avanzar en buscar las causas estructurales de los efectos que investigan.

Entre otros hemos relevado los resultados de investigación de Ester Badenas y Telma Rotstein ("Caracterización de la industria manufacturera de la provincia del Chubut"; "Caracterización del sector comercio de la provincia del Chubut", "Caracterización del sector servicios de la provincia del Chubut'), Víctor Zamora y Gladys Ramírez ("Porque cierran los negocios en Trelew"); Ester Livigni y María Sendín (“Composición del desempleo en Chubut. Período 1984-1997”) y el de María Sendín y Silvia García ("Medición de la desigualdad de la distribución geográfica de las ramas de la industria manufacturera entre los departamentos de la provincia del Chubut usando el índice de Gini').

Es muy valiosa para todo investigador que intente acercarse a la historiografía sobre Patagonia, la obra de síntesis desarrollada por Susana Bandieri en su "Historia

\footnotetext{
104 Ver Pérez Álvarez, Gonzalo (2007c) Calidad de Vida y desigualdad en Chubut, Trabajo final del
} seminario de Postgrado "Geografía y bienestar. Argentina, S XXI", dictado por el Dr. Guillermo Velásquez. 
de la Patagonia". Allí se realiza un gran estado de la cuestión que sintetiza el grueso de lo producido hasta el año 2005. Esta obra se completa, en su capacidad de sintetizar los principales abordajes sobre la historia de la Patagonia, con la producción colectiva dirigida por Bandieri, Graciela Blanco y Gladys Varela ("Hecho en Patagonia. La historia en perspectiva regional').

Más cercano en el tiempo (por el año de edición de su libro, 2008, y por la temporalidad que abarca) otra síntesis es la desarrollada por Ernesto Bohoslavsky en su "La Patagonia: de la guerra de Malvinas al final de la familia ypefiana". El autor logra integrar las últimas contribuciones a la investigación sobre Patagonia, prestando especial atención a las transformaciones sociales, políticas y económicas que se vivieron en esta región en los últimos treinta años. Además sus preguntas se centran en el interés por el tipo de representaciones que se construyen acerca de la Patagonia, y el contenido ideológico y político que estas conllevan.

Este interés ha sido desarrollado también por otros investigadores. En un período anterior Susana López observa esta problemática en su tesis de doctorado ( "Representaciones de la Patagonia. Colonos Científicos y Políticos (1870-1914)') y con una pregunta más vinculada a nuestros intereses, ya que se centra en buscar entender qué tipo de representación se realiza acerca de la clase obrera y cómo impacta esto en sus procesos de lucha y organización, encontramos los trabajos de Paz Escobar (entre otros "La Patagonia Rebelde: representaciones cinematográficas de las formas de lucha de la clase obrera" y "Cine e Historia: la Patagonia en imágenes (1936-1976)"). Hay en este caso el reconocimiento de la centralidad del cine y de las imágenes visuales en la construcción de representaciones sociales en la actual fase del capitalismo, una preocupación que también es compartida por Bohoslavsky, quién, entre otras cosas, construye un estado de la cuestión de las películas que "hablan" de la Patagonia.

No hay casi producción científica acerca de las protestas y conflictos sociales en la historia reciente de la provincia del Chubut. Sí aparece una rica producción en la región sur de la provincia acerca de períodos previos, especialmente los años cuarenta y el período de la provincialización. Son trabajos desarrollados especialmente por profesionales vinculados a la carrera de Historia de la sede Comodoro Rivadavia de la UNPSJB.

Destacamos la relevancia de la producción de Daniel Marqués (entre otros "El peronismo y los trabajadores petrolíferos estatales en la Patagonia Austral: Entre la madurez de una racionalidad socialmente inclusiva y la emergencia de un nuevo formato sindical (1945-1955)"; "Del pozo al socavón. Trabajadores petroleros y mineros estatales en la Patagonia Austral: un estudio comparativo" y "Entre la crisis del 
valor social del trabajo y la fragilidad de la identidad del trabajador: cuenca del Golfo San Jorge'), específicamente dirigido a pensar el problema de las identidades laborales y políticas y la construcción de las organizaciones sindicales en comunidades de la cuenca petrolera del golfo San Jorge y la región minera de Río Turbio. Su trabajo junto a Mario Palma Godoy ( “Comodoro Rivadavia en tiempos de cambio. Una propuesta para la revalorización de nuestras identidades culturales") da una mirada de conjunto que permite pensar la conformación de la provincia del Chubut y su particularidad de funcionar como tres grandes áreas casi sin relaciones entre sí, y que mantienen una mayor conexión con las regiones limítrofes de las otras provincias patagónicas.

En una perspectiva semejante encontramos aportes a pensar la problemática de los trabajadores en Patagonia en los artículos de Gabriel Carrizo ("Entre Ongaro y Vandor. Una mirada al sindicalismo comodorense: la huelga de SUPE en 1968'), Daniel Borquez ("Luchas Político-Gremiales y la puja por la ldentidad Nacional Comodoro Rivadavia 1943-1955') y, más cercano en la temporalidad que llega a abordar, el de Ester Ceballos ("Conmemoración del 1ํ de Mayo entre 1955 y 2002, en Comodoro Rivadavia, según la prensa local').

Edda Crespo busca comprender los procesos de construcción de imaginarios por parte de los trabajadores, recuperando especialmente los procesos de construcción de clubes sociales por parte de los trabajadores petroleros. En ellos se denota que los trabajadores tomaban contribuciones de la cultura dominante, permeando dichos elementos a través de sus tradiciones, necesidades y perspectivas ( "El fantasma de Rodó. Ariel, públicos lectores y nacionalismo petrolero en Comodoro Rivadavia").

Por último citamos los excelentes trabajos de Hernán Camarero sobre el desarrollo del Partido Comunista en las décadas del veinte y el treinta, en los cuáles investiga especialmente la construcción de este partido en Comodoro Rivadavia, la conformación de las primeras células y las huelgas que dirigió (ver "A la conquista de la clase obrera. Los comunistas y el mundo del trabajo en la Argentina, 1920-1935"; "Reflexiones acerca de dos luchas obreras impulsadas por los comunistas: la huelga petrolera en Comodoro Rivadavia y la huelga de la carne en Avellaneda (1932)').

Sobre el área noroeste de Chubut encontramos un amplio conjunto de trabajos con un enfoque tradicional, que construyen una mirada que no problematiza la historia oficial de la región. Son, en general, desarrollados sin una metodología científica y en muchos casos por investigadores sin formación profesional. Entre otros vemos los libros de Jorge Oriola ("Esquel... del telégrafo al pavimento", "El Trocha y los ferrocarriles patagónicos", "Esquel... del sismo al no a la mina”), el de Marcelo Troiano ("Y nació Esquel...") y los de Jorge Fiori y Gustavo De Vera ("Trevelin. Un pueblo en 
los tiempos del Molino"y "1902. El protagonismo de los colonos galeses en la frontera argentino-chilena").

Un excelente estado de la cuestión sobre esas producciones lo realiza Marcos Sorrouille ("La incorporación del territorio del noroeste cordillerano de la actual provincia de Chubut al modo de producción capitalista") quién sí consigue iniciar un recorrido que permite encontrar los componentes fundamentales del proceso socio histórico que constituye a esa región y a su proceso de incorporación al desarrollo capitalista.

Sobre la conflictividad social son destacables los libros del Chele Díaz ("1937: el desalojo de la tribu Nahuelpan") y Eduardo Hualpa ("Sin despojos. Derecho a la participación mapuche-tehuelche'), que presentan distintos conflictos vinculados a la problemática de la ocupación de la tierra y al desalojo de sus habitantes originarios.

Es más complejo encontrar trabajos sobre la conflictividad actual. Solamente hay una importante producción sobre los conflictos vinculados a la cuestión ambiental, especialmente desarrollados tras la gran movilización popular que impidió la concreción del proyecto de una mina de oro en Esquel. Son claves allí los artículos desarrollados desde la Revista Themoai, que están disponibles en la web: http://theomai.unq.edu.ar/Theomai_Patagonia/index.htm.

Los trabajos de Guido Galafassi ("Minería de oro y plata y conflictos sociales. Un proceso de historia reciente en Patagonia"; "Un nuevo despojo en la Patagonia Andina. La lucha de la comunidad mapuche Pillan Mahuiza y de decenas de campesinos por sus tierras"; "Movilización social contra la devastación minera en la Patagonia'), presentan un mapa muy interesante acerca de los diversos sujetos que intervienen en estas protestas y en la construcción de estos movimientos sociales.

Asimismo hay una preocupación por investigar el componente estructural de estos grandes proyectos de explotación de recursos naturales, por ejemplo en el trabajo que Galafassi realiza junto a Andrés Dimitriu ("El Plan "B" de los Capitales Mineros. A propósito de las notas sobre "Inversiones mineras en Argentina"), el de Luís Clips ("Navidad, minería y saqueo en la meseta de Chubut") y el de Carlos Espinoza ("¿Más valor que el oro? Los movimientos populares en oposición a la minería con cianuro").

Desde una perspectiva más militante, en muchos casos casi como un relato interno acerca de estas experiencias, están los trabajos que compila Lucas Chiappe ("Bosques del Sur, reflexiones sobre las amenazas ambientales que enfrentan" y "La Patagonia de pie. Ecología versus negociados"). En una línea semejante (aunque abarcando una dimensión mas amplia de conflictos que solamente lo ambiental y tomando diversas regiones de Patagonia) encontramos la compilación de diversos 
artículos realizada por el Centro de Investigación y Formación de los Movimientos Sociales Latinoamericanos en el libro "Patagonia: resistencias populares a la recolonización del continente".

Si bien en todos estos enfoques hay aspectos interesantes que contribuyen a una mirada de conjunto sobre la conflictividad social en la Patagonia, es claro que sus perspectivas se limitan a observar solamente los conflictos ambientales. Así dejan afuera de su abordaje al resto de los conflictos y movimientos que atraviesan a la sociedad en esos mismos momentos, sin cuyas articulaciones, enfrentamientos y negociaciones no podemos comprender las especificidades de estos procesos.

Desde historiadores de la ciudad de Trelew, pero enfocados en conflictos de la región sur de la provincia, encontramos dos artículos sumamente ricos en aportes para nuestra investigación. El primero es el de Mauricio Fernández Picolo y René Rivera Guerrero ("Sindicatos participacionistas y terrorismo de estado. Las huelgas de Guilford en Comodoro Rivadavia 1975-1976'), presentado en las jornadas interescuelas del 2009, donde los autores logran hacer observable en torno a las huelgas en la textil más importante de Comodoro Rivadavia, el tipo de prácticas que eran comunes en el sindicalismo de la provincia.

Además aquí se pone en juego la histórica rivalidad entre la región sur y la noreste de la provincia, ya que la dirección del sindicato, que enfrenta la huelga y denuncia a sus activistas como "subversivos" ante la dictadura, se encuentra en la ciudad de Trelew. La construcción de dirigencias sindicales afines a los objetivos del plan desarrollista, y que compartían la ideología de la doctrina de la seguridad nacional, es un componente central para comprender la constitución de la clase obrera de nuestra región, así como el desacople que constantemente se presenta entre algunas de estas direcciones y los grupos de trabajadores que planteaban otro tipo de estrategia.

El otro articulo es el que desarrollamos junto a Susana López y Mónica Gatica ( "Son errores que tuvimos que pasar para después en un futuro no volverlos a hacer" La experiencia de Jaime, un ex trabajador de YPF), cuyos aportes están vinculados a las relaciones entre las bases obreras y sus dirigencias, las consecuencias de los procesos de privatización y las transformaciones en la estructura económica-social de Patagonia. Se destaca también la importancia de las fuentes orales para la construcción de una historia que permita abordar la complejidad de los distintos sujetos que intervienen en ella.

En el caso del noreste de Chubut hemos ido relevando todas las producciones realizadas sobre protestas y cambios en la estructura económica social a las que pudimos acceder. No son muchos y varios de estos trabajos son de difícil acceso ya 
que no han sido publicados y sólo se encuentran en materiales impresos de forma particular, fotocopias o informes de proyectos de investigación. Hay una especial carencia de investigaciones sobre la historia de lucha de la zona, casi ninguna de las grandes huelgas o de los procesos de conformación de organizaciones esta relevado o trabajado en forma sistemática. Por eso cobran especial relevancia aquellos trabajos que nos aportan elementos en ese sentido. La larga y rica historia de luchas de la clase obrera en la región ha sido sistemáticamente silenciada por una "historia oficial", construida desde los grupos de poder de la provincia, que habla de la paz social y de la ausencia de conflictos entre los "vecinos".

Cuestionando esta historia oficial se ha conformado un interesante corpus de investigaciones que hoy se encuentra en pleno desarrollo, centrado especialmente en aquellos producidos desde el Departamento de Historia de la sede Trelew.

Desde un enfoque más vinculado a la utilización de estadísticas, y a una mirada economicista, aporta elementos la síntesis que realiza Fernando Laveglia en su libro "Apuntes de la economía del Chubut". Allí el autor vuelca una gran cantidad de datos, desarrollados desde la Dirección de Estadísticas de la provincia (de la cual el autor es su director) aunque no aparecen preguntas ni problemas que tensionen esos datos y que busquen encontrar respuestas a las transformaciones económicas y sociales que se podrían hacer observables.

Por otro lado está la valiosa contribución que desde un enfoque urbanístico realizan Delia Irusta y Lidia Rodríguez ("Aportes para el estudio del desarrollo urbano de Trelew'). Allí las autoras presentan una síntesis de la historia de Trelew, mostrando el proceso general de crecimiento y desarrollando como problemática particular el de la ocupación del territorio y la disputa por la tierra. Desde un punto de vista metodológico es interesante observar como al investigar consecuentemente el desarrollo de esta ciudad, deben abordar la historia de toda la provincia del Chubut, especialmente de su región norte. Demuestran así que el crecimiento de las ciudades del noreste chubutense se realiza en base al abandono, en términos de planificación y del despoblamiento, de la meseta central y hasta de la región cordillerana.

Pero, como decíamos, lo central de los aportes sobre la región se ha construido desde las investigaciones históricas. Los trabajos de Horacio Ibarra ("Patagonia Sur. La construcción interrumpida de un proceso de desarrollo regional') y Carlos Hernández ("Capital comercial y elite local. Trelew y su hinterland: 1889-1930'), y el informe final del proyecto de investigación que realizaron en conjunto ("Estado, Economía y Sociedad. Trelew y su hinterland: 1989-1999'), construyen una de las mejores investigaciones acerca de la región que estudiamos. Es una de las pocas que permite tener una mirada de conjunto del proceso histórico, integrando los diversos ámbitos de 
la sociedad desde una perspectiva metodológica sólida y fundamentada. Desde nuestra mirada discutimos con los autores el poco interés que ponen en la investigación de los conflictos sociales que se desarrollan y en las organizaciones que se conforman desde las clases subalternas.

Los investigadores centran su mirada en el plano institucional y en las organizaciones de los sectores dominantes, algo entendible en un abordaje que parte fundamentalmente del marco teórico de Weber y Schumpeter y que por eso no ve en la lucha de clases y en el conflicto social al factor explicativo fundamental del cambio histórico.

En distintos trabajos realizados por Susana López ("La Historiografía sobre Patagonia. Un comentario"; "Patagonia y la mirada de los colonos galeses del Chubut. Dos proyectos y una nación"; "Una aproximación a los diseños políticos para Patagonia") y por Mónica Gatica (entre otros citamos a "Los hacedores de caminos"; "Identidades conflictivas o víctimas de una experiencia de desarrollo en Patagonia. Las trabajadoras de INTECO S.A.”, “Industrialización, Proletarización y Subproletarización. ¿Una nueva identidad para la mujer en Trelew?"; "Trelew, ¿un polo de desarrollo y modernización?'), encontramos los aportes más renovadores en relación a construir una historia que dé cuenta de los procesos colectivos, de los conflictos sociales y de la lucha de clases.

Mi formación como investigador junto a ellas pasó por distintas instancias, donde desarrollamos una primera aproximación hacia una síntesis del proceso histórico para nuestra región, desde sus primeros conflictos sociales hasta los procesos actuales. Este trabajo ("Patagonia desarrollo y neoliberalismo", del que también fue parte María Laura Monedero) abarca desde las primeras huelgas obreras en la región, el desarrollo de distintas organizaciones por parte de las clases dominantes y subalternas, las disputas por la provincialización, el debate acerca de los distintos proyectos político-económicos, hasta las transformaciones sociales actuales que trajo consigo el dominio del capital financiero. Junto a López y Gatica también redactamos el artículo "Argentina: implicaciones del Neoliberalismo en el Noreste del Chubut", que logra presentar una aproximación a esta problemática, algo que intentamos seguir desarrollando en esta tesis.

El surgimiento del movimiento obrero es abordado recientemente por un artículo que realizamos junto a Mónica Gatica ("El surgimiento del movimiento obrero en el noreste del Chubut'), completando y discutiendo la información aportada por otros investigadores, como los ya citados Ibarra y Hernández, lo que aportó María Laura Monedero en el libro de nuestro grupo y el trabajo de Gonzalo España ("El movimiento 
anarquista en Trelew a principios del siglo XX. El caso del Centro Obrero Tierra y Libertad').

También buscando reconstruir el comienzo del Siglo XX en nuestra región y el proceso de conformación de organizaciones sociales, comunitarias y étnicas, destacamos el reciente trabajo de Pablo Lo Presti ("Fraternidad, romerías y disputas. La Asociación Española de Socorros Mutuos de Trelew. 1908-2008').

Sobre los años treinta la única contribución específica es la tesis de licenciatura de Martín Di Santo ("Derecha, nacionalismo y fascismo en el Valle Inferior del río Chubut. Discursos y representaciones de la prensa escrita en la década de 1930'), un muy buen trabajo que muestra las expresiones de derecha en la región y su relación con el proceso nacional e internacional. Lamentablemente el trabajo no aborda la relación del crecimiento de estas expresiones ideológicas con el desarrollo del movimiento obrero y de sus herramientas de lucha y organización.

En este sentido son claves para Chubut las huelgas petroleras que trabaja Camarero (2008), que muestran que no se trataba solamente de "discursos", sino de reacciones conscientes y organizadas de las clases dominantes ante lo que consideraban un peligro latente. Ya lo habían hecho en el período anterior de surgimiento de importantes conflictos (ver el artículo de Ernesto Bohoslavsky y Alberto Harambour "El miedo rojo más austral del mundo. Clase dominante local y Estado nacional frente a los trabajadores en la Patagonia argentino-chilena (1917-1922)').

En Mónica Gatica hay un especial interés por la experiencia de los trabajadores y específicamente por la historia de grupos constantemente invisibilizados, como las mujeres y los trabajadores inmigrantes. Especialmente trabaja la historia de los migrantes de nacionalidad chilena, que deben soportar la persecución política y las prácticas xenófobas tradicionales en los sectores dominantes de Patagonia.

La pregunta sobre el papel de las mujeres en los procesos de lucha en la Patagonia se hace extensiva a varios trabajos. Especialmente Edda Crespo ha desarrollado esta problemática (por ejemplo en su reciente compilación junto a Myriam González "Mujeres en palabras de mujeres", donde entre otros trabajos destacamos los de las compiladoras: "Más allá del ritual de belleza. Las reinas del petróleo en sus imágenes y palabras" y "Trayectorias laborales y prácticas espaciales de mujeres de sectores populares. El caso del barrio San Martín en Comodoro Rivadavia'), también Martha Díaz ("Movimientos Sociales en Patagonia y el papel de la mujer: Significaciones e ideas fuerzas') y los artículos ya citados de Verónica Trpin y Glenda Miralles, entre otros.

Uno de los conflictos permanentes en la región tiene relación con la ocupación de tierras ante la falta de viviendas, que se presenta como un problema permanente por la 
continua llegada de inmigrantes y la especulación inmobiliaria. La tesis de licenciatura de Gabriel Costa y Carlos Ratti ("Crisis y conflicto social: asentamiento en Primera Junta") investiga uno de estos casos, aunque desde una perspectiva que se queda en la descripción de la situación económica, sin evaluar las características de la ocupación de tierras en términos políticos y sociales.

En cambio es muy valioso el trabajo que desde la geografía desarrolla Daniel Barberena ("Los Barrios Populares de Trelew en la década del 70: El Barrio La Laguna'), quién permite abordar el proceso de constitución de un barrio popular y su enfrentamiento desde el poder. Construye una perspectiva de largo plazo, que observa los procesos políticos y sociales de constitución de conciencia, y el desarrollo de organizaciones populares.

Hay allí una importante valoración del papel de estas organizaciones barriales en los procesos de movilización popular de 1972 en Trelew, complementando los trabajos clásicos de Tomás Eloy Martínez (“La pasión según Trelew”) y de Mauricio Fernández Picolo, Wilda Western y Alejandro De Oto ("Autoritarismo y participación popular: Trelew, Octubre de 1972').

El avance de investigación de Juan Manuel Draguicevich ("Desarrollo fabril en el Valle inferior del Río Chubut y su competencia con los grupos fabriles nacionales: compañía cervecera chubutense, un caso testigo') hace a un momento clave del desarrollo económico de la región, cuando esta se termina de insertar en el mercado interno nacional. Allí la mayoría de las empresas locales no consiguen soportar la competencia con las grandes empresas nacionales, y se quiebra un modelo de crecimiento económico con cierta autonomía regional, que había podido crecer, pese a los costos diferenciales de producción que se tenían en la región, por la relativa situación de aislamiento que aseguraba la dificultad en los transportes.

Un trabajo clave es el de Raquel Caprano, Dora Palacios y Leticia López ("Economías de enclave y estrategias empresariales. El Caso Aluar"; "ALUAR ¿Privado o Estatal?'), que logra investigar en profundidad la conformación de uno de los proyectos de polos de desarrollo que se ponen en marcha en los años setenta. Con una gran base documental y una cobertura muy extensa de los diversos documentos y debates que atravesaron la conformación de Aluar, las autoras logran generar un insumo clave, que se complementa con diversos documentos sobre los planes de desarrollo para la región. Ya trabajaremos los aportes de esta investigación en capítulos posteriores.

Destacamos también el libro de María Paniquelli y Bruno Sancci ("El Chubutazo: octubre de 1990", basado en su tesis de licenciatura: "Conflicto político y protesta urbana. Chubut, octubre de 1990'), que investiga el proceso de protestas 
populares que se desarrolla en 1990 en la provincia de Chubut. Su abordaje es más bien descriptivo y si bien intenta acercarse al proceso provincial se centra en la región noreste de la provincia. No hay una problematización acerca de la ubicación de estos hechos en el marco del ciclo de luchas a nivel provincial ni nacional. Tampoco se plantea la pregunta-problema acerca de los procesos de conflictividad social que se desarrollaban a nivel nacional, que eran parte y expresión de la conformación de la hegemonía del capital financiero tras la hiperinflación de 1989. Por esto no hay tampoco una mirada que permita observar las líneas de continuidad con el proceso anterior de organización obrera y las conexiones y desacoples entre trabajadores estatales, privados y desocupados. Pese a estas falencias, la investigación es una de las pocas buenas descripciones sobre un proceso de protestas en la región, convirtiéndose así en un insumo importante para nosotros, ya que se ubica en el comienzo del período que estudiamos.

La tesis de licenciatura de Rubén Tomas ("El desequilibrio de la clase media en Trelew. La crisis de hiperinflación y la discusión neoliberal. 1989-1993") no consigue abordar científicamente el problema que se plantea, teniendo fuertes problemas conceptuales y metodológicos. Su aporte al conocimiento es limitado, permitiendo en algunas entrevistas observar las consecuencias que para algunos sectores sociales tuvo el proceso de cambios que atravesó a la sociedad de la región durante esos años.

Son escasas las investigaciones que intentan presentar una mirada de conjunto sobre la provincia del Chubut. Si bien centran su interés y su conocimiento en la región noreste los trabajos ya citados de Ibarra y Hernández (2005) y de Gatica, López, Monedero y Pérez Álvarez (2005) son los mejores ejemplos de esta intención, algo que repasaremos en los capítulos específicos.

La "Historia de Chubut" de Clemente Dumrauf (1996), es un relato narrativo, sin problematización, sin aplicación de metodología científica, que se restringe a recoger las fuentes tradicionales y a conformar una historia "oficial" de la construcción de lo que hoy es la provincia del Chubut. Allí no aparece el conflicto ni la lucha, constituyéndose como una historia legitimadora de los grupos dominantes en la provincia. 


\section{El movimiento de la sociedad: los conflictos sociales en el noreste del Chubut $1990-2005$}

\subsection{Cómo estudiar un proceso en un espacio y tiempo delimitados}

En este capítulo abordaremos en forma específica el proceso de conflictos sociales que se desarrollan en el período de años que estudiamos en la región noreste del Chubut. Como ya lo desarrollamos en alguna medida en el primer capítulo se nos presenta un debate metodológico de importancia central, en torno a la posibilidad que tiene un estudio de estas características de aportar a una comprensión global del movimiento de la sociedad.

El abordaje del movimiento de la sociedad en una porción de territorio delimitado por razones históricas y en un período definido a partir de una concepción acerca de los hitos de cambio en el movimiento de la sociedad argentina ¿puede contribuir al conocimiento acerca de ese movimiento de la sociedad?

Obviamente la pregunta así formulada no tiene otra respuesta que la afirmativa. Pero no pretendemos escapar tan esquemáticamente al debate. Es lógico que la discusión no puede ser el recorte en sí mismo sino, en todo caso, las características del recorte. Al modo de un experimento científico en el que se trabaja con una muestra, de lo que se trata es de saber si esa muestra representa en su particularidad al cuerpo general del que se parte. Para que el examen sobre la muestra sea válido, y nos presente conclusiones que puedan ser aplicadas al hecho que buscamos comprender, debemos asegurarnos de que la muestra tenga cierta homogeneidad interna y que su elección no sea arbitraria.

Aquí la enorme complejidad del movimiento de la sociedad argentina es analizada para poder ser abordada científicamente. Tomamos una muestra de ese movimiento de la sociedad para poder estudiarla, para manejar volúmenes de información que puedan ser procesados por nosotros y que no hagan imposible nuestro trabajo.

Ese recorte lo realizamos tanto en términos temporales como en términos espaciales. Delimitamos así un territorio social sobre el cual enfocamos nuestra atención: el noreste de la provincia del Chubut entre 1990 y 2005. La fundamentación de este recorte ha sido desarrollada en el primer capítulo y no nos extenderemos demasiado aquí.

Decíamos allí que nuestra hipótesis es que el abordaje del estudio de este tipo de procesos en determinadas regiones del territorio que conforma Argentina, permite avanzar en el sentido de comprender el movimiento del conjunto de la sociedad. 
El espacio delimitado por los actuales departamentos de Biedma y Rawson, en los cuales se ubican las ciudades de Trelew, Rawson y Puerto Madryn, se genera como espacio histórico desde 1865, a partir de la llegada a la zona de la inmigración galesa. Lejos estamos con este planteo de negar la historia previa de los pueblos originarios de Patagonia, sino que sostenemos que es a partir de la llegada de los migrantes galeses cuando esta porción de territorio empieza a tener una historia en común, distinta de otros espacios, y se empieza conformar como un territorio social con características particulares. A través de los sucesivos años se va construyendo un entramado de relaciones sociales que va configurando una serie de características sociales, económicas e ideológicas que serán constituyentes de este territorio.

La región que seleccionamos constituye una unidad económica social articulada por una historia en común, por un mismo proyecto político y social que conformó este territorio social como una región con características diferenciadas de otras, como el noroeste o el sur de la provincia. En los tres casos estas regiones, que conforman el triangulo de la provincia de Chubut, tienen relaciones de articulación mucho más significativas con las ciudades más cercanas de las provincias limítrofes que entre sí.

Así para nosotros es más importante para comprender la dinámica de la conflictividad social en el noreste del Chubut entender lo que sucede en el sureste de Río Negro (ciudades de San Antonio Oeste y Sierra Grande), que en las otras regiones del Chubut. Lo mismo puede demostrarse sin demasiada dificultad en el caso de Comodoro Rivadavia (relacionada claramente con la zona norte de Santa Cruz,) y con el noroeste chubutense, con una historia social y económica en común con la región suroeste de Río Negro.

La región que recortamos ha sido entonces constituida por una historia común y por ello el entramado de relaciones sociales que la constituye y reconstituye día a día tiene características que la hacen plausible de ser investigada como unidad (unidad que, como toda unidad desde nuestra perspectiva, es en verdad una síntesis de múltiples contradicciones). Observamos que en la región noreste del Chubut los trabajadores de Rawson, Trelew y Puerto Madryn se trasladan entre estos tres núcleos urbanos, tanto para buscar nuevas fuentes de trabajo como para buscar vivienda cuando los alquileres en una ciudad suben demasiado. Esto se hace más visible en el caso de ocupaciones más inestables como la pesquera o la construcción.

Ya hemos explicado que partimos de plantear que los procesos particulares deben entenderse en el marco del proceso general, del cual son parte y expresión. Lo particular debe comprenderse como expresión de lo general, donde a su vez lo 
general es constituido dialécticamente a partir de las múltiples particularidades, constituyéndose en una expresión unitaria de lo múltiple (Marx, 1997).

Para pensar esta problemática hemos retomado aportes teóricos fundamentales de Gramsci y Lenin, y el enfoque que, recuperando esos aportes, realizan a la realidad argentina Nicolás Iñigo Carrera, Jorge Podestá y María Celia Cotarelo (1999). Lo regional no está al margen de las relaciones de fuerzas en una sociedad ni es una mera situación local de esas relaciones. Es un ámbito en que las relaciones de fuerza de la sociedad se combinan con las relaciones de fuerza locales, que tienen sus especificidades, desde las cuales inciden en lo general.

Nuestra reflexión metodológica se vio enriquecida por el artículo de Eduardo Grüner "Lecturas culpables: Marx(ismos) y la praxis del conocimiento". Allí el autor retoma a Jean Paul Sartre, proponiendo la rediscusión del método progresivo/regresivo a través del cual Sartre pretendía recuperar la praxis planteada por Marx en la tesis XI sobre Feuerbach y la introducción de 1857.

Aquí Grüner desarrolla desde Sartre el debate sobre el abordaje que desde el marxismo debemos darle a la relación entre lo local y lo general: "La verdad deviene, dice Sartre: es una totalización que incesantemente se (des/re)totaliza a sí misma. Los hechos particulares deben ser rescatados en toda su singularidad compleja, pero ello no significa que tengan en sí mismos un sentido completo: no son verdaderos ni falsos, salvo "en la medida en que se encuentran relacionados, por la mediación de diferentes totalidades parciales, con la totalización-en-progreso" (Grüner, en Boron, Amadeo y González, 2006).

Por ello no hay posibilidad de conocer el todo o la parte por "sí mismos". Se trata, como siempre, de encontrar el conflicto, hacerlo observable y poder explicarlo, en su lucha y movimiento. En el fondo vuelve a aparecer el conflicto, la praxis, la acción creadora: "La opción "binaria" entre particularismo y universalismo es falsa e ideológica: el auténtico "universalismo" crítico es el conflicto entre la parte y el todo, entre el particular concreto y el universal abstracto. $Y$ es la permanencia de ese conflicto la que no permite que el universal se cierre sobre sí mismo" (Grüner, en Boron, Amadeo y González, 2006).

Desde esta perspectiva es que buscamos desarrollar nuestro trabajo. Pretendemos comprender la dinámica particular de nuestra región en el marco del proceso general, del cual es parte, pero no una parte pasiva, sino que es, al mismo tiempo, una de las instancias que construyen ese todo y una de las expresiones particulares del movimiento global de la sociedad argentina.

Hemos marcado también en varios trabajos la necesidad que solemos tener los historiadores que investigamos procesos en regiones de las provincias argentinas de 
desarrollar estos debates ${ }^{105}$. De no hacerlo el sentido común historiográfico nos asigna a los "estudios regionales" o a los "estudios de casos". Este sentido común ha sido construido a lo largo de decenios a partir de un núcleo de investigadores de las universidades centrales del país, que en una poderosa operación simbólica han construido una definición historiográfica de lo "nacional" que se limita a la región pampeana.

Así una investigación que aborde las provincias de Buenos Aires, Santa Fe, Córdoba y poco más, es asimilada sin demasiadas discusiones a una investigación "nacional". De hecho gran cantidad de investigaciones sumamente difundidas y aceptadas como parte del canon historiográfico fundamental, son producciones "nacionales" que sólo abordan procesos sociales desarrollados en la provincia de Buenos Aires, y en algunos casos únicamente en la Capital Federal.

Parece obvio afirmar que esta situación no es un simple discurso o una práctica retórica, y que hace a las configuraciones de poder que se han cristalizado en el desarrollo capitalista de la formación económica social que construyó Argentina. La centralidad económica de la región pampeana y el peso clave de Buenos Aires en lo político, social e ideológico, se manifiestan necesariamente en todos los ámbitos de la vida social, entre ellos en la producción historiográfica. Igualmente obvio es que esta realidad no puede llevarnos a seguir naturalizando esta situación y a no cuestionar esta matriz pampeano céntrica de la historiografía argentina.

Este sentido común historiográfico es parte de la configuración del capitalismo en Argentina, tiende a legitimar esa situación y a perpetuarla en el tiempo. Y a la vez construye legitimidad y poder para el grupo de investigadores que lo ha formulado y que lo reproduce permanentemente, ya sea a través de la constante publicación de nuevos trabajos que se inscriben en esta perspectiva, como de su aparición en tanto representantes socialmente legitimados de la "historiografía nacional".

Una de las herramientas claves del desarrollo de este sentido común fue la construcción y desarrollo del concepto de "economías regionales". Esto ya lo criticábamos en capítulos anteriores y hace a la misma mirada que asigna a los estudios que se centran en provincias ese mote despectivo o subordinado de estudios regionales. Se piensa así en una totalidad que está integrada por un sector central (obviamente la región pampeana) y regiones periféricas que se integran a ella. Esa totalidad que es una formación económica social, en lugar de ser comprendida como

\footnotetext{
${ }^{105}$ Por ejemplo en Gatica, Mónica y Pérez Álvarez, Gonzalo (2009) "El surgimiento del movimiento obrero en el noreste del Chubut", op. cit.; en Perren, Joaquín y Pérez Álvarez, Gonzalo (2009) "Las "nuevas" provincias como problema historiográfico. Una primera aproximación a los casos patagónicos" en Actas XII Jornadas Interescuelas Departamentos de Historia, Bariloche, Universidad Nacional de Comahue, publicada en CD ISBN 978-987-604-153-9; y otros.
} 
una unidad (que es a su vez síntesis de múltiples contradicciones) es considerada una simple sumatoria de partes a un núcleo central que permanecería relativamente inalterable, y que es lo único que da sentido y articulación al resto.

No se asume que en verdad hay un sistema complejo, que funciona en forma dialéctica, combinando cada una de las estructuras económicas sociales concretas, y cada uno de los territorios sociales que se conforman, en directa relación y complementariedad con el resto. No hay posibilidad de comprender la economía de la supuesta región central sin entender que las llamadas economías regionales son parte de ese mismo sistema económico. Es la misma lógica que piensa al sistema capitalista como integrado por países desarrollados y subdesarrollados (o, desde una mirada más optimista, o cínica, "en vías de desarrollo"), en lugar de aplicar conceptos que asumen una mirada de totalidad como el de imperialismo. No es una simple coincidencia que al mirar solamente la parte el conflicto y la dominación se invisibilizen. Es al hacer observable la totalidad cuando necesariamente aparece el conflicto, porque se encuentran las múltiples contradicciones que sustentan toda aparente armonía.

Creemos que no hace falta fundamentar nuevamente la indiscutible importancia del estudio de la totalidad del territorio social argentino para lograr comprender las dinámicas de sus grandes procesos de transformación social. Ninguno de los ciclos de conflicto social fundamentales que se han dado en la historia del país pueden ser entendidos realmente sin implicar en el análisis y en la síntesis a procesos que se desarrollaron por fuera de la región central.

Es tarea del conjunto de los cientistas sociales el desmontar este sentido común, develar lo oculto y construir conocimiento acerca de la totalidad del país, de las interrelaciones entre sus partes y de las síntesis contradictorias que se desarrollan. Para esto debemos desarrollar un esfuerzo sistemático en dos sentidos. Por un lado debemos nacionalizar nuestra perspectiva, buscar integrar todos nuestros estudios en una mirada que apunte a una comprensión de la integralidad del proceso. Un elemento fundamental para esto es romper con las falsas barreras, entre ellas las de las fronteras políticas, que si bien son importantes para comprender los procesos sociales, no explican la mayoría de las veces factores fundamentales.

Así creemos que en muchos casos la investigación de procesos "provinciales" también encubren muchos elementos. Especialmente esto sucede en provincias desarticuladas como las patagónicas, donde, como ya vimos, tenemos distintas regiones sumamente aisladas entre sí por grandes distancias y por historias de conformación muy diversas. Necesitamos afinar nuestra mirada y encontrar cuáles son las regiones que se construyen como unidades económicas y sociales en su desarrollo 
social. Para ello debemos perder el temor a esa forma de discriminación que asignaría estas investigaciones el rol de "estudios regionales" o "estudios de casos" (algo supuestamente aún peor que lo "regional", menos generalizable, ya que ni siquiera estamos enfocando a una provincia en total).

Y así como por un lado debemos nacionalizar la perspectiva de nuestras investigaciones (y no quedarnos en el estrecho margen de los "estudios regionales" a la que los sectores dominantes de la historiografía argentina nos han condenado), debemos también "provincializar" o "regionalizar" los resultados de investigaciones que siempre se han considerado nacionales. Recuperando el planteo de Dipesh Chakrabarty (en su obra del 2008: "Al margen de Europa ¿Estamos ante el final del predominio cultural europeo?"106), de lo que se trata es de llevar a su justa medida aquellos elementos que se impusieron socialmente como pretendidamente universales o generales y que en verdad solamente responden a procesos desarrollados en las regiones más poderosas, ya sea del mundo o de nuestro país. El investigador indio nos pide a los habitantes de todos los países dominados que generemos este quiebre epistemológico con respecto a los saberes y presupuestos construidos por Europa (y continuados por EEUU). Nosotros debemos hacerlo también con respecto a Buenos Aires.

En estas reflexiones tomamos elementos de varios trabajos. Ya marcamos diversos estudios sobre la conflictividad social en regiones del país que no se aislaban ni aceptaban el mote de ser estudios regionales y apuntaban a una mirada general. Así recuperamos investigaciones realizadas en el marco del PIMSA, trabajos desarrollados desde el CICSO, otros de Oscar Videla, entre diversas producciones que ya hemos citado en el capítulo dos.

Acerca del sentido común historiográfico retomamos reflexiones de Omar Acha (especialmente centradas en dos trabajos del 2009 y 2008: "Intelectuales en el ocaso de la ciudad letrada: Ios albores de una nueva generación crítica en América Latina" y “La nueva generación intelectual. Incitaciones y ensayos"), del mismo Acha junto a Nicolás Quiroga (del 2009: "Pliegues de la normalización de los estudios sobre el primer peronismo: complementos y aclaraciones") y especialmente del muy interesante artículo de Agustín Nieto "Notas críticas en torno al sentido común historiográfico sobre ‘el anarquismo argentino'”, del año 2010.

\footnotetext{
106 Seguimos aquí indicaciones teóricas de Agustín Nieto, ver (2010) "Notas críticas en torno al sentido común historiográfico sobre 'el anarquismo argentino' ”, en II Encuentro Internacional Teoría y práctica política en América Latina. Nuevas derechas e izquierdas en el escenario regional; Universidad Nacional de Mar del Plata, publicada en CD ISBN 978-987-1314-96-6. Debemos especialmente el interés por los investigadores del grupo de estudios subalternos al constante debate con nuestra colega en la sede Trelew de la UNP, Mariela Flores Torres (2009) "Palestinos en Argentina y Chile. Representación y construcción del conocimiento histórico", Proyecto de Tesis Doctoral. Universidad de Quilmes.
} 
Nieto desarrolla una polémica mirada acerca de cómo se construye un "sentido común" acerca de la importancia, la periodización y el significado como movimiento histórico del anarquismo en Argentina. Pero su interés no se queda allí y apunta directamente a lo que plantea como una historiografía "socialdemócrata progresista" acerca de la historia argentina, que se construye especialmente desde la UBA, originada en el Programa de Historia Económica y Social Americana (PEHESA). Si bien mucho del debate que esta lectura puede desarrollar no será abordado aquí, sí nos interesa que Nieto hace hincapié en que esta construcción del sentido común historiográfico tiene como punto fuerte esa "nacionalización" de lo capitalino que nosotros criticamos. Así lo explica “...notamos que del conjunto de trabajos sobre la temática emerge un eufemismo que, por medio de una violentación semántica, establece lo capitalino como "nacional” (Nieto, 2010: 6) o “...se dio lugar al eufemismo que establece lo capitalino como ‘o nacional', 'lo argentino'” (Nieto, 2010: 11).

Si bien el trabajo de Nieto profundiza en forma correcta diversos elementos, creemos que en este aspecto específico no profundiza lo suficiente su mirada crítica. Como ya lo destacamos no se trata solamente de una operación semántica o de una trampa del "discurso". Son relaciones de poder puestas en juego, en este caso en el ámbito de la producción historiográfica. Estamos ante una historiografía que legitima y reproduce, muchas veces sin poder hacerse consciente de este proceso, las relaciones de desigualdad y opresión entre las diversas regiones del país, así como legitima y reproduce las relaciones de dominación y opresión que se desarrollan en el sistema capitalista.

Nuestra investigación se inscribe en esta vertiente crítica a la historiografía dominante, en especial en lo que hace a esta perspectiva pampeano céntrica. Creemos que de esta manera será posible avanzar en nuestro interés por un desarrollo sistemático de conocimiento científico acerca de los procesos sociales que tuvieron lugar en las distintas regiones del país. Superando la perspectiva de la configuración de diversas historias regionales, de lo que se trata es de construir una verdadera historia nacional (o una historia comparada de América Latina), que no sólo permita discutir la validez de tantos postulados supuestamente universales, sino que fundamentalmente aporte nuevos problemas a una historia que permanentemente debe rediscutir sus categorías y poner a prueba sus marcos de análisis.

La tarea que realizamos se contextualiza en los esfuerzos de renovación en el campo historiográfico que desarrollamos junto a investigadores de distintas universidades e institutos, no como camino hacia la formulación de una "historia de la región", sino como aportes a la formulación de una historia que busque dar explicaciones holísticas del proceso social en nuestro país, que rompan con la matriz 
"pampeano céntrica" que permea a gran parte de la producción académica. Es claro que la mayoría de las historias nacionales del movimiento obrero, dejan fuera de su mirada procesos tan ricos como los que aquí enunciamos, construyendo postulados de supuesta validez nacional a partir de investigaciones que solamente se realizan en la región central.

Otro problema, es que en general los investigadores que vivimos en las provincias (más aún los que vivimos en regiones alejadas de Buenos Aires) hemos aceptado esos postulados como válidos, sin criticar esa mirada acotada de la dinámica del país. Es a este tipo de prácticas, tan naturalizadas, tan incorporadas inconcientemente a nuestras investigaciones, a las que nos referimos cuando hablamos del desarrollo de un "sentido común historiográfico". Muchos otros investigadores han caído en un error similar, cuando sus trabajos se formulan desde la lógica de buscar lo "excepcional", lo "extravagante" y lo "particular" en la historia de la región, sin enmarcar lo que acontece como parte de la historia nacional y mundial, siendo que sólo allí un hecho social toma su real significación e importancia.

En el trabajo creemos que demostramos la existencia de una clase obrera que se organizó y llevó adelante diversas luchas, que por cierto no escaparon al devenir del proceso social argentino y latinoamericano. La periodización de los conflictos muestra la profunda articulación con los procesos generales.

En este capítulo entonces nos abocaremos a buscar hacer observable el movimiento de la sociedad en el noreste del Chubut específicamente en relación al ámbito de la relación de fuerzas políticas, aunque necesariamente abordaremos también en alguna medida el ámbito de la relación de fuerzas objetivas. Intentaremos construir el proceso de conflictos sociales, con especial hincapié en las luchas obreras, relacionándolos con el resto de la conflictividad social y con las transformaciones globales de la estructura económica y social.

La carencia casi absoluta de estudios previos que aborden la historia de los conflictos sociales y las luchas obreras en el período analizado en la región noreste del Chubut, hizo necesaria una difícil y compleja tarea de construcción de esa historia. Ya desarrollamos algunos aspectos de esta tarea en el apartado de fuentes, especialmente destacando la necesidad que tuvimos de construir fuentes que nos permitieran conocer aspectos de este proceso que de otras maneras (y a partir de las fuentes ya existentes) quedaban por fuera de nuestra mirada.

Esa necesidad de construir la historia de las luchas obreras en nuestra región casi desde cero, nos planteó la obligación de realizar una aproximación "molecular" al proceso, en el sentido que a ese término le da Antonio Gramsci (1997). En "Apuntes sobre la historia de las clases subalternas. Criterios metódicos", Gramsci nos alerta 
sobre las dificultades para investigar la actividad de los trabajadores, sus acciones y la formación de sus organizaciones. Esa historia que suele ser "una función "disgregada" y discontinua de la historia de la sociedad civil” ${ }^{107}$.

Si bien en la historia hay una clara tendencia a la unificación de estos grupos (aunque sea a niveles provisorios), dicha intención es atacada por los grupos dirigentes y, muchas veces, derrotada. Por eso para Gramsci "todo indicio de iniciativa autónoma de los grupos subalternos tiene que ser de inestimable valor para el historiador integral; de ello se desprende que una historia así no puede tratarse más que monográficamente, y que cada monografía exige un cúmulo grandísimo de materiales a menudo difíciles de encontrar".

Para ello debemos hacer observable ese "... proceso molecular, minucioso, de análisis extremo, capilar”. Debemos presentar “... este lento trabajo del cual nace una voluntad colectiva con cierto grado de homogeneidad, con el grado necesario $y$ suficiente para determinar una acción coordinada y simultanea en el tiempo y en el espacio geográfico en el que se verifica el hecho histórico"(Gramsci, 1997: 99).

Gramsci busca en la expresión "molecular" la posibilidad de referirse a la unidad mínima de la experiencia vital, al particular inmediato, tomado de la vida cotidiana. Es la búsqueda de ponerse en el punto más cercano a la experiencia de los hombres y mujeres que realizan la historia.

Partimos de que los procesos particulares deben entenderse en el marco del proceso general, del cual son parte y expresión. Por eso deben ser estudiados pensando lo particular en tanto expresiones de lo general, donde a su vez lo general es constituido dialécticamente a partir de las múltiples particularidades (ver Marx, 1997). Desde este punto de vista la cuestión de las relaciones entre lo regional y lo nacional e internacional no puede entenderse como una contradicción excluyente: pensamos lo regional como un ámbito en que las relaciones de fuerza de la sociedad se combinan con las relaciones de fuerza locales, que tienen sus particularidades y desde las cuales inciden a su vez en lo general.

Esto se aplica tanto al ámbito de las relaciones de fuerzas objetivas como al ámbito de las relaciones de fuerzas políticas. $O$, para decirlo en los términos que usaremos aquí en algunas ocasiones, este principio metodológico lo debemos aplicar tanto cuando estudiemos las transformaciones a nivel de la estructura económica social como cuando estudiemos las transformaciones en los procesos de lucha y organización de las distintas clases y fracciones de clases.

${ }^{107}$ En www.gramsci.org.ar. 
Un elemento central en este sentido será abordar el estudio de la conformación de la clase obrera en la región y sus características particulares. La interrelación de estas características y esa historia particular, con el proceso de conformación, desarrollo y conflictos que genera la clase obrera a nivel nacional, será el hilo conductor que buscaremos encontrar a lo largo de nuestra investigación.

Esto no es una tarea fácil y, sobre todo, no es una tarea que podamos concretar en esta tesis. Falta mucho aún por investigar, toda una historia de la clase obrera en nuestra región que está por construirse. Hoy trabajamos en el marco del proyecto "Historia y Memoria de la clase obrera en el noreste del Chubut" (dirigido por Mónica Gatica) para construir esa historia, desde las primeras huelgas a fines del siglo XIX hasta este convulsionado presente.

Así encontramos que es central investigar los distintos elementos que inciden en la conformación ideológica de la clase, en su cultura y en el desarrollo de sus niveles de conciencia. Veremos que la conformación de una clase obrera en constante recambio por la llegada de nuevos contingentes inmigrantes, la heterogeneidad de sus trayectorias de vida, la falta de tradición de organización obrera y, en muchos casos, hasta de trabajo fabril y de vida urbana, serán factores claves en la historia de este grupo social.

En la última parte del capítulo 4 retomaremos más directamente este debate, que intentaremos volcar también en la reconstrucción molecular del proceso de luchas y organización, tanto a nivel general como en algunas fracciones particulares de la clase obrera. Utilizamos como elementos metodológicos claves para pensar este problema a las reflexiones de George Rudé y su mirada acerca de cómo se construye la cultura obrera a partir de ideas derivadas e inherentes. $Y$ especialmente nos nutrimos con los aportes de Antonio Gramsci, en este punto en torno a sus comentarios, expuestos en varios fragmentos, acerca de la conformación de un "sentido común" en la sociedad y de su relación con la noción de hegemonía.

Gramsci buscará comprender los complejos procesos a través de las cuáles se construye una concepción del mundo en común, que opera de forma invisible y no cuestionada, ya que casi nunca se hace conciente. Por eso ya veremos que Gramsci se pregunta qué sucede cuando una parte del comportamiento humano en sociedad se transforma en una "pasión", en un elemento de su accionar social que se desarrolla como por fuera de toda reflexión intelectual conciente.

Pero esto es solamente la apariencia. La realidad es que por detrás operan las relaciones de dominación en una sociedad basada en la explotación de clase. A eso hace referencia la noción de hegemonía. El concepto de hegemonía hace visible la dominación y permite por eso la crítica. La crítica a su vez hace posible la 
transformación práctica. Ya retomaremos este debate más adelante y por esta senda trataremos de seguir en lo que viene.

\subsection{Periodización del proceso: los hitos y los ciclos}

Una tarea que nos planteamos es periodizar el ciclo de rebelión en la región, observando su articulación con el proceso nacional. La periodización es un procedimiento central en la búsqueda de avanzar en el conocimiento del proceso histórico. Marca la selección y el tratamiento de los hechos y la concepción que tiene un historiador sobre las causas del movimiento de la sociedad. Es clave definir los puntos de quiebre, los cortes, y, dado que para nosotros es la lucha de clases la que explica fundamentalmente los procesos de cambio social, buscamos esos hitos ${ }^{108}$ en el marco del enfrentamiento social.

Por eso marcábamos en el primer capítulo que consideramos que el período seleccionado para nuestra investigación (que abarca desde 1990 al 2005), incluye dos ciclos históricos en términos de la tendencia general que expresa el movimiento de la sociedad. Planteamos allí que consideramos que el primero de los ciclos comienza en 1975-1976 y se cierra en 2001-2002, teniendo como hitos de su comienzo al proceso conocido como "rodrigazo" y al golpe militar de 1976, y como hito de su cierre a las jornadas de diciembre de 2001. Este primer ciclo está caracterizado por el avance del proyecto del capital financiero que toma la ofensiva en un período claramente contrarrevolucionario, donde la alianza social que gobierna impulsa y desarrolla este proyecto, logrando imponerlo como un programa hegemónico en la sociedad.

Durante los noventa se desarrolla un ciclo de rebelión que acumula fuerza social y experiencias, las cuales se sintetizan en los hechos de diciembre de 2001 y la continuidad de movilización social durante el 2002. Estos hechos marcan lo que creemos se plantea como el cierre de la ofensiva hegemónica del proyecto del capital financiero. A partir de allí la alianza social que había ocupado el gobierno se fractura y es posible que estemos ante un cambio de período que ya no tomaría las características de una fase contrarrevolucionaria. Este segundo ciclo se abre en 2003 y abarca entonces la parte final del período seleccionado. Las hipótesis que construyamos sobre este segmento del período tendrán un carácter más provisorio ya que es un proceso que aún esta en curso, siendo su continuidad la que nos permitirá llegar a lecturas más precisas.

En términos teóricos seguimos criterios de periodización propuestos por la tradición del CICSO y continuados por el PIMSA. Los mismos, y la importancia clave

108 Consideramos a los hitos como los hechos en que las distintas fracciones de clase modifican sus alianzas sociales y sus correlaciones de fuerzas en el marco de los enfrentamientos sociales. 
de la periodización en la investigación histórica, están claramente expuestos en el artículo de Irma Antognazzi "Argentina de los 60 a los 80: buscando criterios de periodización" 109 .

Proponemos una periodización provisoria, dividiendo en distintos apartados la exposición de los procesos de conflicto social en la región, intentando articular esa exposición con los principales sucesos a nivel nacional y, en algún caso, también a nivel latinoamericano. Los apartados que figuran a continuación en este capitulo, intentan plantear una mirada de conjunto que caracterice los rasgos fundamentales de cada fase como parte del período que estudiamos.

Desarrollamos entonces una periodización del proceso, tomando como momentos de inflexión fundamentales a los hitos del ciclo de rebelión que comienza con el santiagazo de diciembre de 1993 (Iñigo Carrera y Cotarelo, 2004). Así trabajaremos con un primer período entre 1990 y 1993, una segunda fase entre 1994 y 1996, la tercera entre 1997 y 1999, la cuarta que toma del año 2000 hasta mediados del 2002 y la última desde mediados del 2002 hasta fines del 2005.

Para el PIMSA el primer momento ascendente ${ }^{110}$ se desarrolla desde diciembre de 1993 hasta agosto de 1997: del "motín" de Santiago del Estero hasta la huelga general de agosto de 1996 y los cortes de rutas de abril-junio de 1997 en Cutral Có, Plaza Huincul, Jujuy, Salta y Cruz del Eje. Allí comienza un momento descendente de las luchas sociales, en el que los cuestionamientos son canalizados hacia el proceso electoral, que genera expectativas por el posible recambio en la figura presidencial y en los funcionarios del poder ejecutivo nacional tras los diez años de gobierno de Carlos Menem. No hay huelgas generales en 1998 y sólo una en 1999, convocada únicamente por la Central de Trabajadores Argentinos (CTA).

En diciembre de 1999 se reinicia un momento de ascenso desde los enfrentamientos en Corrientes, y continúa con la emergencia del "movimiento piquetero" en Buenos Aires. En dos años hay ocho huelgas generales en las que puede observarse mayor grado de unidad y menor aislamiento de los trabajadores. Esto se extiende hasta junio del $2002^{111}$, pasando por la insurrección espontánea de diciembre de 2001.

\footnotetext{
${ }_{109}^{109}$ Publicado en Antognazzi y Ferrer (comp. 1997), Argentina, raíces históricas del presente, UNR, Rosario.

110 Los momentos ascendentes y descendentes de las luchas (más allá del carácter general del período) se miden por el grado de alianzas o aislamiento, y unidad o fractura de la clase obrera.

111 En un trabajo que apunta a analizar y sistematizar los datos recogidos acerca de los hechos de rebelión desde el año 2002 hasta el 2007, el PIMSA (2007), destaca "2002 es, cuantitativamente, el punto culminante. El nivel de movilización registrado en 2001 se prolongó en los primeros cinco meses del año siguiente: casi el 60\% (59,6\%; 2.053 hechos) del total de 3.444 hechos registrados en 2002 se produjo entre enero y mayo de este año; desde junio de 2002, la cantidad de hechos disminuyó, para volver a incrementarse en 2004." (en "Los hechos de rebelión en Argentina 2002-2007").
} 
Como vemos en términos generales nuestra periodización provisoria recupera la que construyen los investigadores del PIMSA a nivel nacional, aunque aplicando algunos elementos propios del desarrollo del conflicto en la región. Como ya lo destacamos en capítulos anteriores consideramos que las dinámicas de unidad y división de la clase en esta región se enmarcan en el proceso nacional, con una clara sintonía en torno a los periodos observados. En cambio los procesos de alianza y aislamiento tienen una dinámica más propia, basada en la resistencia que durante un breve lapso del período estudiado mantiene la burguesía con intereses en la región ante el proyecto hegemónico del capital financiero, y para la cual teje alianzas con algunas fracciones de la clase obrera.

Por otro lado la diferencia en el recambio del personal político en la provincia del Chubut con referencia a lo que sucede a nivel nacional también plantea algunas particularidades que intentaremos hacer observables. Se muestra allí la importancia de tomar en cuenta las relaciones de fuerzas locales, y las disputas políticas que se expresan, en el desarrollo de los procesos de conflicto social en regiones particulares del país. El hecho de que la política de ofensiva del capital financiero en la provincia de Chubut fuera encabezada por gobiernos de signo radical y que este partido se mantuviera en el gobierno en forma continua hasta el 2003, genera algunas diferencias con el proceso nacional.

Específicamente para nosotros no se manifiesta en la región la caída del proceso de rebelión en 1999 que se hace observable a nivel nacional en torno al reemplazo del gobierno de Menem por el de la Alianza y las expectativas que este recambio generaba en una parte importante de la sociedad.

Muy brevemente trataremos de esbozar aquí tres debates que se plantean en torno a los criterios de periodización para los años que trabajamos y sobre los cuales fijamos posición ya en la periodización provisoria que planteamos como hipótesis. Además de esos debates hay dos elementos de consenso entre la gran mayoría de los investigadores que han trabajado estas temáticas ${ }^{112}$.

Trataremos de avanzar en un sentido cronológico para hacer quizás más entendible la exposición. El primer debate es el que se plantea en torno a la situación de la clase obrera en Argentina tras la dictadura militar que culminó en 1983.

Tomamos como eje para el desarrollo de este debate al artículo de Pablo Ghigliani (2008) "La noción de derrota en la historia reciente del movimiento obrero

\footnotetext{
112 Consenso en términos de la periodización, aunque a la vez hay grandes diferencias sobre porqué tomar a esos hechos como puntos de inflexión.
} 
$\operatorname{argentino~}^{\text {"13 } 13}$, donde se sintetizan las diversas miradas acerca de la situación de la clase obrera argentina tras la dictadura militar, en torno a la intención de repensar el concepto de derrota y los diversos usos que se hacen del mismo. Ghigliani parte de poner en duda que la utilización recurrente de esta noción sugiera un consenso o una perspectiva común, y muestra cómo, tras la misma palabra, se esconden distintas miradas e interpretaciones sobre el cambio en la correlación de fuerzas sociales.

Es obvio que este debate es importante para nosotros ya que nos plantea cuál es el punto de inicio de nuestra investigación. De todas maneras debemos exponer que es un debate que nos muestra una carencia fundamental en nuestra construcción investigativa y es la ausencia de investigaciones amplias sobre la situación de la clase obrera en la región durante los años ochenta. Será una tarea que nos tocará desarrollar una vez completada esta etapa de nuestra formación como investigador.

Ghigliani plantea que hay tres grandes vertientes que utilizan el término derrota para explicar la situación de la clase obrera tras la dictadura militar. El primero de ellos tiende a restringir la derrota observada a que la dictadura logró poner fin a "un proceso revolucionario o un proyecto político de transformación social". El autor pone en esta línea a Izaguirre, Löbbe, Lorenz, Marín y Sartelli. Creemos que la perspectiva de Izaguirre y Marín no concuerdan con esta lectura de Ghigliani, ya que ambos proponen una mirada más amplia e integradora del proceso, que tiende a hacer observable la imbrincación de las relaciones de fuerzas objetiva y política, comprendiendo así la derrota en un sentido más integral ${ }^{114}$.

En segundo término se propone la concepción que destaca la existencia de una derrota histórica de la clase obrera como tal, derrota que se expresa específicamente en cuestiones materiales: la pérdida de numerosas conquistas laborales y un importante retroceso de su participación en el ingreso. Sin embargo este enfoque (que para Ghigliani desarrollan específicamente Werner y Aguirre) se termina limitando al análisis del aniquilamiento de sus expresiones de izquierda.

Por último se destaca el enfoque que el autor propone como el más fundamentado. Aquel que “...subrayando también la existencia de una derrota histórica de la clase obrera, incluye entre los perdedores a sus direcciones reformistas, esto es, a la dirigencia sindical y al peronismo histórico". Sería esta la línea interpretativa de Abós, Campione, Gilly y Horowicz.

\footnotetext{
113 Presentada en las V Jornadas de Sociología de la UNLP y I Encuentro Latinoamericano de Metodología de las Ciencias Sociales, Universidad Nacional de La Plata, publicada en CD, ISBN: 978950-34-0514-7.

${ }^{114}$ Ver, entre otros, Marín, Juan Carlos (1984) Los hechos armados. Un ejercicio posible; Cicso, Buenos Aires. Izaguirre, Inés (1994b) Los desaparecidos: recuperación de una identidad expropiada. Centro Editor de América Latina, Buenos Aires.
} 
Por otro lado se destaca un grupo de investigadores que se propuso recuperar la acción de la clase obrera durante la dictadura y su capacidad de convertirse en antagonista de la misma, aún en condiciones de gran debilidad. Desde esa perspectiva autores como Pozzi, Bitrán y Schneider han rechazado el uso de la noción de derrota. En términos generales rechazan que en los procesos históricos puedan hacerse lecturas de resultados tan específicos, pensando que en verdad toda situación es coyuntural y lo que hoy puede aparecer como una derrota en el largo plazo pueden aportar elementos para una victoria posterior. Pero a la vez, y más específicamente, no consideran que la dictadura haya significado un cambio cualitativo en el proceso, sino que se planteó como un paso más en la larga secuencia de pérdida de poder que venían sufriendo los trabajadores desde 1955.

Esto obviamente no implica que no reconozcan que el asesinato de miles de activistas obreros y la ruptura de la mayoría de sus organizaciones políticas y sindicales, fue un duro golpe para los trabajadores. Pero en su perspectiva los obreros supieron resistir a la dictadura y fueron el factor clave en la caída de ese régimen de gobierno.

Sin embargo Pozzi y Schneider sí reconocen una derrota del movimiento obrero entre 1991 y 1993. Convergiendo con un consenso bastante generalizado (al que ya haremos referencia) que observa un cambio cualitativo en los primeros años de la presidencia de Carlos Menem, estos autores proponen que entre 1976 y 1991 “...la resistencia a los cambios impulsados por la clase dominante fue parcialmente exitosa en preservar formas de organización y en frenar la decadencia de las condiciones de vida. A partir de esa fecha en cambio, año en que son derrotadas las huelgas telefónicas y de ferroviarios, afirma Pozzi, comienza la destrucción de las formas tradicionales de organización de los trabajadores, cae en términos absolutos los niveles de vida, y es posible constatar el agotamiento de formas y expresiones culturales que habían históricamente expresado la resistencia de la clase obrera frente a la explotación y la dominación capitalista." (Ghigliani, 2008).

En este más que resumido planteo (de un artículo que el propio autor reconoce como una síntesis esquemática de la cual quedan afuera muchos elementos) concluimos, como Ghigliani, que de lo que se trata es de observar a la última dictadura militar como una profunda reestructuración capitalista. Poner este elemento en el centro del análisis, lo cual no implica desconocer los factores subjetivos ni la disolución de organizaciones clasistas y revolucionarias, es intentar recuperar el movimiento de la clase de manera orgánica, observar su situación en términos globales para evaluar un diagnostico adecuado. 
Para Ghigliani un elemento central será romper con la visión esquemática de otorgar a priori una supuesta "vocación combativa y revolucionaria a los trabajadores de base y una vocación conciliadora y traidora a toda dirigencia reformista", que se sintetiza en el mal usado concepto de burocracia sindical. Ya veremos este problema en otro apartado del capítulo 4. Pero aquí lo que nos interesa destacar es que recuperar una perspectiva que haga al movimiento orgánico de la clase en el marco de la situación de relaciones de fuerzas sociales, tanto a nivel estructural como en lo político, hace necesario que entendamos a la dirigencia sindical y política de la clase como parte de ella. Por eso la herencia de la dictadura no puede comprenderse sin tener en cuenta una mirada que haga a la totalidad del proceso. Consideramos que esta sí sería la posición defendida por Marín, Izaguirre y las distintas producciones que partieron del marco teórico del CICSO.

Partir de la perspectiva de comprender este proceso como una profunda reestructuración del capitalismo nos hace percibir "...que la política laboral de la dictadura no se detuvo en el aniquilamiento de las corrientes revolucionarias sino que estuvo dirigida a llevar lo más lejos posible la desorganización de la clase para facilitar el éxito del proceso de acumulación y disciplinar el campo popular, tanto social como políticamente".

Los investigadores que trabajan desde el PIMSA no son analizados en el artículo de Ghigliani. Sin embargo han abordado en muchas investigaciones estos debates. Aunque en general no han hecho referencia explicita al concepto de "derrota" (factor que quizás explica la ausencia de esta perspectiva en el artículo de Ghigliani), siempre se han planteado como un problema clave el de encontrar los momentos de quiebre en las relaciones de fuerzas sociales.

En varios trabajos clásicos de este programa ${ }^{115}$ se ha profundizado en estas discusiones. Dicha inquietud es retomada constantemente, estando presente en varios de sus artículos más recientes. En "El desarrollo del capitalismo argentino y la clase obrera 1975 - 2005”, Nicolás Iñigo Carrera (2010), plantea que: “Cuando, a partir de diciembre de 1983, los cuadros militares en función política fueron reemplazados en el gobierno por los cuadros políticos, se desarrolló el dominio de la oligarquía financiera hasta llegar a hacerse hegemónica después de las hiperinflaciones de 1989 y 1990. La construcción de esa hegemonía tuvo sus hitos en la manera en que se resolvió la

${ }^{115}$ Entre otros en Iñigo Carrera, Nicolás, Cotarelo, María Celia, Gómez, Elizabeth y Kindgard, Federico (1995) La revuelta. Argentina 1989/90; en PIMSA DT № 4, Bs. As. y en Iñigo Carrera y Podestá (1997b) Las nuevas condiciones en la disposición de fuerzas objetivas. La situación del proletariado, en PIMSA DT № 5, Bs. As. 
guerra por las Malvinas, el acuerdo que permitió la salida del gobierno militar y las ya citadas hiperinflaciones. "(Iñigo Carrera, 2010: 297)

Estos hitos son repasados también en el artículo de Iñigo Carrera junto a Carlos Figueroa Ibarra (2010), "Algunas reflexiones sobre Historia Reciente", donde debaten acerca de los momentos de quiebre en la historia reciente, tanto a nivel mundial, como en América Latina y en sus respectivos países (enfocando específicamente su atención en los casos de Argentina y Guatemala).

También en el trabajo ya citado de Donaire y Lascano (2002), se comprende que desde 1975 se está ante un momento de transformación social, que para esta perspectiva (compartida por nosotros) se conceptualiza como contrarrevolucionario.

En este sentido el debate sobre el uso de la noción de derrota nos parece importante pero no definitorio. No importa tanto el uso del término sino comprender si estamos o no ante un cambio cualitativo en la correlación de fuerzas sociales. Discutimos entonces sí con aquella perspectiva que no considera que la dictadura militar generó un profundo cambio en las relaciones de fuerzas y también con las que consideran que los golpes desarrollados desde el poder tuvieron como único objetivo a las organizaciones revolucionarios o a la fuerza social que apoyaba un proyecto de transformación hacia el socialismo. Esto no implica desconocer la continuidad de las luchas obreras aún en las peores condiciones sociales, sino observar que esas luchas se dan en una correlación de fuerzas cada vez más desfavorable.

Para nosotros no hay dudas que hubo un cambio cualitativo en la relación de fuerzas sociales, una reestructuración de la sociedad que tuvo como principal perjudicada a la clase obrera en su conjunto. Como lo destacan Donaire y Lascano la etapa de la dictadura fue la victoria por la guerra del proyecto del capital financiero. Los años siguientes fueron los de la construcción de su hegemonía, tarea que tiene como base objetiva la transformación de las relaciones de fuerzas impuesta mediante la fuerza militar: "El aniquilamiento y desarticulación de la fuerza social revolucionaria y la subordinación del capital industrial y una mayor centralización y concentración del capital financiero fueron el resultado de este enfrentamiento. Con el período abierto con el gobierno militar de 1976, el capital financiero comenzó a asentar por la fuerza las bases de su dominación. Sin embargo todavía le quedaba como tarea pendiente construir el consenso social de esa dominación. El capital financiero había ganado la guerra, todavía le faltaba ganar la paz" (Donaire y Lascano, 2002: 77).

¿Cuándo consigue ganar la paz? Decíamos antes que para nosotros se plantean varios debates que son necesarios aclarar para especificar nuestras elecciones al momento de periodizar. $Y$ que también aparece un elemento de consenso bastante generalizado, al menos en el presente, entre los investigadores 
que estudian los conflictos sociales y los procesos de transformaciones económicas y sociales.

Ese consenso es el observar a los años que van de 1989 a 1993 como un momento de profundos cambios cualitativos en la relación de fuerzas sociales. Como ya lo marcamos en el capítulo 1 nosotros tomamos las indicaciones de Donaire y Lascano (2002), Iñigo Carrera y Cotarelo (2004), Bonnet (2008, 2007, 2002), Piva (2007) y otros, que ven a la hiperinflación de 1989-1990 como un hito a partir del cual se realiza la hegemonía del capital financiero en nuestro país.

Aquí sí es interesante retomar, al menos como elemento de comparación, a la perspectiva de Pozzi y Schneider, quienes no plantean a la dictadura como un momento de derrota pero sí lo hacen cuando observan los años de 1991 a 1993. En un sentido similar utilizan esta noción Adrián Piva (2009 y 2001) y Agustín Santella (2008).

Las transformaciones fueron tan veloces y abruptas, y la capacidad de oposición de la clase obrera fue tan limitada, que aún los investigadores más renuentes a utilizar esa concepción la toman para explicarse el desarrollo del proyecto del capital financiero y la incapacidad para articular respuestas efectivas desde los trabajadores.

Aquí la derrota se hace evidente. Específicamente se hace inocultable la victoria del enemigo. El cambio profundo en las relaciones de fuerzas que se produce en estos años aparece hoy como un elemento común en la mayoría de las investigaciones. Lo que no aparece tan claro es el papel de la hiperinflación en este proceso. La construcción de la hegemonía del capital financiero tras la hiperinflación es destacada en el artículo que Donaire y Lascano desarrollan en el 2002, rompiendo con la perspectiva de pensar el proceso hiperinflacionario como un problema económico, y poniéndolo como una manifestación central de la lucha de clases.

Los autores demuestran que la hiperinflación impone una ruptura en ese proceso de lucha de clases y se transforma en un nuevo factor de disciplinamiento social. Al disciplinamiento por el terror de Estado impuesto por la dictadura, se le suma ahora el disciplinamiento por el terror económico. Las relaciones dinerarias se quiebran, la moneda desaparece como elemento de mediación. Siguen así lo ya expuesto en la investigación de Nicolás Iñigo Carrera, María Celia Cotarelo, Elizabeth Gómez y Federico Kindgard “La revuelta. Argentina 1989/90"116.

Este aporte es un insumo clave para nuestra investigación. Marca el punto de inicio del proceso que pretendemos comprender. Allí destacan “... ¿qué es lo que

\footnotetext{
${ }^{116}$ Publicado en 1995 desde el PIMSA, DT № 4, Bs. As.
} 
aparece como propio de ese momento en la Argentina, tanto en 1989 como en 1990? La llamada hiperinflación, es decir el momento en que, técnicamente, las mercancías no tienen precio y una moneda determinada ha dejado de funcionar como equivalente general. Socialmente, el momento en que se ha roto lo que aparece mediando todas las relaciones que forman la base de la sociedad capitalista. Esto es lo que tendría de específico la situación argentina en 1989/90. La "raíz ética" del hecho, tiene, en realidad, un asiento material: la imposibilidad de reproducir su vida material para una parte de la sociedad, en las condiciones dadas, y la ruptura, no de los lazos de unión solidaria sino de la mediación en las relaciones materiales en la sociedad capitalista." (Iñigo Carrera y otros, 1995).

Esta perspectiva del disciplinamiento que impone la hiperinflación ya había sido desarrollada también por Alberto Bonnet, quién la profundiza en diversos trabajos hasta la actualidad (desde su artículo de 1995, "Argentina 1995: ¿Una nueva hegemonía?", hasta su libro “La hegemonía menemista”, publicado en 2008). Tanto él como Adrián Piva, van a hacer hincapié en que este momento de cambio genera a su vez una profunda reestructuración en las formas en que la clase obrera desarrolla sus luchas.

Desde una perspectiva que se enmarca en términos generales en los resultados de investigación del PIMSA, nosotros no observamos que lo fundamental es que haya un cambio en las formas de lucha. Lo fundamental es el cambio en la relación de fuerzas sociales, y esto se refleja en cambios en los sujetos que desarrollan los conflictos, en las personificaciones que se construyen, las formas en que se producen las protestas, las organizaciones que se construyen, etc. Los sectores oprimidos de nuestra sociedad enfrentan esa hegemonía del capital financiero a partir de una larga serie de luchas que desenmascararon la naturaleza del sistema, y que tuvieron como hito máximo, hasta el momento, a las jornadas del 19 y 20 de diciembre del 2001.

En ese sentido siempre nos sirvió para pensar este proceso la hipótesis de Iñigo Carrera y Cotarelo, cuando observan que tras la hegemonía del capital financiero que se realiza en 1989-90, la clase obrera había quedado muy debilitada, en el marco de un ciclo contrarrevolucionario que empezó hacia 1975-1976, cuando se cierra el ciclo de luchas ascendentes comenzado en los años treinta. Pero como la lucha nunca se detiene cuando las condiciones sociales la marcan como necesaria para garantizar la vida, los trabajadores y el pueblo vuelven a iniciar un ciclo de luchas que comienza por su escalón más bajo, por la revuelta, y que iría tomando grados cada vez mayores de desarrollo a partir de su manifestación embrionariamente conciente, que es el motín de Santiago del Estero a fines de 1993. 
Esta diferencia enmarca y sirve de fundamento para dos debates que consideramos relevantes alrededor del cómo periodizar el proceso que estudiamos. El primero de ellos hace a si las huelgas generales continuaron funcionando como un indicador confiable para periodizar el conflicto social. El otro hace a si el ciclo de luchas que se hace observable en los noventa tiene como su punto de inicio al santiagazo de 1993 o a los cortes de ruta y puebladas de 1996. Al igual que aquellos que ya intentamos sintetizar, estas discusiones ameritan un abordaje de mucha mayor profundidad y por lo tanto sabemos que dejamos muchos elementos fuera de nuestro análisis y que la presentación de las perspectivas tendrá seguramente algún carácter esquemático.

Para el primer debate de los dos mencionados tomamos como insumos fundamentales a los artículos de Adrián Piva (2009, "El desacople entre los ciclos del conflicto obrero y la acción de las cúpulas sindicales en Argentina (1989 - 2001)"; una versión previa había sido publicada en 2006 en la revista de la ASET, Estudios del Trabajo, № 31) y de Nicolás Iñigo Carrera (2009, "La huelga general como indicador de momentos de ascenso y descenso en la lucha de la clase obrera. Argentina 1984 2002').

Para Piva no hay dudas de que la propuesta de Iñigo Carrera de tomar a las huelgas generales como indicador para periodizar funciona para los años previos a los noventa. Sin embargo considera que allí se plantea un quiebre en torno al "desacople" que para él se manifiesta entre la acción de las cúpulas sindicales y el conflicto obrero.

En este sentido se propone "analizar la evolución de la conflictividad obrera en el período comprendido entre 1989 y 2001, con el fin de establecer una periodización general y por fracciones. En segundo lugar, contrastar la evolución de la conflictividad obrera con la acción de las centrales sindicales para los períodos enero de 1984 mayo de 1989 y junio de 1989 - diciembre de 2001. Por último, intentar dar cuenta de los cambios en la relación entre conflictividad obrera y acción de las cúpulas sindicales." (Piva, 2009).

Es importante destacar que Piva mide conflictos laborales (toma la base de datos de conflictos laborales construida en sucesivos proyectos de la Universidad Nacional de Quilmes bajo la dirección de Ernesto Villanueva y Marcelo Gómez), mientras la base de datos del PIMSA toma como dato a los hechos de rebelión. Así, para nosotros, la perspectiva de Piva limita el universo del conflicto social al ámbito laboral y, al circunscribirlo al conflicto laboral, tiende a impedir hacer observable la articulación entre diversos hechos y entre diversas clases o fracciones de clases.

El número de conflictos laborales alcanza el punto máximo del período 19892001 en el año 1994. Luego comienza un descenso en 1995, año con el mayor 
número de conflictos defensivos. Allí hay un cambio de ciclo, a partir de 1996, cuando tanto los conflictos ofensivos como defensivos bajan, generando "un período de baja conflictividad laboral relativa que no es revertida por el ascenso de la conflictividad laboral en 2001." (Piva, 2009).

La hiperinflación aparece como “... la derrota/fracaso de la estrategia dominante de la clase obrera frente a la crisis final del "modelo sustitutivo de importaciones", a saber, una estrategia centrada en la lucha salarial y ligada a la defensa del viejo patrón de acumulación." (Piva, 2009). Se conforma como hegemónica la alternativa neoliberal como única salida posible ante la crisis. Se conforma un amplio consenso en torno al programa de la convertibilidad y una sólida unidad burguesa que apoya el programa de reestructuración. La contrapartida fue la fractura sindical y la fragmentación de la conflictividad.

Se genera así una nueva relación de fuerzas que lleva a la derrota de los intentos de resistencia de algunos sectores de trabajadores contra las privatizaciones, específicamente de la llamada "estrategia vandorista", defendida, según Piva, por el ubaldinismo. Contra ella se sostuvo desde el Estado un apoyo al desarrollo de "... la estrategia neoparticipacionista de vinculación de los sindicatos al estado", que garantizó a su vez la tendencia hacia la fragmentación del conflicto obrero.

El cambio de ciclo en 1996 tiene como punto destacable que mientras caen los conflictos protagonizados por obreros ocupados, aumentan los conflictos generados por trabajadores desocupados. Así si bien observa un vínculo claro entre las huelgas generales y el conflicto obrero entre 1984 y 1989, la situación es distinta para el período 1989-2001. Discute directamente con el análisis de Iñigo Carrera (2002), que pone el pico del ciclo de luchas, iniciado para él en diciembre de 1993, en 1996. En cambio para Piva ese es el momento de menor cantidad de conflictos y desde 1996 no se recuperarán los niveles de conflictividad registrados anteriormente.

¿Cuáles son los elementos de cambio? En primer lugar la fractura del movimiento sindical. Piva discute la concepción de medir la unidad de la clase obrera desde la unidad de los cuadros sindicales, más aún ante la división en distintas centrales. Específicamente para Piva la acción de la CGT deja de tener relación con el conflicto obrero, en cambio sí es más cercano el papel de la CTA y el MTA. Se expresan así profundas transformaciones en la relación estado-sindicatos-clase obrera, manifestada centralmente en el predominio de la estrategia sindical neoparticipacionista que llevó adelante la CGT hasta 1999 y que continuó la CGT-Daer hasta 2001: "Es esta estrategia la que permite comprender el sentido de la acción de la CGT en relación al estado y el desacople con los ciclos de conflictividad obrera." (Piva, 2009). 
Emergen distintos sujetos que toman un papel fundamental en el conflicto. Específicamente los movimientos de desocupados se transforman para él en la clave de la conflictividad actual y, junto a otros sectores, desde 1996 comienzan a autonomizar en un grado importante a los conflictos laborales de la dirección y el control que las cúpulas sindicales supieron garantizar en otros momentos.

La perspectiva de Nicolás Iñigo Carrera en primer término destaca que es necesario darle mayor relevancia al aspecto cualitativo en el análisis del proceso por sobre la preponderancia a los registros estadísticos de conflictos laborales que se sostienen en otros enfoques.

Es necesario plantear claramente una escala de luchas para hacer observables los cambios de calidad. Por eso ni el registro ni el análisis pueden limitarse a exponer datos acerca de un aumento o descenso de la cantidad de conflictos relevados, sino que deben asimilar el tipo de conflictos, las acciones que se realizan, los sujetos que las desarrollan.

Desde esta mirada los enfrentamientos sociales que toman la forma de huelga general constituyen un indicador clave para periodizar los procesos de conflictividad social, siendo un instrumento muy superior, en su capacidad analítica, al registro de las huelgas por empresa, sindicato o rama. Mientras la huelga general implica la movilización real o potencial del conjunto de los obreros contra el conjunto de los capitalistas, los conflictos por sector solamente involucran a parcialidades de cada una de las clases.

En la huelga general necesariamente la clase obrera se encuentra con el gobierno del Estado, y por ello la lucha toma un carácter político, sin que esto signifique nada en torno al nivel de conciencia que expresan los obreros en referencia a la situación que viven y a los caminos para superarla.

Para poder comprender esta dimensión se hace necesario no restringir la mirada al nivel de lucha económica ni al de la lucha política: se debe observar también la lucha teórica, la lucha por la dirección que se imprime desde la misma clase obrera al proceso histórico:

"Porque, aunque todo hecho contiene a las tres direcciones de la lucha (económica, política y teórica), lo hace con diferentes densidades de cada una de ellas. (...) La huelga se localiza fundamentalmente en el momento económicoprofesional de las relaciones de fuerzas políticas, así como la huelga general lo hace generalmente en el momento del grupo social aunque, en determinadas situaciones, pueda pasar al momento siguiente, el momento del partido, es decir, el momento en que la lucha se da entre fuerzas sociales, alianzas sociales." (Iñigo Carrera, 2009). 
Para el autor el ciclo de luchas comienza en 1993, con el santiagazo. Pero 1996 es a la vez un nuevo salto cualitativo. Allí "la desocupación abierta y la subocupación crecieron hasta alcanzar el pico más alto (casi $30 \%$ de la PEA) anterior a 2001", y las huelgas generales con movilización, que se empiezan a suceder con mayor frecuencia, van articulando a las diversas formas de lucha y a los distintos sujetos sociales que las estaban protagonizando. La huelga general se convertía así en la instancia fundamental de articulación de las diversas luchas, el momento en que la fragmentación era superada y se generaba la unidad de la clase, al menos en la acción. La perspectiva que mide conflicto no puede observar esto ya que se queda en el nivel del sector particular. Al mirar "hechos" la perspectiva del PIMSA hace observable no solamente el momento de la fragmentación, sino también la instancia de unificación.

A la huelga se suman los cortes de rutas y calles, las ollas populares, los escraches, los ataques a bancos y quemas de neumáticos, etc. Es en el momento de la acción, del enfrentamiento social, cuando la tan publicitada y aparentemente absoluta fragmentación de la clase es, al menos coyunturalmente, superada. Especialmente esto se hace observable en la confluencia en la lucha durante esas jornadas del movimiento obrero ocupado y los movimientos de trabajadores desocupados (aunque también se suman otras fracciones, como los estudiantes).

Por eso para Iñigo Carrera "Obviamente la fragmentación aparece como el rasgo más destacado si lo que se observa son sólo los conflictos parciales por empresa o rama, o las manifestaciones realizadas sólo por desocupados, que, por definición, sólo involucran a parcialidades de la clase obrera." (Iñigo Carrera, 2009).

Coincidimos en términos generales con el enfoque de Iñigo Carrera y ya veremos que en nuestra región su propuesta de tomar las huelgas generales como indicador clave para la periodización parece ser claramente operativa. Sin embargo también retomaremos los cuestionamientos de Piva, ya que muchos de ellos permiten complejizar el abordaje del proceso. Específicamente intentaremos retomar el debate acerca de los cambios en la relación Estado - sindicatos - bases obreras, acerca de la complejidad de la forma sindicato y los cambios que en esta se operan en el período abordado para estudiar cómo esto impacta en el desarrollo de la lucha de clases. A su vez, como lo marcamos en el capítulo 2, intentaremos retomar el mayor hincapié que tanto Piva como Bonnet y otros autores de su grupo, brindan a la noción de hegemonía y a la relación entre modo de acumulación capitalista y las características del proceso de lucha y organización obrera.

El otro debate ya ha sido desarrollado al exponer las perspectivas de las distintas investigaciones sobre el conflicto social en la Argentina reciente. Como 
veíamos en el capítulo 2 la mayoría de los investigadores coinciden en señalar un cambio en el ciclo de luchas a partir de 1996. Se destaca allí la aparición de lo que se denominan "nuevas formas de protesta" (los cortes de rutas y las puebladas) y "nuevos sujetos sociales" (los piqueteros o los movimientos de trabajadores desocupados). Desde esta perspectiva la conflictividad desde 1996 no pasa centralmente por los sectores ocupados ni por las herramientas tradicionales de organización corporativa de los trabajadores. Al contrario, hacen su aparición sectores medios, "vecinos", piqueteros, y hasta un "nuevo sindicalismo", todo en clave de ruptura con el proceso anterior de luchas.

Desde esos enfoques, abordados aquí muy genéricamente, la clase obrera ocupada pierde centralidad en el proceso de conflicto social. Pero además lo pierde la misma noción de clase, ya que no habría instancias de articulación entre las distintas luchas de fracciones de esa clase obrera, ya sea entre distintas fracciones de trabajadores ocupados, o, especialmente, entre trabajadores ocupados y trabajadores desocupados. Estos últimos suelen ser analizados desde una perspectiva que tiende a ocultar su extracción de clase y que los asimila al conjunto de "nuevos sujetos sociales", igualando sus organizaciones al resto de los llamados "nuevos movimientos sociales". Sostenemos que para nosotros lo que manifiestan los movimientos de trabajadores desocupados es una profunda articulación con la historia de luchas de la clase obrera argentina, expresando sus históricas fortalezas y debilidades.

La perspectiva que nosotros tomamos marca que el ciclo de luchas comienza en el motín de Santiago del Estero (ver, entre otros: Cotarelo, 1999: Iñigo Carrera y Cotarelo, 2004) y se entronca con el proceso anterior de luchas obreras y populares. En nuestra mirada los elementos de continuidad son más fuertes que los de ruptura y esto se expresa tanto en las debilidades como en las fortalezas de los procesos de lucha que se desarrollan durante los años noventa y hasta el 2001 (debilidades y fortalezas en términos de sus niveles de conciencia, de la capacidad para articular proyectos alternativos a los impuestos por el régimen de dominación, a la capacidad para construir organizaciones en defensa de sus intereses corporativos, en su capacidad para desarrollar conflictos sociales de amplia visibilidad, en conseguir articular sus reclamos con otros sectores sociales, etc.).

Así el ciclo comienza desde su escalón más bajo, en una forma de lucha que expresa solamente en forma embrionaria algún nivel de conciencia y que se manifiesta fundamentalmente en términos de una política "negativa". El antecedente de este hecho de rebelión es la revuelta del hambre de 1989, que ni siquiera es lucha, porque allí no hay expresión de conciencia en el cómo se desarrolla el conflicto. En la revuelta el odio, expresión de una conciencia en su fase más rudimentaria, es ciego, no hay 
elección de los oponentes, no hay plan ni sistema. En el motín el odio tiene una embrionaria conciencia, hay elección de los objetivos, de los oponentes, y observando el desarrollo del conflicto se puede marcar un recorrido que tiene un plan, no construido a priori, sino en el calor del enfrentamiento social.

Allí esta la importancia de comprender que es en el enfrentamiento cuando se producen los cambios, tanto a nivel de la conciencia como en las formas organizativas y en las personificaciones sociales que se construyen. La mirada del PIMSA recupera la importancia de las luchas no institucionales, de los complejos procesos de formación de conciencia, del desarrollo de formas de lucha y organización que van desde lo menos sistemático a lo más organizado y, especialmente, el concepto de acumulación de experiencias y de fuerza social.

Para analizar el quiebre de 1993 hay un parte aguas entre quienes ven al Santiagazo desde nuestro enfoque y quienes lo observan como un hecho aislado, que culmina en sí mismo y no se encadena claramente ni hacia atrás ni hacia delante. La conceptualización clásica de estos investigadores fue la de "estallido", similar a la que le dieron la gran mayoría de los medios de prensa. Allí obviamente no hay acumulación de experiencias ni construcción de fuerza social.

En cambio para nosotros 1993 es un punto de inflexión, sin el cual no puede comprenderse el desarrollo de formas más organizadas y sistemáticas en 1996. Lo que otros autores observan como el inicio del ciclo para nosotros es el resultado de varios años de acumulación de fuerza entre los sujetos que venían protagonizando la rebelión.

Se fue formando un movimiento popular de protesta que se extendía a lo largo del país ${ }^{117}$. Los enfrentamientos callejeros que iban construyendo este proceso, tendían a verse como hechos aislados, que se subsumían a la lógica asistencialista e institucional de los poderes locales. Así parecía que todo volvía a la "normalidad" y que se sostenía una fragmentación absoluta de esos conflictos.

Por sobre esa apariencia se hacia necesario destacar los elementos de continuidad. Las experiencias de cada lucha se iban retomando de un conflicto a otro, generándose una acumulación de fuerza que se manifestaba en el pasaje de formas más espontáneas a otras más sistemáticas.

Esto podía, a su vez, estar encaminándose hacia la conformación de una fuerza social política que pudiera cuestionar al menos algunos aspectos del orden

\footnotetext{
117 Seguimos aquí a Paula Klachko (2006) "Entendiendo por movimiento no a "una" organización monolítica con fines determinados, sino a fracciones y/o capas sociales del pueblo que se activan contra un enemigo en común, con objetivos similares, con formas organizativas, de lucha e identidades que van acumulándose y retomándose de lucha en lucha y extendiéndose en el territorio, adquiriendo permanencia y continuidad en el tiempo".
} 
social vigente. Para poder hacer observable este proceso es fundamental ubicar el inicio del ciclo en 1993. Es lo que nos permite ver que las luchas sociales de los noventa atraviesan un proceso de acumulación que se inicia desde las formas más elementales de lo espontáneo. En los enfrentamientos sociales se van desarrollando nuevas formas organizativas que se inscriben en este proceso de acumulación, como las formas asamblearias y las autoconvocatorias, que serán claves en un momento del ciclo.

Como veíamos en el capítulo 2 la gran mayoría de los demás grupos de investigadores ven el punto de inflexión y el inicio de un nuevo ciclo en 1996. Destacan allí la aparición de nuevos sujetos, que serán a partir de allí actores centrales del proceso, generando nuevas formas de lucha y conformando nuevas formas organizativas. Esto reemplazaría al sujeto tradicional del conflicto social capitalista (la clase obrera ocupada), a las formas tradicionales de lucha (la huelga y la manifestación, pero específicamente la huelga, que por eso perdería su centralidad como elemento de periodización del conflicto) y a las herramientas organizativas históricamente más importantes para la clase obrera argentina, básicamente los sindicatos.

El último momento clave para la construcción de la periodización de nuestro trabajo es el que hace a intentar medir la importancia histórica de las jornadas de diciembre de 2001. Obviamente la evaluación que se realice de estos hechos tiene directa relación con el análisis del mismo, cómo se lo conceptualiza desde cada grupo de investigadores y qué elementos se destacan como los centrales.

Sin embargo no hemos encontrado aún demasiados análisis ni debates claros sobre este acontecimiento. Podemos destacar aquí el trabajo de Iñigo Carrera y Cotarelo (2003a) "La insurrección espontánea. Argentina diciembre 2001. Descripción, periodización, conceptualización". Allí los autores sostienen la hipótesis de que el 2001 puede haber marcado el punto de inflexión a un ciclo contrarrevolucionario que se iniciara en 1975-1976. La acumulación de fuerza social que se desarrolló en el ciclo comenzado en 1993, generó una fuerza social que se puso en movimiento de forma articulada en los días que van del 13 al 21 de diciembre. Las jornadas comienzan con la huelga general convocada por la CGT para el 13 de diciembre, que funciona como un articulador de las múltiples luchas que se venían desarrollando.

Por su parte desde el CEICS ${ }^{118}$, Sebastián Cominiello (2007) "Tres semanas de cortes que iniciaron el argentinazo", sostiene una mirada parecida en términos de que diciembre del 2001 aparece como un punto de inflexión, aunque destaca que el

\footnotetext{
${ }^{118}$ Centro de Estudios e Investigaciones en Ciencias Sociales, grupo dirigido por Eduardo Sartelli y nucleado originalmente alrededor de la revista Razón y Revolución.
} 
momento de inicio del punto más álgido del enfrentamiento no comenzó con la huelga general del 13 de diciembre sino con las tres semanas de cortes de rutas desarrolladas por el movimiento piquetero durante julio y agosto del 2001.

Desde el grupo de Bonnet y Adrián Piva hay una coincidencia general con esta mirada. Tomando como eje al artículo de Alberto Bonnet "Crisis e insurrección en Argentina 2001", publicado tempranamente en 2002, vemos que tras la tregua luego de las elecciones que dan la victoria a la Alianza, el proceso de luchas se intensifica desde el 2000, en especial a través de los cortes de ruta y los movimientos de desocupados. Destaca el papel de los trabajadores desocupados, el surgimiento de los sectores medios (como respuesta al corralito y al ajuste) y resalta la importancia de esa alianza social que se estableció entre trabajadores y sectores medios. Lo conceptualiza como un cierre del período reaccionario y un posible inicio de un período de ascenso, sobre todo por la fuerza y la experiencia que quedó en el sujeto social colectivo que protagonizó la protesta.

Debates semejantes podemos encontrar en otros autores acerca del sujeto central y de la constitución de una fuerza social que desarrolla este hecho de rebelión, elementos que ya hemos volcado en el capítulo 2. Los que nos interesa aquí es destacar que en la gran mayoría de los investigadores que han abordado el estudio de estos hechos hay una coincidencia en que se trata de un punto de inflexión en la historia del país. Con grandes diferencias en torno a la magnitud del cambio, hay un amplio consenso en que se trata de un "cambio de época", por utilizar la figura propuesta para Latinoamérica por Maristella Svampa (2008).

Para nosotros entonces el ciclo de rebelión popular que se desarrolla entre diciembre de 1993 y diciembre de 2001/junio de 2002 tiene lugar en el marco de un período contrarrevolucionario que comienza hacia mediados de 1975 , se materializa en la dictadura a partir de 1976 y continúa durante los gobiernos de Alfonsín, Menem y De la Rúa. La insurrección espontánea de diciembre de 2001 es un punto de inflexión en el proceso, marcando el cierre de este ciclo tal como lo conocíamos y abriendo un nuevo período, cuyas características aún hoy son difíciles de evaluar con precisión.

Los enfrentamientos sociales que se desarrollan en la semana del 13 al 20 de diciembre de 2001 constituyen el momento más alto del ciclo. Allí están contenidas y se expresan todos los años de acumulación de fuerza social y de experiencias. Todos los sujetos participan, todas las fracciones sociales que se activaron durante esos años se ponen en marcha, todas las formas organizativas se manifiestan y todas las formas de lucha se ponen en acción y se articulan entre sí, para poner en carpeta un hecho cualitativamente superador de todas ellas. Un hecho que se produce a escala 
nacional, atravesando todas las estructuras económicas sociales concretas de la Argentina.

\subsection{La rebelión en el NE del Chubut: 1990 - 1993}

Ya en los años ochenta se plantean problemas para el modelo de industrialización asistida que se había desplegado en el noreste de la provincia en las décadas del sesenta y setenta. A partir de 1987 se interrumpe la promoción a nuevos emprendimientos y ese año se produce un importante conflicto por el cierre de la fábrica Gebco, que es tomada por sus trabajadores. La lucha termina en una derrota ya que los empresarios se llevan las máquinas y los trabajadores no logran cobrar sus indemnizaciones.

A ese marco en lo referente a las industrias se sumaba la problemática del Estado provincial. Desde 1988 Chubut recibe un menor porcentaje de coparticipación y ve congelados sus recursos. Además YPF $^{119}$ deja de adelantar dinero a cuenta de futuras regalías, un método por el cual las provincias petroleras solían cerrar su déficit en el pasado. Esto lleva al atraso en el pago de los sueldos de estatales, situación que se hace crítica hacia el final de 1989. Se generan importantes protestas en varias provincias, con mayor profundidad en el caso de Chubut, Santa Cruz y Jujuy. En las tres se conforman multisectoriales y renuncian sus gobernadores. Para las provincias patagónicas estos sucesos son expresión de la crisis del capitalismo de estado en enclaves y de las disputas que se desarrollaban en torno a cual sería la continuidad del proceso (Luque, Martínez y otros, 2000).

En Chubut dichas protestas no se articularon con la continuidad del ciclo. Por eso nosotros lo enmarcamos como parte del proceso anterior, como la última batalla que dan algunos sectores de trabajadores (en especial estatales) y de la pequeña burguesía por mantener la mejor situación que el modelo de "polos de desarrollo" les garantizaba.

Desde enero de 1990 se profundizan las diferencias internas en el peronismo, con críticas entre sus diversos sectores. Por el atraso salarial se comienza con paros desde ATE $^{120}$ y algunos gremios municipales como el SEyOM ${ }^{121}$ de Puerto Madryn, anunciando que la medida se mantendría hasta que el gobierno pague todo lo adeudado. El hospital zonal de Trelew declara su adhesión al paro por tiempo indeterminado de ATE.

\footnotetext{
${ }^{119}$ Yacimientos Petrolíferos Fiscales.

${ }^{120}$ Asociación Trabajadores del Estado

121 Sindicato de Empleados y Obreros Municipales
} 
En Casa de Gobierno se reúnen los representantes de los gremios estatales (ATE, ATECH, Jubilados del Estado, Luz y Fuerza, SOYEAP y ATSA ${ }^{122}$ ) en un marco de movilización e incidentes. El gobierno promete pagar los sueldos de enero con el aumento retroactivo a diciembre, pero exige el levantamiento de las medidas de fuerza.

El 8 de enero se movilizan en Buenos Aires miles de trabajadores contra la privatización de ENTEL, mientras el SMATA lanzaba un plan de lucha contra la suspensión de cinco mil trabajadores. Así se manifiesta parte de la invisibilizada resistencia de la clase obrera a la ofensiva neoliberal. En Chubut finalmente se levanta la huelga, en el marco de fuertes presiones del gobierno y del intento de algunos dirigentes sindicales de frenar el proceso de movilización.

El mes de marzo se inicia con gran conflicto. La CGT regional ratifica la convocatoria a una huelga regional para el día 2 exigiendo un "cambio de rumbo a la política económica" y los diarios de Trelew advierten sobre la supuesta presencia de "agitadores sociales profesionales", "activistas de ultraizquierda" que vendrían a desatar saqueos y desbordes ${ }^{123}$. Estas personas serían provenientes de Rosario y Córdoba. Sin embargo no parece necesaria ninguna agitación exterior: en Puerto Madryn los gremios se reúnen y convocan una movilización a Rawson por la suspensión y despido de los obreros de la pesquera Estrella de Mar y el marco general de caída en el nivel de vida y precarización del empleo. Los empleados del CENPAT se movilizan continuamente y se registran constantes conflictos fabriles en Trelew, el más reciente en la fábrica Windsor.

El paro de la CGT cuenta con la adhesión de numerosos sectores sindicales, políticos y universitarios (SETIA ${ }^{124}$, Camioneros, Asociación profesionales del Hospital, ATSA, Partido de los Trabajadores, ATE, ATECH, Apinta ${ }^{125}$, FOETRA ${ }^{126}$, Gastronómicos, Judiciales, Luz y Fuerza, Municipales, SOYEAP, Federación Universitaria Patagónica, Juventud Universitaria Peronista, etc).

La protesta tuvo una multitudinaria manifestación (alrededor de tres mil) en la plaza central de Trelew y varios incidentes. En especial el titular de la CGT, Miguel Gutiérrez, fue abucheado, no pudiendo hacer uso de la palabra. Esto desató una pelea entre los sectores más combativos y los que respaldaban a la conducción de la CGT, quienes ya habían sufrido una derrota al intentar llevar al acto al intendente Pitiot, del

\footnotetext{
122 Atech es la Asociación de Trabajadores de la Educación del Chubut, SOYEAP el Sindicato de Obreros y Empleados de la Administración Pública y ATSA la Asociación de Trabajadores de la Salud.

${ }_{23}$ Diario Jornada, 1/3/1990, reflejando supuestas fuentes de inteligencia, pág. 11.

124 Sindicato de Empleados Textiles e Industrias Afines.

125 Asociación del Personal del INTA.

${ }^{126}$ Federación de Obreros y Empleados Telefónicos de la República Argentina.
} 
PJ, como una de las figuras centrales, quién debió retirarse rápidamente ante el rechazo a su persona.

En la movilización hubo roturas de vidrios de supermercados, hoteles de lujo y algunos destrozos en la fábrica Dos Muñecos. Sus propietarios denunciaron a miembros del $\mathrm{MAS}^{127}$ y al titular de la $\mathrm{AOT}^{128}$. Por su parte los sindicalistas repudiaron los incidentes y los atribuyeron a "niños de 10 a 13 años"129. Al finalizar el acto en Trelew la cúpula de la CGT se reunió con el gobernador Perl, planteando un frente común, ya que para ellos el eje de la pelea debía ser la defensa de los derechos de la provincia ante la nación.

El 21 de marzo se produce una nueva movilización a Rawson de los empleados estatales, en el mismo día en que a nivel nacional se produce una importante movilización contra el plan económico de Menem convocada por la CGT Azopardo. Ante unas cuarenta mil personas, Ubaldini no descartó el llamado a una huelga general. Este fue un reclamo central del acto realizado en Rawson, donde se acusó a las cúpulas de la CGT San Martín de traidoras. Fueron oradores los dirigentes de ATE, ATECH, Sitravich ${ }^{130}$, Soyeap y un representante de la Federación Universitaria Patagónica. Los docentes anunciaron tras la movilización que acordaron un aumento de salarios para el sector, hecho que provocó el levantamiento de la huelga docente.

El 6 de abril, y en lo que se constituyó como una muestra de la fuerza hegemónica que había desarrollado el programa del capital financiero, alrededor de 150 mil personas se movilizaron a Plaza de Mayo para apoyar la política de privatizaciones y reforma del Estado. La debilidad de la clase obrera a nivel nacional se demostró en que uno de los principales convocantes fue la CGT oficialista, junto a las 62 organizaciones peronistas, varias cámaras empresarias, el peronismo y la UCeDé ${ }^{131}$, entre otros.

En mayo se profundizó el conflicto entre los estatales. Para el 17 finalizó el paro de 72 horas de ATE, con una concentración de unos mil empleados públicos frente a la casa de gobierno. En esos días la crisis santacruceña llevó a la suspensión del gobernador Del Val, asumiendo su vice, Ramón Granero, en lo que aparece como un anticipo del proceso que se daría en Chubut: se inicia una nueva fase para la Patagonia.

\footnotetext{
${ }^{127}$ Movimiento al Socialismo.

${ }^{128}$ Asociación Obrera Textil.

${ }^{129}$ Diario Jornada, 3/3/1990, pág. 6.

${ }^{130}$ Sindicato de Trabajadores Viales del Chubut.

131 Unión de Centro Democrático.
} 
En junio se conformó en Chubut la CGT "regional noreste", alineada con la CGT menemista o CGT "San Martín", agrupando a sindicatos de Trelew y Puerto Madryn. Se expresa el apoyo al gobierno nacional y se elige secretario general al dirigente de la AOT, justamente un sindicato que agrupaba a parte de los trabajadores más castigados por el plan económico.

En Rawson se movilizan más de dos mil quinientos empleados estatales reaclamando mejores salarios. Se producen algunos incidentes menores, que son repudiados por el gobierno y los sindicatos. El 12 de junio el gobierno endurece su posición, exige solidaridad a los trabajadores estatales con los demás trabajadores que viven la crisis y niega la posibilidad de un aumento. La CGT se sigue negando a tomar medidas de lucha y en cambio asisten a una entrevista personal con miembros del gobierno nacional en Buenos Aires para solicitar la promoción para el parque industrial.

EI 21 de junio se realiza otro paro docente en Chubut por mejoras salariales. EI plan de lucha continúa con paros el 25 y 26. El gobierno lanza una ofensiva mediática de fuerte denuncia a los dirigentes sindicales (sobre sus patrimonios personales y supuestos aprietes a empleados para obligarlos a realizar los paros) y de propaganda de los sueldos de los empleados estatales.

El 12 de Julio, y ante el no pago de los sueldos, declaran el paro indeterminado ATE, ATECH y Judiciales. Ese mismo día el gobierno anuncia que comenzará con el pago de lo adeudado. El 15 de Julio la UCR emite un duro comunicado contra el gobierno titulado de manera muy significativa "Les queda una semana menos", en clara alusión a la fuerte crisis interna, económica e institucional que atravesaba la gestión provincial ${ }^{132}$. También la Federación Empresaria del Chubut (FECH) destaca su preocupación por la situación de la provincia. Aquí ya se muestra el quiebre dentro del propio gobierno ya que se encontraban presentes en la reunión importantes figuras del PJ y hasta el vice gobernador Fernando Cosentino. La necesidad de un reemplazo en la cúpula del gobierno ya parece ser una decisión tomada por un sector de la clase dominante de la provincia.

El 25 de Julio dos importantes referentes del PJ (el senador nacional Mac Karthy y el intendente de Puerto Madryn Osvaldo Sala) critican públicamente a Perl, solicitándole que pida licencia en su cargo. Pocos días después Mario Das Neves renunciaba a su función como Secretario General de la Gobernación, con el apoyo de Mac Karthy. Así se terminaba de aislar a Perl en su posición de seguir al frente del gobierno.

$\overline{{ }^{132} \text { Ver Diario Jornada, 15/6/1990, pág. } 3 .}$ 
Las CGT regionales de las principales ciudades de Chubut salen a apoyar a Perl, denunciando que se intenta no dejarlo gobernar. Declaran el apoyo al reclamo docente, pero afirman que es necesario volver al dictado de clases la semana siguiente y, si bien se oponen formalmente al programa de "despidos masivos", sí apoyan la reestructuración del Estado. El 20 de agosto la CGT de Trelew y Puerto Madryn le reclaman al ministro de Economía de la Nación, Erman González, la reactivación de la economía y la restitución de la promoción industrial.

Ese día Sitravich y ATE movilizan contra el programa de gobierno, repudiando la reunión del foro ministerial (reunión de los distintos ministros de economía de las provincias, que se realizaba ese día en Rawson) donde se discutía cómo implementar el ajuste en cada jurisdicción. Para el 22 aún se mantiene la medida que se extiende desde el regreso del receso invernal.

A fin de agosto los docentes de Chubut llamaron a movilizarse a Rawson y a mantener la huelga, rechazando la intimación del Ministerio de Trabajo y la resolución de su organización nacional, CTERA, que anunció el levantamiento de todas las medidas de acción directa. Esto se produjo el domingo 26 en una masiva asamblea que culminó con una movilización por las calles de Trelew. El gobierno emite una intimación de presentación al lugar de trabajo, y de no hacerlo se procedería a cesantear a todos los docentes "en rebeldía".

Durante septiembre y octubre se producen grandes movilizaciones reclamando el pago de salarios atrasados y contra los despidos en el Estado. El proceso es dirigido por los sindicatos estatales y sólo los textiles nucleados en la agrupación "Celeste y Blanca" y en otros grupos de izquierda se suman a las marchas. En cambio la CGT local enfrentó el reclamo de los estatales, apoyando los planes de ajuste de Menem. La crisis lleva lentamente a la renuncia del gobernador, y a su relevo por parte del vicegobernador, quién es apoyado por el gobierno nacional.

El 4 de septiembre se produce una manifestación de trabajadores estatales que culmina con varios incidentes. El clima político se calienta cada vez más y ya las manifestaciones van adquiriendo elementos de mayor confrontación, con roturas de vidrios, choques con la policía, etc.

Para el 12 se anuncia la retención de servicios de los docentes por no haber cobrado sus salarios. ATE convoca a movilizar a Rawson contra el proyecto de disponibilidad de empleados públicos, por el cual se los podría suspender por 180 días dada la crisis financiera. Partidos políticos como el MAS y el $\mathrm{PO}^{133}$ se suman al reclamo. Durante toda la semana hay conflictos y el 18 se queman cubiertas frente a la

${ }^{133}$ Partido Obrero. 
Casa de Gobierno. Tres sindicalistas de ATE inician una huelga de hambre en el interior de la gobernación y los manifestantes arrojan varios elementos contra los vidrios y puertas.

La situación terminó de estallar el 19 con muchos incidentes, un incendio en el interior de la gobernación (del que nunca quedó claro su origen) y más de cuarenta detenidos. Esto se produjo por la madrugada, mientras se mantenía la protesta con quema de cubiertas, en una situación de gran tensión social. El gobierno acusó a activistas de organizaciones políticas y los sindicalistas de ATE y Sitravich (varios de ellos detenidos) aseguraron que el incendio fue provocado para generar la posibilidad de la represión y con el fin de quemar documentación comprometedora en casos de corrupción.

Estos días son los conocidos a nivel nacional y local como los del "Chubutazo". Es un momento de gran movilización popular, de agudización de la confrontación entre distintos sectores y de fuertes luchas, que tiene como trasfondo un profundo cambio en la estructura económica social que impactaría negativamente en la clase trabajadora y avanzaría en el proceso de concentración de la riqueza y la propiedad.

Es un momento clave en nuestra historia que hasta el día de hoy no ha sido estudiado profundamente, relacionando este proceso con otros muy semejantes que se dieron en varias provincias del país. En general los pocos estudios sobre el tema realizados, pretendieron ver lo "original" del proceso, cuando lo que debe estudiarse es cuáles son sus características comunes con los otros procesos de movilización popular dados en el país al momento en que se desarrollaban estos cambios en las estructuras económico sociales de las provincias, en consonancia con el proceso que se daba a nivel nacional de imposición de la hegemonía del capital financiero.

Por eso no se puede estudiar al chubutazo sin relacionarlo con los hechos de Santa Cruz, Jujuy, Tierra del Fuego, San Juan y las revueltas de 1989; en definitiva no se lo puede estudiar desvinculado de la totalidad histórica que se expresa en cada conflicto, en el cual se muestran las estructuras económicas y sociales puestas en movimiento. Es allí cuando podríamos encontrar las características "originales" o "excepcionales" de cada hecho, ya que las mismas sólo pueden serlo, justamente, como excepciones de lo "normal", de lo que se expresa en términos de regularidad.

Los gremios estatales realizan un plenario con la presencia de ATE, Sitravich y ATECH, decidiendo mantener el proceso de lucha hasta que se pague lo adeudado. La crisis social se sigue expresando al interior del gobierno y ahora el vice gobernador solicita públicamente la renuncia de Perl. La UCR propone juicio político, acompañando el pedido que ya había hecho la Comisión de Padres de Puerto Madryn 
y Comodoro Rivadavia. Entre los voceros de esas comisiones hay varios dirigentes radicales que ocuparían puestos en el futuro gobierno de la UCR.

EI 2 de octubre los jubilados toman el Instituto de Seguridad Social reclamando el pago en término. Los empleados del Siprosalud ocupan la sede central del organismo y se mantiene el paro en todos los hospitales por la deuda del $50 \%$ del sueldo de agosto. Mientras esto sucedía, Perl viajaba por enésima vez a Buenos Aires a gestionar fondos para cubrir los salarios. Se produce una movilización de personal de hospitales rurales a Rawson, se corta la calle del Hospital Zonal en Trelew y los jubilados ocupan el Banco Provincia en Comodoro Rivadavia. Los sindicatos estatales anuncian que el lunes 8 iniciarán un nuevo plan de lucha.

Ese día en Rawson unas mil quinientas personas se movilizan convocados por los "padres de alumnos". Asisten también los sindicatos estatales y municipales. La movilización evita dirigirse a la Casa de Gobierno. El Instituto de Seguridad Social sigue ocupado, y hasta los panaderos de Rawson se pliegan a la protesta popular, negándose a hacer cualquiera de sus productos.

Al día siguiente se convoca una movilización desde la reunión multisectorial que se había producido la noche anterior. Estaban presentes sindicatos estatales, comisiones de padres, cámaras de industria y comercio, jubilados, estudiantes y otras organizaciones sociales. El acto tuvo más de tres mil personas y, en un contexto de profunda crisis política, también participaron el intendente de Rawson (del PJ, quién cerró el acto como orador) y los concejales de esa ciudad. Hubo un cierre total de los comercios y se contó con el apoyo de muchas organizaciones sociales y comunitarias de la provincia. Los periódicos se encargaron de remarcar la aceptación de los movilizados al intendente de Rawson y la supuesta repulsa a la adhesión del Movimiento al Socialismo. Desde Buenos Aires, Perl anunciaba que en unos días llegaría la ayuda prometida.

El 10 nuevamente la movilización se acentúa, con más de dos mil personas en Trelew. Se corta la ruta nacional N3 durante algun as horas (es el primer hecho de estas características que tenemos relevado en la región), después de haber ocupado las instalaciones de ENTEL. La manifestación, al igual que el día anterior, tiene fuertes discursos y consignas contra el proyecto del gobierno nacional y se exige la asistencia financiera a Chubut. Los rumores sobre la renuncia de Perl se hacen cada vez más fuertes.

Tanto el corte de ruta, como la toma de ENTEL (usada para hablar por teléfono a los medios nacionales) son acciones realizadas con el objetivo de que "nos 
escuchen en Buenos Aires" ${ }^{\text {34 }}$. Al finalizar la protesta se reúne la asamblea multisectorial con trabajadores estatales, la Cámara de Industria y Comercio, partidos de izquierda y miembros de la Municipalidad de Trelew. Se decide allí una movilización a Casa de Gobierno.

El 11 de octubre es un día histórico para nuestra región. En 1972 miles se levantaban en la ciudad de Trelew contra una dictadura militar para reclamar la liberación de 16 militantes sociales detenidos por su actuación política.

Dieciocho años después más de ocho mil personas se movilizaron a Rawson, reclamando soluciones concretas a sus problemas salariales. El gobernador Perl salió a la calle a intentar hablar frente a la multitud, buscando correr el eje hacia el enfrentamiento provincia-nación. Esta práctica es típica en las provincias y se puede expresar como una forma menor del nacionalismo, un mecanismo para velar las contradicciones de clase y buscar que la movilización social apoye los reclamos de la burguesía con intereses en la región.

Perl es abucheado y se le impide dar su discurso. Finalmente recibe a los integrantes de las multisectoriales, reconociendo que no sabía cuando podría pagar los salarios. En Trelew se realiza sobre las 20.30 una asamblea en el Teatro Español para decidir la continuidad de la lucha.

En estos días Chubut vive la extraña sensación de ser tapa de todos los diarios. "Chubut es un volcán" dice el diario "Sur", "La patagonia rebelde" titula Página 12, “Crece la protesta en Chubut” propone Clarín. También La Rioja y Ushuaia presentan cuadros semejantes en cuanto a la crisis y las huelgas, aunque sin este caudal de movilización popular.

El 15 de octubre Perl pide una reunión extraordinaria a Menem, quién no se la concede. Se afirma que Menem le exige la renuncia para enviar una partida financiera de emergencia. El candidato a gobernador por el PJ, Osvaldo Sala, saca una solicitada en los diarios de la región exigiendo la renuncia de Perl.

La Multisectorial de Trelew expresa que su reclamo no es solamente salarial, ya que se plantea también un repudio a la política económica nacional. Es la visión que sostuvo durante años la imagen del chubutazo como una primera reacción contra el proyecto neoliberal. Pese a que es cierto que había consignas, banderas y discursos que hacían referencia a la oposición al neoliberalismo, más allá de lo que se diga, lo clave para entender los procesos es analizar lo que realmente se hace, y es allí donde nosotros vemos que el grueso de la movilización no logra sobrepasar el reclamo corporativo económico.

\footnotetext{
${ }^{134}$ Ver Diario Jornada, 11/10/1990, pág. 1-14-15.
} 
Una nueva movilización masiva, de unas diez mil personas, se concentra en Rawson el 17. Intentan hablar frente a la manifestación miembros de todos los bloques de diputados (excepto del $\mathrm{PACH}^{135}$, quienes afirman que la movilización no es el ámbito para lograr las soluciones), en medio de reclamos y expresiones de repudio. Se proponen medidas como cortes de ruta, corte del gasoducto o frenar los embarques de petróleo. El "chubutazo" ya está instalado en todos lados. Además de los diputados son oradores miembros de las multisectoriales y dirigentes sindicales, reafirmando que la lucha debía superar el marco de reclamar el pago de los sueldos atrasados, para llegar a romper con el proyecto económico nacional.

En esos días se precipita el intento de resolución de la crisis desde la institucionalidad burguesa, con el juicio político a Perl que llevaría a su suspensión y el relevo por parte del vice, Cosentino. A fin de mes el juicio político impulsado por las Comisiones de Padres de Puerto Madryn y Comodoro Rivadavia avanza hacia la suspensión de Perl, quién presenta antes su renuncia al cargo. A nivel nacional el gobierno anuncia que esto frena toda posibilidad de intervención y apoya a Cosentino con declaraciones de funcionarios de primera línea.

Al otro extremo del país una movilización de una multisectorial concentraba unas diez mil personas en la capital de la provincia y obligaban al gobernador a presentar su renuncia. Esto se producía en Jujuy, con una multisectorial integrada, al igual que las de Chubut, por padres de alumnos, comerciantes, profesionales y sindicatos estatales. Como en Santa Cruz, aunque con mayor virulencia, se produjeron hasta choques armados, con disparos de balas de plomo y varios heridos.

¿Casualidades o procesos supuestamente originales y particulares que se dan, sin embargo, casi exactamente en los mismos días en dos o tres provincias del país? Obviamente ni lo uno ni lo otro, sino un proceso de lucha que es expresión y resultado del momento de recomposición de la dominación capitalista a nivel nacional.

Es por eso que el proceso de luchas también se expresa a nivel nacional con características muy semejantes en distintos puntos del país. Creemos que una de las principales características de estos hechos, fue la "provincialización" de los mismos. Eran conflictos de carácter nacional que la burguesía tuvo la capacidad de lograr se expresarán como problemas particulares. Como aparentemente se trataban de problemas de mala administración de tal o cual funcionario, la solución pasaba por reemplazarlo y realizar una administración ordenada que, obviamente, involucraba el ajuste y la reformulación del Estado en función de la nueva fase del capitalismo.

${ }^{135}$ Partido de Acción Chubutense. 
El 8 de noviembre Cosentino exige una tregua de noventa días y anuncia por decreto que se descontarán los días no trabajados. La Multisectorial pospone una marcha ya votada para el día 15, con el objetivo de que se realice en conjunto con la movilización nacional de la CGT Azopardo. ATECH convoca a una nueva huelga para oponerse al decreto que descontaba los días de huelga. Por su parte ATE levanta el campamento y olla popular que mantenían en Rawson, ya que se habían cobrado los sueldos de septiembre, y anuncian que presentarían un recurso de amparo contra el decreto.

El viernes 9 se realiza la "marcha blanca", convocada por la comisión de padres, que reclama la solución del conflicto educativo y el regreso a clases. Se entrega un petitorio al intendente de Trelew, quién es aplaudido por haber salido a hablar frente a la manifestación. La burguesía había logrado estabilizar la situación y generaba nuevas expectativas con el recambio del personal gobernante en la provincia.

A nivel nacional el gobierno logra una victoria, al romper a la CGT Azopardo justamente cuando ésta decidía salir a confrontar. Varios sindicatos renuncian a la central, siendo los más importantes la $\operatorname{UOM}^{136}$ (que tenía la Secretaría Adjunta) y el de Obras Sanitarias. Mientras tanto en Trelew se conformaba la mesa de esta CGT con Sitravich, ATECH, ATE, Apinta, Saon ${ }^{137}$, Judiciales y ADEFA ${ }^{138}$. Son cinco gremios estatales y solo dos privados de escasa magnitud, contra veinte gremios que integran la CGT "oficial", la cual repudia la manifestación convocada por su "carácter político". EI MAS también se pronuncia por no ir a la nueva marcha, ya que para ellos los sindicatos estatales han quebrado la unidad de la movilización popular al romper con el funcionamiento de las multisectoriales y las asambleas ${ }^{139}$.

En ese marco la movilización a Rawson es muy escasa si tenemos en cuenta el marco de protestas que se había vivido en la provincia y que no había soluciones de fondo a la problemática social y económica. Son menos de quinientos, con escasas adhesiones sociales. A nivel nacional tampoco se logra una movilización significativa ni un marco de adhesión importante al acto contra la política económica.

Comentamos en extenso este proceso de protestas estatales por su importancia. Lo hicimos sin involucrar la narración del resto de los conflictos generados por otros grupos de trabajadores porque los mismos no se articularon y para no quebrar la lógica descriptiva. Para esta fecha se cierra el conflicto, dejando como principal saldo, en términos corporativos, el logro de conseguir frenar el intento

\footnotetext{
${ }^{136}$ Unión Obrera Metalúrgica.

137 Sindicato Argentino de Obreros Navales.

138 Asociación de Empleados de Farmacia.

139 Diario Jornada, 15/11/1990, pág. 6.
} 
de despidos masivos en el Estado, manteniendo esos puestos de trabajo a cambio de aceptar el congelamiento salarial y la quita de derechos laborales. Esta suerte de "acuerdo tácito" entre gobiernos provinciales y trabajadores estatales atravesó gran parte de la década del noventa.

Al reestablecerse el pago salarial y llegarse a este acuerdo tácito, la movilización rápidamente fue perdiendo su potencialidad. Esto expresa, para nosotros, una demostración de que el contenido central de la misma no superaba el marco económico corporativo de los estatales, y por ello no expresaba una oposición al proyecto neoliberal. De hecho la continuidad de medidas propias de este proyecto no tuvieron una resistencia significativa por parte de los estatales, como lo veremos más adelante. Esto no implica que aquellos sectores que planteaban una oposición, al menos discursiva, al proyecto neoliberal, no fueran significativos para entender el conflicto. Sí implica que su programa no era la dirección del mismo.

Retomaremos ahora sí el resto de la conflictividad social. Mientras los estatales realizaban este proceso los trabajadores de sectores privados la pasaban aún peor. La agonía en la que ya había entrado el parque industrial a fines de los ochenta, se aceleró al permitirse la libre importación de productos. Como síntoma de las transformaciones, en marzo de 1990 se produjo una protesta de una organización de trabajadores desocupados que se presentan como tales. La "Comisión de Obreros Desocupados" realizó un acto en la plaza central. Poco tiempo después es duramente atacada por militantes del PJ cuando se movilizan en Trelew contra un aumento de la tarifa de luz. Es un intento (el primero y no el último) de las autoridades políticas de frenar este proceso de organización de la clase obrera de la región. La Comisión era un pequeño grupo, vinculado especialmente a miembros del Partido Obrero y a algunos trabajadores de la construcción y textiles que habían perdido sus empleos.

Los sindicatos textiles denuncian las continúas suspensiones y el cierre de algunas fábricas. Se realizan medidas de fuerza por planta, pero ningún paro general. Las empresas textiles reclaman un cambio del plan económico y convocan al diálogo a los obreros para defender el parque industrial. La suspensión de los beneficios y la quita de los aranceles a los productos importados hacen, según ellos, imposible la subsistencia de las empresas textiles en la región. La AOT y el Setia apoyan el reclamo de los empresarios contra la libre importación y por el restablecimiento de los subsidios.

El dirigente del SETIA pide que se confíe en la negociación y asegura que no es posible la toma de las fábricas o la gestión de los obreros ante los cierres. En febrero se firma un acuerdo entre el gobierno, entidades empresarias y sindicatos sosteniendo que no habría despidos ni medidas de fuerza hasta abril de 1990. La 
Subsecretaría de Trabajo anuncia que gestionará una solución concertada a los problemas. Informa que los conflictos laborales se incrementaron en un $200 \%$ con respecto a enero de 1989, especialmente en la construcción y en la rama textil. Se suman a los problemas las firmas Huamac, Indulana, Oceanic y Punilla en el parque industrial textil e Inducon en el rubro construcción.

El mismo día en que se firma el acuerdo los obreros de Modecraft toman la planta en contra de la suspensión de todo el personal, y logran frenar el cierre de esa empresa. Se marca aquí el desacople entre la estrategia de la dirigencia sindical (basada en la subordinación a los intereses de los empresarios con intereses en la región) y la de algunos sectores obreros (que buscaban una resistencia más decidida, donde los obreros encabezaran una alianza con sectores de la pequeña burguesía).

En este conflicto de Modecraft los trabajadores debaten la posibilidad de tomar la fábrica y ponerla a producir sin la patronal (ver Pérez Álvarez, 2009c). Estos grupos son los que apoyan en su momento la lucha de los estatales y desarrollan una mayor resistencia contra el proceso de caída del parque industrial textil. Ocupando la fábrica logran frenar lo que iba en el camino del cierre de la empresa. Se marca aquí una fractura entre la estrategia de la dirigencia sindical y la que buscan otros sectores obreros para enfrentar el proceso.

Los sindicatos textiles llaman en estos meses a algunas huelgas nacionales reclamando mejores salarios, logrando importantes porcentajes de adhesión. Pero no se producían medidas colectivas contra el proceso de caída general que se registraba en el parque industrial, siendo cada grupo de obreros el que daba su "batalla" individual por la permanencia de sus puestos de trabajo. Es significativo que los sindicatos casi no enfrentaban a los despidos pero seguían luchando por mejores salarios. Expresaban así un nivel de conciencia aún más limitado que el de verse solamente como vendedores de fuerza de trabajo. Los trabajadores no llegan siquiera a expresar su conciencia como asalariados, ya que esta llevaría a que reclamasen que les compraran su fuerza de trabajo. Se manifiesta únicamente la competencia entre trabajadores, y por lo tanto su incapacidad para articular sus intereses como grupo social.

Los años de 1991 y 1992 son atravesados por la derrota y el miedo. Mientras los cambios estructurales en la economía se seguían produciendo, los trabajadores perdían posiciones y no lograban generar respuestas contundentes. La clase aparece aislada y dividida.

El embajador de EEUU, Terence Todman, visita la región y se entrevista con las autoridades y empresarios del Chubut. Mientras se recibía con honores a Todman, 
el gobierno anuncia la disponibilidad de la administración pública por 180 días para analizar sus funciones y cesantear al personal "excedente".

Los gremios textiles informan que la grave situación de las fábricas de Trelew era también una realidad en Puerto Madryn, con un parque de menor envergadura pero que también sufría las transformaciones económicas.

El 12 de febrero unos cien docentes se movilizan a Rawson al Consejo Provincial de Educación. Ese día el gobierno afirma que no revocará las medidas. La ATECH amenaza con que no se iniciarán las clases hasta que se modifique la resolución.

A nivel nacional los ferroviarios profundizan las medidas de lucha, con un paro en cinco de las seis líneas de riel. El gobierno rompe el diálogo y amenaza con la intervención militar en el conflicto. Claramente el paro surge en oposición al proceso privatizador y no cuenta con un apoyo importante de la dirección sindical.

La CGT de Chubut presenta un "acuerdo" con las autoridades del CPE ${ }^{140}$ para apoyar la reestructuración del sistema educativo; o sea para apoyar el despido de trabajadores y llevar a la derrota la lucha de los estatales. Se reemplaza al miembro de ATECH por un integrante de UTEDyC como representante de los trabajadores de la educación en el CPE. El $1^{\circ}$ de Marzo se aprueba en Ia Legislatura de Chubut el decreto de disponibilidad hasta el 31 de diciembre de 1991. Hubo algunos incidentes con los docentes movilizados.

El congreso de la ATECH decidió no ir a la huelga, y el 11 de marzo se iniciaron las clases con relativa normalidad. Según sus dirigentes esto se debió al miedo que se había logrado imponer en los docentes. Tanto el MAS como el PO criticaron, por separado, la decisión de la $\mathrm{ATECH}$, acusando a su dirigencia de traicionar a los trabajadores ${ }^{141}$. Por su parte la $A T E C H$ denunció que estos grupos no fueron al Congreso ${ }^{142}$.

La AOT anuncia que esta preparando un corte de ruta en consonancia con el paro nacional textil en reclamo de aumento salarial. Nada se dice de los despidos y suspensiones. Esta medida luego no se realiza y la huelga textil del 18 y 19 sólo se expresa en nuestra región (seguramente la más castigada en ese momento por la política nacional) con paros de treinta minutos cada dos horas. El otro sindicato textil, SETIA, ni siquiera adhiere a esta tibia medida.

En lo económico abril es un mes de fiesta para el capital financiero, logrando realizar la venta definitiva de Aerolíneas y con su gobierno enviando el primer proyecto

\footnotetext{
${ }^{140}$ Consejo Provincial de Educación.

${ }^{141}$ Comunicados del PO y el MAS, ver Diario Jornada, 12/3/1991, pág.24.

142 Diario Jornada, 10/3/1991, declaraciones de Alberto Zeid, dirigente de Atech, pág. 2.
} 
de privatización de YPF al Congreso Nacional. Chubut era ahora un alumno ejemplar, firmando el primer contrato de concesión de un área petrolera con empresas privadas. Días después se anunciaba la privatización del yacimiento Huemules (oro, plata, zinc y plomo).

Junto a esto se puso en marcha el ataque a los delegados sindicales combativos. Esta práctica tuvo el acompañamiento de casi toda la dirigencia sindical. El caso más claro fue el juicio contra los delegados de Modecraft, cuya derrota implicaba el freno a los intentos de resistir en forma más decidida la destrucción del parque. Se realizó una verdadera "limpieza" de los trabajadores combativos o de alguna corriente de izquierda. Es aquí cuando para nosotros se expresa la derrota de la intención de un sector de los trabajadores que buscaba defender sus antiguas conquistas encabezando una alianza con otros sectores sociales. Se derrotaba así la estrategia de resistir la caída del parque con la lucha en las calles, buscando una alianza junto a la pequeña burguesía de la región que fuera dirigida por los obreros. A esto lo denominamos una estrategia de resistencia obrera.

Retomamos aquí el análisis de Beba y Beatriz Balvé "La distinción del momento en que los sindicatos expresan al conjunto social más vasto al momento en que sólo expresan los intereses de su sector, refiere a las condiciones en que se manifiesta y hace efectiva la estrategia proletaria, ya sea que predomine el reformismo obrero, que toma a toda la clase como corporación o el reformismo burgués que representa sólo a esa fracción homogénea de intereses de tipo profesional." (Balvé y Balvé, 1991: 8).

¿Por qué en este caso elegimos hablar de resistencia y no de reformismo? Lo que observamos es que estas dos estrategias se presentan ante el hecho de una ofensiva, de un ataque del capital financiero que destruye el antiguo territorio social de los obreros de la región. Lo que se intenta desde los trabajadores no es reformar aspectos del proyecto sino resistir el ataque, mantener lo que se había conquistado en los años previos. El concepto "resistencia" es una forma de expresar que ambas estrategias son parte de la situación de defensiva de la clase y de su incapacidad para poder articular una fuerza social que fuera capaz de postular una alternativa que rivalice con el proyecto del capital financiero. Creemos que esta situación cambia en los siguientes años y ya lo marcaremos.

Contra esta estrategia se plantea la dirigencia gremial, que logra conducir a la mayoría de la clase hacia el intento de contener los aspectos más regresivos del proyecto neoliberal a partir de una alianza en la cual se subordinaban a la burguesía con intereses en la región. El problema es que esa burguesía cada vez se subordinaba más a la hegemonía del capital financiero. Se impone la estrategia centrada en formar 
una alianza dirigida por la burguesía con intereses en la región. Es lo que llamamos una estrategia de resistencia burguesa, donde los obreros se subordinan a la lucha interburguesa (negando la posibilidad de que la clase pudiera formular una alternativa propia).

Esta estrategia se impone allí como hegemónica pero ya era la dirección del movimiento desde antes. Es en el marco de este proyecto que tanto la CGT como la patronal de la industria apoyan el ajuste en el Estado provincial, esperando que a cambio de ello se mantenga la promoción industrial. No es otro el sentido del enfrentamiento de la CGT al "chubutazo".

Lo que sigue de 1991 es de avance patronal. Hay despidos y rebajas salariales (una de las más importantes es, justamente, en Modecraft). Según los dirigentes de la AOT intentaron generar protestas pero los trabajadores se negaron por el temor a no ser reincorporados "cuando pase la crisis"143: aún no había conciencia del carácter estructural de los cambios que se estaban viviendo. El temor expresaba la situación de aislamiento de la clase, reforzada por la dificultad para comprender la transformación que estaban sufriendo.

Como un simbolismo de la decadencia, mientras se cerraban fábricas, se privatizaba YPF, agonizaba Sierra Grande, caía la construcción,... surgían los casinos. En julio de 1991 se inauguraba el casino de Puerto Madryn, a fines de 1992 otro en Playa Unión y en mayo de 1993 otro más, ahora en Trelew.

Mientras tanto continuaba la crisis en Santa Cruz, con el no pago de los sueldos estatales, y en Sierra Grande se agravaba la situación de desinversión y atraso en los sueldos de HIPASAM. Y a nivel nacional se profundizaba el proceso de división de los cuadros sindicales al retirarse la CTERA de la CGT Azopardo, en lo que se constituyó como un paso importante hacía la conformación de la CTA.

Se inicia con mucha fuerza la campaña política para las elecciones de gobernadores, intendentes y diputados, cuya primera vuelta sería el 8 de septiembre. Como suele suceder esto quita fuerza al proceso de lucha, que ya venía en caída desde el cierre del "chubutazo". El 16 de junio se lanza la candidatura a gobernador de Maestro por la UCR. EI PJ por su parte va dividido en muchos sub lemas (se había aprobado ese año la ley de lemas para evitar la ruptura del PJ tras la crisis de 1990).

ATE presentó su reclamo de aumento salarial como proyecto de ley ante la Legislatura del Chubut, la cual promete tratarlo. Esto es destacado como un hecho positivo por la dirección de ATE. En el marco de este proceso electoral la disputa por

\footnotetext{
${ }^{143}$ Ver Diario Jornada, 2/10/1990, declaraciones de Roberto Jímenez y Ernesto Opazo, dirigentes de la AOT, pág. 8.
} 
los salarios se desplaza desde las calles y los métodos de lucha directos, hacia el terreno de la institucionalidad burguesa.

El 25 de junio la intersindical de Caleta Olivia corta la ruta 3 por algunas horas. Es el mismo marco que se vivía en nuestra provincia, agravado en esa localidad por el desguace de YPF. Caleta, al igual que Sierra Grande, Trelew y tantos otros pueblos y ciudades, sufría la reconversión del capitalismo. Se empezaba a extender el corte de ruta como una forma de hacer visible el conflicto.

La conducción de la AOT afirma que la situación de los textiles no es tan grave como algunos lo plantean. Sin embargo durante las últimas semanas el conflicto fabril aparecía siempre en las primeras planas de los diarios de la región. Parecían ya definitivos los cierres de Huamac, Lanaco, Ifet, Gebco y Azubel, lo que implicaba la pérdida de unos 500 puestos de trabajo, sumados a los cientos de suspendidos y a la baja en la producción y los salarios en casi todas las fábricas.

La desocupación empezaba a sentirse como un problema cada vez mayor. Ya no era simple reinsertarse en otra actividad y esto golpeaba especialmente a las ramas de la construcción, la textil y la pesquera.

El 4 de Agosto los trabajadores de HIPASAM acompañados por mujeres, niños y por la comunidad de la ciudad, cortan la ruta 3 por algunas horas. Durante los siguientes días se produce una huelga general de todos los comercios y se mantiene cortada la ruta por plazos de tres horas hasta el martes 6 , cuando deciden pasar a cortar por tiempo indeterminado. El corte se levanta tras la firma de un compromiso del gobierno nacional de reabrir la planta en treinta días.

El 30 de agosto Menem visita Trelew, recibiendo la bienvenida de casi todos los sindicatos y cámaras empresarias de la zona. Sólo los sindicatos estatales critican su presencia. Por su parte el intendente de Sierra Grande encabeza una marcha de doscientos mineros hasta Trelew.

En las elecciones provinciales Maestro se constituye en primera fuerza con el $32 \%$, contra el $26 \%$ de Sala (primero entre los cinco sublemas del PJ). Ambos deben ir a la segunda vuelta como Di Benedetto (UCR, 30,23\%) y Das Neves (PJ, 20,80\%) en Trelew; Salazar (Pach, 31,64\%) y Aristarain (PJ, 29,75\%) en Puerto Madryn y Ventura (Unión Vecinal, 23,49\%), Papaiani (UCR, 23,12\%) y Bastida (PJ, 21\%) en Rawson.

Son significativos dos datos: hay una gran cantidad de votos en blanco, en especial para diputados (11\%) y tanto Salazar (Puerto Madryn) como Ventura (Rawson) habían sido intendentes de facto de esas ciudades durante la última dictadura militar. También en Trelew un ex intendente de la dictadura, Boiero, logra el $13 \%$ de los votos. 
El 8 de octubre se hace presente en la región el ministro de economía Cavallo para hacer campaña a favor del candidato justicialista. Promete mantener la promoción industrial y medidas de incentivo para la actividad lanera, los chacareros y la actividad pesquera. Un grupo de estudiantes que se manifiestan en contra del ministro, son abucheados y expulsados del teatro al grito de "que se vayan a Cuba" por parte de los concurrentes ${ }^{144}$.

En la segunda vuelta gana el candidato radical, Carlos Maestro, con el $51 \%$ de los votos. Este hecho constituye en apariencia un duro revés para Menem ya que es la primera provincia que el PJ pierde tras su asunción. Para los analistas políticos es una reacción a la problemática de Sierra Grande, Somisa e YPF. Sin embargo el problema no era mayor: ya antes de asumir se muestra la continuidad del proyecto y el acuerdo entre los dos grandes partidos acerca del programa neoliberal, cuando en noviembre la UCR vota la prorroga de la ley de emergencia económica.

La hegemonía del proyecto político-económico del capital financiero también se hace visible en dos pronunciamientos sindicales. Al finalizar el año los delegados locales de la UOM informan que el plenario de esa organización ha ratificado su coincidencia con la política económica nacional. Se apoyaba así la política que llevaba al cierre de casi todas las pequeñas y medianas metalúrgicas locales. En una visión semejante la UOCRA remarca que si bien 1991 ha sido un año muy malo para la construcción, al mismo tiempo se habían implantado las bases para un nuevo sistema político, económico y social del país, por lo cual el balance era positivo.

En enero de 1992 la UOM lanza un paro nacional por aumento salarial. Como en el caso de los textiles poco y nada se dice de los despidos que sufrían los metalúrgicos en todo el país. Los sindicatos actuaban como si el antiguo marco social siguiera en curso: casi no enfrentaban los despidos pero seguían reclamando por salarios.

Son continuos los conflictos en la pesca en Rawson y Puerto Madryn: quiebras de empresas, despido de trabajadores, formación de cooperativas "truchas", etc. Los contratados adhieren en muy bajos porcentajes a las medidas, citando en forma constante "el temor a ser despedidos" "145. Como ya lo marcamos la constante apelación al temor expresaba la situación de debilidad y aislamiento de la clase.

La AOT realiza una reunión con Maestro, solicitando la conformación de una mesa de concertación para solucionar la crisis textil. Los diarios de la zona realizan análisis que plantean un terrible panorama para el parque industrial. Se empieza a

\footnotetext{
${ }^{144}$ Ver Diario Jornada, 9/10/1991, pág. 2.

145 Ver, por ejemplo y entre muchos otros casos, Diario Jornada, 15/3/1992, declaraciones de operarios ante una huelga en la pesquera Protepat, pág. 16.
} 
hacer común la expresión: "vamos a terminar como Sierra Grande"146. Los empresarios afirman que desde la quita de los beneficios, y con la mano de obra cara y el alto costo de los fletes, ya no tiene sentido mantener la inversión en la zona.

En mayo de 1992 por primera vez la AOT declaraba que los nuevos desocupados "difícilmente puedan conseguir ahora otro empleo"147. La desocupación se empezaba a sentir como algo que había llegado para quedarse. Se comenzaba a expresar una mayor conciencia de que se estaba ante una nueva situación estructural.

En Rawson se producen varias movilizaciones entre junio y julio por la crítica situación de la actividad pesquera. El Soipra ${ }^{148}$ exige al gobierno provincial que se ponga al frente de la pelea por mantener los puestos de trabajo. Se denuncia el despido de trabajadores y la política del STIA $^{149}$ (el otro sindicato que agrupa trabajadores del sector) de acordar con las empresas no realizar protestas a cambio de que tomen como empleados a aquellos que estén afiliados a su sindicato. En Puerto Madryn agrupaciones que integran el Somu ${ }^{150}$ se manifiestan por la ciudad contra la desregulación de la actividad, que permitiría la contratación de marineros extranjeros y llevaría, según ellos, a que se produzcan muchos despidos en el sector.

La movilización y el clima de tensión continuaron en el puerto de Madryn los siguientes días. Se producen algunos choques con la policía y la prefectura cuando los trabajadores del Supa ${ }^{151}$ impiden que se produzca la descarga de productos de los barcos. Hay balazos de goma, gases lacrimógenos y hasta balas de plomo, aunque no se producen heridos de gravedad. Finalmente al octavo día de "vigilia" del Supa se llega a un acuerdo de sesenta días de tregua, durante los cuales se frenaría todo cambio a la antigua situación del sector.

Se habían producido fuertes enfrentamientos entre trabajadores, que tuvieron una nueva expresión cuando a los diez días el dirigente del Supa es asesinado de dos balazos. El gobierno afirmó que el motivo había sido una pelea personal, anterior al conflicto. Ya veremos que no sería el último asesinato en Puerto Madryn contra alguna persona con poder en las actividades portuarias o de la pesca.

Comienzan a aparecer protestas más decididas. En agosto hay una movilización de delegados de AOT contra nuevos despidos. Se reclama al gobierno que evite los despidos producidos por las reestructuraciones anunciadas en Foderami,

\footnotetext{
${ }^{146}$ Ver, también entre muchos otros casos, Diario Jornada, 31/3/1992, declaraciones de obreros de Fibrasur, pág. 3. Diario Jornada, 9/9/1992, documento emitido tras plenario de la AOT, pág. 3. Es interesante pensar en el caso Sierra Grande como una muestra lo que podía provocar el proyecto del capital financiero, destruyendo un territorio social construido a lo largo de generaciones. Este ejemplo operaba sobre las poblaciones de las ciudades vecinas como una forma de terror social.

${ }_{147}$ Diario Jornada, 9/5/1992, declaración de González, secretario general de la AOT, pág. 7.

148 Sindicato de Obreros de la Industria del Pescado de la República Argentina.

149 Sindicato de Trabajadores de la Industria de la Alimentación.

150 Sindicato de Obreros Marítimos Unidos.

151 Sindicato Unidos Portuarios Argentinos.
} 
Supersil, Polysur y Windsor. AOT expresa su disconformidad con los resultados de la reunión y rechaza una nueva mesa de concertación. A los pocos días se realiza una reunión con el gobierno, la CGT y los delegados por fábrica, en la cual se vuelve a prometer una "promoción industrial local".

En estos días todo lo que se habla en la zona es acerca de crisis, cierres de empresas, caída de la producción, despidos y éxodos. Se suceden las reuniones, que hacen hincapié en la supuesta búsqueda de "soluciones concertadas", en especial al tema pesquero y texti ${ }^{152}$. Mientras tanto los trabajadores empiezan a vivir la angustia de la desocupación, del no poder llevar el pan a sus casas. Es significativo ver a futuros dirigentes o integrantes de organizaciones de desocupados formadas a fines de los noventa, reclamando por haber sido despedidos de alguna pesquera o de alguna fábrica textil.

Continuando con las discusiones en relación a la crisis, se convoca a la unidad de empresarios y trabajadores en defensa de la región, "ha llegado la hora de la gran alianza entre los trabajadores y los empresarios ${ }^{\prime \prime 153}$, afirma Soriano, vicepresidente de la UIP ${ }^{154}$, tras una reunión junto a la CGT regional. Mientras tanto se acelera el éxodo de población hacia el norte del país, especialmente desde la ciudad de Trelew.

En septiembre los textiles realizan un corte de ruta durante dos horas con quema de cubiertas. Son despedidos convocados por AOT y Setia para reclamar la promoción industrial. Mientras la CGT nacional se sienta con Menem y acuerda llamar a una "concertación social", en Trelew por primera vez se produce un corte de ruta por parte de los obreros textiles.

Para octubre la CGT regional se pronuncia por la convocatoria de un paro nacional, fundamentado tanto en la situación general de deterioro del país, como por la especial crisis que se sufría en la Patagonia. En estos momentos hay un proceso de confrontación hacia el interior de la CGT nacional, con los sectores liderados por Ubaldini y Barrionuevo intentando recuperar terreno a partir de apoyarse en el planteo de la necesidad de convocar a una huelga general contra la política económica.

En noviembre la CGT convoca la primera huelga general durante el menemismo, para el día 9. Si bien se afirma que el diálogo se mantiene se realizan fuertes críticas a la flexibilización laboral, al ajuste contra los trabajadores, la represión a los jubilados y a la caída de fábricas, negocios e industrias. Se reclama mayor participación sindical en la toma de decisiones políticas y económicas. El sector de Ubaldini y Barrionuevo se adjudica el triunfo de sacar la CGT a la lucha.

\footnotetext{
152 Ver Diario Jornada, 7/8/1992, pág. 7, sobre los textiles; y Diario Jornada, 11/8/1992, pág. 15, sobre la actividad pesquera.

${ }^{153}$ Diario Jornada 31/8/1992, declaraciones de Lorenzo Soriano, pág. 2.

154 Unión Industrial Patagónica.
} 
La CGT regional hace un llamado a los empresarios para que se plieguen al paro, sin lograr respuestas. Casi todos los sindicatos de la zona (Supa, Uocra, Sitravich, UTA, UPCN, Pecifa, Camioneros, Setia, etc) adhieren al paro nacional. EI hecho de mayor peso es un nuevo corte de ruta de la AOT sobre la ruta provincial N25, durante todo el día de huelga, que se transfo rma en el centro de la medida. La huelga tiene impacto en los trabajadores del sector privado, mientras los docentes y estatales adhieren en menor medida. En la zona empezaba una mayor crítica desde abajo, mientras a nivel nacional aparecían medidas más decididas. La estrategia de la resistencia burguesa empieza a tener mayores cuestionamientos.

El 12 de noviembre son unos trescientos estatales, encabezados por ATE, los que se movilizan a la Legislatura, logrando acordar un proceso de diálogo para evaluar aumentos salariales. Los acompañan en la protesta unos treinta trabajadores de la mina de Río Turbio, con quienes luego se dirigen a la Capital Federal para participar del lanzamiento de la CTA.

En estos días se genera un importante conflicto social alrededor de la toma de tierras en la parte norte de Trelew, en terrenos cercanos al Parque Industrial. Desocupados y obreros toman estos terrenos que estaban asignados para planes de viviendas de la AOT. Durante varios días la Municipalidad amenaza con el desalojo violento, pero la resistencia y la voluntad de permanecer en el lugar les termina dando la victoria parcial a los ocupantes. Tras meses de lucha, donde se produce una importante solidaridad de algunos sectores de la comunidad, muchos consiguen terrenos en otro barrio más alejado y otros se quedan en ese lugar que habían elegido para vivir con sus familias.

La CGT convoca a una concentración popular en Trelew para el viernes 18 de diciembre, reclamando una salida a la crisis de la ciudad. Un día antes deciden suspender la medida, fundamentando esta decisión en la falta de adhesión de las cámaras de comercio y las cámaras empresarias. Se habían pronunciado a favor la iglesia católica, el PTP, la Agrupación "7 de julio" de ATE, la ATECH, el Sindicato de Camioneros, Uocra, el SEC, Setia, AOT, Foniva, Smata, Gastronómicos y Barracas. Es sin dudas una muestra de que la mayoría de la dirigencia sindical de la zona no veía posible enfrentar al modelo neoliberal sin la dirección de la burguesía con intereses en la región. No hay confianza en las fuerzas propias.

El año 1993 comienza con la continuidad de los conflictos que habían quedado irresueltos. Los empleados municipales de Rawson (que venían de meses de conflicto) continúan con medidas de protesta contra el atraso en el pago de sus salarios. Comienzan el 4 de enero, con el regreso de la huelga y una concentración frente al municipio; el 5 alrededor de un centenar cortan la ruta que conecta Rawson con Playa 
Unión (el balneario de la ciudad), recibiendo el apoyo de ATE y del Centro de Jubilados. Se realiza una olla popular que se mantiene el día 6, cuando se corta el puente de Rawson. El intendente amenaza con la posibilidad de despidos, pero ante la fuerza de la protesta y las muestras de solidaridad de la comunidad debe volver atrás con la medida.

Sí se anuncian nuevos despidos y suspensiones en el parque industrial y en la construcción. La Uocra denuncia que los despidos se concentran en los obreros con cargas familiares numerosas. Por su parte la agrupación textil "Unidad y lucha"155 repudia públicamente a las empresas por los despidos y suspensiones, y critica a los dirigentes de la AOT por "su inercia y falta de imaginación... están más preocupados por salir de vacaciones que por solucionar los problemas"156. Se afirma que en Trelew ya hay al menos 2000 desocupados y 2500 subocupados, de los cuales unos 500 ya habrían emigrado a otras ciudades.

La empresa Textil Oceanic despide a cinco obreros por medidas de "ajuste" y Foderami, considerada una de las empresas líderes, hace una presentación formal ante la Subsecretaría de Trabajo por la crisis productiva. Anuncian que antes de 1991 y el paquete de medidas de apertura de la economía, tenían doscientos trece operarios, debiendo bajar en la actualidad a sólo ciento sesenta y cuatro ocupados, mientras que de doscientos ocho telares en funcionamiento en ese año, hoy sólo producían con cincuenta, por el gran stock acumulado. Es por eso que seguirían con despidos (solicitaban no pagar indemnizaciones completas por la crisis) y suspensiones rotativas a los diversos turnos de trabajadores.

Los obreros de Polysur vuelven a reclamar el 5 de febrero la solidaridad de la sociedad con su lucha contra el atraso en el pago de sus salarios. Realizan diversas acciones desde el 12 de enero y, en un planteo significativo en relación al rol que cumplía el sindicato en estos conflictos, solicitan que las donaciones se lleven directamente a los trabajadores y no a la AOT.

Son despedidos ochenta y tres trabajadores de la construcción de la empresa Niaco, en Puerto Madryn. Ya habían sido despedidos algunos obreros (especialmente los que tenían más carga familiar), habían suspendido a diecinueve la semana anterior y ahora realizaban esta medida masiva. Ante esto los trabajadores tomaron el obrador y exigieron la intervención del gobierno, ya que la obra es una concesión del Instituto Provincial de la Vivienda.

\footnotetext{
155 Una línea interna del peronismo, dirigida por Oscar Secco, quién había sido dirigente de la AOT y concejal por el PJ.

${ }^{156}$ Diario Jornada 12/1/1993, declaraciones de integrantes de la agrupación, pág. 5.
} 
La Cámara de Industria y Comercio del Chubut, CICECH, lanzó en abril una "campaña de protesta patagónica", consistente en repartir volantes y cintas rojas y verdes, simbolizando el alerta por la crisis, y la esperanza. Afirman que la crisis es muy grande y que se necesitaban cuatro mil puestos de trabajo industriales sólo para Trelew. Esta es la clase de tibias respuestas que lograron articular esos sectores de la pequeña burguesía acomodada ante el cambio de estructura.

Tras meses de aislamiento, en abril se generó un marco de unidad de los estatales. Se convocó una marcha hacia Rawson, repudiando al gobierno, y exigiendo el pago en término de los salarios. La protesta reunió alrededor de 350 empleados que marcharon a la Legislatura, la municipalidad de Rawson y la Casa de Gobierno de la provincia, donde se prendieron fogatas y se arrojaron petardos. Se entregó un proyecto de ley y se realizó una reunión con las autoridades del gobierno, donde se produjeron discusiones e insultos cruzados entre sindicalistas y funcionarios.

En esos días comenzó un conflicto de los trabajadores de Conarpesa, que reclamaban el pago de la deuda que la empresa tenía con sus setecientos empleados, y decidieron ocupar la planta. Tras quince días, y pese a que su sindicato se oponía a la toma, lograron que la empresa pague lo adeudado.

El 14 de mayo hay una nueva movilización por lo que se califica, en forma general, como "la crisis educativa". Es una movilización importante, con alrededor de un millar de estudiantes, docentes y padres. Fue convocada por la Atech y varios centros de estudiantes, y si bien su contenido se expresaba como de crítica al programa del gobierno se permitió hablar al intendente de Trelew. Los judiciales ratificaron la huelga por no haber cobrado el sueldo de abril.

Los obreros de Surjet declararon una huelga en reclamo de los aumentos prometidos por elevación de la productividad. Rápidamente se dictó la conciliación obligatoria. Se anunciaba también que Polysur (ochenta y cinco operarios, que no recibían sueldos completos desde enero) y Oceanic estaban en una grave crisis, teniendo su producción detenida. Polysur reclamaba un préstamo de alrededor de cuatro millones para pagar los sueldos y comprar materias primas. Los obreros apoyaron el reclamo de los patrones, solicitando a la AOT que exija que se les otorgue ese préstamo a la brevedad.

En julio de 1993 los sindicatos textiles conforman una comisión que integra a trabajadores despedidos y suspendidos. Se invita a las cámaras empresarias, intendentes y diputados. La estrategia de los sindicatos sigue siendo apostar a estos espacios de "concertación".

A los pocos días cien obreros son despedidos en varias empresas. En septiembre otra planta anuncia que cierra sus puertas. Varios delegados denuncian el 
papel pasivo de las conducciones sindicales. Ya lo veíamos en 1992, pero ahora aparece con mayor fuerza el rasgo de que algunos trabajadores daban muestras de que buscaban otra estrategia para resistir el proceso, superando de a poco los golpes que habían sufrido.

El 27 de julio se produce una importante protesta de productores rurales, convocados por la FAA, la CRA y Coninagro. En un hecho que denominan "tractorazo", ocupan la Plaza de Mayo reclamando contra la política del gobierno de apertura comercial. La movilización tuvo un importante apoyo popular y de los diversos sectores de la oposición oficial.

También se produjo una importante huelga de chóferes de colectivos de corta y media distancia, que paralizó Buenos Aires. Es un paro de características contundentes, con enfrentamientos y atentados contra aquellos que no adherían, siendo detenidos varios militantes acusados de amenazas. Junto con el tractorazo son hechos nacionales que van configurando una nueva correlación de fuerzas hacia lo que sería el importante cambio que se da con el santiagazo de diciembre de 1993.

El 5 de agosto se reanima el conflicto en Conarpesa. Los trabajadores realizan una asamblea masiva, reclamando el pago de la deuda que la empresa mantenía con sus empleados. A los cuatro días, y tras reuniones con funcionarios sin obtener respuestas, deciden tomar nuevamente las instalaciones de la planta. El conflicto se va a mantener durante varios días con la ocupación de la fábrica, amenazas de desalojo, etc. En la medida se cuestiona a la dirigencia del Stia y sólo se recibe al dirigente del Somu ya que también hay marineros involucrados en el problema.

Finalmente, tras otros quince días de toma de la fábrica, el 27 de agosto los trabajadores de Conarpesa logran que la empresa pague lo adeudado, a través de un acuerdo con el Somu. De todas maneras no queda claro cual será la continuidad de la empresa y, sobre todo, de los trabajadores.

Agosto culmina con incidentes en Santiago del Estero, que son preámbulos del combate que se da durante el motín de diciembre. Tanto en La Banda como en la capital, se producen protestas de estatales, estudiantes y jubilados, se cerca durante horas la Casa de Gobierno, con quema de neumáticos, rotura de vidrios y apedreos contra la policía.

El 3 de septiembre se realiza un paro docente a nivel nacional al que adhieren Atech y la UDA en Chubut. Los diarios coinciden en señalar que es el primer paro con importante repercusión en la provincia desde los hechos del chubutazo. Si bien el gobierno dice que la adhesión fue del $26 \%$ (contra un $70 \%$ calculado por los sindicatos) la importante movilización a Legislatura termina de evidenciar que hay un proceso de recomposición de la posibilidad de encarar luchas en mejores niveles de 
relaciones de fuerza. El PJ provincial se manifiesta en apoyo de la protesta, aún cuando la misma cuestionaba claramente las medidas de ajuste del gasto público que había diseñado el gobierno de Menem.

Octubre se inicia con nuevos despidos en el parque industrial textil, son alrededor de cincuenta. Los trabajadores de Polysur anuncian la posible toma de la fábrica si no hay soluciones a sus problemáticas, mientras el Setia afirma que el éxodo de las industrias es imposible de frenar si no cambia la política nacional.

El mes de noviembre termina con una "batucada de protesta" de la UOM contra el programa de ajuste presentado por ALUAR, que incluye como punto fundamental la rebaja de sueldos a partir de enero. La protesta dura media hora con unos ciento cincuenta participantes, ante los cuales el dirigente gremial niega las versiones de que ya había un acuerdo de la UOM con ALUAR. La empresa argumenta que su propuesta es la única posibilidad de resolución sin que haya despidos, informando que el recorte sería del $25 \%$, afectando a la totalidad de los novecientos treinta trabajadores (seiscientos cincuenta operarios, y personal de supervisión y dirección).

El 2 de diciembre la AOT realiza un plenario de sus delegados para realizar una modificación del estatuto (que restringe la participación de los afiliados) y postergar las elecciones. Supuestamente esto se debe a los inconvenientes financieros, que se expresaban a nivel nacional con la baja de treinta y cinco mil afiliados y unos ocho millones de déficit. Mientras tanto Polysur seguía tomada, sin que los trabajadores lograran soluciones a sus reclamos.

El 3 se realiza una movilización de unos quinientos trabajadores de Aluar dirigida por la UOM, que logra una importante repercusión, siendo recibidos por el gobernador de la provincia y el intendente de la ciudad. Maestro y el dirigente de la UOM local plantearon una posición que corría el eje de la disputa contra la patronal de Aluar hacia el conflicto Buenos Aires - Patagonia. En sus declaraciones centraron los reclamos en la necesidad de generar políticas diferenciales para la región que achiquen las diferencias de costos. Era una línea muy cercana a lo que planteaba la misma Aluar, que además reclama la firma del Pacto Fiscal. La empresa afirma que había perdido ocho millones en el último ejercicio finalizado en junio.

El 10 de diciembre toman más fuerza los reclamos en La Rioja y Santiago del Estero. Esta movilización es el preámbulo directo del histórico motín popular del 16 de diciembre en Santiago del Estero, con el incendio de la Casa de Gobierno, el saqueo de casas oficiales, la quema de vehículos estatales, al menos cuatro muertos y centenares de heridos. Es calificado por toda la prensa como un "estallido social contra el ajuste". Desde el Vaticano, donde había sido nombrado conde de la nobleza vaticana, Menem anuncia la intervención de la provincia. La policía tiene que retirarse 
del combate contra la masa popular y el gobernador deja la ciudad. Mientras esto sucedía en Santiago, La Rioja continuaba en un clima de conflicto similar.

El 17 se extiende y mantiene la lucha en Santiago, con acciones también en la ciudad de La Banda. Se rechaza a Araoz como interventor, reclamo que debe ser aceptado por el gobierno nacional. Las viviendas y comercios, especialmente de funcionarios y representantes del poder político, siguen siendo saqueadas e incendiadas por los manifestantes. Se realizan barricadas en el centro de las ciudades contra el avance de la gendarmería.

El mismo día se realiza otra marcha en La Rioja pese a la derogación de la ley de ajuste. Ante el temor de otro Santiago, pero de mayor costo político por ser la provincia del presidente, el gobierno nacional lanza un programa especial con tres mil puestos de "trabajo temporal" para esa provincia.

Pese a que pocos días después Menem instó a continuar con el ajuste, estos hechos marcan un importante punto de cambio en las luchas de la clase obrera. Tras años de avance casi sin freno ni oposición de los proyectos del capital financiero, estos empiezan a encontrar una creciente resistencia por parte de los trabajadores. Resistencia que si bien no logra frenar totalmente el avance del proceso, sí comienza a poner frenos, al menos a la velocidad y la profundidad de estos cambios estructurales que se venían realizando sobre el conjunto de la sociedad argentina.

\subsection{La rebelión en el NE del Chubut: $1994-1996$}

Marcamos la periodización alrededor de los hitos del ciclo de rebelión que atraviesa la década del noventa, desde el santiagazo de 1993 hasta la insurrección espontánea de diciembre del 2001. Los hechos de diciembre de 1993 marcan un incremento de la lucha contra el proyecto del capital financiero, cuyo avance global no se detiene, pero sí empieza a encontrar mayores dificultades.

Al comenzar 1994 la UOM rechaza nuevamente el descuento salarial anunciado por Aluar. El 12 de enero los trabajadores de Aluar informan que en la asamblea realizada resolvieron rechazar el descuento del $25 \%$ de sus salarios. La empresa les da plazo hasta el sábado 15 para que revean la postura, ya que sino debería realizar despidos para equilibrar sus cuentas.

Aluar anuncia el despido de veinticuatro trabajadores y la UOM local convoca una asamblea, donde se reafirma la decisión dejando en claro que ellos asumen que el conflicto se trata de un caso testigo a nivel nacional para intentar bajar los sueldos de todos los trabajadores. 
Para el 19 los despedidos ascienden a cuarenta y uno, y más de quinientos trabajadores se movilizan desde Aluar hasta la plaza central de Puerto Madryn. Acompañan la marcha las familias de los obreros. También asiste el secretario de organización de la UOM nacional. La medida tuvo cobertura y repercusión nacional. En ella hay fuertes críticas de los trabajadores a la dirección nacional de la CGT, especialmente al líder de la UOM, Lorenzo Miguel, quién pocos días antes había salido en televisión jugando al golf con Carlos Menem.

Son significativas las declaraciones de los dirigentes sindicales, quienes ya dan por hecho el despido definitivo de los trabajadores, planteando que su línea es defender la integridad de los salarios pese al costo de los despidos. El dirigente nacional afirma que el plan de convertibilidad es exitoso y que "tenemos un país del primer mundo pero con salarios y trabajadores del tercer mundo"157 y dejando claro que eran preferibles esos despidos a la rebaja salarial. También es significativo que uno de los despedidos era un ex delegado de la UOM, muy crítico a Lorenzo Miguel, quién afirma que "el gremio no hizo absolutamente nada", y que "Aluar no esta en crisis, esta diseñada para elaborar 140000 toneladas anuales y actualmente esta sacando 180000". Para él "es inaudita la decisión de una movilización ya que hay gente despedida"158.

Al otro día se mantiene el quite de colaboración y la declaración de asamblea permanente. Hay expresiones de solidaridad de muchos sectores, desde diversas corrientes internas de la UCR, el PJ, gremios y otras organizaciones sociales, en especial de Puerto Madryn.

Recién el 21 vuelven a realizarse medidas de algún peso y que afectan a la producción de la empresa, con paros sorpresivos por turno y sector. La UOM vuelve a afirmar su posición de rechazar el recorte salarial, aunque sin exigir la reincorporación de los cuarenta y un compañeros de trabajo. El 28 se producen los anunciados nuevos despidos de Aluar: son otros treinta y dos los que se quedan sin trabajo. Para la UOM es el final del programa de ajuste, y vuelven a reivindicar que lograron frenar el plan piloto de rebaja de sueldos que se exportaría desde Aluar a todo el país si ellos lo hubieran aceptado.

Otra vez se muestra la capacidad para defender el salario y la debilidad ante los despidos. La investigación nos ha mostrado que la mayoría de los despedidos integraban la lista opositora a la conducción sindical. Ya veremos este conflicto en mayor detalle en el apartado 4.3.

\footnotetext{
157 Diario Jornada, 20/1/1994. Declaraciones de Gregorio Minguito, Secretario de Organización de la UOM, pág. 17.

158 Diario Jornada, 20/1/1994. Declaraciones de Oscar Castro, ex dirigente metalúrgico y despedido en este conflicto, pág. 17.
} 
Las autoridades municipales de Puerto Madryn informan que el desempleo en la ciudad, provocado por el cierre de pesqueras, textiles, y ahora también por los despidos de Aluar, llegaba al menos al $20 \%$ de la población económicamente activa.

La problemática de la desocupación se hace más visible. En marzo se presenta la primera agrupación de desocupados en Madryn. La comisión de cuatro miembros esta integrada por ex obreros de los sectores pesqueros, textil, metalúrgico y portuario, un real muestrario de la transformación económica de Madryn.

Unos meses después se realiza en Trelew una asamblea de desocupados en un teatro. Se expresa allí que la mayoría de los asistentes sólo es conciente del problema de la desocupación al nivel individual, como un problema a solucionar mediante la capacitación o la generación de "buenas ideas", y no como un conflicto social y colectivo.

Marzo se desarrolla bajo el signo de las campañas electorales para convencionales constituyentes nacionales y provinciales que se realizarían el 10 de abril en todo el país. EI PJ denuncia que a pesar del apoyo del gobierno nacional que recibe la administración provincial, esta tiene un enorme déficit y no se sabe donde han ido los 500 millones pagados por las regalías petroleras. El radicalismo, por su parte, hace campaña en base a las obras que se vienen haciendo desde su gobierno, y lanza como primer candidato al gobernador Carlos Maestro.

En Chubut es importante la victoria de la UCR que hace recuperar fuerza al gobierno de Maestro. De hecho esto posiciona a Maestro como el máximo dirigente político de la provincia. A nivel país Menem logra una significativa victoria, con más del $35 \%$ de los votos, y crece el Frente Grande que logra ganar en Capital Federal.

El 10 de mayo se produce un nuevo conflicto en una pesquera de Rawson, ahora es en Nautilus. Un centenar de obreros se movilizan al Concejo Deliberante y al Municipio, para reclamar soluciones ante la falta de pago de los salarios.

Se acrecienta el conflicto por el progresivo cierre del parque industrial en Tierra del Fuego. Para el 25 de mayo ya son ocho los días de paro total de los metalúrgicos de la isla, y ese día se realiza una marcha de más de dos mil personas en Ushuaia. El conflicto se profundiza, con marchas también en Río Grande. Se pliegan a la protesta trabajadores de ATE, sanidad y gastronómicos.

El 23 de junio ciento setenta obreros de Arcoplus (nombre de la antigua Modecraft tras un cambio de propietarios) inician un paro por tiempo indeterminado en reclamo de aumento salarial y mejores condiciones de trabajo. Denuncian que no tienen aumentos desde 1990, y que luego de 1991 sufrieron un fuerte descuento salarial. No es menor que tras tantos años los obreros de esta planta logren volver a la lucha. 
Menem y otros funcionarios del gobierno desarrollan una dura campaña contra la Marcha Federal que se había programado para el 6 de julio. Desde Chubut parten unas trescientas personas, representando a los sindicatos estatales, estudiantes, el Frepaso, el Mopoch, agrupaciones textiles y de la construcción, entre otros.

El Frente Estatal convoca a un paro en la provincia. Convocada por la CTA, el MTA, la FUA, la CCC y otras organizaciones, la marcha tiene la afluencia de columnas de casi todo el país, siendo la más numerosa la que viene desde el Noroeste. La movilización ocupa la Plaza de Mayo, con alrededor de cincuenta mil manifestantes de las organizaciones sindicales, estudiantiles, partidos de izquierda y de la UCR, el Frepaso y el Modin, entre otros grupos. En la manifestación se convoca a un paro nacional para el 2 de agosto y el orador por la "columna patagonia" reclama políticas de promoción para la región y marca las problemáticas específicas del sector industrial, petrolero, de Sierra Grande y del sector pesquero.

Nuevamente la AOT demuestra su estrategia de apoyo a las patronales cuando anuncia una movilización para exigir la rebaja de las tarifas eléctricas para las empresas. Esta presión termina de definir un largo conflicto entre la Cooperativa Eléctrica de Trelew y las empresas del parque, que finalmente consiguen el descuento que pretendían. Obviamente hay una fuerte presión psicológica sobre los trabajadores, planteando desde las empresas que al subir los costos ellos serían despedidos. La movilización se suspende, mientras los operarios de Arcoplus seguían su largo conflicto con la patronal.

En Trelew se conforma una Comisión Multisectorial como síntesis del proceso de la marcha federal y para convocar al paro del 2 de agosto. Lo integran los gremios de la CTA y el MTA, más centros estudiantiles, de jubilados y comisiones de desocupados. Asisten también pesqueros de Puerto Madryn, quienes denuncian que la política pesquera del gobierno y el nuevo acuerdo con la $\mathrm{CEE}^{159}$, implicó la pérdida global de ocho mil puestos de trabajo en Chubut, cuatro mil en Madryn, tres mil en Comodoro y mil en Rawson.

Se adhiere al paro nacional del 2 de agosto, con una concentración en la ruta №3 y un acto en la plaza central de Trelew. Además de la CTA y el MTA adhieren partidos políticos, grupos de desocupados, la FUP y centros de estudiantes. Se movilizan alrededor de cuatrocientas personas, aunque la adhesión a la huelga no alcanza niveles muy altos. El transporte debe suspenderse pese a la intención de hacerlo funcionar con el personal jerárquico, quienes denuncian atentados a los vehículos. A nivel nacional la huelga tiene bastante peso con una adhesión que según

\footnotetext{
${ }^{159}$ Comunidad Económica Europea.
} 
las organizaciones convocantes llega al $70 \%$. También se producen atentados a medios de transporte y se detiene a varios dirigentes acusados de estos hechos.

En septiembre ya se comienza a ingresar en el ambiente pre electoral. Maestro lanza su campaña para la reelección, afianzándose en la buena relación con el gobierno de Menem. Octubre marca el recalentamiento de la interna peronista. Muchos de los cuadros sindicales orientan su actividad a la disputa interna del PJ, y esto será una razón clave para la importante caída de las acciones de protesta. También dentro de la UCR se producen disputas, en especial por la postura de Maestro de no apoyar al candidato presidencial de la UCR, lo cual era un apoyo implícito a Menem. De hecho circulan boletas compuestas de Menem presidente, Maestro gobernador, uno por el PJ, el otro por la UCR. En ese marco los pocos hechos de conflicto se canalizan casi totalmente hacia la vía institucional.

Los primeros días de noviembre la UOCRA realiza un pedido de aumento salarial en el marco de una reunión con la Cámara de la Construcción, en la cual estos afirman que sólo podrían dar el aumento si reciben ayuda oficial. La AOT vuelve a denunciar nuevos despidos, ahora en Windsor, y posibles suspensiones de personal. Y ATE destaca que ya ha juntado alrededor de dos mil firmas en apoyo a su proyecto de aumento. No hay acciones en la calle.

El 28 los trabajadores del Procopa (Programa Coparticipativo de trabajo, uno de los planes de empleo temporal que impulsa el gobierno provincial) reclaman ante el intendente de Trelew el pago de asignaciones familiares, sin conseguir ninguna respuesta. Este pago estaba contemplado en el proyecto de ley aprobado hacia pocos días, pero fue vetado por Maestro. En Buenos Aires nuevamente hay incidentes en otra marcha de jubilados, donde la bronca aumentó la ya difícil situación, al no haber cobrado el aguinaldo antes de Navidad.

El 30 de diciembre los desocupados del Procopa (que ahora pasaría a llamarse Preno, según el anuncio del gobierno ratificando la continuidad del plan), cerraron el año cortando la calle frente al municipio de Trelew, realizando un simbólico brindis de fin de año con agua y pan duro. Manifiestan allí que sus protestas continuarían durante el verano para lograr que se reintegre el pago de asignaciones familiares a los planes.

Ya en 1995 se hace más común que los desocupados realicen acciones de protesta en Trelew y Puerto Madryn, como marchas y cortes de calles. Desde grupos que se conforman de manera coyuntural logran algunas mejoras en los subsidios que recibían por parte del Estado provincial.

Los miembros del antiguo Procopa instalan el 11 de enero un campamento en la plaza independencia de Trelew, reclamando la puesta en práctica del anunciado nuevo plan y el pago del salario familiar. La realidad es que pese a las promesas aún 
no fueron reubicados. Afirman que no pueden cobrar solo $\$ 200$ como pretende el gobernador para alimentar a sus familias, que cuentan con un promedio de tres o cuatro niños.

El 17 de enero lograron un acuerdo con el gobierno que establecía que el primero de febrero comenzaría el nuevo plan y que se daría un adicional de $\$ 50$ para los que tuvieran hasta dos hijos y de $\$ 100$ para los de tres y más. Es una pequeña victoria para esta incipiente y transitoria forma de organización de un pequeño sector de los desocupados.

Luego de que en los últimos meses la dirigencia de Setia (especialmente) y también de AOT destacaban la recuperación del parque y la solución de los conflictos, la AOT debe salir en febrero a denunciar una ola de suspensiones y despidos que ya involucra a trescientos obreros en muy pocos días. Según ellos los empresarios especulan, despidiendo y suspendiendo para presionar hacia la obtención de créditos del gobierno. A los problemas en Windsor y Sitma se suman suspensiones en Mulcosur, Casa Roma y Propulsora Patagónica.

El 10 de abril a nivel nacional se produce una ola de paros y movilizaciones en varias provincias del país, aunque no hay convocatorias a medidas nacionales. Sin embargo en Chaco, Tierra del Fuego, Jujuy, La Rioja, Córdoba, Río Negro, Santiago del Estero y Entre Ríos, se desarrollan movilizaciones, paros, toma de fábricas, ollas populares, etc, de trabajadores estatales y privados por diversas demandas, todas atravesadas por los cambios estructurales que generaba el dominio del capital financiero.

El 12 de abril en Ushuaia se desarrolla un enfrentamiento entre los trabajadores y las fuerzas represivas. Estas atacan disparando balas de plomo que hieren a más de treinta manifestantes y se cobran la primer víctima en una manifestación desde la vuelta a los regímenes constitucionales en 1983. Se trata de un trabajador metalúrgico de 30 años, Víctor Choque, cuyo nombre se hará bandera de lucha en los años siguientes.

Mientras tanto, en Trelew se produce un hecho significativo en torno a la conciencia de los trabajadores y las prácticas de la clase dominante para quebrar su organización. La patronal de Windsor acepta reincorporar a diecinueve obreros que había despedido tras una huelga, pero a cambio exige la renuncia de dos delegados de la AOT. Los obreros apoyan esta solicitud y la AOT acepta las renuncias de los delegados, aunque afirmando que este hecho constituía una gran derrota para los trabajadores. Días después los textiles se movilizan por los servicios de su obra social y aparecen cuestionamientos hacia la dirigencia: un panfleto reivindica a los delegados, planteando que los dirigentes no habían hecho nada para defenderlos y 
que les habían planteado a los trabajadores que la única alternativa era votar a favor de lo que pedía la empresa.

La CTA, el MTA y la UOM convocan al paro nacional contra la política económica del gobierno y en repudio a la represión en Tierra del Fuego. En Trelew y Puerto Madryn adhieren varios gremios, haciendo especial hincapié en la denuncia por el asesinato de Víctor Choque. Así lo hace la UOM, ATE, Atech, Judiciales, Camioneros y Sitravich.

La huelga no tiene una gran repercusión al no haber adherido varios de los sindicatos más poderosos enrolados en la CGT. Sí fue importante en Tierra del Fuego y en toda el área de transportes. En Chubut los gremios afirman que la adhesión fue del $65 \%$, siendo importante en el sector de transportes (hubo denuncias de los propietarios de las empresas sobre clavos miguelitos y roturas de parabrisas). Según Maestro ni siquiera los sindicalistas faltaron al trabajo en el área estatal.

Aparecen elementos novedosos para la zona, como el intento de saqueo de un supermercado por parte de una marcha de obreros desocupados de la UOCRA. EI hecho es frenado por la dirigencia gremial, aunque hay enfrentamientos y pedradas a los comercios.

El 14 de mayo se realizan las elecciones para intendentes, gobernadores y presidente de la nación. En Chubut logra la victoria Maestro, logrando su reelección al igual que Menem a nivel nacional. Es significativo el corte de boletas, que muestra la alianza de Menem y Maestro, ya que si bien la UCR logra una amplia victoria para gobernador es derrotada también ampliamente para presidente en el distrito Chubut.

Se desarrollan fuertes protestas en Córdoba, con la presencia de trabajadores estatales que reclaman contra la ley de emergencia económica que pretendía imponer Angeloz. Hay denuncias de corrupción y un clima político que lleva a que la protesta se masifique y tome escenarios de mayor confrontación, como la quema de la casa radical, todo un signo del poder político cordobés. También hay saqueos y enfrentamientos con las fuerzas represivas.

El 26 de julio se producen choques entre la policía y los manifestantes en San Juan. El hecho es nombrado como un "estallido social" por la prensa. Hay retraso salarial y se intenta avanzar con el ajuste. Quedan decenas de heridos, importantes destrozos de edificios públicos, incendio de vehículos policiales, además de saqueos a varios comercios.

La patronal de la industria en Chubut, acentúa el proceso flexibilizador buscando una mayor explotación de la fuerza de trabajo ocupada. Se impulsa el reemplazo del personal más antiguo por nuevos empleados que ingresan en condiciones precarias a través de contratos temporales. Las breves coyunturas 
favorables que se generan para algunas fábricas permiten la incorporación de nuevo personal que entra bajo modalidades precarizadas (sistema americano de seis por dos, turnos rotativos, mayor cantidad de telares a cargo de cada operario, vacaciones más cortas y en cualquier fecha, etc). En Foderami se expresa el proceso de quita de beneficios y exacerbación de la explotación, con el hecho de la prohibición a los obreros de ingresar al comedor, obligándolos a comer junto a la máquina en la cual trabajan, al mejor estilo "Tiempos Modernos" del gran Charles Chaplin.

La CGT convoca a un paro nacional para el 6 de septiembre. Llaman a una "masiva concentración pacífica" como respuesta al nuevo récord de desocupación. Esta es la postura de la conducción de la CGT representada por el menemismo y fundamentada especialmente por Gerardo Martínez, de la UOCRA, quién plantea que en realidad se trata de un cese de actividades para garantizar la concentración, ya que las huelgas no solucionan nada y son necesarias más inversiones. Mientras tanto los sectores del MTA exigen una huelga general para el 22 de Agosto y medidas más contundentes para enfrentar al "modelo". Esta perspectiva es defendida especialmente por Palacios, de la UTA, y por Hugo Moyano, de camioneros. Se producen algunos incidentes con pedradas contra el edificio de la CGT y enfrentamientos entre miembros de camioneros y la Uocra.

El paro no tiene casi repercusión en Chubut y finalmente no se realizó ninguna medida en las calles de la región. De hecho los gremios de la zona casi no emitieron porcentajes de la adhesión, aunque sí admitieron que fue escaso. En la rama textil la adhesión habría sido del 35\%, en la educación del 25, en Smata del 30, en la Uocra de alrededor del 70 y la UOM paró cuatro horas por turno en Aluar. Otra vez la huelga sólo fue contundente en el transporte interurbano.

A nivel nacional fue, hasta ese momento, la protesta gremial más importante desde que Menem llegó al poder en 1989. Al menos sesenta mil personas se concentraron en la plaza de los Dos Congresos donde el único orador fue el secretario general de la CGT, Gerardo Martínez, quién criticó a Cavallo por su plan económico pero no a Menem. Así incorporaba la huelga como parte de la disputa interna cada vez más clara entre Cavallo y Menem. Ante esto los sectores del MTA y el CTA silbaron a Martínez y se retiraron antes de que termine el discurso, exigiendo un plan de lucha con nuevos paros. Martínez desestimó esa posibilidad y tampoco presentó un plan para combatir la desocupación, como se lo reclamaban otros sectores sindicales.

En esos días se profundiza el conflicto en Río Negro, llegando el 19 a una serie de hechos calificados como "estallido social" por la prensa y los políticos. Es una masiva movilización de trabajadores estatales, jubilados y estudiantes, en contra del 
proyecto de privatizar el banco provincial y realizar un ajuste en el empleo estatal, y reclamando el pago de salarios atrasados.

También en Neuquén se habla de estallido el 2 de octubre. El movimiento de desocupados marcha contra la casa de gobierno por la falta de pago de los subsidios, generándose choques con la policía, roturas de vidrios, computadoras e incendios de varios vehículos oficiales. El gobernador Sobisch acusa a dirigentes de izquierda de ser los responsables de los incidentes. Mientras tanto en Sierra Grande unos quinientos manifestantes cortan la ruta 3 en apoyo a la jornada de protesta del Frente Estatal Rionegrino y reclamando la reapertura de Hipasam.

Aluar informa que en 1995 lograron una ganancia de 100 millones de dólares y que ampliaría su capacidad de producción. Atrás quedó el déficit, recomponiendo la rentabilidad con la reducción de personal y el aumento de la productividad. Días después se produce una explosión que causa heridas a seis obreros de empresas contratistas, resultado directo de ese aumento en la explotación.

A fines de octubre comienzan a ser importantes las protestas en relación al proyecto de instalación de un repositorio nuclear (conocido como "basurero nuclear") en Gastre, un pequeño poblado del centro de la provincia del Chubut. Organizaciones ecologistas como Fundación Patagonia Natural, Movimiento Antinuclear Chubutense $(\mathrm{MACH})$ y Greenpeace se empiezan a mover en relación a este tema y logran generar una gran movilización social contra este proyecto, impidiendo finalmente su realización.

El 11 de diciembre Maestro reasume en el gobierno su segundo mandato (es el primer reelecto en Chubut, antes esto no estaba permitido). Un día antes Menem volvía a asumir a nivel nacional.

Entre fines de 1995 y principios de 1996 los trabajadores de la empresa de transportes "Don Otto", realizan un proceso importante, con piquetes a las entradas de los talleres y pasando hasta las fiestas de navidad y año nuevo en el lugar. Finalmente consiguen cobrar las deudas y que se mantengan sus puestos de trabajo.

El 16 de febrero la planta pesquera Bonasur de Rawson, cerró sus puertas, dejando a diecinueve obreros en la calle y arreglando retiros voluntarios con otros cuarenta y cuatro. Los delegados del sindicato sólo atinaron a reclamar que se paguen las indemnizaciones correspondientes. Los rumores afirmaban que se trataba de un cambio de firma para escapar de algunas deudas que tenían los empresarios con entidades bancarias.

Como evidente indicador del proceso de pauperización, en la ciudad de Trelew se manifestaba un gran aumento de la demanda en los comedores comunitarios. Para principio de marzo se distribuían al menos dos mil bolsas de alimentos, más las 
raciones en los comedores. La municipalidad decidió que si una persona del grupo familiar tenía trabajo, esa familia no recibía ayuda alimentaria de ningún tipo, ya que el presupuesto no daba abasto.

Se desarrolla una larga lucha de los trabajadores de Supersil por su fuente de trabajo. Generan marchas, toman la fábrica, cortan la ruta y queman cubiertas. Sin embargo durante todo el proceso ni ellos ni los sindicatos que los agrupan, logran plantear una propuesta que no sea apoyar el pedido de los empresarios de que la provincia les otorgue otro préstamo. Supersil decide suspender a sus setenta obreros por dos semanas e informan que de no recibir el crédito no podrán reactivar la fábrica. Setia y AOT ratifican su apoyo a los empresarios en el reclamo del préstamo y plantean la urgencia de dar soluciones, ya que a los obreros se les adeudan dos meses de sueldo. Además la empresa sólo pagaría a los suspendidos el $50 \%$ de sus haberes.

A los tres días Setia y AOT anuncian la ocupación de la fábrica, con el objetivo de preservar las fuentes de trabajo. En verdad el miedo de los trabajadores era a que los empresarios se lleven las máquinas, algo que ya había ocurrido en varias suspensiones anteriores en otras fábricas. Además un grupo se moviliza hasta el Concejo Deliberante y al Municipio reclamando apoyo del gobierno para la reapertura de la fábrica. El intendente de la ciudad les expresa su apoyo al otorgamiento del crédito, aunque el gobierno provincial hasta ahora se negaba.

El conflicto de Supersil seguía en curso y el 23 los obreros deciden cortar la ruta provincial 25 (cercana a la planta que están ocupando) para interceptar el paso del gobernador cuando debía asistir a una exposición agropecuaria. Sin embargo no logran encontrarlo, ya que el gobernador, avisado de la circunstancia, viaja por un camino alternativo. Sí logran ser "escuchados" por Mac Kharty y Das Neves, ambos miembros del PJ, que expresan su solidaridad con el reclamo y se pronuncian a favor de que se otorgue el crédito para preservar el trabajo.

Las entidades representantes de la patronal empresaria (Consorcio del parque industrial), de la burguesía y pequeña burguesía acomodada de la zona (Cicech) y de los sindicatos textiles (Setia y AOT) firman el 26 de abril un plan de acción común para reclamar en conjunto la extensión y ampliación de la promoción industrial. La exigencia fundamental pasa por igualar las condiciones de las provincias del acta de reparación histórica y por condiciones especiales en términos laborales y de transporte. Se acuerda además una tregua social por noventa días, durante los cuales no podría haber despidos ni suspensiones de personal, pero tampoco protestas de los obreros. Nada se había consultado sobre la firma de este acuerdo a los obreros de Supersil, 
que aún reclamaban su deuda, o a los despedidos de Matepa que nunca habían cobrado la indemnización.

El conflicto de Supersil culmina en una derrota para los obreros, decidiendo levantar la toma el 8 de mayo ante el acuerdo de la AOT con el municipio de Trelew de que éste controlaría que no se lleven las máquinas. No había novedades sobre el posible crédito o sobre medidas de lucha más contundentes. El único camino que deja abierto la estructura sindical es el judicial, planteando de hecho que la continuidad del reclamo pasaría por la presentación de recursos judiciales contra la empresa. Así funcionaba la famosa "tregua social" firmada por los sindicatos y la patronal.

Por su parte en la hilandería de Sedamil (planta II) se vota el rechazo masivo a la modalidad americana de seis por dos, con la que pretendía avanzar la empresa, profundizando el proceso de flexibilización y bajando los salarios al no pagar como horas extras los sábados y domingos. Según la empresa esta decisión es egoísta, ya que hubiera permitido tomar más personal. Delegados de otras plantas (Sedamil I, Propulsora patagónica, Soltex, Matepa, Punilla y Tendlarz) felicitan y apoyan la decisión de los obreros. Es la primera de varias fábricas en las cuáles se frenan cambios que implicaban una mayor explotación (sistema americano de seis por dos, turnos rotativos, etc). Son indicios de que algo empezaba a cambiar, aunque muy lentamente.

Las marchas contra el proyecto de basurero nuclear continúan, ahora unas mil personas se movilizan en Puerto Madryn el 7 de mayo, siendo el principal orador el diputado nacional por el PJ, Corchuelo Blasco. También en Trelew se movilizan casi dos mil personas, en su mayoría estudiantes secundarios. Hablan frente a la multitud Rodríguez Pardo, dirigente ambientalista que anuncia una caravana hasta Gastre para el día 16, y el diputado por el PJ, Mario Das Neves, quién es silbado y debe terminar abruptamente su discurso. Un grupo se dirige luego hasta Rawson, donde realizan un acto frente a la residencia del gobernador.

Durante toda la semana hay movilizaciones y actos protagonizados en su gran mayoría por estudiantes secundarios. Hay expresiones de oposición a Menem. El 12 realizan una movilización a la plaza independencia, el 13 una marcha de antorchas en Trelew con más de dos mil participantes y otra el sábado 14 en Gaiman con gran cantidad de habitantes de otras ciudades. Se suman al repudio las asociaciones vecinales, judiciales, diputados de todos los bloques, agrupaciones ecologistas de todo el país, sindicatos, etc.

El 16 se realiza la caravana hacia Gastre, organizada por los grupos ambientalistas. Se suman, al ver la masividad del hecho, diputados de todos los bloques y el gobernador Maestro pretende encabezar la marcha pese a unirse más 
tarde al recorrido (realiza la mayor parte del viaje en helicóptero, para poder ponerse primero en la fila). De todas maneras no logra hegemonizar el acto, sufriendo varios rechazos a su figura en la marcha y durante su discurso. Son más de 1500 los que se movilizan alrededor de $400 \mathrm{Km}$. hasta el pequeño pueblo de Gastre en la meseta patagónica.

En junio y julio Cutral Có y Plaza Huincul hacían su entrada en la historia con los cortes de ruta que marcan un nuevo quiebre en el proceso nacional. Así como el santiagazo fue el inicio de la resistencia más decidida, estos hechos, y la continuidad de huelgas y cortes en 1996 y 1997, marcaron el freno al avance del proyecto global del capital financiero.

Por su parte en la región el 7 de julio se realiza una asamblea de la Comisión de Desocupados de Puerto Madryn en la plaza central, dirigida por Armonía Navarro. Se reclama trabajo, alimentos, gas, frazadas, calzado, ropas y subsidios para emprendimientos. En los días siguientes realizan asambleas en el mismo lugar, aumentando la cantidad de participantes y nombrando una comisión con representantes de los barrios populares de la ciudad. Se autodenominan "Desocupados de la plaza" por haber ocupado ese lugar como centro de sus reuniones. Recién el 23 de julio se levanta la olla popular en Madryn, continuando el plan de lucha con marchas todos los días jueves, convocando a los sindicatos y demás organizaciones sociales a acompañarlos. Denuncian en el comunicado la entrega de los recursos naturales por parte del gobierno a los grupos internacionales. La suspensión de la medida es repudiada por un grupo de los desocupados, quienes afirman que no se realizó una asamblea para tomar esta decisión. Este grupo realiza una asamblea con desocupados de Trelew y Rawson, que llegaron a solidarizarse con la medida de lucha que estaban desarrollando.

El 16 de julio la CGT anuncia un paro nacional para el 8 de agosto, que sería el tercero durante el gobierno de Menem. El secretario general Gerardo Martínez informa que no habría movilización. Nuevamente se expresan contra Cavallo, denunciando la eliminación de las asignaciones familiares. La interna del gobierno explota el 27 de julio con el despido del ministro Cavallo por parte de Menem.

En la región se decide adherir a la huelga convocada por la CGT para agosto. Se convoca a una misa para el 7 de agosto (día de San Cayetano) y a una marcha a las 12 horas del día 8 en la plaza independencia de Trelew. La AOT decide realizar el paro entre las 6 de la mañana del 8 y las 6 del día 9. La UOM anuncia también su apoyo a la medida. 
Se suman los miembros de Bancarios, UOM, Setia, Uocra, Viales Nacionales, Sutiaga $^{160}$, Gastronómicos, Luz y Fuerza, Comercio, Telefónicos, Atech, AOT, Municipales, APUNP, Viajantes, Sitravich, ATE, Smata, Centro de jubilados, Apinta, UTEDyC, UOCRA, UPCN, UATRE, APEL ${ }^{161}$, SeyOM, SOMU, UTGRA, la FUP, el Centro de Estudiantes de Humanidades, el Fuich ${ }^{162}$ y la CUEPA ${ }^{163}$. También anuncian su apoyo la CICECH y la CAME. Por su parte la Atech afirma que el paro será muy significativo y plantea que no sólo se enfrenta a Menem sino también a Maestro.

La movilización fue masiva, con más de dos mil trabajadores. El parque industrial directamente no abrió sus puertas. En el acto se repudió el modelo económico, haciendo responsable al gobierno nacional y a los gobiernos provinciales "cómplices". Al otro día Maestro se reposicionó con respecto al gobierno nacional, afirmando que "Menem deberá hacer cambios porque no se puede gobernar con un pueblo en contra"164. Es una muestra clara de la contundencia de la huelga.

El 12 se anunció un paquete de medidas a nivel nacional con aumentos en la nafta, el gasoil, el gas y otras subas de impuestos varios. En Chubut el gobierno firmó un nuevo "pacto social" con los dirigentes sindicales textiles, determinando que por cuarenta y cinco días no podía haber suspensiones ni despidos y tampoco medidas de fuerza por parte de los trabajadores. El pacto sólo dura dos días ya que el 12 los dueños de Arcoplus (ex Modecraft) suspendieron a ciento diez trabajadores. Las estrategias de conciliación con el gobierno y el empresariado se seguían mostrando como un camino seguro hacia la derrota de los obreros.

Los trabajadores suspendidos por Arcoplus firman el acuerdo por el cual aceptan la suspensión, con la promesa de ser reincorporados a mediados de septiembre. El acuerdo es apoyado por los sindicatos, sosteniendo que es la única manera de mantener los puestos de trabajo ante la difícil situación que atravesaba la empresa. No hay denuncia del quiebre del pacto social por parte de la patronal, ni realización de medidas de fuerza. Dos días después AOT firma un convenio semejante con Britalco (unos setenta y ocho empleados), aceptando la suspensión de su personal dos días por semana, lo que significa una rebaja salarial del $20 \%$. Al igual que en Arcoplus y Britalco, la fábrica textil de Gaiman, Del Estero, anuncia la suspensión de su personal dos días por semana, alegando también la acumulación de stock y la baja en las ventas. Nuevamente los sindicatos aceptan la medida de la patronal sin dar ningún tipo de disputa.

\footnotetext{
${ }^{160}$ Sindicato Unificado de Trabajadores de la Industria de Agua Gaseosas y Afines

${ }^{161}$ Asociación Provincial de Empleados Legislativos.

162 Frente Universitario Independiente del Chubut.

163 Corriente Estudiantil de Unidad Patagónica.

164 Diario Jornada, 9/8/1996, declaración de Carlos Maestro.
} 
Los sindicatos de la zona que se habían movilizado por el paro nacional, conforman la Mesa de Enlace Sindical del Este del Chubut, agrupando a veinticuatro gremios de los treinta y dos existentes en la zona, según los datos dados por los sindicalistas. Se muestra así el proceso de reagrupamiento de los cuadros sindicales y la profundización de sus posturas, sacando un documento en el que repudian el modelo económico y admitiendo que habían cometido un grave error cuando muchos de ellos aceptaron y apoyaron la implementación de ese proyecto.

Toda la actividad política se centra en la nueva huelga convocada para septiembre. Manifiestan su adhesión Atech, Atsa, Sitravich, UOM, ATE, Bancarios, Supa, Foniva, Seyom, municipales, judiciales, AOT, SEC, Setia, Apunp, UTEDyC, Apinta, UPCN, AOMA, Viajantes, la FUP y los centros de estudiantes de Humanidades y Naturales, el Fuich y la Cuepa, el MID, el Frepaso y el PSA. Hasta expresa su apoyo el gobernador Carlos Maestro. Por esta razón tanto en Trelew y Rawson como en Madryn (donde además se suma la coordinadora de gremios marítimos formada por Somu, Supa, Stia, Saon, capataces, Seom, Siconara, la Asociación Argentina de capataces de pesca, entre otros) se esperan importantes porcentajes de huelga. En Puerto Madryn los trabajadores del Estado resuelven adherir, pero con asistencia al lugar de trabajo por el temor al descuento salarial del presentismo (el cual no se deroga, pese al apoyo expresado verbalmente por el gobernador).

EI 26 es impresionante la movilización producida en Trelew, con más de cuatro mil trabajadores, que inaugura la huelga de 36 horas. El acto es calificado como "el más importante de las últimas décadas"165 por uno de los voceros de los gremios privados, pero en verdad es la movilización más importante en la zona desde las de 1990, durante el chubutazo. Además de los sindicatos se movilizan las vecinales, los centros universitarios y secundarios, las cámaras empresarias, veteranos de Malvinas, comisiones de desocupados, Hijos seccional Trelew, diputados nacionales y provinciales, concejales y dirigentes políticos radicales y del Frepaso. Participan en el acto trabajadores de Puerto Madryn, especialmente de la UOM. El paro tiene alrededor del $85 \%$ de adhesión en la zona, siendo menor en el ámbito estatal con un $60 \%$ de acompañamiento.

En Madryn, donde no se había producido movilización como en Trelew, se decide el corte de ruta de acceso al parque pesquero desde las 21 horas del 26 hasta la tarde del 27, por parte de los trabajadores del Stia y en adhesión a la huelga nacional.

$\overline{165}$ Diario Jornada, 27/9/1996, pág. 4. 
A nivel nacional la protesta es masiva, con más de cien mil movilizados a Plaza de Mayo. Allí se hacen presentes todos los sectores de la oposición política y sindical a Menem, y hasta sectores sindicales que eran históricamente su apoyo pero que ahora salían a confrontarlo. Además de las centrales sindicales están el Frepaso, la UCR, Nueva Dirigencia y todos los partidos de izquierda. Al palco sólo suben los dirigentes del Frepaso, además de la dirigencia sindical, pero el único discurso es del secretario general de la CGT.

En su discurso Daer reclama que se termine con la actual política económica. De todas maneras se cuida de no nombrar a Menem en forma particular. Por su parte Lorenzo Miguel sí lo realiza en declaraciones a la prensa, culpando al presidente de hacer volver a la lucha a los trabajadores.

Sin dudas esta huelga es la más contundente desde la caída de Alfonsín, expresando el mayor grado de unidad de los cuadros sindicales y del pueblo en general, en oposición al proyecto del capital financiero. Ese proyecto debe frenar su avance ante la profundización de la lucha, y el gobierno entra en crisis. Por su parte la gran burguesía ya comienza a buscar los cuadros políticos que pudieran montarse en esta fuerza social en construcción para dar continuidad a su proyecto, con algunos cambios menores en lo discursivo y en el plantel dirigente, para intentar llevar adelante las medidas que Menem ya no logra impulsar.

El gobierno del Chubut se pronuncia en relación al paro, volviendo a expresar una posición semejante a la sostenida en la huelga anterior. Se resalta el alto acatamiento en la región y se lo presenta como un paro solamente contra Menem y no en contra de Maestro, informando que en el único lugar donde la adhesión fue baja es en el Estado.

En este marco de agudización del conflicto social se acentúan las internas en varios sindicatos, entre ellos la AOT. La conducción gremial venía aceptando suspensiones y despidos, sin hacer caso a las asambleas y sin llamar a medidas de fuerza. $Y$ mientras tanto era claro que por abajo crecía la voluntad de resistir. Esto impacta en la conducción gremial, llevando a la renuncia de la mayoría del Consejo Directivo y al reclamo de la inmediata remoción del secretario general Miguel Llouful ${ }^{166}$.

En octubre se declaró la quiebra de la planta Mulcosur, la más grande de Rawson. Los obreros realizaron una asamblea y decidieron tomar la fábrica. Esta empresa era la textil más importante de Rawson que se comenzó a construir en 1972 y comenzó a producir en 1975, con ciento ochenta trabajadores ocupados y ciento

\footnotetext{
${ }^{166}$ Poco tiempo después Llouful es desplazado y desde la dirección nacional se nombra a Sergio Cardozo como delegado normalizador. Ya veremos que el enfrentamiento continúa.
} 
ochenta mil kilos de producción. En los últimos años del ochenta fue perdiendo clientes del parque industrial de Trelew, cayendo su producción a cien mil kilos. La caída continúo en los siguientes años, por lo cual solicitó un préstamo de seiscientos mil pesos en 1995, que le fue otorgado por el gobierno provincial. Pese a esto igual fue a la quiebra un año después, siendo otro ejemplo de las grandes estafas del empresariado con la evidente complicidad del personal político.

El delegado gremial de la planta afirma que si el gobierno les da un préstamo la fábrica se puede autogestionar. Es llamativa la diferencia en las reacciones para expresar posibles alternativas, actitud muy distinta a la que se solía tomar ante los primeros cierres de fábricas. Son signos de que empieza a cambiar la fase: ya no es sólo política negativa ${ }^{167}$, ni "resistencia pura" ${ }^{168}$.

Noviembre marca el inicio de lo que llaman la "normalización de la CGT", pero que en verdad era el quiebre de la importante unidad entre los cuadros sindicales que se había conseguido tras la huelga de agosto, y que había convocado la exitosa marcha de septiembre. El Setia apoya el proceso afirmando que de realizarse esto se abrirían del espacio de la Mesa de Enlace Sindical. Denuncian que este espacio estaba siendo "politizado".

Para el 8 nuevamente hay conflicto en la planta de Conarpesa, ahora con la empresa que alquila la planta y la utiliza para procesar productos del mar. Participa el Stia en el reclamo por el atraso en el pago de horas y contra el intento de pagar por debajo de lo convenido, en un marco de convenios laborales muy precarizados. La planta es tomada por unos ciento cincuenta obreros, quienes afirman que se mantendrán en el lugar hasta cobrar lo adeudado.

El 5 se vota una nueva prórroga de la Ley de Emergencia en el Chubut, sin que se produzcan marchas ni protestas. ATE se expresó a través de una nota, repudiando la ley y denunciando que será el octavo año en funciones de este tipo de leyes supuestamente de "excepción".

El 9 hay una importante movilización de pequeños productores agrícolas del valle inferior del Río Chubut. Se lo denomina "tractorazo", con más de cuatrocientos asistentes que cortan calles y rutas con sus tractores, finalizando en Gaiman frente a la Compañía de Riego. Allí reclaman políticas de promoción para el sector, la renuncia

\footnotetext{
167 Gramsci usa este concepto cuando se busca impedir que determinado acontecimiento se realice, sin poder plantearse la posibilidad de provocar otro hecho alternativo. Es una situación propia de una voluntad colectiva en su fase de formación, cuando se mantiene todavía en una actividad pasiva, sin poder articular una fase activa y constructiva.

${ }^{168}$ Balvé y Balvé (1989), citan: "En la resistencia pura falta la intención positiva, y por lo tanto, en este caso nuestras fuerzas no pueden ser dirigidas hacia otros objetivos sino que deben limitarse tan sólo a hacer fracasar las intenciones del enemigo... La preservación de nuestras propias fuerzas tiene un objetivo negativo, y conduce a desbaratar las intenciones del enemigo, es decir, a la resistencia pura..." (en pág. 106, de "De la guerra"; Von Clausewitz, Edic. Solar, Bs. As. 1983, pág. 36).
} 
de las actuales autoridades y la fijación de un canon de riego accesible para todos. El gobierno propone recibir una delegación de los regantes en los próximos días, pero con la condición de que no se realice un tractorazo hacia Rawson como algunos de los manifestantes impulsaban.

Los textiles deciden movilizarse al no solucionarse el conflicto en Matepa, con veintinueve suspendidos y treinta y tres despedidos, para los cuales se reclamaba el pago total de las indemnizaciones. Se reclama una audiencia con Maestro para solucionar el problema y se comenta que el temor de los trabajadores es que se produzca lo mismo que en Oceanic, donde se llevaron los créditos y las máquinas de la provincia, y dejaron en la calle y sin ningún pago a los trabajadores.

Finalmente la CGT decide convocar a una huelga general para el 26 de diciembre, en contra de la ley de flexibilización y reclamando un cambio de la política económica. Al paro adhieren las demás centrales y líneas políticas sindicales, aunque con fuertes críticas por no convocarse movilizaciones o un paro de por lo menos 36 horas, como el último realizado el 26 y 27 de septiembre.

La mesa de enlace sindical manifiesta su apoyo y adhesión al paro, fijando las culpas del modelo no solamente en Menem y Cavallo, sino también en Maestro, a quién acusan de violar leyes laborales en forma permanente. En cambio la CGT se reúne el mismo día con el gobierno, en la figura de su ministro de producción Lorenzo Soriano. Si bien adhieren a la huelga formalmente, casi no se expresan en relación a esto, haciendo énfasis en el apoyo al gobierno provincial en su reclamo de continuidad de la promoción industrial.

La división generaba debilidad. Esto se hace evidente al observar la escasa contundencia de la huelga en la región, con una adhesión significativa solamente en el transporte y en la UOM. En el Estado la adhesión ronda el $40 \%$, es muy bajo en el comercio (donde el sindicato denuncia que si algún trabajador adhiere al otro día lo echan) y en textiles es de alrededor del $70 \%$. Nuevamente no hay acciones en la calle.

A nivel nacional el paro es importante en todo el transporte y en el interior, donde en varias provincias se producen conflictos, en especial en Córdoba, Santa Fe, Santiago, Jujuy, Tucumán, Mar del Plata y Mendoza. Hay amenazas a trenes y atentados contra vehículos. Organizaciones como Patria Libre, Quebracho, y Jubilados que responden a Raúl Castells cortan el Puente Pueyrredón.

\subsection{La rebelión en el NE del Chubut: 1997 - 1999}

El año 1996 marca un punto de quiebre en el proceso, así como también lo había marcado el santiagazo a fines de 1993. Pero aquí entramos a una fase más rica 
en procesos disruptivos, y que ya pone por delante el proceso de acumulación de fuerza y experiencia que desembocará en los hechos de diciembre de 2001.

Destacamos al final del anterior apartado que ya no estamos ante una situación de resistencia pura, en los términos de Von Clausewitz, o de política negativa, en la conceptualización de Gramsci. Tras años de dominación hegemónica del proyecto del capital financiero casi sin fisuras, este empieza a mostrar brechas. Desde la resistencia pura empieza un proceso de acumulación que ahora ya hace posible que aparezcan intenciones positivas, que se pueda entrever, aunque sea de forma poco sistemática y sin estructuración, el surgimiento de elementos de un proyecto alternativo.

Al comenzar 1997 se realizan distintos informes que evidencian las graves consecuencias que tuvo el proceso de reconversión capitalista sobre la mayoría de las producciones tradicionales de la zona. Allí se destaca el proceso de caída del parque industrial textil, la concentración y centralización de la venta comercial (con el consiguiente cierre masivo de pequeños y medianos comercios) y la crisis casi terminal de la producción ovina lanar (caracterizada por la caída de los pequeños y medianos productores, la extranjerización de la tierra y la conformación de grandes latifundios). La burguesía tradicional con intereses en la región y la pequeña burguesía acomodada sufrían estos golpes, y en muchos casos vivía un proceso de proletarización, al perder sus medios materiales de existencia. Sin embargo no lograban articular casi ningún hecho de protesta y seguían subsumidos a la hegemonía del proyecto del capital financiero.

Las trabajadoras contratadas temporalmente por la pequeña empresa "Confecciones Patagónicas", que no están bajo convenio y por eso son apoyadas sólo por la CGT y no por algún sindicato en particular, reclaman el pago de la deuda que mantiene la patronal. Este grupo empresarial es el mismo que dirigía Matepa, donde se ratifican otros veintiún despidos definitivos.

Los obreros textiles de Matepa y Confecciones se movilizan a Rawson el día 13 de enero. En Trelew marchan a la Subsecretaría de Trabajo, luego se concentran en la ruta 25 cortándola durante algunos minutos para subir a los colectivos que los llevan a Rawson. Allí cortan el puente con quema de cubiertas y luego se dirigen al Ministerio de Producción, donde son recibidos. La noticia es la aparente venta fraudulenta de Matepa a una firma uruguaya, violando todas las condiciones de la promoción y dejando impagas deudas con los trabajadores y la provincia. No hay respuestas claras para los trabajadores sobre su continuidad laboral.

Este hecho se transforma en un nuevo escándalo relacionado con la entrega de créditos sin controles. El 15 hay otra marcha en Trelew, ocupando por algunas 
horas la Municipalidad, donde reclaman el apoyo del intendente y una reunión con Maestro para los próximos días. Esta reunión se realiza recién el 22, frenando así el proceso de luchas y dejando la supuesta posibilidad de resolución en las "buenas gestiones" de los funcionarios públicos. Los obreros van a la reunión marchando y queman un ataúd y un muñeco, que simbolizan a la empresa y a la empresaria que es su representante legal en la región ${ }^{169}$. Maestro compromete el apoyo del gobierno, pero no hay soluciones concretas cuando se solicita una alternativa laboral.

El reclamo de las trabajadoras de Confecciones Patagónicas toma mayor fuerza con la ocupación de la planta de Matepa en el Parque Industrial. La empresaria anuncia que pagará lo adeudado cuando desocupen la fábrica, posibilidad rechazada por las obreras, quienes sostienen que sólo se irán cuando se les pague y Maestro confirme la salida laboral prometida.

Al otro día se retira de la toma el personal de Setia y hasta tienen un altercado con uno de los delegados que pretendía entrar a trabajar. Las obreras denuncian al Setia por abandonarlas y rescatan a AOT que seguía junto a ellas.

Los obreros despedidos de Matepa toman la sede de la AOT, desalojan al delegado normalizador Sergio Cardozo y reinstalan al anterior secretario general Miguel Llouful. Estos trabajadores se desempeñaban en la planta tomada y acusan a Cardozo de haber generado la toma que les impide cobrar las indemnizaciones acordadas. El conflicto tomaba características complejas con enfrentamientos entre los obreros y reclamos de que cada gremio se ocupe sólo de los trabajadores que representa (recordemos que las obreras de Confecciones no tenían gremio y eran representadas por la CGT).

El 21 se reúne la CGT para analizar este tema y la única resolución es un mayor aislamiento de la toma de la fábrica, ya que el Setia sigue considerando un grave error esta decisión y la AOT se ha dividido por la toma. Se suma el ministro de producción al coro que denuncia a las trabajadoras como parte de una maniobra. Por su parte el secretario desplazado de la AOT decía que los trabajadores de Matepa, en lugar de tomar el sindicato, deberían haber ocupado la fábrica para exigir soluciones.

Ya veremos cómo se soluciona este conflicto con una derrota para ambos grupos de trabajadores. En otros apartados más adelante, recuperaremos elementos de este conflicto para pensar los límites de la forma sindicato como herramienta organizativa, los niveles de conciencia que se expresan, la dificultad para quebrar la

\footnotetext{
${ }^{169}$ Analía Innocenti era la titular del directorio de la firma y su representante en la región. Matepa había recibido un préstamo de la provincia por 2.900 .000 dólares, por el cual adeudaba seis cuotas de amortización. El conflicto adquiere por ello mucha visibilidad social y política, y esta empresaria es duramente criticada, tanto por los trabajadores como por el gobierno provincial.
} 
perspectiva corporativa y los enfrentamientos entre distintas fracciones de la clase a los que llevan este tipo de proyectos.

La crisis pesquera se agrava en marzo con la quita de permisos para la flota regional. Para el 10 hay una movilización de más doscientos pesqueros de Rawson, exigiendo frente al Ministerio de la Producción respuestas al cumplirse diez días sin poder trabajar. El gobierno provincial, a través de su ministro Soriano, pone el eje del problema en el enfrentamiento con la Nación y en cómo esto afectaba a todo Chubut, e incorpora a dos trabajadores en la comitiva que iría a Buenos Aires a reclamar soluciones ${ }^{170}$.

El 12 se produce la reunión con Felipe Sola, quién extiende algunos permisos de pesca por un mes, aunque no soluciona de fondo la problemática. Como siempre ni siquiera se tratan los verdaderos problemas de la pesca, relacionados con la depredación por parte de la flota pesquera de la CEE, Corea, Japón y otros países.

Según un informe de la Dirección de Estadística y Censos de la Provincia, la desocupación en Chubut mantenía altos índices tanto en el desempleo como en la subocupación en las principales ciudades: Trelew (13,63\% de desocupación y 13,25\% de subocupación), Puerto Madryn (12,19 de desocupación y 9,95 de subocupación), Comodoro con una desocupación del 12,93\% y una subocupación de 9,1\% y Rawson (13,12 de desocupación y 15,64 de subocupación).

En Neuquén la gendarmería y la policía atacan a los manifestantes que cortaban la ruta nacional 22 en las localidades de Cutral Có y Plaza Huincul. Utilizan armas de fuego, y es asesinada Teresa Rodríguez. Desde hacía días se vivía en Neuquén un alto grado de conflicto, con cortes de rutas, huelgas docentes y enfrentamientos con las fuerzas represivas. Casi todos los sectores políticos y sindicales repudian la represión, marcando el proceso de desgaste del gobierno de Menem. La Ctera, la CTA y el MTA convocan a una marcha a Plaza de Mayo, a la que se suman la FUA, la FUBA y otras organizaciones. El Frepaso exige la renuncia de Corach, mientras los camioneros y organismos de derechos humanos se suman al repudio. La CGT debe reaccionar ante la contundencia del repudio social a la represión y llama a una hora de paro por turno para el 17.

Tras estos hechos comienza la negociación que logra levantar el corte de ruta, con la entrega de puestos de trabajo y medidas de promoción para las ciudades de Cutral Có y Plaza Huincul. Es un hecho de importancia a nivel nacional ya que nuevamente se logra doblar el brazo al gobierno nacional, obligándolo a generar respuestas (planes sociales y demás recursos asistenciales) que, pese a que pueden

\footnotetext{
${ }^{170}$ Ver Diario Jornada, 11/3/1997, pág. 14-15.
} 
ser usados por el sistema como mecanismo de dominación, también son herramientas que se le arrancaron a un modelo que no tenía pensado ni siquiera dar esas respuestas para estos grupos, directamente condenados a la desocupación estructural según el proyecto inicial del capital financiero.

A nivel regional es convocada por casi la totalidad de los sindicatos una movilización a la Plaza Independencia. Adhieren la CGT del Valle, la Mesa de Enlace Sindical, Atech, la FUP, el Centro de Estudiantes de Humanidades, ATE, Sindicatos de Ladrilleros, de Viajantes, UPCN, Frepaso, Frente Grande, Partido Socialista Autentico, el MID, Apel, el MAS, entre otros. El día de la marcha también se pronuncian la Agrupación Justicialista Chubut y su Gente ${ }^{171}$, la Juventud Radical (que además asiste a la marcha), el bloque de diputados justicialistas, varias escuelas de diferentes localidades, etc. Es destacable el repudio de varios grupos que habían apoyado durante años este modelo, otro signo de la pérdida de poder del gobierno.

La marcha es muy importante, con casi dos mil personas y una alta adhesión al paro entre los docentes y más bajo en los otros estatales. Los docentes denuncian que el ministerio de educación exigió listas de los que adhieren al paro. La columna más numerosa proviene de la universidad, representada por la FUP y los centros de estudiantes de humanidades, naturales, económicas y abogacía.

Para el $1^{\circ}$ de mayo se convocan dos actos: uno más pequeño llamado por la Comisión de Lucha contra la Desocupación, mientras la FUP, los centros de estudiantes de humanidades, económicas y naturales, ATE y Atech, llaman a un acto en la planta de Matepa, en solidaridad con las trabajadoras que están tomando la fábrica.

Durante este mes se producen varios cortes de la ruta 34 en Salta y Jujuy. En Salta se consiguen miles de puestos de trabajo temporal y un programa de emprendimientos. Las luchas iban generando experiencias al pueblo sobre cómo organizarse. El gobierno organiza una campaña de denuncia del corte de rutas como metodología de protesta. Afirmando su carácter anticonstitucional, se intenta generar el consenso social para reprimir estas protestas. Para ello se utilizan solicitadas, afiches, spots televisivos, etc. A ello se suman las declaraciones sobre supuestas infiltraciones guerrilleras, o de grupos narcotraficantes en las protestas. Especialmente importante es la recuperación discursiva de la figura del "subversivo" o del "revolucionario profesional", indicado como un peligro para la sociedad y la "democracia".

${ }^{171}$ Dirigida por Mario Das Neves. 
Pero esto no consigue frenar el ciclo. $Y$ el proceso impacta también aquí. En junio se forma un espacio que agrupa desocupados de Trelew, denominado "Red de Vecinos Solidarios". Convocan a un acto al cual asisten los concejales del PJ. Se plantean dos posturas: los que pretenden encarar el reclamo por vías institucionales realizando un proyecto de ley, y otro grupo que plantea tomar medidas directas.

Este sector se retiró del acto denunciando el manejo que intenta hacer el PJ y al otro día cortan la ruta nacional N3. Esto marca un cambio importante en la zona, ya que por primera vez en Chubut un grupo de desocupados decidió cortar una ruta pero ya con la decisión de tomar la posición y defenderla, aún ante las fuerzas represivas. Es un corte distinto a los anteriores ya que aquí el corte no es una forma de "hacer visible" una demanda, sino que la posición de cortar la ruta e impedir la circulación de mercancías se instituye como la medida en sí misma. No hubo una organización formal que dirigiera la lucha, pero cumplen importantes roles antiguos delegados textiles y pesqueros. La experiencia de esos trabajadores despedidos organizaba a los sectores de la clase desplazados de la relación asalariada. Ya se hacía clara una recuperación de sectores de la clase, que comenzaban a plantear elementos de una propuesta con iniciativa propia, recuperando aportes de la estrategia de resistencia obrera, pero superando esa condición puramente defensiva. Indudablemente la medida es parte del proceso nacional de acumulación de fuerzas y experiencia.

Días después se produce la segunda marcha federal. Al acto asisten, además de los organizadores MTA, CCC, CTA y FUA, casi todos los partidos políticos de oposición (UCR, con el mismo Alfonsín, el Frepaso, partidos de izquierda, etc), grupos de la iglesia como los representados por Farinello y, sobre todo, la columna de las 62 organizaciones y de la UOM, encabezadas por Lorenzo Miguel. La CGT no asiste ni emite opinión. Otros grupos cortan rutas y puentes planteando su adhesión al reclamo pero también la necesidad de acciones más contundentes. Desde la zona asisten especialmente sectores estudiantiles de la FUP y los centros de estudiantes de humanidades, naturales y económicas.

Tras la marcha federal se convoca una huelga nacional para el 14 de agosto, llamada por el MTA, la CTA y la UOM, entre otros. Adhieren Atech, UTA, ATE y la totalidad de los sindicatos que conforman el CTA y el MTA en la zona (Setia, Apinta, Sitravich, ceramistas, ladrilleros, portuarios, obreros navales, municipales, judiciales). En la zona la huelga tiene importante adhesión en los gremios privados pero es escasa en el Estado. Se marcha desde Puerto Madryn y Trelew a la Casa de Gobierno en Rawson. Al finalizar hay inconvenientes al negársele a los desocupados de Puerto Madryn la posibilidad de hablar en el acto. 
Estos desocupados al otro día cortan la ruta en Puerto Madryn, exigiendo asistencia social y planes de empleo. La acción aparece como más organizada que lo ocurrido en Trelew y Comodoro (donde se produjo un corte de ruta el 20 de julio). Aquí ya hay dirección de un grupo que está organizado más allá del hecho en sí mismo. Esto no quita que este grupo dirigente expresara un nivel de conciencia muy bajo, con un discurso discriminatorio y de oposición a los inmigrantes de origen boliviano ${ }^{172}$. Se reclama trabajo y reconexión de servicios, expresando su voluntad y su capacidad organizativa (llevan ollas, alimentos, etc.) para mantenerse en el corte hasta obtener respuestas. El corte dura 20 horas, se amenaza con reprimir pero se llega a una salida negociada.

A estos dos cortes se suma uno semejante desarrollado en Comodoro Rivadavia. Se dan en fechas cercanas entre sí en las tres principales ciudades de Chubut, pese a lo cual podemos asegurar, de acuerdo a los datos recabados en nuestras entrevistas y a la consulta de los expedientes judiciales, que no hubo coordinación entre los mismos. Esta forma de lucha se enmarca en el contexto de acumulación de fuerza social y experiencias que estaba desarrollando la clase a nivel nacional.

Hacia fines de agosto y septiembre vuelve a salir a la luz el largo conflicto de Matepa y Confecciones Patagónicas. Los trabajadores de Matepa son acompañados por el Setia, mientras en AOT se mantienen fuertes internas con respecto a este conflicto. Los empleados arman carpas frente a la empresa, planteando que se quedarían allí hasta conseguir una respuesta. El gobierno no acuerda con la empresaria de Matepa el precio de la mercadería en stock, siendo ese dinero el que cubriría la deuda con los trabajadores.

Al otro día se amenaza con trasladar el campamento a Rawson, frente al Ministerio de la Producción. Ya el reclamo se centra solamente en el pedido del pago completo de la indemnización.

Se produce un nuevo conflicto en Alpesca. Los trabajadores reclaman guantes y otros elementos de trabajo y ante esto la patronal decide frenar el fileteado. Esto implica una baja en lo que cobrarían los obreros por productividad. Ante este lock-out los trabajadores se mantienen en una toma "pacífica" de la empresa, cumpliendo sus turnos aunque sin poder trabajar.

Mientras a nivel nacional se consolida la Alianza con muchas perspectivas de derrotar al menemismo, Maestro critica la conformación del Frepaso en Chubut. Comienza una larga polémica en la cual la UCR provincial no acepta negociar lista

\footnotetext{
${ }^{172}$ Al momento de su formación, en junio de este año, el dirigente del grupo, Miguel lbarra, citaba como uno de los culpables de la desocupación a la importante inmigración boliviana.
} 
única con el Frepaso pero lo presiona para que baje sus candidatos, planteando que la Alianza en Chubut debía ser sólo la UCR. Es importante considerar que el Frepaso lo constituyen en gran medida los dirigentes sindicales de ATE y Atech, muy enfrentados con el gobierno provincial. De hecho el candidato a diputado nacional es el dirigente de Atech, Gustavo Monesterolo.

Sobre fin de septiembre se anuncia la suspensión de los quinientos setenta trabajadores de Alpesca, durante un mes. No se sabe si tendrán algún porcentaje del sueldo. La empresa, parte del grupo Alpargatas, se escuda en el procedimiento de crisis. El Stia manifiesta su "sorpresa", pero no da ninguna alternativa de acción.

El conflicto pesquero se agrava en octubre con problemas en otras plantas por la veda pesquera. Hay fuertes críticas al gobierno nacional, en especial al secretario del área Felipe Solá. El 17 se realiza una reunión de los gremios del sector, junto al intendente de Puerto Madryn, el diputado nacional del PJ Corchuelo Blasco, y varios concejales de la ciudad. Se reclama especialmente que Maestro encabece la protesta ante la nación y se lo critica por no haber ido a la reunión. Recordemos que en pocos días se realizaría la votación a nivel provincial y nacional. Al otro día los pesqueros se movilizan por las calles de Madryn, con la presencia de la CGT y de los gremios Stia, Saon y el Centro de Patrones Fluviales.

Las elecciones de diputados nacionales dan una importante victoria a la UCR sobre el PJ en Chubut. A nivel nacional es un duro golpe para el menemismo y para el PJ, especialmente por la derrota en todo el país, donde la Alianza llega al $43 \%$ de los votos contra un $36 \%$ del PJ.

Los problemas en Matepa se mantienen. El personal despedido reclama que la provincia pague la ropa en stock para asegurar el cobro de las indemnizaciones. Según los trabajadores ellos se sienten engañados por la patronal y el gobierno, pese a que siempre buscaron caminos pacíficos de protesta y se negaron a otras medidas como el corte de ruta.

El año termina con el aumento de marchas y protestas por situaciones de la llamada "inseguridad". Son familiares de víctimas de delitos que reclaman leyes más duras. Se hacen comunes los tópicos de que "los delincuentes entran por una puerta y salen por la otra" o "las leyes protegen a los delincuentes y no a la sociedad". El pedido de leyes más represivas tiene el apoyo y la fuerte presencia de algunas iglesias evangélicas ${ }^{173}$.

\footnotetext{
173 En general este reclamo atravesará el período que estudiamos presentando formas reaccionarias. Seguimos en este sentido a Maria Celia Cotarelo (2007a): "Consideramos que el reclamo por mayor seguridad resulta reaccionario o antipopular dadas las características de los hechos en que se lo esgrimió. Si bien puede tratarse de un interés legítimo para buena parte del pueblo, la convocatoria a marchas y otros hechos partió desde distintas expresiones del régimen político y formó parte de la
} 
Durante 1998 son constantes los problemas en la pesca por la caída del recurso natural ante la sobreexplotación que realizan las flotas extranjeras. Se producen movilizaciones, tomas de fábricas, piquetes a los puertos. Todo en un marco donde era muy complejo prever un buen futuro para estos trabajadores.

Se empiezan a hacer más comunes los procesos de lucha dirigidos por sectores autoconvocados. Esto, que será claro después de los sucesos de Corrientes en 1999, aparece ya con fuerza en 1998. En especial surgen estos grupos en docentes, trabajadores estatales del área de salud y trabajadores pesqueros, realizando medidas de lucha que no encontraban apoyo de sus dirigencias sindicales. En los docentes es donde aparece más clara la pérdida de legitimidad del sindicato. Este proceso se agudiza en 1999, cuando la crisis económica lleva al gobierno a no pagar los salarios en término. También hay conflictos en forma permanente en casi todas las fábricas textiles. Mientras los sindicatos siguen buscando soluciones "concertadas" el sector agravaba su crisis.

A fines de enero se anuncia el despido de noventa y tres obreros textiles del sector hilandería de Sedamil. Son personal de Setia y AOT. Se dicta el procedimiento preventivo de crisis, con la intervención de la Subsecretaría de Trabajo. En febrero se firma un acuerdo de Sedamil con los gremios textiles que vuelve a frenar el conflicto en la planta. Se logra mantener trabajando a la mayoría del personal, aunque con descuentos salariales, en especial para los que pasan al sector tintorería. Además un número no precisado acepta retiros voluntarios.

Los pesqueros de la flota amarilla ${ }^{174}$ de Rawson se movilizan el 21 de febrero. El hecho se transforma en una asamblea con más de quinientas personas, que es apoyada por el intendente de la ciudad, Pablo Helmer. Los pesqueros deciden volver en forma anticipada al puerto, denunciando que en los cuadrantes autorizados hay ejemplares juveniles. Exigen que se cambie la veda, afirmando que a la Secretaria de Pesca no le interesa preservar el recurso. A la movilización se suman las familias de los marineros y el personal de las plantas en tierra.

Los trabajadores de Poseidón vuelven a protagonizar un conflicto con abandono del trabajo y quema de cubiertas ante nuevos despidos. Los despedidos son los que habían firmado el acta de acuerdo con los empresarios en el anterior

constitución de una fuerza social que levantó -y levanta- la bandera del orden contra el "delincuente pobre" y el "rebelde pobre" (213).

${ }_{174}$ Son los pequeños barcos costeros, de hasta 21 metros de eslora, que operan en el puerto de Rawson. En su mayoría son propiedad de propietarios locales, que trabajan con tripulaciones estables, los cuales cobran en relación a la pesca lograda, realizándose la distribución entre los distintos miembros de la tripulación (con porcentajes muy distintos para el capitán, los maquinistas, marineros comunes, etc). Así hay una coincidencia de intereses entre los propietarios y los pesqueros, cuyas ganancias también dependen de la cantidad de pesca conseguida. En los últimos años también hubo un avance de las grandes empresas de capital concentrado en esta actividad. Especialmente la española Conarpesa ha adquirido varios barcos de esta flota. 
conflicto. El sindicato apoya la medida y los trabajadores comienzan a armar carpas en la puerta de la empresa. Finalmente se firma un acuerdo del Stia con la empresa, que acepta algunas reivindicaciones laborales y la reincorporación de los despedidos, excepto uno a quién se lo habría despedido con causa justa.

Los integrantes de la flota amarilla vuelven a movilizarse el 27 de febrero. Ocupan la escalinata de la Casa de Gobierno y exigen que los reciba Maestro. La protesta tiene gran contundencia, con quema de cubiertas y enfrentamiento a las fuerzas represivas. Maestro accede a recibir a los manifestantes y tras algunas horas de reunión se logra destrabar el conflicto, autorizando la pesca en otros cuadrantes y la no imposición de inspectores hasta el 31 de marzo. La manifestación y la negociación la encabezan los empresarios y patrones de barcos, quienes movilizan tras sus intereses sectoriales a los trabajadores.

Al iniciarse marzo se formaliza un acuerdo entre Menem, Maestro y Kirchner para apoyarse mutuamente en sus proyectos re-reeleccionistas. El gobierno nacional aportaría los fondos para la realización de consultas populares a través de fondos ATN. Mientras la UCR reglamenta desde la Legislatura el llamado a plebiscito para el 17 de mayo, el PJ local quedaba totalmente desorientado, viéndose obligados a declarar en contra Menem. Das Neves presenta un proyecto en la Cámara de Diputados para exigir que Corach dé explicaciones sobre el ATN otorgado a Maestro.

Los siguientes días se precipita sobre la zona un fuerte temporal que azota a todas las ciudades analizadas, en especial a Trelew. Las lluvias inundan distintos barrios, dejando en evidencia la mala planificación y la falta de obras básicas de infraestructura. Cientos de habitantes ven sus casas derrumbadas o inutilizables y miles pierden sus posesiones al entrar el agua a sus viviendas. Llega a la zona el secretario de desarrollo social de la Nación, Ramón "Palito" Ortega, quién anuncia una gran cobertura de asistencia para los damnificados.

Obviamente casi toda esta ayuda nunca llega a los perjudicados en forma directa, y así se realizan protestas de habitantes de los barrios populares el 26 y 28 de marzo. Muchos de ellos son desocupados, algunos conformaron los intentos de agrupaciones de desocupados y otros realizan sus primeras experiencias en este tipo de hechos. Maestro se ve obligado, por la magnitud del desastre y por las protestas populares, a posponer la consulta por su re-reelección.

Luego de comprar todos los canales de la zona Supercanal Holding inicia los despidos de personal a fines de mayo. La empresa pretende imponer al personal condiciones de trabajo absolutamente precarizadas. El SAT decide un paro de actividades y el corte de la calle frente al edificio del canal en Trelew. Es un conflicto 
que toma gran relevancia social, en especial porque deja sin televisión a toda la provincia.

Supercanal no acepta la conciliación. EI SAT denuncia que la policía les había impedido ingresar al canal a hablar con algunos empleados que volvieron a trabajar. El 2 de junio colocan carpas frente a las oficinas en Trelew y Comodoro Rivadavia. Los trabajadores reciben la solidaridad de varios sectores, y a través de comunicados de la FUP, el FUICh y la UOCRA. Supercanal finalmente acepta la conciliación, debiendo reincorporar los despedidos de Trelew, Puerto Madryn y Comodoro. Es una victoria parcial del reclamo que supo tener gran impacto en la población, especialmente por las denuncias de monopolio y extranjerización. De todas maneras el conflicto seguiría.

El 31 de julio reaparece la crisis en Supercanal. Luego de la conciliación se produjeron unos cincuenta y tres despidos encubiertos bajo la forma de retiros voluntarios y se anuncian nueve despidos directos para los próximos días. EI SAT amenaza con medidas de fuerza, mientras aparecen pintadas y se denuncian sabotajes a la señal de cable.

Al iniciarse agosto el SAT se moviliza cortando la calle principal de Trelew. Se convoca a un paro por tiempo indeterminado hasta asegurar la continuidad de los trabajadores. El 2 y 3 se suma la quema de cubiertas al corte de calle y el 3 además se logra ingresar al edificio del canal, tomando sus instalaciones aunque sin impedir que continúe la emisión de la señal. Ese día por la noche se inician las negociaciones que culminan con un acuerdo por el cual se reincorpora a seis de los despedidos, aceptando los otros un retiro voluntario. Es un conflicto importante, porque muestra el proceso de cambio en la estructura económica social (con sus elementos de concentración económica y extranjerización de la propiedad) y las consecuencias para los trabajadores. Pero a su vez presenta elementos de fuerte resistencia entre los trabajadores, aún en condiciones de gran debilidad por la situación monopólica de la empresa.

El 10 de agosto Maestro anuncia, al igual que ya lo había hecho Menem, que dejaba de lado su intento re-reeleccionista, suspendiendo el plebiscito convocado para octubre. Son muestras claras de la situación de desgaste social y de la pérdida de hegemonía absoluta de su proyecto.

Tras varios conflictos en fábricas textiles, los gremios vuelven a solicitar la formalización de un "pacto social" con el gobierno provincial y las cámaras empresarias, proponiendo que no haya despidos ni suspensiones hasta que se obtengan las nuevas leyes de promoción presentadas al gobierno nacional. Mientras se seguía hablando de pacto, Foderami produce catorce despidos directos y no 
renueva dieciséis contratos, y Pelama anuncia el cierre de su planta por tres semanas. Al otro día se dicta la conciliación obligatoria en el caso de Foderami.

La nueva reforma laboral votada por la cámara de diputados de la nación en septiembre tiene una visión bastante positiva entre los dirigentes sindicales de la región. Los sindicalistas de Setia, AOT, Uocra y el Sec coinciden en señalar que no es tan negativa como el proyecto inicial sostenido por la UIA, que eliminaba en mayor medida los derechos de los trabajadores y el poder de los sindicatos. Sin embargo también coinciden en que esta ley no solucionaría el desempleo. Mucho más crítico es Vernetti, subsecretario de trabajo de la provincia, quién destaca que se perdieron conquistas históricas, citando la legalización de los "contratos basura" y la rebaja de las indemnizaciones como una herramienta que permitirá reemplazar a los trabajadores de planta por otros precarizados.

El 26 de octubre Arcoplus decide cerrar las puertas de la fábrica en forma sorpresiva. Aducen que no hay materia prima para procesar. Los noventa empleados solicitan la intervención de los gremios que inician negociaciones con la empresa y el gobierno. Al final del día se decide abrir la fábrica aunque la problemática sigue latente, ya que la empresa plantea que si no logran vender la fábrica a otro grupo ellos no pueden asegurar la continuidad. Son capitales mexicanos que habían comprado la antigua Modecraft. También había problemas en Windsor, que decide cerrar dos días por semana, y Lanera Austral, que extendió la suspensión del personal.

Ante la falta de pago de los salarios, los docentes de casi todas las escuelas medias de Puerto Madryn deciden suspender el dictado de clases a partir del día 12 de noviembre. La medida es acompañada por los alumnos y surge en forma auto convocada desde la escuela 750. Al otro día los docentes de varias escuelas de Trelew también toman medidas, con acciones de protesta como sentadas, carteles en las puertas de las escuelas, etc. Se remarca en las declaraciones que no hay representación por parte de la Atech, dejando en claro que esta medida no es convocada por el sindicato.

Estos hechos se constituyen en un fuerte cuestionamiento a esa dirigencia gremial. Un día antes la Atech había convocado una huelga en el marco de una medida nacional, consiguiendo una adhesión que apenas superaba el 10\% y sin poder realizar ninguna acción en la calle.

Al comenzar diciembre se hace ya oficial el proceso de liquidación de Arcoplus. Los trabajadores ya saben que se quedaran definitivamente sin trabajo y ahora la pelea pasa por intentar cobrar lo que les deben. La propuesta de la empresa es pagarles las quincenas adeudadas y el aguinaldo en cinco cuotas, en tanto que de las vacaciones e indemnizaciones sólo pagarían el 50\% y en diez cuotas. Los sindicatos 
se niegan a aceptar esto, denunciando que hay un intento de vaciar la fábrica con el desarme de las máquinas, y afirmando que la empresa no se va por crisis económica sino por una decisión empresarial. Se dicta entonces la conciliación obligatoria que tendría una larga negociación por delante.

El 9 se da puntapié a un importante proceso de luchas por el atraso salarial en el Estado, que tendría su punto más alto en este mes de diciembre. La conducción de la Atech intenta recuperar parte del terreno perdido como representación de los docentes realizando una olla popular en la plaza de Trelew y amenazando con medidas de fuerza directas.

El 11 los empleados y médicos del Hospital de Puerto Madryn realizan una asamblea y una sentada frente al edificio, mientras los docentes de la ciudad inician medidas de fuerza negándose a dar clases. Esto se hace por fuera de la Atech, como "autoconvocados". Para el 14 la cosa tomaba más calor. La falta de compromiso de fecha de cobro, y el temor de lo que pudiera pasar en enero y febrero, llevaba la protesta más allá de lo esperado. La conducción de Atech es superada por los docentes que se agrupan en formas autoconvocadas, denunciando la falta de representatividad del gremio y su política de "buenas relaciones" con el ministerio de educación. Un grupo de docentes de Rawson realiza una sentada frente a la Casa de Gobierno, abandonando sus lugares de trabajo, mientras en Trelew y Madryn marchan docentes y personal del hospital a las plazas de cada ciudad. Uno de los diarios de la región plantea que puede sentirse un clima de repudio al gobierno como no se palpaba desde $1990^{175}$.

El 15 el gobierno toma la decisión de suspender las clases hasta febrero de 1999. Intentaban frenar el proceso de protestas al vaciar las escuelas. Sin embargo ese día una marcha docente toma el ministerio de educación. Nuevamente el 17 hay marchas y actos en Trelew, Rawson y Puerto Madryn. Se cortan calles y se ocupan durante horas las escaleras de entrada a la Casa de Gobierno en Rawson. Son más de setecientos docentes de Rawson, Trelew y Madryn. Hay duras críticas al gobierno provincial, amenazando con no comenzar las clases en 1999. Además se comprometen a reunirse el quinto día hábil de enero y febrero si se repite el atraso en el cobro. En Trelew ya se había hecho costumbre concentrarse para marchar desde la sede de la "iniciativa popular" que seguía impulsando el proyecto de re-reelección de Maestro, en un claro desafío al poder del gobernador.

El inicio de 1999 tuvo a los trabajadores de Arcoplus y de $\operatorname{Ados}^{176}$ pasando esta fecha ocupando sus lugares de trabajo para reclamar el pago de salarios atrasados.

\footnotetext{
175 Diario Jornada, 15/12/1998, pág. 8-9.

${ }^{176}$ Asociación de Obras Sociales.
} 
En el caso de Arcoplus esto es más triste, porque esos trabajadores ya saben que son nuevos desocupados. Las trabajadoras de Ados deciden continuar con la ocupación de las oficinas hasta el 7 de enero, cuando toman el sanatorio y directamente impiden toda prestación de salud hasta que se les pague lo que les deben.

EI 5 de enero la AOT sigue intentando solucionar algunos de los conflictos, en especial los de Arcoplus, Pelama y Surjet. Destacan que cuando asumieron tenían 1800 afiliados y ahora sólo hay 1210 y que están angustiados por verse obligados a estar constantemente negociando indemnizaciones. El problema es que sus propios límites políticos, anclados en la búsqueda de acuerdos con la patronal, circunscriben su accionar a las negociaciones legales. No hay protestas ni luchas significativas.

El 22 los trabajadores de Harengus realizan una protesta quemando gomas frente a la empresa y luego se dirigen al centro de la ciudad poniendo una carpa frente al municipio de Puerto Madryn. Reclaman el pago del aguinaldo y las vacaciones.

Febrero comienza con el reclamo de las trabajadoras de Ados de que se paguen los dos meses que todavía les adeudan, y que se vuelva atrás la decisión de despedir a dos trabajadoras. Denuncian la falta de acompañamiento de Atsa. El directorio de Ados no reconoce estos reclamos, solicitando que se presente el sindicato reconocido como representante legal, mientras las trabajadoras defienden la comisión interna elegida por asamblea.

Surjet decide, luego de haber trasladado la tintorería a Buenos Aires, suspender al resto del personal por treinta días sin pago. Tras las negociaciones se acepta una suspensión parcial por sesenta días, durante la cual los obreros cobrarían el $75 \%$ del sueldo. La empresa plantea que la crisis brasileña le produjo un sobre stock de tres millones de metros de tela. La dirigencia de AOT destaca a los empresarios de Surjet por su apertura al diálogo, criticando en cambio a los de Foderami.

Allí el conflicto sigue, y para el 26 Foderami anuncia el despido de sesenta trabajadores y recurre al procedimiento de crisis para pagar sólo el 50\% de las indemnizaciones. El Setia rechaza la medida y propone la posibilidad de aceptar una suspensión o una reducción de jornadas. Como viene sucediendo no hay medidas de protesta pública o algo que pudiera presionar a la empresa o al gobierno.

En marzo comienza un conflicto en Windsor, donde los trabajadores deciden tomar la planta ante el despido de seis operarios. Los delegados internos de la AOT afirman que la patronal despide de forma arbitraria, buscando luego justificaciones y que ellos no aceptarían estas prácticas. Por su parte la patronal amenaza con que ahora se llegaría al menos a veinte despidos, debido a los agravios recibidos por el encargado y los dueños. El problema habría surgido porque los operarios se negaban 
a operar veinte telares, aceptando tomar solamente doce, como era costumbre en el parque.

Esos días también vuelven a aparecer los conflictos en Del Estero (donde los ex trabajadores de esa fábrica cerrada inician juicios por el pago de las deudas), en Britalco y Fipasa (con atrasos salariales y problemas de producción en ambas fábricas de Puerto Madryn y Dolavon) y en Prosur (donde el 10 de marzo se inicia la retención de servicios por el atraso en el pago de quincenas).

Mientras el Setia se despega de la toma en Windsor (los despedidos son todos de la AOT), la patronal denuncia penalmente a los delegados de la AOT por la ocupación. El Setia además afirma que se debe tener cuidado con la intransigencia en el caso de Foderami porque esta empresa tiene planta en San Juan y podría convenirle cerrar su planta de Trelew y pasar todo a esa provincia, donde hay promoción industrial ${ }^{177}$. Este tipo de declaraciones aumentaban el temor y la desmoralización de los trabajadores y daban argumentos a los empresarios para imponer sus condiciones.

La ocupación de Windsor se levanta cuando la empresa acepta reincorporar a los despedidos, aunque decide una sanción disciplinaria de cinco días sin pago y se niega a pagar los días de toma a todo el personal.

La Atech decide convocar un paro de actividades para el inicio de clases. Los delegados de Comodoro Rivadavia reclaman que el paro sea por tiempo indeterminado, pero esto no es aceptado. La huelga se realiza el día 15, fecha del inicio de clases, y tiene una adhesión del 60\%, según la Atech (para el gobierno es del $9 \%$, mientras que algunos relevamientos más serios dan alrededor de un $35 \%$ global). En Rawson el paro es importante, con la adhesión de los autoconvocados, que además marchan a la Casa de Gobierno y la Legislatura. Se plantea que el próximo paso sería una huelga de 48 horas.

Ese día también comienzan protestas de varios sectores estatales por el atraso en los sueldos. El personal del Hospital de Trelew empieza una retención de servicios hasta el cobro y cortan la calle durante varias horas. Los empleados judiciales realizan paros parciales en sus lugares de trabajo. Los conflictos se frenan con el pago de los salarios a todos los estatales.

Los jubilados provinciales realizan una importante marcha de casi cuatrocientas personas el 12 de abril. Se concentran en Rawson jubilados de esa ciudad, Trelew, Comodoro, Puerto Madryn y Esquel, con el apoyo de ATE, Sitravich, Judiciales y

\footnotetext{
${ }^{177}$ Diario Jornada, 9/3/1999, declaraciones de Juan París, secretario general de Setia, pág. 8.
} 
empleados legislativos. Reclaman el pago en término y que la obra social de la provincia sea administrada por los trabajadores estatales.

También ese día en Puerto Madryn se inician las protestas de todos los meses por el atraso en el pago salarial. El punto importante de cambio es que la movilización retoma el grado de unidad alcanzado el último mes, y se presenta como "Frente de Gremios Estatales", agrupando judiciales, viales, hospitalarios, municipales y los docentes autoconvocados. Los judiciales realizan una retención de servicios de dos horas por turno. Se conoce ese día que algunos de los docentes autoconvocados habían sido expulsados de la Atech en el último congreso del gremio.

El conflicto textil sigue en curso, con el anuncio de que Foderami finalmente despedirá treinta y siete obreros desde el 31 de junio. Los gremios plantean que nada se puede hacer en contra de esta medida. Asimismo hay deudas en Prosur y Windsor, mientras varias fábricas están echando gente poco a poco, arreglando las indemnizaciones en forma individual. Setia y AOT siguen planteando como estrategia la presentación de la promoción industrial, haciendo especial hincapié en recurrir a los diputados nacionales de extracción sindical como Saúl Ubaldini.

En mayo comienza un proceso de protestas contra el decreto del gobierno nacional que determinaba un recorte al presupuesto educativo. Esta decisión generó el rechazo de gran parte de la sociedad, al punto que creo divisiones en el gobierno que llevaron a la renuncia de la ministra de educación Susana Decibe. El 7 más de doscientas personas realizan una clase pública frente al municipio con la participación de los Centros de Estudiantes de Humanidades, Abogacía, Naturales, Económicas, la Federación Universitaria de la Patagonia, las agrupaciones Fuich, La Corriente, Franja Morada, ATE, Atech, Sitravich, Apunp, docentes y autoridades de la universidad, estudiantes secundarios, vecinalistas y el Frepaso. La Atech convoca al paro nacional para el martes 11 que había salido desde la Ctera, la FUA, FUBA y la Conadu.

En Puerto Madryn el 8 se realiza una asamblea en conjunto de la UTN y la sede local de la UNP, convocando a un acto para el lunes con el apoyo de la CTA, docentes Autoconvocados y ATE. El lunes 10 se realiza una "toma activa" de la sede Trelew, que consistía en la realización de clases públicas. En Madryn más de doscientas personas se movilizan en la plaza y en Comodoro una gran marcha recorre los cuatro kilómetros que separan la Universidad del centro de la ciudad.

El gobierno provincial decide declarar día no laborable en la educación para el 11, sin embargo luego ningún funcionario asiste a las marchas en las distintas ciudades de la provincia. En Trelew alrededor de setecientas personas se concentran en las puertas de la UNP marchando hasta la plaza independencia, donde se realiza 
un acto. En Madryn también se realiza una concentración en la plaza, aunque con menor número de participantes.

Para junio es el conflicto pesquero el que hace eclosión. El $1{ }^{\circ}$ ciento cincuenta trabajadores pertenecientes a los gremios de la Coordinadora de Gremios Marítimos (en especial del Stia) se movilizan en Puerto Madryn y luego se dirigen a la Capital Federal para participar de una marcha nacional. También participan de la protesta obreros del Somu, llevando los barcos al puerto, con carteles y haciendo sonar las sirenas.

Los días siguientes el problema de la pesca y la veda a la captura de merluza llena de internas y disputas a la ciudad de Madryn. Se realiza un debate público en el cual se expresan los sectores fresqueros, congeladores, las plantas en tierra y los sindicatos. Las luchas internas se expresan entre las grandes empresas transnacionales con flotas de congeladores y las empresas no tan importantes (también muchas extranjeras pero con mayor participación nacional) de barcos fresqueros con plantas en tierra.

En los últimos años la flota congeladora originaria de la Comunidad Europea se había visto favorecida por las leyes y la falta de controles. Se habían realizado negocios multi millonarios al costo de vaciar los mares argentinos y dejar sin puestos de trabajo estables a las ciudades que dependían de este recurso. El acuerdo de 1992, ratificado por el Congreso recién en 1994, autorizaba a que los grandes congeladores de origen europeo compraran permisos de pesca de buques fresqueros, cuando el impacto sobre el recurso no era comparable. Entre 1992 y 1998 la captura de merluza hubsi en Argentina se duplicó, como consecuencia de la presión que generaban los barcos congeladores, depredando un recurso que hasta ese momento se había explotado de forma más racional.

Al comenzar julio Surjet anuncia el despido de veintiún operarios textiles, estos eran parte de la tintorería que había cerrado tiempo atrás. Para la AOT este hecho constituye una "traición" de la empresa ya que estaban en un marco de negociaciones ${ }^{178}$.

La Uocra realiza un corte de la ruta 3 por cinco horas, que es levantado tras el anuncio de Maestro de que les daría una audiencia. El reclamo específico pasa por la reactivación de la obra pública y el pago en término a las empresas, para que estas puedan pagar los salarios en fecha.

En Puerto Madryn se conforma la "Agrupación de Mujeres Desocupadas" que reclama, en una asamblea pública, se garanticen soluciones a sus problemáticas de

\footnotetext{
${ }^{178}$ Diario Jornada, 1/7/1999, declaraciones de Sergio Cárdenas, dirigente de AOT, pág. 11.
} 
trabajo, vivienda y servicios. Esto se había agravado con la crisis pesquera, actividad donde muchas de ellas tenían trabajo.

Además de ellas son varios los grupos de desocupados que vuelven a hacerse visibles. Un grupo comienza una protesta que consiste en ocupar la plaza central de Trelew. Allí pasan meses, en una especie de campamento improvisado, rompiendo el cerco que durante años había dejado el problema delimitado a los barrios pobres, y generando la solidaridad de agrupaciones estudiantiles y algunos sindicatos.

El grupo que ocupa este espacio desde el 22 de julio es sumamente heterogéneo y sin una línea política clara. Durante la protesta cambian varias veces el nombre con el que se autodenominan y, mientras al iniciar el hecho lo canalizan hacia reclamos más institucionales (planteando la junta de firmas para presentar un proyecto de ley y postulando a uno de sus dirigentes como candidato a intendente), tras un mes de lucha llaman el 23 de agosto a no votar y a desconocer los espacios institucionales, ya que los desocupados sólo lograrían sus pedidos a través de la movilización en la calle $e^{179}$.

Atech convoca a un paro con asistencia al lugar de trabajo desde el 9 de agosto reclamando el pago del incentivo docente y los salarios. Pese a que se paga el incentivo, el atraso salarial lleva a fijar la huelga formal desde el 10, y a iniciar movilizaciones.

En septiembre el grupo que ocupaba el centro de la plaza de Trelew, ahora denominado "Coordinadora de Trabajadores Desocupados y Excluidos Sociales", se moviliza al Concejo Deliberante y al Municipio de Trelew en varias oportunidades.

Al comenzar octubre el Stia realiza durante varios días una protesta con quema de cubiertas frente a Conarpesa por los despidos sin causa justificada. Especialmente repudian el intento de la empresa de imponer un régimen de asistencia obligatoria.

Casi toda la actividad política de este mes se plantea alrededor de las elecciones que se realizarían el 24 de octubre. Es así que vemos caer significativamente los hechos de protesta, algo ya registrado desde los meses pasados. La provincia se ocupa de pagar los sueldos de los estatales en término para evitar las marchas y paros que se repetían todos los meses anteriores.

A nivel nacional, y tras diez años de gobierno del $\mathrm{PJ}$, es elegido como presidente el candidato de la Alianza, Fernando De la Rúa. Esto provoca expectativas en varios sectores de la clase obrera y en especial de la pequeña burguesía. Esa expectativa será rápidamente defraudada, y la lucha comenzará a expresarse nuevamente en alza.

\footnotetext{
179 Diario Jornada, 24/8/1999, declaraciones de Alicia Velásquez y María Barrientos, integrantes de la coordinadora de desocupados, pág. 10.
} 
En Chubut triunfó el candidato del oficialismo, José Luís Lizurume, con el importante efecto arrastre del hombre fuerte de la provincia, Carlos Maestro, que era el primer candidato a diputado nacional. A intendente de Trelew ganó la Alianza con el $45 \%$, en Rawson el PJ con el 38\% (por menos de un punto sobre la Alianza), en Puerto Madryn también el PJ con el $46 \%$, en Gaiman el PACH con el $43 \%$ y en Comodoro Rivadavia la Alianza con el $37 \%$.

Durante todo el mes de diciembre en Puerto Madryn se realizan una serie de marchas reclamando "seguridad". Son convocadas por la Cámara de Industria, Comercio y Producción de Madryn y adhieren la Cámara de Microempresarios, la Asociación de Taxis, el Consejo de Localidad Peronista y otras organizaciones empresariales. Es fundamentalmente la pequeña burguesía acomodada de la ciudad que empezaba a sufrir la situación de empobrecimiento a la que se veían empujados amplios sectores de la clase obrera, y que veían como solución de esa problemática la persecución de esos sectores desplazados de la producción.

Las marchas van creciendo en el número de participantes. En la última marcha ya había asumido la intendencia Aristarain, del PJ, quién se compromete a encabezar este reclamo. Las cámaras convocantes deciden dejar las movilizaciones como una manera de expresar la confianza en el nuevo gobierno municipal.

Alpesca anuncia la suspensión de todo su personal por la veda de merluza. El Stia reclama que, al igual que en las otras plantas, se tome este período como vacaciones y no como suspensión. Según la empresa sólo podría hacer esto si recibe un préstamo de la provincia ya que se encuentra sin dinero (esta es la principal planta fresquera de la ciudad).

Convocados por la Uocra el 17 de diciembre los trabajadores de empresas contratistas de Aluar realizan una asamblea pública. Reclaman el pago de un premio de $\$ 150$ por productividad que debía habérseles abonado hacía varios días.

Desde el 10 de diciembre, fecha de asunción del nuevo gobierno nacional, estaba cortado el puente que comunica Corrientes con Chaco. La pelea entre distintos sectores políticos de la provincia había agravado la ya difícil situación de la población, provocando la falta de pago de los salarios y la caída general de la economía. El gobierno de De la Rúa ordena la represión para el día 17 que, en manos de la gendarmería, se realiza de madrugada sobre una multitud que se encontraba "atrapada" en el puente ante los disparos. Allí la Alianza se cobra los primeros dos muertos en movilizaciones populares de los muchos que se llevaría en su corto periodo de gobierno.

Pese a que todos los datos mostraban que las balas habían surgido de los rifles calibre 22 de la gendarmería, tanto Storani como Chacho Álvarez y Alfonsín 
acusan a "grupos infiltrados", nombrando a Quebracho y Patria Libre ${ }^{180}$. El gobierno anuncia la intervención de la provincia y una partida especial de dinero para pagar los sueldos.

ATE convoca a un paro nacional para el 20, mientras en Corrientes una multitudinaria manifestación acompañaba los restos de los dos jóvenes asesinados, uno de ellos changarín y el otro cartonero. En Trelew la CTA, ATE y el centro de estudiantes de Humanidades realizan un acto en repudio de los asesinatos.

También había conflicto en Sierra Grande, donde desde el 16 de diciembre se realiza un corte de ruta que dura hasta el 20. Reclaman la reincorporación de obreros despedidos por Hiparsa (Hierros Patagónico S.A.), empresa que estaba ahora en manos de la provincia. Además se les deben los sueldos de octubre y noviembre.

El año termina con la decisión de la Ctera de levantar la carpa blanca ante el compromiso del gobierno nacional de cumplimentar los reclamos que la Confederación venia realizando. En verdad el levantamiento de la carpa obedecía a que la dirigencia de la Ctera era parte del proyecto del Frepaso, de hecho sus dirigentes llegan a la reunión con el gobierno junto al vicepresidente, Carlos Álvarez. La Atech festeja el acuerdo con el gobierno nacional realizando un brindis en el local del sindicato.

\subsection{La rebelión en el NE del Chubut: $2000-2002$}

El período que enmarcamos aquí va desde el enfrentamiento en el puente que une Chaco y Corrientes hasta los sucesos del Puente Pueyrredón, en el límite entre Avellaneda y Capital Federal. Entre uno y otro puente se desarrollan los hechos de diciembre de 2001, que marcan, sin dudas, un punto de inflexión en la historia del país $y$, aún más evidentemente, en el ciclo de luchas de la clase obrera. A nivel nacional el PIMSA sostiene que aquí se produce un momento ascendente dentro del ciclo que había comenzado a fines de 1993 y que venía de un momento descendente entre 1997 y 1999. Así como lo hacemos en toda la descripción de los hechos que vamos trabajando, intentaremos volver a poner en debate esta periodización nacional con el proceso regional en la parte final de nuestra tesis.

En el nuevo gobierno provincial había asumido como responsable de la Subsecretaría de Trabajo uno de los máximos dirigentes del Setia, Patricio Rivera. Este hombre destaca la reactivación de la economía y la ausencia de conflictos graves, salvo los "normales" de atrasos en el pago de salarios. Es llamativo su apoyo a un gobierno que ya había planteado sacar una nueva reforma laboral que implicaba una profundización en la precarización de los derechos laborales. De la Rúa rechaza

\footnotetext{
${ }^{180}$ Diario Jornada, 18/12/1999, pág. 15.
} 
toda posibilidad de romper con el FMI o con la convertibilidad, como le reclamaba el sector sindical que lideraba Hugo Moyano.

Durante los siguientes días se realiza una constante propaganda acerca de una supuesta reactivación en la economía regional, especialmente en el parque textil. Según los dirigentes sindicales los anuncios de aranceles contra la importación de textiles asiáticos daban un marco más promisorio a la actividad. En los últimos dos meses se habrían incorporado unos ciento setenta nuevos trabajadores, aunque muchas de estas incorporaciones se debían a la necesidad de cumplimentar el número mínimo de empleados que reclamaba la ley de promoción industrial. Además seguía habiendo problemas con los salarios en Windsor, Prosur, Foderami y Punilla.

A fines de enero el personal de la textil Britalco, de Puerto Madryn, comienza una protesta pública que desde el 22 se convierte en una retención de servicios por el atraso salarial. Lentamente, mediante el pago de pequeñas sumas en lugar del pago total de las quincenas, se había acumulado una deuda de cuatro quincenas. La AOT apoya el reclamo mientras también genera una protesta con quema de cubiertas frente a Prosur, en Trelew.

Se realiza una reunión de varios gremios que se pronuncian en contra de la reforma laboral. La expresión pública de este rechazo es la publicación de solicitadas en los diarios, donde se denuncia que la ley avanza en la precarización y la quita de derechos, buscando atacar a la organización sindical como ámbito de defensa de los trabajadores. Firman el Setia, AOT, SEC, Telefónicos, Judiciales, Luz y Fuerza, UOM, Panaderos, Somu, Smata, Supa, Viajantes, Sutiaga, Ceramistas, Municipales, Bancarios, Uocra, Apinta, Stia, Atsa, Saon, Uatre y Fentos.

La CGT ratifica el paro y movilización llamado para el 24 de febrero, fecha en la cual se trataría la reforma laboral en diputados. El 22 la CGT del valle del Chubut, en la voz del dirigente del Setia, anuncia que no habría paro en la zona. Se dice que se intentaría enviar gente a la movilización, medida que luego no se realiza.

También la CTA de la zona se declara en contra de la reforma laboral y decide adherir a la movilización convocada para el 24. Para la CTA es una situación compleja que la atraviesa de fuertes internas, ya que significaba confrontar con el gobierno del cual muchos de sus dirigentes eran parte. A la vez no hacer nada era dejar en manos de la CGT el rol de oposición a un avance contra los derechos de los trabajadores. Finalmente convocan, pero a un acto aparte del llamado por la CGT, dividiendo la fuerza de una posible acción unitaria.

Para el 24 los cuadros sindicales llegan aún más divididos a la lucha contra la reforma laboral. Mientras la burguesía se unificaba con la expresión favorable a la reforma de todos los sectores empresarios, la clase obrera no lograba expresar una 
táctica común. A la ya planteada división entre CTA y CGT, se sumaba ahora la división dentro de la CGT, ya que el sector de Daer acepta negociar una serie de cambios al proyecto original y a cambio de esto se "baja" de la marcha y el paro.

Por su parte el sector de Moyano más la UOM, el Smata y la Uocra, mantenían la medida y asumían un fuerte discurso de confrontación con el gobierno. Las marchas no logran frenar la votación favorable en diputados, aunque sí se concentra una importante movilización en Plaza de Mayo. Es pequeña en cambio la movilización convocada por la CTA.

Moyano ratifica su confianza en que la ley se frenaría en el senado por el voto en contra del PJ que en esa cámara mantenía su mayoría. También para el PJ era complicado fijar una posición, ya que se mezclaba la intención de oponerse al primer paso fuerte del gobierno de la Alianza con la lógica de su condición de cuadros de la burguesía y con el programa que habían votado durante todo el gobierno de Menem. Finalmente optaron en su mayoría por su condición de cuadros de la burguesía, expresión reforzada con el recurso a los sobornos que varios de ellos habrían recibido a cambio de votar a favor (algo propio de la burguesía del capitalismo en decadencia en el que vivimos, donde los negocios parasitarios son parte estructural del sistema). También este tema generaba problemas dentro de la Alianza, ya que se contradecía con su postura cuando era oposición (especialmente en el caso del Frepaso) y, como veíamos en el caso del CTA, porque producía contradicciones en los intereses de algunos dirigentes que venían del sindicalismo. En diputados votan en contra de la reforma Alicia Castro, Alfredo Bravo, Héctor Polino, Jorge Rivas y Elisa Carrió.

Los gremios textiles realizan reuniones con los bloques de diputados para solicitar la sanción de una ley que imponga sanciones más duras a los empresarios que se lleven las maquinarias compradas en el marco de la promoción industrial. Denuncian que los empresarios cierran las fábricas y se llevan las máquinas a otras provincias con promoción como San Luís o Tierra del Fuego, algo sabido tiempo atrás y con lo cual había una inocultable connivencia de funcionarios del gobierno.

Los últimos días de marzo son de anuncios nada buenos para los trabajadores de la provincia: volvería a implantarse la veda a la pesca de merluza, termina la promoción industrial para Foderami, una de las empresas más importantes del sector textil, y la Uocra y un grupo de desocupados reclaman en los medios que se les otorguen planes trabajar.

En los primeros días de abril se anuncia desde la CGT-Moyano la convocatoria a una huelga y movilización para el día en que se trataría el proyecto. A nivel regional la CGT y la Iglesia anuncian que para el $1^{\circ}$ de mayo realizarán una misa de los 
trabajadores, en homenaje a lo que llaman "el día del trabajo", y para solicitar una mejor situación laboral.

El mes termina con el anuncio del despido de veinte trabajadores de la empresa Nylotex, argumentando una grave caída en su actividad. La AOT manifiesta su repudio planteando que la medida es ilegal y expresan que están "decepcionados", porque ellos vienen trabajando en evitar conflictos con las empresas para cuidar los puestos de trabajo pero reciben estas respuestas de los empresarios ${ }^{181}$.

El 1ํ de mayo se realiza la misa en la plaza central de Trelew, con la presencia de la iglesia católica, de los dirigentes sindicales de la CGT y de políticos del PJ y la UCR, incluido el vicegobernador de la provincia.

Para el 5 se convoca una huelga general por la CGT "disidente" (dirigida por Hugo Moyano) y la CTA, contra la reforma laboral. La huelga tiene escasa adhesión en nuestra región, sólo es total en el transporte, donde se denuncian ataques con miguelitos. En la administración pública el paro no tiene incidencia, como tampoco en los textiles, metalúrgicos y pesqueros. No hay manifestaciones en la calle de ningún sector.

A nivel nacional el paro tiene una adhesión importante y un fuerte impacto político, con la paralización del transporte público y de cargas y la adhesión de docentes y estatales. Hay cortes de rutas, piquetes de huelga, enfrentamientos con la policía, toma de supermercados y ataques a micros de corta, larga y media distancia. El ministro de economía, Machinea, anuncia que además de la reforma laboral se realizaría en poco tiempo un nuevo ajuste para estabilizar la economía.

El 12 hay enfrentamientos en Salta entre piqueteros y gendarmería, que intenta desalojarlos de los cortes de rutas que mantenían desde hacía diez días. Hay varios heridos, incendios de edificios públicos, negocios y viviendas de General Mosconi y una situación nacional que iba agravando el clima de confrontación social. Este clima se sentía también en nuestra región y es así que, aunque aún no se producían hechos importantes de lucha en la calle, el gobierno sale a denunciar la supuesta presencia de "agitadores trotskistas" en Trelew y Comodoro Rivadavia, que serían "ex integrantes del ERP y Montoneros que agitan a los sectores necesitados"182.

Como es cada vez más común otro grupo de desocupados corta la ruta №3 hacia fines de mayo. El corte solicita comenzar a negociar con el gobierno y que se terminen con los ataques como los de Maglione. No hay intención de tomar la posición

\footnotetext{
181 Diario Jornada, 29/4/2000, declaraciones de Sergio Cárdenas, pág. 5. Pocos días antes Juan París, también hablaba de "decepción" ante la aprobación de la nueva ley de reforma laboral, ver Diario Jornada 28/4/2000, pág. 8.

${ }^{182}$ Diario Jornada, declaraciones de Enrique Maglione, secretario de seguridad de la provincia, 19/5/2000, pág. 3.
} 
y defenderla hasta conseguir lo que reclaman o de enfrentar una posible represión, sino que levantan el corte antes de que se produzca cualquier enfrentamiento. Sí amenazan con volver a cortar si no reciben respuestas, en especial alimentos y planes sociales.

El 30 de mayo se realiza una nueva marcha nacional pesquera, con la llegada de alrededor de mil quinientos trabajadores de nuestra región. Se reclama el procesamiento del pescado en tierra. Ese día en Comodoro Rivadavia se produce un corte de la ruta 3 por parte de petroleros, que reclaman la reincorporación de trescientos desocupados del sector.

En junio se realiza otra huelga nacional convocada por la CGT oficial, la CGT disidente, la CTA y la CCC. Se pronuncian en contra del anuncio del gobierno nacional de un nuevo ajuste, con reducción de salarios y fusión de organismos públicos. Las Cámaras de Comercio de Trelew y Puerto Madryn convocan a adherir y llaman a no descontar el día, ya que el ajuste quitaba beneficios a la región.

Para el 9 de junio hay pronunciamientos de la gran mayoría de la sociedad de la región en apoyo a la huelga. Se expresan la CGT regional, la Mesa de Enlace sindical, la CTA, Ate, Atech, Sindicato de Comercio, de Camioneros, Municipales de Madryn, Trelew y Rawson, Judiciales, la Asociación Bancaria, Luz y Fuerza, Apinta, Utedyc, Pecifa. EI MID y el Partido Socialista apoyan el paro nacional aún desde dentro de la alianza, así como el Frepaso de Madryn se opone al ajuste aunque no se expresa sobre la huelga. UPCN convoca a un paro el 8 además del paro nacional del 9. $Y$ mientras el ministro de gobierno dice que no hay motivos para hacer paro en Chubut y llama a no confundir lo provincial con lo nacional, la "Nueva comisión de Desocupados", junto a los Centros de Estudiantes de Humanidades y Naturales de la Universidad, centros de estudiantes secundarios y los sindicatos SAT, ATSA, Sitravich, ATE, Atech, APUNP y judiciales, convocan a una movilización para el día del paro a la plaza central de Trelew. La huelga tiene adhesión en todas las ciudades menos en Rawson (no fue importante en la administración pública) y un gran impacto político tanto en Puerto Madryn como en Trelew.

En Trelew la movilización es importante, en una marcha que culmina frente a la Universidad Nacional de la Patagonia y a la que asisten muchos integrantes de sindicatos industriales que no habían sido convocados por sus dirigencias. Y es que pese a los discursos sobre una "reactivación", siguen los cierres de fábricas, las suspensiones y despidos. La expectativa en que el nuevo presidente cambiaría la política hacia el sector textil y pesquero se desvanecía rápidamente.

Además de esta movilización se producen quemas de cubiertas frente a los supermercados en Madryn y en Trelew. En Madryn se realiza un pequeño acto en la 
plaza con la presencia de municipales, judiciales, personal de la DGI, ATE, Apunp y el Movimiento de Autoconvocados.

A nivel nacional la huelga tuvo gran repercusión, debiendo reconocer su éxito hasta el gobierno nacional que plantea una reapertura del diálogo. La adhesión supera el $80 \%$ y se producen marchas, cortes de rutas y choques con la policía en casi todas las provincias.

Durante la primera parte del 2000 avanza en su organización estable en Trelew un grupo de desocupados, que se estructura como parte del MIJD ${ }^{183}$. Es un cambio importante en el proceso de organización de este sector de la clase obrera de nuestra región ya que por primera vez se consolida un grupo con referencia nacional y dirigencia estable que permanecerá en el tiempo. Es una superación con respecto al proceso anterior, caracterizado por la aparición de pequeños grupos que no permanecían con una identidad común más que unos pocos meses. Ya para julio el MIJD se moviliza repetidas veces al Ministerio de Trabajo de la Nación para reclamar la puesta en marcha de distintos proyectos comunitarios.

También los desocupados de Puerto Madryn avanzan en su organización y se movilizan al Concejo Deliberante tomándolo por algunas horas el 13 de julio. Reclaman planes trabajar, bolsas de alimentos, garrafas y subsidios para la luz y los medicamentos.

Se produce una fuerte polémica entre funcionarios nacionales y provinciales de la Alianza, por el proyecto de Nación de que Chubut financie un fondo de reserva energética para Aluar. También se iban acrecentando las internas dentro del radicalismo chubutense, en especial el enfrentamiento entre el ex gobernador Maestro y el intendente de Trelew Di Benedetto.

Durante septiembre los trabajadores de Pymes de Trelew queman cubiertas durante varios días frente a la sede de Anses por la falta de pago de las asignaciones familiares. Los desocupados agrupados en el MIJD marchan ahora al municipio, reclamando trabajo y alimentos.

Vuelven a aparecer las manifestaciones por la "inseguridad". Vecinos de Puerto Madryn, en especial comerciantes y profesionales, marchan reclamando leyes más duras y se pronuncian en contra de una justicia supuestamente permisiva con los delincuentes.

Un rasgo interesante acerca de la intención de avanzar en grados de unidad es el desarrollo en Trelew de un pequeño núcleo llamado "Frente de Acción Solidaria"

\footnotetext{
${ }^{183}$ Movimiento Independiente de Jubilados y Desocupados. Dirigido por Raúl Castells, en los primeros años es parte formal de la Corriente Clasista y Combativa, luego se aparta de la misma y se conforma como un movimiento independiente.
} 
(FAS), que intentó unir a sectores de desocupados, estudiantes y estatales, en una especie de herramienta política común que finalmente sólo dura unos meses. Desde esta organización se realiza el 11 de octubre una concentración para manifestarse en contra del modelo económico y reclamar fuentes de trabajo.

Mientras tanto en Salta volvía a escribirse otra página importante del ciclo de rebelión. Tras quince días de corte sobre la ruta 34 y ante la brutal represión de la gendarmería que costó la vida de Aníbal Verón, miles de personas tomaron las ciudades de Tartagal y Mosconi, destruyendo lo que tuviera conexión con el gobierno y el poder. Este proceso realimenta la lucha en todo el país, generándose cortes de ruta por reivindicaciones propias y en solidaridad en La Matanza, Jujuy, Chaco, La Rioja y Neuquén, entre otras provincias.

La AOT anuncia que está dispuesta a tomar "medidas extremas" como cortes de rutas porque el diálogo ya esta agotado. Mientras tanto el gerente de Foderami ratifica los despidos, aunque ahora afirma que serían unos veinte (arreglando otros retiros "voluntarios"), que se tomarían entre los de menor antigüedad.

Durante noviembre aumenta el clima de bronca en Trelew por la crisis industrial. Sin embargo los sindicatos mantienen su intención de que todo quede entre las paredes de las reuniones, sin medidas en las calles. Se realiza una reunión con el intendente de Trelew, el ministro de gobierno de Chubut y los sindicatos textiles, donde el gobierno exige a las empresas que no se lleven las máquinas y amenaza con multas. La AOT vuelve a hablar de posibles cortes de ruta, mientras el Setia advierte que "son ilegales" aunque tampoco los descarta.

La CGT dirigida por Moyano anuncia un paro nacional de 36 horas para el 23 y 24 de noviembre, al cual adhieren de inmediato la CTA y la CCC. La medida se plantea en contra del modelo económico". A la vez en todo el país seguían los cortes de ruta, ahora también en Tucumán, Florencio Varela, Pacheco y otros puntos del conurbano.

Cerca de la huelga es claro que la CGT oficial no puede dejar de oponerse al ajuste que implica el nuevo presupuesto. Por ello finalmente adhiere a la huelga pero sólo por 24 horas y sin movilizaciones.

Tanto a nivel nacional como para la región esta huelga es fundamental, especialmente lo sucedido durante el 24 , cuando se suman todas las fracciones del movimiento obrero y gran parte del conjunto de la masa obrera y explotada, que se moviliza y realiza medidas bajo distintas personificaciones.

En nuestra región AOT y Setia se movilizan por separado el 22. Setia marcha desde Foderami hasta Prosur, realizando un abrazo simbólico a las fábricas y solicitando la prórroga de la promoción y el no retiro de las máquinas. AOT se dirige a 
Rawson pero sólo con los delegados de fábrica (unos cuarenta representantes). Allí son recibidos por Lizurume quién les dice que no hay novedades pero que confía en que serán buenas en poco tiempo. Maestro asegura desde Buenos Aires que tiene el compromiso del presidente de mantener los subsidios a los combustibles y la prórroga de la promoción industrial.

Casi todos los gremios de la zona se pronuncian en adhesión al paro. La Mesa de Enlace Sindical además llama a una movilización en la plaza de Trelew. La Cicech da libertad de acción a sus integrantes, pero reclama al gobierno que asegure la libertad de trabajo.

Las primeras 12 horas de paro en el día 23 tienen fuerte repercusión en todo el país. En la región nuevamente se movilizan los textiles de la AOT a Rawson, queman cubiertas frente a la casa de gobierno y exigen que se confirme la promesa de Maestro. El gremio denuncia que en tres años se perdieron setecientos puestos y que ahora se perderían seiscientos más en poco tiempo.

Entre las 16.30 y las 19 horas, los grupos de desocupados (el más organizado y numeroso es el MIJD) más agrupaciones universitarias (Fuich, La Corriente) y el FAS, realizan un corte de la ruta nacional №3. El número de manifestantes no es muy importante, pero es la medida más fuerte que se realiza durante la jornada. La universidad se mantiene totalmente cerrada y los empleados toman la sede de Vialidad Nacional. Adhiere al paro también la Uchari (Unión de Chacareros) por la aguda crisis que afecta a todos los sectores. Según todas las estimaciones el paro del 24 tendrá un fuerte peso.

En Madryn la adhesión a la huelga no es muy importante el día 23, excepto en el transporte, donde es total. Como medida pública solamente se realiza una "radio abierta" en la plaza central de la ciudad. La Cámara de Comercio llama a adherir al paro y la marcha del 24.

A nivel nacional la huelga tiene un alto acatamiento y se dan cortes de rutas y ollas populares en varios puntos de la Capital Federal y el conurbano. Se realiza un acto frente al Congreso donde es único orador Moyano, cerrando con un cacerolazo. La huelga docente logra un alto acatamiento en casi todas las provincias.

El 24 la huelga es muy fuerte en todo el país. Hay cortes de rutas, piquetes a empresas, marchas masivas. Es una fuerte expresión de repudio al plan económico que sustenta la Alianza, continuidad del sostenido por Menem. La expectativa que sectores de la clase obrera y el pueblo habían puesto en el recambio dirigencial se cae, y en once meses ya es el tercer paro nacional convocado por las tres centrales.

En Chubut la adhesión es muy importante en la actividad privada pero baja en el Estado, excepto en algunos sectores como vialidad. El gobierno intimida a los 
estatales de distintas maneras para impedir el paro. A esto se suma la escasa representatividad de algunos dirigentes sindicales.

En Trelew el paro es contundente y la concentración en la plaza es de unas mil personas. Convergen allí todos los sectores sindicales, desocupados y estudiantiles, menos la AOT y Setia. No se permite la participación de otros oradores que el designado por la CGT y ante eso comienzan las protestas de los grupos más combativos, quienes llaman a marchar hacia la ruta. Al comenzar la movilización por el centro de la ciudad este grupo propone dirigirse a la ruta y varias columnas se dividen de sus dirigentes y acompañan esa propuesta. Además del Mijd, el Fuich y la Corriente se suman al corte de ruta dirigentes del Sitravich, Ate y Apinta entre otros sindicatos, sumando unas cuatrocientas personas, más del triple del día anterior. La medida se sostiene por cuatro horas y tiene una gran trascendencia porque muestra la necesidad de tomar medidas más fuertes que las marchas y reuniones con los funcionarios. A partir de allí estos grupos ya no serán marginales, sino que empezarán a disputar la dirección del movimiento en las calles, por capacidad de convocatoria, fortaleza política y decisión ante la necesidad de la confrontación.

En Madryn también la huelga es contundente, con una marcha de más de mil personas y la unidad de todos los sindicatos de la ciudad. El Frente de Lucha Social (nucleamiento que agrupa a los distintos sectores sindicales) es el convocante. El MTD de Madryn se dirige en pequeño número (unas cincuenta personas) a cortar la ruta 3 desde las 13 hasta las 15 horas, aunque habilitando el tránsito cada 20 minutos.

Desde el principio del 2001 se vive un clima que hace presagiar el desenlace del año. Las distintas protestas tienden a unirse entre sí y a tomar características de fuerte confrontación. Constantemente se cortan calles y rutas, se queman cubiertas, se desafía el poder represivo del Estado. Las decisiones en asamblea y la democracia directa son parte central de los distintos hechos que relevamos en la región, tal como sucede en casi todo el país

Cortan calles quemando cubiertas desde enfermeras de sanatorios, empleados de Pymes que no cobraban las asignaciones familiares en término, desocupados de distintos grupos, docentes, estudiantes, pescadores, marineros, textiles, viales, etc. Se toman fábricas y barcos, se ocupa durante días la universidad, se realizan piquetes en las rutas y los puertos y hasta marchan y paran los trabajadores de la Base Aeronaval Almirante Zar. En varios de estos casos es significativa la solidaridad que reciben de otros sectores, a diferencia del aislamiento en que se solían dar estos hechos en otros años. 
El 9 de enero desocupados del MIJD toman por algunas horas la sede del ministerio de trabajo nacional en Trelew, exigiendo la prórroga de los planes de empleo y contra la caída de un proyecto de diez beneficiarios.

Los trabajadores de Unilán resisten la implementación del sistema americano de seis por dos (seis días de trabajo por dos de descanso y eliminación de las horas extras al ciento por ciento). Finalmente la empresa desiste de poner esto en marcha, pero amenaza con no instalar en la fábrica la nueva maquinaria que había adquirido y que iba a aumentar la productividad de la planta.

El 9 de febrero un grupo de empleadas despedidas de Ados queman cubiertas y toman las instalaciones de la obra social exigiendo el pago del acuerdo de indemnización. Finalmente, tras nueve horas de protesta, lograron cobrar una de las cuotas, pero el resto seguían atrasadas. Por ello votan en asamblea permanecer en el lugar día y noche, y ya para el 12 instalan una carpa frente a la administración de Ados, realizando una olla popular. Son amenazadas por personal del Stia (cuyo dirigente, Luís Nuñez, esta al frente de la obra social) y esto provoca la solidaridad de un grupo de desocupados y estudiantes, que comienzan a pasar las noches en ese lugar, apoyando el reclamo.

A los pocos días trabajadores de Pymes queman cubiertas frente al Banco del Chubut y Anses ante el atraso en el pago de las asignaciones familiares. Nuevamente el MIJD toma el ministerio de trabajo de Trelew exigiendo la renovación de los planes de empleo. Ante la falta de respuestas se movilizan al municipio, y ocupan durante dos días el edificio quemando cubiertas durante la noche.

En marzo se mantiene la toma de la textil Prosur que parecía ir hacia su cierre. Otra planta, Casa Roma, anuncia que cerraría ya que no puede competir con los importados. EI MTD de Madryn realiza una protesta frente al Hospital Zonal y luego marchan hasta el Concejo Deliberante quemando cubiertas frente a ese edificio. Exigen que el hospital sea provisto de medicamentos para los desocupados.

Durante este mes se nombra a Lopez Murphy ministro de economía de la nación. Comienzan los rumores sobre un profundo ajuste, con descuentos salariales y despido de personal. El FMI, la embajada norteamericana, los analistas financieros de Wall Street y de Brasil, se expresan en apoyo a la persona nombrada. Por su parte la UIA y la Carbap se expresan en contra, planteando que es un hombre de pensamiento ortodoxo que profundizará el modelo económico y la recesión. Los gobernadores peronistas anuncian que rechazarán todo ajuste a las provincias. También la Iglesia Católica se pronuncia en contra de un ajuste. Ante ese marco los anuncios oficiales se demoran varios días, intentando generar el consenso previo necesario. 
Finalmente el viernes 16 de marzo se lanza el paquete de medidas, que a través de recortes a las provincias y a las universidades, la derogación del incentivo docente, la quita de subsidios regionales (como al combustible y el gas en la Patagonia), entre otras medidas, preveía reducir en dos mil millones el déficit fiscal para cumplir con el $\mathrm{FMI}^{184}$. Un sector importante de los funcionarios del gobierno renuncian a sus cargos. La Ctera convoca un paro nacional para el martes y miércoles, mientras la CGT disidente convoca un paro nacional para el miércoles 21.

Casi todos los sectores de la sociedad de la región se expresan en contra del ajuste. Desde la UCR y el Frepaso, el PJ, la Democracia Cristiana, la Cámara de Comercio, la totalidad de los sindicatos, los docentes universitarios, todos los centros de estudiantes, etc.

En Trelew las agrupaciones universitarias que responden al PJ y la Franja Morada se expresan en oposición y convocan una asamblea de la "comunidad universitaria" para el lunes a las 20 horas. El Fuich convoca para las 17 horas y hace extensivo el llamado al conjunto de la sociedad de Trelew. Finalmente se realiza una sola asamblea, donde asisten desocupados y trabajadores estatales, y se produce un enfrentamiento entre los grupos que no querían realizar una toma del edificio universitario y los que plantean que esa era la única medida viable. Finalmente es votada la última moción con el apoyo de trabajadores y desocupados (a los cuales el otro sector les pretendía negar el derecho a voto) y la universidad fue tomada durante dos días, hasta la renuncia de Lopez Murphy. En Puerto Madryn la reacción fue similar, también se decide la toma de la UNP y se programan distintas protestas para el miércoles.

El martes se anuncia la renuncia de Lopez Murphy y el nombramiento de Domingo Cavallo otra vez como ministro de economía, ahora de la Alianza. Si bien siguen las protestas por unos días su nombramiento genera cierta expectativa en la población, y una breve caída en el nivel de conflictos durante abril.

El miércoles 21 en Trelew se realiza una marcha convocada desde la Atech, donde asisten estatales, viales, judiciales, trabajadores del INTA, personal de la construcción, del hospital zonal, no docentes de la UNP y las agrupaciones estudiantiles de la universidad. El paro tiene mucha fuerza en el transporte y la educación, y es menor en otros sectores. En Madryn la movilización es importante, con más de mil personas convocadas desde el Frente Social, estando presentes desde los gremios docentes, la UOM, el intendente y concejales de la ciudad, el

184 “Con Ricardo López Murphy como ministro de Economía, el gobierno nacional decretó un nuevo recorte de gastos estatales del orden de \$1.962 millones para el 2001 (previendo llegar en 2002 a una reducción de \$2.485 millones), fundamentalmente a partir del presupuesto de educación, y el incremento del IVA en servicios de esparcimiento" (Salvia, 2009: 206). 
diputado nacional "Manara" González, estudiantes de la UNP y la UTN, etc. Al terminar el acto en el centro de la ciudad el grueso de los movilizados marcharon por diez kilómetros hasta la ruta № 3, a la cual cortaron durante 3 horas.

Para mayo se profundiza el conflicto social en todo el país. Se transforma en un hecho político aglutinante el corte de ruta de la CCC y la FTV en La Matanza, que no lograba destrabarse por la oposición de algunos sectores del gobierno nacional de negociar ante piquetes. En Madryn el MTD corta la calle frente a la secretaría de promoción social y queman cubiertas por dos horas reclamando planes sociales.

Por su parte en el sector textil se agrava la situación de crisis general, con conflictos en tres fábricas. En "Reinamoras" de Puerto Madryn los trabajadores no cobran sus asignaciones familiares desde hace nueve meses, ante lo cual marchan por la ciudad. En Surjet se toma la planta por salarios adeudados, parte de los cuales se pagan ese mismo día por la noche. Foderami anuncia otros doce despidos, a los cuales pretende pagar el $50 \%$ de la indemnización.

Durante junio se producen varias protestas de trabajadores de la pesca en Madryn. Fileteros de dos empresas queman cubiertas reclamando aumento. El personal de la ex Alpesca se moviliza hasta la plaza central reclamando el pago de la totalidad de los salarios que les debían y la continuidad de sus fuentes de trabajo. Queman cubiertas durante todo el día frente a la planta en tierra. Los marineros toman los dos barcos de la firma que tenían alrededor de cien toneladas de langostino en sus bodegas.

El gobierno pretende cortar el avance de la rebelión popular con la represión, y por eso en Salta ataca a los piqueteros que nuevamente cortan la ruta 34 . Son asesinados Carlos Santillán y José Barrios.

En julio se profundiza el conflicto de Aerolíneas Argentinas y adquiere importancia el reclamo de los viales nacionales. Estos ocupan el distrito Chubut y queman cubiertas, en el marco de la posibilidad de desguace del organismo. El 9 los trabajadores de Aerolíneas y Vialidad Nacional marchan hasta el acto central por el día de la independencia. Son aplaudidos al llegar y los niños de una escuela suben las banderas de Aerolíneas y de Vialidad al escenario, mientras se reparten panfletos llamando a defender la soberanía del país.

Los desocupados del MIJD cortan la ruta ante la falta de respuestas a su reclamo de más planes. Reciben el acompañamiento de agrupaciones universitarias. El corte es decidido por asamblea y se levanta tras un acuerdo con el gobierno.

La crisis política y la debilidad del gobierno se profundizan. Las tres centrales sindicales llaman a un paro nacional para el 19, más sectores se retiran de la Alianza por oponerse al nuevo ajuste de Cavallo, los gobernadores justicialistas se niegan a 
firmar el llamado "pacto de la independencia" y el alfonsinismo también critica las medidas del gobierno. A nivel regional adhieren las dos CGT y la CTA.

La huelga no es importante en la región. En especial es casi nula entre los estatales, quienes podrían ser los principales afectados por el recorte, que por ahora sólo se había anunciado para los empleados de nación. Solamente en Puerto Madryn es importante la adhesión de los municipales. Como siempre sí se siente en el transporte, y también en la mayoría de las industrias y la construcción. No se produce ningún hecho en la calle.

A nivel nacional en cambio la huelga es muy fuerte. La adhesión se calcula en un $90 \%$, y si bien no hay convocatoria a la Plaza de Mayo, sí se producen muchos cortes de calles, de rutas y escraches, en especial en Capital Federal y provincia de Buenos Aires. Al otro día se genera un breve corte de ruta en Puerto Madryn de un pequeño grupo del Movimiento de Trabajadores Desocupados. El corte se levanta ante la amenaza de represión policial y son detenidos cuatro piqueteros.

Se realiza el primer Congreso Nacional Piquetero el 24 de julio en La Matanza, donde se reúnen delegaciones de casi todo el país. Se decide un plan de lucha contra el plan económico con varios días de cortes de rutas a nivel nacional. A principio de agosto, y en el marco de la segunda jornada del plan de lucha piquetero, se realiza en Trelew un acto convocado por estudiantes y diversos grupos piqueteros. Tras terminar el acto se dirigen a la universidad, la cual queda tomada como se había decidido en una asamblea más temprano.

Agosto comienza con un pronunciamiento público de la CGT del Valle llamando a una "tregua social" para evitar un posible "estallido", según las declaraciones de su secretario general. Pide conformar el Consejo Económico y Social con la $\mathrm{CICECH}$, la Cámara de la Pequeña y la Mediana empresa y el Poder Ejecutivo Provincial para frenar la ola de despidos en el área privada ${ }^{185}$.

Durante todo agosto y septiembre se suceden los conflictos de distintos grupos. Hay constantes hechos, aunque sin articulación entre sí, y sin tener ninguno una magnitud significativa por sí solo. No podríamos describir la totalidad de los hechos sin tener que extendernos demasiado. Solamente como ejemplo citamos que en esos días se produce un hecho indicador del significativo grado de movilización social: por primera vez en su historia marchan los trabajadores de la Base Aeronaval Almirante Zar. Realizan un paro de actividades y se movilizan desde la Base hasta la ciudad de Trelew.

\footnotetext{
${ }^{185}$ Diario Jornada, 3/8/2001, declaraciones de Mario Negrette, secretario general CGT del Valle, pág. 6.
} 
Al iniciarse octubre los conflictos se trasladan centralmente al ámbito estatal. Realizan varios días de huelga los trabajadores no docentes de la UNP, se moviliza el Sitraed en el marco de un paro nacional de Ctera y el personal del Hospital de Trelew realiza desde el 9 paros de cuatro horas por turno en contra del recorte. El 11 y 12 se cortan calles en Trelew y Puerto Madryn.

A mediados de octubre se realizan las elecciones. En Chubut, a contramano de lo que sucedía en el país, logra una nueva victoria la UCR. Pero el dato fundamental de las elecciones es el gran porcentaje de "voto bronca": votos anulados o en blanco que expresan el rechazo a los políticos, rechazo que luego se expresaría de forma más contundente en las calles. En Chubut esto sí repercute, siendo el voto bronca más del $20 \%$ del total de votantes, pudiendo sumarse un $30 \%$ que directamente no fue a votar ${ }^{186}$.

Tras el anuncio del cierre definitivo de la textil Windsor (tras constantes conflictos laborales en los últimos cuatro meses), el 2 de noviembre la pesquera Tramar anuncia el despido de ciento doce operarios de Trelew, ya que según ellos tenían los barcos inactivos por falta de permisos de pesca. El 5 se vuelven a movilizar los enfermeros del hospital para rechazar el recorte de las horas de guardia, que en muchos casos implicaba una caída del $50 \%$ en los sueldos. El mismo día en Rawson los municipales protestan contra el proyecto de rebajarles el sueldo un $15 \%$. Con la ocupación del Concejo logran que los concejales voten en contra.

A fin de mes la CGT del Valle convoca un acto en Trelew. La convocatoria no supera las cien personas, pese a que en la región se producen protestas constantes. Durante esos días los integrantes del MIJD realizan un acampe cortando la calle frente al ministerio de trabajo. Reclaman la aprobación de proyectos de trabajo que habían presentado meses atrás.

El mes termina con el intento de los integrantes del MIJD de cortar la ruta. Son reprimidos y diez de ellos son detenidos. Junto a otros grupos que se solidarizan se movilizan por la noche hasta conseguir su liberación.

Diciembre comienza con el anuncio por parte de Cavallo de una nueva serie de recortes para los trabajadores. El más impactante es la bancarización de todas las compras y ventas. El 6 se anuncia que Sedamil despediría a doscientos trabajadores a partir de enero por el cierre de la sección hilandería y del $50 \%$ de la sección tintorería. Tanto en Trelew como en Puerto Madryn se constituyen comisiones que llevan

\footnotetext{
${ }^{186}$ María Celia Cotarelo incluye este hecho en una mirada de largo plazo y como parte del proceso de rebelión en curso: "En un país donde el voto es obligatorio y donde la participación electoral ha sido tradicionalmente alta, desde 1991 se observa un crecimiento de la abstención electoral y el voto en blanco y nulo. (...) En octubre de 2001, esta tendencia alcanzó su punto más alto, entonces principalmente bajo la forma del voto anulado, el llamado "voto bronca", que constituyó un instrumento de lucha más dentro del proceso de rebelión popular que venía desarrollándose." (Cotarelo, 2004: 140)
} 
adelante la campaña por el plebiscito propuesto por el Frente Nacional contra la Pobreza (Frenapo), que propone una consulta popular a favor de un subsidio universal para los desocupados. En Madryn se realiza un festival en contra de la pobreza, con presencia de artistas, bailarines y la organización de los sindicatos de la CTA.

Mientras seguían los despidos y cierres de fábricas, con sus correspondientes protestas y reclamos de los trabajadores, se anuncia la adhesión de las dos CGT de la zona para la huelga nacional del 13. Sin embargo no se ponen de acuerdo entre sí y llaman a actos por separado. Así la CGT del Valle, que responde a Daer, convoca en Trelew, mientras la CGT del Noreste, en línea con Moyano, llama a un acto en Puerto Madryn.

En Trelew la movilización es de unas mil personas, con la presencia de los sindicatos de la CGT del Valle y sin el acompañamiento de los demás sectores (grupos de desocupados, agrupaciones estudiantiles y sindicatos estatales). En Madryn el acto es más importante, con la presencia de gremios del CTA y la adhesión de la UTA, UOM, Camioneros y dirigentes del PJ local. El Stia, que luego se moviliza hacia Trelew, corta durante una hora la ruta en el acceso norte de la ciudad.

El 14 en Mendoza y Rosario comienzan los saqueos a supermercados, con varios enfrentamientos con la policía y unos veinte detenidos. Estos hechos siguen durante toda la semana extendiéndose a casi todo el país. Cuando los saqueos llegan al Gran Buenos Aires ya la crisis se muestra como insostenible. En nuestra región la crisis se vive con menor dramatismo pero con igual intensidad: no hay saqueos pero sí permanentes marchas y protestas de distintos sectores.

El 19 estalla la crisis en todo el país. Los saqueos se masifican y hay enfrentamientos, en especial con las fuerzas represivas y en algunos casos entre particulares. Por la noche De la Rúa realiza un último intento al declarar el estado de sitio en todo el país durante treinta días. Así intenta sostenerse sobre la base ideológica del terror de Estado, todavía operante en la sociedad argentina, y del apoyo de las fuerzas represivas. Ante esto empieza la insurrección espontánea. Miles de personas no esperan a terminar de escuchar el discurso del presidente y salen a manifestarse en contra del estado de sitio, golpeando sus cacerolas y marchando a las plazas de cada ciudad. Obviamente el caso más visible es en Buenos Aires, donde tras unas horas de "caceroleos" en los barrios, comienza la marcha masiva hacia la Plaza de Mayo. Por la noche, y en lo que se constituye en uno de los más importantes desafíos de la historia de nuestro pueblo contra la violencia del Estado, la plaza central del país está ocupado por miles que reclaman la caída de Cavallo y el presidente. La 
protesta se dirige especialmente contra lo que se considera el gobierno de los grandes bancos, del imperialismo y de los partidos políticos corruptos $^{187}$.

El enemigo señalado es la cúpula de la gran burguesía, las formas de organización preexistentes son superadas en el marco de los enfrentamientos, surgiendo otras al calor de la lucha, que se van encadenando entre sí, llegando a la insurrección espontánea, como momento de mayor grado de unidad del pueblo y mayor grado de debilidad de la cúpula de poder burgués. Sobre todo lo que ha surgido aquí es la materialización en las calles y en la lucha de un nuevo sujeto: el pueblo, la unidad de los excluidos del poder político ${ }^{188}$.

Como en muchas ciudades del país, también en Trelew cientos de personas se concentran frente a la Municipalidad desde las 23 horas del día 19, con cacerolas y banderas argentinas. La movilización no tuvo una convocatoria clara, sino que surgió de forma "espontánea"189 o al menos no tuvo una convocatoria única. Las personas que vivían más cerca del centro de la ciudad marchan hacia ese lugar y después empiezan los llamados a muchos que vivían en zonas más alejadas y que estaban viendo el conflicto por la televisión. Finaliza recién alrededor de las 3 de la mañana, cantando el himno nacional y quedando en volver a encontrarse al otro día después de ver como seguía el conflicto a nivel nacional. No hay incidentes ni intentos de saqueo y ningún medio de comunicación cubre la protesta.

En la Plaza de Mayo y sus inmediaciones la lucha callejera se extiende durante toda la noche y casi todo el día posterior. Es una batalla que da la fuerza popular en contra de las fuerzas represivas que atacan con balas de plomo, gases lacrimógenos y demás armas de combate. Pese a ello se resiste a estos ataques, y la fuerza popular continúa enfrentando a las fuerzas represivas del poder, usando piedras y palos.

\footnotetext{
187 Como ya lo destacamos consideramos al trabajo de Iñigo Carrera y Cotarelo (2003a) como una excelente síntesis para pensar este proceso: “...la nueva articulación tiene como condición que todos los sujetos que se han movilizado en esos doce años lo hacen ahora simultáneamente en estos nueve días" (pág. 306; los doce años son los que van de 1989 al 2001, los nueve días los que van del 12 al 20 de diciembre).

${ }_{188}$ "También puede observarse que así como entre el 14 y el 18 se desarrollan los saqueos, que desembocan en revuelta y motín el 19 y 20, en esos días se desarrollan las manifestaciones que desembocan en la manifestación de masas del 19, que conduce al combate del 20 cuando no lo dejan expresar pacíficamente. En el combate se observa el papel de los jóvenes. Los que se expresan en ese enfrentamiento son los excluidos del poder político y su meta es antiimperialista y democrática para lograr revertir o superar las condiciones en que desarrolla su vida. La "insurrección" de los hambrientos y la "insurrección" de la pequeña burguesía convergen en la insurrección espontánea del pueblo. Es por eso que el hecho constituye una unidad" (Iñigo Carrea y Cotarelo, 2003: 308)

${ }^{189}$ En verdad, como dice Gramsci, nada es totalmente espontáneo y en todo caso lo que se nos presenta como espontáneo lo es solamente como forma embrionaria de lo consciente o por la incapacidad de conocer todos los aspectos de la realidad que operan para que se provoque un hecho determinado: "...la espontaneidad "pura" no se da en la historia: coincidiría con la mecanicidad "pura". En el movimiento "más espontáneo" los elementos de "dirección consciente" son simplemente incontrolables, no han dejado documentos identificables" ( en www.gramsci.org.ar; "Espontaneidad y dirección consciente"). Lo que es claro en este hecho es que la convocatoria de la marcha no puede ser atribuida a ningún sector, persona u organización en particular.
} 
EI PJ no acepta ningún acuerdo y finalmente De la Rúa renuncia y a las 19.56 del 20 de diciembre se retira de la Casa Rosada en helicóptero. Es sin dudas un hito histórico en el ciclo de luchas populares en la Argentina.

También en Chubut se producen fuertes enfrentamientos. En especial en Trelew, Madryn y Comodoro Rivadavia hay importantes movilizaciones de habitantes de los barrios más pobres hacia el centro de las ciudades, reclamando alimentos y realizando algunos intentos de saqueos contra los supermercados. La reacción del poder político es la represión con todas las fuerzas que tenía disponibles.

En Trelew desde muy temprano del día 20, habitantes de barrios pobres y militantes de grupos de desocupados se concentran frente al Concejo Deliberante reclamando bolsas de alimentos. Al conocerse la noticia comienzan a llegar más personas y los bolsones no alcanzan. Algunos grupos se dirigen en primer término al supermercado Tía (distante a dos cuadras) donde se produce un breve saqueo tras la rotura de sus ventanales. Los grupos especiales de la policía y la gendarmería atacan con balas de goma, gases y tiros al aire de balas de plomo.

En pocos minutos el centro del conflicto se dirige al supermercado "La Anónima" (a una distancia de siete cuadras del Concejo Deliberante y a cinco del supermercado Tía, está ubicado en el lugar más alto de la ciudad). Allí hay efectivos de gendarmería que disparan desde el techo del supermercado, mientras policías motorizados circulan por las calles. El ataque se intensifica y también la respuesta popular que combate con piedras. El enfrentamiento se prolongó durante toda la noche, en especial en las barriadas populares cercanas al centro. Allí por la noche hay enfrentamientos con balas de plomo, tanto de las fuerzas represivas como de habitantes de esos barrios que llegan a responder de esta manera la agresión sufrida. Hay ataques a los móviles de los medios de prensa, vistos por los que luchan como parte del enemigo.

También en Puerto Madryn hay enfrentamientos. La municipalidad había exigido que se espere el reparto de alimentos en los barrios, pero los vecinos se movilizan al centro de la ciudad, y tras algunas amenazas de saqueos logran recibir bolsones donados por los dos supermercados de la ciudad. Horas después se producen enfrentamientos con la policía que detiene a alrededor de treinta manifestantes.

En Trelew el 21 continúa la tensión, con constantes rumores de saqueos y marchas. El gobierno intenta frenar las protestas entregando alimentos en lugares alejados del centro de la ciudad, con un importante marco de seguridad. El 22 desocupados queman cubiertas y cortan la calle frente al municipio sin conseguir 
respuestas y después rodean durante horas el supermercado Norte. Finalmente se entregan alimentos donados por ese supermercado.

El 24 otra vez hay hechos en Trelew que tienen un carácter autoconvocado, producto del ánimo de movilización que se vivía en el pueblo. Empleados, jubilados y desocupados se concentran frente al Banco Chubut, cerrado por el feriado bancario, para reclamar el pago de sus haberes. La protesta es cada vez más fuerte, hay quema de cubiertas, cortes de calles y rotura de vidrios y puertas del banco. A las 11 horas se abre el banco, cuando el feriado bancario oficial se extendía hasta el 27 de diciembre.

A nivel nacional se nombra a Rodríguez Saá en el gobierno, en el marco de una fuerte disputa interburguesa. Otro cacerolazo y la falta de apoyo político, dieron rápida salida del gobierno a Rodríguez Saá. En ese marco se gesta, en una alianza de sectores del radicalismo con el peronismo de Buenos Aires, la asunción de Duhalde prevista hasta fines del 2003. Esto genera algunas protestas, pero finalmente la burguesía cierra filas tras la figura fuerte de Eduardo Duhalde.

El 2002 comienza con movilizaciones, escraches y cacerolazos en las ciudades de la región, con una especial dinámica en Trelew. Aquí el proceso lo realizan desocupados (que centralmente reclaman planes) y sectores medios (comerciantes, chacareros y pequeños empresarios) que ubican sus reclamos en la "reforma política". Este espacio, que al principio moviliza en conjunto y sin diferenciarse claramente, se va dividiendo de acuerdo a sus distintas estrategias y reivindicaciones.

El 6 de enero el congreso vota la salida de la convertibilidad. El dólar pasa a cotizarse en 1,40 pesos, mientras se mantiene el corralito ${ }^{190}$ y se impone un feriado bancario de dos días. Es la victoria final, tras una profunda lucha interna en la burguesía, entre los dolarizadores y los devaluadores ${ }^{191}$.

En Trelew el 7 de enero se realiza un cacerolazo frente al municipio reclamando planes de empleo y ayuda alimentaria. El municipio dice que aún no tiene respuestas a nivel nacional. Otro cacerolazo se produce el 11 en la plaza, esta vez más concentrado en repudiar el corralito y a lo que denominan "la clase política". Este cacerolazo es realizado por un sector más cercano a la clase media, sin presencia de organizaciones políticas ni sociales.

En la noche del jueves 10 y la madrugada del viernes 11 se produce el primer gran cacerolazo contra Duhalde. En particular se reclama contra la ampliación del

\footnotetext{
190 Se denominó corralito a la restricción de la disposición de dinero en efectivo de plazos fijos, cuentas corrientes y cajas de ahorros decidida a través de un decreto de Fernando de la Rúa el 3 de diciembre de 2001. Supuestamente así se pretendía evitar la salida de dinero del sistema bancario, intentando frenar el retiro masivo de los depósitos. La medida recién finalizaría oficialmente en diciembre del 2002, aunque muchos de los pequeños y medianos ahorristas nunca recuperaron la totalidad de sus depósitos.

${ }^{191}$ Desarrollamos en mayor profundidad este punto, y especificamos nuestra mirada sobre la cuestión, en el capítulo 5 .
} 
corralito. Representantes de las distintas cámaras empresarias de Trelew y otras ciudades del Valle convocan un acto para el martes con el objetivo de manifestarse contra el corralito y la situación económica de la región. Se cerrarían todos los comercios y empresas y se realizaría un acto.

El acto del martes 15 es sintomático de la situación. La movilización es de más de dos mil personas, desbordando lo esperado por los convocantes. No pueden asistir, por el rechazo masivo, los miembros de los distintos partidos políticos patronales y cuando Saturnino Zarate (dirigente de la CICECH y encargado de leer el documento consensuado por las cámaras empresarias) comienza con la lectura es abucheado, acusándolo de que ellos eran parte de los que habían saqueado la región. Distintos trabajadores que estaban entre el público literalmente toman el palco y comienzan a hacer uso de la palabra. El acto se transforma espontáneamente en una gran asamblea popular, en contra de la protesta ordenada y por reclamos corporativos que buscan las organizaciones convocantes. Los distintos grupos políticos populares de la ciudad no asistieron en forma organizada, pero surge desde los sectores estudiantiles la convocatoria a una nueva asamblea popular en la plaza independencia para el día siguiente. El objetivo propuesto es acordar un petitorio "Del pueblo de Trelew" y constituir una asamblea popular estable.

La crisis de dominación ${ }^{192}$ política se hacía clara a cada paso. También en Rawson el intento de "reclamo pacífico" de los comerciantes culmina en una movilización a la casa del gobernador, quién es insultado, empujado y se le arrojan petardos. Es una multitud que se había ido juntando al correrse el rumor de que se estaba movilizando contra Lizurume.

En Puerto Madryn el cacerolazo se dirige al Banco Chubut y es encabezado por integrantes de ATE, que reclaman el pago en término para todos los empleados.

El 16 en Trelew se realiza la primera asamblea popular en la Plaza Independencia. Allí se aprueba un documento que rechaza a la "clase política", exige cambios profundos en la economía del país y medidas para la reactivación de Trelew. Se autodenominan "Comisión Popular" y está compuesta especialmente por sectores medios, en su mayoría empleados y pequeños comerciantes. Son repudiados, y se les exige que se retiren de la asamblea, varios militantes indicados como "punteros del

\footnotetext{
192 Por crisis de dominación nos referimos a una situación de excepcional agravamiento y cuestionamiento de las instituciones políticas y mecanismos de control social a través de los cuales la clase dominante ejerce "normalmente" su dominación. Se produce como consecuencia de la combinación de una fuerte crisis económica, del empeoramiento de las condiciones de vida de las masas y de un alza significativa de su movilización y actividad. Este cuadro no llega a configurar una situación revolucionaria en virtud de la inmadurez en el desarrollo de los factores subjetivos referidos a la organización y conciencia de la clase trabajadora, pero, a la vez, es una situación de mayor gravedad y urgencia para la clase dominante que una crisis de hegemonía, la cual puede extenderse por un plazo más largo sin afectar su control directo sobre el movimiento de la sociedad.
} 
PJ" y a integrantes de Franja Morada. A los pocos minutos ocupan el municipio de Trelew y, entre otros hechos, se destruye el cuadro con la imagen del ex intendente Di Benedetto. Finalmente convocan a una nueva asamblea para el 17 y a una "pueblada" para el martes 22, en Rawson frente a la Legislatura.

Por su parte en Rawson otra movilización recorre la ciudad, haciendo eje en la Legislatura, el Concejo Deliberante, el Municipio y la Casa de Gobierno. Reclaman la baja en un $70 \%$ de las dietas y beneficios de los funcionarios y hacen hincapié en que la protesta no tiene banderías políticas.

Nuevamente es masivo el cacerolazo en Trelew. Lo distintivo en esta ocasión es que hace su entrada parte de la institucionalidad burguesa y no es rechazada: los concejales del PACH y el PJ se suman y presentan un proyecto de ordenanza bajando los sueldos políticos en un $50 \%$. Los concejales de la Alianza se niegan a sesionar de urgencia y denuncian la "politización" de la protesta. En el municipio el intendente sale a la calle y busca responder al petitorio presentado, diciendo que no tenía posibilidades reales de resolver la mayoría de los reclamos. El petitorio exige respuestas ante la crisis en todos los ámbitos, la rebaja de sueldos políticos, soluciones para los desocupados, insumos para el hospital, eliminar jubilaciones de privilegio y que se reduzcan impuestos al parque industrial.

En Trelew el 24 se vota en el Concejo Deliberante el proyecto que negociaron la Alianza y el PJ de recortes del $30 \%$ en los sueldos políticos. El PACH se opone proponiendo un recorte mayor. La movilización ocupa el Concejo Deliberante y hay algunos choques con rotura de uno de los vidrios, pero la situación es controlada por el sector más moderado. Este grupo, conformado por comerciantes y chacareros del Valle, se apartó unos días antes de la asamblea popular y se autodenomina "Movimiento Ciudadano de Trelew". De allí surgen estas iniciativas que desvían la movilización hacia la institucionalidad burguesa. Desde ese grupo surgirá la conformación del ARI en la región, y ya plantean la oposición al acompañamiento de los desocupados por sus supuestos métodos violentos.

El 25 por la noche y durante la madrugada del 26, se produce un nuevo cacerolazo a nivel nacional. En Trelew más de mil personas marchan por la ciudad, escrachando las casas de algunos dirigentes políticos de la UCR y el PJ y de empresarios vinculados a negocios mafiosos y al poder político local. Se hacen "paradas" en el Concejo Deliberante, Tribunales, el Hospital Zonal, varios bancos y en el Municipio, donde se finaliza cantando el himno nacional. La marcha indica el rechazo a todos los símbolos del poder local.

Las movilizaciones son muy heterogéneas, juegan un papel importante en la elección de los "blancos" a repudiar desde los sectores más combativos del 
movimiento estudiantil y piquetero, los integrantes del "Movimiento Ciudadano" (que siempre marcan como límite cualquier hecho de "violencia") hasta sectores del PJ, el Pach y algún grupo interno de la UCR. Pero realmente ninguna medida que no tenga el apoyo de la mayoría puede ser llevada adelante, porque enseguida se encuentra con un firme rechazo.

También en Rawson se moviliza un grupo más pequeño de vecinos, dirigido por comerciantes que concentran la protesta frente al Banco del Chubut. $Y$ en Madryn se desarrolla un cacerolazo frente al Banco Chubut, cortando la calle durante algunas horas. Además la coordinadora de Gremios Marítimos y Portuarios se declara en estado de alerta y movilización ante la falta de certidumbres sobre el futuro de la actividad portuaria.

El $1^{0}$ de febrero (en el marco de los cacerolazos nacionales de todos los viernes) el Movimiento Ciudadano convoca junto a agrupaciones de desocupados e integrantes de agrupaciones estudiantiles a otro cacerolazo que recorre el centro de Trelew, escrachando a distintos dirigentes políticos y empresariales.

Al otro día grupos de desocupados toman el municipio ante la falta de respuestas por las conexiones de gas (muchos tenían cortado el servicio por falta de pago), las bolsas de alimentos y la convocatoria que sólo se había hecho a asociaciones vecinales y sindicatos aliados para la primera reunión del Consejo Consultivo $^{193}$.

Es así que el espacio más amplio va desgranándose. Si bien se siguen generando marchas, los que protestan se van separando según sus distintas estrategias. Esto es claro cuando los grupos de desocupados se comienzan a movilizar por planes sociales, mientras otros sectores destacan alternativas como el trueque, el cual sería una salida "pacífica" a la crisis, en oposición a la lucha "violenta" de los piqueteros.

El fenómeno del trueque se extiende pero no logra sedimentar en formas organizativas autónomas del poder, siendo la gran mayoría de los nodos manejados por representantes de partidos políticos del sistema.

Varias agrupaciones de desocupados se movilizan el 14 de febrero. Ya algunas nuevas agrupaciones van tomando forma propia, en especial a partir de la articulación

\footnotetext{
${ }^{193}$ El Consejo Consultivo fue una herramienta diseñada por el gobierno de Eduardo Duhalde junto a la cúpula de la Iglesia Católica, donde se pretendía integrar a "los distintos sectores de la comunidad" (iglesias, asociaciones vecinales, sindicatos, corporaciones profesionales, grupos de desocupados "reconocidos", etc) para que estos decidieran acerca de la entrega de los planes sociales. Esos Consejos se conformaron en casi todas las ciudades del país y buscaban, entre otras cosas, que la decisión sobre el reparto de los planes se desarrollara en un marco estrictamente institucional y sin apelar a medidas de lucha.
} 
en torno a un dirigente y en muy pocos casos en el marco de alguna organización nacional ya existente.

Duhalde afirma que ya está en marcha la salida de la crisis. Remarca el papel de la iglesia que con su "Mesa de Dialogo Social" opera para frenar el proceso de luchas. El gobierno aparece fortalecido tras el acuerdo con las provincias y la apertura de nuevas negociaciones con el BID.

Los integrantes del Consejo Consultivo informan que los planes a distribuir en Trelew son cuatrocientos veinte y que se repartirían con prioridad a los desocupados con mayor cantidad de hijos. No dicen nada sobre la escasa cantidad para una población desocupada estimada en cinco mil personas, solamente para Trelew. En ese marco los pocos grupos de desocupados que se habían integrado al Consejo (Patria Libre, MIJD y Unión Popular) se retiran del mismo por la presión de los otros grupos que llaman a movilizarse para conseguir más planes. Este proceso de continúas marchas, y de un proceso de interesante debate político entre los grupos de desocupados y otras organizaciones sociales, se desarrolla en la última quincena de febrero.

El 7 de marzo parte de los grupos se movilizan al municipio y entregan un listado de personas que necesitan el plan. Es una forma de expresar la negativa a ir a discutir al Consejo Consultivo y exigir al poder político que se haga cargo de generar respuestas. El Consejo estaba integrado por Asociaciones Vecinales, sindicatos y miembros de asociaciones intermedias, donde se terminaba disputando el plan con otro vecino del barrio o con la clientela de los punteros políticos.

Sobre esta base política se inicia el corte de ruta con el reclamo de trescientos puestos de trabajo, y el llamado a la unión de los que luchan después de haber cortado durante el 11 y 12 una de las principales calles céntricas de Trelew y de tomar el Ministerio de Trabajo de Nación por varias horas sin recibir respuestas.

Los grupos de desocupados de Trelew cortan la ruta 3 durante seis días en marzo. El piquete recibe amplia solidaridad y se organiza alrededor de la asamblea. El lunes 18 se da un hecho importante que tiene repercusión a nivel nacional (es tapa del Diario Clarín), cuando docentes autoconvocados deciden realizar un simbólico inicio del ciclo lectivo en el piquete. Si bien todos los docentes venían desarrollando medidas de fuerza en reclamo de mejoras en el salario, es el grupo de docentes que se organiza aparte del sindicato oficial el que se manifiesta aquí, reclamando la ampliación de la copa de leche y los comedores escolares. Los docentes participantes son amenazados por la ministra de educación con que serían sumariados, medida que luego no se realiza. 
Por su parte la huelga llamada por Atech y Sitraed tiene poco acatamiento en Trelew y Rawson (aunque la mayoría de los docentes manifiesta su adhesión en los discursos de inicio, el problema expresado es el fuerte descuento por presentismo que sufrían), es importante en Comodoro Rivadavia y de un 50\% en Puerto Madryn. En Rawson se realiza un acto de los docentes autoconvocados frente al ministerio de educación. Allí reclaman el pago en término, aumento salarial, mejoras en las escuelas y la integración de todos los sectores a la mesa paritaria donde sólo estaba la Atech. Representantes de los piqueteros viajan hasta el acto para solicitar el apoyo al corte de ruta, pero no son bien recibidos por la mayoría de los docentes. En Puerto Madryn el Sitraed se moviliza al Concejo Deliberante y vota la continuidad del plan de lucha con un nuevo paro por 72 horas.

El acto de los docentes de Trelew en la ruta debilita la posición política del gobierno, que comienza a buscar posibles salidas negociadas del conflicto. Esa tarde hasta la iglesia oficial le exige al gobierno que dé una respuesta al "justo reclamo" de los piqueteros. La asamblea del piquete decide entonces aprovechar la situación para endurecer la medida, cortando los caminos alternativos que se habían abierto a unos cien metros de la ruta, por donde circulan algunos vehículos.

En ese momento el punto más complejo para resolver el levantamiento del corte es la exigencia de los grupos de desocupados de manejar ellos mismos los planes, desarrollando el control de la adjudicación y la prestación y llevando adelante los proyectos que considerarán necesarios y no los que imponía el municipio.

Aquí se manifiestan algunos rasgos de conciencia como grupo social, al expresar la negativa a trabajar en forma directa para el Estado. Los desocupados que habían obtenido los planes con su lucha querían que esos planes fueran para su beneficio y no para convertirlos en mano de obra barata. Sus referentes expresan públicamente que los planes del gobierno los llevarían a enfrentarse con los trabajadores ocupados, presionando hacia la baja a sus salarios y funcionando como ejército de reserva ante todo tipo de conflictos laborales.

Finalmente el martes 19 por la tarde llega el acuerdo final, con el otorgamiento de trescientos cincuenta y siete planes de empleo a las organizaciones de desocupados, a través de la mediación institucional de la iglesia. El hecho culmina con una marcha triunfal por el centro de Trelew de los grupos que participaron en el corte.

El 27 de marzo los mismos grupos de desocupados se movilizan al municipio con más de cuatrocientos participantes en reclamo de alimentos. Al no tener respuestas satisfactorias se dirigen a los supermercados de la zona, consiguiendo una importante entrega de parte de La Anónima. El 29 se movilizan al otro supermercado "Hiper Tía" (que el 27 no había aceptado otorgar ningún aporte), impidiéndole abrir sus 
puertas y consiguiendo, tras nueve horas de bloqueo, una importante provisión de alimentos.

La situación de la economía provincial es grave, más aún con el compromiso de bajar el déficit que firmó Lizurume. Las protestas se suceden día a día y aparecen los rumores de posible renuncia del gobernador. Es claro el agravamiento de la interna en la UCR que deja a Lizurume con escaso apoyo, mientras Maestro no aparece en escena y el presidente de la UCR, Cimadevilla, critica públicamente al gobernador y presenta su proyecto de cara a las elecciones del 2003.

El 12 de abril el Banco del Chubut queda al borde de la quiebra. Los empleados bancarios decretan el paro por tiempo indeterminado y se movilizan junto al Frente de Gremios Estatales (viales, ATE, sanidad, Luz y Fuerza, jubilados y empleados legislativos) a la Casa de Gobierno en Rawson. Se rompe un vidrio para poder ingresar y obligan al gobernador a dar explicaciones frente a la movilización, utilizando un megáfono y debiendo responder a algunas de las exigencias.

La UOCRA corta la ruta 3 el día 15 entre las 10 y las 21 horas. Alrededor de cien manifestantes levantan el corte ante la promesa del gobierno provincial de que se realizaría un plan de cincuenta viviendas en Trelew.

Ese día hay paro docente. La Atech vota el paro por tiempo indeterminado hasta el pago de los salarios, Sitraed por 72 horas y adhieren los distintos grupos autoconvocados de Trelew y Rawson. La adhesión es importante, pese al problema del presentismo.

Se realizan grandes manifestaciones en Trelew los días 16 y 17 de abril, con más de mil quinientos participantes. Son parte del hecho los docentes, bancarios, judiciales, centros de estudiantes secundarios y universitarios, y los grupos de desocupados. El detonante es la falta de respuestas a algunos reclamos sectoriales de los estatales y, especialmente, el cierre temporal del Banco Chubut, debido a las deudas producida por una administración fraudulenta, en la cual están involucrados los principales políticos y empresarios de la zona. En Rawson los docentes autoconvocados realizan escraches en la Casa de Gobierno, en Legislatura y luego cortan el puente de acceso a la ciudad.

El 18 de abril todos los grupos que venían movilizándose en Trelew, Rawson, Puerto Madryn y algunos de Comodoro Rivadavia, se concentran en Rawson, donde participan de la manifestación más de dos mil personas. Se enfrenta y supera el cordón de seguridad policial que cerca la Legislatura, y se entra en ella rompiendo los vidrios y tomando las instalaciones por más de veinte minutos, sin que la policía pudiera hacer nada para impedirlo. Al producirse el enfrentamiento con las fuerzas represivas, sectores sindicales (especialmente el Sitraed) se retiran denunciando a los 
desocupados por los "hechos vandálicos". Ese discurso es reproducido por los medios de comunicación, que plantean la "diferencia" entre los trabajadores que reclaman por sus legítimos derechos y los "violentos" que sólo buscarían generar conflictos. En el interior de la legislatura se rompen bancos, vidrios, computadoras, se salta sobre las bancas de los diputados, se rompen los retratos de Lizurume y De la Rúa, etc ${ }^{194}$.

La manifestación luego sigue hacia Casa de Gobierno y en esas cuadras se retiran la mayoría de las columnas sindicales. Al finalizar la movilización se produce un ataque de la policía provincial con balas de goma y gases sobre los desocupados y estudiantes secundarios y universitarios de Trelew, quienes habían quedado casi en solitario y se disponían a tomar los colectivos hacia su ciudad. Se detiene a diez integrantes de los movimientos de desocupados que son liberados al finalizar el día (a cuatro de ellos se les inicia un proceso judicial).

El hecho de Legislatura marca una división entre los sectores más radicalizados y los que buscan una salida negociada. A partir de aquí se plantea una divisoria entre los que intentan continuar la movilización hasta la caída del gobierno y los grupos que prefieren frenar el proceso que se había radicalizado más allá de sus intereses. El gobierno centra su discurso en la necesidad de que todas las manifestaciones fueran "pacíficas" y en el rechazo a los "violentos".

Se aísla a los movimientos de desocupados de la movilización de los otros sectores (docentes, bancarios, judiciales, etc). Las organizaciones de desocupados deciden no participar de las movilizaciones de los otros sectores ante el hecho de que al ser reprimidos no hubo solidaridad ni apoyo de casi ningún grupo. Esa decisión agrava el aislamiento que se busca generar desde el poder. Algunos de los movimientos se comienzan a quebrar y dejan de movilizarse.

La lucha igual continua. Los docentes sobrepasan su dirección sindical y ratifican el paro. El 23 de abril realizan un histórico cerco a la Legislatura de Chubut. Se deja encerrados a los diputados, impidiéndoles salir, aún a comprar comida o a ver a sus familias. Finalmente el 24 los diputados aceptan sesionar dando respuestas parciales a algunos de los reclamos históricos, como la vigencia del nomenclador docente y la declaración de la emergencia educativa (que otorga partidas para becas y comedores escolares). De esta manera se logra quebrar más de diez años de ley de emergencia económica, que había cancelado muchos derechos laborales de los empleados provinciales. Pese a lo duro de la medida es llamativo que durante su

\footnotetext{
${ }^{194}$ Estos hechos tienen trascendencia nacional y son retomados en el Diario Clarín. En base a las notas allí publicadas, James Petras y Henry Veltmeyer relatan: "Por toda la provincia de Chubut, miles de desempleados y sindicalistas marchaban en las principales ciudades por trabajo y contra los recortes presupuestarios (...) El 18 de abril, los empleados públicos y los desocupados de las provincias de Chubut y Jujuy se enfrentaban a la policía al tiempo que se abrían paso hacia el parlamento provincial." (Petras y Veltmeyer, 2004: 40)
} 
realización la mayoría de los docentes se expresan en contra de la llegada de los "piqueteros", por los posibles hechos de violencia que podrían provocar. Es claro que no veían a su propia acción como "violenta".

El personal de Vialidad provincial, dirigido por el Sitravich, ocupa la sede del organismo, reclamando la renuncia de su interventor. Tras tres días de toma consiguen su exigencia, mientras sigue el paro de los judiciales por el atraso en el pago de sueldos. El 29 una nueva asamblea de los docentes autoconvocados de Trelew ratifican la continuidad del paro, ya que aún no han cobrado su salario. Los docentes y demás empleados estatales (alrededor de mil personas) se movilizan hasta Rawson en reclamo del descongelamiento de la antigüedad. Se consigue el pago del $100 \%$ de la antigüedad para todos los empleados estatales que cobran menos de $\$ 1500$ y discutir en paritarias la puesta en marcha del nomenclador. Queda sin definición el pago de los días de huelga.

Finalmente el gobierno acepta en la mesa paritaria dar marcha atrás con el descuento de los días no trabajados. Con estas medidas, y el acuerdo con otros sectores sindicales, logra recomponer su situación, descomprimir la conflictividad social y termina de aislar a los sectores que expresan demandas más profundas de cambio en las políticas del Estado. El cambio de situación económica por los altos precios del petróleo y, especialmente, por la devaluación que acrecienta los ingresos por exportaciones, le permite a la provincia contar con fondos frescos y comenzar una política de acordar con distintos sectores para aquietar la problemática social.

Esta serie de continuas movilizaciones en la región son el correlato local del proceso que se vivía a nivel nacional. Pero si bien continúa el caudal de protestas, estas ya tienen un sentido más controlable para el poder. Han perdido su carácter disruptivo y fueron recuperando el tradicional carácter corporativo de las demandas, expresión de los niveles de conciencia que se manifiestan en la mayoría de las protestas durante este ciclo, y de la estrategia que se hace posible observar al estudiar el encadenamiento de enfrentamientos sociales.

En junio se realiza un corte de la ruta 3 por parte de los grupos de desocupados y al mismo tiempo por la UOCRA. El gobierno acepta negociar con el sindicato pero no con los piqueteros. Los medios de comunicación y el gobierno plantean la diferencia entre aquellos que supuestamente "quieren trabajar" y los que "siempre reclaman". Se desarrolla un profundo aislamiento político del corte de los 
desocupados a partir de la negociación con la UOCRA, que levanta el corte el día 5, y cuyos dirigentes se pliegan a la campaña del gobierno ${ }^{195}$.

El piquete de los grupos de desocupados culmina con una importante derrota, de la cual no logran recuperarse por meses. Además del aislamiento político, se realiza un cerco por parte de las fuerzas de seguridad que impiden la llegada de nuevos integrantes al corte, el regreso de aquellos que habían vuelto a sus casas y el suministro de alimentos y gomas para calefaccionarse ante las bajas temperaturas. El corte debe ser levantado ante la poca cantidad de participantes y la amenaza concreta de la represión. Fueron procesados cinco militantes a los pocos días de su finalización.

A partir de allí se inaugura una etapa de retroceso en lo político y lo organizativo. Especialmente se marca un gran descenso en las manifestaciones públicas de protesta, y en la incidencia política de los movimientos.

Días después se produce en Buenos Aires el hecho conocido como "la masacre de Avellaneda". Para nosotros es parte de la misma avanzada contra los sectores combativos. Estos hechos son el inicio de un descenso de las movilizaciones a nivel nacional y regional. Duhalde decide anticipar las elecciones y la entrega del poder en más de seis meses, por la contundente reacción popular al conocerse la verdad de los hechos ${ }^{196}$.

\subsection{La rebelión en el NE del Chubut: $2002-2005$}

Para estos meses de 2002 se calcula que el $20 \%$ de la población de Trelew es asistida a través de diversos planes sociales ${ }^{197}$ y los datos de la EPH de mayo del 2003 para el aglomerado urbano Rawson-Trelew muestran que un 51,8\% de su población vive en la pobreza. Es una realidad cada vez más alejada de la antigua historia de prosperidad y crecimiento vivida en los setenta y ochenta.

Los docentes convocan a una huelga, que logra poco acatamiento. Es más importante la movilización al ministerio de educación reclamando que se ponga en marcha la paritaria por el nomenclador. Adhieren la Atech, el Sitraed y Comunidades Educativas. Se dice que las negociaciones han fracasado y se convoca por ello a asambleas docentes en Trelew, Puerto Madryn y Rawson.

En las asambleas se decide volver al paro el 31 y movilizar a Rawson. Se vota una huelga contundente, de 72 horas. El paro masivo del 31 (para el gobierno de un

\footnotetext{
195 Declaraciones de funcionarios, integrantes de la UOCRA, de la $\mathrm{CICECH}$ y de camioneros afectados por el corte, entre otros. Diario Jornada, 5/6/2002, editoriales y noticias varias, con, pág. 4-5. Diario Jornada, 6/6/2002, pág. 1-4-5. Diario Jornada, 7/6/2002, pág. 1-3. Diario Jornada, 8/6/2002, pág. 4-5.

${ }^{196}$ Recordemos que la versión del gobierno fue atribuir el asesinato a internas de los piqueteros hasta que aparecieron las fotos que demostraban que los asesinos eran policías de alta jerarquía en la bonaerense.

${ }_{197}$ Diario Jornada, 5/10/2002. Informe del Consejo Consultivo de Trelew, pág. 5.
} 
$70 \%$, para los docentes de más del $90 \%$ ) y la protesta en la calle revitalizan la lucha docente durante agosto, por el incumplimiento del pago del nomenclador.

Logran aún mayores niveles de acatamiento en el segundo y tercer día de paro. En Madryn el Sitraed moviliza al Concejo Deliberante. El gobierno declara "ilegal” el paro porque los docentes rechazan la conciliación obligatoria. De todas maneras la protesta sigue. Se ratifica el paro, que sigue con altos acatamientos.

El 4 de agosto el gobierno anuncia un aumento "de emergencia" de $\$ 100$ a todos los empleados del Estado provincial. Se intenta frenar la posibilidad de movilización de los demás sectores y se enfrenta el reclamo docente. En un intento por dividir a los docentes, se les plantea que deben decidir entre el nomenclador o el aumento de emergencia (se busca enfrentar a los ingresantes con los de mayor antigüedad, a los primeros les convenía el aumento de emergencia, mientras al resto el aumento por nomenclador). Las asambleas deciden ratificar su reclamo de nomenclador e imponen el paro por tiempo indeterminado. Ante esta demostración de fuerza, y una vigilia con olla popular frente a la Legislatura, finalmente el 7 de agosto los diputados aprueban la puesta en marcha del nomenclador desde enero de 2003. Esto implica un importante aumento de salario para la mayoría de los docentes. Las asambleas deciden levantar la huelga.

Se comienza a hacer más común a nivel nacional y en la región las marchas en relación a la "inseguridad", reclamando leyes más duras contra delitos comunes. En el nivel local ya habíamos relevado una presencia importante de estos hechos a finales de 1997 y mediados del 2000. En general son realizadas por sectores propietarios (comerciantes, taxistas, etc), de la pequeña burguesía acomodada, y son más comunes en Puerto Madryn que en Trelew. También en términos generales, su ascenso se enmarca en momentos de una baja de las protestas de los trabajadores.

En Madryn, durante septiembre, asociaciones intermedias y patronales convocan concentraciones "contra la inseguridad", que son apoyadas por los medios de comunicación. Se realizan también "jornadas nacionales", que comienzan a tener repercusión en la zona, con apagones en Trelew y Madryn.

En el parque textil la situación sigue siendo compleja, pese a la expectativa de recuperación por la devaluación del peso. La provincia entrega subsidios a las empresas y los trabajadores para sostener los puestos de trabajo y evitar mayores conflictos.

A fines de octubre y principios de noviembre el MIJD corta la calle frente a la municipalidad de Trelew reclamando alimentos y garrafas. En la primera ocasión son desalojados por la policía durante la noche. Para noviembre avanzan con carpas y elementos de mayor organización, pero siguen sin obtener respuestas. No son 
acompañados por otros sectores ni por otros grupos de desocupados. Su reclamo sólo plantea el pedido de cincuenta garrafas y bolsas de alimentos para los miembros del MIJD.

En estos meses comienza una lenta recuperación de la capacidad de movilización de los grupos de desocupados pero en general no consiguen sus objetivos. Hay una tendencia general a la baja de todas las protestas, donde tras las soluciones que dio el gobierno a algunos sectores (especialmente docentes y estatales), los hechos de protesta se han desarticulado y no suelen conseguir lo que reclaman.

La flota amarilla de Rawson frena su actividad el 6 de diciembre. Es un reclamo de los marineros que exigen el pago en precio dólar, como fija el convenio firmado hace dos años y medio. Además plantean que les pesan los cajones en $33 \mathrm{~kg}$ cuando los mismos suelen superar los 35 . Es la primera vez que se vive una situación así, nunca se habían dado paros totales en este sector porque implican una pérdida para los trabajadores que cobran por lo pescado en cada salida al mar. Mientras esperan una respuesta de los armadores se movilizan frente al ministerio de trabajo, pidiendo que se sume al reclamo el Somu y Siconara, pese a que la mayoría no esta afiliado.

Para el aniversario del 19 y 20 de diciembre Trelew es calificada como "ciudad de alto riesgo" por los organismos de seguridad, y se refuerza la presencia policial y de gendarmería. Los supermercados son rodeados por personal de seguridad y los grupos especiales patrullan las calles. El intendente denuncia, a través de propagandas radiales, la presencia de agitadores y llama a no salir a las calles. Se organiza un masivo reparto de bolsas de asistencia para esos días desde las asociaciones vecinales y los centros comunitarios más alejados del centro de la ciudad.

El 20 de diciembre el acto se desarrolla con normalidad, aunque es muy pequeño. Sólo están algunos grupos de desocupados (CTD "Aníbal Verón", Patria Libre, Evita, agrupación "Che Guevara") e integrantes de la agrupación estudiantil Fuich. Se entregan petitorios al municipio reclamando alimentos para los comedores populares de barrio INTA y Primera Junta. La campaña del gobierno surte efecto ya que casi no hay participación de la sociedad.

También ese día se dicta la conciliación obligatoria en el conflicto de la flota amarilla. Aparentemente había un preacuerdo de aumento que se pondría en marcha tras los 15 días de conciliación. La CAPIP ${ }^{198}$ había reclamado una pronta solución al conflicto.

\footnotetext{
${ }^{198}$ Cámara Argentina Patagónica de Industrias Pesqueras, agrupa a las principales empresas con buques congeladores.
} 
A nivel nacional se realizan dos actos en Plaza de Mayo, que muestra la división entre dos estrategias. Por la mañana se movilizan los piqueteros llamados "blandos" (CCC y FTV), que no plantean la caída del gobierno ni la construcción de un nuevo sistema social, sino un programa de reformas económicas en consonancia con que se mantenga el sistema capitalista. Por la tarde lo hacen los "duros" (Bloque Piquetero Nacional, Polo Obrero, partidos de izquierda, centros de estudiantes, asambleas populares y organismos de derechos humanos), donde en términos generales se plantea la necesidad de que Argentina avance hacia un sistema alternativo al capitalista. En este aniversario no realizan ningún tipo de acciones en las calles el grueso de las centrales obreras, en una nueva demostración de cuáles fueron las debilidades fundamentales de los hechos de diciembre de 2001.

Durante todo el 2003, hay continuos conflictos en la pesca. Hay muchos problemas con los fileteros que han sido precarizados, y con los marineros que reclaman aumento en sus salarios al bajar la cantidad de pesca por la escasez del recurso. Se producen marchas, tomas de plantas, piquetes y otras acciones, que hacen presagiar la aguda conflictividad que el sector tendría en los siguientes años.

En Rawson se despide a 130 fileteros que rodean la planta de Conarpesa quemando gomas y amenazando con tomarla. Interviene la Subsecretaría de Trabajo de la provincia y el 13 de enero, tras varios días de conflicto, el Stia acepta la propuesta de los empresarios que consiste en firmar contratos con los trabajadores hasta junio. Así estos trabajadores son precarizados y pierden su estabilidad laboral, pasando a trabajar formalmente para una tercerizada.

Sobre fin de mes se realiza un corte de la ruta provincial № 25 en reclamo de la reapertura de la fábrica textil "Antártida 2000". Participan del corte las agrupaciones "Che Guevara" y "Patria Libre", que reclaman poner en marcha la fábrica con puestos para los desocupados. Son recibidos por autoridades municipales, pero no consiguen ninguna respuesta sólida.

En Trelew y Puerto Madryn se realizan varios asentamientos. Son los hijos de aquellos obreros que habían construido sus casas durante el período de crecimiento, que ahora han formado sus propias familias pero seguían viviendo con sus padres. Reclaman de esta manera la posibilidad de conseguir una vivienda propia. Desarrollan varias marchas, actos y hasta un corte de ruta.

En febrero los desocupados realizan varios cortes de ruta, de acuerdo al plan de lucha nacional convocado por las principales organizaciones piqueteras. Se reclama el aumento de los planes y la adjudicación a más beneficiarios. El 3 y 10 de febrero, se realizan estos cortes en los que participaron la CTD "Aníbal Verón", el MIJD, Evita, Patria Libre, agrupación "Che Guevara" y el Fuich. Los desocupados 
continúan realizando medidas pero sin la contundencia de principios del 2002. Sus alianzas sociales son menores y, pese a momentos de unidad en la acción que son coyunturales, están más divididos entre sí.

Ya en el 2003 se marca una mejor situación económica. El precio del petróleo aumenta y si bien todavía no se evidencia con claridad, hay elementos que muestran una recuperación de la producción industrial gracias a la devaluación, en especial la incorporación de mayor cantidad de personal en el parque textil y las barracas laneras. Muchos integrantes de los grupos piqueteros consiguen trabajo y dejan las organizaciones.

Al iniciarse marzo el actual gobernador Das Neves lanza su candidatura para las elecciones del 9 de noviembre. Es un acto importante, con casi cuatro mil personas en el gimnasio municipal de Trelew. Hacia fines de mes se produce un corte de la calle frente a la sede universitaria de Trelew por organizaciones estudiantiles. Es en el marco de una jornada nacional reclamando más presupuesto.

Permanece el asentamiento de los ocupantes en varios barrios de Trelew. El sector identificado como "Barrio Norte", realiza un corte de la ruta 3 el 2 de abril, en reclamo de soluciones. Dicen que están siendo discriminados porque se sientan a hablar con todos los ocupantes menos con este grupo. Son los que están más complicados en términos legales, ya que tomaron tierras privadas y no lotes públicos como la mayoría de los ocupantes.

La CTD "Aníbal Verón" se moviliza al Ministerio de Trabajo de Nación ubicado en Trelew, reclamando más planes laborales y asistencia social en el marco de una jornada nacional de su agrupación. Es una de las primeras marchas que la CTD tiene la capacidad de realizar en forma particular, pero si bien esto es positivo para esa agrupación se sigue mostrando la división entre los grupos de desocupados que no se juntan ni siquiera para los reclamos específicos del sector. El 23 de abril es el MIJD quién reclama frente al municipio, solicitando que intercedan para acelerar la entrega de planes sociales.

Llegan las elecciones presidenciales del 27 de abril y son elegidos como los dos candidatos más votados en la primera vuelta Carlos Menem, con el 23,8\% y Néstor Kirchner con el 21,75. En Chubut ganó ampliamente Kirchner, con un 48,5\% sobre el $18 \%$ de Menem y el $10,7 \%$ de Carrió. La elección de un patagónico genera expectativa en la provincia. Kirchner se presenta como el seguro ganador de la segunda vuelta, mostrando que la estrategia pensada por Duhalde había sido la correcta para derrotar a Menem. A mediados de mayo Menem desiste de presentarse a la segunda vuelta ante la dura derrota que se preveía, y Kirchner es proclamado nuevo presidente, asumiendo formalmente el 25 de mayo. 
Pero el mayor resultado de esta elección fue que se logra recomponer la institucionalidad burguesa. Los altos porcentajes de votación muestran la recuperación de la confianza popular en que las instituciones y los mecanismos de recambio del régimen podían garantizar un cambio en la sociedad. El nuevo gobierno desarrolla una práctica centrada en desmovilizar a los movimientos de desocupados y los sindicatos, buscando dividirlos y cooptarlos.

Recién el 27 de mayo se retoma una lucha en conjunto de varios grupos de desocupados de Trelew, cuando la CTD "Aníbal Verón” junto a la CCC y la agrupación "Evita" marchan al municipio en reclamo de setenta y cinco puestos de trabajo. El 26 de junio se realiza un acto en conjunto de las cuatro organizaciones de desocupados que todavía tenían actividad permanente en Trelew (CTD Aníbal Verón, MIJD, Evita y CCC) en homenaje a Kostequi y Santillán, a un año de su asesinato. También participan miembros de agrupaciones estudiantiles.

Al día siguiente estas organizaciones de desocupados cortan la avenida principal de Trelew ante la llegada del presidente Kirchner a Chubut, a quién una delegación le entrega un petitorio en la ciudad de Rawson reclamando aumentos de los planes, insumos para los proyectos y mayor cantidad de planes ${ }^{199}$. No aparecen otros conflictos, excepto algunos muy pequeños y aislados. Son indicios claros de la recuperación de la institucionalidad burguesa tras la profunda crisis de dominación. El nuevo gobierno generaba expectativa y eso frenaba la posibilidad de nuevas luchas. La batalla tan fuerte en los años anteriores también planteaba para los trabajadores la necesidad de recomponer la situación y analizar el nuevo marco social y político.

Casi únicamente los desocupados siguen motorizando conflictos contundentes, aunque estos se dan sin el acompañamiento social de otros momentos. El 21 de julio las cuatro organizaciones de desocupados inician un corte de ruta reclamando doscientos nuevos planes. Al otro día se levanta el corte tras el acuerdo con el ministro de gobierno, quién promete entregar los planes en tres cuotas.

La rápida resolución de esta protesta tiene relación con la coyuntura electoral. Pese a que la política del gobierno hacia las organizaciones de desocupados desde abril del 2002 había sido negarse a recibirlos o negociar, en este momento prefieren no arriesgar a que se genere una escalada de protestas cerca del proceso eleccionario.

A partir de allí casi toda la actividad se traslada a las elecciones provinciales. El PJ termina de cerrar su interna con Das Neves como candidato. En cambio las internas de la UCR son muy fuertes. Los dos principales candidatos (el gobernador

$\overline{{ }^{199} \text { Diario Jornada, 28/5/2003, pág. } 6 .}$ 
Lizurume y el anterior gobernador Carlos Maestro) quedan casi empatados, se proclama ganador a Lizurume en medio de denuncias de fraude, y se produce una virtual fractura de la UCR. Aparecen pintadas y expresiones acerca del apoyo que sectores del "maestrismo" darían a Das Neves para "vengarse" de la traición de Lizurume.

A fines de octubre los docentes agrupados en Comunidades Educativas marchan en Trelew en reclamo de mejores sueldos y en solidaridad con el reclamo de los trabajadores de la salud. Se oponen a la conducción de la Atech, que apoya a Lizurume y afirma que estas marchas perjudican a los docentes ya que las mejoras podían conseguirse con la negociación aprovechando la etapa electoral ${ }^{200}$. También el Sitraed se moviliza en Puerto Madryn ante la visita de Lizurume.

El conflicto entre los estatales y sus conducciones gremiales se agudiza en esta fase. Los trabajadores de salud dicen sentirse traicionados por los dirigentes de ATE que aceptan la conciliación obligatoria dictada por el gobierno ${ }^{201}$ y rechazada por las asambleas, y los docentes no aceptan un aumento de $\$ 150$ que Atech reivindica como el éxito de sus gestiones.

En noviembre Kirchner visita la provincia a pocos días de las elecciones. Expresa un tibio apoyo a Das Neves y muchos elogios a Lizurume, quién aparecía como el seguro ganador. Sin embargo el PJ logra la victoria en Chubut y sus ciudades más importantes. El nuevo gobierno asume el 10 de diciembre y este cambio genera expectativa en la población.

Para el segundo aniversario del 19 y 20 de diciembre del 2001, se realizan varios actos a nivel nacional, que muestran la división que ya estaba generando en el movimiento popular las características del nuevo gobierno. En Plaza de Mayo hay tres actos, uno de los sectores cercanos al gobierno (Barrios de Pie, MTD Aníbal Verón, organismos de derechos humanos, en especial los de familiares), más tarde marcha la CCC en una postura intermedia entre el rechazo y el dialogo y finalmente los sectores que se definían como opositores (Bloque piquetero nacional, MIJD, partidos de izquierda y otros sectores de derechos humanos). En este último acto explota una bomba en un tacho de basura que hiere a varios manifestantes. Al otro día se realiza una nueva marcha exigiendo que se investigue este hecho, pero nunca se avanza en este sentido.

Desde el gobierno provincial se produce un fuerte ataque mediático a los grupos de desocupados, en especial desde el director de empleo, Etchepareborda que

\footnotetext{
200 Diario Jornada, 22/10/2003, declaraciones de Hugo Schvemmer, Secretario General de Atech pág. 5. Días después ratifica esta postura el secretario de promoción social, Fernando Mondo: Diario Jornada 30/10/2003, pág. 5 .

${ }^{201}$ Diario Jornada, 28/10/2003, declaraciones de Raúl Idiarte, delegado de base de ATE, pág. 3.
} 
además es dirigente de la AOT, quién asegura que se avanzara en sacarles todos los planes. Ante esto el 2004 comienza con varias protestas de los grupos de desocupados. En enero los desocupados de la CTD "Aníbal Verón”, Peñi Namun y Evita, se movilizan al municipio, cortan calles y toman edificios públicos, reclamando nuevos planes y que no haya persecuciones.

Durante el 2004 todavía hay una importante presencia de los grupos de desocupados. Pero cada vez aparece más desdibujada su capacidad para presentarse como una alternativa para otros sectores. Sus reclamos se hacen más corporativos. La burguesía había logrado frenar su crisis de dominación y recuperado la confianza de la sociedad en el sistema institucional.

El gobierno provincial anuncia la decisión de suspender los permisos de pesca de la empresa Barillari, de Comodoro Rivadavia. Esto es a raíz de las condiciones de casi esclavitud y total desprotección en las que trabajaban los fileteros. Allí queda claro que las supuestas "cooperativas" que contrataban el personal eran formas de encubrir la explotación laboral y una modalidad de evasión impositiva. Si bien la medida es progresiva no se avanza en prohibir estas cooperativas, por lo cual esto aparece más como una acción en contra de este empresario en particular, que como una política en contra de la explotación laboral.

A fin de febrero se potencia otro conflicto en la pesca. El Stia quema cubiertas frente a Naramar, denunciando el despido de trabajadores, entre ellos los que se habían postulado como candidatos a delegados gremiales. La medida continúa varios días, con algunos enfrentamientos con el personal que pretendía entrar a trabajar. Se firma la conciliación obligatoria, pero la empresa no acepta esta disposición oficial y el 27 anuncia que cerraría la planta, despidiendo a todo el personal.

Marzo se inicia con el conflicto docente. Es un duro enfrentamiento entre la dirigencia de Atech y el nuevo gobierno provincial. Se había avanzado en la votación de la llamada "ley de incompatibilidad", por la cual se prohibía tener más de una cantidad determinada de horas cátedra por docente. Además el gobierno había anulado el acuerdo de aumento realizado por la Atech con Lizurume. El congreso provincial decide el no inicio de clases, votando un paro en toda la provincia para ese día y un paro por tiempo indeterminado en Comodoro Rivadavia. La decisión dividida debilita el conflicto y tiene relación con la mayor presencia de fuerzas opositoras a la conducción de Atech en esa ciudad.

El Frente de Gremios Estatales se manifiesta en apoyo a la lucha de los docentes, aunque solamente a través de un comunicado. El Sitraed rechaza el paro, y, tras una reunión con el gobernador, avala el inicio de clases diciendo que confian en 
que se cumpliría el compromiso de incorporar $\$ 100$ al básico en abril. La Atech denuncia que el acuerdo con Sitraed fue a cambio de licencias gremiales.

Finalmente la huelga solamente tiene adhesión importante en Comodoro. En Esquel sólo se produce una movilización por la tarde. El gremio no brinda datos sobre Trelew, Rawson y Puerto Madryn, hecho que muestra la escasa adhesión, sin darse tampoco manifestaciones en la calle. En Rawson el paro es nulo y los docentes autoconvocados así lo hacen saber, diciendo que no darían entidad a una dirección como la de Atech.

Reaparece en Puerto Madryn la movilización con eje en la "inseguridad". Tras el asesinato de un operador de radio de una agencia de remises, se producen tres marchas. La última es una convocatoria muy importante, con más de mil personas, entre ellas las autoridades políticas de la ciudad. La consigna es "seguridad y justicia" y la protesta es dirigida contra el poder judicial.

Estos hechos se encadenan en abril con el proceso que encabeza Blumberg, generando reclamos masivos por leyes más represivas. En ese marco hay nuevas marchas en Madryn, aunque sin el grado de masividad de las anteriores. En Trelew se convoca a marchar apoyando el petitorio de Blumberg, pero la escasa convocatoria lleva a que no se realice ninguna medida.

Para mediados de mes la interna del PJ en Trelew ya trabajaba en el camino de reemplazar a Gómez de la intendencia ${ }^{202}$. Se sabía que sus días como intendente estaban contados, que sería reemplazado coyunturalmente por Marconetto, hombre de confianza de Das Neves, y que luego iría de candidato el hijo del viejo referente del PJ, Mac Kharty. La decisión provenía de cierta incapacidad que había mostrado Gómez para estar al frente de este cargo y, fundamentalmente, de que manejaba ciertos grados de autonomía con respecto al poder de Das Neves.

El 12 de mayo hay una jornada nacional de lucha del movimiento piquetero que no tiene repercusión en la región. El bloque piquetero nacional, la CCC y el MIJD cortaron calles, puentes y rutas contra la tipificación como "delito" del corte de de vías de circulación pública, por subsidios al gas y a la luz y por trabajo genuino.

Sí se movilizan el MIJD, la Evita, la CTD “Aníbal Verón” y la Peñi Namun, al otro día. Marchan y toman el Concejo Deliberante contra el aumento de la luz. Finalmente el aumento se aprueba (es de un 7\%), con el compromiso de que habría una tarifa social para los desocupados.

\footnotetext{
202 Horacio Gómez había sido elegido intendente como parte de la lista de Das Neves y por escasa diferencia sobre la UCR. Su gestión estuvo desde el principio atravesada de internas políticas entre las distintas líneas del PJ de Trelew, potenciadas por algunos problemas de índole personal del intendente.
} 
Durante mayo se moviliza en varias ocasiones el Sitraed, reclamando aumento salarial. Ante la falta de respuestas votan un paro de actividades. Así este sindicato que había rechazado el paro cuando lo hacía la Atech, llama a una huelga ahora, pero en soledad, mientras la Atech ahora se llama a silencio. De los dos lados se mantiene la división de la lucha docente.

La huelga no tiene peso, excepto en Puerto Madryn. Sí es importante la movilización de más de doscientos cincuenta docentes a Rawson, donde el Sitraed es acompañado por miembros de Comunidades Educativas de Trelew. Marchan a Casa de Gobierno, Legislatura y al Ministerio de Educación.

Los trabajadores de la pesca toman la planta de Iberpesca en Rawson, el 9 de junio. Al otro día el conflicto se profundiza. Marchan a la Legislatura reclamando soluciones y la entrega de los permisos de pesca que pide la empresa. Allí queman cubiertas y cuando los bomberos intentan apagarlos hay enfrentamientos, se rompen vidrios y hay bomberos golpeados. Los trabajadores se dirigen al municipio donde rompen los vidrios de la oficina del intendente y cuando deciden avanzar contra la Casa de Gobierno llega al lugar el dirigente del gremio, Luís Nuñez, quién les pide que no se realice dicha acción.

Se desconcentran y se dirigen a la sede gremial, donde una hora después son atacados por la policía, enfrentamiento que culmina con nueve heridos por balazos de goma entre los trabajadores, un policía herido por un balazo de otro policía y cuatro detenidos. El dirigente del Stia se despega diciendo que ellos no convocaron la protesta y que la culpa es del empresario que presiona a sus trabajadores. Sí exige la expulsión de los policías que reprimieron. El gobernador también se desentiende, acusando de inacción a los Consejos Municipales de Pesca y de falta de responsabilidad a los empresarios ${ }^{203}$. Horas después el empresario paga parte de los sueldos que debía.

El Stia marcha a la puerta de la comisaría para reclamar la liberación de los detenidos, que salen por la tarde. Reciben el acompañamiento de dirigentes del Sitravich, Atech y ATSA.

La CGT regional convoca a una huelga y movilización para el 17, al cumplirse una semana del ataque contra los trabajadores de la pesca. La convocatoria surge desde la CGT y el Stia. El gobierno realiza una fuerte campaña en contra, articulando la acusación de Das Neves de que la marcha tenía contenido político y que era manejada por los empresarios para presionar por más permisos y la amenaza de represión desde el ministro de gobierno, Mac Karthy, y el ministro coordinador de

${ }^{203}$ Diario Jornada, 11/6/2004, declaraciones de Luís Nuñez y de Mario Das Neves, pág. 2. 
gabinete, Yahuar, quienes afirman que habría infiltrados de Quebracho y activistas de Mar del Plata para provocar disturbios que ellos no permitirían que sucedan ${ }^{204}$.

Hasta el último día el gobierno realiza gestiones para impedir la marcha (el 16 hay una reunión de más de tres horas con la dirigencia de la CGT) y muchos sindicatos se bajan de la convocatoria. La pretendida concentración de unas cinco mil personas no supera las mil y por eso el gobierno afirma que el paro fue un fracaso ${ }^{205}$. La intención de un sector del sindicalismo vinculado al PJ de tener una postura autónoma con respecto al gobierno pareció ser derrotada en este hecho, que midió las fuerzas de uno y otro lado. Además los trabajadores no reciben el apoyo de otros sectores, como los desocupados o los estudiantes.

Lo que resta de junio y julio son protestas muy localizadas y restringidas a los reclamos corporativos. Rápidamente se deja de lado el reclamo de que el gobierno tenga un costo político por la represión. Recién a fin de julio hay un hecho significativo en la calle, cuando se movilizan las cuatro agrupaciones de desocupados al municipio de Trelew. Pero su reclamo se restringe a las necesidades de sus grupos, solicitando aumento de los planes y cincuenta nuevos planes para cada agrupación.

En agosto se desencadena la crisis del gobierno de Trelew. De acuerdo al plan acordado en una reunión de la dirigencia provincial del PJ, se obliga al intendente a renunciar, se nombra como intendente provisorio a Marconetto (hasta allí secretario de desarrollo social de la provincia) y se llama a nuevas elecciones en noventa días.

No hay ninguna reacción popular frente a este hecho. Se producen sí algunas movilizaciones de grupos que reclaman que el nuevo intendente mantenga los acuerdos que se habían realizado con el anterior. Así los taxistas solicitan el aumento de tarifas y las agrupaciones de desocupados que se ratifiquen los proyectos ya aprobados.

Desde hacía unos meses todos los miércoles se movilizan en Puerto Madryn un grupo de familiares de víctimas. Son movilizaciones pequeñas, que reclaman justicia para los casos de sus familiares y leyes más represivas.

En septiembre los trabajadores de vialidad provincial marchan hasta la Casa de Gobierno reclamando la reincorporación de veintiún empleados que habían sido despedidos. El ministro de gobierno de la provincia dice que el gobierno apoya y ratifica el despido de los trabajadores por su bajo rendimiento.

\footnotetext{
204 Diario Jornada, 16/6/2004, pág. 5.

205 Diario Jornada, 18/6/2004, declaraciones de Norberto Yahuar, ministro coordinador de gabinete de Chubut, pág. 2.
} 
El 8 se corta la ruta 3 en Trelew reclamando la liberación de Castells. Marchan las cuatro agrupaciones (Peñi Namún, CTD “Aníbal Verón”, la Evita y el MIJD), y queman cubiertas.

Mientras tanto ya estaba totalmente lanzada la campaña electoral por la intendencia de Trelew. Muchas de las organizaciones trasladan su actividad a actuar alrededor de este hecho. Se aíslan las luchas de los trabajadores. Recién el 13 de octubre hay una medida fuerte. Es un nuevo corte de ruta exigiendo la libertad de Castells. Pero en lugar de los cuatro grupos, como en los anteriores cortes, ahora es sólo el MIJD el que realiza la medida.

Al otro día los taxistas protestan contra los remises truchos que, según ellos, eran avalados por el gobierno del PJ. Lo que desencadena un fuerte conflicto es que la caravana de vehículos comienza con un escrache a una de las tantas remiserías ilegales, pero justamente a una que funcionaba en un local de campaña del candidato del PJ, Gustavo Mac Kharty.

El paro total de los taxistas dura más de cinco horas y tanto el candidato del PJ como el intendente provisorio denuncian que fue un hecho político ${ }^{206}$. Mientras esto sucede el candidato de una UCR muy dividida, Claudio Conrad, realiza campaña con el ex gobernador Carlos Maestro. El PJ despliega una campaña significativa en cuanto a la cantidad de fondos, con gran cantidad de locales y un enorme despliegue para asegurarse el poder en la ciudad "más política" de la provincia.

Durante octubre es constante la discusión sobre el tema pesquero, por el recorte a los cupos de merluza para la provincia. Hay marchas y reclamos de distintos grupos de trabajadores y muchas internas entre las empresas. A principio de noviembre aparentemente se soluciona el conflicto con la apertura de un nuevo cupo para la captura de merluza en Chubut. Sin embargo surge otro conflicto con el reclamo de los marineros de la flota amarilla, que exigen un aumento de un $38 \%$ en sus sueldos, el incremento de la garantía para cuando no había trabajo y la inclusión de un seguro especial para sus familiares en caso de accidentes fatales. Se movilizan hasta la sede de la secretaria de pesca y el 10 se soluciona el conflicto de los marineros, con un aumento del $20 \%$ para la merluza y del $30 \%$ para los langostinos.

Las agrupaciones de desocupados Peñi Namún, CTD “Aníbal Verón”, la Evita y el MIJD se movilizan el 3 de noviembre ante el municipio. Vuelven a reclamar los doscientos nuevos planes y el aumento del pago. Dicen que aún no reciben respuestas del petitorio entregado hace más de un mes. En los días siguientes se

\footnotetext{
${ }^{206}$ Diario Jornada, 15/10/2004, declaraciones de Aldo Marconetto y Gustavo Mac Kharty, pág. 6-7.
} 
endurece el conflicto. Al no haber respuestas el 9 la CTD "Aníbal Verón", la Evita y el MIJD cortan la ruta nacional №3, durante más de treinta horas.

En la asamblea se decide levantar el corte para marchar hasta el municipio, considerando que, por la cercanía de las elecciones, allí sería más contundente el reclamo. Al llegar los desocupados toman el municipio, ante una fuerte presencia policial y la amenaza de represión. Es una medida que no había sido preparada y se da en medio de una fuerte disputa política por ser el día de cierre de campaña para la elección del intendente. Hay roturas de varios vidrios, es lastimado un policía en un confuso hecho y llegan las divisiones especiales de la policía provincial.

Tras varias horas se concreta un acuerdo de desalojar el municipio a cambio de una reunión con autoridades nacionales que viajarían el lunes 15 (tras la elección del domingo 14). Hay mucha discusión entre los desocupados, especialmente por un sector que pretendía mantener la toma durante todo el fin de semana.

EI PJ logra una victoria contundente en las elecciones, superior a lo que se preveía. El gran despliegue y la falta de apoyo a las otras opciones (en especial a la UCR) hace que el conflicto político y social que se venía viviendo en la ciudad no impacte contra del PJ. Consiguen el $55,27 \%$ de los votos, contra el $27 \%$ de la UCR y el $8 \%$ del PACH.

La negociación del lunes adquiere otro carácter para el gobierno, que llega muy fortalecido. Los funcionarios nacionales no viajan y los desocupados no reciben ninguna respuesta seria del intendente, quién les dice que deberán esperar a que asuma el intendente electo. La movilización es claramente más pequeña que la del viernes pasado.

El 2005 es un año de fuertes conflictos. Especialmente los más importantes se desarrollan en la pesca, por lo cual aquí sólo haremos mención de ellos, realizando una descripción y un intento de análisis más fino en el apartado 4.2.

Ya el 6 de enero se movilizan desocupados de la pesca al municipio de Trelew. Reclaman por puestos de trabajo, denunciando que algunas empresas estaban contratando trabajadores traídos de Mar del Plata. El 14 son los trabajadores de los buques de Alpesca, afiliados al SOMU, los que se movilizan frente a la subsecretaria de trabajo. Reclaman el pago de las vacaciones, los días de franco y la firma del Convenio Colectivo de Trabajo. El 17 se realiza un escrache a la empresa, quemando cubiertas frente al acceso de la pesquera. Luego de la protesta se realiza una asamblea en la cual se decide continuar con el plan de lucha por amplia mayoría. A fines de mes se genera un conflicto en las pesqueras de Rawson por la no renovación de los contratos de casi doscientos trabajadores en Conarpesa, Argenova y Agropez. 
Conflictos de este tipo siguen en forma permanente. Al iniciarse marzo los trabajadores pesqueros cortan la ruta que conecta Rawson con Playa Unión.

También reaparece la protesta de los desocupados agrupados en la CTD Aníbal Verón, la Peñi Namún y la Evita. Cortan durante más de tres horas la calle frente al municipio y no reciben una respuesta concreta. $Y$ comienza el conflicto en la universidad, donde la FUP y el Movimiento Estudiantil Liberación cortan calles, reclamando el cambio de gestión del rector Bersán, quién se mantenía al frente de la UNP desde hacía más de diez años. Otros reclamos centrales son el subsidio al Comedor Universitario para garantizar el bono a $\$ 1,50$, las becas estudiantiles, el albergue, la falta de aulas y la transformación de la Escuela de Derecho en Facultad.

El 4 de abril los estudiantes universitarios se movilizan hasta la Facultad de Económicas, denunciando una reunión secreta entre los decanos y el rector. Allí son recibidos por las autoridades sin lograr respuestas. Se convoca una nueva asamblea para el lunes 11 , donde ya se decidiría la toma de la UNP.

Ese día comienza una importante toma universitaria en la sede Trelew, como parte de un plan de lucha de la FUP que involucraba a las demás sedes de la UNP (en Comodoro Rivadavia la toma se había iniciado el viernes 8). La toma es votada por una asamblea de casi mil estudiantes, comenzando un proceso de los más recordados en la lucha estudiantil de la región. El grado de movilización, la participación masiva del estudiantado, la práctica asamblearia permanente, la formación de Comisiones de trabajo en funcionamiento constante y la activa solidaridad de gran parte de la sociedad, son factores que hacen de la toma un proceso muy significativo. Además se logran la mayoría de sus reclamos fundamentales.

Es interesante la dirección del conflicto por parte de la FUP, dirigida políticamente por el Movimiento Estudiantil Liberación, que en la sede Trelew genera un marco de unidad entre casi todas las fuerzas, y provoca un gran crecimiento de la fuerza de izquierda en la UNP. Durante el proceso de la toma se incorpora como reclamo central la democratización de la Universidad, y por ello pasa a ser una consigna clave la reforma de estatuto.

El gremio no docente convoca a un paro de actividades mientras dure la toma, adhiriendo a los reclamos estudiantiles. En el caso de Esquel la APUNP local se niega a sumarse al paro. Los docentes universitarios también se suman activamente a la toma, siendo su dirigente gremial el presidente de la asamblea en Comodoro Rivadavia ante los choques que en dicha sede se producían entre las distintas fuerzas estudiantiles.

Las autoridades se comprometen a convocar un Consejo Superior, que se realizaría el martes 19 en Comodoro Rivadavia en el marco de la toma, garantizando 
la resolución de casi la totalidad de los puntos reclamados. Se ratifica en las asambleas la continuidad de la toma hasta la sesión.

La discusión igual es compleja ya que muchos sectores se niegan a sesionar sin que se levante la toma, amenazando con no dar quórum. Las asambleas ratifican su postura de que no hay levantamiento ni suspensión de la toma y que no reconocerían el Consejo Superior si este no se realiza en el marco de la medida de fuerza, garantizando la seguridad de los consiliarios con las Comisiones de Seguridad estudiantiles.

Finalmente el 19 se realiza la sesión del Consejo Superior. Viajan estudiantes de Trelew y otras sedes, más la importante movilización en Comodoro Rivadavia. La sesión se realiza en el marco de una gran tensión, con mucha presión estudiantil y del gremio docente y no docente. Los consiliarios terminan votando todos los reclamos estudiantiles y la dirigencia de la FUP juega un papel central. En verdad el Superior funciona en el marco de la continuidad asamblearia y sólo puede ratificar lo que las asambleas ya habían votado. Son los mismos consiliarios, decanos y rector que durante años se habían negado a escuchar a los estudiantes.

Al otro día se realizan grandes asambleas en las distintas sedes donde se decide el levantamiento de la toma, habiendo conseguido el subsidio para los comedores, las becas, el llamado a asamblea para la transformación de Derecho en facultad, el comienzo del proceso de reforma de estatuto, la extensión del calendario académico, la no persecución a los estudiantes y otra serie de puntos menores.

En abril del 2005 también comienza una larga huelga en el sector pesquero, que se extiende durante más de treinta días. Veíamos ya que en los meses anteriores se desarrollaban continuamente pequeños conflictos por planta. Pero sobre todo se va calentando el reclamo de aumento salarial.

Desde el inicio hay una relación de tirantez entre trabajadores de algunas plantas, que reclaman desde hace meses el llamado a huelga, y la dirección sindical. Tras casi un mes de continúas negociaciones con autoridades del gobierno y de las cámaras empresarias, finalmente el 13 de abril se convoca desde el Stia a un paro total de actividades por tiempo indeterminado en todas las pesqueras de la provincia. En la negociación la CAPIP (Cámara Patagónica de Industrias Pesqueras) hace una oferta de llevar la hora a un "máximo" de \$6. El sindicato plantea que como mínimo acepta 7,80 , siendo su reclamo original $\$ 8,10$ por hora.

Con piquetes se impide la operatoria de las plantas pesqueras y en una primera fase se consigue amplia solidaridad, desarrollando fuerza moral y material que llega hasta la declaración de un paro general en Puerto Madryn para el lunes 25 de abril. Este es un momento clave de la huelga, un hito en la misma. Por un lado el 
conflicto en la región noreste de Chubut toma un carácter político. El reclamo se descorporativiza, tomando todos los obreros la lucha de un sector como propia. Al mismo tiempo la patronal rompe la unidad de los obreros a nivel provincial: los trabajadores de Comodoro Rivadavia levantan la huelga, en una decisión avalada por los representantes del Stia de esa ciudad.

Si bien el paro general no fue muy contundente, especialmente no se siente en Aluar y en el Estado, sí fue impactante la movilización, a la cual se sumaron más de cinco mil trabajadores. A partir de ese día el gobierno empieza a operar para derrotar la huelga. La misma había superado los límites de lo aceptable. En los discursos de la marcha había quedado claro que era el Estado el que podía destrabar el conflicto si intimaba a los empresarios. Es allí donde el conflicto toma carácter político.

En Madryn se vivía también una huelga entre los ceramistas, y unos días antes se realizaron medidas en Aluar, en todos los casos por aumento salarial. Pero ahora el conflicto había logrado ser aislado. Cada reclamo se da sin trascender lo corporativo. Se va perdiendo fuerza moral y el proceso ingresa en una fase descendente.

En ese marco para el 5 de mayo sigue sin haber novedades. El gobierno estira el conflicto, al igual que la patronal, negociando con los demás gremios que no se generen movilizaciones o nuevos paros generales. En Puerto Madryn se mantiene el corte parcial a la ruta № 1 y tres piquetes en el camino al puerto. Los trabajadores de Rawson mantienen también un corte de la ruta de Rawson a Playa Unión.

La presión del gobierno para frenar el conflicto impacta en los dirigentes sindicales, la mayoría de ellos de militancia en el PJ. Se acepta bajar el reclamo hasta los \$7 por hora. El SUPA levanta la medida de fuerza ante una ayuda económica gestionada por el intendente de la ciudad. Además se acuerda con el Stia que se les permita operar los buques poteros ${ }^{207}$. La huelga va quedando aislada y se le quita contundencia. Luego de haber frenado la posibilidad de que la lucha tome un carácter general el gobierno frena las expresiones de solidaridad y divide a los trabajadores.

La falta de dinero empieza a hacer mella en la lucha. Mientras el Stia solicita donaciones, los obreros de Iberpesca (Rawson) toman las instalaciones y abren las cámaras frigoríficas amenazando con vender la mercadería. Se discute la necesidad de medidas contundentes para torcer el rumbo. La dirigencia del Stia decide impulsar una marcha desde Madryn hasta Rawson, donde le entregarían un petitorio a Das

\footnotetext{
207 Los poteros son barcos que utilizan artes de pesca selectivas para la captura especializada de calamar. Estos buques, en su mayoría originarios de China, Corea o Japón, pescan normalmente de noche, cuando los cardúmenes son concentrados mediante la iluminación de sus potentes lámparas. Este tipo de pesca genera una rápida depredación del recurso, que al concentrarse en una sola especie impacta fuertemente en la cadena trófica del resto de la pesquería.
} 
Neves. Son más de $80 \mathrm{~km}$ que se hacen en su mayor tramo a pie. Para muchos se trata de una forma de descomprimir el conflicto en Puerto Madryn.

La larga marcha parece haber estirado otros dos días el conflicto. Así es que los días siguientes casi no hay novedades. La huelga sigue pero no hay iniciativas del sindicato. Días después se da una nueva muestra de debilidad al aceptar la vuelta al trabajo del personal administrativo de las plantas.

La CAPIP eleva una nueva propuesta al Stia el día 18, supuestamente mejorando la oferta patronal. Se realiza una asamblea de más de mil quinientos trabajadores en el gimnasio municipal, donde la propuesta es rechazada, se ratifica el paro y se decide la toma del Concejo Deliberante.

Finalmente el 20 de mayo se llega a un acuerdo, tras fuertes presiones del gobierno provincial. El Stia termina aceptando 6,50 la hora (antes del conflicto era de 3,40 ). El salario asegurado tiene un aumento significativo (es el salario en tiempo de inactividad por falta de recurso, pasa a 1014 el mínimo) y entre los fileteros se pasa de 0,30 por kilo a 0,42 . Pero más allá de los aumentos, lo que demuestra que se esta ante un golpe al sindicato es el compromiso firmado de un año de paz social en el marco de un acuerdo que no define si se pagarían o no los treinta y ocho días de huelga.

En términos generales vemos que la burguesía ha logrado recomponer su crisis de dominación. Ahora los reclamos obreros ya no logran trascender lo corporativo, y cuando intentan hacerlo (como en el caso de la pesca) son duramente enfrentados.

Esto se evidencia en las distintas huelgas que se desarrollan este año y en el debilitamiento de los grupos piqueteros que habían expresado los sectores más combativos en la región. Es significativo que estos grupos apenas desarrollan alguna acción aislada de solidaridad con la toma universitaria y que directamente no aparecen a lo largo de la huelga pesquera, pese a los distintos hechos de cortes de rutas y manifestaciones.

Integrantes de la CTD "Aníbal Verón" cortan la ruta el 6 de junio. Es parte de un plan de lucha nacional por aumento de la cantidad de planes. Tras esta medida recién un grupo de desocupados vuelve a movilizarse el 28 , cuando la CTD marcha para solidarizarse con los integrantes de ATE detenidos en Santa Cruz.

El 30 de junio nuevamente se corta la ruta, pero otra vez lo hace una sola agrupación sin acompañamientos. En esta ocasión es el MIJD, reclamando la liberación de Raúl Castells y los demás detenidos por participar en luchas sociales.

El 18 de julio se realiza otro corte con los mismos reclamos, pero por la CTD "Aníbal Verón". Al otro día otra vez se corta la ruta, pero ahora por el MIJD y la 
Agrupación Evita, con casi idénticos reclamos. Este corte es más contundente, impidiendo pasos alternativos y manteniendo el mismo hasta la noche. Pero ante la poca gente que se mantuvo en el mismo se los logra desalojar por la madrugada. Las medidas repetidas y aisladas daban facilidad al gobierno para atacar a los grupos piqueteros y afinar su estrategia de cooptación de algunos y represión de los que pretendían seguir luchando. Se anuncia que les sacarán los planes de empleo a los integrantes del MIJD y la Evita.

Hacia fines de agosto y principios de septiembre los docentes de Comodoro Rivadavia comienzan un plan de lucha, con huelgas que van ganando en contundencia y en movilización callejera. La dirección provincial de Atech no reconoce el llamado a huelga y se enfrenta con los dirigentes de Comodoro. Por su parte los no docentes provinciales de Puerto Madryn también realizan una huelga reclamando aumento salarial. Desde ATE, en lugar de buscar empalmar el proceso con la huelga docente, se hace eje en las diferencias entre porteros y docentes, acusando a estos últimos de ser "privilegiados".

Sí se suma a estas acciones el Sitraed, aunque votando medidas propias que tienen peso fundamentalmente en Madryn. El proceso de luchas atraviesa todo el mes de septiembre sin obtener respuestas positivas del gobierno.

Para octubre el conflicto se profundiza. El 4, 5 y 6 el Sitraed realiza una huelga por 72 horas, logrando alto acatamiento y desarrollando marchas a las que se sumaron los porteros afiliados a ATE que aún estaban en conflicto.

En Comodoro también crecía el conflicto entre los petroleros. Tras huelgas y movilizaciones, la Subsecretaria provincial de trabajo ordena el pago del adicional que reclaman. Ante el desconocimiento del hecho por las empresas los trabajadores deciden tomar la planta de almacenamiento y distribución de petróleo ubicada en Comodoro.

$Y$ esto profundiza la conflictividad que se vive en toda la provincia, pero que se hace especialmente latente en Comodoro. Para el 10 de octubre los petroleros ya llevan 16 días de huelga y cinco de toma de la planta de Termap y ese día los docentes de la ciudad deciden, en contra de la dirección provincial de su sindicato, el llamado a paro por tiempo indeterminado. El gobierno provincial apoya discursivamente el reclamo de los petroleros pero enfrenta el de los docentes. Mientras esto sucede se ingresa en la recta final hacia las elecciones de diputados nacionales del 23 de octubre.

El conflicto docente se hace provincial, pero se mantiene mucho más radicalizado en Comodoro. En Trelew y Rawson hay huelga el 13 y se movilizan frente al ministerio y a la Atech, criticando el abandono de la dirigencia del gremio. 
El 19 se produce una importante movilización en Rawson. Son casi mil personas entre docentes de Comodoro Rivadavia, Puerto Madryn y las ciudades del Valle, más trabajadores de ATE salud, porteros de escuelas y estudiantes nucleados en la FUP. No hay respuestas del gobierno y se ratifica el paro por tiempo indeterminado de los porteros y docentes de Comodoro y Madryn (dirigidos por la delegación local de Atech en Comodoro y por Sitraed en Madryn, con la oposición de la Atech a nivel provincial) y un paro de 48 horas de los docentes del Valle (dirigidos por los antiguos autoconvocados que formaron Comunidades Educativas). A este contexto se suma el conflicto entre los policías, incorporándose en Comodoro las esposas de los agentes a la movilización, y tomando la seccional primera y la unidad regional.

Para el 20 el conflicto ya hacía eclosión por todas partes. Mientras las fuerzas políticas cerraban la campaña electoral (con una significativa movilización del aparato del PJ, especialmente en Trelew donde hay dos mil personas en el acto final), se producen marchas en las distintas ciudades. La más numerosa es en Comodoro, supera las cinco mil personas con el ingrediente de que la policía se auto acuartela y quema cubiertas frente a la seccional. También hay protestas de policías en Rawson y Trelew. En esa ciudad sectores de docentes, estudiantes y desocupados marchan frente al acto por el aniversario de la ciudad.

En Madryn hay enfrentamientos porque el gobierno envía personal de planes sociales a limpiar las escuelas, generándose choques con Ate y Sitraed. Además se produce una movilización del personal policial, acompañado por el Sitraed.

Las protestas se extienden hasta el sábado previo a las elecciones legislativas. Tras una nueva marcha en Rawson, un grupo constituido principalmente por docentes rodea la Casa de Gobierno y la residencia del gobernador. Tras algunas horas, se pinchan las cubiertas del vehículo oficial de Das Neves y se le corta el gas y la luz a su residencia. Momentos antes el gobernador había hecho gestos obscenos a los grupos movilizados y desde los días anteriores había amenazado a los sectores en lucha, en especial con su continuidad como empleados estatales. EI PJ denuncia que la marcha y todo el conflicto social tienen connotaciones político-electorales ${ }^{208}$.

El domingo la victoria del PJ es muy contundente. Consiguen el $55 \%$ contra el $25 \%$ de la UCR y el $10 \%$ del PACH. Contra el candidato oficial se presentaba Carlos Maestro de la UCR, quién fuera gobernador de la provincia durante los años noventa. Esto fortalece al gobierno y quita fuerza a la movilización social. Avanza la política de cooptación, sustentada en un gobierno que aparecía como cada vez más fuerte.

\footnotetext{
${ }^{208}$ Ver, entre otros, Diario Jornada, 22/10/2005, declaraciones de Mario Das Neves, pág. 5.
} 
El lunes 24 los docentes de Comunidades Educativas se vuelven a movilizar ante la sede de gobierno en Rawson, ratificando que el conflicto no era políticoelectoral, aunque debilitados por el apoyo que había logrado el gobierno. Unas horas después militantes del PJ, funcionarios y trabajadores estatales, realizan una marcha de "desagravio", a favor de Das Neves.

Mientras seguían los acuartelamientos policiales el gobierno otorga un importante aumento para la policía, que se sanciona el martes 25. Ante esto la policía deja de lado toda protesta, y desde el gobierno se amenaza con sanciones al personal que se movilizó.

Los docentes ratifican las medidas de fuerza que se realizan en toda la provincia, excepto en la cordillera. La adhesión más alta es en Comodoro Rivadavia (un $80 \%$ ), mientras en Puerto Madryn y Trelew ronda el 65\% y es más baja en Rawson. El gobierno afirma que recibirán a los docentes si dejan de lado las huelgas. La conducción de Atech sigue negándose a convocar un paro que la gran mayoría de los docentes ya esta realizando.

El gobierno realiza reuniones con las conducciones de ATE y Atech el día 26. ATE acuerda un aumento salarial para los porteros, mientras la conducción de Atech ratifica que no reconoce al paro docente como legal. Así se genera una fuerte debilidad política de la huelga, reforzando el hecho de la victoria electoral del gobierno

Al otro día esto se refleja en la asamblea de Comunidades Educativas en Trelew, donde más de seiscientos docentes deciden suspender el paro hasta el martes $1^{\circ}$ de noviembre. Se movilizan por el centro de la ciudad, siendo más de mil los participantes. Muchos docentes han recibido cartas documentos instándolos a regresar a la escuela ya que el paro era considerado ilegal.

En noviembre el conflicto docente entra en horas decisivas. La situación es muy compleja ya que al mismo tiempo que se pierde fuerza política los sectores que han llevado adelante el mayor peso de la huelga (los de Comodoro) profundizan la lucha, mientras sectores del Valle ven que es necesario recuperar fuerzas. Se cree que no es el momento para acrecentar las diferencias con la conducción del gremio, sino de asegurar que la Atech firme el aval al paro, algo a lo que se ha comprometido su Secretaria General frente a la última asamblea en Trelew.

En el caso de los docentes del Valle su principal referente se ha ido de la región denunciando amenazas de muerte por parte de integrantes del gobierno. Esto quita fuerza moral, mientras las intimaciones del gobierno, con cartas documentos, amenazas y grupos movilizados en contra de cada marcha, se redoblan.

El gobierno anuncia un aumento para toda la administración pública. En el caso de los docentes el aumento era escaso para los ingresantes ya que se traslada el 
pago por presentismo y por título al básico. Se vuelve a amenazar con sanciones y posibles expulsiones a los trabajadores en lucha. No hay negociación ni acuerdo con los gremios.

Todo esto sucede el mismo $1^{\circ}$ de noviembre. Se produce una importante marcha en Rawson, tras la cual los docentes se dirigen a la Escuela Don Bosco donde realizan una asamblea. Allí se rechaza el aumento y se vota la composición de un frente de lucha provincial. Pero pese a esto la realidad es que luego se decide la modalidad por asambleas de cada ciudad. Trelew vota realizar un paro el día siguiente e ir evaluando cada 24 horas en asamblea, Rawson vota un paro de 48 horas, mientras que Comodoro Rivadavia y Puerto Madryn ratifican la huelga indeterminada.

El 2 de noviembre se levanta el paro docente en Trelew, como consecuencia del debilitamiento de la huelga. La adhesión ha bajado, pero aún más clara era la presencia de menos de doscientos docentes en la asamblea. En Rawson se mantiene el paro por un día más pero con una clara situación de debilidad.

En Comodoro se ratifica la continuidad de la huelga en una asamblea numerosa que culmina en las primeras horas del día 3, tras analizar una propuesta que les lleva el Ministerio de Educación el 2 por la tarde. En Puerto Madryn el Sitraed decide continuar la huelga pero evaluándola día a día, hasta que el 14 levantan la medida.

Los docentes de Comodoro Rivadavia recién levantan la huelga el 21. Desde el 9 toman el Concejo Deliberante y reclaman la presencia de la ministra de educación y el ministro de economía para negociar. Sin embargo el gobierno sabe que está con fuerza y se niega. Marchan hasta la Legislatura en Rawson el 17, día en que se vota el aumento planteado por el gobierno. Tras esto los últimos días de huelga docente en Comodoro ven aparecer a los cortes de ruta como una medida central, que ya había sido propuesta en varias asambleas. Consiguen el apoyo de trabajadores petroleros de base, lo que mueve a este Sindicato y al de Comercio a plantearse interceder para asegurar la resolución del conflicto. La asamblea del 21 de noviembre acepta la oferta de suspender la medida a cambio de una mesa de negociación, en la cual se promete que se garantizaría dejar sin efecto las suspensiones y descuentos. Ese día la cúpula de la iglesia católica local, que había apoyado el reclamo docente, sale a "despegarse" de la huelga y se reúne con el gobernador Das Neves.

En definitiva se vive la realidad de una derrota. Pese a lo valiente de la medida, tras la victoria electoral del gobierno ha caído el acatamiento y día a día más docentes vuelven a trabajar. La huelga termina en una derrota por la falta de acompañamiento de la Atech y por el aislamiento que sufrieron los docentes de Comodoro, tanto por la falta de movilización en otras ciudades como por la escasa conciencia de lo central 
que es articular los reclamos de Comodoro con las condiciones de menor movilización del resto de la provincia.

Este último año es significativo para cerrar el período de estudio. Tras el crecimiento de la rebelión social en los noventa y la acumulación de fuerza y experiencias que se expresaron en las jornadas de diciembre de 2001, la clase dominante se encontró ante una profunda crisis de dominación. Sin embargo el tipo de reclamos y los niveles de conciencia que expresaba la mayoría de la clase, no superaban la reivindicación corporativa, manifestándose esto en el desarrollo de una estrategia reformista.

Durante este último apartado (de junio del 2002 a diciembre del 2005) vimos que la burguesía terminó de poder cerrar la crisis de dominación que se abre hacia fines del 2001, a través de la recreación de la confianza en la institucionalidad burguesa y en sus canales de cambio formal como mecanismos posibles para encaminar la transformación social que los grupos movilizados reclamaban.

Esto se expresó claramente en las protestas que se desarrollaron durante el 2005. Las mismas tuvieron gran contundencia y repercutieron en toda la sociedad, pero no lograron en ningún caso (huelga pesquera, huelga docente y toma estudiantil) articular en torno a su reclamo a otros sectores sociales. Los que más cerca estuvieron de ello, en un momento de la huelga, fueron los pesqueros, aunque luego este intento fue derrotado.

Pero además de los límites, los grandes conflictos de este año expresaron también la potencialidad de la conciencia desarrollada y de la fuerza y experiencia acumulada a través del ciclo de rebelión. Estos hechos marcaron un salto con respecto a los años anteriores al 2001. Nada será igual después de la insurrección espontánea y su derrotero posterior de luchas, escraches, asambleas y cortes de rutas. Queda en la conciencia la necesidad de superar estas barreras pero no se encuentran aún los caminos para hacerlo. La crisis de hegemonía sigue, aunque se haya logrado cerrar la más urgente crisis de dominación.

A lo largo de los años estudiados consideramos que es posible observar una estrategia mayoritaria entre los trabajadores de la región. Esa estrategia es reformista, expresando los intereses de los obreros en tanto asalariados. Por ello esa estrategia tendió siempre a buscar la conformación de alianzas con "sus" patrones, sean los dueños de las empresas en que trabajan o el Estado provincial.

Al mismo tiempo se fue perfilando otra estrategia, que es la que consideramos impulsó distintos hechos a lo largo de los años estudiados y que se expresó en los tres grandes conflictos del 2005. Es una estrategia que definimos como un reformismo 
obrero, en oposición a la anterior a la que denominamos reformismo burgués ${ }^{209}$. Allí se quiebran las alianzas con la burguesía y se postula un programa que hace a los problemas de la clase. Además se busca la unidad con los demás sectores de la masa obrera y explotada.

Esta segunda estrategia se hace observable en el primer ciclo de la huelga pesquera y en varios momentos de la huelga docente y la toma universitaria. Pero creemos que es una estrategia que no logra hegemonizar el movimiento ya que no tiene una propuesta clara de cómo resolver los conflictos. Se busca quebrar lo corporativo profesional pero no se tiene aún la fuerza material y moral para construir un programa alternativo.

Hay un rasgo que es evidente en los tres grandes conflictos: la dinámica asamblearia. Otro es la voluntad de confrontación y la decisión de tomar medidas contundentes. Son rasgos que van en la línea de que algo ha cambiado después del 2001. Abonan, además, conclusiones semejantes a las que desarrolló la investigación de Paula Klachko (2006). Retomaremos estas reflexiones, que aquí dejamos sin cerrar y en forma de hipótesis, en nuestras conclusiones y cuando hayamos podido completar el recorrido completo de nuestra investigación.

\footnotetext{
209 Juan Carlos Marín (1984a) define al reformismo obrero como aquel que toma como corporación a la totalidad de la clase obrera, y que intenta desplegar una política que incluya a todas sus fracciones en sus reivindicaciones. En cambio el reformismo burgués abarca solamente a una parcialidad de la misma, en tanto fracción de intereses de tipo profesional. Balvé y Balvé (1991) retoman el concepto haciendo más hincapié en el papel de los sindicatos, tal como ya lo citamos en el apartado 3.3.
} 


\section{Afinando la mirada}

En el capítulo 3 intentamos presentar un mapa del movimiento general de la sociedad en la región noreste del Chubut durante los años estudiados. Allí buscamos hacer observable, desde una narración, descripción y periodización del proceso, las tendencias generales del movimiento. Retomaremos esas tendencias generales en las conclusiones, hacia el final de esta tesis, cuando intentemos sintetizar los distintos aportes que consideramos brinda nuestra investigación.

En los capítulos que siguen intentamos profundizar esta mirada. Avanzar desde la perspectiva más general que busca observar a la totalidad en movimiento (pero a la cual necesariamente se le escapan elementos que quedan indeterminados ante la complejidad del proceso general), en un análisis de las partes que la componen, para luego recuperar un intento de síntesis.

Aquí desarrollamos un enfoque particularizado sobre distintas fracciones de la clase obrera en la región. Si bien nuestro enfoque plantea la necesidad de observar la totalidad, no integramos en este capítulo a otros sujetos sociales como la pequeña burguesía pobre, la pequeña burguesía acomodada o la gran burguesía. En otra instancia de nuestras investigaciones buscaremos avanzar en el conocimiento acerca de cómo impacta el proceso de imposición del dominio del capital financiero en forma más particularizada sobre cada uno de estos grupos sociales y sobre sus distintas fracciones.

Por ahora buscamos desarrollar esta tarea para las tres fracciones centrales de la clase obrera de la región, en términos de su importancia económica, política y social. Además integramos como un apartado propio a la investigación sobre el proceso de organización del sector de la clase obrera que se ve impedido de conseguir sus condiciones materiales de existencia a través del trabajo asalariado: los llamados "trabajadores desocupados". Si bien ellos no constituyen específicamente una fracción de la clase, son un sector clave de la misma, especialmente para comprender el ciclo de rebelión durante los noventa y hasta el 2002 y el ciclo de recomposición posterior.

En cada apartado integramos elementos conceptuales acerca de cómo entendemos la formación de fracciones obreras, cómo se integra la clase obrera en la región, su historia, sus vinculaciones con los procesos nacionales y sus especificidades ${ }^{210}$. Cerramos el capítulo con un apartado donde buscamos integrar

\footnotetext{
${ }^{210}$ Pensar la clase desde sus distintas fracciones y hacer observables sus disputas y enfrentamientos internos es un abordaje que busca complejizar el concepto de clase y mostrar su heterogeneidad. En este sentido retomamos planteos de varios autores, entre otros, de Inés Izaguirre "La heterogeneidad en la constitución de una clase social no es un hecho ni teórica ni empíricamente novedoso, y puede ser considerado un indicador global del momento de desarrollo capitalista que atraviesa una sociedad. La
} 
estos distintos aportes, pensando la vinculación entre bases y direcciones obreras, las estrategias que se desarrollan, los proyectos políticos en disputa y las formas organizativas que se estructuran.

Si bien en el capítulo 5 es donde centralmente buscaremos enfocar nuestra atención en la estructura económica social (entendida como el ámbito de las relaciones de fuerzas objetivas), es claro que ya integramos aspectos de este ámbito en el capítulo 3 y lo haremos también en los apartados a continuación. Tratando de no repetir elementos, buscaremos presentar brevemente los contenidos fundamentales que hacen entendible el proceso de desarrollo y conformación de cada fracción obrera como parte clave del desarrollo de una rama específica de la actividad económica en una región particular.

\subsection{Los trabajadores textiles}

Nos centramos aquí en la fracción formada por los obreros textiles. La descripción de algunos conflictos y su análisis nos permitirá avanzar en la comprensión de los procesos sociales que impactaron en la conformación de la experiencia de los trabajadores del parque textil durante la liquidación de sus fuentes de trabajo y el cambio abrupto de su territorio social.

El proyecto de promoción económica a la región comienza con la sanción del decreto 10.991/56, que exime de impuestos a las importaciones al sur del paralelo 42 . El aporte estatal se va haciendo importante, con inversiones en infraestructura, créditos para empresas privadas, distintos privilegios a esas mismas empresas, etc. En los años sesenta las franquicias de importación son reemplazadas por la exención de impuestos y se impulsó la producción de fibras textiles sintéticas, proyecto que competía con la lana de oveja, producción tradicional de la zona.

En 1971 se crea el Parque Industrial de Trelew. La ciudad de Trelew vivió un rápido crecimiento entre 1970 y 1985, cuadruplicando la población de la ciudad y generando más de seis mil puestos de trabajo industriales. Muchos de los migrantes llegan desde el interior de la provincia, son habitantes de la zona rural, que abandonan sus tierras por las dificultades económicas. La caída del precio de la lana repercute especialmente en los productores más chicos. En ese marco avanza la conformación

acumulación de cuerpos en ciertos territorios, los niveles de calificación obrera, el ejercicio de oficios en actividades industriales de mayor o menor composición orgánica, la coexistencia de mercados originados en modos productivos distintos, la heterogeneidad de las fracciones de burguesía con las que están ligadas las correspondientes fracciones obreras, la heterogeneidad salarial, las relaciones jerárquicas en el ámbito ocupacional, son a su vez todos ellos indicadores o variables de heterogeneidad en el plano objetivo de las condiciones materiales de existencia obrera." en Izaguirre, "Problemas metodológicos y construcción de observables en una investigación sobre luchas obreras", en Daniel Campione (comp. 1994), La Clase Obrera De Alfonsín a Menem, Bs. As. CEAL. 
de nuevos latifundios a través de la absorción de las pequeñas y medianas propiedades, que son adquiridas a muy bajo precio

En las ciudades en cambio se vive una situación de pleno empleo, con inauguración frecuente de ampliaciones y nuevas fábricas. La estabilidad laboral, las buenas condiciones de trabajo y los salarios altos aparecen como seguros. La capacidad de negociación de los sindicatos textiles es muy alta y obtienen buenas condiciones de trabajo casi sin necesidad de protestas.

A mediados de los ochenta comienzan los problemas para el futuro del parque industrial. Las grandes empresas de capital concentrado buscan un nuevo modelo de articulación del Estado con el capitalismo de empresas privadas, donde se asegure el beneficio a la fracción más concentrada de la gran burguesía ${ }^{211}$.

En 1985 ya encontramos una caída en la producción industrial ${ }^{212}$. A partir de 1986 se ponen trabas a la promoción para nuevos proyectos industriales, quedando cerrado este beneficio en 1988. Comienzan los cierres de fábricas, despidos y suspensiones. La producción industrial se estanca en 1985, comienza a caer entre 1986 y 1987 y se derrumba desde 1989. La agonía se aceleró con la entrada de productos asiáticos en la década del noventa.

Los golpes se sintieron rápidamente. El personal del parque pasa de unos 4200 empleados en 1974 a 5500 en 1985, momento de mayor expansión (número que llegaba a 6500 con personal temporario). Desde allí la caída es pronunciada, con 5000 empleados en 1986, 2400 en 1993, 1700 a mediados de los noventa y unos 1200 para el $2002^{213}$. En 1997 de las cuarenta y seis fábricas textiles existentes en Trelew en los años ochenta, sólo quedaban en funcionamiento unas veinticinco. La mayoría de las que sobrevivían no producían más que al $50 \%$ de su capacidad, con baja cantidad de personal y pocas perspectivas de subsistencia. El avance del proyecto neoliberal llevó al cierre de las pequeñas y medianas empresas (que dependían de políticas de sostenimiento por parte del Estado), y a un proceso de centralización y concentración de la propiedad y la riqueza.

Es fundamental partir de que una determinada fracción de la clase obrera es conformada por la fracción capitalista que desarrolla esa actividad en el marco de la división social del trabajo. Es conformada desde un proceso objetivo: la burguesía de cada fracción desarrolla la clase obrera que necesita para asegurar su reproducción como parte de la clase dominante, y luego va intentando modificar aspectos parciales

\footnotetext{
211 Trabajamos este proceso en: Pérez Álvarez, Gonzalo (2010a y 2008c, entre otros).

212 Datos coincidentes con el trabajo sobre Trelew de Irusta y Rodríguez (1993) y con la investigación de Luque, Martínez, Avalos y Auzoberría (2000), en la cual marcan a 1985 como un punto de inflexión para Santa Cruz.

${ }^{213}$ Diario Jornada, 29/6/2002, pág. 3, datos de AOT y SETIA.
} 
de sus características de acuerdo a los cambios que se producen. Pero a su vez, estas fracciones de clases se conforman mutuamente en el proceso de lucha de clases.

Para intentar profundizar la reflexión debemos evaluar las características del grupo social que conforma a los obreros textiles. Estos obreros constituyen un grupo social reciente, con poca experiencia de vida urbana y de trabajo fabril. No era un grupo homogéneo, con historias y costumbres en común. Lo que primaba era la heterogeneidad, muchos no tenían experiencia como obreros y la mayoría eran migrantes de otras provincias del país o de la zona rural de la Patagonia.

En su formación como clase para el capital fue hegemónico el discurso del modelo de polos de desarrollo, que planteaba la supuesta comunidad de intereses entre obreros y patrones de la región, cuyos objetivos comunes eran asegurar el desarrollo de la Patagonia ante el "olvido" de la nación. Este posicionamiento se reforzaba con la necesidad de mantener la paz social para no poner en riesgo los planes de promoción industrial y la conformación de una dirigencia sindical cercana al poder que enfrentó toda construcción que pudiera plantear proyectos alternativos ${ }^{214}$.

Durante los años de la dictadura son escasas las manifestaciones de protesta, aunque se deben explorar distintas expresiones de resistencia que los trabajadores fueron desarrollando (negarse a cumplir horas extras, formar una liga de fútbol apartada de la liga oficial que financiaban las empresas, etc). En ese proceso de resistencia casi invisible van despuntando iniciativas que discuten ese discurso de paz social y comunidad de intereses.

Esto se hace manifiesto tras la caída de la dictadura, cuando comienza el proceso de lucha por la recuperación del gremio, especialmente en la AOT. Se conforma la agrupación textil "1ํ de Mayo", que en 1985 logra desplazar a quién había sido secretario general del gremio durante la dictadura. Allí convergen distintas expresiones políticas, desde grupos del peronismo (que encabezan la lista) hasta militantes del PC, el PI, el MAS y el PO.

Fue un proceso significativo de movilización política y social, que luego no logró traducirse en un cambio profundo en las características de la conducción sindical. Si bien en los primeros años se plantearon cambios hacia una mayor democracia interna y una mayor presencia en las calles, poco a poco la conducción sindical se fue apartando de ese modelo y adoptó las características de la conducción nacional de la

${ }^{214}$ Como ya lo marcamos tenía una incidencia clave la Doctrina de Seguridad Nacional. Esto se reflejaba en el discurso de la necesidad de poblar la Patagonia, como región estratégica por su riqueza en recursos naturales. Además se proyectaba, a través de la creación de nuevos centros industriales, el dividir a una clase obrera que en los núcleos clásicos venía cuestionando puntos fundamentales del sistema. No es menor que tanto la concreción del Parque Industrial Textil en Trelew, como la licitación de Aluar, se lanzan en 1971, tras el Viborazo. 
AOT. Esto se mantuvo durante distintos cambios que luego se produjeron en las personas que encabezaron el sindicato. En las entrevistas los trabajadores nos marcan la importancia que tuvo la presión de la conducción nacional, especialmente a través del ahogo financiero, cuando desde la regional se pretendían tomar posturas que iban en contra de la línea nacional de generar los menores conflictos posibles y restringir los reclamos al ámbito institucional.

Esos cambios en la conducción sindical implicaron la ruptura del proyecto de la "1o de mayo", conformándose agrupaciones más identificadas con los distintos partidos políticos que tenían participación entre los trabajadores textiles. La más significativa fue la "Celeste y Blanca", dirigida por integrantes del PI, que conducía la comisión interna de la fábrica Modecraft, expresión de los sectores más combativos del parque $\mathrm{e}^{215}$. Por su parte en el Setia no hay procesos significativos de lucha interna, aunque sí repercuten en algún punto los procesos que se dan en la AOT. Los trabajadores textiles hasta mediados de los ochenta viven un período casi sin desempleo y de constante demanda de nuevos trabajadores. Estaban acostumbrados a un buen nivel de vida, a un trabajo estable y a la posibilidad de ir mejorando sus condiciones de vida. El problema lo tuvieron ante la caída del parque. La respuesta de la negociación institucional ya no daba los resultados de antes.

Los cierres de plantas, despidos y suspensiones (que se habían hecho evidentes en 1987 con la caída y toma de la planta de Gebco) se agudizan desde el principio de la década. Al iniciarse 1990 los sindicatos textiles realizan medidas por fábrica, pero ningún paro general. Las empresas reclaman que cambie el plan económico ya que la suspensión de los beneficios y la quita de aranceles hacen, según ellos, imposible la subsistencia de las empresas textiles en la región. Los sindicatos apoyan el reclamo de los empresarios.

Mientras tanto seguían las suspensiones y despidos. En Modecraft se suspende al personal durante enero y febrero. La AOT pide una audiencia al gobernador Perl junto a las entidades empresarias y el Consorcio del Parque Industrial. El $90 \%$ de las plantas registran una caída vertical de su producción, con cortes permanentes de las cadenas de pago. La situación de la mayor parte de las fábricas textiles era la siguiente:

Cuadro № 3: Situación Fábricas textiles febrero de 1990. Datos de AOT, Setia y Subsecretaria de Trabajo.

\begin{tabular}{|l|l|}
\hline Fábrica & Situación \\
\hline Alter & funcionando al 20\% \\
\hline Casa Roma & funcionando al $20 \%$ \\
\hline
\end{tabular}

215 Ver Pérez Álvarez (2009c) "Lucha y memoria obrera en el noreste del Chubut. Una aproximación desde la fábrica Modecraft 1990-1991”, op.cit. 


\begin{tabular}{|l|l|}
\hline Cirsa & funcionando al $20 \%$ \\
\hline Dhicann & suspensión de su personal por 30 días \\
\hline Foderami & funcionando al 50\% \\
\hline Modecraft & suspensión de todo su personal \\
\hline Ma.Te.Pa. & funcionando al 50\% \\
\hline Nylotex & opera al 40\% de su producción \\
\hline Supersil & funcionando al 50\% \\
\hline ClTEX & funcionando al 50\% \\
\hline Indulana & treinta días de suspensión de su personal \\
\hline Mulcosur & solo trabaja 24 horas semanales \\
\hline Sitma & funcionando al 50\% \\
\hline Future & funcionando al 50\% \\
\hline Lanaco & funcionando al 50\% \\
\hline Gebco & sin funcionamiento \\
\hline Propulsora patagónica & funcionando al 20\% \\
\hline Soltex & funcionando al 50\% \\
\hline Surjet & funcionando al 50\% \\
\hline Pelama & funcionando al 50\% \\
\hline Tendlarz & funcionando al $60 \%$ de producción, usando 50\% de maquinaria \\
\hline Huamac & sin funcionamiento \\
\hline $\begin{array}{l}\text { Ifet, Ponce, Polysur, Proner, Pancromatico, Sedamil, Textil } \\
\text { Oceanic, Punilla, Unilán, Welert, Windsor, Barraca Hart, } \\
\text { Del Estero, Fibrasur, Briozzo, Kinsey y Lanera Austral }\end{array}$ \\
\hline
\end{tabular}

Nota: no siempre se tienen datos de todas las empresas ni es igual la muestra tomada. En algunos casos cambia de nombre la fábrica sin poder seguir los cambios empresariales que se producen

EI secretario general del SETIA, Juan Paris, asegura que la resolución de los conflictos se realizará por la negociación, que no es posible la toma o cogestión de los obreros y que se debe confiar en la buena voluntad del gobierno. Se firma un acuerdo entre el gobierno, las entidades empresarias y los sindicatos de que no habría despidos ni medidas de fuerza hasta abril de 1990. El mismo día los obreros de Modecraft toman la planta en contra de la suspensión. Los trabajadores mantienen la toma durante varios días y se movilizan por las calles de Trelew.

A través de estas medidas logran frenar lo que iba en el camino del cierre de la fábrica, generando una resistencia exitosa contra el proceso de vaciamiento. Se marca aquí una diferencia entre la estrategia de la dirigencia sindical (basada en la búsqueda de acuerdos con los empresarios con intereses en la región) y la de algunos sectores de los obreros (que buscaban una resistencia con medidas en las calles y donde los obreros encabezaran una alianza con sectores de la pequeña burguesía).

En abril se profundiza la crisis, con nuevos problemas en varias fábricas. Mientras seguían sin producirse medidas colectivas, el SETIA llama a una huelga reclamando aumento salarial. Los sindicatos actuaban como si el antiguo marco social siguiera en curso: casi no enfrentan a los despidos pero siguen reclamando mejores salarios.

Durante septiembre y octubre de 1990 se producen grandes movilizaciones en la provincia reclamando el pago de salarios atrasados y contra los posibles despidos 
en el Estado. El proceso es dirigido por sindicatos estatales y no hay articulación con los sectores privados. Sólo algunos sectores de textiles se suman a las marchas (en especial la agrupación "Celeste y Blanca"). La conducción de la CGT local enfrenta el reclamo de los estatales, apoyando los planes de ajuste. Este proceso para nosotros es expresión del cierre de la fase de dominio del capital industrial en la región.

Como lo describimos en forma más extensa en el apartado 3.3, nuestra hipótesis ${ }^{216}$ es que el "chubutazo" representa la última batalla que dan algunos sectores de trabajadores y de la pequeña burguesía por mantener la mejor situación que el modelo de "polos de desarrollo" les garantizaba. A partir de allí el dominio del capital financiero ya se hace evidente, no solamente a nivel de la estructura económica social sino también en las políticas de gobierno, que se modifican con la caída de Perl y la asunción de Cosentino, avalado este último por el gobierno nacional de Carlos Menem.

Se avanza en el cierre de los proyectos de promoción industrial y en las políticas de readecuación del Estado para que sirva a la nueva alianza de clases en el poder. La burguesía con intereses en la región ligada a los proyectos de polos de desarrollo (especialmente la que había invertido en el sector textil) se subordinará sin demasiada resistencia a esa nueva dirección política, que ya había construido su hegemonía a nivel nacional.

En ese contexto al iniciarse 1991 el parque textil está en una situación cada vez más frágil. En marzo, la AOT anuncia que prepara un corte de ruta en el marco del paro nacional textil por aumento salarial. Nada se dice de los despidos y suspensiones. Esa medida luego no se realiza y la huelga sólo se expresa con paros de treinta minutos cada dos horas.

Se pone en marcha, como estrategia de las patronales, el ataque a los delegados sindicales combativos. En general esta práctica fue acompañada por la dirigencia sindical. El caso más claro fue el juicio contra los delegados de Modecraft que eran dirigentes de la agrupación "Celeste y blanca". Un conflicto parecido se da después en Prosur. El ataque contra Modecraft no era casual: expresaba lo más avanzado de la estrategia de resistencia obrera.

Luego se produce una verdadera "limpieza" de los delegados y militantes combativos o de alguna corriente de izquierda. Es aquí cuando para nosotros se derrota la intención de un sector de los trabajadores de resistir en forma decidida, buscando defender sus antiguas conquistas encabezando una alianza con otros sectores sociales.

\footnotetext{
${ }^{216}$ Hipótesis que intentaremos confirmar en la siguiente fase de nuestro proyecto de investigación, que se enfocará en la década de los setenta y los ochenta.
} 
Contra esto se plantea la dirigencia gremial que logra dirigir a la mayoría hacia otra estrategia, que era resistir los aspectos más regresivos del proyecto neoliberal a partir de una alianza en la cual se subordinan a la burguesía con intereses en la región. El problema era que esa burguesía cada vez se subordina más a la hegemonía del capital financiero.

Lo que sigue de 1991 es de avance de las patronales. Hay despidos, suspensiones y hasta rebajas salariales (una de las más importantes es, justamente, en Modecraft). Según los dirigentes de la AOT intentan generar protestas pero los trabajadores se niegan por el temor a no ser reincorporados "cuando pase la crisis": aparece como real que aún no se observa el carácter estructural de los cambios que estaban sufriendo. El temor expresa la situación de debilidad y aislamiento de la clase.

En 1992 la AOT informa sobre nuevas suspensiones en el parque que agravan la situación de crisis. Fibrasur (de Dolavon) suspende a todo su personal (ciento veinte operarios) por quince días, Windsor suspende por treinta días, Modecraft acorta jornadas de trabajo, Prosur también suspende a su personal. Ante esto la dirigencia sindical vuelve a solicitar una "mesa de concertación" al nuevo gobierno provincial encabezado por Maestro de la UCR. Se conforma con el Coplade, la CICECH, la UIP, el Consorcio del Parque Industrial, la Sociedad Rural, la AOT, SETIA y el Centro de Empleados de Comercio. Sólo se llega a un diagnóstico de la situación y se acuerda solicitar un régimen de promoción a la nación.

Como ya lo planteamos anteriormente, en mayo de 1992 los dirigentes de la AOT declaran públicamente que les preocupa que los nuevos desocupados no puedan ya reinsertarse en la actividad productiva. Se comienza a hacer evidente que se está ante una nueva situación estructural que no se modificaría en poco tiempo. Con nuevos datos se vuelve a instalar socialmente la grave situación del parque:

Cuadro № 4: Situación Fábricas textiles alrededor de mayo de 1992. Datos AOT, Setia y Subsecretaria de Trabajo.

\begin{tabular}{|l|l|l|l|}
\hline \multicolumn{1}{|c|}{ Fábrica } & \multicolumn{1}{|c|}{$\begin{array}{c}\text { Cantidad de } \\
\text { trabajadores }\end{array}$} & $\begin{array}{l}\text { Porcentaje de } \\
\text { ocupación }\end{array}$ & $\begin{array}{c}\text { Despidos en la } \\
\text { última semana }\end{array}$ \\
\hline Alter & 62 & 50 & \\
\hline Briozzo & 35 & 50 & \\
\hline Casa Roma & 89 & 50 & \\
\hline Cirsa & 70 & 50 & \\
\hline Dhidann & 57 & 50 & \\
\hline Foderami & 207 & 70 & \\
\hline Kinsey & 30 & 50 & \\
\hline
\end{tabular}

${ }^{217}$ El porcentaje de ocupación laboral se calcula tomando en cuenta los trabajadores realmente ocupados sobre los que deberían estar trabajando si la planta estuviera funcionando al tope de su capacidad instalada de producción. Así en su momento de máxima producción una planta como "Alter" empleaba a más de 120 trabajadores. Este cálculo no tiene la exactitud debida, ya que muchas veces no toma en cuenta los posibles avances en la productividad, sea por la instalación de nueva maquinaria o por la profundización del ritmo de explotación laboral en las fábricas. Pese a esto lo utilizamos, ya que es un indicador más del agudo proceso de transformación que vivía la producción textil en la región. 


\begin{tabular}{|l|l|l|l|}
\hline Modecraft & 198 & 60 & 8 \\
\hline Ma.Te.Pa. & 101 & 60 & \\
\hline Nylotex & 158 & 70 & \\
\hline Polysur & 91 & 50 & \\
\hline Prosur & 97 & 60 & 15 \\
\hline Supersil & 180 & 60 & \\
\hline Soltex & 115 & 80 & \\
\hline Sedamil & 255 & 80 & \\
\hline Surjet & 128 & 70 & \\
\hline Punilla & 32 & 20 & 12 \\
\hline Windsor & 149 & 60 & \\
\hline Oceanic & 37 & 60 & \\
\hline Tendlarz & 143 & 60 & \\
\hline Welert & 47 & 80 & \\
\hline Fibrasur & 125 & 45 & \\
\hline CITEX & 8 & 50 & \\
\hline Indulana & 34 & 60 & \\
\hline Barraca Hart & 25 & 60 & \\
\hline Pelama & 15 & 60 & \\
\hline Ponce & 3 & 50 & \\
\hline Mulcosur & 45 & 80 & \\
\hline Lanera Austral & 110 & 80 & \\
\hline Propulsora patagónic & 110 & 60 & \\
\hline Sitma & 32 & 60 & \\
\hline Unilan & 130 & 70 & \\
\hline Del Estero & 150 & 60 & \\
\hline Future, Huamac, & Están cerradas & & \\
\hline Lanaco, Gebco & & & \\
\hline
\end{tabular}

Nota: no siempre se tienen datos de todas las empresas ni es igual la muestra tomada. En algunos casos cambia de nombre la fábrica sin poder seguir los cambios empresariales que se producen

Pese a estos datos, y a las declaraciones de los dirigentes, recién en agosto hay una movilización de delegados de la AOT contra los nuevos despidos. Se realiza un plenario en septiembre repudiando a legisladores y funcionarios por la falta de resoluciones. Parece evidente que la estrategia de la dirigencia sindical empieza a tener cuestionamientos desde abajo.

La CGT regional hace un llamado a los empresarios de la región para que se plieguen al paro de noviembre, que sería la primera huelga general durante el gobierno de Menem. La AOT busca que el paro sea activo, con un corte de la ruta 25 en el acceso al Parque Industrial de Trelew durante las 24 horas. Este es el hecho de mayor peso político, transformándose en el centro de la huelga.

En diciembre los obreros de Oceanic deciden ocupar la planta por el atraso en el pago y la falta de aumento. Los delegados se oponen y dan intervención a la Subsecretaria de Trabajo, aceptando la tregua pedida por la empresa. Nada se resuelve con la tregua y los obreros finalmente toman la planta tras cinco días de retención de servicios. A las 48 horas de ocupación la empresa acepta los reclamos.

Al iniciarse 1993 otra fábrica presenta su quiebra. Se hacen patentes varios negociados de empresarios con funcionarios políticos. Las quiebras encubren la 
transferencia de riquezas generadas gracias al aporte del Estado y el trabajo de los obreros. Los empresarios que afirman no tener un centavo para los sueldos "extrañamente" sí podían invertir millones en estancias, acciones o edificios.

La realidad del parque industrial seguía agravándose, presentando el siguiente cuadro de situación:

Cuadro № 5: Situación Fábricas textiles alrededor de Febrero de 1993. Datos AOT, Setia y Subsecretaria de Trabajo.

\begin{tabular}{|c|c|}
\hline Fábrica & Situación \\
\hline Alter & suspensión por producción parada desde diciembre de 1992 \\
\hline Briozzo & regular con muy baja producción \\
\hline Casa Roma & 10 despidos, baja producción y amenaza de nuevos despidos \\
\hline Cirsa & 30 despidos, baja producción \\
\hline Dhicann & normal, con retiros voluntarios \\
\hline Foderami & $\begin{array}{l}70 \text { despidos, reducción de jornadas y no pago del total de } \\
\text { indemnización }\end{array}$ \\
\hline Kinsey & $\begin{array}{l}\text { cerrada, sin definir si reabre después de vacaciones. Debe } \\
\text { sueldos. }\end{array}$ \\
\hline Modecraft & $\begin{array}{l}\text { suspensión de } 7 \text { a } 14 \text { días por este mes, tras haber aceptado } \\
\text { rebaja en sueldos }\end{array}$ \\
\hline Ma.Te.Pa. & $\begin{array}{l}30 \text { despidos, reducción de jornada, en febrero vacaciones } \\
\text { obligatorias }\end{array}$ \\
\hline Nylotex & baja producción. En febrero vacaciones obligatorias \\
\hline Polysur & atraso salarial, despidos y suspensiones \\
\hline Prosur & suspensión total por 30 días y despido de 15 obreros \\
\hline Supersil & $\begin{array}{l}\text { prácticamente cerrada, } 150 \text { despidos y suspensión al resto desde } \\
\text { julio } 92\end{array}$ \\
\hline Sedamil & reducción de jornada y 8 despidos \\
\hline Punilla & suspensiones, reducción de jornada y no pago en término \\
\hline Windsor & 60 despidos, suspensiones y reducción de jornadas \\
\hline Oceanic & $\begin{array}{l}\text { con problemas de pago, suspendidos el mes de enero, baja } \\
\text { producción }\end{array}$ \\
\hline Fibrasur & cerrada, en quiebra, deben sueldos \\
\hline CITEX & 5 despidos y posible suspensión \\
\hline Indulana & 30 despidos, sin producción \\
\hline Mulcosur & reducción de jornada y despidos por reestructuración \\
\hline Sitma & reducción de jornada desde octubre, noviembre y diciembre \\
\hline Unilan & 8 despidos, por lo demás funciona normalmente \\
\hline Future & cerrada, 30 obreros sin trabajo \\
\hline Lanaco & cerrada, en quiebra \\
\hline Ifet & cerrada, 30 obreros sin trabajo \\
\hline Gebco & cerrada, 25 obreros sin trabajo \\
\hline Lan Mar & cerrada, 20 obreros sin trabajo \\
\hline Azubel & cerrada \\
\hline Del Golfo & cerrada \\
\hline Lanico & cerrada \\
\hline Huamac & en quiebra, con 40 trabajando pero les adeuda sueldos \\
\hline $\begin{array}{l}\text { Lanera Austral, } \\
\text { patagónica, Wele } \\
\text { Barraca Hart, Brite }\end{array}$ & $\begin{array}{l}\text { Estero, Propulsora } \\
\text { ndlarz, Ponce, Pelama, } \\
\text { oltex, Surjet }\end{array}$ \\
\hline
\end{tabular}

Nota: no siempre se tienen datos de todas las empresas ni es igual la muestra tomada. En algunos casos cambia de nombre la fábrica sin poder seguir los cambios empresariales que se producen.

Tras un largo conflicto, los obreros despedidos de Polysur toman la fábrica en marzo. La AOT acepta una propuesta de la Subsecretaría de Trabajo y forma una 
comisión que viaja a Buenos Aires para negociar. A fines de mayo los dueños de Polysur reclaman un préstamo de alrededor de cuatro millones y los obreros apoyan el pedido de sus patrones.

En julio la AOT y el SETIA convocan un acto donde entregan un documento al gobierno y las cámaras empresarias. La estrategia de los sindicatos sigue siendo apostar a estos espacios de "concertación". A los pocos días cien obreros son despedidos. Los delegados denuncian el papel cómplice o pasivo de la conducción sindical. Algunos trabajadores daban muestras de que buscaban otra estrategia para resistir el proceso, superando de a poco el golpe que les habían dado entre 1990 y 1991.

Cuadro № 6: Situación Fábricas textiles alrededor de julio de 1993. Datos AOT, Setia y Subsecretaria de Trabajo.

\begin{tabular}{|c|c|}
\hline Fábrica & Situación \\
\hline Alter & de 60 a 35 ocupados, producción regular \\
\hline Briozzo & $\begin{array}{l}\text { de } 50 \text { a } 20 \text { empleados, con serios problemas productivos por } \\
\text { máquinas viejas }\end{array}$ \\
\hline Casa Roma & producción normal, con 70 empleados (antes 120) \\
\hline Dhicann & cerrada por tiempo indeterminado \\
\hline Foderami & de 200 a 130 ocupados, producción mejorando \\
\hline Modecraft & ocupa 210 operarios, la mayoría mujeres en situación precaria \\
\hline Ma.Te.Pa. & de 160 a 110 ocupados \\
\hline Nylotex & $\begin{array}{l}\begin{array}{l}\text { supuesta recuperación por un crédito, sube de } 60 \text { a } 168 \\
\text { empleados }\end{array} \\
\end{array}$ \\
\hline Polysur & de 170 a 80 ocupados, producción regular \\
\hline Prosur & de 110 a 40 ocupados \\
\hline Supersil & en convocatoria de acreedores, sin producir \\
\hline Sedamil & de 250 a 220 ocupados, producción regular \\
\hline Punilla & de 110 a 30 ocupados, solo en producción lavandería \\
\hline Windsor & de 180 a 110 ocupados, producción regular \\
\hline Oceanic & en convocatoria de acreedores, sin producir \\
\hline Indulana & de 80 a sólo 9, producción regular \\
\hline Mulcosur & de 300 a sólo 40 ocupados, en serios problemas \\
\hline Sitma & $\begin{array}{l}\text { de } 70 \text { a } 35 \text { ocupados, con problemas para vender y con su } \\
\text { maquinaria sin renovación ni mantenimiento }\end{array}$ \\
\hline Future & cerrada en forma definitiva \\
\hline Tejeduría del Chubut & cerrada en forma definitiva \\
\hline Welert & $\begin{array}{l}\text { sin producir, con un supuesto convenio con fábrica de otra } \\
\text { provincia }\end{array}$ \\
\hline Lanera Austral & de 170 a 120 obreros, problemas para vender sus productos \\
\hline Tendlarz & redujo de 260 a 90 ocupados \\
\hline Surjet & de 160 a 130 ocupados, planta muy completa y moderna \\
\hline Ponce & apenas tiene 3 operarios \\
\hline Del Estero & de 200 a 120 ocupados \\
\hline \multicolumn{2}{|c|}{$\begin{array}{l}\text { Propulsora patagónica, Pelama, Barraca Hart, } \\
\text { Soltex, }\end{array}$} \\
\hline
\end{tabular}

Nota: no siempre se tienen datos de todas las empresas ni es igual la muestra tomada. En algunos casos cambia de nombre la fábrica sin poder seguir los cambios empresariales que se producen

En diciembre la AOT realiza un plenario para votar una modificación del estatuto que restringe la participación de los afiliados y posterga las elecciones. 
Mientras tanto Polysur estaba nuevamente tomada sin que los trabajadores lograran soluciones a sus reclamos y el año se cerraba con el siguiente marco de situación del parque industrial:

Cuadro № 7: Fábricas cerradas definitivamente. Datos AOT, Setia y Subsecretaria de Trabajo.

\begin{tabular}{|l|l|}
\hline Prenil Surlon & de Rawson, con 100 operarios \\
\hline Roseda & Puerto Madryn, de 100 operarios \\
\hline Pancromático & de Trelew, 30 operarios \\
\hline Del Golfo & de Madryn, 100 operarios \\
\hline Lanico & de Madryn, 50 operarios \\
\hline Gebco & de Trelew, 200 operarios \\
\hline Lanaco & de Trelew, 25 operarios \\
\hline Ifet & de Trelew, 30 operarios \\
\hline Huamac Patagónica & de Trelew, 120 operarios \\
\hline Future & de Trelew, 30 operarios \\
\hline Lan Mar & de Trelew, 30 operarios \\
\hline Azubel Hnos. & de Trelew, operarios trasladados a Oceanic \\
\hline
\end{tabular}

Cuadro № 8: Situación Fábricas textiles diciembre de 1993. Datos AOT, Setia y Subsecretaria de Trabajo.

\begin{tabular}{|c|c|}
\hline Fábrica & Situación \\
\hline Alter & $\begin{array}{l}60 \text { operarios, } 50 \% \text { de producción, suspenderá personal luego de } \\
\text { vacaciones. }\end{array}$ \\
\hline Briozzo & $\begin{array}{l}30 \text { operarios, con atraso en pagos y amenazas de reducción de } \\
\text { personal }\end{array}$ \\
\hline Casa Roma & 10 despidos, baja producción y amenaza de nuevos despidos \\
\hline Cirsa & $\begin{array}{l}40 \text { operarios en turnos de } 12 \text { horas, } 40 \text { despidos, producción al } \\
60 \%\end{array}$ \\
\hline Dhicann & cerrada, 70 operarios despedidos, pago de indemnización total \\
\hline Foderami & 110 operarios, 120 despedidos, $80 \%$ de producción \\
\hline Kinsey & $\begin{array}{l}\text { cerrada y en convocatoria, } 16 \text { despedidos, y } 15 \text { en dependencia a } \\
\text { los que adeuda el pago. Situación muy incierta }\end{array}$ \\
\hline Modecraft & $\begin{array}{l}\text { suspensión de } 7 \text { a } 14 \text { días por este mes, tras haber aceptado } \\
\text { rebaja en sueldos }\end{array}$ \\
\hline Ma.Te.Pa. & 60 en actividad, 28 despidos, $70 \%$ de producción, atraso en pagos \\
\hline Nylotex & baja producción, febrero vacac oblig. \\
\hline Polysur & atraso salarial, despidos y suspensiones \\
\hline Prosur & 40 operarios, 60 despedidos, $70 \%$ de producción \\
\hline Supersil & $\begin{array}{l}90 \text { operarios en actividad y } 90 \text { despedidos a los que se les adeuda } \\
\text { pago. En convocatoria de acreedores, al } 70 \% \text { de producción }\end{array}$ \\
\hline Sedamil & 250 operarios en turnos de 12 hs, en $80 \%$ de producción \\
\hline Punilla & 50 operarios, $90 \%$ de producción \\
\hline Windsor & $\begin{array}{l}120 \text { operarios, suspenderá personal luego de vacaciones por "falta } \\
\text { de trabajo no imputable al empleador" }\end{array}$ \\
\hline Oceanic & $\begin{array}{l}17 \text { operarios, en convocatoria de acreedores, posible quiebra y } \\
\text { situación muy incierta. No pago indemnización a despedidos }\end{array}$ \\
\hline Fibrasur (Dolavon) & cerrada por quiebra \\
\hline CITEX & cerrada, 25 \\
\hline Indulana & 15 en actividad, a solo $30 \%$ de producción \\
\hline
\end{tabular}




\begin{tabular}{|l|l|}
\hline Mulcosur (Rawson) & $\begin{array}{l}50 \text { en actividad, } 60 \% \text { de actividad, en concurso preventivo y con } \\
\text { probables conflictos por atraso en pagos }\end{array}$ \\
\hline Sitma & reducción de jornada desde octubre, noviembre y diciembre \\
\hline Unilan & 130 en actividad al $90 \%$ de producción \\
\hline Lanera Austral & 90 operarios. $80 \%$ de actividad \\
\hline Tendlarz & 100 operarios, $80 \%$ de producción, ingreso de personal temporario \\
\hline Welert & 45 en actividad, $50 \%$ de producción, situación en serio riesgo. \\
\hline Del Estero (Gaiman) & 90 en actividad al $80 \%$ de producción \\
\hline $\begin{array}{l}\text { Propulsora } \\
\text { patagónica }\end{array}$ & 120 operarios, $80 \%$ de producción, pago en término. \\
\hline Surjet & 100 en actividad, producción normal \\
\hline Ponce & cerrada por quiebra, 20 operarios sin trabajo \\
\hline Pelama & 30 en actividad al $70 \%$ de producción \\
\hline Barraca Hart & 25 en actividad, al $80 \%$ de producción \\
\hline Texcom (Esquel) & 240 operarios al $90 \%$ de producción \\
\hline Britalco (Madryn) & $\begin{array}{l}70 \text { operarios, suspensiones por falta de trabajo, atraso en pago de } \\
\text { haberes y producción mínima }\end{array}$ \\
\hline Soltex & Funcionamiento normal pese a la crisis \\
\hline
\end{tabular}

Nota: no siempre se tienen datos de todas las empresas ni es igual la muestra tomada. En algunos casos cambia de nombre la fábrica sin poder seguir los cambios empresariales que se producen

El aumento de la protesta social que en diversos trabajos se observa a partir de 1994 no tiene un efecto evidente entre los trabajadores textiles de la región. Recién en junio los obreros de Arcoplus (nombre de la ex Modecraft) inician un paro en reclamo de mejoras en el salario y las condiciones de trabajo.

La cámara empresaria del parque reclama una tarifa diferencial de luz. Esto produce una larga pelea política que ganan las empresas cuando la AOT amenaza con una marcha en apoyo de los empresarios. Para los últimos meses del año se agrava la crisis. Entre otros conflictos, cierra la planta de Oceanic, que se presenta como un caso especial porque sus dueños recibieron un préstamo del gobierno que no fue invertido para reactivar la fábrica.

En 1995 la dirigencia de SETIA destaca una leve recuperación del parque. La realidad es más compleja y la caída sigue, sólo que ahora sin tantos conflictos porque hay menos fábricas y menos trabajadores. En abril la AOT denuncia lo que denomina una "ola" de suspensiones y despidos que ya involucra a trescientos obreros. Según ellos los empresarios especulan para presionar en la pelea por nuevos créditos del gobierno.

Se produce un hecho que consideramos significativo en torno a las prácticas para quebrar la organización de los trabajadores. La patronal de Windsor acepta reincorporar diecinueve obreros pero a cambio exige la renuncia de dos delegados de la AOT. En un hecho sin precedentes en el parque industrial esto es aceptado y los delegados presentan sus renuncias. Los trabajadores no se oponen a esto, planteando que “...son diecinueve familias contra dos,218.

\footnotetext{
${ }^{218}$ Declaraciones de un obrero de Windsor, Diario Jornada 19/4/95, pág. 7.
} 
La CGT convoca otra huelga general contra el gobierno de Menem para el 6 de septiembre. El paro tiene poca repercusión en la región y no se realizan medidas en la calle. La adhesión en la rama textil es de alrededor del 35\%.

Un nuevo plenario de delegados de la AOT muestra en los informes que la estrategia patronal pasa por la acentuación del proceso flexibilizador para conseguir una mayor explotación de los obreros. Una breve coyuntura favorable para algunas fábricas permite incorporar personal que ya entra bajo modalidades precarizadas y que en varios casos reemplaza al personal con más antigüedad. El informe por fábrica es el siguiente:

Cuadro № 9: Situación Fábricas textiles diciembre de 1995. Datos de AOT.

\begin{tabular}{|c|c|}
\hline Fábrica & Situación \\
\hline Cirsa & $\begin{array}{l}\text { Pago de haberes normal, sin despidos ni suspensiones. Trabajando al } \\
50 \%\end{array}$ \\
\hline Foderami & $\begin{array}{l}\text { En } 80 \% \text { de producción, presionando a trabajadores para imponer más } \\
\text { explotación. No paga productividad, no permite usar el comedor y despidió } \\
\text { a dos trabajadores y luego tomó a } 10 \text { pero en turnos rotativos de } 6 \text { hs. }\end{array}$ \\
\hline Arcoplus & $\begin{array}{l}\text { Producción y pago normal. Conflicto por incorporación de empleados } \\
\text { extranjeros e intentos de imponer nuevo régimen de trabajo flexibilizador }\end{array}$ \\
\hline Ma.Te.Pa. & $\begin{array}{l}\text { Despidos de otros } 5 \text { trabaj. Hay atraso en los salarios y la producción al } \\
30 \%\end{array}$ \\
\hline Nylotex & Sin problemas salariales. Tejeduría al $20 \%$ e Hilandería al $30 \%$ \\
\hline Prosur & Deuda importante con el personal, producción al $70 \%$. \\
\hline Supersil & $\begin{array}{l}\text { Se puso al día con quincenas, debe algunos adicionales. Recibió un } \\
\text { importante crédito del gobierno. }\end{array}$ \\
\hline Sedamil & $\begin{array}{l}\text { producción casi a tope, con conflictos por estar imponiendo régimen } \\
\text { flexibilizador, en especial el } 6 \text { por } 2 \text { sin reconocer pago del } 100 \%\end{array}$ \\
\hline Windsor & $\begin{array}{l}\text { Situación compleja, hay obreros despedidos que reclaman salarios y } \\
\text { acuerdos no cumplidos pero la patronal anuncia incorporación de nuevas } \\
\text { máquinas }\end{array}$ \\
\hline Indulana & $\begin{array}{l}\text { Situación muy comprometida, con posibilidad de despidos masivos. La } \\
\text { producción solo al } 3 \% \text {. Se reconoce el compromiso de mantener al día los } \\
\text { sueldos }\end{array}$ \\
\hline Sitma & $\begin{array}{l}\text { En estado de conciliación obligatoria, no cumple con pago de salarios ni } \\
\text { con adicionales. Sin embargo promete trabajar a full por nuevas ventas y } \\
\text { tomó nuevo personal }\end{array}$ \\
\hline Unilan & $\begin{array}{l}\text { Funciona al } 100 \% \text { y está ampliando su maquinaria. Sin problemas de } \\
\text { personal y con perspectivas muy buenas por usar lana como materia } \\
\text { prima. }\end{array}$ \\
\hline Surjet & relación laboral optima, sin problemas económicos ni financieros \\
\hline $\begin{array}{l}\text { Propulsora } \\
\text { patagónica }\end{array}$ & $\begin{array}{l}\text { Trabaja de lunes a jueves en un } 90 \% \text { de su capacidad. Sin despidos ni } \\
\text { suspensiones ni atrasos salariales }\end{array}$ \\
\hline Britalco & Trabaja de lunes a jueves, adeuda una quincena y media. Esta al $60 \%$ \\
\hline Pelama Chubut & a un $90 \%$, al día con salarios, sin despidos ni suspensiones \\
\hline Soltex & ha incorporado cinco operarios, produciendo al $80 \%$, sin problemas \\
\hline Del Estero & $\begin{array}{l}\text { Situación crítica, con amenazas de despidos masivos,. Adeuda cuatro } \\
\text { quincenas y produce al } 10 \%\end{array}$ \\
\hline Tendlarz & su ritmo mejora mes a mes, sin problemas laborales \\
\hline
\end{tabular}

Nota: no siempre se tienen datos de todas las empresas ni es igual la muestra tomada. En algunos casos cambia de nombre la fábrica sin poder seguir los cambios empresariales que se producen 
En febrero de 1996 Supersil reclama un préstamo al gobierno provincial. Los trabajadores avalan el pedido que parece la única posibilidad para que se mantenga su trabajo. En marzo la empresa suspende al personal por dos semanas y los trabajadores toman la fábrica por el temor a que los empresarios se lleven las máquinas. Un grupo se moviliza hasta el Municipio reclamando el crédito para la empresa. Ni los sindicatos, ni los trabajadores pueden, en todos los días que dura el conflicto, expresar una posibilidad de resolución que no sea apoyar a los empresarios.

El conflicto de Supersil culmina en una derrota, ya que se levanta la toma en mayo ante el acuerdo de la AOT con el municipio de que este controlaría que no se lleven las máquinas. No había novedades sobre el crédito y no se toman medidas más contundentes. El único camino que deja el sindicato es el judicial, planteando que la continuidad del reclamo era la presentación de recursos contra la empresa.

En la hilandería de Sedamil se vota el rechazo a la modalidad americana de seis por dos con la que pretendía avanzar la empresa, profundizando la flexibilización y bajando los salarios al no pagar como horas extras sábados y domingos. Delegados de otras plantas felicitan la decisión de los obreros de Sedamil.

Los sindicatos de la región adhieren a la huelga nacional convocada por la CGT y la CTA para agosto. La movilización es masiva con más de dos mil trabajadores. El parque industrial directamente no abre sus puertas. Días después el gobierno firma un nuevo "pacto social" con los sindicatos textiles. A los dos días de esa firma los dueños de Arcoplus suspenden a ciento diez trabajadores. Las estrategias de conciliación se siguen mostrando como un camino directo hacia el debilitamiento de los obreros. No hay denuncias de la ruptura del pacto y los suspendidos firman un acuerdo con la promesa de ser reincorporados en septiembre.

Las últimas resoluciones de la AOT aceptando suspensiones sin protestas, profundizan la interna del sindicato. Renuncia la mayoría del Consejo Directivo y exigen que se vaya el secretario general Miguel Llouful. A fin de septiembre se suspende a los cien trabajadores de Mulcosur, quienes, en asamblea, deciden rechazar la medida.

Toda la actividad sindical y política se centra en la huelga general de septiembre. El 26 de septiembre es importante la concentración en Trelew, con más de cuatro mil trabajadores, siendo numerosas las columnas de ambos sindicatos textiles. Se muestra el desgaste del proyecto del capital financiero y, más claramente, del gobierno de Menem. Hasta los sectores que vienen participando en menor medida en el proceso de luchas, como es el caso de los textiles, juegan un rol activo en este momento. 
Días después declara su quiebra Mulcosur. Los obreros deciden en asamblea la toma de la fábrica. Los dueños habían recibido un préstamo del gobierno provincial por seiscientos mil pesos en 1995. Muchos hombres lloran, afirmando que ya nunca podrían trabajar. El delegado dice que si el gobierno les da un préstamo como el que le dio a los empresarios, ellos pueden autogestionar la fábrica. Es llamativa la voluntad para expresar posibles salidas ante el cierre, actitud muy distinta a las que se solían tomar en los años anteriores. La experiencia ya había mostrado que la nueva situación de desocupado no sería algo de corta duración sino parte de un proceso del cual era difícil poder salir.

Un informe del gobierno provincial en 1997 muestra el marco de deterioro general de las fábricas textiles ${ }^{219}$. El cuadro por ciudades es el siguiente:

Cuadro № 10: Situación general de las Fábricas textiles por ciudad, Enero de 1997. Datos de Subsecretaria de Trabajo.

\begin{tabular}{|l|c|c|c|}
\hline Localidad & $\begin{array}{c}\text { Plantas } \\
\text { Iniciales }\end{array}$ & Cerradas & $\begin{array}{c}\text { Personal } \\
\text { ocupado }\end{array}$ \\
\hline Trelew & 46 & 25 & 1764 \\
\hline Puerto Madryn & 4 & 3 & 80 \\
\hline Dolavon & 1 & -- & 30 \\
\hline Gaiman & 2 & 1 & 20 \\
\hline Comodoro Rivadavia & 8 & 6 & 750 \\
\hline Rawson & 1 & 1 & 0 \\
\hline Esquel & 1 & 0 & 240 \\
\hline Totales & $\mathbf{6 3}$ & $\mathbf{3 6}$ & $\mathbf{2 6 4 4}$ \\
\hline
\end{tabular}

Cuadro № 11: Situación particular Fábricas textiles en Trelew, Enero de 1997. Datos de Subsecretaria de Trabajo.

\begin{tabular}{|l|l|}
\hline \multicolumn{1}{|c|}{ Fábrica } & Situación \\
\hline Alter & Con problemas, al 40\%, con 40 empleados. Puso tintorería en BA \\
\hline Casa Roma & $\begin{array}{l}\text { Tiene } 70 \text { empleados y funciona normalmente. Si termina la promoción } \\
\text { cerraría }\end{array}$ \\
\hline Cirsa & con producción mínima, tiene 30 empleados y llegó a tener 360 \\
\hline Dhicann & Cerrada sin deudas. Existe maquinaria \\
\hline Foderami & $\begin{array}{l}\text { son dos plantas con 240 empleados, funciona bien, se iría si cae } \\
\text { promoción }\end{array}$ \\
\hline Modecraft & $\begin{array}{l}\text { cerrada, la compró Arcoplus, con } 150 \text { empleados suspendidos por } 60 \\
\text { días y con 50\% de sueldo }\end{array}$ \\
\hline Ma.Te.Pa. & $\begin{array}{l}\text { dos plantas, ambas cerradas y en marco de serio conflicto legal y } \\
\text { laboral }\end{array}$ \\
\hline $\begin{array}{l}\text { Nylotex (Tejeduría } \\
\text { Chubut) }\end{array}$ & $\begin{array}{l}\text { Dos plantas (compró Tejeduría Chubut) con 180 empleados, al 50\% } \\
\text { de su capacidad. Si termina la promoción la planta se traslada a } \\
\text { Buenos Aires. }\end{array}$ \\
\hline Supersil & \begin{tabular}{l} 
cerrada con las máquinas en su interior \\
\hline
\end{tabular} \\
\hline
\end{tabular}

${ }^{219}$ Diario Jornada, 16/2/1997, pág. 6 y 7. 


\begin{tabular}{|c|c|}
\hline CITEX & esta vaciada y cerrada \\
\hline Indulana & Cerrada y vacía, sin deudas. \\
\hline Sitma & $\begin{array}{l}\text { Viene realizando despidos, es muy incierto su futuro. Tiene solo } 20 \\
\text { empleados que están suspendidos con } 40 \% \text { de sueldo. Tuvo } 160 \\
\text { ocupados }\end{array}$ \\
\hline Future & cerrada, ahora es un depósito de La Anónima \\
\hline Lanaco & cerrada \\
\hline Gebco & Cerrada, sin máquinas, vendió el edificio \\
\hline $\begin{array}{l}\text { Propulsora } \\
\text { patagónic }\end{array}$ & $\begin{array}{l}\text { Funciona bien, con } 110 \text { empleados, pero se iría si termina promoción. } \\
\text { Tiene tintorería en Buenos Aires. }\end{array}$ \\
\hline Soltex & Dos plantas con 120 empleados, funcionando al $100 \%$ \\
\hline Surjet & $\begin{array}{l}\text { Funciona bien, con } 130 \text { empleados. Compraron máquinas modernas } \\
\text { que sólo traerían si sigue la promoción. }\end{array}$ \\
\hline Pelama & $\begin{array}{l}\text { Funciona bien con } 40 \text { empleados. Es lavadero de pelo de cabra y } \\
\text { conejo }\end{array}$ \\
\hline Tendlarz & $\begin{array}{l}\text { Funciona bien ocupando } 150 \text { empleados, con problemas si cae } \\
\text { promoción }\end{array}$ \\
\hline Huamac & cerrada sin maquinarias \\
\hline Prosur & tiene dos plantas, trabajan entre 50 y 55 empleados \\
\hline Loja S.A. & esta vaciada y nunca abrió sus puertas. \\
\hline Surpel y Pelesur & Son del mismo dueño, están cerradas. \\
\hline $\begin{array}{l}\text { Provoust y } \\
\text { Lefebvre }\end{array}$ & Es una barraca lanera trabaja normalmente a nombre de Cumbre SA. \\
\hline Suc. Emilio Segard & es barraca lanera, trabaja normalmente \\
\hline Polysur & cerrada con unos 80 telares en su interior, algunos desarmados \\
\hline Unilán & trabaja normalmente con 120 operarios \\
\hline Dos Muñecos & legalmente cerrada pero tiene 40 personas trabajando en negro \\
\hline Punilla & trabaja bien con setenta y tres operarios \\
\hline Barraca Hart & funciona bien, 56 empleados directos más 30 en cooperativa \\
\hline Kinsey & cerrada con cuarenta máquinas en su interior \\
\hline Textil Oceanic & cerrada con máquinas adentro. \\
\hline Windsor & trabaja bien con 90 empleados \\
\hline Welert & cerrada y en quiebra. Hay posibilidades de reabrirla \\
\hline Ponce & cerrada sin maquinarias \\
\hline Ifet & $\begin{array}{l}\text { no existe hace años, ya se vendió el terreno para una estación de } \\
\text { servicios }\end{array}$ \\
\hline Briozzo & cerrada, hay adentro algunas máquinas viejas \\
\hline Surlon & cerrada, ahora hay un supermercado \\
\hline Lanera Austral & ocupa 90 empleados, con varios inconvenientes \\
\hline Fatexpa & cerrada y vacía, llevo máquinas a Entre Ríos \\
\hline Pancromatico & era de Supersil, esta cerrada y vacía \\
\hline $\begin{array}{l}\text { El mundo del } \\
\text { pijama }\end{array}$ & cerrada, se dedicaba a confecciones, era de Supersil \\
\hline Sar Cuer & cerrada con todas las máquinas \\
\hline
\end{tabular}

Cuadro № 12: Situación particular Fábricas textiles en Puerto Madryn, Enero de 1997. Datos de Subsecretaria de Trabajo.

\begin{tabular}{|l|l|}
\hline \multicolumn{1}{|c|}{ Fábrica } & \multicolumn{1}{c|}{ Situación } \\
\hline Britalco & $\begin{array}{l}\text { ocupa } 80 \text { empleados, realiza suspensiones por 30 días, esta en } \\
\text { crisis. Realiza medias }\end{array}$ \\
\hline Del Golfo & cerrada sin maquinarias \\
\hline Roseda & cerrada sin maquinarias \\
\hline Niessner & cerrada se ignora si hay máquinas \\
\hline
\end{tabular}


Cuadro № 13: Situación particular Fábricas textiles en Comodoro Rivadavia, Enero de 1997.

Datos de Subsecretaria de Trabajo.

\begin{tabular}{|l|l|}
\hline \multicolumn{1}{|c|}{ Fábrica } & \multicolumn{1}{c|}{ Situación } \\
\hline Guilford & $\begin{array}{l}\text { dos plantas con } 650 \text { empleados, trabaja bien con producción al } \\
65 \%\end{array}$ \\
\hline Litex & ocupa 100 personas trabaja normalmente \\
\hline Nicolás Rostas & cerrada, vacía \\
\hline Cortilene & cerrada, vacía \\
\hline Omnipol & cerrada, vacía \\
\hline Los Alerces & cerrada, vacía \\
\hline Las Margaritas & cerrada, vacía \\
\hline Araucan & cerrada, con máquinas \\
\hline
\end{tabular}

La situación en las ciudades más pequeñas no difería, y en todo caso hasta era peor. En Dolavon, Fibrasur está con serios problemas, al igual que Del Estero en Gaiman, donde años antes había cerrado otra fábrica que realizaba jeans. La fábrica Texcom de Esquel es un caso particular, ocupando doscientos cuarenta trabajadores y funcionando normalmente. Realiza tejidos de punto y confecciones. En Rawson Mulcosur está cerrada y en quiebra. Por último había una fábrica de pulóveres en Río Mayo denominada Kholer, que no recibía promoción pero sí créditos del gobierno provincial con quién tenía una importante deuda.

En ese marco se da el conflicto de las trabajadoras de Confecciones Patagónicas (que no estaban bajo convenio y por eso las representa la CGT). Ellas reclaman el pago de la deuda que mantiene la patronal. El grupo empresarial es el mismo que dirige Matepa, donde se ratifican los despidos efectuados tiempo atrás. Los obreros de Matepa y Confecciones se movilizan juntos el 13 de enero.

Recién a mediados de febrero el reclamo de las trabajadoras de Confecciones adquiere más impacto con la ocupación de la planta de Matepa. El problema es que así se dividen del reclamo de los despedidos de Matepa (que buscan cobrar su indemnización) y de los que aún trabajan en la planta. La patronal anuncia que pagará lo adeudado cuando desocupen la fábrica, mientras las obreras sostienen que sólo se irán cuando se les pague.

Se retira de la toma el personal de SETIA y los despedidos de Matepa ocupan la sede de la AOT, desalojan al delegado normalizador Cardozo y reinstalan a Miguel Llouful. Acusan a Cardozo de haber generado la toma que les impedía cobrar las indemnizaciones acordadas. El conflicto toma características complejas, con duros enfrentamientos entre los obreros.

Delegados de la AOT de varias plantas apoyan a los que toman el sindicato, afirmando que el gremio debe "bregar pura y exclusivamente por sus representados 
legalmente ${ }^{\prime 220}$. Se impugna que el sindicato apoye a esas trabajadoras que no eran parte "legal" del mismo. Así la patronal logra quebrar a los trabajadores, enfrentándolos entre sí ${ }^{221}$.

Para marzo se cumplen quince días de la toma de Matepa. También sigue la toma de AOT donde Cárdenas, como parte de la toma, y Etchepareborda, delegado de Sedamil, aparecen como referentes del grupo que exige un cambio en la conducción. El 4 de abril comienza a definirse la continuidad institucional de la AOT con un plenario de delegados que ratifica la remoción de Cardozo de su cargo y la apertura de un nuevo proceso en el sindicato. Son nombrados como normalizadores Etchepareborda y Arenas $^{222}$. Mientras tanto sigue ocupada la planta de Matepa por las trabajadoras de Confecciones, sin luz ni gas y resistiendo el aislamiento y la falta de apoyo de los sindicatos en su lucha por mantener el trabajo. A fin de mayo la policía desaloja a las pocas obreras que aún ocupan la planta.

En junio se produce el primer corte de ruta en Trelew por parte de grupos de desocupados. Es un cambio importante, ya que por primera vez en Chubut se decide cortar una ruta pero ya con la decisión de tomar la posición y defenderla. Tienen importantes roles antiguos delegados textiles y de plantas pesqueras. La experiencia de esos trabajadores que habían sido despedidos se pone en función de organizar a los sectores de la clase desplazados de la relación asalariada.

El 14 de agosto se produce un paro nacional llamado por el MTA, la CTA y la UOM, entre otros. EI SETIA (a nivel nacional parte del MTA) se moviliza aparte del resto, reclamando una nueva ley de promoción industrial. La AOT, parte de la CGT "oficial", no adhiere a la medida.

A principios de 1998 se realiza la elección en la AOT (es indirecta, sólo votan los delegados de las fábricas por los cambios aprobados en el estatuto) dando la victoria al sector de Etchepareborda, Arenas y Cárdenas. La nueva conducción se expresa por la conformación de una Mesa de Concertación para debatir el futuro del parque industrial. La búsqueda de la comunidad de intereses entre empresarios y trabajadores muestra la misma matriz ideológica que la anterior conducción. Hay

${ }^{220}$ Diario Jornada, 24/02/97, documento delegados de la AOT, entre otros firman Arenas, Cárdenas y Etchepareborda, pág. 7.

${ }^{221}$ Son enfrentamientos por los intereses inmediatos de estos trabajadores en la venta de su fuerza de trabajo. La conciencia obrera limitada a verse como vendedores de fuerza de trabajo los lleva a la competencia entre ellos, como le sucede a cualquier vendedor de mercancía en el capitalismo. Sólo una conciencia que exprese sus intereses en tanto expropiados impide esa competencia, ya que pone por encima lo que los une y no lo que los separa. Esto no quiere decir que los obreros y dirigentes que generan estos hechos tuvieran una conciencia "falsa", estuvieran "vendidos" o fueron "traidores". Eso no explica el proceso y sobre todo no explica el acompañamiento de los obreros a esos dirigentes. De lo que se trata es de observar los procesos, que parten de una relación dialéctica entre la experiencia de lucha, la situación objetiva de los grupos sociales, la actitud de las bases obreras y el papel de la dirigencia.

${ }^{222}$ Etchepareborda es hoy, en el año 2010, funcionario del gobierno provincial de Das Neves. Cárdenas y Arenas siguen siendo dirigentes de la AOT. 
nuevos despidos y suspensiones en cuatro plantas. Durante las negociaciones no hay acciones en la calle, restringiendo todo a los trámites que llevan adelante los dirigentes en la Subsecretaría de Trabajo.

En diciembre se hace oficial el proceso de liquidación de Arcoplus. Los trabajadores saben que se quedan sin trabajo y la pelea pasa por intentar cobrar lo que les deben. La empresa propone pagar las quincenas y el aguinaldo en cinco cuotas, y las indemnizaciones al $50 \%$ en diez cuotas. AOT y SETIA firman un acuerdo un tanto mejor pero varios trabajadores no lo aceptan e inician juicios. No se realiza ninguna acción pública.

Tras esto otras fábricas comienzan procesos semejantes. Surjet anuncia que traslada su tintorería a Buenos Aires, despidiendo a veinte obreros en Trelew. Pelama inicia el procedimiento de crisis por el cual dejaría sin trabajo y con indemnizaciones a medias a sus cuarenta trabajadores. Algunos obreros de Arcoplus toman la fábrica el 30 de diciembre por no haberse depositado el pago adeudado. El inicio de 1999 ve a esos trabajadores ocupando su antiguo lugar de trabajo. Sigue presente esa voluntad de resistir por parte de los trabajadores, aún en condiciones de gran debilidad.

Los nuevos dirigentes de la AOT destacan que al asumir tenían 1800 afiliados y ahora sólo hay 1210 , por los despidos. Se muestran apenados, planteando que se ven reducidos a negociar indemnizaciones, pero no sostienen ninguna propuesta que les permita superar esa situación, y siguen limitando su accionar a las negociaciones legales.

En marzo comienza otro conflicto en Windsor por el despido de seis obreros que se negaron a operar veinte telares por obrero, en lugar de doce como era de usos y costumbres en el parque de Trelew. Se decide tomar la planta, aunque el SETIA no lo apoya, y la patronal denuncia a los delegados de la AOT. Finalmente la empresa acepta reincorporar a los obreros. Es una pequeña victoria, dada por una medida que surge desde una asamblea de los trabajadores.

La crisis textil sigue en curso con el anuncio de que Foderami despedirá a treinta y siete obreros. Los gremios dicen que nada se puede hacer y siguen planteando una nueva presentación del proyecto de promoción industrial, haciendo hincapié en la confianza en los diputados nacionales de extracción sindical.

Tras la victoria electoral de De la Rúa los sindicatos textiles se manifiestan esperanzados con la posibilidad de una reactivación por el cambio en el gobierno nacional. Afirman que los conflictos estan bajando, con señales que indicarían que se comienza a salir de la recesión. El dato relevante sería que en el último mes se habían incorporado nuevos obreros en varias plantas. En verdad era parte de la estrategia de 
las empresas, consistente en despedir personal bajo convenio y tomar nuevo personal en condiciones de precariedad.

A principio del 2000 también el gobierno provincial manifiesta su confianza en una posible reactivación industrial, en especial por los aranceles a la importación de textiles. Pero esta vez la AOT resalta que sigue habiendo problemas en varias fábricas.

La primera huelga general contra el gobierno de De la Rúa no tiene incidencia en la región, siendo nulo el acompañamiento entre los textiles. Días después un grupo de desocupados corta la ruta №3. Lo interesante del hecho es que su dirigente, Mario Obredor, era uno de los delegados de Windsor que debió renunciar en 1995 por mandato de la empresa.

El 9 de junio se realiza otra huelga nacional. Ahora sí hay pronunciamientos de la región en contra del ajuste. Hay una movilización a la plaza central de Trelew pero no asisten los sindicatos textiles.

En noviembre Foderami anuncia que despedirá a cuarenta obreros. Según ellos se debe a la falta de continuidad de la promoción en Chubut. SETIA reclama el $100 \%$ de indemnización en lugar de defender los puestos de trabajo. La AOT anuncia que está dispuesta a tomar "medidas extremas", como cortes de rutas, porque para ellos el diálogo está agotado.

Durante los siguientes días se mantiene el clima de bronca sobre la crisis industrial. Sin embargo todo queda entre las paredes de las reuniones, sin medidas en la calle. El 23 y 24 de noviembre está convocado un nuevo paro nacional de 36 horas. Los sindicatos textiles se movilizan por separado el 22. SETIA marcha reclamando la prórroga de la promoción y la AOT marcha en Rawson, sólo con los delegados de fábrica.

Nuevamente el 23 se moviliza la AOT a Rawson, queman cubiertas frente a la Casa de Gobierno y exigen que se confirme la promoción industrial. El paro en el sector tiene un acatamiento del $80 \%$.

El 24 la huelga es contundente en todo el país. Hay cortes de rutas, piquetes a empresas, marchas masivas. Es una clara expresión de repudio al plan económico que sustenta la Alianza, continuidad del desarrollado por Menem. La expectativa que sectores de la clase obrera y el pueblo han puesto en el cambio de gobierno cae rápidamente.

En la concentración en la plaza de Trelew convergen sindicatos, desocupados y estudiantes, menos los sindicatos textiles. Es clara la política de no unificar reclamos con otros sectores por parte de los textiles y la escasa participación de esa fracción en los procesos de lucha colectivos. Su reclamo es desarrollado en el marco de la 
reivindicación corporativa de mejoras para su sector, haciendo coincidir los pedidos de los obreros con los intereses de sus respectivas patronales: en una situación de defensiva, y luchando por mantener sus puestos de trabajo, sólo parecía posible lograr ese cometido asegurando la supervivencia de los empresarios.

Los procesos colectivos amenazaban esa posibilidad, ya que plantear la diversificación de reclamos y hacer hincapié en las exigencias comunes de la clase (aumento salarial, planes para todos los desocupados, basta de despidos) más que en los de su fracción particular, implicaba un enfrentamiento con el gobierno provincial y la posibilidad de que los fondos de este no se destinarán en primer término a los subsidios a las empresas textiles. La lógica de esta estrategia llevaba a que ni siquiera acordaran movilizaciones conjuntas de ambos sindicatos textiles, pese a que los reclamos eran casi idénticos (promoción industrial textil, subsidios para las empresas, aranceles a la importación).

Desde el principio del 2001 se vive un clima social que hace presagiar el desenlace del año. Sin embargo esto, que se observa en casi toda la sociedad, no se hace tan claro entre los textiles. Hay hechos aislados como la oposición de la asamblea de los obreros de Unilán a la implementación del sistema americano de seis por dos, donde realizan trabajo a desgano y paros por turno hasta que la empresa desiste de poner en marcha ese sistema. Pero no hay procesos significativos de lucha, ni los textiles se suman al conflicto social en marcha, pese a que en febrero y marzo se vive una nueva profundización de la crisis textil. Se mantiene desde diciembre del 2000 la toma de Prosur, empresa que parecía ir hacia su cierre definitivo. Otra planta, Casa Roma, anuncia que también cerraría ya que no puede competir con los productos importados. En Surjet se ocupa la planta por salarios adeudados, parte de los cuales se pagan el mismo día de la toma.

En julio se agrava el conflicto en Surjet, donde había empezado una retención de servicios ante un nuevo atraso en el pago de sueldos. Se decide la huelga y la quema de cubiertas en la puerta de la planta, sumándose los trabajadores de Windsor al paro por el atraso salarial. Es uno de los pocos hechos que muestra un rebote de la situación social hacia los textiles.

A fines de ese mes se cumplía más de un mes de retención de servicios en la textil Windsor sin que se produjeran novedades por el pago de las deudas ni sobre el futuro de la fábrica. El secretario general del gremio afirma que el panorama para los textiles es muy malo y que seguirían los despidos ante la continuidad de la crisis. Para septiembre se producen cuarenta despidos más en Soltex, mientras en Windsor se mantiene la ocupación para evitar que se lleven la maquinaria del lugar. 
Marcamos que hay una tendencia a unificar las luchas y a una mayor solidaridad entre los que reclaman. Sin embargo esto no se traduce en las protestas textiles. Pero ello no puede ser planteado como falencia de esos trabajadores: tampoco otros sectores (sumamente movilizados en estos meses) se solidarizan con ellos. Así lo vemos en este largo conflicto en Windsor, que no recibe la solidaridad de casi ningún sector. Es quizás una muestra de que esa tendencia hacia la unificación era contrapuesta, a su vez, por la permanencia de la lógica corporativa, que vimos siempre presente entre los textiles pero que también se hacía evidente en otros sectores, entre ellos en los grupos de desocupados.

Cerca de la finalización de octubre el dirigente de la AOT afirma que la situación de Windsor ya es desesperante y que directamente se debe dar por desaparecida a esa empresa. Así los trabajadores, que hace casi cuatro meses mantenían su lucha, quedarían en la calle.

Ya en diciembre, y mientras seguían los despidos y cierres de fábricas, se anuncia la adhesión de las dos CGT locales a la huelga nacional del 13. Sin embargo llaman a actos por separado. La CGT del Valle, que responde a Daer, convoca en Trelew, mientras la CGT del Noreste, en línea con Moyano, llama a un acto en Puerto Madryn, dividiendo a los textiles en dos actos distintos.

Es conocido lo que sucede durante diciembre de 2001. En la región el proceso también se acelera: no hay saqueos pero sí constantes protestas. El 20 hay enfrentamientos, intentos de saqueos y entrega de bolsones de comida en Trelew y Madryn. No se marca presencia organizada de ningún sindicato, y solamente es evidente la participación de algunos integrantes de grupos de desocupados.

En 2002 la AOT informa que hay más de 600 textiles con reducciones de jornada o suspendidos. La situación es muy compleja, aunque la devaluación y las restricciones a la importación decididas por el gobierno de Duhalde abrían un margen de expectativa en una posible recuperación.

Hay fábricas como Propulsora Patagónica donde la reducción de jornadas ya supera el año (con una fuerte caída en el salario), Foderami donde sigue sin resolución el tema de los despidos y se les debe cuatro meses de sueldo, Tendlarz que pediría procedimiento de crisis, Casa Roma que trabaja tres días por semana y Soltex que suspende a todo el personal por dos meses. En Propulsora la asamblea de trabajadores rechaza una nueva suspensión.

Para mediados de año la reactivación impacta en el aumento de la exportación de lana sucia a granel. Sin embargo esto era un problema, ya que se deja sin materia prima a las fábricas del parque que realizan el proceso de lavado, peinado y tops, 
proceso donde se incorpora valor al producto y se generan puestos laborales. La AOT plantea que se deben quitar los estímulos a ese tipo de exportación.

En la misma línea el Setia reivindica el crecimiento de la producción lanera, pero dice que el problema es asegurar que se complete el proceso de industrialización en la región, siendo esa parte del proceso la que agrega valor al producto y genera puestos de trabajo.

Durante septiembre se anuncian desde el ministerio de la producción datos sobre la situación textil. Se afirma que la provincia ha entregado subsidios a catorce empresas y a 2475 empleados. Las empresas subsidiadas fueron: Sedamil (pretendía despedir a doscientos empleados, se le dio un subsidio de ochenta y ocho mil pesos con el cual volvieron a producir), Sur Jet (subsidio de 17400, con cincuenta personas trabajando a un 70\%), Propulsora (13500 pesos para ochenta trabajadores, están en proceso de reactivación tras más de un año de suspensiones), Cooperativa Textiles Unidos (es la ex Windsor, se dio cien pesos por mes a cada trabajador), Soltex (15 mil pesos, produciendo al 40\%), Casa Roma (se volvió a abrir y estaría con posibilidades de recuperarse), Fipasa (se dio a cada trabajador un subsidio de cien pesos) y Nylotex (también se dio cien pesos por trabajador).

Entre fines del 2002 y principios del 2003 la recuperación del parque textil comienza a sentirse, aunque no esta en ningún horizonte la posibilidad de recuperar los niveles de empleo de antaño. Se han frenado los despidos constantes y hasta hay algunas nuevas incorporaciones de personal. Los datos del gobierno muestran que en el 2002 se duplicaron las exportaciones del sector textil con respecto al 2001.

Según datos del secretario de producción del municipio de Trelew en diciembre de 2001 había 730 empleados en el parque textil sintético, en 2002, 872 y en 2003, 1012. Además en abril emite un informe sobre la situación general de las industrias en Trelew, donde habría un total de 2191 puestos de trabajo con cincuenta y seís empresas en funcionamiento, que se distribuían de la siguiente manera:

Cuadro № 14: Industrias existentes en Trelew, abril de 2003. Datos de Secretaría de la Producción de la Municipalidad de Trelew.

\begin{tabular}{|l|c|l|c|}
\hline \multicolumn{1}{|c|}{ Actividad } & $\begin{array}{c}\text { Cant. de } \\
\text { empleados }\end{array}$ & \multicolumn{1}{|c|}{ Rubro } & $\begin{array}{c}\text { Cant. de } \\
\text { empresas }\end{array}$ \\
\hline Textil Lanera & 631 & Textil sintéticas & 9 \\
\hline Textil sintética & 1015 & Lavad. y peinad. de lana & 5 \\
\hline Barraca & 128 & Barracas & 5 \\
\hline Metalúrgica & 73 & Mecano metalúrgicas & 8 \\
\hline Constructora & 139 & Constructoras & 11 \\
\hline Transporte & 28 & Transportes de carga & 4 \\
\hline Servicios/otras & 177 & Servicios & 5 \\
\hline Total & 2191 & Otras & 9 \\
\hline
\end{tabular}


Ya la asunción de Duhalde como presidente genera expectativa entre los textiles, hecho que se observa en la caída de las protestas que ellos protagonizan y la revitalización de la estrategia centrada en buscar resoluciones corporativas a través de las vías institucionales. Los sindicatos centran sus reclamos en la necesidad de nuevas leyes e intentan llegar a acuerdos con las empresas instaladas en la región.

Esta perspectiva se hace aún más clara luego de la asunción de Kirchner como presidente y de Das Neves como gobernador. Éste afirma que buscara recuperar la promoción industrial con los antiguos beneficios. Su reclamo se complementa con la búsqueda de que sea la provincia quién maneje los cupos de promoción.

Varios dirigentes sindicales de los textiles ocupan puestos como funcionarios políticos en el nuevo gobierno provincial. Etchepareborda pasa a ser el nuevo director de empleo de Chubut, y desde allí crítica a los grupos de desocupados, asegurando que se avanzara en sacarles todos los planes.

Es la continuidad, en su política como funcionario, de su estrategia sindical, que se centra en defender los intereses corporativos de los textiles, no solamente sin abonar la unidad de las diferentes fracciones de trabajadores sino avanzando en su división. En este caso esto es más evidente, ya que los sindicatos textiles disputaban parte de la misma base social que en ese momento dirigían los grupos de desocupados.

En septiembre la municipalidad de Trelew resalta la recuperación de la industria textil en la zona pese a que no se cumplía la promesa de una nueva promoción industrial. Sus datos muestran que entre todas las empresas del parque se pasó de 2438 puestos a fines del 2003 a 2743 para julio del 2004 . A su vez las textiles sintéticas pasaron de 979 a 1116, las laneras de 696 a 717 y en las barracas de 155 a 171. Como vemos la recuperación es real pero muy lenta.

En 2005 vuelven a aparecer, tras varios años, los reclamos de aumento salarial entre los textiles. Así se realizan huelgas en la textil Tendlarz de Trelew. También se denota un avance en la voluntad de resistir los despidos cuando el Setia toma la planta de la Textil Punilla y consigue la reincorporación de los trabajadores que habían sido echados. Otro hecho que parece expresar un avance en la conciencia es la intención de poner en marcha como fábrica recuperada a la textil Del Estero, en Gaiman, que había cerrado a fines de los noventa con los típicos fraudes hacia los trabajadores.

Son leves manifestaciones de que algo había cambiado en la conciencia, aunque esta es la fracción obrera donde esos cambios se hacen menos evidentes. Ya veremos que en las otras fracciones de la clase las manifestaciones que registramos de este "cambio de época", son mucho más contundentes. 


\subsection{Los trabajadores pesqueros}

Como parte de nuestro proyecto hemos realizado trabajos que nos aproximan a distintas fracciones de la clase ${ }^{223}$, como formas de avanzar en el conocimiento de las determinaciones más simples y concretas que hacen al concepto de clase obrera ${ }^{224}$.

En este apartado realizamos un abordaje de los principales procesos de lucha de los trabajadores relacionados con la actividad pesquera. Allí encontramos distintas fracciones: observamos a los marineros, los estibadores y los trabajadores de las plantas en tierra. A su vez hay distintas capas, donde vemos divididos a los obreros de acuerdo al nivel salarial que reciben, el conocimiento de oficio que tienen, el tipo de patronal que los contrata, etc.; hay diferencias entre los marineros de la flota fresquera y de los congeladores, entre el personal de plantas en tierra que esta en blanco y los que están bajo distintas modalidades de precarización y, al interior de estos trabajadores en tierra, entre los fileteros y el resto del personal (peones, estibadores, personal de limpieza, etc). Un elemento de mayor complejidad en la rama lo presenta la gran cantidad de personal femenino ocupado en las plantas, las que suelen sufrir peores condiciones de trabajo.

Dentro de esta variedad de situaciones (que elimina cualquier supuesto de que la utilización del concepto de clase obrera pueda hacerse desde una mirada "esencialista") hacemos hincapié en el análisis del personal en tierra, que es el que realiza la mayoría de las acciones de rebelión. Veremos duros enfrentamientos entre las distintas capas de obreros, de acuerdo a los intereses que se les presentan en la búsqueda de vender a mejor precio su fuerza de trabajo.

Es en el proceso de lucha de clases cuando ellas van adquiriendo conciencia de sus intereses comunes y desarrollando organizaciones y acciones que buscan defender sus intereses y luchar contra aquellos que pretenden perjudicarlos. Dicho proceso se desarrolla en este caso en el marco de un territorio social determinado: el de la actividad pesquera.

\footnotetext{
${ }^{223}$ Entre otros Pérez Álvarez, Gonzalo (2009c) "Lucha y memoria obrera en el noreste del Chubut. Una aproximación desde la fábrica Modecraft 1990-1991" en Historia Antropología y Fuentes Orales, № 41 , Barcelona, España, pág. 25-48. (2008f) "Protestas obreras en el noreste de Chubut: los textiles y los metalúrgicos en la década del 90'”, en e-l@tina, Vol. 6, núm. 24 - http://www.iigg.fsoc.uba.ar/elatina.htm UBA; (2009b) "Aunque parezca, la red no está vacía. Luchas de los obreros pesqueros del noreste de Chubut, 1990-2005" en Revista de Estudios Marítimos y Sociales, № 2, Mar del Plata, pág. 171-183; y (2009a) "Los trabajadores desocupados: el caso del noreste de Chubut, continuidad, ruptura y estrategias”, en Revista Razón y Revolución №19, Ediciones ryr, Bs. As. pág. 53-68.

${ }^{224}$ Para poder retomar esta discusión sobre el concepto de clase obrera y la relación entre lo concreto y lo abstracto, utilizamos la Introducción general a la crítica de la economía política/1857, S XXI, México, de Carlos Marx (1997) y el debate entre Marcel Van der Lienden ("Globalizando el concepto de clase obrera") y Nicolás Iñigo Carrera ("El concepto de clase obrera") publicado en la Revista de Estudios Sociales y Marítimos №1 (2008), pág. 101 a 120.
} 
Aunque hemos relevado una importante base documental, este apartado no deja de ser una aproximación al tema. Distintas problemáticas apenas serán nombradas sin poder ir más alláa ${ }^{225}$. Es clave acercarse a pensar la cuestión de género. Las mujeres representan el $70 \%$ del personal en las plantas en tierra, sin embargo casi nunca aparecen con lugares de dirección a nivel sindical. Los portavoces son siempre hombres, en general fileteros. Las mujeres solamente aparecen como "víctimas", cuando en el marco de una huelga se remarca su sufrimiento, pero pocas veces como sujetos.

También se debe avanzar en la investigación acerca de la conformación de este grupo social que son los trabajadores de la pesca. La gran mayoría son migrantes y allí también se reproducen distintas posturas según el origen de los trabajadores. La fuerte discriminación hacia los trabajadores de origen boliviano, la "denuncia" del origen chileno de algunos de los principales activistas, el enfrentamiento contra los obreros "de afuera" (especialmente de Mar del Plata), muestran otras divisiones al interior de la clase.

Uno de los factores centrales que tenemos como limitantes es la carencia de trabajos que analicen el tema en la región desde un punto de vista histórico ${ }^{226}$. Ante esto recurrimos a la interesante producción de distintos investigadores de la Universidad Nacional de Mar del Plata, quienes desarrollan un proyecto de investigación que pone el centro de su atención en la actividad pesquera y en el puerto como territorio social ${ }^{227}$. Uno de los elementos que se nos presentaba al leer esos trabajos, y que intentaremos reflejar en alguna medida, son las semejanzas y diferencias entre los procesos en la costa bonaerense y la costa patagónica, y cómo las patronales con intereses en cada región (y en muchos casos con intereses en

\footnotetext{
${ }^{225}$ Por ejemplo acerca de las disputas interburguesas, tanto en la región como a nivel país, la relación del estado provincial con el nacional y con las empresas, la cuestión de género, la cuestión del oficio, etc. Otros aspectos de la problemática pesquera, como el de los pescadores artesanales, ni siquiera será mencionada ya que ameritan un abordaje particular. Algo desarrollamos en "¿De qué va a vivir mi pueblo? ¿Estrategias para el desarrollo local o formas de encubrir los problemas estructurales?", trabajo final para el seminario de postgrado "El debate del desarrollo local. Las perspectivas geográfica, sociológica y económica", dictado por el Dr. Patricio Narodowski en el año 2006.

${ }^{226}$ Solamente hemos encontrado unas páginas en lbarra, Horacio y Hernández, Carlos (2005) Estado, Economía y Sociedad. Trelew y su hinterland: 1989-1999, Informe de Investigación, UNPSJB, Chubut y en Beinstein, Jorge (1993) Dinámica global de la economía patagónica, LUDEPA-SME / INTA-GTZ.

227 En especial los trabajos que se vienen produciendo desde el GESMAR (Grupo de Estudios Sociales Marítimos), entre otros Nieto, Agustín (2009) "Conflictividad obrera en la industria de la pesca, 1997-2008" y Colombo, Guillermo (2009) "Cuando los trabajadores se vuelven 'vándalos'. Descripción y análisis de un 'estallido social' en el puerto de Mar del Plata (año 2000)", ambos en "Actas del Primer Congreso Nacional Sobre Protesta Social, Acción Colectiva y Movimientos Sociales"; Colombo y Nieto (2008) "Aproximación a las formas de la lucha obrera en la industria de la pesca, Mar del Plata 1997-2007", LabourAgain Publications (online) http://www.iisg.nl/labouragain/documents/colombo-nieto.pdf, y otros publicados en el №1 de la "Revista de Estudios Marítimos y Sociales" (2008): Masid, Mirta y Mateo, José "De la sustitución a la exportación. El sector pesquero argentino entre 1930 y 1965" y Contreras, Gustavo "En río revuelto ganancia de Pescador. El gremio marítimo y el peronismo". Especial mención merece el libro de Eduardo Maro Pradas (2006) Un acercamiento a la problemática pesquera marplatense, una excelente síntesis histórica de la actividad pesquera en Argentina.
} 
ambas regiones) establecen alianzas sociales con sus respectivos obreros para disputar mayores cupos de captura.

En un principio buscamos aplicar la periodización que hemos construido para el proceso general en la región. Pero al desarrollar el trabajo vimos que la dinámica de conflictos sociales en la rama tenía elementos propios que marcan modificaciones en la periodización. Pensamos que para esta fracción hay un primer período que se extiende desde 1990 hasta 1996, y que está caracterizado por el avance de las grandes empresas.

El año 1990 es un momento de profundas transformaciones para la región. Es el punto límite del antiguo modelo de polos de desarrollo (que ya había entrado en crisis en 1985), vinculado a la fase de hegemonía del capital industrial y a la posibilidad de un desarrollo en extensión del capitalismo en la región patagónica. Se asientan las condiciones para quebrar ese antiguo modelo y se pasa a la construcción del dominio directo del capital financiero y al desarrollo en profundidad del capitalismo.

Se trataba de acentuar la explotación de los trabajadores, concentrar la riqueza y la propiedad y garantizar el acceso a importantes recursos naturales. Este proceso es impuesto desde el gobierno nacional a través de una serie de medidas: el fin de los subsidios a las empresas pequeñas y medianas, la privatización de las empresas estatales y el ahogo presupuestario del Estado provincial.

Como expresión de este proceso en el ámbito de las relaciones de fuerzas sociales objetivas ${ }^{228}$, se produce el proceso de movilización popular conocido como "chubutazo". Los trabajadores de la pesca sufren un evidente deterioro de sus condiciones materiales de existencia durante estos primeros años, pero casi no se registran hechos de protesta. Entre 1990 y 1991 sólo hemos relevado cuatro acciones (una marcha, dos tomas y una huelga de hambre). Son comunes los cierres de plantas y las suspensiones de personal. Como se ha relevado en Mar del Plata ${ }^{229}$ parte de este personal es "reincorporado" a cooperativas truchas, que funcionan solamente cuando hay recurso. Aunque esto se hace presente en la realidad de la región no alcanza el grado de extensión que se registra en Mar del Plata.

\footnotetext{
228 Tomamos como modelo a las indicaciones de Gramsci (1997) en su Análisis de las situaciones. Relaciones de fuerzas, donde plantea la necesidad de analizar a la sociedad como una disposición de fuerzas sociales. En esa relación de fuerzas hay diversos momentos, grados o niveles. El primero de ellos es la relación de fuerzas sociales objetiva. Es el ámbito de la sociedad que se refiere a las relaciones necesarias e independientes de la voluntad de los hombres que viven bajo ellas, que se corresponden con un determinado desarrollo de las fuerzas productivas materiales de la sociedad. El siguiente momento es el de las relaciones de fuerzas políticas, que hacen al grado de homogeneidad, autoconciencia y organización que han alcanzado los diferentes grupos sociales. Dentro de este momento Gramsci divide diversos niveles que va tomando la conciencia política colectiva. Esta perspectiva está mejor desarrollada en los primeros capítulos de esta tesis.

${ }^{229}$ Por ejemplo en Pradas (op. cit.), Colombo y Nieto (op. cit.), donde se aprecia claramente que el modelo de las cooperativas "truchas" es una estrategia de las patronales a nivel general para bajar el costo de la fuerza de trabajo.
} 
A fines de 1991 aparece un rasgo que luego se hace permanente: la toma de plantas con el pescado adentro como mecanismo de presión para cobrar sueldos adeudados. El año siguiente es el único con fuertes conflictos en este primer período (catorce hechos). A diferencia del ciclo general de rebelión (donde notamos una fase descendente hasta 1994, en paralelo al proceso nacional que comienza una fase ascendente tras el santiagazo en diciembre de 1993) notamos una agudización del proceso en este año y una nueva caída hasta 1997.

Durante 1992 se dan dos fuertes enfrentamientos entre trabajadores ${ }^{230}$. Se observa el desarrollo del Stia que desplaza al Soipra como organización sindical que nuclea a la mayoría de los trabajadores de plantas pesqueras. El Soipra pierde durante este año su capacidad de movilización, pero hasta 1996 serán comunes los ataques contra el Stia, las protestas en que ese sindicato no era aceptado, etc.

Dirigentes del Soipra denuncian que en Puerto Madryn hay una reducción del $70 \%$ en el personal ocupado en las plantas y afirman que fueron despedidos los obreros que se oponían al Stia. Durante este año el Soipra realiza varias acciones y es parte de los cinco gremios fundadores de la CTA en Chubut, pero no logra generar alianzas sociales y queda aislado. El Stia crece en clara cercanía con las patronales de las principales empresas. Se hace común que en las medidas por planta el personal contratado no adhiere a las mismas, destacándose en sus declaraciones el miedo a perder el trabajo. Hay algunos enfrentamientos con el personal ocupado de planta.

El otro conflicto entre trabajadores se da ante la desregulación en la estiba. El SUPA se enfrenta en el puerto de Madryn con los trabajadores de una cooperativa que había formado la pesquera Harengus para descargar sus barcos. Hay varios choques, con golpes y uso de distintas armas por parte de ambos grupos. Finalmente se llega a un acuerdo de sesenta días de tregua. A los diez días el dirigente del Supa es asesinado de dos balazos por la espalda. El gobierno afirma que el motivo fue una pelea previa al conflicto portuario.

También los trabajadores del Somu se manifiestan en varias ocasiones contra la desregulación de la actividad, que permitiría la contratación de marinos extranjeros.

Entre 1993 y 1996 el proceso vuelve a descender. Se hacen comunes los enfrentamientos entre trabajadores estables y precarizados en los conflictos por empresa. Obviamente esto debilita a los trabajadores de la rama. Por otra parte es

\footnotetext{
${ }^{230}$ Son enfrentamientos por los intereses inmediatos de estos trabajadores en la venta de su fuerza de trabajo. La burguesía utiliza el ejército de reserva para presionar los salarios hacia la baja. La conciencia obrera limitada a verse como vendedores de fuerza de trabajo los lleva a la competencia entre ellos, como le sucede a cualquier vendedor de mercancía en el capitalismo. Como ya lo destacamos sólo una conciencia que exprese sus intereses en tanto expropiados de las condiciones materiales de existencia puede impedir esa competencia a la que los condena el régimen capitalista de producción.
} 
característico que no se producen conflictos generales. Tomando el concepto que propone Agustín Nieto, vemos que desde la patronal se desarrolla una "guerra de guerrillas" ${ }^{\text {"31 }}$, generando constantes ajustes a nivel de plantas y arrasando la mayoría de las conquistas laborales.

La debilidad de los trabajadores y su aislamiento no implica que estos no desarrollen fuertes procesos. Hay tomas de plantas, entre ellas algunas muy contundentes y extensas, como la de Conarpesa en 1993 que dura más de quince días. Sin embargo la radicalidad de estas medidas parece más relacionada con la debilidad que con la fortaleza: no encuentran formas de generar canales de solución para los conflictos y no hay solidaridad de otros sectores. De hecho Conarpesa sigue procesando su pescado en otras plantas que subcontrata.

En febrero de 1994 la provincia del Chubut realiza un informe reconociendo la fuerte crisis por la que atraviesa la industria pesquera en la provincia. Se da una situación supuestamente paradójica: mientras aumentan las capturas (crece de menos de 200 mil dólares en 1988 a más de 1.400 .000 mil dólares en 1993) desfallece la industria pesquera asentada en la provincia.

En 1995 se produce un conflicto sintomático de la situación de los trabajadores. Cuarenta obreras de la pesquera Bonasur de Rawson, son despedidas. Denuncian que se debe a que días antes había muerto un joven de 16 años por las malas condiciones laborales. Trabajan en negro, entre 12 y 16 horas de forma obligada. Parte de los empleados efectivos declaran en contra de estas denuncias, afirmando que el trato siempre fue correcto y que el personal contratado se debe a la falta de materia prima constante. Exigen que se termine con las denuncias que pueden llevar al cierre de la empresa.

Hacia 1996 el Stia ya se presenta como el gremio más fuerte del sector. Tiene un papel importante en las huelgas nacionales de ese año. Se forma la coordinadora de gremios marítimos integrada por Somu, Supa, Stia, Saon, capataces, Siconara ${ }^{232}$ y la Asociación Argentina de capataces de pesca. En el marco de las huelgas nacionales las movilizaciones en Trelew son las más numerosas desde el chubutazo, mientras en Puerto Madryn se corta la ruta de acceso al parque pesquero por parte del Stia.

Entre 1997 y el 2001 registramos un crecimiento del proceso de luchas en esta fracción. A principio de 1997 ya era inocultable la sobreexplotación del recurso

\footnotetext{
231 En "Conflictividad obrera en el puerto de Mar del Plata: del anarquismo al peronismo..."; №1 de la Revista de Estudios Marítimos y Sociales, 2008. Como el autor afirma la terminología militar es tradicional en los análisis desde el marxismo sobre los procesos de lucha de clases. Es así ya que partimos de comprender a la sociedad como un campo de batalla entre clases con intereses antagónicos.

232 Sindicato de Conductores Navales de la República Argentina.
} 
pesquero. En los años previos, al igual que sucedía con el petróleo, se daban datos del aumento en la cantidad de pesca exportada como si fuera algo positivo, sin evaluar el impacto que esto generaba en la biomasa. La imagen era la del fin de una fiesta, pero en verdad era el comienzo de la lucha interburguesa más fuerte por lo que aún quedaba por pescar. Como toda crisis capitalista de sobrecapitalización esta llevó a una nueva concentración de la propiedad. Las empresas de capital monopólico y actividad diversificada, son las que logran crecer, avanzando con suspensiones, despidos y hasta lockouts ante los reclamos obreros.

Sobre fin de año comienzan reuniones con el intendente de Puerto Madryn y autoridades provinciales para proponer un "proyecto pesquero de la provincia". A principios de 1998 los gremios proponen un programa de doce puntos. Por primera vez en años se inicia un paro total en la rama, por la situación de crisis y los telegramas de despido a trabajadores de Alpesca ${ }^{233}$. El programa es acompañado por la CAPIP, que apoya el proyecto ya que hace énfasis en quitar la veda y reclamar leyes promocionales para la pesca en la región; las consignas no se basan en un programa de clase sino en los intereses comunes de esa rama económica en la región. Por eso decimos que la huelga se realiza como mecanismo de presión hacia el gobierno y no hacia las patronales, tomando un claro contenido de lucha política centrada en la disputa interburguesa.

Los trabajadores defienden sus intereses en tanto asalariados de la rama pesquera del noreste del Chubut y, en una situación regresiva para ellos, buscan defender sus puestos de trabajo defendiendo a "sus" empresarios. Se conforma una alianza social entre los empresarios más concentrados de la rama y los trabajadores. Guillermo Colombo ${ }^{234}$ nos muestra que durante 1997 también se conforma una alianza entre los empresarios fresqueros marplatenses y los sindicatos, en lo que él define como una defensa de la ciudad en tanto "corporación económica". En ambos casos el enemigo es la "otra" alianza y la intención presionar al gobierno nacional para obtener mejores condiciones de explotación del recurso.

Uno de los factores que acelera el llamado a paro general es el conflicto en Alpesca, la empresa que levanta el discurso de los fresqueros contra los congeladores. Finalmente esto se "soluciona" con una suspensión con pago de la garantía horaria ${ }^{235}$. En mayo el conflicto vuelve con duras acciones, como la toma de Alpesca con el personal jerárquico como rehén. Reclaman que se derogue un acuerdo

\footnotetext{
${ }^{233}$ Empresa de capitales nacionales, parte del grupo Alpargatas, cuya flota es de barcos fresqueros. Su planta en tierra es una de las que mayores conflictos ha tenido a lo largo de los años por las rígidas condiciones de trabajo del personal.

${ }^{234}$ En (2008) "Colapso de la merluza y protesta obrera en los inicios de la crisis pesquera (1997-1998)", №1 de la Revista de Estudios Marítimos y Sociales.

${ }^{235}$ Es el importe que la empresa debe pagar a sus obreros cuando no hay recurso para procesar.
} 
por empresa de 1994. El Stia apoya el reclamo pero pide que se libere a los jerárquicos.

También en Rawson se conforma una alianza de hecho. Pero esta tiene un contenido distinto, ya que son los propietarios de los fresqueros de la flota amarilla los que marchan junto a los trabajadores y reciben el apoyo del intendente. El gobernador los recibe y se logra destrabar el conflicto autorizando la pesca en nuevos cuadrantes. La negociación la encabezan los empresarios, mientras los trabajadores plantean que buscan mantener sus fuentes de trabajo.

El discurso de la unidad de las ciudades como corporaciones económicas no tiene una continuidad como práctica más allá del momento de reclamar cupos de pesca. Durante 1998 empieza a hacerse visible la presencia de trabajadores marplatenses, que son traídos para funcionar como "cooperativas" en condiciones de extrema precariedad. La identificación de los empresarios con sus trabajadores queda en el olvido cuando se trata del precio de la fuerza de trabajo. Aprovechan así el impacto más fuerte de la crisis pesquera en Mar del Plata para bajar los salarios a nivel nacional.

Al comenzar 1999 se producen conflictos en Conarpesa y Harengus, las más importantes empresas congeladoras. Pero el proceso significativo comienza en abril, cuando la Coordinadora de Gremios Marítimos expresa su rechazo a la veda que se implementará desde junio. Denuncian que el problema es el saqueo que realizan los buques extranjeros. Esta vez el programa de los sindicatos se enfrenta en algún punto con los intereses de las grandes empresas congeladoras. En especial el Somu levanta la consigna de "Mar para los argentinos", denunciando a las empresas españolas y asiáticas.

El dirigente del Somu hace públicas las terribles situaciones de falta de seguridad e higiene que se vivían en los buques, en especial en los de origen extranjero. Esto tiene relación con una nueva muerte de un joven marinero en una situación muy extraña. Dos trabajadores denuncian también estas condiciones, acusando especialmente a algunos empresarios que actúan bajo la fachada de cooperativas truchas y cambiando la razón social cada pocos años para evitar juicios y evadir impuestos. Ellos colocan carteles y acampan frente al municipio de Puerto Madryn durante varios días, denunciando la complicidad con estos empresarios de la Subsecretaría de Trabajo y del Supa. Afirman que al aceptarse los convenios de trabajo y los cambios de razón social, se lleva a que los trabajadores pierdan la antigüedad, los aportes previsionales y que tengan inconvenientes con la obra social, entre otros problemas. 
En junio la Coordinadora de Gremios Marítimos se moviliza a la Capital Federal para participar de la marcha nacional pesquera. También participan de la protesta obreros del Somu llevando los barcos al puerto, con carteles y haciendo sonar las sirenas. Allí empieza a perfilarse la ruptura del antiguo frente de la ciudad. La polémica entre los fresqueros y los congeladores se hace más fuerte ante la escasez del recurso. La empresa Alpesca publica el 24 de mayo una gran solicitada en la cual hace referencia al saqueo que viene sufriendo el recurso pesquero a manos de las flotas españolas y portuguesas. Compara esta situación con el aniversario de la revolución de mayo, planteando que estamos ante un nuevo colonialismo impulsado por los gobiernos de turno y las empresas transnacionales. A partir de allí se instala el debate en la región.

Los datos muestran que mientras en 1989 sólo el 20\% de la captura total era de congeladores, ahora ese porcentaje ascendía al 60,7\% de la captura declarada ${ }^{236}$. De hecho casi todos los barcos congeladores que pescan durante esos años en la Argentina son barcos de origen europeo que han sido prohibidos en esos caladeros por la depredación que generan en el recurso.

Según estudios específicos en 1996 la Argentina dejó de exportar 455 millones de dólares por haber fomentado la pesca en los congeladores, ya que estos producen un gran descarte de pescado que podría haber sido procesado por la flota fresquera. En los congeladores que procesan el pescado en el mismo barco se descarta la pesca más pequeña que un determinado tamaño y los que no llegan a procesarse en tiempo por la falta de mano de obra. Además se desperdicia el recurso por no tener fábricas de harina de pescado a bordo. Otro debate, central para los sindicatos, pasa por la generación de puestos de trabajo. Según los datos de los fresqueros, difundidos por uno de los diarios ${ }^{237}$, con la misma pesca la flota congeladora asegura 79 puestos, mientras los fresqueros garantizarían 422.

Los días siguientes el problema de la pesca, con leyes contradictorias y la veda a la captura de merluza, llena de internas y disputas a la ciudad de Madryn. EI 5 se realiza un debate público en el cual se expresan los sectores fresqueros, congeladores, las plantas en tierra y los sindicatos. Las luchas internas se expresan especialmente entre las grandes empresas transnacionales con flotas de congeladores y las empresas no tan importantes (también muchas extranjeras pero con mayor participación nacional) de barcos fresqueros con plantas en tierra.

\footnotetext{
${ }^{236}$ Sabiendo que en el caso de estos barcos era muy grande la cantidad de pesca no declarada.

237 Es claro aquí como los diarios juegan como representantes de determinados sectores. "Jornada" se transforma en vocero del sector fresquero. Tiempo después los congeladores fundan su propio medio, el "Diario de Madryn", en manos del propietario de Harengus.
} 
Claramente en los últimos años la flota congeladora originaria de la Comunidad Europea se ha visto favorecida por las leyes del gobierno menemista y la falta de controles de los gobiernos provinciales. Se han realizado negocios multi millonarios al costo de vaciar los mares argentinos y dejar sin puestos de trabajo estables a las ciudades que dependen de este recurso. El acuerdo de 1992, ratificado por el Congreso Nacional recién en 1994, autoriza a esta flota a desarrollar todo tipo de maniobras. Se permite, por ejemplo, que los grandes congeladores de origen europeo compren permisos de pesca de buques fresqueros, cuando en verdad el impacto sobre el recurso que generan unos y otros no es comparable. Es así que entre 1992 y 1998 la captura de merluza hubsi en Argentina se duplica, como consecuencia directa de la presión que generan los barcos congeladores, depredando un recurso que hasta ese momento se había explotado de forma más racional.

Como decíamos los fresqueros hacen hincapié en el debate acerca de la cantidad de puestos de trabajo generados. Tomando una captura anual de 15 a 20 mil toneladas de merluza como la captura normal de un congelador de 70 metros de eslora se asegura que eso es lo mismo que pescan 10 barcos fresqueros de mediana altura (500 HP aproximadamente) o 6 fresqueros de altura (850 HP), que en ambos casos debían procesar el pescado en tierra.

Entonces la comparación de puestos de trabajo generados daría:

Cuadro № 15: Comparación cantidad de puestos de trabajo generados por barcos congeladores y fresqueros.

\begin{tabular}{|c|c|c|}
\hline & 1 Congelador & 10 Fresqueros \\
\hline Personal embarcado & 45 & 90 \\
\hline Apoyo logístico en tierra & 4 & 10 \\
\hline Control de descarga & 3 & 10 \\
\hline Serenos & 2 & 10 \\
\hline Cuadrilla de descarga & 15 & 15 \\
\hline Armado de cajones & 0 & 7 \\
\hline Fábrica de hielo & 0 & 4 \\
\hline Transp. de hielo y cajones & 0 & 3 \\
\hline $\begin{array}{c}\text { Lavado, repos. de cajones } \\
\text { y fábr. de harina }\end{array}$ & 0 & 11 \\
\hline Fileteros de planta & 0 & 150 \\
\hline Peones & 0 & 19 \\
\hline Envasadoras & 0 & 34 \\
\hline Calibrado y pesaje & 0 & 8 \\
\hline Planillaje & 0 & 1 \\
\hline Limpieza de residuos & 0 & 2 \\
\hline
\end{tabular}




\begin{tabular}{|c|c|c|}
\hline Plaquistas & 0 & 10 \\
\hline Camaristas & 0 & 10 \\
\hline Control de calidad en tierra & 0 & 2 \\
\hline Maquinistas de planta & 0 & 3 \\
\hline Capataces y encarg. & 0 & 4 \\
\hline Choferes & 4 & 4 \\
\hline Empleados administrativos & 3 & 13 \\
\hline Agencia Marítima & 2 & 2 \\
\hline Totales & $\mathbf{7 9}$ personas & $\mathbf{4 2 2}$ personas \\
\hline
\end{tabular}

Fuente: Diario Jornada, 7/6/1999, pág. 5.

Por su parte los congeladores identifican sus intereses con los de Puerto Madryn, destacando que son las grandes empresas congeladoras las que crearon la rama económica en la ciudad y que los puestos de trabajo que garantizan son estables y en blanco, mientras en los fresqueros la mayoría del trabajo es en negro y precario. Ambos sectores se disputan a los trabajadores como punto de apoyo de sus respectivos programas. Los sindicatos no parecen en esta ocasión cerrar una alianza, siendo su reclamo que se aseguren los cupos de pesca para garantizar la continuidad de los puestos de trabajo en ambas flotas.

Sí es más clara la situación en Rawson, donde se mantiene la alianza entre empresarios fresqueros, trabajadores y autoridades de la ciudad. A principio del 2000 el gobierno nacional restringe la pesca para los fresqueros y veda casi totalmente la pesca de merluza para los congeladores. En los meses siguientes hay conflictos en las plantas en tierra por la falta de recurso y, ante la falta de acciones del Stia, se producen protestas de trabajadores frente al sindicato reclamando que se convoquen medidas colectivas.

La antigua alianza social de los sindicatos de Puerto Madryn con los congeladores se reditúa para la marcha del 30 de mayo a Capital Federal. La CAPIP fleta sesenta micros y moviliza una gran cantidad de sus trabajadores junto al Somu, el Supa, los Capitanes y Patrones de Pesca y el Stia. Se apoya, ahora sí explícitamente, el reclamo de los congeladores de un corredor exclusivo a cambio de la promesa de la flota española de que descargaría el pescado para que sea procesado en tierra en la ciudad de Puerto Madryn. Se plantea como disputa central la pelea con Mar del Plata por los cupos de pesca.

El 2001 es el año de mayor conflictividad en la rama luego del 2004 y 2005 (21 hechos en 2001, contra 25 en 2004 y 33 en 2005). Hay constantes conflictos por empresa a partir de atrasos salariales, despidos y suspensiones, pero siguen sin desarrollarse medidas generales. Sí es importante que reaparecen consignas de 
aumento salarial, que durante los años previos no habíamos casi relevado, aunque las demandas son en aquellas empresas que pagaban por debajo del promedio.

En un marco de agudización del conflicto social a nivel general, encontramos medidas muy contundentes entre los trabajadores pesqueros. Hay tomas de plantas, piquetes, toma de barcos, toma del Banco Nación (por el atraso en un pago salarial), quemas de cubiertas y movilizaciones. Pero, como decíamos, no se unifican medidas. Recién hacia fin de año el Stia desarrolla un corte de ruta en Puerto Madryn en el marco del paro nacional del 13 de diciembre. Esta huelga es el comienzo de la insurrección espontánea que tendría su punto culmine en las jornadas del 19 y 20 de diciembre.

Un nuevo cambio en la situación de los trabajadores de esta fracción obrera se produce tras la devaluación de la moneda nacional a principios del 2002. Un elemento que debemos destacar para los años anteriores es el amplio porcentaje de desocupación que hubo en forma permanente en el sector. Como la mayoría de los obreros del noreste del Chubut los trabajadores de la pesca provenían de distintas corrientes migratorias de países limítrofes (centralmente de Chile) o de provincias del norte. Al quedar desocupados muchos migraron a sus ciudades de origen o hacia otras provincias. Este fue uno de los factores que llevó a que se descomprimiera el conflicto en el sector. Por otro lado debemos destacar que los desocupados de la pesca tuvieron un activo papel en la conformación de los grupos piqueteros, tanto en Trelew como en Puerto Madryn.

Con la devaluación del peso a principios del 2002 las empresas logran grandes ganancias, especialmente en la región por ser temporadas muy ricas en langostino. La mayoría de los trabajadores desocupados que se habían desempeñado en esta actividad vuelven a trabajar en distintas pesqueras. Pero en general pasan a hacerlo de forma muy inestable, con peores condiciones de trabajo que antes de la crisis, y salarios que ahora habían sufrido el golpe de la devaluación.

Por eso muchas de las protestas que se desarrollan en estos años serán con eje en las reivindicaciones de mejoras en las condiciones de trabajo, tanto salariales como de pase a planta permanente, blanqueo, seguridad e higiene, etc. Pese a esto el proceso de recomposición es muy lento para el personal de las plantas en tierra, que sigue sufriendo la escasez de merluza y por eso la precarización extrema de sus condiciones de trabajo. Durante el 2002 hay solamente cinco hechos relevados. Dos son conflictos por planta de escasa importancia y los otros tres se producen a fin del año, a partir de la huelga de los marineros de la flota amarilla de Rawson.

Esa huelga es, para nosotros, el primer hecho del nuevo ciclo. Hasta allí los trabajadores aún viven el disciplinamiento de años de desocupación y no logran 
generar hechos que les permitieran recuperar parte de lo perdido. Tras dos semanas de huelga total los marineros de la flota amarilla logran el pago a precio dólar y que se coloquen balanzas al pie de los barcos para recibir lo que les correspondía por la cantidad de kilogramos pescado.

Durante el 2003 relevamos doce hechos de protesta en el sector. Casi todos son generados por el personal de las plantas de procesamiento que siguen sin recibir merluza. Por eso deben sobrevivir con el pago de la garantía horaria. Aún peor estaba el personal que se desempeñaba bajo distintas modalidades de precarización. En general se repite lo que vimos en los primeros años de los noventa: cada fábrica luchando por su lado, y los contratados por una vía y los "estables" por otra.

Recién en septiembre aparece un rasgo nuevo que iba preparando el terreno hacia la gran huelga del 2005. En el marco de un plan de lucha del Stia exigiendo la firma del convenio laboral, se realizan piquetes en el parque industrial pesquero, una marcha hasta la sede de la CAPIP en Madryn y un piquete en la ruta que une Rawson con Playa Unión. La CAPIP presenta a la Subsecretaría de Trabajo el pedido de conciliación obligatoria. El Stia acepta la medida y levanta los piquetes tras un día y medio de permanencia.

La CAPIP sostiene que no puede otorgar aumentos salariales si no se habilita la presencia de congeladores al norte de Puerto Deseado y se sanciona la exención de IVA para la importación de repuestos. Por su parte el Stia denuncia que la falta de merluza se debe a que los barcos la tiran para cargar toda su bodega con langostinos. En la paritaria nacional se acuerda un aumento salarial que no fue recibido como un logro importante por los obreros.

El proceso general luego se encamina hacia las elecciones provinciales de noviembre, donde el PJ logra triunfar, cortando doce años de gobiernos radicales. El nuevo gobierno provincial asume el 10 de diciembre. Este cambio genera expectativa entre los trabajadores pesqueros que en su mayoría observan con simpatía al gobierno de Kirchner y su discurso de reivindicación de la Patagonia. Además se conocía su fuerte vinculación con algunas de las principales empresas pesqueras con inversiones en la región, por lo que se suponía que estas lograrían algunos privilegios que les permitirían generar nuevos puestos de trabajo.

En ese contexto las demandas del sector poco a poco comienzan a crecer. Ya para 2004 la movilización de los trabajadores de las plantas en tierra se hace permanente. Es muy claro que las empresas se recuperan y ganan millones, mientras cierran plantas y suspenden al personal porque no les interesa procesar la merluza ante las enormes ganancias que obtienen por la venta del langostino. Hasta junio hay distintos conflictos, con quemas de cubiertas, piquetes y paros parciales. Finalmente 
en ese mes el proceso de luchas se agudiza con la ocupación de la planta de Iberpesca en Rawson.

Trabajadores de esa y otras plantas marchan a la Legislatura provincial, sin el acompañamiento de la dirigencia gremial, en una medida que surge desde sectores que critican a la conducción sindical por la falta de convocatoria a formas de reclamo más contundentes. Queman cubiertas frente a la Legislatura y cuando los bomberos intentan apagarlas hay enfrentamientos, se rompen vidrios a piedrazos y quedan varios bomberos golpeados. Los trabajadores se dirigen luego al municipio de Rawson, donde también rompen los vidrios de la oficina del intendente y cuando deciden avanzar contra la Casa de Gobierno llega al lugar el dirigente del Stia, Luís Nuñez, quién les pide que no se realice dicha acción.

Tras algunas discusiones se acepta el pedido del dirigente gremial y los trabajadores se desconcentran y se dirigen a la sede del sindicato. Allí son atacados por los grupos especiales de la policía provincial una hora después, cuando se encontraban debatiendo en asamblea las siguientes medidas a tomar. El enfrentamiento culmina con nueve heridos por balazos de goma y cuatro detenidos. El dirigente del Stia se despega del conflicto diciendo que ellos no convocaron la marcha y que la culpa es del empresario que presiona a sus trabajadores. El gobernador Das Neves acusa de inacción a los Consejos Municipales de Pesca y de falta de responsabilidad a los empresarios.

El 17 de junio se convoca un acto desde la CGT y el Stia al cumplirse una semana del hecho. El gobierno realiza una fuerte campaña en contra, articulando la acusación de Das Neves de que la marcha era manejada por los empresarios de la pesca para presionar por más permisos y la amenaza de represión desde el ministro de gobierno y el ministro coordinador de gabinete, quienes afirman que había militantes de Quebracho y activistas pesqueros de Mar del Plata infiltrados para provocar disturbios.

Se realiza el acto junto a un paro general en el noreste de la provincia. Hasta el último día el gobierno realiza gestiones (el 16 hay una reunión con la dirigencia de la CGT) y muchos sindicatos se bajan del acto y de la huelga. La concentración (prevista inicialmente por los organizadores en unas cinco mil personas) no supera finalmente las mil. Para nosotros aquí es derrotada la intención de un sector del sindicalismo vinculado al PJ de tener una postura autónoma del gobierno ${ }^{238}$.

\footnotetext{
${ }^{238}$ Es necesario profundizar el estudio sobre las relaciones entre el movimiento obrero (especialmente el que se define como "peronista") y los gobiernos de ese signo político. Se debe romper con las visiones lineales que ven un vínculo inherente entre estos sectores, y por ello no observan las constantes contradicciones que se generan entre los dirigentes sindicales y los cuadros políticos, tensiones que no sólo parten de peleas por cargos o prebendas sino fundamentalmente por su posición y función en el
} 
En septiembre vuelve a plantearse el conflicto pesquero. Varias plantas amenazan con trasladarse a Santa Cruz de no asegurarse mayores cupos para Chubut. Según las autoridades locales el problema es que los cupos se dan para Buenos Aires y que desde el gobierno nacional se otorgan privilegios a las plantas en Santa Cruz.

Mientras día a día aumentan los despidos y suspensiones los empresarios llaman a los trabajadores a conformar un "frente común". Los sindicatos avalan esto no generando protestas mientras se negocia un aumento del cupo pesquero, que finalmente se consigue en noviembre. Allí surge un nuevo conflicto con los marineros de la flota amarilla, que reclaman un aumento del $38 \%$ y la inclusión de un seguro especial en caso de accidentes fatales.

Al cumplirse diez días de este conflicto que paraliza la pesca en Rawson, el Stia marcha reclamando su resolución, aunque sin expresar una solidaridad clara con los trabajadores en huelga. A los tres días se soluciona el paro con un aumento del $20 \%$ para la merluza y del $30 \%$ para los langostinos. Lamentablemente a los pocos días se demuestra trágicamente la justicia del reclamo: el 25 de noviembre se hunde el pesquero "Siempre Don Pablo", muriendo el capitán y dos marineros.

EI 2005 se destaca por la gran huelga pesquera que se desarrolla durante más de un mes, impactando en la región y en todo el país. Es una huelga con características muy importantes, que brinda elementos claves para nuestra investigación. Para nosotros el 2005 no se plantea como un año separado del ciclo 2002-2004, sino que justamente esta huelga demuestra que estamos ante un nuevo momento en la lucha de clases en la rama, una nueva fase que expresa la acumulación de fuerza que se venía realizando en esos años previos, tras la recuperación económica de la actividad.

A principio de año la Cámara de la flota amarilla expresa su rechazo a los cupos de merluza que se le habían otorgado, planteando que el acuerdo se había realizado a favor de Mar del Plata y sin reservar un cupo para los costeros de Patagonia. Se otorgaron 10.700 toneladas, pero esto era para toda la provincia, cuando siempre se daba un cupo especial para los costeros. Se denuncia que se trata de igual manera a barcos con un máximo de 2 mil cajones con los que pescan 7 u 8 mil. Das Neves apoya el reclamo, denunciando además que muchos barcos de Mar del Plata pescan en Chubut con el aval del gobierno nacional.

proceso objetivo de producción y reproducción del capitalismo. Especialmente relevantes en este sentido son las distintas investigaciones sobre las huelgas durante los primeros gobiernos peronistas, como los de Fabián Fernández, Gustavo Contreras, Omar Acha, Marcos Schiavi, etc. 
Pero esta vez los trabajadores no toman como eje de su actividad el reclamo de mayores cupos para los empresarios. Desde principio de año comienzan a desarrollar medidas que tienen como objetivo la pelea por aumento salarial y mejores condiciones de trabajo.

En enero se movilizan desocupados de la pesca al municipio de Trelew. Reclaman por puestos de trabajo, denunciando que algunas empresas están contratando trabajadores traídos de Mar del Plata. En particular se refieren a Naramar, que habría traído cuarenta y seis fileteros, envasadoras y peones.

Más contundente es el reclamo de los trabajadores de los buques de Alpesca, afiliados al SOMU, quiénes marchan frente a la Subsecretaria de Trabajo. Reclaman el pago de las vacaciones, los días de franco y la firma del Convenio Colectivo de Trabajo. Se realiza un escrache a la empresa, quemando cubiertas frente al acceso de la pesquera. Luego de la protesta se desarrolla una asamblea en la cual se decide continuar con el plan de lucha.

Al otro día Alpesca contesta con una solicitada de página entera en los diarios de la provincia. Plantean que no adeudan nada de lo solicitado y que el reclamo de aumento salarial es inviable en los porcentajes pedidos (alrededor de un 60\%). Denuncian que se está impidiendo el derecho a la libertad de trabajo para el personal en tierra, y reclaman que las autoridades aseguren la posibilidad de trabajar. Ese mismo día los marineros acentúan la fuerza del reclamo instalando carpas frente a la planta.

Se pone sobre la mesa la exigencia del pase a planta de los contratados, que se logra en algunas plantas de Puerto Madryn durante el mes de febrero. Los trabajadores de una contratista de mano de obra para las pesqueras queman cubiertas y cortan el tránsito en importantes avenidas de Puerto Madryn, reclamando contra la precarización laboral. El Stia denuncia que esto es parte normal del funcionamiento, con contratos en negro, cooperativas truchas, etc. La empresa es Sistemas Temporarios que contrata personal para distintas plantas, en especial para Poseidón. Se reclama que la empresa desaparezca y que el personal pase a planta en sus respectivas pesqueras. Tras mantener las medidas varios días se consigue un importante triunfo, logrando el pase a planta del personal.

También había conflicto en las pesqueras de Rawson por la no renovación de casi doscientos trabajadores en las plantas de Conarpesa, Argenova y Agropez. Se queman cubiertas frente a las plantas durante varios días y allí comienzan las discusiones sobre la necesidad de medidas más duras. El 3 de marzo se corta la ruta que conecta Rawson con Playa Unión. No hay alianzas con los empresarios del sector 
ni reclamos por sus ciudades en tanto "corporaciones económicas". Los reclamos son de clase, en tanto vendedores de fuerza de trabajo.

Durante todo el mes de marzo se siguen generando conflictos por planta. Pero sobre todo se va calentando el reclamo de un aumento salarial. El 16 de marzo el Stia realiza una asamblea de delegados en la cual se vota un plan de acción por el aumento al básico con más de cincuenta representantes de Rawson, Trelew y Puerto Madryn. Plantean que “...en los últimos catorce años desde 1991 las empresas del sector aumentaron su productividad, ocupando menos trabajadores y con menos horas trabajadas; aunque la productividad por trabajador y por hora trabajada aumentó en forma espectacular, como así también los ingresos corrientes de las empresas (que aumentaron sus ganancias y rentabilidad), mientras no pasó lo mismo con nuestros salarios $^{, 239}$.

Para el 23 de marzo todavía no empiezan acciones colectivas de los trabajadores de la pesca y continúan los conflictos parciales por planta. Ese día los trabajadores de Harengus realizan una jornada de protesta con retención de servicios y quema de cubiertas por las malas condiciones de trabajo y el no cumplimiento del Convenio Colectivo de Trabajo.

Tras casi un mes de continúas negociaciones con autoridades del gobierno y de las cámaras empresarias, finalmente el 13 de abril el Stia convoca una huelga por tiempo indeterminado en toda la provincia por la negativa de la CAPIP de negociar un aumento. Desde el inicio de la huelga hay una relación de tirantez entre los trabajadores de algunas plantas y la dirección sindical. La conducción busca dar unas semanas más a la posibilidad de negociar con la CAPIP, mientras los obreros de tres plantas se movilizan por su cuenta quemando cubiertas frente al sindicato para reclamar que se llame a la huelga.

El 14 se corta la ruta provincial № 1 en tres sectores distintos, como forma de impedir totalmente el funcionamiento de las principales pesqueras de Madryn y afectar la operatoria general del puerto El paro es total en la provincia, con gran fuerza en el reclamo de un aumento del $100 \%$ al básico. La CAPIP reclama a la Subsecretaria de Trabajo que declare ilegal el paro por impedir la libertad de trabajo. El 15 por la tarde se llama a reunión en la Subsecretaria, donde se movilizan los trabajadores que estaban en los piquetes.

Durante el sábado 16 se mantenía el corte también en la ruta de Rawson a Playa Unión, levantando la medida durante algunas horas por la negociación. En los cortes de Puerto Madryn se producen los primeros hechos de tensión al generarse un

${ }^{239}$ Comunicado de la asamblea de delegados del Stia, publicado en Diario Jornada del 17/3/2005, pág. 18. 
enfrentamiento con la policía que casi culmina con la quema de un patrullero. Los trabajadores descubren que a bordo de un patrullero que dejan pasar hacia las plantas iban dos fileteros que pretendían entrar a trabajar. Finalmente se soluciona el problema, debiendo la policía retirarse del lugar tras varias horas en que no se permitía la salida del patrullero y los oficiales.

La negociación no da resultados y el conflicto ya amenaza con extenderse en el tiempo. Das Neves se posiciona a favor del reclamo de los trabajadores, planteando que "En el sector de la pesca tienen que haber mejoras salariales" 240 . También el subsecretario de trabajo de la provincia, Jerónimo García, advierte que el empresariado debía estar “... a la altura de las circunstancias”241. La CAPIP plantea que su ofrecimiento no superaría el $29,8 \%$ y vuelve a denunciar el ataque a la libertad de trabajo, especialmente por el cierre obligado de la operatoria en el puerto.

El presidente de la CAPIP, Mario Ordiales, de origen español como la mayoría de las empresas del sector, califica a los trabajadores de "subversivos"242. Los trabajadores mantienen los piquetes y en una asamblea pública con más de quinientos obreros frente a la Subsecretaria de Trabajo, deciden ratificar las medidas y el paro por tiempo indeterminado. La CTA declara el estado de alerta y movilización en apoyo al reclamo del Stia.

El 19 se agudiza el proceso. A los piquetes del Stia se suman los estibadores portuarios afiliados al SUPA, extendiendo los cortes a la ruta de acceso norte a Puerto Madryn. Ya son cinco los cortes principales y se calculan en unos catorce piquetes en total. El dirigente del SUPA plantea su solidaridad con el reclamo del Stia y denuncia que el derecho a trabajar se los quita la CAPIP, por su negativa a compartir las ganancias. Los trabajadores iban ganando en fuerza moral, generando solidaridad de distintos sectores, mientras el empresariado queda aislado. Se supera así cierta debilidad inicial de la huelga al estar circunscripta a una región del país, mientras el resto de la rama pesquera continúa en actividad. Ya veremos que esta debilidad será clave para entender la resolución del conflicto.

Por la tarde el Subsecretario de Trabajo se dirige junto al intendente al corte principal, para notificar a los sindicalistas el llamado a conciliación obligatoria. Los trabajadores aceptan la reunión, trasladándose a las banquinas de la ruta. En la negociación la CAPIP acepta subir su oferta de 4,70 la hora a un "máximo" de \$6. El

\footnotetext{
240 Diario Jornada, 18/4/2005, pág. 4

241 Diario Jornada, 18/4/2005, pág. 17.

242 Es el propietario de Harengus, destacada por Pradas (2006, pág. 53) como la primera empresa que opera como "pulpo integrado", teniendo fresqueros y congeladores, diversidad de artes de pesca y de captura de especies, plantas en Madryn y Puerto San Julián, 5 barcos propios y otros 11 en joint ventures. Además de poseer, como decíamos, su propio medio de prensa.
} 
sindicato plantea que como mínimo acepta 7,80 , siendo su reclamo original $\$ 8,10$ por hora. La reunión se realiza en la sede del Concejo Deliberante.

Al otro día, tras el fracaso de la negociación, se vuelve a cortar la ruta № 1. La justicia ordena el desalojo y por la tarde del miércoles 20 más de cien efectivos de la guardia de infantería intiman a los trabajadores. Ante la negativa a levantar el corte se acerca al lugar el intendente de la ciudad quién negocia con el dirigente del Stia el levantamiento sobre una vía de la ruta, por lo cual el juez decide suspender la orden de desalojo.

El jueves 21 fracasa una nueva negociación entre las partes. Ordiales es insultado por los trabajadores que se movilizan al lugar, mientras se mantenían los cortes en el muelle y el corte parcial de la ruta № 1. La mayoría de los gremios de Puerto Madryn se convocan en el Concejo Deliberante y allí se comienza a plantear la posible convocatoria a un paro general en la ciudad para el viernes o el lunes. Se solidarizan con el Stia, el SUPA, SOMU, Focra (ceramistas), UPCN, SEyOM (municipales de Madryn), SEC, ATSA, Sitrajuch, ATE, Smata y el Sipolch (sindicato policial). También manifestó su apoyo la UOM y el MTD de Madryn. Por su parte la Cámara de Comercio de Madryn reclama urgentes soluciones a un conflicto que ya afecta la economía de toda la ciudad y la región. El gobierno vuelve a reclamar responsabilidad a los empresarios, y remarcan que no permitirán despidos masivos en el sector.

Se resuelve la convocatoria a huelga general y movilización para el lunes en la ciudad de Puerto Madryn, llamado en conjunto por la CGT y la CTA. En cambio en Comodoro Rivadavia se llega a un acuerdo en la huelga pesquera. Este es un momento clave de la huelga, un hito en la misma. Por un lado el conflicto en la región noreste de Chubut toma un carácter político. El conjunto de los obreros se posicionan de un lado frente al conjunto de la patronal. El reclamo se descorporativiza, tomando todos los obreros la lucha de un sector de la clase como propia.

Sin embargo al mismo tiempo la patronal actua rompiendo la unidad de los obreros de la pesca a nivel provincial. Los trabajadores de Comodoro firman el acuerdo (llevan la hora a 6,04), en una decisión avalada por los representantes del Stia de esa ciudad. Los empresarios más poderosos, con plantas en varios puertos, replantean su táctica, sabiendo que al restringir el conflicto a una región pueden estirarlo, buscando el agotamiento de la fuerza de los trabajadores.

El conflicto en la pesca involucra a unos seis mil trabajadores en toda la provincia, de ellos unos tres mil trabajan en Puerto Madryn, que es el principal parque pesquero de Chubut. La pesca había exportado más de 300 millones de dólares durante el 2003, exportándose unas 100.600 toneladas. Durante el fin de semana se 
mantienen los cortes en Puerto Madryn y Rawson, mientras en Comodoro se ratifica el acuerdo. Esto alimenta la campaña que Ordiales realiza desde el diario de su propiedad, planteando que la dureza de la medida tenía que ver con internas en el Stia. Sin dudas que esa interna existía, especialmente con la dirigencia de Comodoro Rivadavia que veía a Núñez como un defensor de la industria pesquera de Puerto Madryn, pero no era lo que motorizaba el conflicto.

Durante el fin de semana el frío y la lluvia habían complicado la continuidad de los cortes, pero finalmente estos se sostuvieron con una firme disciplina en base a los delegados de las respectivas plantas y el cumplimiento obligatorio de los turnos de ocho horas.

El lunes el paro no fue muy contundente, especialmente no se sintió en Aluar y en el Estado, pero sí la movilización, a la cual se sumaron más de cinco mil trabajadores. Allí la CGT y la CTA ratificaron su apoyo a la huelga y el reclamo a que el gobierno defina la problemática intimando a los empresarios. Núñez remarcó que se estaba ante la mayor movilización en décadas para Madryn, y que se trataba de una lucha contra "...los capitales extranjeros que han venido a instalarse en nuestro país, para llevárselo todo y dejarnos la miseria,243.

A partir de la huelga y la gran movilización el gobierno toma otra postura. Si bien no se desdice de su reclamo a que los empresarios aumenten los salarios, empieza a operar para derrotar la huelga. Es que la misma había superado los límites de lo aceptable, al unificar a la clase obrera en un reclamo común. Era un antecedente peligroso. En los discursos de los dirigentes sindicales quedaba claro que era el Estado el que podía destrabar el conflicto, si es que decidía intimar a los empresarios con quitarles los permisos de pesca. Es allí donde el conflicto toma carácter político.

Por la madrugada se intima el desalojo del corte de ruta provincial. El secretario gremial del Stia acepta levantar el corte y esto provoca una discusión que termina con la internación del dirigente por un puntazo de cuchillo. Los siguientes días son de constantes negociaciones. Se mantienen los piquetes a las plantas pero sin otras medidas. Aparentemente se profundizan las discusiones internas en la patronal, ya que varios de los empresarios pretenden llegar a un acuerdo mientras Ordiales endurece la posición de no aceptar los reclamos del Stia.

En Puerto Madryn se desarrolla también una fuerte huelga entre los ceramistas y unos días antes se realizan medidas en Aluar, en todos los casos por aumento salarial. Pero ahora el conflicto pesquero ha logrado ser aislado. Cada reclamo se da en el marco del sector profesional, sin trascender los límites de lo corporativo. Ese

${ }^{243}$ Diario Jornada, 26/4/2005, pág. 3. 
había sido el pedido del gobierno provincial a las direcciones sindicales cercanas tras la huelga general de Puerto Madryn.

Como muchas veces sucede en estos conflictos, la maniobra de la patronal fue intentar llevar la negociación a nivel nacional y realizarla directamente con la Federación de Trabajadores de la Industria de la Alimentación. Los dirigentes nacionales aceptan reunirse en Buenos Aires, cuando en ningún momento han viajado a la provincia en más de tres semanas de conflicto. Esto trajo duras críticas de los trabajadores, y hasta del dirigente sindical regional Luís Núñez, hacia la conducción nacional.

Pero ya era evidente que se comienza a perder fuerza moral. EI SUPA decide levantar la medida de fuerza ante el anuncio de una ayuda económica gestionada por el intendente de Puerto Madryn. Además se había acordado con el Stia que se les permitiera operar los buques poteros. Luego de haber frenado la posibilidad de que la lucha tomara un carácter general el gobierno ataca ahora las expresiones de solidaridad y divide a los trabajadores. La presión del gobierno para frenar el conflicto impacta en los dirigentes sindicales, la mayoría de ellos de militancia en el PJ. Núñez declara que el STIA acepta ahora bajar su reclamo hasta los $\$ 7$ por hora, pero que no pueden tomar nada por debajo de esa cifra.

La falta de dinero empieza a hacer mella en la lucha. Mientras el Stia solicita donaciones, los obreros de lberpesca (Rawson) toman las instalaciones y abren las cámaras frigoríficas amenazando con vender la mercadería. Se discute la necesidad de medidas contundentes para torcer el rumbo de la huelga. Los trabajadores pesqueros marchan por las calles de Puerto Madryn, realizando escraches a las casas de los empresarios pesqueros y al diario de Ordiales. Pero la huelga ya va quedando aislada, y progresivamente se le quita contundencia.

La dirigencia del Stia decide impulsar una marcha desde Madryn hasta Rawson, para llevar un petitorio a Das Neves. Son más de $80 \mathrm{~km}$ que se harían en su mayor tramo a pie por la ruta №3. Si bien la dirigencia del Stia lo reivindica como un hecho histórico y lo denomina "Marcha de la Dignidad", para otros se trata de una forma de descomprimir el conflicto en Puerto Madryn. De hecho al comenzar la marcha se levantan todos los piquetes.

Son unos cuatrocientos trabajadores los que emprenden el largo camino. Arrancan a las 9.40 desde Madryn y llegan a Trelew alrededor de las 23 horas. Durante el día el tránsito sobre la ruta no fue cortado totalmente pero sí tuvo dificultades. En Trelew duermen en sedes sindicales y al otro día se dirigen hasta Rawson. Los recibe el gobernador Das Neves, quién anuncia un fondo anticrisis para la pesca, el aumento de un $50 \%$ en el valor de los permisos y ayuda social para los 
trabajadores más necesitados. Pero otra vez nada se dice de la posible presión a los empresarios que no aceptan el acuerdo. Hay críticas pero ninguna medida concreta. La CAPIP nuevamente solicita tratar el tema a nivel nacional, a lo cual se oponen el Stia y el gobierno de Chubut. El petitorio del Stia reclama a Das Neves:

"Que se reglamente el artículo 27 de la Ley Federal de Pesca, de cupificación.

La materia prima del producido de la pesca, cualquiera sea la especie, se reprocese en plantas de nuestro litoral marítimo, como solución a los graves problemas sociales que la desocupación genera, con el fin de realizar un mejor aprovechamiento de nuestro recurso y obtener un mayor valor agregado del mismo.

Solicite la revisión de los permisos de pesca nacionales y de la legislación pesquera en general a fin de modificar la realidad adversa a los intereses de nuestro país y sus trabajadores.

Le solicitamos además proponga en el ámbito provincial: a) La sanción de una ley provincial que contemple los intereses de todas las partes. b) La creación de un fondo social para los trabajadores desocupados de la actividad"

Al finalizar la reunión Núñez declara que no sabe cuales serían las siguientes medidas. Otra vez no hay soluciones y la larga marcha parece haber estirado otros dos días el conflicto y cansado a los trabajadores que han hecho ese gran esfuerzo sin resultados concretos. Los días siguientes casi no hay novedades. La huelga sigue, pero sin iniciativas de parte de los trabajadores. El proceso ya ha ingresado en una fase de caída: días después el Stia acepta la vuelta al trabajo del personal administrativo de las plantas, algo reclamado por la Cámara de Comercio de Puerto Madryn.

Recién el 13 vuelven a marchar casi mil trabajadores de la pesca por las calles del centro de Madryn. Nuevamente se hace sentir un fuerte apoyo de los habitantes de la ciudad, con saludos desde las casas y bocinas de los autos. Días después se produce una marcha de las mujeres y los niños, buscando mostrar la difícil situación que atraviesan las familias obreras tras más de un mes de huelga.

El 18 se acelera la resolución. La CAPIP eleva una propuesta al Stia. Se realiza una asamblea con más de mil quinientos trabajadores en el gimnasio municipal, donde la oferta es rechazada. Se ratifica el paro, se decide la toma del Concejo Deliberante y se reclama que el gobierno vuelva a hacerse presente en el conflicto. Según la dirigencia del Stia la propuesta era peor que la presentada en Comodoro Rivadavia y se intenta confundir sumando aumentos no remunerativos. Allí algunos diarios que 
venían cubriendo el conflicto a favor del Stia comienzan a cuestionar su supuesta intransigencia y hablan de "la pérdida de poder" de Núñez ${ }^{244}$.

La toma del Concejo Deliberante se da con algunos sucesos de violencia. Se ocupan las instalaciones y se prende una fogata en la puerta. El gobierno pasa decididamente a atacar la huelga, anunciando que iba a garantizar con la fuerza pública la vuelta al trabajo de los obreros que así lo decidieran. Se asegura que la contrapropuesta del Stia es inviable y que al cumplirse treinta y siete días se había acabado el tiempo de negociar.

El "Diario Jornada" habla de un Núñez "acorralado" en la interna del Stia. El mayor reclamo es que, para el gobierno y la patronal, el dirigente había perdido el control del conflicto. Según ese diario un empresario cuestionó que: "Si no puede controlar una asamblea no puede garantizar un acuerdo,245. Los funcionarios hablan de un "estado de asamblea permanente" y lanzan el rumor de una posible renuncia de Núñez. El 19 por la tarde se ordena el desalojo del Concejo Deliberante, pero el gremio decide retirarse sin llegar al enfrentamiento, decisión que otra vez es criticada por un sector de los trabajadores.

Finalmente el 20 de mayo se llega a un acuerdo y se levanta la huelga. Una asamblea muy reducida había dado mandato a la dirección del Stia para, ahora sí, aceptar la propuesta empresarial ${ }^{246}$. Las presiones sobre el sindicato habían surtido efecto y se termina aceptando 6,50 la hora (antes del conflicto era de 3,40). El salario asegurado pasa a 1014 el mínimo y entre los fileteros se pasa de 0,30 a 0,42 por kilo. Pero más allá de los aumentos, lo que demuestra que se esta ante un golpe al sindicato es la negativa a pagar los treinta y ocho días de huelga y el habilitar convenios por empresa.

Siguen algunos conflictos aislados por planta en la continuidad del año. Se realizan especialmente ante la negativa de algunas patronales de pagar los salarios acordados tras la huelga. Los mayores conflictos se siguen dando entre los trabajadores de Rawson, que ya aparecieron como el sector más decidido a tomar medidas contundentes durante la huelga.

El 8 de junio se toma la pesquera Nedar de Madryn reclamando la falta de pago del garantizado mensual. En julio se agrava el conflicto en Iberpesca de Rawson.

\footnotetext{
244 En especial el Diario Jornada, ahora vinculado directamente al gobierno provincial luego de su adquisición en el 2004 por parte del empresario Jorge Aidar Bestene, por entonces apoderado provincial del PJ.

${ }_{245}$ Diario Jornada, 20/5/2005, pág. 16.

${ }^{246}$ El peso del desgaste en la decisión queda claro en este comentario del Diario "El Chubut": "Ayer no hicieron falta votaciones secretas, el cansancio, el hambre y la impotencia de la gente volcaron la balanza en favor de lograr un acuerdo y volver al trabajo. La inquietud por volver a las plantas se oía hace más de una semana, pero muy por lo bajo, de manera solapada eran los propios trabajadores quienes reconocían que la situación no daba para más.”21/5/2005, pág. 5.
} 
El 15 se ocupa la planta y se marcha a la Subsecretaria de Trabajo, reclamando por la falta de pago de varios ítems del acuerdo. Se empieza a hablar nuevamente de la falta de recurso y de que esto podría complicarse el próximo año. Circula el rumor del próximo cierre de la planta Santa Bárbara, que tiene unos veinte trabajadores y que según sus empresarios no puede pagar los nuevos salarios. El conflicto en Iberpesca sigue durante algunos días con la toma de la planta y el escrache sobre las casas de los propietarios. Finalmente se paga lo adeudado, pero otra vez en agosto vuelven a tener problemas en el pago y retoman los escraches particulares.

Los últimos días del año se viven en el marco de constantes reclamos por un mayor cupo de captura de merluza para el año 2006. Según los empresarios, el gobierno y los sindicatos, un cupo de 11 mil toneladas es el mínimo necesario para sostener la continuidad de las plantas de procesamiento y la mano de obra, tanto embarcada como en tierra.

\subsection{Los trabajadores metalúrgicos}

Hablar de los trabajadores metalúrgicos en el noreste del Chubut es, necesariamente, referirse a la experiencia de los trabajadores de ALUAR. Además de esta gran empresa los metalúrgicos restantes se agrupan en pequeños talleres y en algunas empresas medianas asociadas y dependientes de ALUAR. Los trabajadores de los pequeños y medianos talleres no han desarrollado casi ningún tipo de conflicto social en los años trabajados y por eso este apartado se centra específicamente en los trabajadores de ALUAR.

Así como para pensar la historia de Trelew no puede obviarse la construcción, desarrollo y crisis del parque industrial textil, es más evidente todavía que no hay posibilidad de comprender el desarrollo y crecimiento de la ciudad de Puerto Madryn sin tener en cuenta la construcción y desarrollo de Aluar. A principios de los setenta se instala en la por entonces pequeña localidad de Puerto Madryn ${ }^{247}$, la empresa productora de aluminio primario ALUAR S.A. La empresa tiene características especiales para la región ya que se trata de una gran empresa de capital concentrado que establece una relación particular con el Estado, con la comunidad de la ciudad, y con los trabajadores.

Pese a las profundas transformaciones que sufre la sociedad de la región desde la imposición del proyecto del capital financiero, que abandona las políticas denominadas de "promoción industrial", ALUAR consigue mantener una relación

${ }^{247}$ Cuya población estaba prácticamente estancada desde la década de 1920, cuando había sido un importante puerto en lo que era la línea costera de puertos que abastecían el circuito de buques que atravesaban el estrecho de Magallanes, hasta esos años única forma de pasar del océano Atlántico al Pacífico y viceversa. 
privilegiada con el Estado nacional y provincial, a diferencia de las empresas textiles o de las plantas pesqueras en tierra, que dejan de recibir aportes importantes, siendo casi nulos los nacionales y muy escasos los provinciales.

Por ello intentaremos explicar las características de esta empresa y de las luchas que desarrollan los trabajadores. En 1971 (el mismo año en que se inaugura formalmente el parque industrial textil de Trelew) se adjudica el proyecto de una empresa productora de aluminio a instalarse en la localidad de Puerto Madryn a ALUAR (Aluminio Argentino S.A.). La instalación y adjudicación a una empresa privada del proyecto de ALUAR genera grandes polémicas, acusaciones de corrupción y denuncias acerca de los efectos contaminantes que la instalación de una tecnología poco segura traería para la región.

Este proyecto se impulsa en el marco de la misma política nacional que apoya el desarrollo de los planes de promoción industrial y está aún más claramente vinculado a la política de seguridad nacional que defiende el gobierno de la dictadura autodenominada "Revolución Argentina". Es evidente que el de ALUAR es un proyecto nacido en la Fuerza Área Argentina que apoya como política de Estado la instalación de la planta productora de aluminio primario, pese a las polémicas y discusiones.

En el marco de ese proyecto general ALUAR, como decíamos, se presenta como un caso especial. Esta empresa es la única planta industrial proveniente de los proyectos nacidos en el marco del modelo de polos de desarrollo para la región, que continúa creciendo. Su situación monopólica en Argentina como productora de aluminio primario ${ }^{248}$ le permite ser formadora de precios en el sector y, a partir de esa condición, sostiene una relación privilegiada con el Estado.

Para su instalación se realiza una enorme inversión estatal que se transfiere de hecho a los empresarios propietarios de la planta. La empresa recibe exención total del impuesto a las ganancias durante los primeros cuatro años y pagos reducidos hasta el décimo; exención por un decenio del impuesto de sellos; exenciones en IVA y capitales; franquicias para la importación de equipos y arancel cero para importar materias primas e insumos.

Se construye la central de Futaleufú, el sistema de transmisión transpatagónico para proveerle energía eléctrica y un puerto de aguas profundas. Según datos de

248 Citamos en extenso la descripción de Pérez Artica (2009): "Sus actividades abarcan desde la obtención de aluminio en estado líquido hasta la fabricación de productos elaborados que se utilizan en distintas industrias. Su integración vertical se prolonga asimismo aguas arriba, mediante la producción y transporte de energía eléctrica, y la producción de ánodos (...)Más concretamente, sus principales divisiones son: (a) división primario: donde se obtiene el aluminio líquido y su solidificación en la planta de fundición bajo las distintas formas primarias o de aleación (lingotes, barrotes, bobinas, placas, etc), este constituye el principal negocio de la firma y su producción está destinada principalmente a la exportación; (b) división semielaborados: en la cual se producen lingotes aleados, alambrón, zincalúm y chapa hunter; y (c) la división elaborados: que fabrica perfiles para construcción, tubos, barras, chapas, rollos y papel aluminio" (pág. 113) 
Caprano, López y Palacios (2004) las inversiones del Estado representan el 85\% del total, siendo solamente el 15\% restante inversión formalmente privada.

Es importante considerar que el principal insumo para fabricar aluminio es la energía, tanto que la fábrica de Puerto Madryn en la actualidad consume más kilovatios que todo Rosario o Córdoba. ALUAR está desarrollando un proyecto para expandir su producción en ciento cincuenta mil toneladas anuales y para ello necesita asegurar fuentes de energía confiables y baratas. Futaleufú, la central hidroeléctrica que el Estado construyó en los setenta para abastecer a ALUAR y que hoy, tras su privatización, es de la propia empresa, no puede aumentar su generación. En definitiva la energía adicional necesaria para el proyecto fue provista nuevamente por el Estado a través del interconectado eléctrico que unió a Puerto Madryn con la estación transformadora de Choele Choel ${ }^{249}$.

El debate acerca de la tan sostenida "desindustrialización" que habría sufrido la economía argentina en los últimos treinta años no se condice con el desarrollo de la industria de capital más concentrado que encontramos en nuestra región. Las medidas del Estado nacional, como las privatizaciones y los nuevos programas de promoción industrial, apuntalaron el proceso de centralización económica y consolidación del régimen de gran industria. ALUAR es un ejemplo claro de esta dinámica. Así lo sostiene Daniel Azpiazu: "Otro interesante ejemplo, en este caso de integración vertical plena, lo brinda el grupo Aluar que controla la Hidroeléctrica Futaleufú S.A. (59\%) -de donde proviene el principal insumo energético de la planta productora de aluminio propiedad de este grupo económico, emplazada en la ciudad de Puerto Madryn-, y comparte con Camuzzi Argentina S.A. (40\% cada uno) el control de Transpa S.A. (Transportadora Patagónica), responsable de la transmisión de energía eléctrica en la región" (Azpiazu, 2003: 159) ${ }^{250}$.

En 1993-1994 se resuelve el único momento en que la planta atraviesa una crisis económica, relacionada especialmente con la liberación de los stocks de aluminio de los países de la ex Unión Soviética. Esto hizo caer el precio del aluminio a nivel mundial y genera un desfasaje en las cuentas de la empresa. Es en verdad una

\footnotetext{
${ }^{249}$ Además de recibir enormes subsidios en rebajas impositivas: "Desde que el proyecto comienza a ser mencionado en las memorias, la compañía inició un reclamo para reducir los plazos de recupero de los créditos fiscales del IVA, y conseguir un recorte en los costos financieros asociados. En febrero de 2005, con la aprobación de beneficios fiscales por un monto de 690 millones de pesos: 279 millones bajo la forma de devolución anticipada de IVA, y el resto a través de la amortización acelerada para el cómputo del impuesto a las ganancias." (Pérez Artica, 2009: 116)

250 Junto a Eduardo Basualdo inscriben esta dinámica en un marco más general, donde también son ejemplos de esta integración vertical y horizontal grandes empresas industriales como las de Techint y Acindar: “... los conglomerados empresarios que adquirieron u obtuvieron la concesión de empresas 0 servicios públicos para lograr, directa o indirectamente, un mayor grado de integración vertical y/u horizontal de sus actividades, al ingresar a mercados desde los cuales se proveen de un insumo clave"aguas arriba" y/o "aguas abajo"- para sus principales producciones"(Azpiazu y Basualdo, 2004: 87).
} 
situación coyuntural, pero que la empresa aprovecha para realizar el proceso de reformas estructurales que necesitaba. La crisis es eficazmente resuelta mediante el despido de gran parte de sus obreros y la intensificación de la explotación laboral sobre el personal ocupado a través de la llamada "flexibilización" y las reformas en los métodos de producción. Este proceso de cambio coincide con el traspaso de la propiedad de la planta a la familia Madanes Quintanilla, quiénes modificarán aspectos claves del modelo de gestión.

La intensificación en la explotación de los trabajadores quedó evidenciada cuando en junio del 2007 murieron al menos diez obreros por trabajar sin las condiciones de seguridad necesarias. Mientras tanto la empresa consigue los mayores porcentajes de ganancias de su historia, exportando a precio euro más del $75 \%$ de su producción total y pagando la totalidad de los salarios con el $0,9 \%$ del valor neto de su producción, el equivalente al dinero que recibe por la reutilización de la escoria de metal que hasta hace unos años era clasificado como desperdicio.

Sabemos que cada uno de los apartados que venimos desarrollando en este capítulo tienen aspectos que deberían ser profundizados. De hecho esperamos que nuestro trabajo abra algunas puertas para pensar investigaciones específicas sobre la historia de las distintas fracciones obreras del Chubut. En torno a las fuentes, y buscando evitar ser demasiado repetitivos, se utilizan en los distintos apartados las mismas que fueron destacadas en la parte metodológica y nombradas en el apartado de los trabajadores pesqueros. En este caso decidimos citar más extensamente las entrevistas a algunos trabajadores de Aluar.

Es importante considerar que en este apartado nos centramos en los trabajadores de una sola empresa, que además se caracteriza por haber desarrollado escasos conflictos sociales a lo largo de su historia. Por esta razón decidimos desarrollar en mayor medida los aportes de las fuentes orales, especialmente por los datos que nos brindan en torno a los procesos de trabajo y los cambios que allí se operan a lo largo de los años trabajados. Este aspecto no pudo ser trabajado en la misma medida en otros apartados donde las características productivas diferían en gran medida entre las distintas plantas y se habrían necesitado investigaciones específicas para estudiar esa diversidad de características.

Las entrevistas fueron una fuente privilegiada de información, especialmente para conocer los conflictos internos alrededor de los programas de flexibilización laboral y los cambios en la organización del trabajo. Veremos que en torno a estos procesos se articulan algunos ejes de conflicto, para observar los cuáles tenemos una absoluta carencia de otras fuentes, ya que no aparecen en los medios de prensa, ni en archivos de la Subsecretaría de Trabajo. El control que ejerce Aluar sobre la 
información interna de la fábrica es muy poderoso. Además en varios casos los testimonios sintetizan y transmiten la información de una forma que no hubiéramos podido mejorar.

Como lo planteábamos en el caso de la actividad pesquera, también en relación a la historia de los trabajadores metalúrgicos hay un gran vacío historiográfico en la región. Solamente encontramos buenos trabajos acerca de la estructura económica de Aluar, especialmente centrados en su período de instalación ${ }^{251}$. Luego la "historia tradicional" del sentido común regional, construyó un relato que hace hincapié en la aparente falta de conflictos relevantes, en una empresa "humanitaria,252 que habría privilegiado siempre el diálogo y el consenso. Quizás por eso la historia de esos trabajadores fue prácticamente ignorada por los investigadores, replanteando una mirada (más común de lo debido entre los historiadores del movimiento obrero), que no observa cómo objetos de estudio de enorme relevancia a aquellos colectivos obreros que parecen caracterizarse por una aparente "ausencia de conflictos"253.

Ante esta carencia recurrimos a la interesante producción de distintos investigadores acerca de las grandes empresas metalúrgicas del norte de la provincia de Buenos Aires y sur de Santa Fe. Especialmente distintos trabajos publicados en la revista Historia Regional, centrados en investigar los procesos sociales en Villa Constitución y San Nicolás, nos aportaron elementos para pensar la problemática de los trabajadores de ALUAR ${ }^{254}$.

\footnotetext{
251 Específicamente resaltamos el trabajo ya citado de Caprano, R., Lopez, L., Palacios, D., (2004) “ALUAR ¿Privado o Estatal?”, Avance de Tesis de Licenciatura, Depto de Historia, UNP, Sede Trelew; que lamentablemente no ha sido editado en forma completa ni ha completado el trayecto académico para convertirse en un trabajo de tesis final. Al igual que en el caso de la pesca citamos aquí los trabajos de Ibarra, Horacio y Hernández, Carlos (2005) "Estado, Economía y Sociedad. Trelew y su hinterland: 19891999" y el de Beinstein, Jorge (1993) "Dinámica global de la economía patagónica”, op.cit.; donde, al realizar una mirada de síntesis del proceso histórico en la región, se encuentran elementos que aportan a la comprensión. También hay algunos datos en Gatica, Mónica; López, Susana; Monedero, María Laura; Pérez Álvarez, Gonzalo (2005) "Patagonia desarrollo y neoliberalismo", op. cit..

252 Como la denomina Victoriano Salazar, intendente de Puerto Madryn durante el conflicto de 1994. Diario Jornada, 19 de enero de 1994, pág. 15: "Aluar es una empresa humanitaria, ha dado muestras muy evidente en nuestra zona y en el resto del país $y$, por el alcance que tiene, es una empresa muy humanista".

${ }^{253}$ En una línea de debate semejante Julia Soul (2009) destaca como un desafío su interés de estudiar la historia de los trabajadores de Somisa: "El desafío fue enfrentarnos a un objeto de análisis que expresa bajos niveles de conflictividad abierta $o$ de radicalización y que, sin embargo es una de las concentraciones obreras más importantes del cordón Zárate - Puerto San Martín" (pág. 1). Esto no significa que revisemos nuestra perspectiva de que la centralidad del análisis sobre los conflictos debe buscarse en los momentos de enfrentamiento social, donde los diversos sujetos sociales participan y buscan incidir activamente, poniéndose casi toda la sociedad en acción y movimiento. Sino que este hincapié no puede llevarnos a no mirar a los que, aparentemente, no participan en esos momentos de enfrentamiento social. Entender los porqués de ese tipo de acción (que para la mirada vulgar aparece como pasividad absoluta) es un aporte de indudable importancia para una historia renovadora del movimiento obrero. También es central investigar las prácticas de las dirigencias sindicales supuestamente negociadoras o institucionales. En el mismo trabajo Soul nos indica que "...nos interesa indagar particularmente cómo las dinámicas sindicales institucionales se sustentan en estrategias gremiales que no dejan de construir representatividad respecto de las bases"(Soul, 2009: 2)

254 Sumando también algunos trabajos presentados en congresos, destacamos entre otros a: Soul, Julia (2009) "Cotidianeidad laboral y estrategias sindicales. Reflexiones en torno al caso SOMISA", en Actas XII
} 
Otro artículo importante es el de Rodrigo Pérez Artica $(2009)^{255}$, de quién ya hemos tomado algunos aportes. Allí compara los procesos económicos tras la salida de la convertibilidad en tres grandes empresas metalúrgicas: Acindar, ALUAR y Siderar.

En los ya citados trabajos de Julia Soul (2009, 2007) encontramos una interesante evaluación acerca de una experiencia con muchos rasgos de paralelismo con la que desarrollan los trabajadores de Aluar. La historia de Somisa, también aparentemente caracterizada por una relación donde prima el consenso por sobre la no subordinación, nos brinda elementos de interés para pensar esta historia. Soul destaca allí la necesidad de investigar no solamente a los obreros que luchan sino también a los que aparentemente no lo hacen. Para ello propone profundizar la investigación de las relaciones cotidianas, construyendo observables desde la categoría de "cotidianeidad laboral" que permitan comprender la “... producción y reproducción de relaciones de hegemonía/subalternidad"(Soul, 2007: 34).

En el trabajo de Correa (2006) se destaca especialmente la necesidad de pensar la política de la UOM ante la conflictividad social, su situación de "paradigma" del sindicalismo vandorista y el tipo de relación que entabla con las bases obreras y el empresariado. Lo desarrolla desde una perspectiva institucional y retomando la conceptualización desarrollada por Arturo Fernández en sus trabajos sobre sindicalismo. Para el autor es clave la relación de tensión y complementariedad que se da entre la dirección de la UOM y las seccionales poderosas, que suelen tensar los escasos grados de autonomía que una conducción muy centralizada buscaba reducir al mínimo posible. Ya veremos que en el caso de ALUAR también se produce un

Jornadas Interescuelas Departamentos de Historia, Bariloche, Universidad Nacional de Comahue, publicada en CD ISBN 978-987-604-153-9. Soul, Julia (2007) "Los unos y los otros. La fractura que persiste." Aproximación antropológica al proceso de privatización y reconversión productiva en la ex SOMISA, en Historia Regional № 25. ISP №3. Villa Constitución. Pág: 33 a 56. Simonassi Silvia (2007) "A trabajar y muzzarella" Prácticas y políticas de disciplinamiento laboral en la industria metalúrgica de Rosario 1974 - 1983, en Historia Regional № 25. ISP №3. Villa Constitución. Pág: 57 a 82 . Escobedo, Martín y Prospitti, Agustín (2006) "Estudio de las prácticas sindicales de los trabajadores petroquímicos y metalúrgicos en sur santafesino", en Historia Regional № 24. ISP №3. Villa Constitución. Pág: 47 a 64. Correa, Mauricio (2006) "El fracaso de la concepción sindical vandorista de la UOM San Nicolás en el conflicto por la privatización de SOMISA", en Historia Regional № 24. ISP №3. Villa Constitución. Pág: 65 a 86. Cangiano, María Cecilia (2006) "Revisión del pasado y construcción del presente. Los obreros metalúrgicos de Villa Constitución y el menemismo, 1989-1992”, en Historia Regional № 24. ISP №3. Villa Constitución. Pág: 175 a 195. No citamos aquí los trabajos centrados en los acontecimientos de Villa Constitución en 1975, por tratarse de otro ciclo de la lucha de la clase obrera y porque abordan otro tipo de debates.

255 Pérez Artica, Rodrigo (2009) "Un enfoque micro del ciclo Posconvertibilidad. Los casos de Acindar, Aluar y Siderar”, en Realidad Económica № 246, Revista del IADE, Bs. As. Pág. 105-126. El autor justifica así la elección de estas tres empresas: "(i) el predominio ejercido por las firmas en los negocios siderúrgico (Siderar y Acindar) y aluminio (Aluar); (ii) el notorio protagonismo cobrado por ambas ramas en la fase abierta desde 2002, factor que se explica, a su vez, por: (a) el inusual incremento de su demanda mundial y términos del intercambio en el período, y (b) el dinamismo que adquirió su demanda doméstica, asociada directamente con la reactivación de la construcción, la industria automotriz, las ramas sustitutivas, y más tardíamente, la inversión industrial." (pág. 106). 
intento de conducción alternativa al de la dirigencia nacional, aunque en este caso esta experiencia no logra resultados favorables a mediano plazo. No consiguen, por ejemplo, generar espacios de autonomía financiera y/u organizativa, como sí logran hacerlo, al menos durante algún período, las seccionales de Villa Constitución y San Nicolás.

Otro rasgo de similitud con la historia de Somisa reside en que el proceso de trabajo necesario para la producción de aluminio no estaba regulado legalmente, como tampoco lo había estado la producción siderúrgica. Por eso también surge, al inicio de la puesta en marcha de la fábrica, la iniciativa de conformar un sindicato por empresa, en un proceso que aún no hemos podido trabajar en mayor profundidad. Experiencias similares, aunque aparentemente con mayor grado de conflictividad, registra Soul (2009) en Somisa, tanto en la década del sesenta como en la del setenta ${ }^{256}$.

Escobedo y Prospitti (2006) desarrollan una interesante comparación entre las experiencias organizativas de los trabajadores petroquímicos y metalúrgicos del sur santafesino. En ese marco prestan especial atención a la conformación de esos grupos obreros en tanto colectivos laborales. Siguiendo trabajos pioneros de Juan Carlos Torre, ellos indican que: "El objetivo de las filiales de las compañías multinacionales fue desde el comienzo, sostiene Torre ${ }^{257}$, "La creación rápida de una fuerza de trabajo en consonancia con las demandas de los nuevos sectores industriales en desarrollo, para ello, procuraron sustraerse a las condiciones generales del mercado de trabajo nacional ofreciendo, mediante la concertación de convenios por empresa, salarios más altos y mayores beneficios sociales". La mano de obra empleada combinaba juventud, ausencia de tradición sindical, altos ingresos y estabilidad en el trabajo." (Escobedo y Prospitti, 2006: 55)

También ALUAR ejecuta un programa similar. La empresa selecciona la mayoría de su personal originario entre trabajadores rurales, a los cuales les asegura la vivienda, la escuela para sus hijos, la mudanza hasta Puerto Madryn y un trabajo que por ese entonces era muy bien remunerado. Así buscan asegurarse la "fidelidad" de este personal, que además no traía experiencias significativas sobre organización gremial o política. Sería muy interesante trabajar sobre las historias de vida de estos obreros, que pasan de vivir en el campo a desempeñarse en una industria de alta tecnología.

\footnotetext{
256 "Una característica de la UOM era que en tanto organización sindical diluía la especificidad propia de las tareas siderúrgicas, al ser representativa de los metalúrgicos en general. Esta no es meramente una cuestión nominal. Hasta el año 1975, con la incorporación del capítulo 21 al Convenio Colectivo № 260/75 de la UOM; no se habían establecido las categorías específicas de la rama; ni se contemplaban las condiciones de trabajo propias de una planta siderúrgica integrada. En 1965 tuvo lugar la creación de SOESA (Sindicato de Obreros y Empleados de Siderurgia Argentina), organización sindical que separaría a los somiseros de la UOM." (Soul, 2009: 12).

257 Torre, Juan Carlos (1983) "Los sindicatos en el gobierno 1973-1976", CEAL, Bs. As.
} 
Así nos lo comenta uno de nuestros entrevistados, Fernando ${ }^{258}$ :

"ALUAR se caracterizó siempre desde el principio por traer gente de campo. En el setenta y pico, cuando empieza, no va a buscar en Buenos Aires obreros capacitados ni nada, sino que va a buscar gente a las provincias, La Pampa, Mendoza, gente que no tenía historia sindical. Ahora no sé si les daría el mismo resultado, pero en esa época el trabajo de las cubas, por ejemplo, era muy artesanal, entonces era todo trabajo de fuerza."

Ese trabajo casi artesanal, donde la fuerza física del trabajador jugaba un papel central en el proceso productivo, es clave en la etapa inicial de la empresa y va siendo reemplazado con la maquinización progresiva. Otro de los entrevistados, Héctor, es un ejemplo de esto, ya que trabajaba en una especie de molino de carbón (con los cuáles luego se confeccionaban los ánodos para las cubas) que accionaba a través de su fuerza. Héctor nos cuenta parte de su experiencia:

“... al principio la mayoría de la gente, el operario común era casi toda gente de campo, la mayoría sin ninguna experiencia fabril. No así, por ejemplo, los que tenían su especialidad como electricista, mecánicos y cosas así, que ya venían con su experiencia en fábricas. Y ALUAR para mí, y esto siempre lo comentamos, lo que buscaba era precisamente un obrero sin experiencia en fábrica para poder amoldarlos a su manera, me parece a mí. Los que ya venían con una especialidad, con alguna experiencia ya eran por ahí más reacios, más de cabestrear como se dice. Después también nosotros fuimos amoldándonos a las circunstancias y fuimos aprendiendo lo que era negro y lo que era blanco por supuesto. $Y$ acá se formaron comisiones internas de delegados muy importantes, muy, como se dice en la jerga, muy pesadas."

Se buscaba entonces ese trabajador sin experiencia para poder controlarlo y garantizar su fidelidad. Pero de todas maneras poco a poco va creciendo la resistencia y a través de ella se va conformando una experiencia colectiva entre los trabajadores de ALUAR, personificada en esas comisiones internas que se empiezan a organizar durante la dictadura. De allí surgen los primeros procesos de lucha, aún en medio de la dictadura y con la amenaza constante de la represión. Nos cuenta Gerardo:

“... poco a poco se van conformando por la acción de compañeros que van integrando los cuerpos de delegados, distintas proposiciones, se empieza a cuestionar la conducción sindical. Y se empiezan a dar cosas que nunca habian pasado. Por ejemplo empezamos a distribuir la ley de paritarias entre los compañeros para que se empiece a discutir. Esto en el '79, en plena dictadura.

258 Sobre las características de los entrevistados e información sobre las entrevistas ver el apartado "2.1.a. Fuentes", de esta tesis. 
Ahí tuvimos un conflicto que se origina por el tema del cese de las horas extras. Nosotros nos negamos a hacer horas extras ${ }^{259}$ y pedimos incorporación de personal. Entonces nosotros vamos a un paro porque nos obligaban. $Y$ nos intiman en el Ministerio de Trabajo. En verdad no era un paro, nos negábamos nomás a hacer las horas y la empresa nos intima por usos y costumbres y otras cosas. $Y$ en eso baja uno de los directivos mayores, un hombre que había sido de Fate, y en esa reunión nos dice sutilmente "¿ustedes no saben que esta empresa la manejan las Fuerzas Armadas por intermedio de la Aeronáutica?".

Así intentaba la empresa enfrentar la organización de los trabajadores. Se invocaba el miedo a la desaparición forzada, las detenciones y torturas, a través de estas "sutiles" amenazas. Durante la dictadura no relevamos otros conflictos. Pero esa experiencia fue parte de la acumulación de fuerza que se expresó tras el regreso de los regímenes constitucionales. Del seno de esas comisiones internas surgió la iniciativa de conformar una lista alternativa a la de la conducción sindical que representaba la línea nacional de Lorenzo Miguel. Sigue el relato de Gerardo:

"Ya se estaba dando forma a una agrupación, a una lista que después va a elecciones, por una conducción pluralista del gremio. Nosotros no queríamos que al gremio lo maneje ningún partido político. Y se conforma una lista amplia pero por supuesto con candidatos peronistas a la cabeza, Carlos Rodríguez, después Giussi que era del Partido Socialista Auténtico, y varios de los nuestros, que éramos independientes, estábamos más abajo."

Estos trabajadores de ALUAR que conformaban un grupo heterogéneo, sin costumbres ni tradiciones en común, con poca o nula experiencia sindical y que en muchos casos eran la primera generación que vivía la traumática transición hacia la vida urbana, van, pese a todo, desarrollando una experiencia que les permite avanzar en conciencia y organización.

De todas maneras el modelo empresarial sigue siendo clave durante los años noventa para evitar los conflictos o para que estos no lleguen a medidas de fondo. Es un sistema de control del trabajo que claramente podemos definir como "paternalista" ${ }^{\text {260 }}$, donde la empresa se presenta como protectora del trabajador y como

\footnotetext{
${ }^{259}$ El negarse a realizar horas extras también es la forma central de protesta que tenemos relevada en los primeros años de la dictadura en el parque textil de Trelew. Era un mecanismo legal que no implicaba trascender normativas fijadas, aunque sí vulneraba "usos y costumbres" de la producción. Tenía un especial peso en esos años, en el contexto de una región en crecimiento, con pleno empleo y demanda constante de nuevos trabajadores.

${ }^{260}$ Ver, entre otros trabajos que desarrollan el uso de este concepto, el de Martínez, Susana (2003) "Yacimientos Carboníferos Fiscales y el paternalismo como estrategia empresarial", en Actas IX Jornadas Interescuelas U.N.Córdoba, en CD.
} 
articuladora de todos los ámbitos de su vida: desde el trabajo, a la escuela de los hijos, la vivienda, los clubes de deportes, la asistencia en salud, etc ${ }^{261}$.

Pero a su vez este paternalismo implica una amenaza permanente: la empresa supuestamente le da todo al trabajador, pero éste por eso le debe todo a la empresa. Se apunta a una profunda identificación del trabajador con la firma, cuyo desarrollo no debe ser perjudicado ya que se perjudicarían ellos mismos. Esto se hace aún más fuerte en ALUAR por la fundamental incidencia de la empresa en la vida económica, política y social de Puerto Madryn. Como nos cuentan en sus relatos varios de los entrevistados, enfrentarse con ALUAR significaba casi la obligación de tener que irse de la ciudad para poder conseguir otro trabajo.

La experiencia de ganar la conducción sindical de la seccional a mediados de la década de los ochenta no logró, quizás por algunos de estos elementos, quizás por la fuerza de la conducción nacional o por la falta de preparación de los que luchaban por otro modelo sindical, consolidarse como un proyecto alternativo, como conducción de una estrategia obrera distinta a la que representa la dirección sindical de la UOM. La estructura altamente centralizada de la UOM impedía el manejo de fondos propios y las iniciativas de búsqueda de mayor autonomía financiera y organizativa no consiguieron plasmarse en la realidad. Así lo sintetiza desde su mirada Gerardo:

“Después pasa la falta de experiencia nuestra y la capacidad de ellos. Tenían gente adentro de nuestra agrupación y empiezan a meter la discusión del PJ para dividir hacia adentro. Y sale Rodríguez a apoyar al candidato del PJ a intendente de Madryn y ahí se rompe porque salimos nosotros a decir que la UOM no apoya a nadie..."

En las siguientes elecciones sindicales este frente que había ganado la seccional va en dos listas distintas y eso posibilita la victoria de la lista que representaba la conducción nacional, dirigida por Vicente Jara. Como ya lo vimos muy brevemente, un proceso semejante se desarrolla durante esos años en la AOT de la región. Para nosotros, por sobre las cuestiones organizativas y formales, el límite mayor que encontraron estos intentos de construcción de un sindicalismo alternativo al dominante fue el nivel de conciencia que seguían expresando las bases, y del cual esas direcciones (aún las formalmente más combativas y democráticas) eran expresión. No se consiguió romper con los límites de la perspectiva corporativa de los

\footnotetext{
${ }^{261}$ En un modelo similar al de YPF y otras empresas del Estado, aunque ALUAR siempre fue formalmente privada. Si bien nuestra conceptualización hace eje en la característica de enclave de ALUAR (y por tanto tiene entre sus características la "creación" de ciudades a partir de una sola empresa o de proyectos financiados y orientados por el Estado), retomamos aquí también discusiones tradicionales sobre las relaciones entre estas grandes empresas y su colectivo de trabajadores. Entre otros se pueden citar aquí a Sierra Alvarez (1990); Moraes Morel (1989); Leite Lopes (1986); Neiburg (1988), Rosendo (1989). Sin profundizar el tema conceptualizamos a esta relación como "paternalista", marcando luego un quiebre en este modelo.
} 
reclamos, y eso hizo imposible articular un proyecto alternativo que diera sustento a otro tipo de estrategia. Ya intentaremos más adelante retomar estas reflexiones.

Desde 1989-1990 se consolida en Argentina la imposición del dominio hegemónico del capital financiero sobre la estructura económica social. Esta construcción de hegemonía social de un proyecto que favorecía al sector más concentrado de la gran burguesía fue realizada desde un gobierno que se definía como peronista. La identificación de gran parte de la clase obrera y la dirigencia sindical con el peronismo, y la confianza en que esa fuerza política representaba intereses populares, fue un elemento que también impactó en la conciencia de la clase obrera y en su capacidad para oponerse a esa hegemonía.

En los primeros años de los noventa los trabajadores de ALUAR no sufrieron de forma significativa el proceso de pauperización que atravesó a la mayoría del proletariado en el país. Si bien vivieron una cierta caída en su capacidad adquisitiva, al lado de lo que pasaba alrededor el trabajador de ALUAR se sentía protegido y hasta era visto como un "privilegiado". La empresa todavía adoptaba una estrategia paternalista que apuntaba a una identificación del interés del trabajador con el de la firma. Así por ejemplo nos cuenta Fernando las herramientas que desarrolló la empresa durante la hiperinflación:

“...en la época de Alfonsín, de la hiperinflación, ALUAR encontró un mecanismo de seguir esa inflación, todas las semanas tenías ajustes. Es más se llegó a cobrar la quincena en dos partes, por semana, cada siete días vos cobrabas para recuperar la inflación esa, que nunca llegabas porque se escapaba, pero dentro de todo ALUAR te dejaba conforme con eso"

En ese marco hay algunas medidas de fuerza, pero sin gran contundencia. Especialmente hay paros nacionales convocados por la UOM, como el 2 de julio de 1990, reclamando aumento salarial. Este conflicto sigue durante algunas semanas con medidas parciales, mientras se producen despidos masivos en Somisa sin que haya medidas nacionales del sindicato contra estos hechos. Hacia adentro de la fábrica este proceso nacional pasa sin ser conocido ni casi discutido. Así lo plantea Gerardo:

“... durante todo ese proceso estuvimos mirándonos el ombligo. Nos pasó por arriba todo eso, no fue motivo de discusión dentro de la planta ninguna cuestión de esas. (...) no nos daba el cuero para decir tenemos que hacer causa común con los obreros de YPF, porque ellos también estaban aislados en la lucha, no conseguimos hacer..., no lo conseguimos..."

Como le pasó a la mayoría de la clase obrera de Argentina “...en los noventa el tema de las privatizaciones nos llevó por delante". 
La empresa tiene la capacidad de funcionar como un ámbito aparentemente aislado de la sociedad, donde no ingresa el alto grado de conflictividad que se vive en la provincia durante 1990. Como ya lo vimos no hay allí articulación entre los reclamos de los sectores privados y estatales, y solamente algunos grupos de textiles se suman a las marchas. No hay discusión o debate entre los trabajadores de ALUAR sobre estos hechos y en las entrevistas el recuerdo pasa más por los elementos institucionales del conflicto, siendo más recordado como una interna del peronismo que por los elementos de protesta social.

Recién en octubre de 1991 los trabajadores de ALUAR se movilizan, reclamando el cumplimiento de un acta nacional en la cual se da un aumento por rentabilidad. Un delegado de planta afirma "respaldamos el plan económico y queremos respaldar la legislación vigente ${ }^{\prime 262}$. Si bien en el planteo político aparece expresado un apoyo al proyecto del capital financiero (y donde solamente se reclaman mejoras para los trabajadores si esto coincide con el proyecto global), puede también pensarse este discurso como una forma de legitimar un reclamo de aumento en condiciones de gran debilidad para los trabajadores. Lo que aparece como acompañamiento al proyecto que ataca sus intereses, puede ser pensado como un mecanismo de resistencia en el marco de una estrategia de reformismo burgués y de una ofensiva del capital más concentrado.

Así como ya citamos que varios autores destacan a 1991 como un momento de derrota para los trabajadores (tras el fracaso en sus objetivos de las huelgas de telefónicos y ferroviarios) y nosotros marcamos que hay una derrota en la región que se observa especialmente entre los textiles, Mauricio Correa (2006) marca la derrota obrera en Somisa en ese mes de octubre de 1991, aunque para él es específicamente la derrota de la estrategia vandorista. Los trabajadores de Somisa no logran imponer ninguno de los puntos inicialmente defendidos y sólo consiguen algunas mejoras en las indemnizaciones. A principios de diciembre de 1990 se había realizado un plebiscito convocado por la UOM, donde se aprobó la privatización por el 75\%, en una votación que planteaba como opciones la "oposición con movilización" o la "negociación con participación". Por la opción de la oposición militan los delegados y activistas del MAS y el PC, mientras la negociación era impulsada por la dirigencia sindical encabezada por Naldo Brunelli, en línea con el secretariado general de la UOM (Correa, 2006).

En 1992 la UOM convoca nuevos paros nacionales reclamando aumento salarial a fines de enero y en agosto. La seccional de Puerto Madryn adhiere al

${ }^{262}$ Diario Jornada, 2/10/91, declaración de integrante Comisión Interna de ALUAR, pág. 10. 
primero, pero no lo hace al segundo. Las medidas de lucha se restringen al ámbito de lo corporativo, buscando obtener un mayor precio por la venta de su fuerza de trabajo, pero sin impugnar ninguna de las medidas políticas que se realizan desde el gobierno nacional y provincial y sin articular respuestas ante los despidos masivos de obreros metalúrgicos en otras partes del país.

Esto es así en un marco donde en la región ya se hace evidente el profundo proceso de deterioro de la estructura económica y social y la pauperización que están sufriendo gran cantidad de trabajadores ${ }^{263}$. Junto a ello se profundiza la concentración y centralización de la propiedad en menos manos y la consolidación de una miseria y desocupación estructural como nunca antes había existido. Cierran los pequeños y medianos talleres metalúrgicos y aumentan a niveles muy importantes la desocupación y la subocupación.

En el marco de la convocatoria nacional que realiza la CGT para su primera huelga general contra el gobierno de Menem en noviembre de 1992, la CGT regional hace un llamado a los empresarios de la región para que se plieguen a la medida. Hay críticas a la flexibilización laboral, a la represión contra los jubilados y al constante cierre de industrias.

Casi todos los sindicatos de la zona adhieren al paro. Sin embargo la realidad en Aluar es que no se busca garantizar la participación de los obreros. No se genera en ellos una experiencia que pudiera armarlos de mejor manera para enfrentar las medidas que impulsa el dominio del capital financiero en contra de sus condiciones de vida. Así se vivía el paro nacional desde Fernando: "siempre el paro nacional se vivía como un paro nacional viste, se hacía paro pero no hacíamos nada. Yo me hacía el asadito en casa, el otro se iba a la playa. Por eso te digo que al tipo que estaba dentro de ALUAR le fue un poco transparente todo el proceso de los noventa."

Hacia fines de 1993 todo lo que parecía transparente se hará visible. La imagen de Aluar como un ámbito privilegiado, apartado de la incertidumbre y la caída general del nivel de vida de los trabajadores, empieza a ser abandonada. La ofensiva del capital se desata en forma directa, pero también aparece esa mayor resistencia que ya para ese momento se comienza a vislumbrar a nivel nacional.

\footnotetext{
263 Destacamos que durante ese año algunos dirigentes de la AOT hacen referencia a la dificultad de los desocupados para conseguir nuevos trabajos. También en otros lugares del país es un año donde se va tomando conciencia de los cambios estructurales y de los costos que estos implicaban para los trabajadores. Así Soul (2007) expresa que en San Nicolás “... durante el '92 comenzaban a percibirse los efectos de desocupación y precariedad laboral, protagonizados fundamentalmente por aquellos trabajadores que se habían retirado de la empresa y no lograban reinsertarse en el mercado laboral o habían fracasado como cuentapropistas. El 'miedo a perder el trabajo' se configura como un elemento fundante del disciplinamiento y la aceptación de las nuevas prácticas. Conceptualizamos el período previo a la privatización como el momento de coacción necesario para el establecimiento de un nuevo bloque histórico, remitiendo a los conceptos de Gramsci" (pág. 53).
} 
A pocos días de finalizar el mes de noviembre de 1993 ALUAR solicita a los empleados que acepten una rebaja de salarios y bonificaciones de alrededor del $25 \%$ que afectaría a la totalidad de los novecientos treinta trabajadores directos (seiscientos cincuenta operarios y personal de supervisión y dirección). La empresa argumenta que esta propuesta es la única posibilidad de resolución sin que haya despidos, por los problemas financieros que atraviesa debido a la baja mundial del precio del aluminio. Dicen que acumulan pérdidas por 114 millones de dólares durante los últimos cuatro años.

Como ya lo destacamos esta crisis en verdad es claramente coyuntural, provocada por la entrada al mercado mundial del stock de aluminio del este europeo tras la caída de la URSS. La empresa aprovecha la coyuntura para generar una profunda reconversión productiva, proceso que se relaciona también con el cambio de propietarios del capital accionario. Así lo recuerda Fernando, que por su cargo técnico tuvo más posibilidad de observar de cerca estos procesos:

“...la empresa tuvo una crisis grande económica (...) Y la compra la familia Madanes Quintanilla que la tiene ahora, antes era de Madanes y los hijos, después se la pasa a esta que es parienta de la anterior, pero ahí se arma la reforma. Antes la empresa trabajaba como una empresa estatal, invertía más plata. Ahora esta empresa ya no le da tanta bolilla a la inversión interna y ajusta más. Ahora para sacarle un mango a estos tenes que hacer medidas de fuerza muy fuertes."

Para nosotros lo que aquí se desarrolla es el quiebre de la antigua estrategia paternalista. En el marco del proceso general de cambio en el capitalismo, de la ofensiva del capital financiero y del cierre de su posibilidad de desarrollarse predominantemente en extensión, necesita ahora desarrollarse centralmente en profundidad. Para la empresa lo importante ya no es asegurarse mano de obra permanente y comprometida, sino conseguir el mayor nivel de explotación posible de la mano de obra ya ocupada. La desocupación estructural que se había generado garantiza la provisión de obreros dispuestos a vender su fuerza de trabajo por un precio menor a los que ya están ocupados y esta situación le permite a la empresa presionar con la rebaja salarial. Ya veíamos que en 1992 aparecía el temor a la desocupación estructural como un evidente factor de amenaza para los trabajadores. Pero al mismo tiempo esa evidencia constituía un avance en la toma de conciencia de la nueva situación ante la cual están los trabajadores como clase.

La UOM realiza una primera protesta frente a la planta, rechazando el ajuste. EI hecho dura media hora con unos ciento cincuenta participantes, ante los cuales el dirigente gremial de la seccional local (Vicente Jara) niega las versiones de que ya hay 
un acuerdo a nivel nacional de la UOM con ALUAR. Aparece como claro que este proceso se constituye en un caso testigo de un plan general para imponer la rebaja en todas las grandes industrias del país, y por ello rápidamente el conflicto toma importancia a nivel nacional. Se expresan en apoyo al descuento el ministro de economía Cavallo, el presidente de la UIA (Unión Industrial Argentina) y hasta la conductora televisiva Mirtha Legrand que, en uno de sus clásicos almuerzos televisivos, reclama un "gesto" a "los sindicalistas".

El 3 de diciembre se realiza una movilización de unos quinientos trabajadores de ALUAR que logra una importante repercusión social, siendo recibidos por el gobernador de la provincia y el intendente de la ciudad. El gobernador Carlos Maestro y Vicente Jara plantean una posición que corre el eje de la disputa contra la patronal, reclamando: "políticas diferenciales para la región que achiquen las diferencias de costos $^{264}$.

Se abre una larga pausa donde la UOM negocia ante la Subsecretaría de Trabajo sin realizar medidas de protesta. Es un período de tensa calma y fuertes discusiones internas, que recién se corta el 12 de enero, cuando los trabajadores informan que en la asamblea se resolvió rechazar el descuento salarial. Nos cuenta Héctor: "Hubo mucha discusión (...) porque había algunos que decíamos "preferimos que nos bajen el sueldo", y yo fui uno de ellos, y lo digo. Capaz que estuve equivocado, pero lo prefería antes que quede gente en la calle. Pero bueno tuvimos una reunión acá unos cuantos compañeros y acá decidimos lo que íbamos a decir. $Y$ por ahí varios nos tildaron de que nos bajábamos los pantalones y esas cosas."

La empresa anuncia el despido de veinticuatro trabajadores. Se convoca a una manifestación y al total quite de colaboración con la empresa para el día siguiente. El 19 de enero el número de despidos asciende a cuarenta y uno, y más de quinientos trabajadores se movilizan desde ALUAR hasta la plaza central de Puerto Madryn. Acompañan la marcha también las familias de los obreros. Asiste a la movilización el secretario de organización de la UOM nacional, Gregorio Minguito.

La medida tuvo cobertura y repercusión nacional. En ella hay fuertes críticas de los trabajadores a la dirección central de la CGT, entre ellos al líder de la UOM, Lorenzo Miguel, quién pocos días antes había salido en televisión jugando al golf con Carlos Menem ${ }^{265}$. Héctor recuerda que:

\footnotetext{
264 Diario Jornada, 4/12/1993, declaraciones de Carlos Maestro, pág. 8.

265 Es interesante, como aporte para comprender el posicionamiento de la UOM en este conflicto, el recorrido que realiza Correa acerca de la relación de la dirección nacional de la UOM con el gobierno de Menem. Muy resumidamente lo citamos: "En un primer momento, se lanza a una actitud dura, en alianza con la CGT de Ubaldini, creyendo que de esta manera podría, junto al líder cervecero, condicionar las reformas impulsadas por el gobierno, y obligar a Menem a no apartarse de los lineamientos históricos del peronismo. Una vez que la realidad le demuestre lo infructuoso de esta posición, el líder de la UOM
} 
“...el señor Lorenzo Miguel, el capo supremo de la UOM, estaba jugando al golf en Mar del Plata con el señor presidente CM, porque si digo el nombre por ahí se cae el techo. $Y$ no me voy a olvidar que en esas manifestaciones el señor Minguito, creo que era el nombre, que vino con unos anillos, corbata, una facha bárbara. Y habló ahí en una manifestación que los operarios de ALUAR eran unos privilegiados porque podían mandar a los chicos bien vestidos al colegio. Yo no sé si eso era un privilegio, yo creo que eso era un derecho de los trabajadores."

Menem se pronuncia sobre el tema afirmando que es un conflicto "de neto corte privado" por lo cual el gobierno no se involucraría. El gobernador de Santa Cruz, Néstor Kirchner pide a los empresarios "solidaridad y equidad" mostrándose de acuerdo con la rebaja de los aportes patronales y la baja del "costo argentino" pero sin que eso implique despidos o descuento salarial.

Son significativas las declaraciones de los dirigentes sindicales, quienes dan por hecho el despido definitivo de los trabajadores, afirmando que "...se le dijo no a la rebaja salarial del $25 \%$ aunque vengan los despidos ${ }^{266}$. Minguito afirma que el plan de convertibilidad es exitoso y plantea que eran preferibles los despidos a la rebaja salarial.

Se mantiene el quite de colaboración y la declaración de asamblea permanente, pero sin huelga total. Hay expresiones de solidaridad de muchos sectores, desde corrientes internas de la UCR, el PJ, gremios y otras organizaciones sociales de Puerto Madryn. Recién el 21 vuelven a realizarse medidas que afectan la producción de la empresa, con paros sorpresivos por turno. No hay anuncios sobre posibles paros generales y el 28 se producen treinta y dos nuevos despidos. Para la UOM es el final del programa de ajuste y vuelven a reivindicar que lograron frenar el plan piloto de rebaja de sueldos. El intendente de la ciudad afirma que ALUAR "es una empresa humanitaria" y que él se "hubiera quedado piola,267 si le descontaban el salario. Pocos días después plantea su preocupación por el desempleo en la ciudad, que ya llegaría al $20 \%$.

\footnotetext{
abandonara la alianza con Ubaldini y su posición opositora al gobierno, situándose en la escena política como un oficialista crítico de la gestión nacional" (pág. 74). Para el autor este quiebre se produce durante el conflicto de Somisa, y para 1994 Lorenzo Miguel ya está volcado a un apoyo "crítico" hacia el proyecto menemista. Luego, hacia 1996, volvería a enfrentarse, aunque manteniendo en todo momento los canales de diálogo y negociación. De hecho, en la lógica vandorista, la confrontación no era más que una demostración de fuerza para poder negociar. Pero al mismo tiempo el alineamiento con el gobierno nunca debía ser total, justamente para mantener algún grado de autonomía que le brinde poder para la negociación. Esta compleja relación se refleja en alguna medida en la forma en que se negocia el conflicto que aquí trabajamos.

${ }^{266}$ Diario Jornada, 19/1/94, declaración de Vicente Jara, secretario general UOM local, pág. 15.

267 Diario Jornada, 19/1/94, declaración de Victoriano Salazar, intendente de Puerto Madryn, pág. 15.
} 
Cuando revisamos los diarios nos llamó la atención un pequeño recuadro del 20 de enero, donde uno de los despedidos se presenta como opositor a la conducción de la UOM y afirma que "el gremio no hizo absolutamente nada", y "ALUAR no esta en crisis, esta diseñada para elaborar 140000 toneladas anuales y actualmente esta sacando 180000". Para él era "inaudita" la decisión de una movilización mientras hay gente despedida y afirma que los dirigentes gremiales actuales "dan ganas de vomitar". 268

A partir de allí entendimos que era necesario conseguir nuevas fuentes para ampliar la información que teníamos de este conflicto. La comprensión global de la importancia de este proceso no la habríamos podido desarrollar sin las entrevistas. En ellas vemos que el elemento central no fue solucionar una crisis económica de la empresa, sino concretar la derrota de los obreros que representaban una estrategia que podía poner trabas al proyecto del capital financiero, y lograr imponer el proceso de reforma que permitiera aumentar las ganancias de la empresa a largo plazo.

La conducción sindical, expresión típica del más tradicional vandorismo, acuerda con la empresa lo fundamental del proceso, aquello que Gerardo sintetiza así:

"...despidieron a toda la oposición sindical a la UOM. Porque la empresa dice o despedimos o descontamos y nos despidieron a todos nosotros $y$ no descontaron. El fuego para que una parte importante siguiera cobrando el mismo salario lo pusimos nosotros, el gremio nunca se opuso y nunca propuso nada."

Así también lo entiende Héctor:

“...entre la cabeza del gremio y la cabeza de la empresa fueron a tirar los nombres arriba de la mesa en Trelew, no acá (...) Minguito vino prácticamente a defender la causa de la empresa y a darle un lavado de cabeza al trabajador. Se puede negociar el salario, pero no a quién echamos o a quién no. El gremio debe defender a todos."

Y Fernando nos cuenta que "despiden a unos ochenta obreros, da la casualidad que esos ochenta eran de la lista opositora a la que maneja Jara en la UOM, o sea era como que la empresa y el sindicato hacen un pacto para marcar a quién se tenía que $i^{\text {'269. }}$

Pero Gerardo y el resto de la conducción de la agrupación opositora se oponían a la postura que antes nos planteaba Héctor de aceptar el descuento ("prefería vamos a bajar un poquito, que todos conserven el trabajo y después luchar

\footnotetext{
268 Diario Jornada, 20/1/1994, declaraciones de Oscar Castro, pág. 9.

269 Soul (2009) releva un proceso semejante en Somisa, hacia 1967: "Desde la perspectiva de la organización sindical, estaban siendo despedidos la totalidad de los integrantes de la comisión interna y del cuerpo de delegados que no respondían a la conducción nacional. Los despidos se produjeron con posterioridad a la huelga general del 1ํde marzo de 1967" (pág. 16).
} 
desde adentro pero unidos"). Para Gerardo "la empresa quería una cosa o la otra, pero nosotros veíamos que aceptar la rebaja salarial en lo político era algo impresionante, no se podía aceptar". Eso hubiera sido una derrota mayor, una derrota del conjunto de la clase.

El proceso tiene así elementos contradictorios porque hacía adentro de la planta deja un saldo claramente negativo, pero a nivel general frena un proyecto que probablemente hubiera seguido en todas las grandes industrias. Debemos observar que el conflicto se da en un momento de inflexión en el proceso de rebelión de la clase obrera, a pocos días del santiagazo que expresa el comienzo de un período en que la ofensiva del capital financiero empieza a encontrar mayor resistencia, aunque sigue avanzando sobre los derechos de los trabajadores.

Pero hacia adentro el descabezamiento de toda la dirección alternativa golpea profundamente a los trabajadores. La debilidad por la falta de los compañeros que expresaban lo más decidido de la resistencia a la quita de sus derechos se refuerza por el papel cómplice del sindicato, en el cual ya no se podía confiar. Así aparece el miedo. La situación de los que "quedaron afuera" refuerza el miedo de los que todavía están "adentro". La desocupación funciona como disciplinamiento y como una forma de terror social.

Gerardo fue uno de los despedidos: "...hubo mucho miedo. Incluso yo me encontré con muchos compañeros que me decían 'che yo quiero hacer algo', pero yo les decía cuídate que esto es largo, cuida el laburo, esto es una experiencia, hay que moverse cuando hay posibilidad de ganar algo. Yo los comprendo a los que tienen miedo, porque yo también tengo miedo, todos tenemos."

Porque encima la desocupación se hace más terrible en una ciudad como Puerto Madryn si uno era despedido de una empresa que parecía ocuparlo todo como era (y en gran medida todavía es) ALUAR. Así nos cuenta Héctor “...yo te digo, vos te fuiste con un conflicto, con problema de ALUAR y acá en Madryn olvídate de conseguir trabajo. Es muy difícil acá en Madryn por el peso de la empresa, vas a una empresa nueva y tuviste un problema en ALUAR que era y es el peso pesado y ni te dejan empezar"; y también Fernando: "Después de eso como que el obrero que quedó adentro tenía hasta miedo, porque el que quedó afuera quedaba afuera del sistema directamente, no quedaba afuera de $\operatorname{ALUAR}(. .$.$) los muchachos que quedaron acá en$ la ciudad uno los veía que no conseguían laburo en ningún lado, era muy difícil".

Hacia adentro de ALUAR todo lo que continúa es de derrota. Comienza un profundo proceso de reestructuración productiva buscando una mayor explotación de los trabajadores ocupados y la quita de los derechos laborales fijados por el convenio. Citábamos antes una parte de la entrevista a Fernando donde relacionaba el cambio 
en la gestión empresarial con una privatización. La relación laboral pasó de un estilo "paternal", similar a la que se vivía en otras empresas estatales, a una gestión "dura".

Procesos semejantes trabajan Cangiano (2006) y Soul (2007). El trabajo de Cangiano, centrado en los metalúrgicos de Villa Constitución, muestra como en 1989 se pasó a lo que denomina una "gerencia de línea dura": "A comienzos de 1989, estableció una organización de trabajo "polivalente", organizando la producción por equipos de trabajadores que estarían a cargo no solamente de las tareas de producción, sino también de mantenimiento y supervisión" (Cangiano, 2006: 180)

Es clara la sintonía de esta mirada con la breve síntesis que realiza Fernando:

“...yo trabajaba en el centro de cómputos y me dieron la opción o salía del sector y me iba a mantenimiento o me iba a la calle. O sea no tenía muchas alternativas y hubo toda una reforma dentro de la empresa donde todo el mundo rotó por todos lados y muchos quedaron afuera. Muchos obreros y muchos de parte media de mando. Lo que es supervisores se limpió todo."

En el trabajo de Soul de 2007 se hace hincapié en la figura de que tras la privatización de Somisa se sintió la irrupción de la mano del patrón en la fábrica: "El acto de privatización de la empresa es un hito fundamental en la historia laboral, personal y social de los trabajadores de la ex - Somisa. El tipo de dirección y gestión que los nuevos propietarios imponen al proceso de trabajo implica una ruptura profunda respecto de los modos de organización previos. Esta ruptura es significada por los trabajadores como 'la irrupción del patrón en la planta' y está directamente relacionada con el carácter privado de la gestión" (Soul, 2007: 37)

Es llamativo que si bien en Aluar la gestión siempre fue privada la sensación que vivían los obreros era similar. Fernando lo sintetiza así: "Antes había otra relación me parece, si bien el capital siempre es el capital y aprieta, pero había otra relación con el obrero. Ahora se muestra todo con un capitalismo más exacerbado."

Para 1995 el proceso de reconversión productiva y de ajuste de costos ya le rinde frutos a ALUAR. Además la concentración de la economía sigue su curso y ALUAR se adjudica el complejo hidroeléctrico Futaleufú. Cerca de fin de año informa que en el ejercicio logró una ganancia superior a los cien millones de dólares, exportando el $70 \%$ de su producción, y anuncia que ampliará su capacidad productiva. Logra recomponer la rentabilidad con la reducción del $30 \%$ de su personal (por despidos y retiros voluntarios), la reconversión del proceso productivo y el asegurarse la provisión de energía barata a largo plazo.

En noviembre se muestra la otra cara de la alegría de los empresarios, el cómo estos procesos impactan en la vida de la clase obrera: se produce una explosión en ALUAR que causa heridas a seis obreros de empresas contratistas que estaban 
trabajando en uno de los hornos. Estos "accidentes" son consecuencias del aumento en la explotación del trabajo y de las menores condiciones de capacitación y seguridad que permitía imponer el régimen de contratistas. No se sabe el motivo de la explosión ni la evolución de los heridos, y no hay pronunciamientos de la UOM o la UOCRA (bajo ese convenio estaba el personal accidentado).

Como una parte más del proceso, en junio de 1996 se firma un acuerdo laboral de ALUAR con la UOM que avanza en la precarización y la quita de derechos de los trabajadores. Para su firma ahora sí viaja Lorenzo Miguel. Así lo recuerda Fernando:

"Antes cada rama tenía su oficio y se respetaban las categorías, el oficio que tenías. Hoy por hoy hay solamente tres categorías tanto en producción como en mantenimiento y todo el mundo hace de todo y no sabes si pasas de una categoría a la otra para que te la paguen. (...) Todavía nosotros estamos en la flexibilización, no pudimos volver a los convenios originales. Esto lo firmó el gremio, dejando a la empresa y a las comisiones internas de cada empresa que arreglaran las categorías y los mecanismos de mando dentro de cada empresa. Entonces acá en Aluar se hicieron tres categorías, se definieron sus tareas y se dejó de lado el convenio al cual ya no se le dio más bolilla."

Según Lorenzo Miguel este convenio permitiría la apertura de una planta de llantas de aluminio que crearía nuevos puestos de trabajo en Puerto Madryn. La fábrica nunca se realiza, al menos no hasta el año 2010 en que escribimos este trabajo. Si bien por fuera de ALUAR la rebelión social crece en estos años (cortes de rutas, huelgas generales), hacia adentro la derrota es aún muy fuerte: "Todo ese paquete lo arma el gremio con el Estado y la empresa, y nosotros lo recibimos casi calladitos la boca y sin hacer nada".

Este proceso de reconversión productiva amerita otra investigación en mayor profundidad. También nos aporta Fernando que:

"Cuando se firma la flexibilización la empresa entra y decide que la parte de mando directo, que es la parte de supervisores, se eliminaba. Achicó la parte de mando y con las teorías modernas de mando que viste que son más chicas, hay pocos intermediarios y todo lo que estaba en el medio se fue de la empresa, unificaron gerencias que antes había muchas más. Investigación y desarrollo desapareció que antes era una gerencia entera, todo eso se fue y se implementaron las teorías nuevas estas de que el técnico, justamente el de la escuela técnica, desaparece".

Es muy interesante pensar este desguace del área de desarrollo tecnológico como parte del proceso de acentuación de la dependencia del país y del reforzamiento del carácter de enclave de la producción. Claramente estamos ante un avance del 
régimen de gran industria y de la reorganización del proceso productivo. Aquello que la mirada del sentido común, y de muchos investigadores, ha clasificado como procesos de "des industrialización", se nos presenta a nosotros como concentración de la producción y la riqueza y reforzamiento de la dirección del régimen de gran industria sobre la estructura económica social concreta de la región.

Mientras cerraban casi la totalidad de los pequeños y medianos talleres metalúrgicos, ALUAR comienza su fase de crecimiento que aún hoy sigue en auge. En la misma línea piensa la temática Silvia Simonassi (2007) “... fue la desaparición de múltiples pequeños y medianos industriales que cerraron o vendieron sus plantas; esto indica que ciertas fracciones del capital se vieron claramente afectadas por las políticas adoptadas y otras rotundamente beneficiadas." Por eso propone utilizar "la expresión de reestructuración productiva como alternativa a la de desindustrialización" (Simonassi, 2007: 74). Citamos nuevamente a Soul, cuya mirada refuerza nuestra conceptualización: "Desde la perspectiva de la organización de los procesos de trabajo, tenemos una tendencia a la profundización del régimen de gran industria sobre la base de la renovación de los medios de trabajo. El resultado de conjunto es una contracción de la cantidad de puestos de trabajo a ocupar, luego de una contracción - en una proporción aún mucho mayor - de la cantidad de trabajadores." (Soul, 2007: 38)

Hasta los conflictos ocurridos en 2005 y 2007 es muy poco lo que pasa en términos de protestas y organización de los trabajadores. Hay algunos conflictos, siempre muy moderados, por despidos de personal o reclamos salariales. Pero la realidad es que la situación de retroceso no puede modificarse fácilmente. El despido de los trabajadores más formados en la lucha, la modificación del proceso de producción y la transformación en el tipo de relación con la patronal, ha dejado desorientados a estos trabajadores que no logran retomar acciones fuertes para defender sus derechos.

Obviamente el marco social tampoco ayuda. Si bien durante casi doce años los obreros de ALUAR no reciben un aumento de sueldo, esto, que implica en lo concreto una rebaja salarial, era sentido por muchos de ellos como un factor de estabilidad ante el desastre que observan en otras empresas de la región.

En noviembre de 1996 la UOM declara el estado de alerta y se dispone el quite de colaboración por el despido de cinco trabajadores. No hay una continuidad del conflicto que obligue a la empresa a reincorporar a los despedidos. Durante marzo de 1997 se producen algunos conflictos en ALUAR por la reestructuración tecnológica que sigue realizando la patronal. Como lo veíamos se avanza en la multiplicidad de tareas del personal, el recargo de trabajo y la asignación de labores del antiguo 
personal de categoría superior sin aumento salarial. Flexibilización y quita de derechos en el avance de una gran empresa sobre su propia fuerza trabajo ocupada. La UOM plantea que tiene que intervenir ante los planteos del personal y que, aunque la empresa debe buscar acuerdos, también se debe entender que los avances son necesarios y lógicos. Así manifiestan lo que denominan "una voluntad conciliadora" en el marco de las negociaciones.

Durante 1998 se concreta un nuevo avance en la concentración de la propiedad, al comprar ALUAR la empresa Uboldi. Consigue así controlar la elaboración de productos de mayor valor agregado, como la fabricación de envases de aluminio. A principios del 2000 la UOM denuncia que ALUAR había realizado tres despidos en los últimos veinticinco días, de gente con 20 a 25 años de antigüedad. Sin embargo no plantean ninguna medida.

Para marzo del 2001 ALUAR destaca que con su ampliación estará entre las plantas más grandes del mundo ${ }^{270}$. La nota, de más de una página, es publicada como publicidad en ambos diarios de la región. Allí aclara que la obra de interconectado Choele Choel - Puerto Madryn se necesita para asegurar la provisión de energía eléctrica para la nueva planta que empezaría a construir. Ese interconectado demandará una inversión de 80 millones, de los cuales ALUAR sólo pondría el 20,5\%, mientras el 79,5\% restante sería aportado por un fondo estatal. Se trata de una nueva transferencia de fondos públicos para ALUAR.

A fines del 2002 se muestra que el aluminio ha pasado a ocupar el segundo lugar entre los productos exportados por Chubut por detrás solamente del petróleo y desplazando de esa posición a la pesca ${ }^{271}$. Chubut exporta fundamentalmente petróleo, aluminio, lana y pesca, en una economía cada vez más centrada en la explotación de recursos naturales, en especial recursos no renovables. El único caso que parece distinto es el de la producción de aluminio, pero debemos recordar que lo que exporta ALUAR es centralmente energía (el mayor insumo para su producción) la cuál consigue a muy bajo precio gracias a los recursos naturales hídricos y a la provisión de gas subsidiado.

\footnotetext{
270 "La crisis económica y financiera doméstica no parece haber afectado a Aluar del mismo modo que a Acindar. Por el contrario, las posibilidades de exportar y acceder al mercado financiero internacional, permitieron que la firma se encontrara en ese mismo período en pleno proceso de expansión. Durante 1999 ejecutó una inversión de US\$ 340 millones, que incrementó su capacidad productiva en un 40\%" (Pérez Artica, 2009: 113)

271 "En efecto, en 2000 y 2001, las exportaciones de aluminio primario crecieron un 50 y un $8 \%$ respectivamente, mientras las ventas domésticas cayeron 38 y 19 por ciento." (...) "Ciertamente, la recesión interna operó en el mismo sentido para todas (reduciendo los volúmenes y la participación de las ventas domésticas en el total comercializado). Sin embargo, las siderúrgicas debieron enfrentar simultáneamente un recrudecimiento de la competencia mundial que las forzó a implementar estrategias de redefinición de la oferta y de los mercados externos atendidos. Aluar, por lo contrario, contó en ese momento con una demanda externa dinámica que le permitió sortear en mejores condiciones las dificultades comerciales locales." (Pérez Artica, 2009: 114 -122)
} 
Tras varios años en que no logran presentarse reclamos fuertes por aumento salarial y mejores condiciones de trabajo la situación empieza a cambiar a partir del comienzo del nuevo siglo. El proceso de luchas que atraviesa a toda la sociedad argentina impacta en alguna medida hacia adentro de la planta, entre los trabajadores de ALUAR. Junto a ello se produce el ingreso de una camada de nuevos obreros que no cargan con esa identificación entre los intereses propios y los de la empresa, que sí aparece en muchos trabajadores más antiguos. Esto será un importante factor de transformación en la actitud para salir a luchar por sus derechos y en la contundencia de las medidas que se deciden a realizar.

A fines de abril del año 2005 comienza una huelga general del personal de ALUAR reclamando un aumento salarial del 50\%. La medida es con permanencia frente a la planta, respetando las actas esenciales. Según estas actas se deben mantener guardias mínimas en las cubas electrolíticas ya que por ser un sistema de producción continua la no asistencia del proceso puede implicar la solidificación del aluminio al enfriarse y con eso la inutilización de las cubas, generando pérdidas millonarias para la empresa.

Tras cuatro días de huelga el lunes 2 de mayo se levanta la medida y la UOM negocia con la patronal un aumento del $28 \%$, que es visto como un triunfo por los trabajadores. Sin embargo este aumento luego no se traduce en lo concreto y además varios de los obreros antiguos pasan a cobrar por encima del mínimo no imponible, hecho que lleva a nuevas medidas en noviembre solicitando la elevación del monto por el cual se paga impuesto a las ganancias.

Para entender la contundencia de las medidas adoptadas en el paro del 2007 debemos comprender que la bronca se venía acumulando desde el 2005. El aumento prometido no había sido tal por varias "trampas" de la empresa, que pasa adicionales al básico sin que esto se traduzca en incrementos en el sueldo de bolsillo. Nos cuenta Ricardo: “...la gente esta harta de toda una forma de conducción y viene con bronca desde el 2005 que también hubo una huelga, si bien no tan fuerte como esta. Fue una medida donde se llegó a un arreglo salarial y después resultó que ese arreglo no fue lo convenido. Con un montón de artilugios no aumentaron nada y a partir de ahí se genera este malestar en la gente."

Durante este proceso la Comisión Interna de la fábrica fue avanzando en su enfrentamiento con la dirección sindical. Pese a la fuerte oposición del sindicato, resuelve en asamblea realizar un paro general desde el viernes 8 de junio en reclamo de una recomposición del 45\%, cuando la empresa ofrecía un 12\%. Los trabajadores realizan piquetes a los cinco portones de acceso, tanto a la planta central como a las 
dos de semi elaborados y a TRANSPA, la distribuidora de energía que tiene sede de operación en ALUAR.

A las pocas horas se cede a la presión de gendarmería que intima a los trabajadores para que dejen ingresar al personal de Transpa. La situación se agrava el sábado por la madrugada, cuando debían entrar los trabajadores de la UOCRA que están realizando la ampliación de la fábrica. La dirección de ese gremio intima a los trabajadores de la construcción a entrar a la empresa, amenazando con despidos, y agrede a los obreros en huelga con palos y armas de fuego. Este hecho es presentado por los medios de comunicación como una pelea entre sindicatos.

Las agresiones generan aún más bronca entre los obreros. En la asamblea del sábado por la tarde se resuelve parar las cubas electrolíticas, desconociendo las actas esenciales que nunca en la historia de la empresa han sido dejadas de lado. De inmediato llegan más de ciento cuarenta telegramas de despido y empieza una fuerte campaña en todos los medios de comunicación. Se acusa a los obreros de que llevarían al cierre de ALUAR y se presiona a las familias con solicitadas y llamando a las mujeres de los trabajadores cuando estos no están en sus casas por encontrarse en los piquetes de huelga.

La conducción central de la UOM acepta la conciliación a nivel nacional, mientras los trabajadores la rechazan en la asamblea de Puerto Madryn. Junto a esto la UOM nacional amenaza con quitar los fueros legales a los delegados de ALUAR si no se acata la decisión. El dirigente de la UOM local dice en los medios que no hay que ser intransigente, y si bien era fuertemente repudiado en las asambleas por el sector más activo, su postura incidía en muchos obreros.

La unidad de la huelga comienza a flaquear justo cuando debía hacerse más fuerte, ya que la fábrica llega a su punto crítico de funcionamiento y la perspectiva indica que necesitarían negociar para evitar pérdidas millonarias. En la asamblea del jueves 14 por la tarde la insistencia de la dirigencia de la UOM sobre la necesidad de aceptar la conciliación fue ganando espacio, y la Comisión Interna no supo responder a la situación. La asamblea general de la noche vota volver a trabajar, aceptando la conciliación.

La huelga no fue victoriosa pero tampoco derrotada. Si bien se vuelve al trabajo con cierta sensación de desánimo la empresa no pudo avanzar con los despidos a los obreros más combativos. En lo salarial se consigue un aumento de alrededor del $20 \%$, pero que por primera vez se acuerda directamente en Buenos Aires y no en Puerto Madryn.

Sumamos en este apartado una huelga que excede el período que incluimos para el resto de las fracciones obreras y para el estudio general. Esto se debe a que 
consideramos que esa huelga del 2007 expresa elementos semejantes a los tres procesos significativos que relevamos en 2005: la huelga pesquera, la toma universitaria y la huelga docente.

La huelga de Aluar de 2005 es rápidamente negociada, en gran medida porque tanto la empresa como la UOM reciben fuertes presiones del gobierno provincial para evitar un conflicto más generalizado en la región. Recordemos que ese paro surge en medio de la huelga pesquera y en el marco de su primera fase, cuando presentaba elementos que podían evolucionar hacia una potencialidad que ponía en riesgo la conducción política por parte de una estrategia conciliadora. Si a la huelga pesquera se le sumaba un conflicto fuerte en el "peso pesado" de la economía regional, la situación podía agravarse a niveles difíciles de controlar.

Por eso planteamos que la huelga de Aluar del 2007 se enmarca en la continuidad del 2005 y es expresión del mismo proceso general. De hecho destacamos allí tres elementos claros: la decisión de todas las medidas en asambleas, la postura de asumir medidas de lucha muy contundentes y la aparición de una nueva camada de activistas obreros, que expresaban otra actitud hacia la patronal y hacia la dirigencia sindical tradicional. A su vez también presentaban los límites que hemos encontrado en los otros conflictos: la imposibilidad de articular lazos con otras fracciones obreras y sociales, lo que imposibilitaba el sostener una estrategia que fuera más allá del reclamo corporativo. De hecho en este conflicto se da el fuerte enfrentamiento con la dirección de la UOCRA, como expresión evidente de esas limitaciones y del uso que de ellas hacía la patronal y la dirigencia sindical que sustentaba otro proyecto político.

Para nosotros estos conflictos expresan la recuperación de los obreros tras años de retroceso. El avance de la lucha popular que se refleja en múltiples sucesos a lo largo de los noventa y en el nuevo siglo, impacta hacia adentro de ALUAR. Los trabajadores recuperan una cierta organización propia desde la Comisión Interna y con ello reafirman la confianza en su propia fuerza. Por ello estas huelgas marcan, tras años de ofensiva de la patronal, el intento de quebrar el sentido del proceso y recuperar su antiguo nivel de vida.

Se marca durante toda la huelga la división entre dos grupos de obreros: los más antiguos en la planta, anclados a la vieja relación paternalista, que ven a la fábrica como algo estructurante de sus vidas y que además tienen un salario más alto por su mayor antigüedad y por cobrar ítems que los trabajadores nuevos ya no reciben. Ellos no ven con buenos ojos las medidas muy contundentes que pueden afectar la producción de la empresa o plantear la ilegalidad del paro. La mayoría de este grupo esta cerca de la jubilación y manifiestan un gran temor a quedar 
desocupados. Por otro lado los más jóvenes no expresan ningún tipo de identificación personal con la empresa. Para ellos este es un trabajo más, como cualquier otro. $Y$ encima es un trabajo donde no recibían un sueldo tan superior a otros como para soportar los mayores niveles de insalubridad y de riesgo que el trabajo en ALUAR determina.

Estos trabajadores jóvenes están más decididos a tomar medidas contundentes y enfrentar decididamente a la patronal y la conducción sindical. Son los que votan el rechazo de las actas esenciales y la no aceptación de la conciliación. Sin embargo se evidencia en el hecho la falta de experiencia de esta nueva camada de obreros. Ellos no observan que los trabajadores más antiguos no coinciden con estas posturas tan extremas y que eso va dividiendo la huelga, y quizás tampoco valoran en su justa medida la fortaleza de los enemigos a los que están enfrentando.

En un interesante trabajo, desde un enfoque micro sociológico, Maristella Svampa (2000) destaca una división similar entre los trabajadores metalúrgicos del Gran Buenos Aires ${ }^{272}$.

En el conjunto de los trabajadores se denota que si bien hay un fuerte rechazo a la conducción sindical, no lo hay hacia sus estructuras orgánicas. De hecho la dirección del proceso queda en manos de la Comisión Interna, que sí es respetada y valorada por los trabajadores aunque recibe muchas críticas por algunas decisiones. Pero en definitiva el hecho fundamental para quitar fortaleza a la huelga fue la falta de apoyo de la UOM. Los trabajadores no ven como posible poder derrotar a ALUAR sin el acompañamiento de su gremio.

\subsection{Los trabajadores desocupados}

Buscamos aquí enfocar nuestra atención en la conformación de los movimientos de trabajadores desocupados en el noreste de Chubut desde 1990 (cuando se produce un temprano intento de organización), pasando por distintas experiencias hasta 1996, dando un salto cualitativo con los cortes de ruta de 1997 en Trelew, Puerto Madryn y Comodoro Rivadavia y generándose en los años siguientes la conformación de grupos permanentes, algunos de ellos con vinculaciones a nivel nacional. Son estos grupos ya conformados, con algún nivel de institucionalización y que van generando una permanente relación de tensión, enfrentamiento y negociación con los distintos poderes del Estado, los que se constituyen como una parte fundamental del proceso de crecimiento de la rebelión social durante el 2001 y 2002.

\footnotetext{
272 Ver Svampa, Maristella (2000) "Identidades astilladas. De la patria metalúrgica al heavy metal", en: Svampa, M. (ed.) Desde abajo. La transformación de las identidades, UNGS/Biblos, Bs. As.
} 
Con el recambio en la gobernación de la provincia (en el 2003 asume el PJ tras doce años de gobierno de la UCR) toma mayor importancia la búsqueda de la cooptación por parte del Estado. El proceso hasta el 2005 se ve atravesado por esta tensión entre la búsqueda de algunos grupos de mantener su independencia, el intento de otros de sumarse directamente a ámbitos del gobierno y las dificultades de sostener los niveles de confrontación en una situación de cierta recuperación económica.

Buscaremos entonces mostrar este proceso cargado de tensiones, reflejando la capacidad organizativa de estos hombres y mujeres que muchos consideraban "excluidos" de la sociedad y a los que no daban ninguna posibilidad de autoorganización. Desde allí discutiremos cuál es el aporte de esta experiencia al ciclo de rebelión, cuáles son los niveles de conciencia que se desarrollan en el proceso y si hay intención y/o capacidad de articular un proyecto alternativo al hegemónico en la sociedad.

Discutiremos también qué estrategia mayoritaria se expresa a lo largo de los distintos conflictos que van desarrollando estos grupos durante los años que abarca el período. Esa estrategia no se desarrolla en soledad sino que hace a sus relaciones con los otros sectores movilizados en la sociedad, por eso veremos cuáles son las continuidades y rupturas entre estos movimientos de trabajadores desocupados y las luchas de los trabajadores ocupados y de otros sectores sociales.

$\mathrm{Al}$ igual que en los otros apartados debemos destacar la falta de trabajos específicos sobre los movimientos de desocupados en la región y en toda la provincia del Chubut. En cambio a nivel nacional hay una profusa bibliografía, de muy diversa calidad y amplia variedad ideológica. La gran mayoría de los trabajos que consideramos relevantes ya han sido destacados en forma específica en el capítulo 2 , tanto de trabajos que observan el proceso a nivel nacional como de los que lo hacen centrando su mirada en Patagonia. Destacamos aquí a otros trabajos que no han sido citados allí, como los de Gabriela Delamata y Pablo Vommaro ${ }^{273}$.

En la descripción que realizamos en este apartado es donde quizás se presenten más elementos repetidos con la descripción general. Esto se debe a que los movimientos de trabajadores desocupados fueron un factor clave en el crecimiento de la rebelión social, y por eso ya registramos y expusimos muchos de los hechos protagonizados por ellos, especialmente después de 1997. Por esta razón aquí

\footnotetext{
273 Delamata, Gabriela (2004) Los barrios desbordados. Las organizaciones de desocupados del Gran Buenos Aires, EUDEBA-Libros del Rojas, Bs. As; Vommaro, Pablo (2005) "Las organizaciones sociales en la Argentina reciente: una aproximación hacia los procesos de trabajo y las subjetividades contemporáneas". Ponencia presentada en las X Jornadas Interescuelas de Historia realizadas en la ciudad de Rosario.
} 
retomaremos algunos conflictos ya presentados (buscando profundizar en algún aspecto de la descripción) y no desarrollaremos otros que serían importantes para tener un acercamiento más general y completo de la historia de estos grupos en nuestra región, pero que ya fueron volcados en capítulos anteriores.

Como síntoma y parte de las profundas transformaciones económico - sociales que se venían desarrollando en la región, en marzo de 1990 ya se produce una protesta de una organización de trabajadores desocupados que se presentan como tales. La "Comisión de Obreros Desocupados" realiza un acto en la plaza central. Poco tiempo después es duramente atacada por militantes del PJ cuando se movilizan contra un aumento de la tarifa de luz. Esto muestra la voluntad de resistencia y la práctica organizativa de estos sectores obreros desplazados de la producción y la fuerte oposición a cualquier forma de organización independiente de la clase obrera por parte de los sectores dominantes. Este grupo no logra mantenerse en el tiempo y es desarticulado por la represión selectiva contra algunos de sus dirigentes.

En 1991 ya es importante la desocupación entre los trabajadores de la construcción, los textiles y los pesqueros. Los sindicatos plantean públicamente la situación de continúas suspensiones y cierre de fábricas y obras. En ese marco realizan medidas de fuerza parciales y convocan huelgas por mejores salarios para su sector, pero no se producen medidas colectivas.

Luego de haber desarticulado el intento de la Comisión de Obreros Desocupados los sectores dominantes organizan el ataque a los delegados sindicales combativos. Es aquí cuando para nosotros se produce la derrota de la intención de un sector de los trabajadores de resistir en forma decidida. Buscaban defender sus antiguas conquistas encabezando una alianza con otros sectores sociales y dando la lucha en las calles. En el marco de esa estrategia estaba también la intención de organizar a los trabajadores que se empezaban a quedar sin trabajo.

Lo que sigue de 1991 y 1992 está atravesado por la derrota y el miedo. Mientras los cambios estructurales en la economía se siguen produciendo los trabajadores pierden posiciones y no logran generar respuestas contundentes. La clase aparece aislada y dividida.

En 1992 empieza a hacerse manifiesta la conciencia de que se está ante una nueva relación de fuerzas sociales. Como parte de esta situación la desocupación se ha convertido en estructural y por lo tanto no se modificaría en poco tiempo. La estrategia de la dirigencia sindical de restringir los reclamos al ámbito legal y buscar soluciones "concertadas" con el gobierno y las patronales, empieza a tener mayores cuestionamientos. 
Estos trabajadores, acostumbrados durante años a la posibilidad de ir mejorando su nivel de vida y a tener un trabajo estable, empiezan a vivir la angustia de la desocupación, la pauperización y de no poder llevar el pan a sus casas. En 1993 el proceso de rebelión comienza a crecer. Si bien los desocupados siguen sin poder articular protestas propias participan en las que se realizan desde algunos sindicatos. Aparecen cortes de rutas de textiles y pesqueros, ocupados y desocupados. Pero el corte aún es una medida accesoria a otra fundamental y no la forma de lucha que en sí misma puede resolver la necesidad. Esos cortes todavía están más vinculados al clásico piquete fabril que a la ocupación y defensa de una posición, propia del movimiento piquetero.

Se empieza a hacer más común que ante nuevos despidos y suspensiones algunos delegados denuncien el papel de las dirigencias sindicales. Hay protestas por la facilidad con la que se aceptan suspensiones y descuentos salariales. Algunos trabajadores dan muestras de que buscan otra estrategia para resistir el proceso, superando de a poco el golpe que les habían dado entre 1990 y 1991.

Tras el santiagazo la problemática de la desocupación se va haciendo más visible. En marzo de 1994 se presenta la primera agrupación de desocupados en Puerto Madryn. La comisión está integrada por ex obreros pesqueros, textiles, metalúrgicos y portuarios. En Rawson se forma una Cooperativa llamada "Trabajo del Sur", que se propone agrupar a obreros de la construcción sin trabajo para buscar soluciones a su problemática.

A fines de mayo se reúne con el intendente un grupo denominado "Comisión de Desocupados Textiles de Trelew". Acompaña a la comisión el dirigente del Setia, Juan París, quién hace de vocero. Convocan una movilización a la plaza central para el 30 de junio. La movilización tiene una escasa convocatoria pese al acompañamiento de Setia, Sec, Sindicato de Viajantes y algunas vecinales.

Tras la marcha federal el gobierno admite que la desocupación sigue sin bajar y se anuncian planes de empleo temporales. Se trata de la respuesta a la marcha federal y la escalada de luchas que podía preverse. En Trelew se realiza una asamblea de desocupados en un teatro céntrico, en la que se intenta "buscar alternativas para generar empleos", con la presencia de funcionarios y dirigentes gremiales. Se reclama la continuidad de los planes temporales y la creación de fuentes de trabajo, pero no se habla de marchas o protestas, sino de dialogo y consenso. Hay también voces contrarias: un grupo plantea que no se debe permitir la presencia de los funcionarios ya que son ellos los que vienen llevando adelante este proyecto político. Esta posición es minoritaria, la mayoría aún entiende el problema de la desocupación 
como una cuestión individual y no social, como un problema a solucionar mediante la capacitación personal o la generación de "buenas ideas".

La Comisión de Desocupados invita a la exhibición de un vídeo en el local de Setia sobre cooperativismo, planteando que "no debemos resignarnos al no se puede porque de nosotros, como comunidad cristiana, depende que todo siga igual o peor $^{\text {1274 }}$. Se mantiene esta postura de la confianza en que la resolución del problema vendría por el esfuerzo individual y las soluciones que emergieran de un poder superior, y no de la lucha social y la organización colectiva.

En diciembre los trabajadores desocupados que están incorporados al plan de empleo Procopa (Programa Coparticipativo de trabajo, uno de los planes provinciales) se comienzan a movilizar en Trelew para solicitar su continuidad. El 30 de diciembre cierran el año cortando la calle frente al Municipio, realizando un simbólico brindis de fin de año con agua y pan duro.

Desde el inicio de 1995 le dan continuidad a su lucha. El 11 de enero instalan un campamento en la plaza central de Trelew. Tras seis días de soportar amenazas de represión logran un acuerdo que establece un nuevo plan, con un adicional de \$50 para los que tuvieran hasta dos hijos y de $\$ 100$ para los de tres y más. Es una pequeña victoria para esta transitoria forma de organización de un sector de los desocupados. En el largo conflicto no hemos relevado muestras de solidaridad, ni siquiera durante el campamento realizado en pleno centro de Trelew. El drama de la desocupación comienza lentamente a hacerse visible, rompiendo el cerco de los barrios periféricos.

En Puerto Madryn una organización denominada "padres desocupados" se moviliza al municipio en junio y entregan un petitorio al intendente reclamando trabajo, alimentos e insumos para calefacción. Por esa fecha los desocupados de la UOCRA se movilizan por las calles de Trelew hasta el municipio, donde se producen algunos incidentes. La convocatoria no es muy grande pero se observan elementos de fuerte confrontación para la historia de la región, con pedradas, rotura de vidrios y hasta un intento de saqueo de un supermercado que es frenado por la dirigencia del sindicato.

El gobernador Maestro visita en octubre un barrio de Trelew y es recibido por una movilización de la Comisión de Lucha contra la Desocupación que le reclama trabajo (es un grupo distinto al que se reunía en los locales sindicales, plantea una línea más combativa). Maestro se niega a recibir este grupo, no reconociéndolos como representantes de los desocupados. Esta nueva Comisión se reúne en la plaza central, invitando a todos los desocupados a sumarse a su lucha. Todavía el reclamo

${ }^{274}$ Diario Jornada, 28/7/1994, comunicado de prensa de la Comisión, pág. 8. 
es más testimonial que político, aunque su vocero, Luís López, dice que "no descartamos hacer algo similar a lo que pasó en otras provincias donde hubo estallidos sociales por falta de trabajo"275. Días después se instala una olla popular en la plaza.

En 1996 se desarrollan con más fuerza estos grupos con algún nivel de permanencia y organización. En Puerto Madryn se conforma la Comisión de Desocupados en la plaza central. Reclaman trabajo, alimentos, gas, frazadas, ropa y subsidios. Se autodenominan "Desocupados de la plaza" por haber ocupado ese lugar como centro de sus reuniones.

El 15 de Julio inician una olla popular y la permanencia en la plaza en repudio a la mala calidad de los alimentos recibidos. Tras dos días de permanencia los desocupados reciben nuevas bolsas de alimentos de parte del municipio. Pese a esto recién el 23 de julio levantan la olla popular, continuando el plan de lucha con marchas los días jueves. La suspensión de la protesta es repudiada por un grupo de los desocupados que afirman que no se realizó asamblea para tomar esta decisión. Por la tarde ellos realizan una asamblea con desocupados de Trelew y Rawson que llegaban a solidarizarse con la medida de lucha que venían desarrollando.

Cutral Có y Plaza Huincul hacen su entrada en el ciclo de rebelión con los cortes de ruta que marcan un nuevo quiebre en el proceso nacional. El 15 de agosto los desocupados de Puerto Madryn se movilizan al Concejo Deliberante. Ahora se identifican como UTD (Unión de Trabajadores Desocupados). Cortan la calle reclamando alimentos y el cese de los cortes de gas y luz. Al otro día vuelven a movilizarse y ocupan el Concejo Deliberante. Desde los medios de prensa hay un fuerte repudio a estos desocupados, acusándolos de "patoteros" y de "invadir el Concejo que es de todos ${ }^{\prime 276}$.

Toda la actividad política se centra luego en la huelga general de septiembre. El acto en Trelew es muy importante, con más de 4 mil asistentes. En Puerto Madryn se decide el corte de ruta de acceso al parque pesquero por parte del Stia. Como ya lo marcamos ante la agudización de la protesta se acentúan las internas en varios sindicatos. En octubre se declara la quiebra de la planta Mulcosur, la más grande de Rawson. Los obreros realizan una asamblea y deciden tomar la fábrica. Es evidente la diferencia en la reacción, actitud muy distinta a la que se solía tomar ante los primeros cierres de fábricas. Ya se había mostrado que la situación de desocupado no sería

\footnotetext{
${ }^{275}$ Diario Jornada, 31/10/95, declaraciones del vocero de la Comisión de Lucha contra la Desocupación, pág. 6.

${ }^{276}$ Ver Diario Jornada, 17/8/1996, pág. 5.
} 
algo de corta duración, sino parte de un proceso de pauperización del cual era muy difícil poder salir.

En 1997 se producen cortes de ruta de trabajadores desocupados en las tres principales ciudades de Chubut. Esto marca un cambio importante en la dinámica social de la zona, ya que por primera vez en la provincia grupos de desocupados cortan una ruta con la decisión de tomar la posición y defenderla, aún ante el avance de las fuerzas represivas. Son cortes distintos a los anteriores, ya que aquí no se trata de una forma de hacer visible otra demanda sino que el mantenerse cortando la ruta, e impidiendo la circulación de mercancías, se instituye como la medida que podría garantizar el reclamo de trabajo. Estos cortes se dan en fechas cercanas entre sí pese a lo cual los datos recabados en entrevistas, diarios y expedientes judiciales, muestran que no hubo coordinación entre los mismos. La aparición de esta herramienta de lucha se enmarca en el contexto de la profunda crisis económica y el ejemplo de los cortes en otras regiones del país.

En Trelew se forma un espacio amplio de habitantes de los barrios pobres, denominado "Red de Vecinos solidarios" (donde conviven por pocos días militantes del PJ, de izquierda, de diversos grupos de desocupados y de vecinales) que convoca a un acto el 7 de junio. Hay críticas a la UCR y se perfilan dos posturas entre los desocupados: los que pretenden encarar el reclamo por vías institucionales realizando un proyecto de ley que se entrega a los concejales del PJ y otro grupo que exige tomar medidas de lucha en la calle.

Este sector se retira del acto denunciando su carácter "político" ("nos mintieron, lo único que faltó fue que nos hagan cantar la marchita'277) y al otro día cortan la ruta nacional $\mathrm{N} 3$, en un hecho que se inscribe como parte del proceso nacional de acumulación que va realizando la clase a través de la lucha que los trabajadores desocupados desarrollan en el país. Si bien no hubo una organización que dirigiera la lucha (las negociaciones las realizan individualmente los participantes en la protesta con los funcionarios) cumplen importantes roles antiguos delegados textiles y de plantas pesqueras. La experiencia de esos trabajadores que habían sido despedidos se pone en función de organizar a los sectores de la clase desplazados de la relación asalariada. Entre los piqueteros están presentes los que luego serían los principales referentes del MIJD (Movimiento Independiente de Jubilados y Desocupados), la agrupación Evita, la Peñi Namún y la Coordinadora de Trabajadores Desocupados (CTD) Aníbal Verón.

${ }^{277}$ Diario Jornada, 9/6/1997, declaración de un piquetero, pág. 2 y 3. 
El día 8 por la noche el gobernador Carlos Maestro y sus ministros de Bienestar Social, Carlos Lorenzo, y de Gobierno, José Luís Lizurume, acuden al corte. Durante el siguiente día el ministro Lorenzo comienza a encuestar a los participantes en la misma ruta, prometiendo la pronta resolución de sus problemas y la creación de puestos de trabajo. Si bien algunos de los manifestantes consiguieron trabajo el destino fundamental de las encuestas fue el dar la información necesaria para iniciar una famosa causa contra doce piqueteros. Maestro inicia una campaña de distintas denuncias y rumores, planteando ese mismo día que en el corte de ruta había "activistas de Quebracho traídos desde Neuquén"278.

También se publica un supuesto informe de la SIDE que busca criminalizar y demonizar el conflicto. Así se mezcla a supuestos militantes traídos desde el norte "en un colectivo amarillo por el dirigente Luis Cuello"279 que serían militantes del MTP, se habla de conspiraciones entre una dirigente de desocupados de Puerto Madryn, Armonía Navarro, con "miembros de la Atech y activistas de Comodoro Rivadavia"280 y supuestas complicidades de los piqueteros con empresas privadas que pretendían chantajear al gobierno provincial para conseguir créditos y terrenos.

Días después se recurre al viejo recurso xenófobo de la clase dominante en Argentina, y especialmente de Patagonia, denunciando una supuesta "infiltración chilena"281. Se habría descubierto la acción de los servicios de inteligencia chilenos a través de estos piqueteros para desestabilizar la región. La mayoría de los nombrados en este "informe" eran habitantes de la ciudad de Trelew afincados en el Barrio Tiro Federal, con años de trabajo en fábricas y pesqueras, y con familia e hijos nacidos en esta provincia.

El Juez Federal Esteban Cerra ${ }^{282}$ (cuñado del gobernador Maestro) procesó a doce piqueteros bajo la figura de "promotores o cabecillas", no sólo por el "delito" de cortar la ruta sino por el de sedición. Según este Juez un grupo de personas que reclamaban por sus derechos más elementales estaban alzándose en contra del Estado y las leyes fundamentales de nuestra Constitución. Finalmente el juicio no se realizó y la causa terminó prescribiendo.

Se anuncia el levantamiento del corte de ruta por 72 horas, planteando que se volvería a realizar la medida si el gobierno provincial no cumplía los distintos compromisos asumidos. El gobernador reclama al gobierno nacional más cupos en el

\footnotetext{
${ }^{278}$ Diario Jornada, 9/6/1997, declaraciones de Carlos Maestro, pág. 4.

279 Diario Jornada, 9/6/1997, reproduciendo supuestos informes de la SIDE, pág. 6 y 7.

${ }_{280}$ Diario Jornada, 9/6/1997, reproduciendo supuestos informes de la SIDE, pág. 6 y 7.

281 Diario Jornada, 13/6/1997, reproduciendo informes extra oficiales de inteligencia surgidos del "...cruce de informaciones entre la delegación Chubut de la Dirección Nacional de Migraciones, la División de Inteligencia de la Jefatura de la Policía Provincial y el Servicio de Informaciones del Estado (SIDE)", pág. 2.

${ }^{282}$ Años después fue destituido por diversas causas de índole jurídica y personal.
} 
programa de planes trabajar para hacer frente a la emergencia, y la reapertura de políticas de promoción industrial para la región. Hay una importante solidaridad con el corte de ruta, distintos sectores sociales llevan alimentos, lonas y otros elementos para hacer frente al frío del invierno. En la última asamblea surgen algunos problemas entre los manifestantes al decidirse el levantamiento del corte, por diferencias entre los que estaban desde el principio del hecho (que habían conseguido respuestas a sus reclamos) y los que habían llegado más tarde, a los cuales se les reclamaba esperar unas semanas.

El 10 de junio la Red de Vecinos (el sector que no había realizado el corte de ruta) se moviliza al Municipio de Trelew exigiendo soluciones a sus problemáticas y haciendo entrega de un petitorio al intendente. Se muestra la diferencia entre Di Benedetto (intendente de Trelew) y Maestro, ya que el primero destaca como un error el haber ido a la ruta, planteando que esto legitima ese tipo de acciones. Exige que la provincia le otorgue más dinero para asistencia social, ya que ahora todos los sectores le pedirían respuestas. La lucha de los de abajo creaba fracturas entre los de arriba, generando algunas fisuras en el proyecto del capital financiero.

Los hechos van encadenando un proceso de crecimiento de la organización. También en junio se conforma una nueva Comisión de Desocupados y Subocupados en Puerto Madryn, presentando como vocero a Miguel Ibarra, un ex concejal del PJ. Ibarra marca como uno de los culpables de la desocupación al dirigente de la UOCRA local (de origen boliviano) porque según él "tiene preferencias por los desocupados de su país'283. El discurso xenófobo dividía a la clase trabajadora, siendo los bolivianos una parte fundamental de la clase obrera madrynense.

El 15 de agosto este grupo realiza un corte de la ruta 3 en Puerto Madryn. La decisión surge tras participar en el acto por la huelga nacional del 14 de agosto en la ciudad de Rawson. Se realiza la "Caravana de la Dignidad" que parte desde Puerto Madryn hacia Rawson, donde se movilizan a Casa de Gobierno y entregan un documento al gobierno provincial criticando la política nacional y provincial. Al finalizar se producen algunos inconvenientes al negársele a los desocupados la entrada a la Casa de Gobierno y también la posibilidad de hablar en el acto final, siendo único orador el dirigente de la UOM, Vicente Jara. Ante esto los desocupados se retiran antes, entre insultos y forcejeos, expresando que siguen sin recibir respuestas concretas y que se ven obligados a realizar acciones directas.

\footnotetext{
${ }^{283}$ Diario El Chubut, 24/6/97, declaraciones de Miguel Ibarra, pág. 4. La UOCRA desmiente esto y afirma que ellos también sufren el problema de la desocupación, calculando en mil seiscientos los trabajadores de la construcción sin empleo en Puerto Madryn.
} 
Al otro día se inicia un corte de la ruta 3 en Puerto Madryn. Como veíamos el conflicto de los desocupados de la ciudad se iba agravando y culmina en esta acción que aparece como más organizada que lo ocurrido en Trelew y Comodoro Rivadavia. Aquí sí hay dirección de un grupo que está organizado más allá del hecho en sí mismo. Esto no quita que, como ya vimos, este grupo dirigente expresa un nivel de conciencia muy bajo, con un discurso discriminatorio y de oposición a los inmigrantes de origen boliviano. Son unos noventa desocupados, que exigen trabajo y reconexión de servicios, expresando su voluntad y su capacidad organizativa para mantenerse en el corte hasta obtener respuestas. Se denuncia que nunca se cumplió lo firmado en un acta acuerdo realizado hacia casi un mes con el gobierno provincial.

Por su parte el radicalismo justamente esta lanzando la campaña, realizando el primer acto de cara a las elecciones de diputados nacionales. El corte dura unas veinte horas, se amenaza con reprimir pero finalmente se llega a una salida negociada con la intervención directa del gobernador quien promete soluciones y la creación de planes municipales que se anuncian el día 20. Hacia agosto de 1998 lbarra es criticado por varios integrantes de su grupo, quienes lo acusan de haber privilegiado su intención de volver a hacer carrera política por sobre los intereses del conjunto. La organización se desarticula y ya no vuelven a protagonizar hechos de protesta en los años siguientes. Todavía ningún grupo logra consolidar una organización permanente.

Durante 1998 no hay casi acciones de movimientos de trabajadores desocupados que se identifiquen como tales. Sí son constantes los problemas en la pesca, donde trabajadores pesqueros sin trabajo producen movilizaciones, tomas de fábricas y piquetes a los puertos. Además empiezan a hacerse más comunes los procesos de lucha dirigidos por sectores autoconvocados. Los hechos protagonizados en la región por desocupados son aislados, y siguen sin poder consolidar organizaciones estables.

Para 1999 esto empieza a cambiar. Desde principio de año distintos grupos realizan algunas acciones en Trelew y Puerto Madryn, aunque sin continuidad ni repercusiones significativas.

Pero en julio de 1999 comienza una medida que modificará la invisibilidad que aún sufrían los conflictos protagonizados por los desocupados en la región. Los trabajadores desocupados organizados en la Agrupación "8 de septiembre" ocupan la glorieta de la plaza central de Trelew. Allí pasan varios meses, en una especie de campamento permanente, con carteles y banderas que plantean sus problemáticas y realizando diversas actividades que instalan el drama de la desocupación en la vida política de la ciudad en forma definitiva. 
El grupo es heterogéneo y sin línea política clara. Luego cambian su nombre y mientras al iniciar la protesta la canalizan hacia reclamos institucionales (plantean un proyecto de ley y postulan a un candidato a intendente por el grupo), después llaman a no votar y a desconocer los espacios institucionales. Se movilizan varias veces al Concejo Deliberante y al Municipio. La protesta se mantiene hasta fin de año y si bien la mayoría de los protagonistas no consiguen beneficios concretos, sí logran generar una alianza con otros sectores (estudiantes y algunos sindicatos) e instalan la problemática de la desocupación a nivel social.

Durante la primera parte del 2000 avanza en su organización en Trelew el MIJD, que dirige Raúl Castells a nivel nacional y que en ese momento estaba dentro de la CCC (Corriente Clasista y Combativa). Es un cambio importante en el proceso de organización de este sector de la clase obrera de nuestra región, ya que por primera vez se consolida un grupo con una referencia nacional y una dirigencia estable. Hasta allí los agrupamientos eran casi circunstanciales, modificando sus posturas en forma continua y disolviéndose tras las medidas de lucha, o al poco tiempo. Durante la segunda mitad del año este grupo genera constantes hechos de protesta para que el Estado provincial lo reconozca como una organización con personería legal ${ }^{284}$.

También se organiza otro grupo de desocupados en Trelew, denominado "nueva comisión de desocupados". En mayo marchan a Rawson y unos días después cortan la ruta №3, durante una hora. El ministro de gobierno Capraro calificó al grupo de cincuenta desocupados como "totalmente marginal" y a su vocero, Mario Obredor como "uno que se disfraza de Robin Hood"285. Es interesante citar que Obredor era uno de los delegados de la AOT en Windsor, que había sido despedido en 1995 por mandato de la empresa.

Las primeras 12 horas de la huelga nacional del 23 y 24 de noviembre tienen fuerte repercusión en todo el país, aunque el hecho central es el paro del 24, donde se suman todos los sindicatos (la CGT "oficial" sólo convocaba para ese día). Durante el 23 algunos grupos de desocupados (MIJD y otros sin organización estable) más agrupaciones universitarias (Fuich, Frente Universitario Independiente del Chubut, y La Corriente) y dirigentes sindicales estatales, realizan un corte de la ruta nacional №3. Es la medida más fuerte durante esa jornada.

El 24 la huelga tiene impacto en todo el país, con cortes de rutas, piquetes a empresas y marchas masivas. La concentración en Trelew es de unas mil personas y no se permite otro orador que la CGT. Allí comienzan las protestas de los grupos que llaman a cortar la ruta y al comenzar la marcha por el centro de la ciudad varias

\footnotetext{
${ }^{284}$ De esa manera podían presentar proyectos, administrar planes sociales, etc.

285 Diario Jornada, declaraciones del Ministro de Gobierno de Chubut, Héctor Capraro, 23/5/2000, pág.3.
} 
columnas se dividen y acompañan esa propuesta. Además del MIJD, el Fuich y la Corriente son parte del corte de ruta integrantes de varios sindicatos. La medida tiene trascendencia porque muestra la necesidad de tomar medidas más fuertes que las reuniones con los funcionarios. Presenta rasgos de una estrategia distinta a la que impulsa la mayoría de la dirigencia gremial.

A partir de allí estos grupos ya no serán marginales, sino que empiezan a disputar la dirección del movimiento en las calles. En los movimientos de desocupados se expresa la acumulación de la experiencia de resistencia de muchos años del movimiento obrero y se presenta a nivel regional la conformación de esa fuerza social que se desarrolla en todo el país y que realizaría diciembre del 2001.

Desde el principio del 2001 las protestas tienden a unirse y toman características de fuerte confrontación. Se cortan calles y rutas, se queman cubiertas, se desafía constantemente el poder represivo del Estado. Las decisiones en asamblea y la democracia directa son parte central de los hechos que relevamos en la región, y esto se hace especialmente evidente entre los grupos de desocupados. Para mayo se profundiza el conflicto en todo el país. En Trelew se producen cortes de ruta en julio y hay acciones en el marco del primer plan de lucha nacional piquetero.

Durante diciembre de 2001 en la región el proceso también se acelera. El 20 hay enfrentamientos, intentos de saqueos y entrega de bolsones de comida en Trelew y Puerto Madryn. En Madryn hay más de treinta detenidos y en Trelew la policía y gendarmería atacan con balas de goma, gases y hasta balas de plomo para defender los supermercados. En estos hechos hemos relevado una activa participación de militantes de grupos de desocupados, aunque no se marca presencia organizada de los mismos (excepto en Comodoro Rivadavia).

El 2002 comienza con el PJ, la UCR y el Frepaso cerrando filas en torno a Duhalde. Siguen las constantes protestas y cacerolazos y esto también se mantiene en la zona estudiada, en especial en Trelew. El proceso lo realizan desocupados (que centralmente reclaman planes sociales) y sectores medios (comerciantes, chacareros y pequeños empresarios) que ubican sus reclamos en la "reforma política".

A fines de enero se acepta la presencia de concejales de la oposición, que proponen un proyecto por el cual se bajan sus sueldos. Los desocupados dicen que eso no soluciona nada. En cambio otro sector lo reivindica como una victoria y se conforma como "Movimiento Ciudadano de Trelew", apartándose de la asamblea que se realiza en la plaza central. Desde ese grupo surgirá después el ARI en Trelew.

El espacio inicial va desgranándose. Los que protestan se van separando según sus distintas estrategias. Esto es claro cuando los grupos de desocupados se comienzan a movilizar por planes sociales. 
En marzo cortan la ruta 3 durante seis días la mayoría de los grupos de desocupados de Trelew. Este corte surge tras semanas de movilizaciones y de una profunda discusión alrededor de la integración o no a los Consejos Consultivos formados por el gobierno de Duhalde. Esa discusión era compleja, ya que hay grupos con una referencia nacional como el MIJD, militantes sin organización pero con importante influencia en las bases de los movimientos (que luego formarían la "Víctor Choque") y grupos sin referencias nacionales como la agrupación "Evita", "Patria Libre", "Menfa", "Constitución" y la "Unión Popular"286. Además era importante la presencia de estudiantes nucleados en el Centro de Estudiantes de Humanidades, dirigido por el Fuich, y del MIECE ${ }^{287}$.

Finalmente ganan la discusión los sectores que plantean la necesidad de desconocer los consultivos (entre otros la Evita, los militantes que formarían la Víctor Choque y los estudiantes) y los grupos que se habían integrado (Patria Libre, Unión Popular y MIJD) se apartan del mismo. El corte de ruta logra una amplia solidaridad y se organiza alrededor de la asamblea general como instancia común de decisión, en la cual participan todos los que permanecían en el corte. El hecho toma trascendencia nacional cuando un sector de docentes autoconvocados decide comenzar el ciclo lectivo en el piquete. El acto sale en primera plana del diario "Clarín" y a partir de allí el gobierno acepta negociar, siendo el punto más complejo la exigencia de los desocupados de llevar ellos mismos los proyectos que consideran necesarios y no los que imponía el gobierno (trabajo en escuelas y hospitales, proyectos de mejoramiento barrial, etc).

Aquí se manifiesta algún rasgo de conciencia como grupo social, al buscar que esos planes no los convirtieran en mano de obra barata y los llevaran a enfrentarse con los trabajadores ocupados, presionando hacia la baja de sus salarios y funcionando como ejército de reserva ante posibles conflictos laborales. Así lo expresan varios de los dirigentes en las asambleas realizadas durante el mismo corte de ruta. Finalmente se consiguen la mayoría de los reclamos y comienza un proceso de lucha de docentes y estatales junto a desocupados y estudiantes. Esto se profundiza en abril, con la crisis del Banco de Chubut, y la falta de pago a los trabajadores.

El 18 de abril grupos de Trelew, Rawson, Puerto Madryn y Comodoro, se concentran en Rawson, donde participan de la manifestación más de dos mil

\footnotetext{
${ }^{286}$ Este grupo de movimientos no tenía vinculaciones a nivel nacional, pese a que algunos de sus nombres eran tomados de agrupaciones nacionales de piqueteros $u$ otras organizaciones políticas. Los grupos "Menfa" y "Constitución" tomaban sus nombres de los barrios de los cuáles eran originarios casi la totalidad de sus integrantes.

${ }^{287}$ Movimiento Independiente de Estudiantes de Ciencias Económicas.
} 
personas. Se enfrenta al cordón policial que cerca la Legislatura y entran rompiendo los vidrios y tomando las instalaciones. Al producirse el enfrentamiento, sectores sindicales se retiran denunciando a los desocupados por los "hechos vandálicos". La manifestación sigue hacia Casa de Gobierno y al finalizar la policía ataca a los desocupados y estudiantes. Se detiene a diez desocupados que son liberados al finalizar el día (a cuatro se les inicia un proceso judicial). El hecho en la Legislatura tiene repercusión nacional y marca una división entre los sectores más radicalizados y los que buscan una salida negociada.

Este es el punto más alto de confrontación al que llegan los grupos de desocupados. Aquí los mismos ya se presentan como una alternativa política y social propia que representa a los sectores más combativos de la clase obrera. Son los que expresan lo más avanzado de este profundo proceso de acumulación de fuerza social y de distintas experiencias que la clase fue desarrollando a lo largo del ciclo de rebelión. Es clave en este proceso la coordinación y la discusión política constante entre los distintos grupos de desocupados y con importantes sectores del movimiento estudiantil. La acción del gobierno luego va quebrando esa unidad y aísla a los desocupados de los otros sectores sociales.

El gobierno acepta las reivindicaciones del sector docente, consigue descomprimir la conflictividad y termina de aislar a los que expresan demandas más profundas. Además se comienza a quebrar la coordinación que habían logrado los distintos movimientos de desocupados entre sí y con los estudiantes. Se otorgan privilegios a unos sobre otros, a cambio de que no movilizaran en conjunto. Son claras las diferencias políticas entre los grupos que asumen un discurso con elementos que propugnan una transformación social de fondo y los que ya comienzan a discutir con los partidos tradicionales posibles acuerdos para las próximas elecciones.

En junio se realiza un corte de la ruta 3 por parte de cuatro de los grupos de desocupados y al mismo tiempo por la UOCRA. El gobierno acepta negociar con el sindicato pero no con los piqueteros. El piquete culmina con una derrota de la cual los desocupados no logran recuperarse por meses. Días después se produce en Buenos Aires el hecho conocido como "la masacre de Avellaneda", donde se asesina a dos integrantes de movimientos piqueteros. Es parte de la misma avanzada contra los sectores combativos, articulando distintas formas pero con el mismo contenido.

Los desocupados continúan realizando medidas durante el 2003 pero sin la contundencia de principios del 2002. Sus alianzas sociales son menores y están más divididos entre sí. Desarrollan los planes de luchas nacionales, pero ya no se presentan como una alternativa propia. Sus reclamos van quedando reducidos a lo corporativo, a lo que exigen para su sector (y luego cada vez más sólo para los 
integrantes de su agrupación) dejando atrás las prácticas que los vinculaban (aunque más no fuera en forma embrionaria) con la necesidad de una transformación social de fondo.

Varias de las agrupaciones de desocupados desaparecen o se integran como parte del sistema partidario e institucional. Por su parte el núcleo de la "Víctor Choque" se fusiona con el grupo "Constitución" y forman la "13 de marzo"288 y luego la "CTD Aníbal Verón" (como parte de esa coordinadora nacional). Durante el 2003 se conforma un grupo que se referencia como parte de la CCC, pero a fin de año se aparta de esa organización y conforma la "Peñi Namun"289, agrupación que se va orientando hacia una reivindicación más basada en lo étnico que en lo económico.

En Chubut gana ampliamente las elecciones presidenciales Néstor Kirchner. La elección de un patagónico genera expectativa en la provincia. A partir de allí casi toda la actividad se traslada a las elecciones provinciales. EI PJ logra la victoria y este cambio genera expectativa en la población, aún más en los barrios populares de los cuales provienen la mayoría de los grupos de desocupados.

Ya en el 2003 se evidencia una mejor situación económica en la región, en especial por la devaluación que mejora lo que recibe la provincia por los distintos productos que se exportan. El precio del petróleo aumenta a nivel mundial y la exportación a precio dólar o euro vuelve a hacer competitivas (al menos en el corto plazo) a la producción textil y las barracas exportadoras de lana.

Esto genera la creación de puestos de trabajo en estos sectores y el nuevo gobierno impulsa la obra pública, lo cual mejora también el empleo en la construcción. Muchos de los integrantes de los grupos piqueteros consiguen trabajos estables (en general los cuadros medios) y poco a poco van dejando sus responsabilidades en las organizaciones. Este proceso, junto a la expectativa que genera el nuevo gobierno y la influencia que la identidad peronista aún tiene en amplios sectores populares, debilita a los grupos piqueteros.

El gobierno desarrolla una práctica centrada en desmovilizar a los movimientos, dividirlos y cooptarlos. Se asignan funcionarios en forma específica para hacerse cargo de las relaciones con cada grupo y buscar influir sobre sus dirigentes. Ofrecen distintas alternativas de microemprendimientos, cooperativas y hasta puestos en el Estado, como forma de intentar cooptarlos.

Junto con estos mecanismos se ataca a los grupos y dirigentes que siguen movilizando, impidiendo que accedan a distintos beneficios que los otros grupos sí logran y con una represión "molecular", por ejemplo deteniendo en forma continua a

\footnotetext{
${ }^{288}$ Por la fecha de inicio del corte de ruta de 2002.

289 Significa "Hermanos de Pie" en lengua mapuche.
} 
algunos de ellos (especialmente a los que representan a los sectores más combativos).

Pese a esto todavía durante el 2004 hay un fuerte proceso de protestas e importante presencia de los grupos piqueteros. Pero cada vez aparece más desdibujada su capacidad para presentarse como una alternativa de organización para otros sectores de la clase. Sus reclamos se hacen más corporativos y hay poca lectura de los cambios políticos. La burguesía había logrado frenar lo más profundo de su crisis de dominación y recuperado la confianza de la sociedad en el sistema institucional, pero varios de los grupos pretendían seguir dando los enfrentamientos como si la situación fuera la misma de principios del 2002.

Los desocupados de la CTD “Aníbal Verón”, Peñi Namun y Evita, se movilizan en enero reclamando insumos para los proyectos y el alquiler de locales para funcionar. Luego de cortes de calle y tomas de edificios públicos se consigue que el gobierno firme un acta acuerdo comprometiéndose a asegurar estos pedidos. Luego se produce un fuerte ataque mediático a los grupos de desocupados y desde la provincia se amenaza con sacarles los planes. Ante esto la CTD "Aníbal Verón" y la Peñi Namun marchan al municipio e ingresan al mismo reclamando que no haya persecuciones.

En agosto la interna del PJ de Trelew termina haciendo renunciar al intendente de la ciudad y asume en forma interina un funcionario del gobierno provincial. Las cuatro agrupaciones de desocupados se movilizan, cortan la calle y queman cubiertas reclamando que se ratifiquen los acuerdos con el anterior intendente. Enseguida se abre la nueva campaña electoral por la intendencia para el 14 de noviembre.

Las agrupaciones se movilizan el 3 de noviembre ante el municipio. Vuelven a reclamar nuevos planes y el aumento de los mismos. El 9 se profundiza el conflicto. Ante la falta de respuestas cortan la ruta nacional №3 por la mañana y se mantienen allí durante todo el día. Levantan el corte recién al otro día, tras cumplir casi treinta horas de corte total.

El 10 se agudiza la situación. Los desocupados toman el municipio en medio de una fuerte presencia policial. Es una medida que no había sido preparada y se da en medio de una difícil situación política por ser el día de cierre de campaña. Se rompen vidrios, es lastimado un policía en un confuso hecho y llegan las divisiones especiales de la policía provincial. Finalmente se llega a un acuerdo, desalojando el municipio a cambio de una reunión con autoridades nacionales que viajarían el lunes 15. Hay fuertes discusiones entre los desocupados, porque un sector pretende mantener la toma durante todo el fin de semana. 
El domingo el PJ logra una victoria contundente, superior a lo que se preveía. Ante esto la negociación del lunes toma otro carácter ante un gobierno que llega muy fortalecido. Los funcionarios nacionales no viajan y no se recibe ninguna respuesta seria, diciendo que deberán esperar a que asuma el intendente electo. Se nota que la movilización es bastante más pequeña que la del viernes pasado.

Recién en marzo del 2005 se desarrollan nuevas marchas de los desocupados agrupados en la CTD Aníbal Verón, la Peñi Namún y la Evita, reclamando planes e insumos para proyectos productivos. Se logran algunos de los reclamos al negociar directamente con funcionarios provinciales, yendo los cuestionamientos del dirigente de la Peñi Namún hacia el secretario de acción social de Trelew ${ }^{290}$, mientras remarca la buena relación que tenía con el gobierno provincial.

En abril se desarrollan varios conflictos: entre otros la huelga en el sector pesquero y la toma estudiantil de la Universidad. En ambos conflictos la participación de los grupos piqueteros es muy poco significativa.

La CTD “Aníbal Verón” corta la ruta 3 en junio. Es parte de un plan de lucha nacional y la medida se sostiene por varias horas, aunque hay un camino alternativo a pocos metros. No hay acompañamiento de los otros grupos. El 30 de junio nuevamente corta la ruta 3 una sola agrupación. En esta ocasión es el MIJD que corta totalmente la ruta durante nueve horas, reclamando la liberación de Raúl Castells.

En julio se realiza otro corte de ruta con el mismo reclamo, participando en este caso la CTD "Aníbal Verón". Al otro día el PJ lanza la campaña electoral para las legislativas y mientras eso sucedía se corta la ruta otra vez, pero ahora por el MIJD y la Evita. Este corte es más contundente, impidiendo pasos alternativos y buscando mantenerse toda la noche. Durante la madrugada se forma un operativo de la policía provincial y ante la amenaza de represión los desocupados deciden retirarse. Estas medidas repetidas y aisladas dan mucha facilidad al gobierno para atacar a los piqueteros y afinar su estrategia de cooptar a algunos y reprimir a los que pretenden seguir luchando.

Además la medida del corte ya no tiene el efecto disruptivo y la contundencia de antes. Al usarla como una medida más y de forma repetida, pierde su significado original de ser la última instancia, la medida que no se levantaría hasta lograr lo que se busca. Podríamos decir que el corte se ha institucionalizado, aceptándose desde el poder la medida si es que la misma no se mantiene por más de determinadas horas o si se dejan caminos alternativos (cosa que el gobierno ya había asegurado a través de

\footnotetext{
${ }^{290}$ Era un integrante de la Asociación Obrera Textil, con los cuáles muchos de los dirigentes piqueteros tenían relaciones de disputa de larga data, ya que varios de ellos eran antiguos delegados o trabajadores textiles que habían sido despedidos
} 
obras en las zonas donde se habían desarrollado los primeros cortes). Si no era así se intenta reprimir, pero ante esto no se producen mayores conflictos. Ya no se motoriza una activa solidaridad de otros sectores, ni se genera una gran repercusión social.

Tras este hecho se produce la reunificación, al menos en la calle, de las cuatro agrupaciones piqueteras de Trelew. Se movilizan ante Tribunales y el Municipio para repudiar el operativo policial. Sin embargo se mantienen las distintas posturas entre los grupos en torno a cómo desarrollar la lucha en este período. Si bien las posiciones nunca se explicitan aparece la Peñi Namún como la más cercana al gobierno provincial $y$, aunque tiene roces con algunos funcionarios del gobierno municipal de Trelew, cada vez se va alejando más de las medidas con elementos de confrontación callejera y busca el camino de la negociación.

Los otros tres grupos pretenden sostener la movilización en las calles, pero con distintas perspectivas, que se hacían evidentes desde el conflicto por la toma del municipio en 2004. La CTD "Aníbal Verón" ha logrado una mayor presencia social y varios sectores del gobierno responden a sus demandas. Al mismo tiempo este grupo reconoce el apoyo social que tiene el gobierno, y plantea que las medidas deben sostenerse pero bajando el grado de enfrentamiento para no ser blanco fácil de la represión.

Se manifiesta la necesidad de una capacidad de maniobra táctica que permitiera atravesar tanto el peligro de la cooptación como el de la desarticulación, en lo que se entiende como un período de baja en la movilización popular. El objetivo fundamental que se plantea es sostener a la agrupación como organización de lucha.

Por su parte la Evita mantiene un discurso de mayor confrontación permanente, sostenida en un liderazgo muy particular y personalista. Así alterna períodos de fuerte participación con períodos en que dicha agrupación no participa en ningún hecho, de acuerdo a las decisiones de su dirigente.

EI MIJD tiene fuertes disputas internas, con posturas que iban desde medidas muy duras y difíciles de sostener hasta negociaciones con el gobierno que en ocasiones se hacen desconociendo los acuerdos con los otros grupos. Si bien en estos dos grupos había una vocación de buscar y sostener mayores niveles de enfrentamiento, no se denota una preparación consecuente para afrontar los mismos, ni una reflexión sobre las condiciones sociales en que se venía desarrollando el proceso de movilización popular tras el auge del 2001 y 2002.

Tras estas protestas conjuntas la unidad se disuelve y el proceso se encamina hacia las elecciones del 23 de octubre. De hecho no hay nuevas manifestaciones de los grupos de desocupados, pese a que hay huelgas y marchas de docentes y otros trabajadores estatales, incluida la misma policía provincial, por aumento salarial. La 
victoria del PJ es contundente. Esto fortalece al gobierno y quita fuerza a la movilización social.

Siguen algunas movilizaciones pero sin articulación entre sí. Los reclamos de los grupos piqueteros son atendidos por el gobierno cuando se refieren a pedidos particulares para sus integrantes y no cuando reclaman algo que hace a un proceso social más amplio. Por ejemplo ante reclamos contra aumentos en la luz o en el boleto de colectivo se terminan negociando exenciones para los integrantes del grupo que se moviliza. Así los reclamos se hacen corporativos, se quiebra la unidad entre los grupos y aún más su antigua capacidad para interpelar a otros sectores sociales.

Si bien en los años siguientes la continuidad de las movilizaciones de alguno de los grupos (en especial la CTD Aníbal Verón y en menor medida la Evita) sigue presente, no se logra romper esta limitación. La continuidad del proceso mostrará si estas organizaciones pueden volver a cumplir el papel que alguna vez supieron jugar o si se formarán otras que intenten romper los límites corporativos en que la organización sindical suele encerrar a los trabajadores.

Retomaremos en las conclusiones un análisis más fino sobre el proceso que desarrollan los trabajadores desocupados en nuestra región. Creemos que es en esta fracción donde se hace más claramente observable la coincidencia de la periodización local con la nacional que ha construido el PIMSA.

Los grupos de desocupados empiezan a aparecer en $1994^{291}$, se consolidan muy lentamente durante los siguientes años con algunas pequeñas victorias y una mayoría de fracasos, dan un salto organizativo a partir de 1997, para decaer en la cantidad de hechos protagonizados hasta 1999. A partir de esa fecha se constituyen ya en un factor clave de la rebelión.

La recuperación económica, el proceso de los primeros seis meses del 2002 y el cambio de gobierno nacional y provincial durante el 2003, les presentaron nuevos

\footnotetext{
291 Ya destacamos la temprana aparición de un grupo de trabajadores desocupados en Chubut hacia 1990, aunque este hecho se enmarca, para nosotros, en el anterior ciclo de rebelión de la clase obrera de la región. La organización de los trabajadores desocupados en la región durante los años noventa no registra a este grupo como un antecedente de su accionar. Sí creemos importante señalar que aparece como un dato clave el hecho de que en momentos de agravamiento de crisis económica hay una tendencia de los trabajadores desocupados en nuestro país ha agruparse y conformar embriones de organizaciones sindicales que defiendan sus intereses como grupo. Así lo destacan, por ejemplo, Nicolás Iñigo Carrera y Fabián Fernández en "El movimiento obrero ante la organización y formas de rebelión de Ios desocupados: 1930 - 1935”; en Revista Ciclos, Año XVII, Volumen XVI, № 31/32; pág. 125 -152. Ya en 1897 esta registrada la primera manifestación de los 'sin trabajo' en la calle Florida de Buenos Aires (ver Fernández Chein, 2010). Podemos pensar que los trabajadores de nuestro país, cuando se quedan sin trabajo, recurren a sus fuertes tradiciones de organización sindical corporativa, marcando una correspondencia histórica de largo plazo con lo que nosotros observamos entre los desocupados de la región en el período estudiado. Aquí los hechos protagonizados por los desocupados adquieren una mayor importancia y un significativo peso, pero, para nosotros, esto no se debe a que estemos ante la aparición de nuevos sujetos sociales o ante la desaparición o el debilitamiento de la clase obrera, sino porque estamos ante una nueva fase del desarrollo capitalista caracterizado, entre otros rasgos, por la cada vez mayor presencia de población sobrante para las necesidades de reproducción del capitalismo actual.
} 
desafíos ante los cuáles estos grupos no encontraron respuestas satisfactorias para continuar el proceso de autoorganización.

Su práctica política (que en un principio parecía apuntar a superar las barreras del corporativismo propio de la organización sindical) se vio cada vez más limitada a la defensa de sus intereses como grupo, limitando además la conciencia de ese grupo a un espacio cada vez más reducido de individuos. Así, más que un nuevo sujeto social, los movimientos de trabajadores desocupados parecen expresar las tradicionales fortalezas y debilidades de la clase obrera argentina. Estos sujetos, a los que muchos condenaban a una total pasividad, construyen organizaciones, desarrollan estructuras, formulan proyectos y realizan protestas y luchas de todo tipo.

Pero no consiguen que esas prácticas sedimenten en la formulación de un proyecto alternativo de sociedad. No logran que la rebelión se haga fuerza conciente. Los primeros seis meses del 2002 son quizás el momento más claro de esta limitación, justamente cuando se muestra toda su fortaleza y potencialidad en las calles. Esa incapacidad para articular una fuerza social alternativa es lógica: ellos solos no podían lograrlo. Hubieran necesitado de la articulación y el acompañamiento de los otros sectores. Como ya lo decíamos, volveremos a estas reflexiones más adelante.

\subsection{Acerca de bases, dirigencias, estrategias y proyectos políticos}

Otro aspecto de las luchas de la clase obrera que nos interesa abordar en forma específica es el que hace a las relaciones internas de la clase. Hemos visto que en forma permanente se nos ha planteado como un problema el observar las relaciones entre bases obreras y dirigencias y explicar cómo se conforman y qué expresan esas direcciones obreras. Este debate se traduce al de las estrategias que se hace posible observar a partir del estudio de los enfrentamientos sociales, las prácticas organizativas de la clase, las alianzas que se conforman y los intereses que representan.

Consideramos central poder hacer observable las luchas internas de la clase obrera, las disputas entre distintas fracciones y capas de trabajadores y los enfrentamientos a su interior de acuerdo a los alineamientos políticos que se establecen. Los distintos proyectos políticos, las diferentes estrategias que se desarrollan y las alianzas que se conforman, marcan divisiones verticales al interior de la clase obrera, al igual que sucede en las otras clases sociales.

El otro eje fundamental de este apartado será abordar la discusión de la relación entre sindicato y proyecto u organización política, y el vínculo que se 
establece entre las estrategias que se desarrollan, los proyectos políticos ${ }^{292}$ que en ellas están presentes y el tipo de organización necesario para llevar adelante dichos proyectos. En este sentido la intención es repensar la clásica discusión sobre el papel de los sindicatos y su posible constitución en obstáculo al desarrollo político de la clase.

Una parte fundamental de nuestra investigación busca hacer observables cuáles son las estrategias que la clase obrera desarrolla en cada período de su historia en el marco del proceso de lucha de clases. Esa estrategia va a estar condicionada por la correlación de fuerzas sociales, tanto la que se estructura a nivel objetivo como a nivel de la relación de fuerzas políticas.

Consideramos que la posibilidad de comprender los procesos de constitución de las dirigencias obreras debe comenzar por entender que lo que determina el proceso es el proyecto político que dirige a la mayoría de los trabajadores, proyectos que se expresan en una estrategia y en la conformación de una dirigencia. Una cuestión que queremos plantear en este trabajo es que esos proyectos hacen a las formas organizativas que se adoptan y a los límites que ellas generan sobre el proceso.

Los proyectos políticos se expresan en formas organizativas, las cuáles necesitan de aparatos administrativos dada la complejidad de tareas que deben asumir. Son administrados por la capa dirigente de la clase, que va desarrollando una relativa autonomía e intereses propios, en la mayoría de los puntos coincidentes con los que expresa la clase, pero que en otros pueden ser distintos ${ }^{293}$.

Esa capa depende de que se mantenga esa forma organizativa y ese aparato administrativo, fuente de su poder y al que considera la victoria de su proyecto político. Es aquí donde se produce un quiebre en el proceso y toman realidad los enfrentamientos entre esa capa dirigente y los procesos de radicalización que se producen en algunos sectores de la clase, especialmente durante los momentos de

\footnotetext{
292 Consideramos que los proyectos políticos que se ponen en disputa hacen a las diversas concepciones de la sociedad que se busca construir, a los distintos ideales de organización social que se anhelan y a los caminos que se consideran necesarios para hacer posible esa intención. Ese proyecto político puede estructurarse como un conjunto de ideas, articulado y sistemático, y hasta tener una organización política propia que lo lleve adelante, o puede expresarse en formas más difíciles de hacer observables.

${ }^{293}$ En la carta de Engels a Conrado Schmidt del 27 de octubre de 1890, se muestra como la división social del trabajo genera una burocracia estatal que pasa a tener intereses propios con algún grado de independencia relativa y ese "...nuevo poder político, que aspira a la mayor independencia posible y que, una vez instaurado, goza también de movimiento propio", comienza a su vez a influir sobre el proceso global. Se encuentra en Marx y Engels, Correspondencia, Bs. As. Edit. Cartago, 1973, pág. 383. La propuesta de tomar esta carta para pensar la categoría de burocracia sindical, fue planteada por Nicolás Iñigo Carrera en las Jornadas Interescuelas de Historia del 2009. En un sentido semejante Gramsci plantea que "De esta manera se viene creando una verdadera casta de funcionarios y de periodistas sindicales, con un espíritu de cuerpo en absoluto contraste con la mentalidad obrera; espíritu que ha llevado a aquellos a adoptar, frente a la masa obrera, idéntica postura que la de la burocracia gubernativa frente al Estado parlamentario". Antonio Gramsci, Consejos de fábrica y estado de la clase obrera, México DF, Edit. Roca, 1973, pág. 46.
} 
enfrentamientos sociales. El quiebre entre la conciencia restringida a la situación de vendedores de fuerza de trabajo y la conciencia como expropiados de sus condiciones materiales de existencia ${ }^{294}$ encuentra ahora una oposición a su desarrollo en esa capa. Ese cambio podría implicar la pérdida de su poderío, ya que la clase necesitaría otras formas de organización que le permitieran seguir avanzando hacia un proyecto alternativo de sociedad. Aquí el sindicato, como forma organizativa, se transforma en una traba al desarrollo de la plena conciencia obrera.

Esto no quiere decir que esa capa dirigente (o "burocracia", como se ha hecho común llamar a la mayoría de las conducciones sindicales en Argentina), no represente en algún nivel los intereses de sectores de la clase obrera o no sea dirigente de los procesos de lucha. Nosotros consideramos que en verdad lo que se manifiesta en los procesos organizativos de la clase obrera argentina, más que un divorcio entre "burocracia" y "bases", es una significativa correspondencia entre las formas de conciencia dominante en la mayoría de los trabajadores y las direcciones sindicales.

La cuestión es que la conciencia no es algo estático, sino un proceso en continua transformación. Y es esa posible transformación de la conciencia la que esa capa dirigente que se ha conformado en Argentina enfrenta en casi todos los sindicatos, ya que implicaría que sectores de la clase pasen a estar dirigidos por otro proyecto político, que a su vez plantea la necesidad de otras formas organizativas que superen los límites de la forma sindicato.

\section{5.a. El sujeto: ¿burócratas, bases o la clase?}

Gran parte de la izquierda argentina ha utilizado en forma poco precisa la categoría de burocracia sindical en sus lecturas sobre la situación de la clase obrera. Se ha construido la imagen de una dirigencia siempre opuesta a generar procesos de lucha y enfrentada a bases que constantemente estarían dispuestas a luchar y radicalizar los procesos ${ }^{295}$.

Para nosotros partir de esta visión imposibilita una explicación científica del cómo se desarrollan los conflictos de la clase obrera y, por lo tanto, impide encontrar las respuestas políticas correctas. El mayor problema de esta perspectiva es que fragmenta a la clase, por suponer que las dirigencias están por fuera de ella, formando

\footnotetext{
${ }^{294}$ Proceso que explica Carlos Marx en el capítulo segundo, acápite V de Miseria de la Filosofía (Bs. As., Editorial Cartago, 1985): "Las huelgas y las coaliciones de los obreros".

${ }^{295}$ Inés Izaguirre alerta que "...cuando se trata de analizar los conflictos políticos al interior de un gremio, se tiende a polarizar entre "la base" y "las cúpulas" sindicales, es decir, tendiendo a un corte jerárquico en términos de poder institucional ó político-sindical y prestando poca atención a la fractura vertical de "la base" que se expresa en enfrentamientos de vección horizontal."; en Izaguirre (1994a) "Problemas metodológicos y construcción de observables en una investigación sobre luchas obreras", en Daniel Campione (comp.), La Clase Obrera De Alfonsín a Menem, Bs. As. CEAL.
} 
una capa que no comparte ningún interés con la clase de la cual proviene y que no representa en ningún nivel los intereses y formas de conciencia de esa clase. Desde esa perspectiva se supone que es posible la existencia de bases sin dirigencias.

Esta visión, sostenida especialmente desde sectores de la izquierda partidaria, se conformó en gran medida como una respuesta a la visión tradicional de la historiografía que pretendía explicar la historia de la clase solamente desde lo institucional. La historia de los trabajadores pasaba a ser la de sus sindicatos y, especialmente, la de los dirigentes. Se escondía el enfrentamiento social, el conflicto, algo que sí está presente en la mirada de la izquierda.

La respuesta que proponemos trata de recuperar una mirada holística del proceso social, que no lo fragmente en el abordaje (aunque esto sea necesario luego, pero como instancia de análisis que debe completarse con la síntesis) y que tome como sujeto a la clase en su conjunto, donde se comprenda a las bases obreras y a sus dirigencias como partes de esa clase en constante transformación y no como arquetipos ya definidos en forma apriorística.

Decíamos que la forma en que se utiliza el concepto de "burocracia" suele encubrir una deficiente profundización acerca de la relación entre bases y direcciones. Debemos investigar seriamente el papel de esas direcciones y su relación con las bases, buscando las causas de los procesos: “...causas que no deben buscarse ni en los móviles accidentales, en los méritos, en las faltas, o en los errores o traiciones de algunos dirigentes, sino en todo el régimen social..."(Engels, 1976: 11) 296.

Es interesante observar que en las más de veinte entrevistas que hemos realizado a militantes obreros de la región casi no aparece el concepto de burocracia, a pesar de que era permanentemente utilizado por la izquierda partidaria (sólo es usado en los testimonios de Jaime y Gerardo ${ }^{297}$ ). Sí, en cambio, es permanente la denuncia a las actitudes persecutorias de la mayoría de las conducciones, sus ataques a la oposición sindical y sus prácticas de connivencia con la patronal.

En casi todos los casos hay una valoración negativa de las dirigencias. Así, si bien no aparece el concepto de burocracia, sí se hace evidente la idea de que estos dirigentes, aún los que venían con un pasado combativo, una vez que llegaban a la dirección del gremio dejaban de tener como problema central el asegurar los intereses de sus compañeros de trabajo. El sindicalista pasaba a ser visto como "distinto", y dejaba de ser considerado un "compañero".

\footnotetext{
${ }^{296}$ Federico Engels (1976) Revolución y Contrarrevolución en Alemania, Edit. Polémica, Bs. As.

297 Jaime fue militante petrolero y dirigente del Movimiento Al Socialismo durante muchos años. Gerardo fue parte de la lista opositora a la conducción histórica de la UOM en Puerto Madryn, trabajaba en Aluar y era simpatizante del Partido Comunista.
} 
A través de distintas anécdotas se hace patente la idea de que hasta en el estilo de vida ya no eran los mismos ${ }^{298}$. ¿Por qué sucedía esto? La primera respuesta que emerge de los relatos, simple y sin problematización, es que la mayoría de esos dirigentes se vendieron. Pero es claro que esto no explica mucho: ¿cómo podía ser que esos hombres, que habían expresado a parte de los sectores más combativos de los obreros de la región, pudieran traicionar lo que habían defendido durante años?

También podríamos pensar que el hecho de que alguien traicione no puede considerarse tan llamativo en una sociedad como la capitalista, basada en la legitimidad de la búsqueda del bienestar personal a costa del bienestar del resto. La pregunta sería entonces ¿cómo y por qué puede repetirse tantas veces la misma traición? ¿Cómo y por qué "las bases" pueden observar una y otra traición sin que se produzcan reclamos significativos ante esos hechos? La respuesta, es claro, está contenida en la indicación de Engels, citada en este apartado: debemos buscarla a partir del estudio de la totalidad del régimen social en el cual esos hechos se inscriben.

Es claro que la cuestión es más compleja. Un elemento importante es el tipo de estructura gremial existente en Argentina, ultra centralizada y que impone unas normas que hacen casi imposible la supervivencia política de aquel que intente apartarse de ellas. Una vez en la dirigencia, esos trabajadores encuentran que su posibilidad de acción está constreñida a cumplimentar determinadas reglas, prácticas y discursos ${ }^{299}$.

La práctica de buscar en primer lugar el acuerdo con la patronal, de restringir los reclamos al trámite legal y de anular la iniciativa autónoma de los trabajadores planteando que es la dirigencia la que soluciona los problemas, es un camino directo hacia esa diferenciación entre dirigentes sindicales y bases obreras.

Es central en esta situación el tipo de relación que se construye con y desde el Estado. Campione lo explica así: "A partir del régimen de "personería gremial", que combina la centralización sindical, con las fuertes facultades de aprobación e intervención por el estado de las actividades sindicales. Con base en la personería unificada, se instrumentó un sistema de convenciones colectivas de trabajo, limitado a las asociaciones sindicales reconocidas, y sujeto a la "homologación" del estado. Este rol protagónico y tutelar del estado, construido en torno a la unificación sindical es

\footnotetext{
${ }^{298}$ Desde el mudarse de su casa de siempre en uno de los barrios pobres al centro de la ciudad a vestirse distinto, ir a otros bares, dejar de ir a jugar al fútbol con el equipo de la fábrica, etc.

299 Retomamos aquí muchos elementos del trabajo de Daniel Campione (2002) "Estado, dirigencia sindical y clase obrera", en http://fisyp.rcc.com.ar/Dirigencia\%20sindical\%20y\%20clase\%20obrera.pdf. Allí plantea que "La repetida "burocratización" de dirigentes honestos y combativos una vez que asumen cargos de dirección, no puede ser leído desde el ángulo conspirativo, como traiciones, sino como la respuesta casi obligada frente a la inclusión en una burocracia muy estructurada, que tiende a "asimilar" a todo cuerpo extraño".
} 
analizado por Omar Moreno en "La última oportunidad del sindicalismo argentino"300, en donde le asigna un rol causal en la práctica de los sindicatos de privilegiar su influencia posible sobre el estado antes que los vínculos con su base”. (2002: 20) ${ }^{301}$.

El testimonio de Jaime nos trae otro elemento clave: ¿cuál era la conciencia de esa base que hacía posible que esos hombres fueran su dirigencia? Si bien es uno de los que usa la categoría de burocracia, cuando reflexiona sobre la escasa reacción ante la privatización de YPF, reconoce que la postura del sindicato (que no superó una oposición formal) tenía apoyo entre los trabajadores, que en su mayoría coincidían en que la empresa sería más eficiente una vez privatizada y soñaban con ser contratistas y/o empresarios ${ }^{302}$.

En verdad esa dirigencia sindical actuaba como expresión del nivel de conciencia y de la disposición de sus bases. Se le puede criticar no haber discutido la perspectiva de los obreros, pero no se les puede negar el ser legítima expresión del estado de esa fracción de la clase en ese momento de hegemonía del capital financiero.

\section{5.b. Estrategias y alianzas}

Desde la concepción de que el sujeto que debe ser investigado y observado es la clase obrera en su totalidad, avanzamos en la perspectiva de que debemos profundizar la comprensión acerca de cómo se mueve esa clase, cómo se transforma. $Y$ para nosotros ese cambio se desarrolla en el marco de los enfrentamientos sociales.

Es en ese proceso de lucha cuando las clases van adquiriendo conciencia de sus intereses comunes, desarrollan organizaciones y acciones para defenderse, y luchan contra aquellos que pretenden perjudicarlos. Pensamos que es posible encontrar, en el conjunto de los enfrentamientos que se van desarrollando, distintos objetivos entre los sujetos que participan.

\footnotetext{
300 Moreno, Omar (1993) "La última oportunidad del sindicalismo argentino" en Holm-Detlv Kohler and Mandred Wannoffel (edit.) Modelo Neoliberal y Sindicatos en América Latina, Fundación Friedrich Ebert, México, pp. 53-56.

${ }^{301}$ Más adelante en su trabajo Campione desarrolla nuevamente estas ideas, llegando a conclusiones semejantes a las ya citadas de Engels y Gramsci: "Como mediador frente a la clase obrera, se conformó una estructura sindical caracterizada por una menguada autonomía política y organizativa, a cambio de una amplia tutela económica y política por parte del estado. Desde entonces nació y creció una dirección sindical burocratizada que, con matices, conservó su rol de mediación a lo largo de las cuatro décadas siguientes. (...) No se trata ya de cooptar a una dirigencia sindical que se mantenga "exterior" al Estado y la clase dominante, sino de incorporar en un sitio de cogobierno a esa dirigencia, darle contenido estatal a su actividad". (2002: 25)

${ }^{302}$ Aquí debemos destacar, sin profundizar la reflexión, la necesidad de pensar la distinción entre los trabajadores estatales y los privados. Creemos que en el caso de los estatales, los procesos de desarrollo de conciencia como expropiados de sus condiciones materiales de existencia y de ruptura de la hegemonía del estado capitalista, generan elementos de suma complejidad. Hay una identificación de sus intereses con los del estado que hace muy difícil la negación del mismo en tanto estado capitalista y, por tanto, complejiza la posibilidad de enfrentar su dominación. Intentaremos repensar esta distinción en las conclusiones de la tesis.
} 
La demarcación de las formas de acción, de los niveles de conciencia, de los formatos de organización, de la relación entre lo conciente y lo espontáneo y entre lo institucional y la acción por fuera de lo institucional, nos posibilita encontrar un sentido general del proceso de lucha. A ese sentido general lo denominamos estrategia.

A su vez esas estrategias necesitan de determinadas alianzas sociales, las cuáles tienen directa relación con el proyecto político que dirige el proceso. Siempre que la lucha deviene política se realiza entre fuerzas sociales, las cuáles se conforman a partir de alianzas de clases o fracciones de clases que levantan un programa común. Según cuál interés sea el predominante en el programa podremos analizar cuál es la clase que hegemoniza esa fuerza social.

A lo largo de los años que hemos estudiado es posible observar una estrategia mayoritaria entre los trabajadores del noreste del Chubut. Esa estrategia es reformista, expresando los intereses de los obreros en tanto asalariados que viven en dicha región. Por ello suele avanzar hacia la conformación de alianzas con "sus" respectivos empresarios. Así se conforman alianzas entre obreros y empresarios textiles, entre obreros y empresarios pesqueros, etc.

El modelo de polos de desarrollo instalado en la región tuvo como elemento central un discurso que planteaba la comunidad de intereses entre obreros y patrones de la región, cuyos objetivos comunes eran asegurar el desarrollo de la Patagonia. Esto se reforzaba con la necesidad de mantener la paz social para no poner en riesgo los planes de promoción industrial.

Estos rasgos hacen que esa estrategia reformista, que para nosotros es mayoritaria también a nivel nacional, presente en la región elementos de menor confrontación. Sin embargo algunos grupos de obreros van perfilando otra estrategia, que se expresa en la oposición a la conducción de la AOT y la UOM, en las tomas de fábricas textiles y plantas pesqueras durante los noventa, en los movimientos piqueteros, en las huelgas del 2005, etc. Es una estrategia que definimos como un reformismo obrero, en oposición a la anterior a la que denominamos reformismo burgués.

El reformismo obrero se plantea desde diversos grupos y surge con distinta fuerza en cada conflicto importante. Pero en general no logra hegemonizar los procesos, ya que no suele tener un proyecto que vaya más allá de la lucha. Hay un intento de quebrar lo corporativo y de construir un proyecto que integre a otros sectores de la clase, pero no se logra acumular la fuerza material y moral para construir un programa alternativo con peso social.

Contra el planteo de salir a defender a los empresarios "que invierten en la región", estos trabajadores planteaban la voluntad de unir a los de abajo. La búsqueda 
de romper con lo corporativo, construir y buscar la unidad de la clase, se constituye como una estrategia alternativa a la dirigencia gremial. Si bien no implicaba romper el reformismo de las demandas, sí permitía ir más allá a partir de generar un programa propio de la clase en su conjunto.

En cambio el programa defendido por la mayoría de las dirigencias gremiales dejaba la lucha circunscripta a cada fracción obrera, al grupo económico corporativo. En ese estrecho círculo sus intereses parecían igualarse con los de sus patrones: la posibilidad de seguir trabajando estaba en que a "sus" respectivos patrones les fuera bien y no quedaba otra que defender a las patronales como único camino para defender "la fuente de trabajo".

Es en el plano de la lucha, donde esas estrategias se hacen más evidentes. Cuando ellas entran en confrontación y cuando se expresan choques entre las distintas fracciones y capas de obreros, enfrentamientos que muchas veces se dificulta hacer observables, tanto por la falta de fuentes como, especialmente, por limitaciones de índole ideológica ${ }^{303}$ En el plano de la teoría, y estructurada como un conjunto de propuestas, sí encontramos formulada la estrategia del reformismo burgués que encarna la mayoría de la dirigencia sindical. No así la del reformismo obrero, estrategia que debemos rastrear desde un estudio molecular de los procesos y leyendo la historia a contrapelo.

\section{5.c. Ideas inherentes y derivadas}

Rudé ${ }^{304}$ propone que la cultura popular proviene de dos elementos, de los cuales uno es propio de las clases oprimidas mientras que el otro es adoptado desde la clase dominante. Del primer elemento surgen una serie de ideas a las que llama "inherentes", basadas en las tradiciones, en la memoria colectiva. Para él es como la "leche materna" de las clases subalternas. Este aporte se manifiesta de forma espontánea, sin lograr desarrollar un sistema de ideas estructurado.

\footnotetext{
${ }^{303}$ Retomamos nuevamente a Inés Izaguirre: "Del mismo modo que ocurre con el manejo vulgar de la noción de lucha de clases, a la que el sentido común ilustrado tiende a reducir a un enfrentamiento entre clases dominantes y clases subordinadas, omitiendo el enfrentamiento interburgués, y en general el que se da entre fracciones de una misma clase, el análisis de los conflictos obreros tiende a no hacer observable la lucha entre fracciones obreras..." En una nota al pie a continuación de esta cita Izaguirre plantea que esta limitación hace a una problemática aún mayor, que tiene relación "...con el uso ideológico ya mencionado de los conceptos teóricos relativos al proceso de la lucha de clases, que lo simplifica como proceso social independizándolo de las formas concretas en las que se desarrolla ". Así no se aplica a la lucha de clases una mirada de totalidad, que permitiría recuperar “...un desarrollo conceptual más complejo que ya estaba presente en los análisis clásicos del marxismo y en varios desarrollos contemporáneos: que la lucha de clases es un proceso de enfrentamiento entre fuerzas sociales, es decir entre alianzas sociales en pugna, cada una de las cuales expresan articulaciones complejas de relaciones sociales en oposición y/o en antagonismo. Cfr. entre otros Gramsci, Antonio Notas sobre Maquiavelo, sobre política y sobre el Estado moderno, Bs.Aires, Lautaro, 1962, pág. 65 y ss. Marín, J.C. Acerca del origen del poder. Ruptura y Propiedad. Bs. Aires, 1984, Cuadernos de Cicso, Serie Teoría No. 10., y Jacoby, Roberto, El asalto al cielo, Buenos Aires, 1986, mimeo."

${ }^{304}$ George Rudé (1981) Revuelta popular y conciencia de clase. Barcelona, Crítica.
} 
Estas ideas inherentes son claves para comprender ese desacople que se manifiesta entre algunas dirigencias sindicales y las bases obreras. Las diferencias muchas veces no se expresan desde lo político, sino desde aspectos culturales. La posibilidad de acceder a otros ámbitos sociales, el compartir costumbres y gustos con otra clase social, va permeando a esa dirigencia que cada vez se parece más en el estilo de vida a la patronal que a los obreros ${ }^{305}$.

El otro elemento que para Rudé constituye la cultura popular, al que denomina ideas "derivadas", se presenta como un sistema más estructurado de ideas, que parte de lo inherente pero es permeado por ideas provenientes de otras clases. Es el que estructura las visiones más concientes sobre el proceso histórico, el que da sustento a los programas que elabora e intenta desarrollar la clase obrera.

Así la cultura popular siempre está integrada por elementos propios y externos, pero por su condición de subalternidad, son esos elementos externos los que juegan un papel central en la posibilidad de formular proyectos sistemáticos ${ }^{306}$.

A lo largo de los conflictos que hemos relevado en la región, vemos que los trabajadores que por sus prácticas proponían un reformismo obrero no logran plasmar esa práctica en un proyecto político alternativo que logre un apoyo mayoritario. Cuando la lucha supera lo económico y entra en el terreno político-ideológico se quedan sin herramientas para seguir adelante.

Planteamos como hipótesis que el reformismo obrero opera más como una idea inherente que como una propuesta política alternativa en la clase obrera argentina, y le da sustento a esa división muchas veces observada entre la fuerza y combatividad de su organización sindical a nivel de base y las posturas más conciliadoras a nivel de las dirigencias ${ }^{307}$. Es la leche materna que hace que, en

\footnotetext{
305 Si bien la comparación puede ser forzada, creemos que la metáfora que realiza George Orwel en su "Rebelión en la granja" cuando los otros animales no logran ya diferenciar a los hombres de los cerdos, es una imagen que sirve para comprender el proceso. Uno de los entrevistados nos contaba una anécdota, que a él lo indignaba, de haber ido a una audiencia en la Subsecretaria de Trabajo y haberse encontrado con un dirigente sindical nacional de su gremio, al cual confundió con un abogado o un funcionario, porque estaba vestido de traje. También es parecida la descripción que realiza el metalúrgico Héctor acerca del dirigente nacional de la UOM, Gregorio Minguito, que viajó a Puerto Madryn durante el conflicto de 1994 en Aluar.

${ }^{306}$ El debate acerca de esta temática ha sido central en la historia del desarrollo organizativo de la clase obrera. Para una excelente síntesis de las distintas posiciones ver Paula Klachko, La forma de organización emergente del ciclo de la rebelión popular de los '90 en Argentina, Tesis de Doctorado en Historia, UNLP, 2006.

${ }_{307}$ Ver, entre muchos otros: Adolfo Gilly (1990) "La anomalía Argentina. Estado, corporaciones y trabajadores" en El Estado en América Latina: teoría y práctica. México, D.F. Siglo Veintiuno; Adrián Piva (2009) "El desacople entre los ciclos del conflicto obrero y la acción de las cúpulas sindicales en Argentina (1989 - 2001)", en Actas XII Jornadas Interescuelas de Historia, Bariloche, UNCo, publicada en CD ISBN 978-987-604-153-9. Citamos nuevamente a Campione: "Con todo, el panorama no queda completo, si no se señala la influencia que tomó, a partir del peronismo, la organización obrera a I interior de las fábricas (comisiones internas y cuerpos de delegados), que siempre estuvieron en la base de las acciones con mayor potencialidad anticapitalista de los trabajadores argentinos (como las Coordinadoras de Gremios en Lucha, en 1975). No en vano, esta organización de base, fue vista como una pérdida de poder por los capitalistas, que veían disputada su hegemonía práctica en las fábricas. Ver Gilly (1990), que considera a
} 
general, el individualismo sea mal visto y que la solidaridad y el compañerismo sean los valores más importantes para gran parte de la clase. Pero esto no se materializa luego en una expresión política y programática concreta.

Si el reformismo obrero podría operar como idea inherente en la cultura obrera de nuestro país, el reformismo burgués opera como la corriente hegemónica, a partir de la fuerza central que tienen las ideas derivadas de la ideología burguesa, expresadas fundamentalmente en la influencia del justicialismo y su propaganda acerca de la posibilidad de una armonía de clases y la coincidencia de intereses entre patronales y obreros. Así se manifiestan esas formas de conciencia de la clase obrera que aparecen como contradictorias, y que integran en su mismo seno la reivindicación de la posibilidad de una armonía de clases con el reclamo de justicia social ${ }^{308}$ y la defensa de los derechos laborales ${ }^{309}$.

Así el reformismo obrero es capaz de organizar a los trabajadores a nivel de base y en los procesos de lucha sindical, pero esto no se materializa en un programa político distinto al de las patronales. Cuando se pasa al nivel de la discusión programática el reformismo burgués es hegemónico y dirige tras su práctica a la mayoría de la clase.

\section{5.d. E1 "sentido común"}

El abordaje de Gramsci complejiza la mirada de Rudé. En varios fragmentos de sus "Cuadernos de la Cárcel" discute qué significa la conformación de un "sentido común" en la sociedad. Específicamente realiza esta indagación para fundamentar y repensar el desarrollo de la noción de hegemonía. Busca comprender los complejos procesos a través de las cuáles se construye “... una misma y común concepción del mundo (general y particular, transitoriamente operante --por vía emocional-- o

esta particularidad, el rasgo distintivo de la organización sindical argentina, y una amenaza virtual al poder de la clase dominante. En sentido parecido, se expide J. C. Torre : " paralelamente a la redistribución del ingreso y al reforzamiento de los órganos contractuales en el mercado de trabajo, los obreros obtuvieron bajo el peronismo una gravitación inédita en la vida de las empresas" (1983, pg. 89)."

${ }_{308}$ Proponemos pensar este concepto de "justicia social" como una combinación del reformismo obrero inherente permeado por la ideología burguesa del justicialismo.

${ }^{309}$ Esta hipótesis deberá ser necesariamente profundizada. Destacamos que la hipotética presencia del reformismo obrero como idea inherente de la clase no implica no observar la fuerte presencia de la competencia entre los obreros a nivel de lo que podríamos denominar sus "bases" (observar cómo hemos trabajado estas temáticas en los apartados donde abordamos directamente los procesos de luchas, especialmente en el de la pesca). De hecho mientras haya reformismo necesariamente habrá competencia entre los obreros, ya que la conciencia no logra romper su limitación a observarse cómo vendedores de fuerza de trabajo, aunque esa conciencia supere en este caso la limitación al grupo corporativo profesional y haga observable que toda la clase comparte esa condición. Solamente la conciencia de los intereses comunes en tanto expropiados de sus condiciones materiales de existencia puede romper los condicionamientos que llevan a la competencia entre los trabajadores. 
permanente, cuya base intelectual está tan arraigada, asimilada y vivida, que puede convertirse en pasión)'310.

Una concepción del mundo que opera de forma invisible y no cuestionada, ya que casi nunca se hace conciente. A eso se refiere Gramsci, cuando plantea que se convierte en una pasión, en un elemento del comportamiento humano que aparece como irracional, como por fuera de toda reflexión intelectual conciente.

Pero obviamente esto es solamente la apariencia. Detrás de esto la realidad es que operan las relaciones de dominación en una sociedad basada en la explotación de clase. A eso hace referencia la noción de hegemonía. Observar el sentido común que se construye, y cómo este parte de la hegemonía que logra imponer la clase dominante, es tarea central del investigador que busca comprender los fenómenos de conciencia de las clases sociales, especialmente de aquellas que están en relación de subalternidad.

En el apartado "Relaciones entre ciencia-religión-sentido común", Gramsci recupera estas reflexiones. Allí observa que un grupo subordinado suele presentar “... por razones de sumisión y subordinación intelectuales, una concepción del mundo no propia, sino tomada en préstamo de otro grupo, y la afirma verbalmente, y hasta cree seguirla, porque efectivamente la sigue en "tiempos normales", o sea, cuando la conducta no es independiente y autónoma, sino, como queda dicho, sometida y subordinada".

Lo que no siempre se da es la conciencia crítica de esta situación, especialmente en tanto el sentido común opera como un factor de dominación invisibilizado. Para el investigador se trata de construir desde allí la noción de hegemonía; demostrar cómo a través de ese sentido común opera la hegemonía de una clase social: “...el desarrollo político del concepto de hegemonía representa un gran progreso filosófico, además de político-práctico, porque implica necesariamente y supone una unidad intelectual y una ética acorde con una concepción de lo real que ha superado el sentido común y se ha convertido --aunque dentro de límites todavía estrechos-- en concepción crítica". El concepto de hegemonía hace visible la dominación y permite por eso la crítica. La crítica a su vez hace posible la transformación práctica.

Sabemos que en estas miradas quedan debates abiertos que buscaremos recuperar, aunque sin pretender cerrarlos. La conceptualización de Rudé suele sufrir la crítica de que esconde una mirada esencialista. Creemos que esto no es así, ya que la

${ }^{310}$ Gramsci, en www.gramsci.org.ar "El lenguaje, los idiomas, el sentido común". 
construcción teórica de estos conceptos recuperan la historia de lucha de la clase como constructora fundamental de su cultura y sus experiencias.

La perspectiva de Gramsci incluye la posibilidad de que lo no expresado en forma sistemática no sea solamente aquello ocultado por considerárselo peligroso o lo que los sectores subalternos no han logrado estructurar como un conjunto de ideas sistematizadas. Sino que lo no dicho opera, fundamentalmente, como una forma de dominación invisible. El sentido común aparecería como el ejercicio clave de la hegemonía, ya que no se hace observable y se transforma en una pasión o "un sentimiento".

Cuando lo que domina no puede nombrarse, no puede conocerse. La dominación se hace entonces casi imposible de combatir, porque no hay posibilidad de conciencia. Nos dice Marín (1984) "Por eso la enajenación en su grado más extremo es el momento más alto, es la expresión última del desarme: la imposibilidad de pensar" (58). Spivak nos muestra también cómo lo que no puede decirse (o lo que no logra ser escuchado), es una poderosa herramienta de dominación. El "no poder hablar" del subalterno es sobre todo no poder desmontar la densa red de ideología que lo domina y le impide tener una voz propia.

¿Donde se cruzan estos caminos y miradas? Para nosotros el reformismo burgués logra conformar un sistema estructurado de ideas y propuestas, algo que no consigue hacer el reformismo obrero. Por eso decíamos que cuando se llega al nivel de la discusión programática el reformismo burgués es hegemónico y dirige tras su práctica a la mayoría de la clase. Pero esa hegemonía se sustenta a la vez en lo no dicho. Se basa en el sentido común operante que plantea como única forma de organización social posible al capitalismo. Para hacer posible el pensar un proyecto social alternativo se debe romper ese sentido común. Se trata de hacer visible la dominación de clase, la hegemonía, para que ello nos permita avanzar hacia la crítica y la posibilidad de la transformación práctica.

\section{5.e. La organización: sindicatos, asambleas, consejos... ¿partidos?}

Son muchas las formas en que la burguesía le pone obstáculos a la posibilidad de que los trabajadores puedan construir un proyecto político propio. Es en el proceso de lucha cuando pueden ser superados. Los enfrentamientos cambian las condiciones y la descorporativización de las demandas llevan a que la lucha pueda tomar un carácter político.

En los conflictos que hemos trabajado es repetida la impugnación de la burguesía a los métodos asamblearios y a la posibilidad de que se unifiquen reclamos. Contra esto se levanta, como única instancia que da seguridad para la negociación, el 
acordar con los dirigentes. Esta práctica organizativa y de toma de decisiones no es una simple anécdota: es parte del proyecto político que dirige a la mayoría de los trabajadores, que no ve como sujeto a la clase sino a su dirigencia y que sostiene como única forma organizativa posible al sindicato. Por eso la otra impugnación clásica es a todo lo que supuestamente esté "politizando" el conflicto.

La oposición de la burguesía es a todo lo que pueda llevar la conciencia a un nivel superior al de vendedores de fuerza de trabajo, un nivel superior al de la lucha económica. Sin caer en fetichismos organizativos consideramos que la forma asamblea puede jugar un papel clave en este proceso, ya que es un formato organizativo que busca romper la personificación del ciudadano vendedor de fuerza de trabajo que negocia con el empresario. Idealmente en la asamblea la clase responde como colectivo, como personificación general de los intereses comunes. Por eso la burguesía no admite lo que en general define como "un estado de asamblea permanente" que "hace imposible cualquier tipo de negociación $n^{\text {,311. }}$

Sin embargo la asamblea puede jugar este rol sólo en contadas situaciones. En general lo hace en momentos de auge y pierde ese carácter cuando dicha situación ha sido dejada atrás. Muchas veces se convierten en procesos de convalidación de decisiones ya tomadas en espacios de organización más sistemáticos. En otros casos pasan a ser parte de un ritual de determinados grupos que toman como eje de propaganda el funcionamiento asambleario, pero sin que esto garantice la ruptura del corporativismo o el nacimiento de nuevas formas democráticas ${ }^{312}$.

Pese a estos límites en la asamblea siempre esta presente (explicita o implícitamente) el debate sobre las formas de decisión. Contra las decisiones tomadas en forma centralizada y sustentadas en el supuesto conocimiento superior de los dirigentes, otros trabajadores plantean la recuperación de instancias colectivas que puedan romper con los límites de la forma sindicato.

Este debate también incluye el cómo superar la inmediatez que puede aportar la forma asamblea. Cómo desarrollar formas organizativas que puedan sustentarse en el tiempo, que abonen la organización obrera de base pero con una perspectiva superadora de lo sindical. Esta discusión tiene un antecedente muy transitado en la comparación que realiza Gramsci entre sindicatos y consejos de fábrica ${ }^{313}$. Allí destaca que es en los consejos donde "...el concepto de ciudadano caduca y es reemplazado

\footnotetext{
311 Declaraciones de altos funcionarios del gobierno provincial ante la huelga pesquera del 2005. Diario Jornada, 20/5/2005, pág. 16.

312 Para observar algunos de los distintos contenidos que puede tomar la forma asamblea, ver el artículo de Pablo Ghigliani (2008) "Dilemas de la democracia sindical: la Federación Gráfica Bonaerense (19661975)", en Alejandro Belkin (comp.) Relatos de Luchas, Desde el Subte, Bs. As.; pp. 91-115.

${ }^{313}$ Antonio Gramsci (1973) Consejos de fábrica y estado de la clase obrera, Edit. Roca, México DF.
} 
por el de compañero" (Gramsci, 1973: 38). El sindicato se restringe a los límites del obrero como ciudadano, como individuo de la sociedad burguesa.

En un interesante trabajo de fines de los setenta, Adolfo Gilly ${ }^{314}$ plantea una mirada semejante: "Mientras la clase obrera tiene que vender su fuerza de trabajo por un salario, necesita el sindicato. Pero éste, hemos visto, no cuestiona el poder de decisión en la fábrica ni la estructura del Estado. Más bien tiende a ser parte normal de esta estructura, como un instrumento de regulación del conflicto entre capital y trabajo. El consejo, en cambio, por su existencia misma constituye un cuestionamiento potencial o actual del poder de decisión del capital y, en consecuencia, indirectamente de su Estado" (Gilly, 1978: 54).

Por eso para Gramsci es en los consejos donde vive la lucha de clases: "El sindicato es un elemento de la legalidad y se ve obligado a hacerla respetar a sus organizados. El sindicato es responsable de cara a los industriales, como lo es ante sus adherentes; él garantiza la continuidad del trabajo y del salario - esto es, del pan y del techo - al obrero y a su familia. El Consejo tiende, por su espontaneidad revolucionaria, a desencadenar en todo momento la guerra de clases; el sindicato, por su forma burocrática, tiende a no dejar que la guerra de clase se desencadene nunca" (Gramsci, 1973: 115).

Decíamos que en las entrevistas casi no aparece la palabra burocracia, pero es constante la denuncia de las prácticas antidemocráticas de la dirigencia. Especialmente hay una valoración negativa de la dirección en los procesos de lucha. Como lo marcamos, parece claro que juega un papel central la estructura centralizada de los sindicatos y la dificultad para hacer algo distinto desde los espacios regionales.

Son coincidentes las historias de la UOM de Puerto Madryn y la AOT de Trelew tras la caída de la dictadura. En la primera elección durante el régimen constitucional ganaron listas que se definían como pluralistas y combativas, siendo en ambos casos reemplazadas por las anteriores conducciones en la siguiente elección.

Pero el fracaso mayor fue no conseguir modificar el rol político de las regionales de esos sindicatos. Desde una relación de fuerzas que hacía difícil otro resultado, las nuevas conducciones no pudieron romper con la lógica corporativa y la búsqueda de acuerdos con las patronales. No logran superar el marco de la defensa de los trabajadores en tanto vendedores de fuerza de trabajo de una fracción particular de la clase en una región particular del país. Por eso no consiguen generar procesos de unidad con otros colectivos de trabajadores y menos aún pueden plantearse una

\footnotetext{
${ }^{314}$ Adolfo Gilly (1978) "Los consejos de fábrica: Argentina, Bolivia, Italia"; en Coyoacan Revista Marxista Latinoamericana № 5; Edic. El Caballito, México DF, pp. 51-86.
} 
lucha en términos más amplios y sostener la posibilidad de dar una disputa también en lo político.

Creemos que aquí se expresa esa indicación de Balvé y Balvé ${ }^{315}$, de lo importante que es saber encontrar: “...ese momento del desarrollo de la lucha de clases en donde el sindicato como institución, se constituye en traba al desarrollo del proceso de producción de los obreros como clase social, en su sentido más estratégico. Esa forma institucional, localizada, fijada a la base material, constreñida a los asalariados ocupados, en cierto momento de un proceso más general, se constituye en traba, obstáculo, al intercambio de acciones entre distintas fracciones que componen al conjunto obrero, debiendo ser subordinada a una forma de organización superior ya que el sindicato no contiene ni puede contener a las masas, y éstas lo desbordan." (Balvé y Balvé, 2005: 221).

La valoración general es que en la región los sindicatos han caído casi siempre en esa incapacidad de generar lazos entre las distintas fracciones de la clase. Esto se hizo evidente ante la falta de respuestas al proceso de despidos masivos. Los sindicatos no plantean una firme oposición, ya que no lograban impugnar el derecho de los patrones a despedir a sus trabajadores. La mayoría de los sindicatos restringen el reclamo a exigir la indemnización, o sea a que se respete la "legalidad".

La gran burguesía ponía al conjunto de la clase ante la realidad de su situación concreta: que son expropiados de sus condiciones materiales de existencia. Eso se vivenciaba en la desocupación. Para luchar contra esto era necesario otro nivel de conciencia, uno que permitiera formular un proyecto alternativo al del poder, que cuestionara la legalidad del sistema, y para eso ya no servía una conciencia limitada a lo corporativo.

Nuevamente encontramos en las reflexiones de Antonio Gramsci indicaciones claras. Para él: "El sindicalismo organiza a los obreros no como productores, sino como asalariados, es decir, como criaturas del régimen capitalista de propiedad privada, como vendedores de la mercancía llamada trabajo. El sindicato une a los obreros según el instrumento de trabajo o según la materia a transformar, o, dicho en otras palabras, el sindicalismo une a los obreros de acuerdo con la forma que les imprime el régimen capitalista, el régimen del individualismo económico (...) El obrero concibe esa su aptitud no como un momento de la producción, sino como un puro y simple medio de ganar dinero" (Gramsci, 1973: 51).

El sindicato no tiene la capacidad de ser una herramienta de transformación social por sí sola, ya que su accionar se dirige a buscar vender a mejor precio la fuerza

${ }^{315}$ Beba Balvé y Beatriz Balvé (2005) El 69 Huelga política de masas, RyR-CICSO, Bs. As. 
de trabajo de un determinado grupo de obreros. En lugar de generar la unidad de la clase, cuando se sostiene un proyecto político que constriñe a la clase a que el sindicato sea su única forma organizativa, se abona esa división: "La naturaleza esencial del sindicato es competitiva; no es, en manera alguna, comunista. El sindicato no puede ser, pues, un instrumento de renovación radical de la sociedad" (Gramsci, 1973: 37).

La estrategia obrera de reformismo burgués deja a los trabajadores como única herramienta organizativa al sindicato. Les restringe la posibilidad de formular un proyecto político alternativo, algo para lo cual deberían avanzar hacia otra forma organizativa, expresión a su vez de otro nivel de conciencia.

En el marco de los límites de dicha estrategia nunca se podría avanzar hacia la forma organizativa final que propone Gramsci, la que él postula como el último punto del proceso investigativo sobre los grupos subalternos y que trata de las formaciones que afirmen la autonomía integral de estos grupos. En el marco de ese proyecto sólo se puede llegar a formaciones propias para reivindicaciones de carácter parcial o a nuevas formaciones que afirmen la autonomía de los grupos subalternos, pero dentro de los viejos marcos.

Resolver esta situación con la acusación de "burócratas" o "traidores" inhibe la necesidad de observar que el problema que se tiene por delante es más de fondo. El problema no es que un dirigente sea un burócrata, sino que la mayoría de la clase apoya un proyecto político y una estrategia que no coincide con sus intereses en términos generales, pero sí con los intereses que su grado de conciencia limitada a lo corporativo sindical le permite comprender.

La imposibilidad de observar esto por parte de importantes sectores de la izquierda argentina no es algo menor. Suponer que el único problema es que determinados dirigentes sean burócratas es ocultar el problema de la necesidad de construir un proyecto político alternativo que tenga apoyo de masas ${ }^{316}$. Es ocultar que en nuestra sociedad opera un sentido común que presenta como única opción al capitalismo, y que funciona para que los trabajadores no puedan sistematizar ni siquiera un proyecto sólido de reformismo obrero.

\section{5.f. Una síntesis provisoria}

Sabemos que las reflexiones vertidas en este apartado tienen un carácter polémico y, por tanto, necesariamente provisorio. Los temas que abordamos hacen a

\footnotetext{
${ }^{316}$ Campione sostiene, antes y mejor, una formulación similar: "En suma, el movimiento social real no puede constituirse en transformador si no asume la problemática total de la sociedad, y como tal la cuestión del poder, entendido como relación social compleja y no como espacio a ocupar."
} 
históricas discusiones sobre las formas de organización de la clase obrera argentina, el papel de los sindicatos, el rol del peronismo, etc.

Conscientes de esto creemos que es necesario profundizar estos debates. La necesidad de relacionar los niveles de conciencia de las bases obreras con sus direcciones, la formación de estrategias dentro de la clase y la posibilidad que han tenido de constituirse como proyectos políticos sistemáticos, es clave para entender la historia de los trabajadores.

La dificultad para elaborar un proyecto alternativo al que la burguesía ha logrado imponer como hegemónico se condice con los niveles de conciencia de la clase y se expresa en la estrategia mayoritaria que desarrolla. Esto no quiere decir que el proyecto político que implica una sumisión al dominio de la burguesía sea seguido en cada uno de sus puntos: la adhesión se da tras pasar por ese tamiz de la cultura popular que transforma aspectos importantes (aunque no esenciales) del mismo.

A su vez se expresa una estrategia alternativa, que logra organizar a los trabajadores a nivel de su lucha sindical pero no lo consigue a nivel de la lucha política. En ese ámbito el dominio de la ideología burguesa hoy parece difícil de confrontar.

Pensar que el problema se reduce a la dirección sindical expresa una grave incomprensión. Suponer que las dificultades de la clase obrera argentina para construir un proyecto alternativo al capitalismo se limita a la necesidad de "acabar con la burocracia sindical" o de hacer llegar a "nuevos dirigentes democráticos", es no salir de los límites del sindicalismo. Es otra expresión de que el problema es más grave y hace a la conciencia de la clase, algo que se refleja en estas posturas de las corrientes de izquierda más numerosas en nuestro país.

$\mathrm{Ni}$ siquiera se comprende que el hecho de que exista (y pueda seguir existiendo) una dirigencia burocrática sin que esto provoque el rechazo absoluto de la base, es expresión de una problemática mayor. Volvemos a Gramsci: "En todo caso es preciso poner de relieve que las manifestaciones morbosas de centralismo burocrático han ocurrido por la deficiencia de iniciativa y de responsabilidad existente en la base, vale decir, por el primitivismo político de las fuerzas periféricas" (Gramsci, 1997: 92).

Pero la profundidad del conflicto va aún más lejos. En el apartado "Algunos aspectos teóricos y prácticos del economismo", Gramsci plantea: "Diferente es el caso del sindicalismo teórico en cuanto se refiere a un grupo subalterno al que con esta teoría se impide convertirse alguna vez en dominante, desarrollarse más allá de la fase económica corporativa para elevarse a la fase de hegemonía ético-política en la sociedad civil y dominante en el Estado. (...) Es innegable que en tal movimiento la independencia y la autonomía del grupo subalterno que se dice expresar son 
sacrificadas a la hegemonía intelectual del grupo dominante (...) Se excluye la transformación del grupo subordinado en grupo dominante..."(Gramsci, 1997: 40).

Decir esto es afirmar que cuando la mayoría de la izquierda argentina se queda anclada en esta dimensión del problema lo que esta dejando de lado es el problema de la hegemonía. Se mantiene en el plano del sentido común dominante, de la hegemonía invisibilizada. $\mathrm{O}$, para decirlo aún más claramente, es continuar con ese viejo estigma de la izquierda argentina que hace que nada esté más alejado de sus preocupaciones que el problema del poder. 


\section{El movimiento de la sociedad: Los cambios en la estructura económica social en el NE del Chubut}

Hasta aquí nos hemos concentrado en un recorrido en profundidad sobre los procesos de luchas y sus distintas características. Pero el trabajo que buscamos realizar involucra también la observación del proceso de cambios en la estructura económica social. La decisión de volcar estos elementos específicos sobre la estructura económica social hacia el final del trabajo (aunque muchos aportes ya fueron desarrollados a lo largo de la exposición) se sostiene en la necesidad de romper con las visiones mecanicistas que muchas veces se reproducen en las producciones que buscan relacionar el ámbito de las relaciones de fuerzas políticas con el de las relaciones de fuerzas objetivas.

Así, en varios casos, se plantea en primer término un mapa del "desarrollo económico", una especie de "contexto", que luego opera a lo largo de toda la investigación como un escenario ya determinado sobre el cual se mueven y/o actúan los sujetos que desarrollan la historia. Ya hemos remarcado en capítulos anteriores la distancia que nos separa de esos enfoques y la intención de retomar la perspectiva del socialismo científico, que piensa a estos dos ámbitos de la sociedad como partes de una misma totalidad en constante movimiento y cambio.

El método de exposición que buscamos intenta remarcar que los cambios estructurales son parte del cambio general en la relación de fuerzas sociales, cambios en los que necesariamente debemos involucrar el conocimiento acerca de cómo se desarrollaron los procesos de luchas, en tanto factores claves para comprender esos cambios generales en las relaciones de fuerzas entendidas, de nuevo, como totalidad.

Comenzamos este último capítulo con un breve estado de la cuestión y algunos debates acerca de los cambios en la estructura económica social. Luego profundizaremos la observación directa sobre esos cambios a través de un apartado más descriptivo y de dos apartados donde aplicamos nuestra metodología para hacer observables muchas de las transformaciones que habíamos planteado como hipótesis al inicio de esta investigación.

\subsection{Un breve estado de la cuestión y algunos debates}

En los capítulos previos hemos repasado especialmente trabajos que hacen a lo que Gramsci denomina el ámbito de la relación de fuerzas políticas. Ahora intentaremos sintetizar los abordajes más significativos que se realizaron sobre las transformaciones de la estructura económica social de nuestro país desde 1980 hasta la actualidad. Destacaremos algunas diferencias con estos enfoques y 
seleccionaremos cual de estas miradas consideramos que nos aporta mayores elementos para comprender el movimiento de la sociedad que estudiamos. Obviamente, como ya lo marcamos, nuestro abordaje se enfocará en aquellas miradas que sostienen la necesidad de estudiar los procesos desde una perspectiva holística, que incluya en sus investigaciones a los distintos ámbitos en que se manifiesta a los hombres esa relación de fuerzas que es la sociedad en movimiento.

Buscamos específicamente los elementos fundamentales en el sentido del cambio en las relaciones de fuerzas objetivas que hacen a la estructura económica social, para poder relacionarlos con el cambio en las relaciones de fuerzas políticas y desde allí construir un intento de explicación del proceso que ha vivido la sociedad en esta región.

Se partirá de la estructura económica social de la región, estudiando sus cambios y su relación con la estructura económica social de Argentina. Se analizarán para ello los datos del INDEC (Censos Nacionales de 1947, 1960, 1970, 1980, 1991 y 2001, Censos Económicos, Censos Agropecuarios y Encuesta Permanente de Hogares, que sólo se realizó sobre el aglomerado urbano Rawson-Trelew en 1994, 2002, 2003, 2004 y 2005). Con ello podremos hacer observables los cambios que se produjeron en el noreste de Chubut en las principales variables y categorías económicas y relacionarlos con los cambios que se producen en el país y la provincia.

Tomamos como punto de quiebre estimativo al censo de 1980. Consideramos que en el censo de ese año ya es posible encontrar los elementos fundamentales que hacen a la nueva configuración del capitalismo, a la fase de dominio del capital financiero. Este es un primer debate con la mayoría de las investigaciones sobre el proceso de transformaciones económicas que tienden a sostener que los cambios fundamentales se produjeron a partir de 1991.

En este sentido consideramos como un trabajo clave al de Nicolás Iñigo Carrera y Jorge Podestá (1985) "Análisis de una relación de fuerzas sociales objetiva: caracterización de los grupos sociales fundamentales en la Argentina actual", y de los mismos autores (1997a) "Elementos para el análisis de una relación de fuerzas sociales objetiva. Argentina 1991" y (1997b) "Las nuevas condiciones en la disposición de fuerzas objetivas. La situación del proletariado".

Dichos trabajos aportan elementos metodológicos claves para nuestra investigación y brindan resultados para el proceso de transformaciones a nivel nacional que sirven de indicadores generales para enmarcar nuestro trabajo.

En la misma perspectiva nuestros resultados parten de tomar como conocimiento acumulado a los resultados de la investigación sintetizada en el ya citado artículo de Nicolás Iñigo Carrera, Jorge Podestá y María Celia Cotarelo (1999) "Las 
estructuras económico sociales concretas que constituyen la formación económica de la Argentina". A su vez las transformaciones que estudiamos en el proletariado toman como indicador comparativo y metodológico a Nicolás Iñigo Carrera, María Celia Cotarelo y Jorge Podestá (1996) "Situación de los grupos sociales fundamentales en Argentina: el proletariado".

Utilizamos también algunos aportes del Colectivo Redes (1998) "Desocupación y Trabajo. Percepciones de la situación..." y especialmente Stella Cavalleri y Jorge Tripiana (1999) "Precisiones en la aplicación del instrumento metodológico en unidades censales menores para el análisis del movimiento de la estructura económica de la sociedad", como referencias para el análisis de los datos a investigar.

Para los años más recientes retomamos del PIMSA la rica producción de Ricardo Donaire. Entre otros citamos sus trabajos de (2006) "Sobre la existencia de una masa de reserva para las funciones intelectuales en Argentina"; (2004) "Diferentes fracciones sociales encubiertas bajo la categoría ocupacional 'trabajadores por cuenta propia' "; (2002) "Aproximación a la situación de los profesionales y los técnicos"; y (2001) "Acercamiento empírico al reclutamiento de los docentes". En estos aportes busca avanzar en el conocimiento de los procesos de cambio al interior de las distintas fracciones sociales, preguntándose específicamente por los procesos de proletarización y pérdida de territorios sociales que sufren fracciones de la pequeña burguesía acomodada y pobre.

Son claves sus trabajos junto a Stella Cavalleri y Germán Rosati. Los tres escribieron (2005) "Evolución de la distribución de la población según la división del trabajo social Argentina, 1960-2001", mientras Donaire junto a Rosati presentaron (2007a) "Aproximación a la evolución de la distribución de la población según grupos sociales fundamentales. Argentina, 1960-2001" y (2007b), "Aproximación a los cambios en la distribución de la población según división del trabajo social y según grupos sociales fundamentales. Argentina, 1960- 2001". También utilizamos el ya trabajado artículo junto a Verónica Lascano ("Movimiento obrero e hiperinflación').

Específicamente las investigaciones acerca de la distribución del trabajo social y de su evolución en los últimos años, nos brindan elementos centrales para nuestras conclusiones, que expondremos más adelante en este capítulo. Además de su capacidad destacamos la generosidad de Ricardo Donaire y Germán Rosati, quienes nos han permitido citar resultados aún inéditos, que serán publicados en: Donaire y Rosati (en prensa) "Estructuras económico sociales concretas que constituyen la formación económica de la Argentina (1980-2001)" en Nicolás Iñigo Carrera (director), "Análisis de una relación de fuerzas sociales objetiva, 1960-2001". 
Citamos también los trabajos de Germán Rosati (2006 y 2007): “Aproximación al análisis de una estructura económica-social concreta: pequeña producción mercantil, principalmente en el campo (1980-2001)"y "Un caso de crisis de la pequeña propiedad agrícola. Acercamiento empírico al movimiento de la estructura económica del campo chaqueño", profundizando el debate acerca de algunos procesos desarrollados alrededor de la población agrupada como población agrícola.

Un aspecto que hemos intentado abordar y poner en tensión en nuestra investigación es el que hace a los conflictos internos a las clases sociales. Así la lucha de clases no se desarrolla como una lucha lineal entre la burguesía y el proletariado (cual dos ejércitos siempre ordenados y enfrentados simétricamente), sino como una lucha que atraviesa a las distintas clases sociales y que se da al interior de ellas mismas, en muchos casos con singular violencia. Esto hace a nuestra perspectiva metodológica de pensar que el conflicto social se desarrolla a través de la lucha de fuerzas sociales, que se constituyen con fracciones y/o capas de diversas clases, que se alinean tras la dirección de una de ellas.

En fases de dominio de la burguesía es particularmente importante hacer observable la lucha interburguesa. Las luchas internas de la clase dominante se constituyen en muchos momentos en un elemento ordenador de la mayoría de los conflictos sociales, que se desarrollan en función de esa lucha interna y alineados tras sus diversas fracciones.

En este sentido los artículos que abordan esta temática en el ya citado libro de Alberto Bonnet y Adrián Piva (comp. 2009) "Argentina en pedazos. Luchas sociales y conflictos interburgueses en la crisis de la convertibilidad", generan aportes de gran interés.

Citamos aquí a Matías Eskenazi ("El espectro de la dolarización. Discutiendo las interpretaciones sobre la disputa interburguesa en el origen de la crisis de la convertibilidad"), Julián Kan ("Vuelta previa al 2001... La devaluación del real de 1999 y algunas implicancias en la burguesía argentina") y Sebastián Salvia ("Estado y conflicto interburgués en Argentina. La crisis de la convertibilidad (1999-2001)').

El conjunto de estos artículos busca debatir centralmente con las interpretaciones sobre el proceso económico que se han hecho hegemónicas dentro de la historiografía argentina. Específicamente las producciones de Daniel Azpiazu y Eduardo Basualdo, con su gran riqueza empírica y en muchos casos su carácter pionero, generaron lecturas sobre la realidad que se han incorporado a una especie de "sentido común", que excede a la academia y que por ello se hacen, en algunos casos, difíciles de debatir. 
Ya hemos marcado en los capítulos iniciales nuestro interés por problematizar algunas de estas lecturas. Específicamente buscaremos retomar algunos debates planteados tanto por los artículos citados como por la perspectiva desarrollada por el PIMSA. Así intentaremos complejizar la supuesta retracción o achicamiento del Estado, la falta de regulaciones a la economía y específicamente la llamada "des industrialización y reprimarización" de la estructura económica. Todos estos procesos serían los ejes fundamentales de la interpretación clásica acerca de los cambios en la estructura económica social que se habría producido en Argentina desde la instalación del dominio del capital financiero y de su proyecto político-ideológico, el neoliberalismo.

El mayor interés para nosotros lo presenta el trabajo de Matías Eskenazi. Este autor hace hincapié en la crítica a la vertiente de Eduardo Basualdo y Daniel Azpiazu acerca de la crisis del 2001. La perspectiva de esta mirada (expuesta por ejemplo en Basualdo, Eduardo (2002b) "La crisis actual en Argentina: entre la dolarización, la devaluación y la redistribución del ingreso" y en Basualdo y Claudio Lozano (2000) “Entre la dolarización y la devaluación: la crisis de la convertibilidad en la Argentina”) pierde de vista a la lucha de clases, no dando lugar en la interpretación de la crisis al papel clave que en su desarrollo cumplen las luchas de los trabajadores.

Para Basualdo la crisis parece ser provocada por la disputa interna de la burguesía, mientras que la propuesta de Eskenazi apunta a pensar que la crisis se desata por la imposibilidad de garantizar la competitividad de la economía argentina bajo la continuidad de la convertibilidad (entre otras razones por la imposibilidad de generar nuevos "ajustes" o de aumentar las tasas de plusvalía por la resistencia de los trabajadores y otros sectores del pueblo) y es ante esa crisis ya desatada cuando se alinean dos propuestas desde la burguesía para intentar superarla ${ }^{317}$.

Dichas propuestas además no parten de dos fracciones absolutamente delimitadas, sino que se ponen en juego y se van debatiendo al calor del proceso de lucha de clases. No hay alineamientos fijos sino dinámicas luchas en un “...proceso de ruptura y polarización política que involucró a todas las clases de la sociedad y, como parte de éste, una confrontación al interior del bloque burgués” (Eskenazi, 2009: 178) La crisis no es la disputa entre dos fracciones de la burguesía, sino que ante la realidad de la crisis la burguesía propone dos mecanismos para intentar superarla. Mientras tanto los trabajadores no logran articular una propuesta propia, y por ello

${ }^{317}$ En este sentido recupera el planteo que desarrolla Alberto Bonnet (2007b) en su artículo "Argentina: ¿un nuevo modelo de acumulación?". Allí Bonnet critica lo que llama una "sociología fraccionalista" que lleva a la "...subordinación del antagonismo entre capital y trabajo a pugnas entre fracciones de la burguesía, cuando no a pujas entre grupos conspirados". Esta perspectiva es considerada uno de "... los expedientes típicos de los análisis populistas. La razón va de suyo: les permite legitimar políticas de alianzas de clases con fracciones de la burguesía” (Bonnet, 2007b: 85). 
muchos de ellos se alinean tras alguna de las variantes que ofrece la burguesía. Como vemos en esta perspectiva está presente la recurrencia a una mirada de totalidad, que no piensa al conflicto interburgués como un "campo" con reglas y dinámicas propias, sino como parte de la lucha de clases que se desarrolla en toda la sociedad.

El artículo de Sebastián Salvia (2009) recupera algunos de estos debates y profundiza otros. Se propone discutir con la interpretación que “...conceptualiza la crisis como resultado de la caída de la demanda interna por la regresividad de la distribución del ingreso, a partir de un proceso de "desindustrialización" y auge de la valorización financiera” (Salvia, 2009: 190, parafraseando artículos de Eduardo Basualdo y Daniel Azpiazu). Allí sostiene que se debe superar la mirada que piensa a la lucha interburguesa como una disputa entre las cúpulas de las empresas capitalistas más concentradas, que se explicaría por la ruptura de la "comunidad de negocios" que se habría gestado en los noventa alrededor del negocio de las privatizaciones.

Criticando esta perspectiva que "...traslada la determinación de las relaciones de clase desde la explotación en la producción material hacia la distribución del producto social" (Salvia, 2009: 190), afirma que el origen de la crisis se debe al deterioro de la capacidad de competir en el mercado mundial por parte de la producción capitalista argentina. La necesidad de incrementar dicha competitividad lleva a profundizar los niveles de explotación sobre la fuerza de trabajo ocupada ante la escasez de créditos y la dificultad creciente para refinanciar el déficit comercial. Pero el aumento de la resistencia obrera y popular a la profundización de la explotación limitaba el excedente obtenido por el conjunto de la burguesía y dificultaba la realización de nuevos ajustes. Es esa contracción de las ganancias lo que profundiza la disputa interburguesa y genera las distintas fracciones que luchan por apropiarse de ese excedente limitado.

Otros trabajos que abordan y problematizan específicamente las disputas al interior de las clases dominantes son los de Aníbal Viguera (1998) "La política de la apertura comercial en la Argentina, 1987-1996"; el de Julia Campos y Julián Kan, (2005) "Aproximación a la lucha interburguesa: configuración de alineamientos en la antesala de la hiperinflación de febrero de 1989"; Sebastián Ortiz, Diego Tavormina y Alejandro Viegas (2005) "De Remes Lenicov a Lavagna: un enfrentamiento particular de la lucha interburguesa reciente".

Desde una óptica distinta, que piensa a estas disputas como enfrentamientos al interior del "bloque de poder dominante", encontramos trabajos como el de Ana Gabriela Castellani y Mariano Szkolnik (2005) "Devaluacionistas' y 'dolarizadores'. La construcción social de las alternativas propuestas por los sectores dominantes ante la 
crisis de la Convertibilidad. Argentina 1999-2001" (junto a los anteriores trabajos citados fueron presentados como ponencias en las $X$ Jornadas Interescuelas de Historia), Martín Schorr (2001) ¿Atrapados sin salida? La crisis de la convertibilidad y las contradicciones en el bloque de poder económico; y otros trabajos producidos en el marco de los proyectos dirigidos por Daniel Azpiazu y Eduardo Basualdo.

Dos interesantes estados de la cuestión sobre el debate acerca del concepto de des industrialización los encontramos en Juan Grigera (2007) "Debates en torno a la industrialización en Argentina hasta los años '70: una reconsideración a la luz de la ‘desindustrialización’”, y en Eduardo Sartelli (2007) “¿Cómo se estudia la historia de la industria?".

Pero obviamente criticar y problematizar una perspectiva no quiere decir no valorar, destacar e incorporar a nuestro corpus los aportes empíricos y metodológicos de sus investigaciones. Así el corpus de producciones de Eduardo Basualdo y Daniel Azpiazu debe valorarse como una producción clave, que ha permitido rebatir la supuesta invulnerabilidad del pensamiento económico neoliberal (por sólo citar algunos de sus trabajos destacamos aquí de Basualdo (2002a) "Sistema político y modelo de acumulación en la Argentina"; (2000) "Concentración y centralización del capital en la Argentina durante la década del noventa"; de Azpiazu (2003) "Las privatizaciones en la Argentina. Diagnósticos y propuestas para una mayor competitividad y equidad social"; y los textos clásicos de Basualdo y Azpiazu (1981) "Cara y contracara de los grupos económicos. Estado y promoción industrial en la Argentina", y de Basualdo, Azpiazu y Miguel Khavisse (2004) "El nuevo poder económico en la Argentina de los años 80”).

La demostración del proceso de concentración y centralización del capital, la caracterización del surgimiento de un nuevo poder económico en la Argentina de los ochenta, base del desarrollo de un nuevo sistema de ejercicio de la representación política que se expondría más claramente en los noventa, y la investigación profunda acerca de las diversas características de cada fracción de la burguesía y de los proyectos político-económicos que sustentaban de acuerdo a sus intereses sectoriales, son aportes claves que hoy son asimilados como propios por la gran mayoría de los investigadores que abordamos la problemática de la historia reciente de Argentina.

Destacamos especialmente el trabajo de Daniel Azpiazu y Martín Schorr (2010) "La industria argentina en la posconvertibilidad", donde, en la misma perspectiva teórica y metodológica, actualizan muchos de estos elementos a la luz del proceso posterior a la salida de la convertibilidad. Sus resultados presentan datos claves para nuestra investigación que retomaremos más adelante, en especial acerca del 
crecimiento de ALUAR, entendida como una empresa fundamental para comprender los cambios económicos que se desarrollan en la región.

Los autores retoman las tesis clásicas de su perspectiva, destacando un “...acentuado proceso de desindustrialización de la economía, la reestructuración regresiva del tejido manufacturero, la reprimarización del perfil productivo..." (Azpiazu y Schorr, 2010: 13). Es interesante el matiz que sostienen en torno al concepto de des industrialización, expresando que lo entienden “...como la perdida de participación de las manufacturas en el PBI global (...) por ejemplo, entre 1991 y 2001 el PBI total (medido a precios constantes) se incrementó poco más de un 29\% mientras que el industrial creció apenas un 10\%"(14).

También en trabajos anteriores Azpiazu, Basualdo y Khavisse (2004) complejizan el uso de este concepto: “... este carácter "desindustrializador" no debe confundirse con un sesgo antiindustrialista, ya que una parte significativa de la expansión de las nuevas fracciones dominantes proviene de haber mantenido, e incluso aumentado, su ya significativa presencia en esta actividad (...) la "desindustrialización" producida, por un lado, disminuye las dimensiones de la estructura industrial por la desaparición de ciertas fracciones del capital y, por otro lo concentra en manos de las empresas que se están analizando"(215).

Basualdo (2000) propone y utiliza en varios momentos de su producción el más acertado concepto de "reestructuración industrial"318, haciendo hincapié en la conformación de una estructura industrial mucho más centralizada y concentrada. Pese a esto siempre se hace central, especialmente en las conclusiones más "políticas" de sus trabajos, la referencia al masificado concepto de desindustrialización.

Estas lecturas matizan el debate sobre la desindustrialización, aunque para nosotros no deja de ser un error conceptual el manejo de este concepto, que no observa la diferencia entre manufactura e industria y no destaca la consolidación del régimen de gran industria como dominante a nivel nacional. Se repite la concepción, clásica desde este enfoque, de pensar la economía desde un análisis fraccionalista. Por eso se analiza esta supuesta caída de la industria desde un "punto de vista sectorial" (Azpiazu, Basualdo, Khavisse, 2004: 90), comparando porcentuales de evolución sobre el PBI de los distintos "sectores económicos", en lugar de buscar hacer observable la totalidad, y allí destacar el peso preponderante que va ganando en la estructura económica social el régimen de gran industria.

\footnotetext{
${ }^{318}$ También Azpiazu revisa el uso de algunos de los conceptos que criticamos, aunque no por eso deja de asentar su construcción científica sobre esas bases. Así por ejemplo plantea que la pretendida "desregulación" en verdad fue una nueva regulación generada y planificada desde el Estado nacional: “... la desregulación -en muchos casos re-regulación también con similitudes manifiestas- de diversos mercados" (Azpiazu, 2003: 7).
} 
De hecho los datos claves que presentan en sus trabajos van en el sentido de la lectura que aquí proponemos ${ }^{319}$. Se destaca la demostración del grado de concentración y centralización económica, procesos que no sólo no cambiaron tras la convertibilidad sino que tuvieron una nueva profundización: "Apenas cinco sectores de actividad dieron cuenta en 2007 de las dos terceras partes de la producción, todos ellos con participaciones crecientes respecto a los niveles promedio de los años noventa" (Azpiazu y Schorr, 2010: 28).

En las exportaciones la concentración es aún mayor, “...en el año 2007 apenas cinco sectores fabriles dieron cuenta de casi el $85 \%$ de las ventas externas totales" (Azpiazu y Schorr, 2010: 49). También se profundizó la extranjerización de la economía, tanto por la venta de muchas empresas de capital nacional como por la orientación de la producción que se destina centralmente al mercado externo ${ }^{320}$, fuente fundamental de la recuperación económica tras la salida de la convertibilidad.

Marcamos aquí brevemente que estos debates no son una simple cuestión de "palabras", sino que va en ellos la utilización adecuada de los conceptos científicos. Esto es clave, ya que la utilización de conceptos hace a las perspectivas teóricas y por eso dichas diferencias se transmiten directamente a las distintas lecturas acerca de las posibles soluciones políticas a los problemas que aquejan a nuestra sociedad. Si el problema es realmente dicha "desindustrialización", la solución pasaría por crear nuevas industrias. Si el problema fuera la perdida de poder del Estado, todo pasaría por recuperar ese poder del Estado. En cambio, si el problema es una forma de organización social de la producción, la distribución y el consumo, de lo que se trata es de debatir cómo construir una forma de organización social alternativa a la del presente ${ }^{321}$.

\footnotetext{
${ }^{319}$ También lo demuestran las declaraciones de personajes claves en la formulación del proyecto políticoeconómico que supuestamente genera esta pretendida "desindustrialización". En este sentido es interesante una cita planteada en el libro de Jaime Fuchs (1981) "Argentina: actual estructura económico social": "El doctor Guillermo W. Klein, una de las principales figuras del equipo económico, al referirse a las consecuencias de la reforma arancelaria, dijo que:... "significan el crecimiento pujante no de una industria nacional estática, sino de una dinámica, en la que determinados sectores puedan crecer más rápido que otros, y dentro de cada sector determinadas empresas se agranden y otras desaparezcan" (Fuchs, 1981: 211).

320 Desde otra perspectiva ideológica así lo refuerza José Castillo (2007), mostrando que esa extranjerización también se expresa en la participación en el propio mercado interno del país: "De las 1.000 empresas que más facturan, el $76 \%$ son de origen extranjero. Tenemos en primer lugar a las petroleras, todas extranjeras - YPF (1ra. en el ranking de facturación nacional), Petrobrás (3ra), Esso (9na), Shell (11ra.), Panamerican Energy (21ra.) - a las telefónicas (Telefónica 5ta. en el ranking y Telecom 7ma.), a las empresas del complejo de la soja (Cargill, 3ra. en el ranking, Bunge y Born, 6ta., Dreyfus, 14ta.) y los supermercados (Carrefour 8va, Jumbo-Easy-Disco, 10mo., mientras que la argentina Coto recién aparece en el puesto 23). Salvo Techint, que es la segunda empresa en facturación dentro del país, no aparece ninguna firma nacional en las 10 que más venden en el propio mercado interno" (Castillo, 2007: 136)

321 James Petras y Henry Veltmeyer critican al Plan Fénix (PF) desde una perspectiva semejante a la que nosotros aquí sostenemos: "El PF es básicamente un plan neo-estructuralista que acepta el proceso de privatizaciones, la distribución de la propiedad y las relaciones de producción existentes. Los dueños realmente existentes de los bancos, las fábricas, las telecomunicaciones, las propiedades, la tierra y los
} 
Volviendo al texto de Azpiazu y Schorr, allí se destaca que entre 2002 y 2007 se registró un aumento de la ocupación en la industria de un $36 \%$. Por ello los autores destacan un proceso que "... ha permitido revertir el proceso de desindustrialización de la etapa anterior" (Azpiazu y Schorr, 2010: 26). A la vez el coeficiente de productividad aumentó un $27,4 \%$ y la producción se expandió un 73,5\%. Sin embargo para Azpiazu y Schorr esta recuperación no plantea un movimiento orgánico sino un ciclo coyuntural, ya que no se desarrollan políticas activas desde el Estado que vayan más allá del dólar alto y el aprovechamiento de los altos precios internacionales de las commodities. De hecho las políticas que impulsa el Estado refuerzan estos procesos, por ejemplo a través de planes de promoción para las empresas de capital más concentrado.

Citamos finalmente a los aportes efectuados desde el espacio denominado "Economistas de Izquierda", que publicaron tres anuarios en los años 2005, 2006 y 2007 (Anuarios EDI 2005, 2006 y 2007). Si bien las producciones allí desarrolladas tienen distinta profundidad en sus niveles de análisis, hay elementos importantes que retomamos en nuestra investigación.

En el primer Anuario (2005) se centran en el debate sobre el canje de la deuda y sus implicancias para la economía argentina. Demuestran allí que estamos ante una nueva vuelta de tuerca de la dependencia, ya que el endeudamiento se consolida en lugar de solucionarse. Los artículos de Claudio Katz (“¿Quién gana con el canje?’), Eduardo Lucita ("Argentina: nueva reestructuración de la deuda") y Guillermo Gigliani ("Argentina después del canje: se redujo la deuda pero crecieron los pagos"), presentan un mapa que evidencia el reforzamiento de los mecanismos que agravan la dependencia estructural de la economía argentina.

Para el 2006 destacamos el debate acerca de los elementos de continuidad y ruptura entre la economía antes y después de la convertibilidad. Nuevamente los artículos de Lucita ("Economía Argentina: ciclo expansivo y desequilibrios estructurales"), y de Katz ("Coyuntura, modelo y distribución") desarrollan datos contundentes acerca de los procesos de aumento de la explotación laboral, de la baja del nivel salarial y del ascenso de la productividad, como elementos claves para la recuperación de la economía ${ }^{322}$ : "En promedio el costo laboral en el sector privado se

minerales para nada son cuestionados. La reforma básica es la de insertar al Estado para que regule su comportamiento, reduzca los excesos del mercado, aumente los impuestos y les convenza de que aumenten sus inversiones en el sector industrial, en el consumo doméstico y en el bienestar social" (Petras y Veltmeyer, 2004: 49)

${ }^{322}$ Estos elementos deben evaluarse en el marco de una lectura de largo plazo. Como ejemplo se puede retomar aquí el trabajo de Azpiazu, Basualdo y Khavisse (2004): "Dado el comportamiento diferencial entre la productividad de la mano de obra - entre 1974 y 1983 creció el 37,6\% - y el costo salarial de esta - decayó el 18,6\% -, la magnitud del excedente captado por el empresariado industrial, en su conjunto, se incrementó, en el decenio, en un 69\%. En otras palabras, más allá de su destino específico, el capital 
redujo desde el 2001 en un 9,2\%. Pero si este es el promedio general las ramas más dinámicas muestran reducciones mucho más significativas: manufacturas industriales

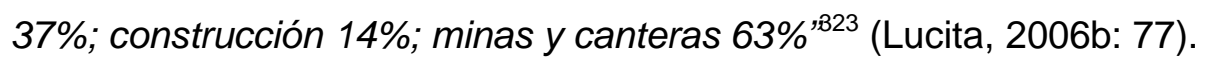

Los datos más contundentes los encontramos en el artículo de Alejandro Bercovich y Guillermo Gigliani ("Productividad y salarios industriales en la "era Kirchner'). Volcamos aquí dos cuadros desarrollados por dichos investigadores que hacen evidente la profundización de los niveles de explotación laboral y el aumento de la productividad ${ }^{324}$ :

Cuadro № 16: Producción y productividad industrial - 1997 a 2005 - en índices $1997=100$. (Extraído de Bercovich y Gigliani, 2006: 88)

\begin{tabular}{|c|r|r|r|r|r|}
\hline Año & $\begin{array}{c}\text { Producción } \\
\text { Industrial }\end{array}$ & $\begin{array}{c}\text { Horas } \\
\text { trabajadas }\end{array}$ & $\begin{array}{c}\text { Obreros } \\
\text { ocupados }\end{array}$ & $\begin{array}{c}\text { Productividad } \\
\text { horas }\end{array}$ & $\begin{array}{c}\text { Productividad } \\
\text { obreros }\end{array}$ \\
\hline 1998 & 99.6 & 95.3 & 97 & 104.5 & 102.7 \\
\hline 1999 & 89.2 & 85.8 & 88.5 & 103.9 & 100.8 \\
\hline 2000 & 87.8 & 79.2 & 82.1 & 110.7 & 106.8 \\
\hline 2001 & 77.7 & 70.9 & 76.7 & 109.6 & 101.2 \\
\hline 2002 & 70.2 & 62.9 & 69.7 & 111.7 & 100.7 \\
\hline 2003 & 82.4 & 70.5 & 73.3 & 116.9 & 112.4 \\
\hline 2004 & 93.9 & 79.2 & 80.7 & 118.6 & 116.3 \\
\hline 2005 & 102 & 84.4 & 86.1 & 120.9 & 118.5 \\
\hline
\end{tabular}

Cuadro № 17: Costo salarial y salario real en la industria ${ }^{325}-1997$ a 2005 - en índices $1997=100$. (Extraído de Bercovich y Gigliani, 2006: 92)

\begin{tabular}{|r|r|r|}
\hline Año & Salario Real & Costo salarial \\
\hline 1998 & 99.4 & 103.6 \\
\hline 1999 & 99.8 & 106.9 \\
\hline 2000 & 101.4 & 103.4 \\
\hline 2001 & 99.8 & 106.9 \\
\hline 2002 & 80.5 & 59.1 \\
\hline
\end{tabular}

industrial se apropió de la totalidad de los recursos generados por la mayor productividad de la mano de obra y, también, de la pérdida de ingresos de los asalariados del sector. Esta significativa transferencia de ingresos desde los sectores obreros al capital aparece como una constante desde el mismo inicio de la gestión militar"(109)

${ }_{323}$ En un contexto general de pauperización y concentración de la riqueza: 'Si en los 70' era considerado pobre el 6\% de la población; este dato trepó al 29\% en 1985; retrocedió al 27\% en 1995; saltó al $51 \%$ en el 2003 y en el 2005 es del orden del 38\% de la población. La brecha entre lo que se apropia el 10\% más rico de la población y lo que recibe el 10\% más pobre que era de 8 veces a mediados de los '70, fue de 13 veces en el '85, de 20 veces en el '95, trepó a 26 en el 2001 y es del orden de las 31 veces en el 2005' (Lucita, 2006b: 76)

324 Estos datos no deben llevar a una lectura simplista acerca de la situación de los trabajadores, suponiendo que ante la caída del costo laboral estos vivirían en peores condiciones que durante la convertibilidad. Dichas mediciones hacen a la relación entre el valor que el obrero recibe y el valor que el obrero produce (lo que Marx denomina "salario relativo") y por lo tanto no se relacionan directamente con los niveles de consumo de los obreros y otras fracciones populares. Es la referencia a la posibilidad de acceder al consumo lo que permitiría pensar si se vive mejor o peor que en los noventa y por ello esa evaluación debería ir por el lado de analizar el poder adquisitivo del salario. La columna de "salario real" del cuadro 17 estaría mostrando que, a pesar del aumento en la explotación laboral, ya para el 2004 hay una mejora en la posibilidad de acceder al consumo, que se hace más significativa hacia el 2005.

${ }_{325}$ "El salario real es el salario nominal deflactado por el índice de precios al consumidor, que mide la evolución de los precios de la canasta familiar. Este índice es relevante para obtener una medición del salario real, esto es, para el cálculo de un salario con poder de compra constante. En cambio, el costo salarial es el salario nominal pero ajustado por el índice de precios de la producción industrial. En otros términos, el costo salarial mide, a lo largo del tiempo, el comportamiento del salario nominal que paga el capitalista vis-a-vis los precios que obtiene el mismo capitalista cuando vende su producción. Esto permite evaluar el salario desde el punto de vista de los costos, y es equivalente al concepto marxista del capital variable" (Bercovich y Gigliani, 2006: 90) 


\begin{tabular}{|r|r|r|}
\hline 2003 & 87.1 & 61.5 \\
\hline 2004 & 105.4 & 72.4 \\
\hline 2005 & 113.1 & 78.5 \\
\hline
\end{tabular}

Es importante destacar que los autores más representativos de este grupo comparten análisis que nosotros intentamos discutir en nuestra investigación. Así Lucita habla en varios artículos (entre ellos en 2005 y 2006a) de "descapitalización" y "desindustrialización", como resultados de las transformaciones económicas durante los años noventa. Es claro que si debatimos con una mirada como la de Basualdo que plantea una des industrialización, lo hacemos aún más fuertemente con los que sostienen que estamos ante una "descapitalización". Así también se reproduce en algunos de estos artículos (Lucita, 2006b) la idea de un Estado que habría perdido su capacidad de control y regulación, considerando que: “...el Estado no está ausente pero que abandonó la mayoría de sus funciones de regulación y control" (Lucita, 2006: 75).

También Pedro Resels ("El modelo neoliberal hoy") coincide en observar una primarización de la economía argentina, destacando que entre 1993 y 2003 se produjeron los siguientes cambios en la composición del PBI: “...los sectores agroganadero, minería y pesca pasaron de significar el 20\% al 37\%, mientras que el sector industrial disminuyó su significación del 56\% al 52\% y la construcción del 17\% al 7\%"(Resels, 2005: 51).

En el tercer anuario (EDI, 2007) se destacan algunos trabajos que buscan profundizar los debates comenzados el año anterior. Rolando Astarita ("Tendencias en la economía mundial y los cambios en Argentina") desarrolla una mirada de largo plazo, concluyendo que "...lejos de producirse un viraje hacia una nueva forma de acumulación distinta de las tendencias que operaron a partir de la crisis de rentabilidad, lo que ha sucedido en los últimos años es una consolidación y confirmación de las mismas" (Astarita, 2007: 10).

Desde una perspectiva similar Adrián Piva ("Modo de acumulación y hegemonía en Argentina'), remarca que no hay un cambio de bloque en el poder sino un nuevo balance de fuerzas al interior del mismo bloque. En ese contexto la recuperación económica se sustenta en la profundización de la explotación de la fuerza de trabajo "La brecha de productividad internacional persistió a lo largo de todo el período y comenzó a incrementarse en la segunda mitad de los '90. Bajo la presión de la competencia externa, las empresas que lograron sobrevivir compensaron esta brecha mediante el aumento de la explotación de la fuerza de trabajo" (Piva, 2007c: $54)$. 
Julio Gambina refuerza esta mirada en su artículo "Las tendencias globales y la economía Argentina". Allí cita de Javier Lindemboin, Damián Kennedy y Juan Graña ( "Distribución, consumo e inversión en la Argentina a comienzos del siglo XXI", 2006), el siguiente dato: “...los trabajadores cedieron 15.000 millones de dólares por la pérdida de ingresos desde diciembre del 2001 hasta diciembre del 2005, correspondiendo por lo tanto unos $\$ 4.500$ a cada uno de los 10 millones de trabajadores,326 (Gambina, 2007: 23).

Bonnet (“Argentina: ¿un nuevo modelo de acumulación?", 2007b) refuerza la perspectiva del aumento de la explotación de la fuerza de trabajo como mecanismo para recuperar competitividad a nivel internacional ${ }^{327}$, con la recurrencia en los últimos años a la inflación como mecanismo de reducción del salario real y de aumento, por esa vía, de las tasas de ganancia empresariales. Una perspectiva similar desarrollan Axel Kicillof y Cecilia Nahón (2007) en "El retorno de la inflación a la Argentina: un problema de salarios y ganancias".

Este muy breve estado de la cuestión pretende esbozar los elementos claves de algunas investigaciones que nos guían en la reflexión acerca de los debates principales en el campo de problemas que hace, específicamente, a la estructura económica social. Recuperamos aquí varios aportes que están más desarrollados hacia el final del primer capítulo. Nos preguntamos allí cuáles son los cambios que se producen en la estructura económica social del noreste del Chubut a partir de la hegemonía del capital financiero. Nuestra hipótesis es que los cambios avanzan en el sentido del conjunto del país, con el desarrollo de tres grandes procesos sociales: centralización y concentración de la riqueza y la propiedad, proletarización y pauperización de importantes masas de la población (con el desarrollo junto a esto de una miseria consolidada) y el incremento de la productividad global en función del gran capital concentrado. Estos procesos ya habían sido destacados hacia 1985 por el citado trabajo de Nicolás Iñigo Carrera y Jorge Podestá.

Durante los últimos cincuenta años (o sea incluyendo al período del desarrollo industrial y a la actual transformación) la historia de la región que estudiamos no tuvo características de "excepcionalidad", sino que avanzó hacia una mayor homogeneización con el resto del país. El objetivo del modelo de "polos de desarrollo" fue incorporar la región patagónica al desarrollo capitalista argentino, pasando por la

\footnotetext{
${ }^{326}$ Los mismos autores refuerzan con otros datos significativos esta imagen de la fuerte concentración y centralización de la riqueza: "Es así como, mientras que en 1993 "el ingreso capitalista" representaba el $32,7 \%$ del consumo privado, hacia 2004 ha llegado al 51,5\%, superando el consumo del resto de la población. En este sentido, no debe perderse de vista que los capitalistas representan una parte mínima de la población" (Lindemboin, Kennedy y Graña, 2006: 80).

${ }^{327}$ Así lo refuerzan varios artículos del tercer anuario, como el de Claudio Katz (2007) "El giro en la economía".
} 
fase del capital industrial para llegar al desarrollo del capitalismo en profundidad, en consonancia con el proceso nacional de realización hegemónica del capital financiero.

La Patagonia mantenía condiciones para desarrollar el capitalismo predominantemente en extensión hasta mediados de los ochenta, y ese fue el objetivo que realizó el modelo de polos de desarrollo. Una vez que se alcanzó el límite comenzó el proceso que ya se había puesto en marcha a nivel nacional: el desarrollo del capitalismo predominantemente en profundidad.

Como ya lo marcamos, destacamos que no estamos ante un proceso de des industrialización, sino, al contrario, ante un avance del dominio del régimen de gran industria que se instala como dominante en el territorio de Argentina. Junto con este proceso se desarrolla el aumento de la explotación del proletariado, tanto en intensidad como en extensión. Estos rasgos son parte de un movimiento orgánico del capital y están inscriptos, por lo tanto, en dinámicas de largo plazo. Pensar en procesos de "des industrialización" (para los noventa) o de "re industrialización" (para el período post convertibilidad), es quedarse en gran medida en el plano de lo aparente, y/o de procesos evidentemente coyunturales.

La des industrialización no debe medirse por los datos de cantidad de fábricas y puestos de trabajo. Como parte del proceso de concentración de la economía y de aumento de la productividad, menos obreros agrupados en menos fábricas con mejores niveles de maquinización han aumentado los niveles de producción. Estos datos, que no son fáciles de observar durante la década del noventa, sí se hacen evidentes en los datos que recogemos para el 2005 y creemos que se corrobora para la continuidad del proceso.

Hay un planteo extendido que caracteriza a este periodo como una fase en que el Estado-nación ha perdido peso, llegando a hablar de la "desaparición" del Estado. Llamativamente tanto desde los defensores del neoliberalismo como de algunos de sus mayores "críticos", se repetía, muchas veces sin casi analizarla, esta afirmación de que el Estado-nación ya no cumplía un rol clave en la planificación y regulación de la economía y la sociedad.

Creemos que las investigaciones a nivel nacional sobre los cambios económicos en el período demuestran que ha sido el Estado el que impuso las condiciones políticas, económicas y jurídicas que posibilitaron la realización hegemónica del capital financiero. Pero este debate sigue siendo un problema a discutir en nuestra región, y más en general en la estructura económica social de capitalismo de estado en enclaves. Es allí donde esa apariencia de la pérdida de peso del Estado se hace más significativa y se presenta como parte del sentido común, de lo que se hace directamente visible para la mayoría de la sociedad. 
Nuestra hipótesis es que en la región estudiada (al igual que a nivel nacional) el Estado sigue siendo el que regula y articula a la economía, pero que esa regulación y esa articulación se hace en el sentido de los intereses de otra alianza de clases que es la que ahora ocupa el poder político. Para nosotros no sólo no deja de haber un capitalismo de estado, sino que esta característica esta aún más acentuada que antes.

La cuestión es que las políticas impulsadas desde el Estado son diferentes a las de décadas pasadas, y van en beneficio de las grandes empresas privadas de capital concentrado, que son las que subsisten y crecen en el marco de la fase hegemónica del capital financiero. Las empresas que no son de capital concentrado dejan de recibir apoyo estatal, realizándose durante estos años un fuerte proceso de concentración de la propiedad y la riqueza que se expresa en el cierre de la mayoría de las pequeñas y medianas empresas, la venta a capitales extranjeros de otras y la caída de la producción de las que quedaron en pie.

La economía de la región pasa a estar directamente en manos del capital financiero transnacional que controla los enclaves de gran capital. Los enclaves generados por el papel del Estado como planificador en el sentido de los intereses del capital industrial, son en gran medida abandonados.

Desde mediados de la década del ochenta, y más claramente durante los noventa, se desarrolló un nuevo modelo de articulación del capitalismo de estado con el capitalismo de economía privada. Se desarrolla una profundización del dominio de los monopolios privados sobre los recursos naturales y la explotación del trabajo asalariado en la región.

Como parte del mismo proceso Argentina ha sufrido una profundización de su dependencia económica y política. Las empresas estatales dejan de apropiarse del trabajo asalariado y esta apropiación se concentra en las empresas de capital privado. Consideramos que así se configura un nuevo tipo de estructura que ya no se organiza como un capitalismo de estado en enclaves, sino que ahora toma la forma de un capitalismo de estado en enclave de grandes empresas privadas en condiciones oligopólicas o monopólicas. En este capítulo pretendemos terminar de demostrar la corrección de estas hipótesis generales.

\subsection{Un repaso descriptivo}

En este apartado buscamos hacer evidente las transformaciones económicas desde la narración de algunos de los principales hechos que tienen relación con el cambio de la estructura económica social en el noreste del Chubut durante el período que abordamos. Construimos esta descripción a partir de las noticias publicadas en los 
diarios de la región, de entrevistas a distintos informantes y prestando especial atención a las decisiones institucionales de los gobiernos provinciales y a los pronunciamientos de las cámaras empresarias. En verdad este apartado es un intento de complementar con mayor información el capítulo 3, donde presentamos una mirada de conjunto que, consideramos, permite hacer observables las transformaciones generales de la sociedad en el noreste del Chubut.

Ya en 1990 comienza a hacerse evidente la crisis de la estructura económica y la concentración de la riqueza con el progresivo cierre de pequeños y medianos comercios en la región. Como contrapartida, se destaca el "optimismo" que expresan los comerciantes mayoristas de la zona en relación al plan económico nacional ${ }^{328}$.

En el rápido proceso de centralización y concentración económica desarrollado por el programa del capital financiero encarnado en el gobierno de Menem, se da un importante paso al firmarse la privatización de ENTEL y anunciarse la "racionalización" de los ferrocarriles (eufemismo para referirse al despido masivo de empleados y el vaciamiento y desfinanciación del servicio para luego privatizarlo).

Hacia fines de enero la Cámara de Comercio del Este del Chubut publica un informe que sostiene que vivir en la Patagonia cuesta un $105 \%$ más caro que en la Capital Federal ${ }^{329}$, dato muy utilizado para la defensa de los regímenes promocionales y para generar la imagen de una "comunidad de intereses" entre todos los habitantes de la región. Esta "disparidad de costos" es una herramienta clásica en el discurso, tanto del empresariado como de parte de los trabajadores para impulsar alianzas entre sectores de la clase obrera y las patronales, que defienden "intereses de la región" en tanto "corporación económica".

Pocos días después se produce un nuevo golpe del capital financiero al conjunto de la masa obrera y explotada argentina, con la imposición del IVA generalizado y el aumento de todas las tarifas de gas, correo, teléfonos y luz, sumado al incremento del combustible. Estas medidas impactan muy fuertemente en la región, que viene de décadas con tarifas subsidiadas.

Tras la falta de reacción contundente a estas medidas el gobierno profundiza su ofensiva a nivel nacional, comenzando el proceso de cambio de moneda y atacando a los gremios en huelga. Los gremios telefónicos continúan su plan de lucha contra la privatización, pero lo hacen en condiciones de gran debilidad.

Hacia fines de abril Menem aseguró que los recursos naturales se transferirían a las provincias. Hace este anuncio en el marco de una reunión con autoridades de

\footnotetext{
${ }^{328}$ Diario Jornada, 3/1/1990, pág. 3.

${ }^{329}$ Diario Jornada, 23/1/1990, pág. 6 . El título de la nota es significativo acerca del tipo de discurso que se construye en Patagonia: "El precio de hacer patria".
} 
Chubut, Santa Cruz y Tierra del Fuego. Eran las primeras negociaciones para impulsar la privatización de YPF.

Se anuncia que a nivel nacional la tasa de desocupación y subocupación era del $17 \%$ ( $9 \%$ de desocupación y $8 \%$ de subocupación), siendo la más alta de las últimas décadas. Estos datos, que en ese momento parecen muy graves, fueron luego naturalizándose para la mayoría de la sociedad.

Los pequeños y medianos empresarios metalúrgicos de la zona solicitan apoyo al gobierno ya que según ellos están en inminente situación de cierre o suspensión de sus trabajadores. Casi la totalidad de estos talleres va cerrando sus puertas a lo largo de la década del noventa. Es imposible para ellos competir con la concentración económica y la entrada sin aranceles de productos importados a menor costo que su producción de base manufacturera, en muchos casos con fuertes resabios casi artesanales.

La grave situación económica de varias provincias de Argentina, provocada por los cambios económicos que se realizan aceleradamente en el marco del avance de los sectores más concentrados del capital financiero, se observa en las reuniones que para analizar esta problemática convocan distintos sectores políticos.

De esas "cumbres" entre gobernadores y ministros de economía de las provincias en crisis, sale un pronunciamiento exigiendo al gobierno nacional que se cumplimente el pago de la coparticipación federal y la totalidad de las regalías. Obviamente este reclamo sólo presenta el intento de recuperar el manejo de fondos propios por parte de muchos gobernadores cuyas provincias están en serios problemas financieros, y no una real disputa acerca del contenido del proyecto económico neoliberal.

El gobierno nacional ratifica en julio de 1990 el anuncio de que no habría reconsideraciones con respecto a la caída de la promoción industrial. De hecho se amplia la apertura de la economía con la baja de los aranceles y la modificación de la ley "anti dumping". Durante los siguientes meses distintos actores de la región intentan modificar esta decisión mediante negociaciones que no consiguen ningún logro significativo.

En el día de la industria los diarios de la zona sacan suplementos especiales, destacando la grave crisis del sector textil y pesquero. En lo pesquero, con 4262 empleados, se habla de leyes que hacen imposible la competitividad, entre ellas los altos aranceles a la importación de tecnología del exterior. Mientras tanto en lo textil esa misma apertura que se reclama en la otra rama es la que perjudica a las empresas de la zona. La entrada masiva de productos importados, junto a la parálisis de los regímenes de promoción industrial, impide la posibilidad de que estas fábricas 
puedan mantener una mínima competitividad en el mercado. Se destaca en varios suplementos el poco desarrollo del turismo, planteado por los editorialistas como la "industria del futuro",330. Claramente desde algunos sectores se empieza a plantear un cambio del tipo de estructura económica, con el paso de una economía productiva a otra de servicios.

En octubre, y en el marco de una aguda conflictividad social en la provincia de Chubut y otras regiones del país, se anuncia la transferencia de áreas petroleras no explotadas o de escasos recursos a las provincias. Este hecho se constituye en uno de los pasos claves hacia la privatización de los recursos energéticos de la Nación. Es una forma de negociar con los gobernadores su apoyo a la privatización, asegurando más posibilidades a las empresas privadas (ya que las provincias no tienen otra forma de explotar esos yacimientos que privatizarlos) y se avanza además en el progresivo vaciamiento y fragmentación de YPF.

Al comenzar el nuevo año Menem asegura que 1991 será el inicio del desarrollo y el crecimiento. Sin dudas fue el año de la consolidación hegemónica del dominio del capital financiero sobre la estructura económica social de Argentina. Dominio que significa también el desarrollo y el crecimiento, sin iguales en nuestra historia, de la pauperización y el empobrecimiento de la masa trabajadora, de la concentración de la riqueza y la propiedad y de la dependencia del país.

El 30 de enero de 1991 es un día de gran importancia para el dominio del capital financiero sobre el país: Domingo Cavallo asume el ministerio de economía. La UIA, entre otras organizaciones empresariales, avala la designación de Cavallo, en este caso "por su permanente compromiso con los sectores productivos del país",331. Lopez Murphy, otro de los cuadros económicos del capital financiero, apoya el proyecto económico y la designación del nuevo ministro. La primera decisión de Cavallo es ratificar la anulación de todos los aranceles y restricciones a las importaciones.

Para mediados de febrero se expresa en la región una parte de las disputas interburguesas que se producen en el país. Hay un pronunciamiento público de la $\mathrm{CAME}^{332}$, a la que adhieren la $\mathrm{FECH}$ y la $\mathrm{CICECH}$, en el cual se amenaza con no pagar más impuestos por la grave situación económica.

Casi todas las provincias del país atraviesan una difícil situación económica por los sucesivos ajustes: Catamarca (tres mil estatales cesanteados), Córdoba con una gran deuda del Estado nacional, Formosa con casi dos meses de atraso salarial, La

\footnotetext{
${ }^{330}$ Diario Jornada, 2/9/1990, pág. 2 del Suplemento Especial por el Día de la Industria.

331 Diario Jornada 30/1/1991, comunicado oficial de la UIA, pág. 24.

332 Confederación Argentina de la Mediana Empresa.
} 
Rioja, Salta, Neuquén, Santiago del Estero, Mendoza, Corrientes, Santa Fe y Entre Ríos, con fuertes déficits y problemas para pagar los salarios en término; en definitiva un marco de profundas dificultades aún en algunas provincias donde todavía no se han generado grandes conflictos sociales.

Poco a poco se avanza en la privatización de YPF. En marzo se licitan diez áreas centrales para que las empresas privadas se "asocien" con YPF. Casi al mismo tiempo se cierran cuatro ramales ferroviarios, con alrededor de trece mil suspendidos y novecientos cincuenta despedidos.

El 21 de marzo se anuncia la ley de convertibilidad. En uno de esos raptos casi teológicos de los teóricos neoliberales en su apogeo, Domingo Cavallo afirma que la paridad cambiaria "será para siempre" ${ }^{333}$. El ministro sostiene que esta decisión no puede sorprender a nadie. Sin embargo hacia pocos meses, al momento de su asunción, Cavallo había afirmado que no habría paridad cambiaria sino libre flotación. Tras esta medida, que implica una pérdida de soberanía para el país ya que el valor de nuestra moneda se fija al valor del dólar, el 26 de marzo los presidentes de Argentina, Brasil, Uruguay y Paraguay firman la constitución del MERCOSUR.

En este marco, y en medio de una estructura económica social que sufre duros golpes por las transformaciones que se desarrollan a nivel nacional, una encuesta realizada en Trelew entre los principales representantes de las cámaras empresarias, del comercio y sindicatos, expresa un amplio apoyo al plan económico propuesto por Cavallo. La mayoría sostiene, en contra de toda evidencia empírica, que ve en ese plan una posibilidad de recuperar la economía de la región y retomar la situación vivida en los años ochenta.

En abril se confirma la venta definitiva de Aerolíneas Argentinas, dando un nuevo paso en la transferencia de grandes negocios al capital financiero transnacional. Días después el gobierno nacional envía un primer proyecto de privatización de YPF al Congreso Nacional.

Hacia mediados de ese mes la UIP ${ }^{334}$ presenta un proyecto de promoción regional. El objetivo expresado en el documento que hacen público es "equilibrar la competitividad perdida por las fábricas ya instaladas en la provincia”,335. Asimismo sostienen que no pagarán las boletas de luz porque sino no podrían cubrir los salarios de los trabajadores.

La transformación de la sociedad se hacía evidente en hechos como la inauguración en agosto de 1990 del primer gran supermercado en Trelew. Ya en abril

\footnotetext{
333 Diario Jornada 22/3/1991, declaración de Domingo Cavallo, pág. 19.

334 Unión Industrial Patagónica.

335 Diario Jornada 17/4/1991, declaraciones de Juan Moravek, presidente de la UIP, pág. 2.
} 
de 1991 se anuncia el cierre del supermercado de la Cooperativa Eléctrica, Supercoop, que hasta esos años vendía a precios diferenciales a sus asociados. Obviamente no pudo competir con los grandes supermercados que se han instalado en la ciudad. Es un símbolo claro del avance de la concentración económica.

Casi al mismo tiempo se produce otro hecho muy simbólico como ejemplo del marco de crisis y caída de la estructura económica social tradicional de la región: en estos días se cierra el único cine de la ciudad de Trelew.

A mediados de 1991 Chubut firma un contrato de concesión por un área petrolera, entregando la explotación a empresas privadas. Esto, que se destaca como un éxito de la eficacia del nuevo gobernador ${ }^{336}$, constituye un significativo avance en la profundización de la dependencia estructural del país. Es importante la declaración del presidente de la empresa concesionaria, quién afirma que la baja rentabilidad del área que se les adjudica no se debe a que no sea rentable, sino al bajo presupuesto que el Estado nacional brinda a YPF, que hace imposible la explotación de esos pozos.

Las disputas interburguesas se expresan a nivel nacional con la presentación de dos listas en la UIA. Se polariza entre el $\mathrm{MIA}^{337}$ que defiende el programa de gobierno de Menem y Cavallo y el grupo opositor que impulsa una política de cambio más "moderada", con alguna defensa de la política centrada en la sustitución de importaciones y los aranceles a los productos de origen extranjero ${ }^{338}$.

En mayo ADITA ${ }^{339}$ advierte que la apertura indiscriminada (eliminación de derechos específicos y la reducción de los aranceles desde el $1^{\circ}$ de abril) producirá una avalancha de productos textiles importados. Para mediados de año ya se proyecta un aumento del $100 \%$ en la importación con respecto al año pasado.

Las mayores tasas de crecimiento de importaciones corresponden a las manufacturas de mayor valor agregado (tejidos $80 \%$, confecciones $20 \%$ ), a partir especialmente del "plan otoño" y de su puesta en marcha de tres aranceles diferenciales: $0 \%$ para fibras naturales, $11 \%$ para fibras manufacturadas y $22 \%$ para tejidos y confecciones. Para los tejidos las importaciones ya equivalen al $20 \%$ del total producido en el país, cifra que en ese momento aparece como escandaloso pero que luego aumentaría muchísimo y muy rápidamente ${ }^{340}$.

\footnotetext{
${ }^{336}$ Recordemos que ya estaba en manos de Fernando Cosentino, tras la caída del gobernador Néstor Perl. Cosentino, quién era el vicegobernador, había sido apoyado directamente por el gobierno de Menem para hacerse cargo del ejecutivo en reemplazo de Perl. Ver el apartado 3.3 para una descripción más profunda del proceso.

${ }_{337}$ Movimiento Industrial Argentino.

338 Denominado MIN, Movimiento Industrial Nacional. Para profundizar en esta disputa interna ver los artículos que citamos en el apartado anterior acerca de las luchas interburguesas.

${ }^{339}$ Asociación de Industrias Textiles de Argentina.

340 Datos publicados en Diario Jornada 31/5/1991, pág. 2.
} 
Cuadro № 18: Importaciones de tejidos y manufacturas primeros cuatro meses de 1991 y comparación con 1990. Fuente: ADITA.

\begin{tabular}{|lccc|}
\hline & Tejidos & Manufacturas & Total importaciones $1^{\circ}$ semestre \\
\hline Enero & 4200 & 800 & $1990=32.000$ \\
Febrero & 4900 & 1000 & $1991=80.000$ (proyectado) \\
Marzo & 3100 & 1400 & \\
Abril & 8000 & 3300 & \\
& \multicolumn{3}{c}{ Según información de ADITA, en miles de U\$S } \\
\end{tabular}

Este aumento de las importaciones se observa a nivel nacional, especialmente en el área textil, como ya veíamos, y en el de los juguetes, siendo la producción argentina en esa rama muy sobrepasada por las importaciones. La Cámara Industrial Argentina de la Indumentaria afirma que este año difícilmente se podría llegar a exportar por 40 millones de dólares, contra más de 90 millones exportados el año pasado.

El 30 de mayo Petrominera, organismo del gobierno del Chubut, anuncia la privatización del yacimiento Huemules (oro, plata, zinc y plomo). Continúa el gran negociado de la minería con capitales extranjeros que se profundizaría durante la década del noventa y que hoy sigue cada vez con más fuerza, sólo frenado, en algunos casos, por la lucha popular contra este saqueo de los recursos.

En julio el presidente de la UIP, Juan Moravek, elogia nuevamente el plan de Cavallo, avalando la búsqueda de la competitividad de las industrias patagónicas. Al mismo tiempo afirma que se deben buscar mecanismos para evitar que la apertura sea destructiva para la industria nacional. Recordemos el marco de degradación de la estructura económica que ya se vivía en la región; en ese contexto pueden sorprender estas declaraciones de apoyo de quién representaba, entre otros, al tan castigado sector textil con inversiones en la Patagonia. Se pueden leer como expresión del acuerdo de la mayoría de los sectores de la burguesía en un proyecto económico general que favorece a sus intereses como clase, aunque perjudique a algunas fracciones de ella, para después disputar a su interior los intereses de cada fracción.

Mientras el Estado nacional y las provincias anuncian un acuerdo para revisar los gastos sociales, y los gobernadores se comprometen a llevar adelante el plan económico de Cavallo, ADITA vuelve a expresar su inquietud por la importación masiva de productos textiles. Ya se ha registrado un aumento superior al $100 \%$ en los valores importados con respecto al primer semestre del año pasado. Mientras la importación de fibras cayó un 5\% (fibras importadas para ser procesadas en el país), aumentó la importación de hilados el $162 \%$, la de los tejidos el $237 \%$ y la de 
manufacturas el $405 \%{ }^{341}$. El dominio de la producción transnacional sobre el mercado textil de Argentina ya se hace evidente y se consolida en el tiempo.

También es crítica la situación del sector lanero. Según la Sociedad Rural de la región, más del $90 \%$ de las explotaciones ganaderas son deficitarias estructuralmente. El mínimo para ser rentables está calculado en 5 mil lanares, y sobre 4216 explotaciones sólo el 5,72\%, 242, tienen esa cantidad de animales. Del resto un $67,95 \%$ tiene menos de mil animales y el $26,33 \%$ entre mil y cuatro mil quinientos. La Sociedad Rural expresa su reclamo contra el parque industrial textil que trabaja con fibras sintéticas (constituyendo una directa competencia a la producción tradicional de la zona) y solicitan desgravación impositiva y subsidios a los combustibles para los productores agropecuarios ${ }^{342}$.

Además se produce un accidente natural que agrava la crisis de la región, en especial de su sector rural en Santa Cruz y Chubut: entra en erupción el volcán Hudson emitiendo una enorme cantidad de cenizas volcánicas que cubre los campos y provoca una caída vertical de la producción, con gran mortandad de animales.

En septiembre ADITA informa que la importación textil ya equivale al $35 \%$ de la producción interna. En el año se había casi cuadruplicado la importación total, tal como se observa en el siguiente cuadro (con base enero de $1991=100)^{343}$ :

Cuadro No19: Importaciones de textiles en 1991. Fu ente ADITA.

\begin{tabular}{|l|l|l|l|l|l|}
\hline Producto & Fibras & Hilados & Tejidos & Manufacturas & Total \\
\hline Enero & 100 & 100 & 100 & 100 & 100 \\
\hline Febrero & 39 & 133 & 112 & 117 & 95 \\
\hline Marzo & 105 & 102 & 77 & 291 & 99 \\
\hline Abril & 85 & 283 & 173 & 640 & 195 \\
\hline Mayo & 56 & 177 & 139 & 697 & 161 \\
\hline Junio & 184 & 340 & 165 & 700 & 229 \\
\hline Julio & 104 & 373 & 297 & 1100 & 311 \\
\hline Agosto & 96 & 887 & 386 & 1644 & 311 \\
\hline
\end{tabular}

En octubre se hace evidente la grave crisis que también atraviesan los pequeños chacareros del valle inferior del Río Chubut (Trelew, Rawson, Gaiman, Dolavon y 28 de Julio). Gran parte de ellos se declaran en bancarrota ya que debido a problemas en la comercialización (no se trasladaron a tiempo sus productos y llegan

\footnotetext{
${ }^{341}$ Datos publicados en Diario Jornada 23/7/1991, pág. 28.

342 Datos publicados en Diario Jornada 31/5/1991, pág. 12.

343 Datos publicados en Diario Jornada 10/9/1991, pág. 10.
} 
grandes cantidades de otros lugares del país o del exterior a precios menores) y a heladas tardías ${ }^{344}$ se ha perdido casi la totalidad de la producción del año.

Noviembre comienza con el anuncio del gobierno nacional del inicio de una nueva fase de la "reconversión". Se eliminan entes reguladores, suprimen aranceles a múltiples productos y dejan sin efecto impuestos a transacciones comerciales y financieras. Es un nuevo y significativo avance de la hegemonía del capital financiero a nivel de la estructura económica social.

Se le da a este proceso el marketinero nombre de "desregulación", presentándolo como un gran logro, ya que ahora todo sería controlado por el libre juego del mercado a través de las empresas privadas, sin más controles ineficientes y corruptos del Estado. Más allá de las palabras que utilizan los funcionarios, obviamente estamos ante otra regulación y otra planificación realizada desde el Estado a favor de la alianza de clases que ahora ocupa el poder, y no del abandono de la regulación y la planificación, como muchos investigadores aún hoy sostienen.

Al iniciarse 1992 el nuevo gobernador de Chubut, Carlos Maestro, anuncia un paquete de medidas de ajuste del gasto público provincial. Incluye la quita de beneficios a los trabajadores estatales, el recorte de algunas áreas (especialmente las de planificación estatal), la venta de inmuebles y vehículos del Estado, etc. Al otro día viaja a Buenos Aires para reunirse con el presidente Carlos Menem y firmar el acuerdo para que la provincia pase a controlar algunas áreas petroleras y se cobren las regalías atrasadas, todo a cambio del apoyo de los diputados y senadores de Chubut al proyecto de privatización de YPF.

Se promulgan nuevas medidas que profundizan la distribución regresiva del ingreso: Cavallo anuncia el aumento del IVA del 16 al 18\%. Se acentúa así el proceso de concentración de la riqueza con el incremento de este impuesto al consumo popular que impacta especialmente en los sectores de menores ingresos.

A fines de marzo se anuncia el acuerdo por la federalización de los hidrocarburos, por el cual ya se podía avanzar directamente hacia la privatización de YPF y la cotización en bolsa de sus acciones. Maestro es uno de los primeros firmantes de dicho acuerdo.

El senador Mac Kharty, dirigente del PJ chubutense, es uno de los principales lobbystas a favor de la privatización de YPF. Afirma en notas periodísticas que la privatización dará casi 18 millones de dólares a la provincia en menos de sesenta días y que lamentablemente todavía no se pudo aprobar en el senado por

\footnotetext{
${ }^{344}$ La falta de previsión y de recursos para actuar preventivamente ante la posibilidad de heladas tardías también parte del escaso capital con que cuentan estos pequeños y medianos propietarios rurales de la región.
} 
"cuestionamientos pueriles" y "exageraciones" como "que estamos entregando la Patria y otras cosas por el estilo"345.

Hacia pocos meses se había formado el Mopoch ${ }^{346}$, integrado por profesionales y empresarios de la zona, algunos de ellos ex funcionarios de la última dictadura y otros provenientes del PJ y del PACH. A través de una solicitada de página completa en los diarios de la región expresan un llamado a todas las fuerzas políticas, al pueblo del Chubut y al gobernador para defender los derechos de la provincia frente a lo que denominan el "olvido de la nación". Se reclama la construcción de obras, declarar a la Patagonia en emergencia económica y social, que se legisle la promoción económica al sur del Río Negro con devolución de recursos económicos (hidrocarburos, pesca, puertos, energía), eliminación del IVA y de derechos de importación para las industrias locales, aduanas zonales que restrinjan la entrada de productos del norte, régimen tarifario especial, facilidad en los créditos ${ }^{347}$. Era el programa de la burguesía con intereses en la región, que esta siendo arrasada y/o subordinada por el avance de la burguesía vinculada al capital financiero más concentrado.

Se constituye una "multisectorial" para analizar la crisis económica en la región y sus posibles soluciones. Es convocada por la Cicech y la Sociedad Rural. Se decide conformar una comisión de emergencia, con sindicatos (Setia, Bancarios, Sec), Cámaras Empresarias y de terratenientes (Cicech, Sociedad Rural, Cámara de la Construcción, Cámara de Comercio de Rawson), y partidos políticos como el Pach y la UCR. Se proyecta una reunión en el Congreso de la Nación junto a representaciones similares de Santa Cruz y Tierra del Fuego.

En esa reunión se plantea que la Patagonia terminará volviendo a ser el "desierto" anterior a la conquista: tanto por el efecto concreto del proceso de desertificación como por la constante "huida" de la población desocupada hacia regiones que permitieran mejores posibilidades de asegurar la supervivencia del nivel de vida familiar ${ }^{348}$.

El historiador y dirigente político Horacio lbarra ${ }^{349}$ publica un artículo en el diario Jornada, haciendo un importante balance de los cambios económicos y demostrando

\footnotetext{
${ }^{345}$ Diario Jornada 24/4/1992, declaraciones del senador César Mac Karthy, pág. 2.

${ }^{346}$ Movimiento Popular Chubutense.

347 Diario Jornada, 27/4/1992, pág. 5.

348 Acerca de la recurrencia del uso de la noción de "desierto" en la historia de Patagonia, y de sus múltiples significados, recomendamos a López, Susana; Gatica, Mónica y otros (2004) Patagonia, la construcción hegemónica del desierto. Su resignificación desde estrategias contrahegemónicas, Mimeo. Trelew.

349 Horacio Ibarra tiene una larga trayectoria en la región, siendo mucho más que un excelente investigador, uno de los pocos que ha trabajado seriamente los cambios económicos y sociales en la región. Además fue miembro de las comisiones de solidaridad con los presos políticos en los sesenta y setenta, fue secretario del concejo deliberante de Trelew, miembro destacado de diversos organismos de planificación, etc. A su vez en 1991 se había postulado como candidato a intendente por uno de los múltiples sublemas que en dicha elección llevó el PJ en el marco de la vigencia de la ley de lemas.
} 
claramente cómo se ha quebrado la estructura económica de la región. Muestra que en octubre de 1988 había en Chubut 13196 personas con problemas de ocupación laboral (siendo 8280 desocupados y 4916 subocupados). En menos de cuatro años se había casi triplicado la cifra con 30059 personas con carencias laborales (el 21\% del total de la fuerza de trabajo de la provincia) con 18236 desocupados y 11824 subocupados. Esto fue producto de la destrucción del modelo de desarrollo que se dio desde que en los años 1987-88 se suspendió la promoción a nuevos emprendimientos por parte del gobierno de Raúl Alfonsín, y se agravó con el programa económico de Menem-Cavallo-Maestro.

Los proyectos de radicación vigentes al año 1988 (y nunca puestos en práctica), mostraban las siguientes alternativas de crecimiento:

Cuadro № 20: Proyectos de radicación para la región noreste de Chubut que no fueron desarrollados por el freno a la promoción industrial para nuevos proyectos.

Procesamiento materias primas provinciales

\begin{tabular}{|l|l|l|l|l|l|}
\hline & Cantidad & Ocupación & $\%$ & Inversión x mil U\$S & $\%$ \\
\hline Lavaderos y peinadurías & 9 & 510 & 12,36 & 79.456 & 31,43 \\
\hline Curtiembres & 4 & 539 & 13,06 & 13.924 & 5,51 \\
\hline Alimentación & 3 & 115 & 2,79 & 30.333 & 12,00 \\
\hline Papel & 1 & 81 & 1,96 & 4.559 & 1,80 \\
\hline Aserradero & 1 & 22 & 0,53 & 318 & 0,12 \\
\hline Pesquera & 10 & 1395 & 33,81 & 41.243 & 16,32 \\
\hline Minera & 1 & 73 & 1,78 & 3.815 & 1,51 \\
\hline Subtotal & $\mathbf{2 9}$ & $\mathbf{2 7 3 5}$ & $\mathbf{6 6 , 2 9}$ & $\mathbf{1 7 3 . 6 4 8}$ & $\mathbf{6 8 , 6 9}$ \\
\hline
\end{tabular}

Procesamiento insumos intermedios

\begin{tabular}{|l|l|l|l|l|l|}
\hline & Cantidad & Ocupación & $\%$ & Inversión x mil U\$S & $\%$ \\
\hline Aluminio & 5 & 184 & 4,46 & 19.640 & 7,77 \\
\hline Metalurgia & 2 & 38 & 0,92 & 3.748 & 1,48 \\
\hline Construcción & 4 & 197 & 4,77 & 4.262 & 1,69 \\
\hline Equipos petroleros & 2 & 47 & 1,14 & 6.532 & 2,59 \\
\hline Textiles & 16 & 666 & 16,14 & 40.028 & 15,83 \\
\hline Confecciones & 1 & 259 & 6,28 & 4.924 & 1,95 \\
\hline Subtotal & $\mathbf{3 0}$ & $\mathbf{1 3 9 1}$ & $\mathbf{3 3 , 7 1}$ & $\mathbf{7 9 . 1 3 4}$ & $\mathbf{3 1 , 3 1}$ \\
\hline Totales & $\mathbf{5 9}$ & $\mathbf{4 1 2 6}$ & $\mathbf{1 0 0}$ & $\mathbf{2 5 2 . 7 8 2}$ & $\mathbf{1 0 0}$ \\
\hline
\end{tabular}

Fuente: Horacio Ibarra, datos Secretaría de Industria y Comercio Exterior.

Actualmente es docente de la carrera de historia en la sede Trelew de la UNP, estando a cargo de las cátedras de Historia Moderna y Seminario de Economía y Sociedad. 
Para Ibarra esto demuestra que había un perfil con claras posibilidades de ampliar la productividad y la industrialización de la región, con creación de puestos de trabajo estables. Sostiene que era posible proyectar un modelo que no se basara únicamente en la extracción depredadora de recursos naturales no renovables ${ }^{350}$. Cuando se dan a conocer los datos del Indec correspondientes a 1992, se muestra que la cifra informada de personas con carencias laborales es de apenas 494 menos que las estimadas por Ibarra en el trabajo relevado.

La Cámara de la Construcción local emite un informe sobre la situación del sector. Según sus datos hace trece años la construcción empleaba en todo el país a un millón de obreros, contra alrededor de 100 mil empleados en 1992. En la zona esto se refleja en el cierre del $60 \%$ de las empresas existentes y en que el $40 \%$ subsistente funciona a menos del $20 \%$ de su capacidad operativa ${ }^{351}$.

Hacia fines de 1992 un grupo de industriales con inversiones en Chubut se dividen de la UIP y conforman una nueva entidad empresaria, la $\mathrm{UICh}^{352}$. Esto se produce en el marco de las luchas interburguesas entre los empresarios con inversiones en la Patagonia. Estas disputas se han profundizado en los últimos meses en torno a reclamos sectoriales ante el gobierno nacional. El avance del dominio del capital financiero y la nueva configuración de la economía de la región que esto traía, provoca una intensa pelea por buscar algún privilegio que permitiera la supervivencia de cada fracción burguesa.

Ya en 1993 la UIP realiza un pronunciamiento público, destacando el gran crecimiento que había tenido la región bajo los proyectos del "desarrollismo" y la crisis que se desató al derogar las leyes de promoción industrial y modificar la estructura económica. Se materializa allí el programa de esta burguesía que iba siendo avasallado por la burguesía transnacional. Su único proyecto real es tratar de volver el tiempo atrás, reclamando que se regrese al modelo de desarrollo capitalista propio de la fase de crecimiento en extensión bajo el dominio del capital industrial, cuando ya el capital financiero había conquistado la hegemonía. Advierten, como dato de interés, que de seguir esta política el desempleo se duplicaría en Chubut en cuatro años.

Habíamos visto la división de la UIA en dos sectores enfrentados especialmente por su posición con respecto al proyecto de Menem que, obviamente, partía de sus intereses económicos y de si salían beneficiados o perjudicados por las reformas. Finalmente triunfa el sector vinculado directamente al proyecto menemista. El mismo día en que se produce esta elección, sectores del espectro político de centro

\footnotetext{
${ }^{350}$ El artículo y los datos expuestos pueden encontrarse en Diario Jornada 12/9/1992, pág. 3.

351 Datos publicados en Diario Jornada 30/9/1992, pág. 5.

352 Unión Industrial del Chubut.
} 
izquierda y grupos desplazados del justicialismo forman el "Frente Grande", que sería la principal fuerza política de oposición a Menem en el marco de los proyectos burgueses para el país.

Durante varios meses se desarrolla una campaña política desde el PJ, denunciando que el gobierno de Maestro no lleva el ajuste con la necesaria fuerza y que de hecho ha vuelto atrás con respecto a los avances de Cosentino, incorporando a 1512 nuevos empleados a la planta pública. Los números hablan de una explosión del personal de la administración pública que pasa de 13762 en 1983 a alrededor de 20481 en $1993^{353}$. Pero en verdad este aumento no era tan importante si lo comparamos con el incremento de la población general de Chubut, y las necesidades crecientes que el gobierno debía cubrir.

Quizás asustado por las críticas del menemismo sobre su falta de fuerza en el ajuste (o quizás interesado en demostrar que era un prolijo defensor de ese proyecto económico social), Maestro lanza en junio un decreto eliminando veinticuatro direcciones y dependencias de la administración pública. El ajuste se descarga especialmente sobre el área de seguridad social.

En septiembre la UICh realiza una de sus primeras acciones públicas de importancia al reclamarle al gobernador en una reunión oficial que la provincia firme el Pacto Fiscal propuesto por Nación. Se sostiene que la región debe entablar buenas relaciones con el gobierno nacional para obtener a cambio un apoyo a las políticas de promoción. Prima claramente en estos sectores la política de tratar de "salvar" las industrias de la provincia sin importar el resto de la Patagonia. Pero, sobre todo, se destaca ya la subordinación de la burguesía con intereses en la región al proyecto hegemónico.

A fines de octubre se realiza una reunión de los gobernadores patagónicos, donde el eje absoluto de debate es el tema de la firma del Pacto Fiscal. Todos los gobernadores reclaman que el poder central "escuche a la Patagonia"154, pero queda claro que más allá de las negociaciones y tironeos, el pacto sería firmado.

Durante la última parte del año el centro político pasa por la reforma constitucional planteada por Maestro para la provincia, en total coincidencia con la reforma impulsada por Menem a nivel nacional. El 16 de noviembre se firma un acuerdo público, (calificado como "histórico" por sus firmantes Maestro, Das Neves, Viglione, Sala y Arrechea) donde se pacta la reelección y la transformación del Estado, entre otros puntos. El acuerdo fija como antecedente el "pacto de Olivos" realizado por

\footnotetext{
353 Datos publicados en Diario Jornada 28/5/1993, pág. 3.

354 Diario Jornada, 26/10/1993, pág. 5. Declaraciones de Horacio Massaccesi, gobernador de Río Negro. Kirchner, en la misma página, afirma "existe en el presidente una muy buena voluntad de reunirse y buscar una solución".
} 
Menem y Alfonsín, asumiendo todos los presentes compartir la postura de ambos líderes políticos. Entre los acuerdos se incluye, como un punto central, la transformación del Banco Provincia en Sociedad Anónima, proyecto que ese mismo día ingresa a la Legislatura de Chubut, impulsado por el gobierno provincial.

El año se cierra con un importante hecho político que es la firma del Pacto Fiscal por parte de Chubut, tras la firma de Tierra del Fuego. El gobierno nacional logra quebrar la supuesta unidad de los gobiernos patagónicos, negociando acuerdos por provincia. El vice gobernador, Norberto Aubia anuncia que el sector productivo, en especial las industrias, se verán beneficiadas por la eliminación del impuesto a los activos. Por ello el gobierno pronostica una gran recuperación del parque industrial de Trelew y de la economía regional. Pese a sus divisiones y diferencias, la UIP, la UICh y la FECH aplauden la firma del pacto fiscal, anunciando que se ha dado un paso decisivo para el sector productivo.

En los primeros meses de 1994 se anuncia la creación de un Fondo Financiero que la provincia realizaría para apoyar la producción. Son más de 21 millones de pesos asignados a cuarenta y un proyectos privados. Este dinero, proveniente de la privatización de YPF, se entrega a empresarios privados casi sin requisitos (al menos no formales) y en proyectos de alto riesgo (algunos realmente descabellados para cualquiera que vive y/o conoce a nuestra provincia). Este proceso se constituye en realidad en una gran estafa, que luego lleva a la quiebra del Banco Provincia, la caída de casi la totalidad de estos proyectos (en verdad la mayoría ni siquiera se instrumentaron) y a la conformación de algunas grandes fortunas personales en la provincia del Chubut.

Se realiza un informe del Estado provincial, reconociendo la fuerte crisis por la que atraviesa la industria pesquera en Chubut. Se da una situación supuestamente paradójica: mientras aumentan constantemente las capturas (crece de menos de 200 mil dólares en 1988 a más de 1.400 .000 mil dólares en 1993) en paralelo desfallece la industria pesquera asentada en tierra. Obviamente tiene que ver con el modelo económico de saqueo del recurso pesquero, del cual los funcionarios del Chubut responsabilizan al gobierno nacional ${ }^{355}$.

En una evidente y dramática expresión de la pauperización de la estructura económica social de la región la Asociación de Cooperadoras Escolares de Trelew (ACET) denuncia que ya desde hace meses hay muchos niños que se desmayan de hambre en las escuelas. Ante esto reclaman el aporte del Estado para otorgar la copa de leche a todos los chicos, sin restricciones y en forma continua. La desnutrición

\footnotetext{
355 Datos expuestos por Sergio Sepiurka, subsecretario de Promoción y Desarrollo Económico de Chubut. Diario Jornada 24/2/1994, pág. 2.
} 
infantil, algo casi desconocido en la región durante los años de crecimiento, empieza a hacerse visible.

La UICh denuncia el 10 de junio la situación de "crisis general" de la industria patagónica. Se declara en "reunión permanente", se pronuncian en contra de la instalación de zonas francas y aseguran que "la continuidad del plan económico conspira seriamente contra la Patagonia sur' ${ }^{1356}$. Son los mismos empresarios que pocos meses atrás reclamaban la firma del pacto fiscal y expresaban su apoyo al proyecto nacional.

En 1995 un nuevo paquete de medidas aumenta el IVA al 21\%, elimina reembolsos por exportaciones, rebaja los aportes patronales y avanza en el ajuste estatal. Los grandes empresarios aplauden, el Banco Mundial y el BID aprueban nuevos créditos y el FMI afirma que esto permite avanzar en las negociaciones.

La concentración de la economía sigue su curso. En la región esto se expresa en un significativo hecho: la adjudicación a Aluar del complejo hidroeléctrico Futaleufú. Esta represa fue construida para alimentar a esa planta, y ahora directamente la empresa toma dominio directo sobre la misma. Así los grandes capitales van adquiriendo posesión directa de los recursos que antes usufructuaban de modo indirecto.

Durante 1996 la discusión central en los medios de prensa de la región pasa por reclamar al Estado nacional la continuidad de los pocos privilegios que aún se sostienen en vigencia como residuos de la antigua promoción industrial. Se afirma, desde diversos funcionarios del gobierno provincial y empresarios con inversiones en la región, que la información del Ministerio de Economía plantea que durante el año en curso serían eliminados totalmente los pocos créditos fiscales que aún recibe la provincia.

El gobernador Maestro dice que él confía en un "salvataje" de Menem, marcando la supuesta diferencia que existiría entre la visión "política" del presidente y la visión unilineal económica de Cavallo. Se denuncia la diferencia que se ha ido acrecentando en la promoción con respecto a las provincias beneficiadas con el acta de reparación histórica (San Juan, San Luís, Catamarca y La Rioja) que año a año reciben cada vez mayor porcentaje del crédito total.

De cuarenta y seis fábricas que llegaron a estar en producción en Trelew, un informe del gobierno muestra que al comenzar 1997 sólo quedaban veintiuna en pie. Pero aún peor era que de más de seis mil trabajadores ocupados se había pasado a

${ }^{356}$ Diario Jornada 11/6/1994, pág. 3. 
apenas $1764^{357}$. La crisis económica se evidenciaba también en otros datos, como que durante 1996 habían cerrado doscientos doce comercios minoristas. Además en un mes de 1997 esa cifra ascendió a cuarenta y cinco, con una caída en las ventas de más del 30\% para los minoristas ${ }^{358}$. El 83\% de los comercios habilitados entre 1990 y 1998 habían cerrado sus puertas. El principal factor es la crisis económica general de la región, la caída del circulante y la gran incidencia de los hipermercados inaugurados durante los primeros años de la década en Trelew y Puerto Madryn.

Por su parte la Sociedad Rural denuncia el proceso de despoblamiento rural. Según sus datos unas diez mil personas abandonaron las explotaciones. Reclaman auxilio del Estado, exigiendo que las promociones dejen de ser solamente industriales. La majada ovina cayó de 6.400 .000 en 1977 a 5.200 .000 en 1988 y 3.200.000 en 1996. Es un agudo proceso de descapitalización que no parece tener límites ni posibilidad de reformas sustentables. Se profundiza el proceso de extranjerización de la tierra y la conformación de grandes latifundios.

Durante las siguientes semanas se produce una polémica entre Amadeo, Secretario de Desarrollo Social de la Nación, y los funcionarios del gobierno provincial. Amadeo califica a la producción lanera como "inviable" ya que para él no tiene posibilidades de ser rentable en la actual economía. Ante esto los funcionarios provinciales intentan demostrar que esa afirmación era un error. Entre ellos el vicegobernador Aubía sostiene "nuestra lana tiene gran futuro"359.

El gobierno de la provincia anuncia que Chubut ha crecido, mostrando para ello datos de la exportación de productos durante 1996. Según esto Chubut exportó 816 millones de dólares, especialmente en petróleo (301 millones), aluminio (175), lana (111) y pesca (201) estando en apenas 4 millones y medio el siguiente rubro que es el de filamentos sintéticos ${ }^{360}$. Se muestra así una economía cada vez más centrada en la explotación de recursos naturales, en especial de recursos no renovables. El único caso que aparece como "excéntrico", como ya lo hemos marcado, es el de ALUAR con su producción de aluminio, pero en verdad debemos pensar que lo que exporta ALUAR es centralmente energía y no aluminio: energía conseguida a muy bajo precio gracias a la utilización de los recursos naturales hídricos.

Al comenzar 1998 se genera un nuevo hecho que evidencia la concentración económica y la centralización de la propiedad. ALUAR adquiere la empresa Uboldi,

\footnotetext{
${ }^{357}$ Diario Jornada, 16/2/1997, pág. 6 y 7 . El título de la nota es elocuente: “Informe reservado: Trelew esta en la ruina industrial".

${ }^{358}$ Diario Jornada, 12/7/1997, datos de la CICECh, pág. 6.

${ }^{359}$ Diario Jornada 26/4/1997, declaraciones de Jorge Aubía, pág. 2.

360 Datos Dirección General de Estadísticas y Censos de la Provincia.
} 
elaboradora de envases y otros productos en base al procesamiento del aluminio primario.

Se destaca también la llegada de varios bancos transnacionales a las ciudades de la región. En dos o tres meses se había instalado el Banco Galicia, el Banco Río y el Banco Francés. Esto aparecía como algo extraño, en especial por la situación de crisis económica que se sufría en la región. Sin dudas es un indicador interesante de la nueva fase del capitalismo, donde los grandes negocios financieros cada vez se "autonomizan" más de los ciclos económicos generales ${ }^{361}$.

Informes de las entidades empresarias plantean que la situación de crisis del parque se debe al gran aumento de las importaciones, en especial desde los llamados "tigres asiáticos" que envían sus remesas a precio de dumping al mercado latinoamericano. Reclaman la devaluación de la moneda (denuncian que desde que los asiáticos habían devaluado, nuestra moneda estaba ya demasiado sobre valuada), además de aranceles a la importación y leyes promocionales para la región. Asimismo demuestran que los mismos productos costaban casi el doble si eran importados por EEUU, dados los aranceles que fijaban las leyes de ese país para defender sus industrias ${ }^{362}$.

Al finalizar el año Maestro acuerda con la UICh reclamar en forma conjunta a Menem el aumento en la coparticipación de impuestos y la sanción de un nuevo régimen de promoción industrial que iguale las condiciones de la provincia con las del acta de reparación histórica. La UICh reclama además al gobierno provincial la rebaja de las tasas de interés del Banco Chubut.

Por su parte la Cámara de Industria y Comercio del Este del Chubut reclama, a través de reuniones con funcionarios del gobierno, la rebaja del impuesto por ingresos brutos. En 1999 denuncian, junto a otras cámaras de la provincia, que los municipios aumentaron aún más las tasas para recibir parte del ingreso que ahora iba a la provincia.

Se da otro paso en la extranjerización de la economía, con la venta de Klaukol a una empresa francesa. Así la empresa Cerámica Patagónica pasa a ser propiedad de Cerámica San Lorenzo, supuestamente sin que se produjera ningún cambio importante para el personal.

Durante el mes de junio Repsol anuncia que ha adquirido el control mayoritario de YPF al concentrar el $62 \%$ del capital accionario. Esto fue posible gracias a que, entre otros accionistas, venden sus acciones a Repsol las provincias de Chubut,

361 Este aspecto de la nueva dinámica de la estructura económica social lo trabajan especialmente Eduardo Basualdo y Daniel Azpiazu en los diversos trabajos que citamos en el anterior apartado.

${ }^{362}$ Estos informes son desarrollados por la UIA y los reclamos son efectuados desde la FITA (Federación de Industria Textil Argentina). Algunos datos pueden consultarse en Diario Jornada 31/8/1998, pág. 6. 
Mendoza y Santa Cruz. Chubut presenta la venta como un importante logro que permitiría cubrir las deudas de la provincia, al recibir 194 mil millones de dólares, mientras la municipalidad de Trelew recibe 10 mil millones. Repsol se coloca así como la novena empresa petrolera del mundo, con la expectativa de duplicar sus ganancias en menos de dos años. El antiguo senador Mac Kharty que tanto había impulsado la privatización (quizás por este logro ahora había sido designado Secretario de Energía de la Nación), asegura que no se producirían despidos pese a la situación casi monopólica de la empresa.

Durante el 2000 ya se va haciendo patente la crisis que estallaría en 2001. Especialmente las provincias arrastran un déficit en sus cuentas que comienza a dificultar la continuidad del pago de sus obligaciones.

En Tierra del Fuego se produce la asunción de Carlos Manfredotti como gobernador. El hombre del PJ declara a la provincia en "economía de guerra" anunciando la necesidad de un fuerte ajuste en las cuentas ya que se ingresa en cesación de pagos, con un déficit mensual de 300 mil pesos. En ese marco apoya el programa de gobierno de De la Rúa, cuyo gobierno claramente se encolumna tras las directivas del FMI.

Días después el ministro de economía de Chubut anuncia que la provincia debe ajustar 40 millones para lograr refinanciar la deuda, ya que sólo de esta manera se cumpliría con los deberes que el FMI le impone al gobierno nacional y que este descarga sobre las administraciones provinciales. Si bien Lizurume reclama excepciones a Chubut, el ajuste se pone en marcha, sin descuentos salariales o despidos pero sí reduciendo la atención presupuestaria en varias áreas del Estado, fundamentalmente las que tienen relación con la asistencia social.

Desde la cámara de comercio de la ciudad se anuncia una profunda caída comercial en Rawson. Se afirma que es la crisis más grave de los últimos años, producida por la falta de circulante, el ahorro que realizan los trabajadores ante la inseguridad de mantener el trabajo y la compra de muchos productos en los supermercados de Trelew. El promedio era de dos comercios cerrados por semana, con un bajísimo consumo de energía y el cierre de sucursales de firmas con casa central en Trelew y Puerto Madryn.

Mientras esto sucede en la región, y en todo el país se agudiza la crisis económica y la conflictividad social, el titular del BID declara que "Argentina ha tocado fondo,863 y que ahora vendría la recuperación de la mano de un necesario nuevo acuerdo con el FMI.

${ }^{363}$ Diario Jornada 5/9/2000, declaraciones de Enrique Iglesias, pág. 24. 
Junto a la disputa y las duras diferencias que ya habían surgido entre los integrantes de la Alianza por el tema de los sobornos en el senado, el nuevo frente de desacuerdo por el proyecto de presupuesto lleva al vicepresidente Carlos Álvarez a renunciar a su cargo. De esa manera rompe de hecho la alianza de gobierno que había asumido a fines de 1999, dejando un poder ejecutivo sumamente debilitado y en medio de una fuerte crisis política y económica. El fondo de disputa interburguesa se muestra en las declaraciones de Alfonsín y Duhalde, llamando ambos a modificar la convertibilidad, ante lo cual salieron a defender ese proyecto De la Rúa, Menem, Machinea, Ruckauf y el mismo renunciante Álvarez.

En este marco de crisis política y económica, Chubut firma el acuerdo fiscal que reclama el gobierno nacional, que es la imposición de un nuevo ajuste del FMI. Con la firma de Chubut sólo falta la de Kirchner, quién ese mismo día encabeza una protesta en Esquel contra el recorte del subsidio a los combustibles para la Patagonia. En Trelew la Comisión de defensa de la Exención Impositiva a los Combustibles intenta generar un proceso de convocatoria que no logra mayor repercusión social. Son "notables" de la ciudad y funcionarios públicos de ambos partidos mayoritarios. En Comodoro Rivadavia, en cambio, sí se conforma un espacio amplio, con organizaciones sociales de muy variada postura política, que se denomina "Patagonia de pie".

Durante todo el 2001, se desarrolla con mucha fuerza la disputa interburguesa entre distintos grupos del capital financiero. Esa disputa se sintetiza en la discusión sobre cual es la salida de la crisis: dolarizar o devaluar. Como ya lo destacamos varios investigadores analizan esta disputa desde diversas perspectivas metodológicas y diferentes enfoques ideológicos.

Finalmente la fracción que sostenía la devaluación como mecanismo para reencauzar la situación fue la que logró imponer su proyecto tras esta larga pulseada. El 6 de enero de 2002 el congreso nacional votó la salida de la convertibilidad. El dólar pasaba a cotizarse en 1,40 pesos, mientras se mantenía el corralito y se imponía un feriado bancario de dos días.

Los funcionarios de la municipalidad de Trelew destacan que las medidas del gobierno nacional, en especial la devaluación, generan una situación muy favorable a una posible recuperación de la economía de Chubut y la ciudad. Esto se debe a que esta provincia exporta el $30 \%$ de su producto bruto interno, a diferencia del resto del país que sólo exporta un $8 \%{ }^{364}$. Además muchos de estos productos son recursos

\footnotetext{
${ }^{364}$ Datos publicados en Diario Jornada 28/1/2002, pág. 4.
} 
naturales que no necesitan insumos importados, como es el caso de la producción lanera que se exporta desde parte del parque industrial de Trelew.

En ese marco de situación se forma "Polatex", un organismo público - privado, formado por el gobierno, productores laneros y empresarios que procesan la lana en la provincia. El objetivo de este organismo sería imponer normas de calidad y mejoramiento de la producción, que vuelva competitiva a la producción lanera local con la del resto del mundo. En ese momento Chubut tiene una majada de 3,8 millones de cabezas $(30 \%$ de la majada de Argentina, en su gran mayoría de merino australiano, la mejor raza para producción de lana), aportando casi el $30 \%$ de producción de lana sucia (15250 toneladas) ${ }^{365}$.

Para el mes de marzo de 2002 el porcentaje de desocupación, que en octubre del 2001 (en el foco de la crisis) se estima en un $18 \%$ de la PEA, pasa a ser de más del $22 \%$ a nivel nacional. Los despidos se incrementan y es cada vez más difícil la situación para los jefes de familia que se han quedado sin trabajo en la región. El Consejo Consultivo informa que el $20 \%$ de la población de Trelew es asistida por planes de empleo temporario. Se calcula en más de 4 mil a los beneficiarios directos, a los cuáles se sumaría su grupo familiar para abarcar dicho porcentaje ${ }^{366}$.

Hacia el 2003 ya se destaca la relativa recuperación económica. Especialmente esto se siente en la producción industrial, como ya lo veremos. El gobierno publica cifras oficiales, mostrando que en el 2002 se duplicaron las exportaciones del sector textil con respecto al 2001. Otro dato es que el aluminio desplazó del segundo lugar en cantidad de exportaciones a la pesca, siendo siempre el primer lugar para el petróleo.

Este informe oficial también permite ver el gran negocio que están haciendo los exportadores de lana, consiguiendo ganancias que en general no llegan a los trabajadores ni a los pequeños propietarios. Se despachan 23802 toneladas, un 9\% más que el promedio de la última década y la mejor en seis años, contabilizando ingresos por noventa y dos millones de dólares. Además esta producción se concentra en la región, siendo exportado desde los puertos de Puerto Deseado y Puerto Madryn el $86 \%$ de la lana y el $36,5 \%$ de los cueros lanares. En Trelew se ubican las dos principales exportadoras laneras a nivel nacional y cinco de las diez principales de todo el país ${ }^{367}$.

Ya vimos en el capítulo 4 (en el apartado de los trabajadores textiles), como hacia abril de este año se destaca la recuperación del parque industrial de Trelew. Según datos de los funcionarios del municipio trelewense, en diciembre de 2001 había

\footnotetext{
${ }^{365}$ Datos publicados en Diario Jornada 15/12/2002, pág. 11.

366 Datos publicados por el Consejo Consultivo de Trelew. Pueden consultarse en Diario Jornada 5/10/2002, pág. 5.

367 Datos publicados en Diario Jornada 24/2/2003, pág. 4.
} 
730 empleados en el parque textil sintético, en 2002, 872 y en 2003, 1012. Si a estos les sumamos las demás empresas, habría un total de 2191 puestos de trabajo con cincuenta y seis empresas en funcionamiento.

Sin embargo esta recuperación es poco dinámica y casi no hay nuevas inversiones, sino la puesta en marcha de áreas que habían estado inactivas por la crisis. Para junio el municipio de Trelew difunde un informe sobre la situación de las empresas instaladas en la ciudad, dando datos en forma particular. La falta de nuevas inversiones y la perspectiva de que la recuperación no pasa de ser un ciclo coyuntural, se observa en que de las empresas existentes en la ciudad sólo una supera los ciento cincuenta empleados y apenas cuatro superan los cien. Por enésima vez se reclama una nueva promoción industrial para retomar el crecimiento de la ciudad. El listado de empresas en funcionamiento en Trelew es el siguiente:

\section{Empresas de Trelew:}

Barracas: Barraca Patagonia (29 personas, barraca de cueros y lana, produce $468 \mathrm{mil} \mathrm{kg}$ de lana para el mercado interno y cueros para el exterior), A. Dewavrin Fils (12 personas y contratos temporarios en zafra, clasifica lana sucia, 4500 th de lana sucia, la mayoría para Francia), Mario Abdala e Hijos (30 personas, acopio de lana sucia y lavada, de 2 mil a 2500 tn, para mercado exterior), Alberto Abdala e Hijos (23 personas, más 12 en una cooperativa de trabajo, produce lana sucia, lavada y peinada, $3600 \mathrm{tn}$, mercado externo e interno), Standard Woll (2 personas ocupadas formalmente, más 20 en una cooperativa de trabajo, produce lana sucia, 7 mil tn, casi todo para el mercado exterior).

Empresas constructoras: Horneva ( 7 personas), Atlas (3 personas), Fapre (19 personas), OP premoldeados (3 personas), Cerámica Tremara (25 personas, ladrillera), Productos patagónicos (10 personas, ladrillera), Tecneco (35 personas, constructora), La media luna (2 personas), Villegas construcciones (3 personas), Conpat (16 personas, constructora), Chubut construcciones (16 personas).

Empresas metalúrgicas: Centro de maquinado (10 personas), Cometal (46 personas, mecano metalúrgica), Carinelli (5 personas), Indar (7 personas), Quinto Cipolletta (2 personas), Tecnas ( 2 personas), Mario Lebet ( 1 persona).

Empresas textil laneras: Chargeurs (74 personas, lavadero y peinaduría de lana, 10500 tn, mercado exterior), Pelama (49 personas, industrialización de pelo y lana, 1000 tn, mercado exterior), Punilla (lavadero y peinaduría de lana, mercado interno), Unilán (180 personas, lavadero y peinaduría de lana, lavada $7 \mathrm{mil}$ tn, sucia 16 mil tn, mercado exterior), Agropecuaria del Sur (54 personas, lavadero y peinaduría de lana, 2400 tn, mercado interno), Cosulán (125 personas, comercialización de lana: peinada 1920 tn, sucia 3840 mil tn; mercado exterior), Lanera Austral (90 personas, industrialización de lana, 1863 tn lana peinada, mercado exterior). 
Empresas Textil Sintética: Propulsora (85 personas, tejeduría, mercado externo), Surjet (58 personas, 3 millones de metros lineales de tafeta por mes, mercado externo), Sedamil (120 personas, hilandería de algodón, estampado y tejido de punto, $1.400 .000 \mathrm{~kg}$ y en tintorería $2.300 .000 \mathrm{~kg}$, mercado interno), Nylotex (58 personas, tejeduría), Alter (40 personas, tejido de punto, mercado externo), Soltex (106 personas, hilandería, tintorería y tejeduría, 50 mil kg mensuales, mercado externo), Textil World (54 personas, trabajo a fasón, hilandería y tejeduría, 113.000 metros mensuales, mercado externo), Tendlarz (54 personas, trabajo a fasón, hilandería y tejeduría, 113.000 metros mensuales, mercado externo), Soleplast (8 personas, fábrica de bolsas de polietileno, mercado interno), Casa Roma (40 personas, tejeduría, tejido plano y artesanal, 1 millón de metros lineales por año).

Otras empresas: Industria pesquera patagónica (43 personas, procesamiento de productos de mar, mercado interno), Gas Trelew (14 personas, mercado interno), Industrias Químicas del Sud (8 personas, productos químicos, mercado interno), Seres ( 6 personas, tratamiento material patológico, mercado interno), Reciclados patagónicos (9 personas, reciclado de plástico, mercado interno) ${ }^{368}$.

En julio se realiza el congreso de la UIA en Puerto Madryn y en ese marco la CAPIP destaca la importancia de la industria pesquera. Reclaman políticas de promoción e inversión estatal para la creación de astilleros y la exención del IVA para la importación de repuestos y la construcción de buques. Además apoyan la devaluación y piden que se vuelva a habilitar la presencia de barcos congeladores al norte de Puerto Deseado. Solicitan también la reglamentación urgente de la Ley Federal de Pesca en el marco de la fuerte disputa interburguesa con los empresarios pesqueros de Mar del Plata.

Al iniciarse el año 2004 el nuevo gobernador de la provincia, Mario Das Neves, afirma que buscara por todos los medios recuperar la promoción industrial con todos los antiguos beneficios para la región. Realiza varias reuniones con los dueños de las textiles de Trelew y recorre las instalaciones de algunas de ellas. Su reclamo se complementa con la búsqueda de que sea la provincia quién maneje los cupos de promoción, y no el Estado nacional como en el pasado, y se compromete a ser "el principal lobbysta'369.

El titular de la UICh declara que es un buen momento para la industria, en especial para la exportadora por la devaluación, pero también para la interna por la reactivación del mercado de consumo. Sostiene su expectativa en que se avance

\footnotetext{
${ }^{368}$ Puede consultarse en Diario Jornada 2/6/2003, pág. 6 y 7.

369 Diario Jornada 28/1/2004, declaraciones de Mario Das Neves, pág. 8.
} 
realmente en la promoción industrial y solicita que se dé vía libre a la explotación minera.

Durante los últimos meses del año vuelve a plantearse en primeras planas el conflicto económico por la falta de recurso pesquero. Esto se da en el marco de la fuerte interna nacional, y con la caída de la cantidad de merluza como condicionante general (algo que es producto de la depredación, que se permitió especialmente durante los noventa, pero a la cual nunca se puso un freno real).

El secretario de pesca de Chubut remarca que sería la peor temporada de la década, ya que a la caída de la merluza se le suma la falta de calamar y langostinos. En este sentido vuelve a observarse la falta de previsión, ya que la sobre exigencia hacia el calamar condiciona aún más la existencia de merluza, ya que el calamar es parte de la cadena trófica de ésta. Pero, aún en ese marco de crisis y dificultad para prever la continuidad de la actividad, la concentración económica y la extranjerización de la región sigue su curso. La empresa italiana Panapesca anuncia que inauguraría una nueva planta de procesamiento de pesca en tierra en Puerto Madryn. Se llama Kaleu-Kaleu, con una inversión de 5,5 millones de dólares y que tomaría a alrededor de cuatrocientos trabajadores.

Nuevas inversiones de empresas transnacionales llegan durante el 2005. Se empieza a discutir la posibilidad de una extensión de los contratos petroleros, que deberían garantizar a las grandes empresas el control del recurso hasta su agotamiento. Este reclamo lo empiezan a publicitar algunos directivos de las principales petroleras y, finalmente, lo comienzan a conseguir en el año 2007, con la renegociación hasta el 2047 de los principales yacimientos de Chubut.

Es fundamental en la estabilización de la situación económica y social, y como parte del cierre de la crisis de dominación más aguda, el acuerdo de canje de la deuda externa, por el cual Argentina comienza a salir del default. "En febrero del 2005, la Argentina salió del default más grande de su historia. Después de más de tres años de declarada la cesación de pagos, el gobierno logró cerrar un acuerdo sobre un monto a refinanciar de 81.800 millones de dólares, con el 76\% de sus acreedores" (Gigliani, 2005: 37).

La recuperación económica sigue su curso, aunque sobre bases más que endebles. Para la provincia el ciclo se basa en la alta tasa de exportación de los productos chubutenses y en la explotación acelerada de recursos naturales, algunos de ellos no renovables (como el petróleo o la minería) y otros que por el modo de explotación se transforman en no renovables (como la pesca).

Como ya lo destacamos, las empresas laneras son las más beneficiadas dentro del sector textil. Son también las que menor valor agregan al producto y las que menos 
puestos de trabajo generan. Para el año 2005 ya muestran mejores niveles productivos algunas empresas textiles sintéticas. Sus ventas se basan más en la paulatina recuperación del mercado interno. En este sector no se generan nuevas inversiones significativas, y el aumento productivo se realiza en base a poner en marcha capacidad instalada que estaba ociosa y al sostenimiento de altos grados de explotación de la fuerza de trabajo y de precarización laboral ${ }^{370}$.

El gobierno de Kirchner firma un decreto presidencial por el cual se prorrogan algunos beneficios impositivos a las empresas industriales instaladas en Patagonia. Esto mejora la previsibilidad de un sector que ya viene recuperándose desde la devaluación, que le ha permitido recuperar algunos niveles de competitividad con la producción internacional.

Se anuncia también la puesta en marcha de la nueva obra de ampliación de ALUAR, que ocuparía a unos mil trabajadores, teniendo una inversión total de 2500 millones de pesos. Este proyecto permitiría a la empresa aumentar su producción en 110.000 toneladas al año.

Es en ese contexto que cobran fuerza los reclamos de aumento salarial. Como ya lo hemos visto, el año 2005 es atravesado por conflictos de diversas fracciones de trabajadores y hasta por otros sectores sociales, como los estudiantes. Estos hechos adquieren gran relevancia pública y logran generar protestas que repercuten fuertemente en la sociedad, aunque sin lograr, en general, superar la dimensión corporativa de sus reclamos.

\subsection{Las transformaciones económico-sociales}

En este apartado buscamos profundizar la comprensión de las transformaciones de la estructura económica social que se producen en el noreste del Chubut desde 1990 hasta alrededor de 2005. Partimos de una visión dialéctica que entiende a lo que llamamos "estructura económica" como parte de la totalidad en movimiento que constituye a la sociedad, y que por ello está profundamente relacionada con los procesos de lucha social. Consideramos que la estructura de una sociedad es una relación de fuerzas (Gramsci, 1997) que como tal está en permanente transformación. Por ello lo que debemos investigar es el movimiento de la sociedad en su conjunto.

\footnotetext{
${ }^{370}$ Citamos a Adrián Piva (2007c) "En el caso de la "producción textil" es importante señalar que además de haber crecido de manera permanente la utilización de su capacidad instalada, lo que puede ser un indicador de la escasa ampliación de su dotación de bienes de capital, presenta un importante aumento del trabajo no registrado, si utilizamos como indicador la proporción de asalariados sin aporte jubilatorio" (61).
} 
En esta estructura se produjeron importantes cambios a partir de la imposición de la hegemonía del capital financiero, que abandonó el antiguo modelo de planificación estatal vinculado a los programas de "polos de desarrollo", propios de la fase de dominio del capital industrial, para pasar a otra planificación, ahora desde el interés del capital financiero ya dominante a nivel nacional. Se produjo así un nuevo marco social y de relaciones de fuerzas que determinaron un fuerte proceso de pauperización de la población trabajadora en la región, traducido en: pérdida masiva de puestos de trabajo, cierres de fábricas, mayor explotación de los obreros ocupados y el desarrollo y agravamiento de una miseria consolidada.

Intentaremos entonces comprender y conceptualizar cuáles fueron los cambios que se produjeron, cuál es la nueva articulación entre el capitalismo de estado y el capitalismo de economía privada y quiénes son los sectores beneficiados y los perjudicados por estos cambios. Nos ocuparemos aquí centralmente de la estructura económica, o sea del ámbito de la sociedad que se refiere a las relaciones necesarias e independientes de la voluntad de los hombres que viven bajo ellas, las relaciones que los hombres contraen en la producción de su existencia y que se corresponden con un determinado grado de desarrollo de las fuerzas productivas materiales de la sociedad (Gramsci, 1997).

Como ya lo vimos los cuestionamientos a la promoción industrial iban creciendo desde principios de los años ochenta. Esta dinámica avanza, especialmente con el fortalecimiento de los sectores más ligados al capital financiero dentro del gobierno de Alfonsín tras el fracaso del intento inicial de retornar a algunos criterios de la fase de expansión del capital industrial (ver Pucciarelli, 2006 y Boron y Thwaites Rey, 2004). Para la región este quiebre se traduce claramente en términos de una periodización estimativa del cambio de la estructura económica. Hacia 1985 ya encontramos las primeras caídas en la producción industrial de la provincia de Chubut (cuando llegaba al 30\% del PBG provincial, su máximo de participación). A partir de 1986-1987 los sectores neoliberales imponen su política con respecto a este tema y se interrumpe la promoción a nuevos emprendimientos (Beinstein, 1993 e lbarra, 1997).

A esa decisión, que planteaba una compleja situación para el futuro de la provincia, se suma la problemática financiera y estructural del Estado provincial. Desde 1988 Chubut comienza a recibir menor porcentaje de la coparticipación y ve progresivamente congelados sus recursos, al igual que otras provincias como Santa Cruz, Jujuy, Tucumán o Santa Fe.

Ese marco lleva a una profunda crisis del Estado provincial y al atraso en el pago de los sueldos de estatales. Ante esto se producen protestas en las provincias mencionadas, adquiriendo mayor profundidad en el caso de Chubut, Santa Cruz y 
Jujuy. Para el caso de las provincias patagónicas estos procesos son expresión de la crisis de la estructura económica social del capitalismo de estado en enclaves y de las disputas que se desarrollaban en torno a cual sería la continuidad del proceso (Luque y otros, 2000).

La agonía en la que ya había entrado el parque industrial de Trelew se aceleró al permitirse la libre importación de productos, especialmente con la entrada a precio de dumping de las exportaciones asiáticas. La curva de evolución del PBG de la provincia muestra que tras un ciclo de crecimiento económico casi sin interrupciones y muy veloz entre 1970 y 1986, se inicia un período de estancamiento entre 1986 y 1989 y una fuerte caída a partir de ese año y hasta 1992.

Desde 1992 comienza un nuevo período de estancamiento, con bajos niveles del PBG que continúan hasta 1996, cuando se inicia una recuperación que lleva a que ya en 1997 se recupere el nivel de producción del "ciclo dorado" de los años ochenta. Tras esto hay nuevas caídas en 1999 y más claramente en 2002. A partir de esa fecha se inicia un período de crecimiento que podríamos extender hasta el presente.

Gráfico №1: curva de evolución Producto Bruto Geo gráfico entre 1970 y 1999, Base $1970=100$.

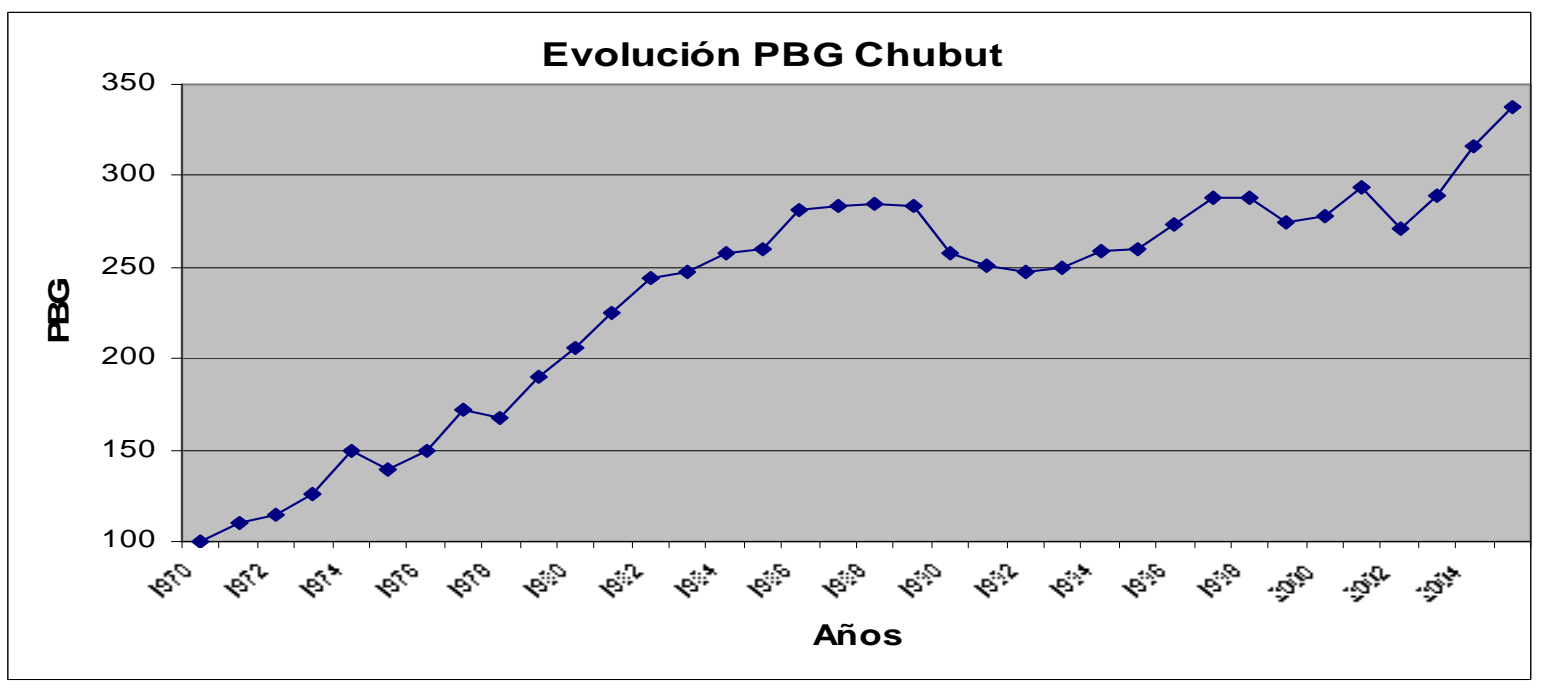

Elaboración propia en base a Beinstein, Jorge (1993), Laveglia, Fernando (2004) y datos de la Dirección General de Estadísticas y Censos de la Provincia del Chubut.

Cuadro N²1: evolución Producto Bruto Geográfico e ntre 1970 y 1999, Base $1970=100$.

\begin{tabular}{|r|r|}
\hline \multicolumn{2}{|c|}{ Evolución PBG Chubut } \\
\hline Año & PBG \\
\hline 1970 & \\
\hline 1971 & 100 \\
\hline 1972 & 110 \\
\hline 1973 & 115 \\
\hline 1974 & 126 \\
\hline
\end{tabular}




\begin{tabular}{|c|c|}
\hline \begin{tabular}{l|l}
1975 \\
\end{tabular} & 139 \\
\hline 1976 & 150 \\
\hline 1977 & 172 \\
\hline 1978 & 168 \\
\hline 1979 & 190 \\
\hline 1980 & 206 \\
\hline 1981 & 225 \\
\hline 1982 & 244 \\
\hline 1983 & 248 \\
\hline 1984 & 258 \\
\hline 1985 & 260 \\
\hline 1986 & 281 \\
\hline 1987 & 284 \\
\hline 1988 & 285 \\
\hline 1989 & 283 \\
\hline 1990 & 258 \\
\hline 1991 & 251 \\
\hline 1992 & 247,3 \\
\hline \begin{tabular}{|l|}
1993 \\
\end{tabular} & 249,7 \\
\hline 1994 & 258,4 \\
\hline 1995 & 259,6 \\
\hline 1996 & 273,1 \\
\hline \begin{tabular}{|l|}
1997 \\
\end{tabular} & 287,9 \\
\hline 1998 & 287,9 \\
\hline 1999 & 274,6 \\
\hline 2000 & 278 \\
\hline 2001 & 293,9 \\
\hline 2002 & 271,7 \\
\hline 2003 & 289,5 \\
\hline 2004 & 315,8 \\
\hline 2005 & 337,1 \\
\hline
\end{tabular}

Elaboración propia en base a Beinstein, Jorge (1993), Laveglia, Fernando (2004) y datos de la Dirección General de Estadísticas y Censos de la Provincia del Chubut.

¿Qué primeras lecturas puede permitirnos esta mirada? La caída del PBG durante gran parte de los años noventa es una de las formas en que se expresa la profunda transformación de la estructura económica social. Dicha transformación se desarrolla especialmente entre fines de los años ochenta y los primeros años de la década del noventa. El derrumbe del PBG (tras años de crecimiento ininterrumpido) se explica por el momento clave que ya se está viviendo en la región: estamos ante un cambio de estructura. Se trataba allí de destruir la estructura económica social preexistente, disolver ese territorio social, atacar las relaciones sociales que le habían dado forma y sustento. Por eso es lógico que en esos años se refleje una "caída y crisis de la economía", pero que en verdad estaba expresando el proceso de cambio, 
estaba consolidando las bases para un nuevo desarrollo de la economía en el marco de nuevas correlaciones de fuerzas.

Una vez que los cambios más profundos se habían realizado se trataba de construir las nuevas relaciones sociales que darían forma al nuevo territorio social. E dominio del capital financiero sobre la estructura económica replanteaba las condiciones de acumulación de capital, transformando las condiciones de venta y compra de la fuerza de trabajo y de negociación y disputa del precio que se pagaría por esa fuerza. Ya vimos como este proceso impacta fuertemente en los trabajadores.

Nosotros marcamos dos hitos en este proceso de cambio en los primeros años de los noventa. El primero fue entre los textiles, hacia 1991, en sintonía con el proceso nacional y en el marco de las derrotas de grandes huelgas como las de telefónicos y ferroviarios. El segundo fue el de ALUAR hacia principios de 1994, más estrechamente relacionado con los últimos estertores de las resistencias desarrolladas por los trabajadores ante la privatización de YPF. Es tras este segundo hito cuando el capital financiero dominante puede relanzar la acumulación capitalista sobre las nuevas bases construidas y recuperar rápidamente los niveles productivos del pasado. Consideramos que es clave observar que en 1993 la burguesía con intereses en la región, que en su mayoría estaba siendo perjudicada por el nuevo proyecto, se termina de subordinar al dominio del capital financiero.

Es cierto que la recuperación económica se basa en gran medida en la explotación de recursos naturales no renovables (pesca y petróleo) y en la buena cotización coyuntural de alguno de estos recursos (básicamente del petróleo). Pero debemos observar que el ciclo de crecimiento posterior a la crisis que se expresa en la caída del 2002, ya muestra un movimiento orgánico de la economía de la región.

Hay un crecimiento sostenido del PBG que supera con creces a los momentos más altos del antiguo período de crecimiento en el marco del modelo de polos de desarrollo. Como ya vimos este crecimiento se sustenta en el aumento de la explotación de los trabajadores ocupados, la creación de un ejército industrial de reserva y el desarrollo y consolidación del régimen de gran industria.

Cuando tomamos sólo la producción industrial vemos que la caída comienza en 1985 y se derrumba desde 1989, con el consiguiente proceso de cierre de fábricas, pérdida de puestos industriales y de múltiples puestos laborales en actividades que giraban en torno a la industrial. La mayoría del parque industrial textil se derrumba, así como muchas plantas pesqueras de procesamiento en tierra, que entran en continuas crisis por la competencia de las empresas multinacionales que procesan la pesca en alta mar. 
Solamente la única gran industria de la región, ALUAR, permanece casi sin problemas, excepto por una crisis de corto alcance a comienzos de los noventa que es eficazmente resuelta mediante el despido de gran parte de sus empleados y la intensificación de la explotación laboral sobre el personal ocupado. Ya hemos desarrollado algunas reflexiones sobre ALUAR, como caso de una gran empresa formadora de precios a nivel nacional que establece otro tipo de relación con el Estado, logrando mantener y hasta acrecentar sus privilegios.

La recuperación de la producción industrial que se observa después del pozo de 1992 tiene una fuerte relación con el proceso de crecimiento de esa gran empresa, que aumenta constantemente su capacidad de producción. Además del crecimiento de ALUAR la recuperación industrial se centra especialmente en la actividad vinculada al procesamiento de materias primas, con escasa agregación de valor y poca generación de empleo (por eso se dan fluctuaciones bastante marcadas, dependiendo del precio internacional, la presencia del recurso natural, etc.). Estas actividades son, especialmente, los lavaderos y peinadurías de lana y el procesamiento en tierra de la pesca.

El crecimiento de la producción industrial en el parque de Trelew, se da centralmente alrededor de la exportación lanera, con poco valor agregado y escasa generación de empleo. Se generaron grandes negocios basados en la diferencia entre el euro o el dólar en el que las barracas laneras vendieron esta producción al exterior y el peso en que pagan la lana y los salarios en la provincia. Sin embargo en los últimos años se ha avanzado en alguna medida en la agregación de valor al producto, desarrollando en mayor proporción la cantidad de lana lavada y peinada que es exportada en comparación con la lana sucia.

La industria textil sintética es, quizás, el ámbito donde más se hace observable la nueva configuración del capitalismo. Como ya vimos hay gran cantidad de cierre de fábricas y permanentes suspensiones del personal. Es una larga crisis de una rama de la economía especialmente afectada a nivel nacional por el cambio general, siendo los golpes aún más fuertes para las empresas que tenían inversiones vinculadas al régimen de promoción industrial al sur del paralelo 42.

Sin embargo hasta esta rama de la producción industrial logra en el último período aumentar sus niveles productivos. De todas maneras nunca llega a estar cerca de su fase de esplendor, retomando apenas los índices de fines de los noventa. Como ya lo marcamos no se registran nuevas inversiones de importancia, sino que estamos ante la puesta en funciones de estructura productiva ya instalada que estuvo ociosa durante la fase más aguda de la crisis. 
Gráfico N²: curva de evolución Producto Industria I entre 1970 y 2000, Base $1970=100$.

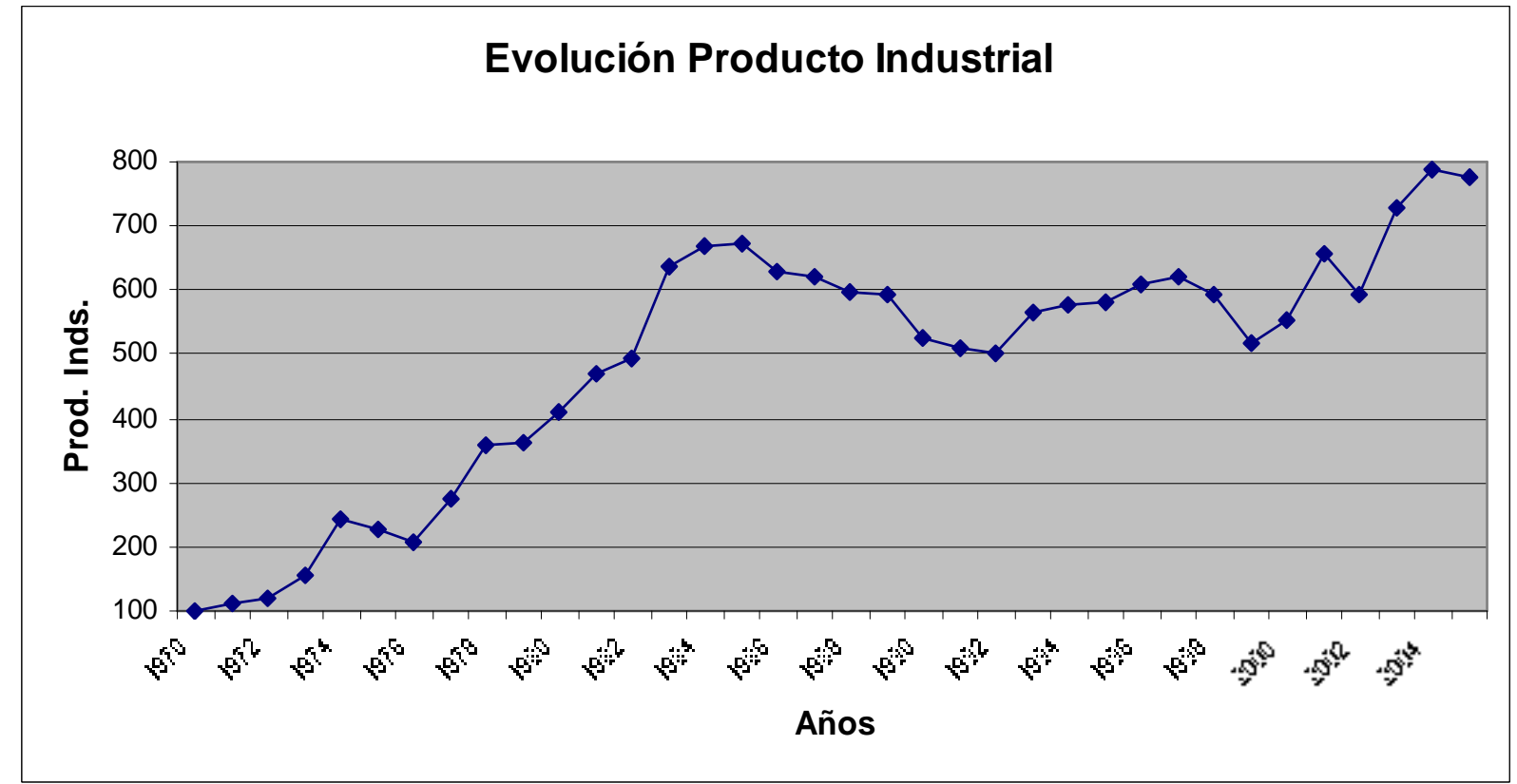

Elaboración propia en base a Beinstein, Jorge (1993), Laveglia, Fernando (2004) y datos de la Dirección General de Estadísticas y Censos de la Provincia del Chubut.

Cuadro N²2: evolución Producto Industrial entre 1970 y 2000, Base $1970=100$.

\begin{tabular}{|r|r|}
\hline \multicolumn{2}{|c|}{ Evolución Prod. Industrial Chubut } \\
\hline Año & Producto Industrial \\
\hline 1970 & 100 \\
\hline 1971 & 112,1 \\
\hline 1972 & 119 \\
\hline 1973 & 157,2 \\
\hline 1974 & 242,3 \\
\hline 1975 & 227,7 \\
\hline 1976 & 207,7 \\
\hline 1977 & 273,9 \\
\hline 1978 & 360,1 \\
\hline 1979 & 363,5 \\
\hline 1980 & 409,3 \\
\hline 1981 & 469,2 \\
\hline 1982 & 491,8 \\
\hline 1983 & 637,4 \\
\hline 1984 & 669,4 \\
\hline 1985 & 671,3 \\
\hline 1986 & 629,7 \\
\hline 1987 & 621,3 \\
\hline 1988 & 596,2 \\
\hline 1989 & 593,9 \\
\hline 1990 & 527,5 \\
\hline 1991 & 508,3 \\
\hline 1992 & 501,6 \\
\hline 1993 & 567,1 \\
\hline 1994 & 578,7 \\
\hline 1995 & 580,8 \\
\hline & \\
\hline
\end{tabular}




\begin{tabular}{|r|r|}
\hline 1996 & 607,2 \\
\hline 1997 & 620,9 \\
\hline 1998 & 594,5 \\
\hline 1999 & 517,4 \\
\hline 2000 & 554,4 \\
\hline 2001 & 656,1 \\
\hline 2002 & 594,1 \\
\hline 2003 & 728,4 \\
\hline 2004 & 786,7 \\
\hline 2005 & 777,5 \\
\hline
\end{tabular}

Elaboración propia en base a Beinstein, Jorge (1993), Laveglia, Fernando (2004) y datos de la Dirección General de Estadísticas y Censos de la Provincia del Chubut.

Tras una caída pronunciada a partir de 1986 (que continúa y se profundiza hasta 1992), comienza allí una paulatina recuperación que durante los noventa no consigue todavía recuperar los niveles de producción industrial de los años ochenta. La producción industrial de la región vivía el peso de la obligación de acomodar su proceso productivo a la competencia internacional, debiendo avanzar en las condiciones que aseguraran la competitividad de sus productos en un mercado cada vez más ceñido a la ley del valor operando sin mayores condicionamientos a nivel internacional.

El piso en 1992 también expresa el momento en que ya se hacía evidente para gran parte de la clase obrera de la región que se estaba ante una nueva situación estructural. Aparecen allí los primeros rasgos de conciencia acerca de la situación de desocupación masiva y de las condiciones que esto traía aún para los obreros ocupados. Pero aún no había fuerza para luchar contra esa situación, entonces de lo que se trataba era de adaptarse a la misma, negociando a la baja los salarios que se aceptaban como precio para la venta de la fuerza de trabajo.

Es sobre ese piso que comienza la leve recuperación de la competitividad. Sin embargo la misma sigue atravesando permanentes fluctuaciones, teniendo profundas caídas hacia 1999 y en 2002, aunque ya todo este período se desarrolla en torno a una nueva base del nivel de producción industrial, semejante a la de fines de los ochenta.

Es tras la devaluación cuando se consolida el nuevo régimen de gran industria. Allí registramos un rápido aumento del producto industrial que supera ampliamente los niveles de mediados de los ochenta. Estamos ante un nuevo marco. Menos obreros en menos fábricas con mejores niveles técnicos producen mucho más que una mayor cantidad de trabajadores en mayor cantidad de fábricas.

El personal empleado en el parque industrial de Trelew pasa de unos 4200 empleados de planta en 1974 a alrededor de 5500 en 1985, momento de mayor expansión del parque (número que en verdad se elevaba a alrededor de 6500 con 
personal temporario, contratado o en negro). Desde esa fecha la caída comienza a ser cada vez más pronunciada, con 5000 empleados para 1986, 2400 en 1993, 1700 para mediados de los años noventa y unos 1200 para el 2002.

La recuperación de la competitividad de varias industrias gracias a la devaluación de la moneda y la fijación de aranceles a la importación de varios productos, impacta rápidamente en la recuperación del empleo. Entre todas las empresas se pasó a 2438 puestos hacia fines del 2003 y a 2743 para julio del 2004. A su vez las textiles sintéticas pasaron de 979 a 1116, las laneras de 696 a 717 y las barracas de 155 a 171. Hacia fines del 2005 la totalidad de los obreros y empleados que trabajaban en el parque industrial estaba cerca de los $3400 .^{371}$

Es claro que, aún en una fase de recuperación, son unos 3 mil puestos de trabajo por debajo del nivel de empleo registrado quince años antes. A la vez se había desarrollado un importante aumento poblacional, que hacia aún más grave la problemática del empleo. Para el 2003, y con esos miles de trabajadores menos ocupados, la industria logra superar ampliamente los niveles productivos de 1985. Números semejantes podríamos encontrar si se pudiera medir la situación de empleo en las pesqueras, aunque es una tarea infructuosa dada la enorme cantidad de empleo en negro y la fluctuación del personal contratado de acuerdo a los ciclos del recurso natural. Pero tanto en dicha actividad como en otras (metalúrgicas, petróleo, etc.) se ha reducido claramente la cantidad de trabajadores, aumentando pese a ello la cantidad de producto generado.

Hacia mediados de la década del noventa también se denota, como parte central de la estrategia patronal, la acentuación del proceso flexibilizador para buscar una mayor explotación de la fuerza de trabajo. Entre los textiles se impulsa el ingreso de nuevo personal bajo modalidades precarizadas (sistema americano de seis por dos, turnos rotativos, mayor cantidad de telares a cargo de cada operario, vacaciones más cortas y en cualquier fecha, etc), que reemplazan al personal más antiguo.

Ya registramos también algunos elementos del profundo cambio y reestructuración del proceso productivo en ALUAR. También en las otras ramas de la economía se avanza hacia la profundización de los niveles de precarización y flexibilización, mecanismos para asegurar una mayor explotación de la fuerza de trabajo ocupada: la aparición masiva de las cooperativas truchas, especialmente entre los trabajadores pesqueros, es quizás la más evidente de las múltiples situaciones que un trabajo que se enfocara en investigar directamente los procesos productivos podría observar.

${ }^{371}$ Datos de AOT, SETIA y de la Secretaria de Producción de la Municipalidad de Trelew. 
Hemos presentado anteriormente los datos de un informe de 1997, que reflejaba la crisis de la producción textil en la región ${ }^{372}$. Entre las fábricas que todavía estaban en funcionamiento, la gran mayoría no producían más que al 50\% de su capacidad, con baja cantidad de personal y pocas perspectivas de subsistencia y menos aún de inversiones. Estos datos en general no registran toda la caída de las fábricas, ya que no se toman como cerradas las que están con suspensión del personal o con posibilidades de reapertura. Durante todo el período investigado es particularmente fluctuante el comportamiento de varias empresas, que cierran o re abren de acuerdo a las coyunturas que plantee la situación económica o a los subsidios que puedan lograr por parte del Estado (sea este nacional o provincial).

Para el 2002 el ciclo de descenso se mantiene con nuevos cierres (muchos con fraudes económicos, sin pagar las indemnizaciones, llevándose la maquinaria que por ley debía quedar en la región, etc.) y suspensiones constantes del personal. Recién con la devaluación del 2002 empieza una posibilidad de recuperación que se comienza a expresar durante el 2003 y tiene efectos importantes en la dinámica del conflicto social, especialmente evidenciados ya para el 2005. Esa recuperación de la producción industrial se realiza con un número mucho menor de empleados y con menos de la mitad de los establecimientos manufactureros que estaban en producción en los años ochenta (si bien no hay estadísticas tan claras sobre las otras ramas de la economía, sabemos que han cerrado casi la totalidad de los pequeños y medianos talleres metalúrgicos, varias plantas pesqueras en tierra, etc.).

Será motivo de la continuidad de la investigación observar si esta recuperación económica expresa un movimiento orgánico de la estructura o si solamente es expresión de una situación coyuntural sin perspectivas de continuidad. Pero lo que sí aparece como un movimiento orgánico, como ya lo marcamos, es el cambio de la estructura económica social y su transformación hacia un régimen donde la gran industria ha acentuado su control sobre el proceso productivo a nivel global.

Sólo a modo de comparación, y hasta como propuesta para pensar un programa de investigación a largo plazo, pensamos que es una situación similar a la que se da en la estructura económica social de la región en los años previos a la instalación de las primeras leyes de promoción industrial (ver un sintético desarrollo de este proceso en el primer capítulo). Alli veíamos como distintas pequeñas fábricas que se habían instalado en la región favorecidas por la desconexión del mercado patagónico con el resto del país, habían sucumbido ante el avance del dominio del capital industrial más concentrado. Estábamos allí ante un primer cambio que tenía

\footnotetext{
372 También citado en Ibarra (1997). La fuente es un informe, supuestamente reservado, del gobierno provincial, que es publicado en Diario Jornada, 16/2/1997, pág. 6 y 7
} 
relación con el avance en extensión del dominio del capitalismo sobre todo el territorio de Argentina. Hoy asistimos en cambio al avance en profundidad del capitalismo sobre un territorio ya totalmente dominado.

Una primera aproximación para observar cuáles son los cambios que se dan en la estructura económica de la región, la buscaremos en las distribuciones de la población que nos brindan los datos del INDEC, tomando los Censos Nacionales de 1980, 1991 y 2001, más las Encuestas Permanentes de Hogares (EPH) de 1994, 2002, 2003, 2004 y $2005^{373}$.

Allí trabajaremos con los criterios de "categoría ocupacional" y de "sector económico", que aunque son inexactos y nos dan solamente una versión acotada de los procesos, nos permitirán hacer observables algunos elementos. Luego avanzaremos en la profundización de estos datos, con la recurrencia a otro tipo de distribuciones a partir de otro marco conceptual, teórico y metodológico.

Cuadro № 23: Depto. Rawson, distribución de ocupados por categoría ocupacional.

\begin{tabular}{|c|c|c|c|c|c|c|c|c|}
\hline & $\mathbf{1 9 8 0}^{\circ}$ & $\mathbf{1 9 9 1}^{\circ}$ & $\mathbf{1 9 9 4}^{\boldsymbol{*}}$ & $\mathbf{2 0 0 1}^{\circ}$ & $\mathbf{2 0 0 2}^{\boldsymbol{*}}$ & $\mathbf{2 0 0 3}^{\boldsymbol{*}}$ & $\mathbf{2 0 0 4}^{\boldsymbol{*}}$ & $\mathbf{2 0 0 5}^{\boldsymbol{*}}$ \\
\hline $\begin{array}{c}\text { Asal/Empl u } \\
\text { Obrer }\end{array}$ & $\mathbf{7 9 , 3 \%}$ & $73,3 \%$ & $68,1 \%$ & $75,9 \%$ & $77,3 \%$ & $79 \%$ & $79,7 \%$ & $79,3 \%$ \\
\hline Cuentapropista & $13,7 \%$ & $18,1 \%$ & $28 \%$ & $17,3 \%$ & $17,8 \%$ & $17,1 \%$ & $16,1 \%$ & $16,6 \%$ \\
\hline Patrón o Socio & $5,2 \%$ & $6,1 \%$ & $3,4 \%$ & $4,9 \%$ & $3,8 \%$ & $3,2 \%$ & $3,5 \%$ & $3,2 \%$ \\
\hline Fliars/rem & $1,8 \%$ & $2,5 \%$ & $0,5 \%$ & $1,9 \%$ & $1,1 \%$ & $0,7 \%$ & $0,7 \%$ & $0,9 \%$ \\
\hline Total & 100 & 100 & 100 & 100 & 100 & 100 & 100 & 100 \\
\hline
\end{tabular}

Fuente: Censo Nacional de Población y Vivienda 1980-1991-2001. EPH 1994-2002-2003-2004-2005. Datos sobre Depto. Rawson. *Datos sobre aglomerado urbano Rawson-Trelew.

Cuadro N²4: Distribución PEA por ocupación en Rw- Tw.

\begin{tabular}{|c|c|c|c|c|c|c|c|}
\hline & $\mathbf{1 9 9 4}^{\boldsymbol{*}}$ & $\mathbf{2 0 0 1}$ & $\mathbf{2 0 0 1}^{\boldsymbol{*}}$ & $\mathbf{2 0 0 2}^{\boldsymbol{*}}$ & $\mathbf{2 0 0 3}^{\boldsymbol{}}$ & $\mathbf{2 0 0 4}^{\boldsymbol{}}$ & $\mathbf{2 0 0 5}^{\star}$ \\
\hline Ocupados & $86,4 \%$ & $76,1 \%$ & $74,8 \%$ & $82,7 \%$ & $83,4 \%$ & $86,2 \%$ & $90,2 \%$ \\
\hline Desocupados & $13,6 \%$ & $23,9 \%$ & $25,2 \%$ & $17,3 \%$ & $16,6 \%$ & $13,8 \%$ & $9,8 \%$ \\
\hline Total & 100 & 100 & 100 & 100 & 100 & 100 & 100 \\
\hline
\end{tabular}

Fuente: Censo Nacional de Población y Vivienda -2001. EPH 1994-2002-2003-2004-2005. Datos sobre Depto. Rawson. *Datos sobre aglomerado urbano Rawson-Trelew.

Cuadro № 25: Total Depto Rawson, distribución de asalariados por sector.

\begin{tabular}{|c|c|c|c|c|c|c|c|c|}
\hline & $\mathbf{1 9 8 0}^{\circ}$ & $\mathbf{1 9 9 1}^{\circ}$ & $\mathbf{1 9 9 4}^{\boldsymbol{*}}$ & $\mathbf{2 0 0 1}^{\circ}$ & $\mathbf{2 0 0 2}^{\boldsymbol{*}}$ & $\mathbf{2 0 0 3}^{\boldsymbol{*}}$ & $\mathbf{2 0 0 4}^{\boldsymbol{*}}$ & $\mathbf{2 0 0 5}^{\boldsymbol{*}}$ \\
\hline $\begin{array}{c}\text { Sector } \\
\text { Público }\end{array}$ & $37,1 \%$ & $38,1 \%$ & $44,3 \%$ & $43,7 \%$ & $47,5 \%$ & $48 \%$ & $40 \%$ & $34,7 \%$ \\
\hline $\begin{array}{c}\text { Sector } \\
\text { Privado }\end{array}$ & $55,9 \%$ & $51,7 \%$ & $51,2 \%$ & $56,3 \%^{*}$ & $43,9 \%$ & $43,7 \%$ & $52,9 \%$ & $55,9 \%$ \\
$\begin{array}{c}\text { Sector } \\
\text { Doméstico }\end{array}$ & $7 \%$ & $10,2 \%$ & $4,5 \%$ & & $8,6 \%$ & $8,3 \%$ & $7,1 \%$ & $9,4 \%$ \\
\hline Total & 100 & 100 & 100 & 100 & 100 & 100 & 100 & 100 \\
\hline
\end{tabular}

Fuente: Censo Nacional de Población y Vivienda 1980 -1991-2001. EPH 1994 - 2002 - 2003 - 2004 2005. *Unificado con el sector doméstico en la fuente.

\footnotetext{
${ }^{373}$ Los datos de la EPH son sólo para el conglomerado urbano Rawson-Trelew, quedando afuera Puerto Madryn dentro de las ciudades importantes en términos numéricos del noreste de la provincia. Por eso se comparan estos datos de las EPH con los datos de los censos nacionales desagregados al nivel del departamento Rawson, que agrupa a Trelew, Rawson y su área rural, pero no a Puerto Madryn que es parte del departamento Biedma. Se toma EPH de 1994, primer año en que se realiza para este conglomerado urbano en forma de prueba. Desde el 2002 dicho conglomerado se incorpora a la medición permanente.
} 
Cotejando 1991 con 1980 vemos fuertes tendencias hacia la transformación de la estructura económica ocupacional de la región. De todos modos estas transformaciones se harán más patentes en los siguientes años, ya que es en 1991 cuando comienzan las reformas fundamentales en la estructura económica social.

Del análisis de los datos de la EPH de 1994 se desprende en primer término el enorme aumento de la desocupación (al menos 13,6\% sin tener en cuenta los planes sociales ni la subocupación) y del sector cuentapropista que pasó del 13,7\% en 1980 al $28 \%$ en 1994 (con un $18,1 \%$ en 1991). Junto a ello se da la caída del sector asalariado de $79,3 \%$ a $68,1 \%$ (73,3\% en 1991$)$, y de los patrones de $5,2 \%$ a $3,4 \%$. El otro dato importante parece ser el gran aumento porcentual del porcentaje de asalariados empleados en el sector público, que pasa de emplear al 37,1\% de los asalariados ocupados en 1980 a ocupar al 44,3\% en 1994 (38,1\% en 1991).

La caída de la cantidad de patrones muestra el proceso de concentración de la propiedad y la riqueza. Pese a algunos cambios coyunturales (hay un aumento de 3,2 a 3,5\% entre 2003 y 2004) este proceso de concentración económica se muestra como un movimiento orgánico de la estructura. Los patrones más pequeños comienzan un proceso de pérdida de sus condiciones materiales de existencia y de progresiva pauperización y/o proletarización.

Por otra parte el gran aumento de los cuentapropistas no presenta, como planteaba durante los noventa el discurso del neoliberalismo, la supuesta movilidad social de los obreros o, mejor, directamente la disolución de la clase obrera. En su gran mayoría esos "cuentapropistas" son los obreros despedidos que con sus indemnizaciones o retiros "voluntarios" intentan desarrollar actividades por su cuenta, y que en su gran mayoría quiebran rápidamente ante la imposibilidad objetiva de competir con las grandes empresas de capital concentrado que ocupan casi la totalidad del mercado.

Para los siguientes años estas personas pasan a ser desocupados (de 1994 al 2001 se pasa del 13,6\% de desocupación al 23,9\% para el departamento Rawson y al 25,2\% para Trelew) o vuelven a ser asalariados en condiciones de gran precarización y sobreexplotación. Con la figura del cuentapropismo se encubre así parte de la subocupación y la sobreexplotación que genera la nueva fase del capitalismo.

Ante el gran aumento de la desocupación evidenciado por el censo del 2001, el gobierno decidió tomar nuevos parámetros para medir esa condición. Por esta razón es difícil cuantificar y evaluar las razones del descenso de ese registro en las EPH de 2002 y 2003. Además la caída de la desocupación tras el pico del 2001 se produce por la entrega masiva de planes sociales a los desocupados a partir de la asunción del 
gobierno de Eduardo Duhalde. Ya vimos que para el 2002 se calculaba que el $20 \%$ de la población de Trelew era asistida a través de diversos planes sociales. En el 2003 el antiguo polo de desarrollo, la que fuera "la ciudad más progresista del sur argentino", era uno de los conglomerados urbanos de mayor pobreza en la patagonia. Sólo detrás de Viedma-Patagones, el par Rawson-Trelew presentaba un 51,8\% de su población en la pobreza y un $41,8 \%$ de sus hogares en esa situación ${ }^{374}$.

La recuperación posterior de la tasa de desocupación ya sí tiene un contenido basado en una evidente recuperación de la actividad económica de la región. Esto se evidencia tanto en la recuperación de los valores históricos de la categoría de asalariado (que a partir del 2003 vuelve a estar por encima del 79\%, recuperando los registros de 1980), como en el cambio en la distribución de los asalariados por sector económico.

Vemos entonces que en la distribución de la PEA por categorías ocupacionales tras la fuerte retracción de la categoría de asalariados en el año 1994, esta recupera sus valores históricos para el 2003, volviendo así a las características propias de una estructura económica de capitalismo en enclaves ${ }^{375}$. El gran aumento del cuentapropismo fue provocado por la pérdida masiva de empleos industriales y la caída global de la economía de la región. Estos antiguos obreros que intentan desarrollar actividades por su cuenta, pasan a ser desocupados o vuelven a ser asalariados, pero en peores condiciones que antes.

Sí, como afirmamos, una parte no fácil de cuantificar de los cuentapropistas son en verdad asalariados en condiciones de precarización (que revisten bajo formas como el monotributo, las cooperativas "truchas", etc.), el porcentual de asalariados aumenta aún por encima de los índices previos a las transformaciones provocadas por el neoliberalismo. Así las afirmaciones acerca de un proceso de "desaparición" o "debilitamiento" de la clase obrera, que se sustentaban en análisis esquemáticos de estas distribuciones por categorías ocupacionales, muestran la falta de profundidad científica de esas miradas, así como el sobredimensionamiento impresionista de procesos coyunturales.

En la división por "sectores" de empleo de los asalariados ocupados podemos encontrar algunos otros elementos. Durante el 2002 y 2003 puede observarse que por primera vez el sector público sobrepasa en porcentaje de asalariados ocupados al

\footnotetext{
374 Diario Jornada, 7/2/2003, datos del INDEC, pág. 4.

375 También la aparente caída de la categoría de asalariados a nivel nacional presentaba un ocultamiento de información y procesos de indole coyuntural. Así por ejemplo Lindemboin y otros señalan que "Como es sabido, la apariencia de caída en el peso relativo de los asalariados a partir del Censo de Población de 1991 es principalmente eso, una apariencia, como lo han mostrado muchísimos trabajos, entre los que puede citarse: Wainerman y Giusti (1994) y Giusti y Lindenboim (1999)". (Lindemboin, Kennedy y Graña, 2006: 75).
} 
sector privado. Sin embargo esto no se presenta como un movimiento orgánico, sino como algo coyuntural, que tiene relación con el gran aumento de la desocupación. Tras la recuperación económica de los años siguientes los porcentuales recuperan valores donde el Estado pasa a emplear un menor porcentaje del total de asalariados que en 1980. En este sentido el Estado provincial parece funcionar como un elemento amortiguador en momentos de agudización de la crisis, encubriendo parte de la población sobrante y buscando frenar de esta forma la posible profundización de algunos conflictos sociales.

Ahora bien, estos datos son sólo una aproximación a la realidad de la estructura económica, ya que son datos que parten de la dimensión de categoría ocupacional y de la distribución por "sectores económicos". Desde allí en general se realizan lecturas a partir de incorporar a la población económicamente activa en tres grandes grupos por "aproximación", tomando a los asalariados como aproximación a proletariado, a los empleadores como aproximación a clase capitalista y a los cuentapropistas como personas que están fuera de las relaciones capitalistas plenas (no son ni patrones ni asalariados), donde se incluye desde trabajadores directos propietarios de dinero hasta trabajadores sin ninguna propiedad ${ }^{376}$.

Pero esto en verdad es sólo una "suposición" que nos permite aproximar datos pero que implica un recorte, una limitación de la realidad, donde se puede estar

\footnotetext{
${ }^{376}$ Así desarrollan estas categorías Donaire y Rosatti (2007a), exponiendo y criticando las definiciones del Censo Nacional de Población, Hogares y Viviendas 2001: "Patrón "es la persona que siendo única dueña o socia de la empresa aporta los instrumentos, maquinarias, instalaciones necesarias o capital, establece las condiciones organizativas del trabajo y emplea como mínimo a una persona asalariada, es decir tiene obreros o empleados". Sin embargo, según la posición y función en la estructura económica estos patrones pueden ser desde personificaciones del capital monopólico (gran burguesía) hasta pequeños propietarios de medios de vida propios que explotan fuerza de trabajo en pequeños proporciones (pequeña burguesía acomodada). Se trata de distintas capas al interior de la burguesía que cumplen funciones distintas en la producción social.

Obrero o empleado "es la persona que trabaja en relación de dependencia con un patrón, empresa u organismo estatal. Se considera también como obrero o empleado al trabajador del servicio doméstico y al trabajador ad-honorem". La relación de dependencia no necesariamente implica venta de fuerza de trabajo, puesto que bajo la forma salarial pueden encontrarse funcionarios del gran capital (gran burguesía), intelectuales en funciones auxiliares (pequeña burguesía acomodada o pobre) junto con quienes efectivamente se encuentran expropiados de sus condiciones de vida.

Trabajador por cuenta propia "es la persona que siendo única dueña o socia de la empresa aporta los instrumentos, maquinarias, instalaciones necesarias o capital, desarrollando su actividad sin contratar a ninguna persona". Bajo esta forma pueden encontrarse encubiertas junto con los pequeños propietarios de sus condiciones de existencia que no compran fuerza de trabajo (pequeña burguesía pobre), una parte de intelectuales que ejercen funciones auxiliares bajo la forma de las profesiones liberales (pequeña burguesía acomodada) y fracciones de proletariado que, ya sea porque formalmente aparecen como prestadores de servicios ("trabajadores autónomos") o ya sea porque venden su fuerza de trabajo a distintos compradores (peones y servicio doméstico por cuenta propia y parte de los trabajadores domiciliarios), aparecen como trabajadores independientes aunque no sean propietarios de sus condiciones de existencia.

Trabajador familiar "es la persona que realiza frecuentemente tareas de ayuda en la actividad de un familiar", dentro de la cual en el año 2001 se distingue entre quienes reciben o no sueldo, distinción que "se refiere a si percibe o no un sueldo por parte del familiar con el que trabaja". La gama de situaciones aquí comprendidas van desde trabajadores que forman parte de la pequeña producción mercantil familiar y por ende son propietarios de sus condiciones de existencia en tanto miembros de la misma unidad familiar (pequeña burguesía) hasta aquellos trabajadores cuya situación no difiere de la del resto de los expropiados siendo su vinculo familiar de carácter eventual."
} 
mezclando en la misma categoría al gerente, al técnico, al supervisor y al obrero de una fábrica. También la recurrencia a los sectores económicos nos impide desagregar esa información, observar quiénes de esos empleados son proletarios y quiénes no, quiénes realizan una actividad productiva y quién improductiva, etc. La observación de la realidad adquiere una mayor profundidad con la división de la población según los grupos sociales fundamentales ${ }^{377}$ y con el recurso a la distribución de la población según la división social del trabajo que realizaremos en el siguiente apartado.

Para desarrollar la división según grupos sociales fundamentales debemos realizar el análisis sobre el total de la provincia ya que la distribución se desarrolla a partir de los datos censales y estos no permiten un mayor nivel de desagregación. Se utilizan como fuentes los censos de 1960, 1980, 1991 y 2001, partiendo de los criterios metodológicos de distribución planteado para los censos de 1960 y 1980 por Iñigo Carrera y Podestá (1985) en "Análisis de una relación de fuerzas sociales objetiva: caracterización de los grupos sociales fundamentales en la Argentina actual'378 y para los censos de 1991 y 2001 por los trabajos ya citados de Ricardo Donaire y Germán Rosatti (2007a, 2007b, 2010). El marco metodológico parte de los distintos trabajos acerca de estructura económica-social desarrollados desde el PIMSA, presentándose una muy buena síntesis de sus principales elementos en PIMSA (2000) Taller: "Estructura social de la Argentina".

La forma en que se presenta la información censal de 1970 no permite construir la distribución de la población para ese año, al menos no de un modo que garantice la fidelidad de los datos. A su vez los datos de los demás censos nos posibilitan ejecutar esta división solamente sobre la población considerada como "económicamente activa" más los jubilados y pensionados, y no sobre el total de la población.

Desde nuestra perspectiva teórica consideramos que los grupos sociales se conforman a partir de conjuntos de seres humanos que se encuentran en una misma situación en la estructura económica-social, con relación al conjunto de las relaciones de producción, cuya materialización político-jurídica son las relaciones de propiedad existentes. Siguiendo a Gramsci (1997), consideramos que estos conjuntos de población constituyen los grupos sociales fundamentales de la sociedad capitalista,

\footnotetext{
${ }^{377}$ No hablamos de "clases", ya que para nosotros las clases se constituyen en los enfrentamientos. Por ello en este apartado, en el que nos remitimos centralmente a la estructura económica, utilizamos el concepto de "grupos sociales", tomando como los fundamentales en una sociedad capitalista a: proletariado y semiproletariado, pequeña burguesía pobre, pequeña burguesía acomodada y gran burguesía.

378 Iñigo Carrera y Podestá (1985) Cuadernos de CICSO № 46. No presentaremos aquí la explicación metodológica de cómo se realiza la distribución por estar contenida en el trabajo citado.
} 
cada uno de los cuales desarrolla una función específica y tiene una posición determinada en el marco de las relaciones sociales de producción (PIMSA, 2000).

Por ello tomamos como indicadores generales para delimitar a los grupos sociales tanto: “...la posición respecto de la propiedad o no propiedad de las condiciones materiales de existencia (incluyendo el reclutamiento como posición que ha ocupado históricamente un grupo social determinado)", como “...la función que representan en la producción y reproducción social, distinguiendo entre quienes cumplen o no funciones intelectuales de mando o auxiliares del grupo social dominante" (Donaire y Rosatti, 2007a).

Pero esta tarea no es nada simple. La distribución de la población en grupos sociales fundamentales a partir de los datos censales presenta muchos problemas y sabemos que se desarrollan alrededor del mismo diversas discusiones. Para hacerlo se debe delimitar una distribución en gran burguesía, pequeña burguesía acomodada, pequeña burguesía pobre y proletariado y semiproletariado ${ }^{379}$. El desarrollo y transformación del capitalismo genera que muchas de las funciones tradicionales del

379 Citamos en extenso a Donaire y Rosati (2007a): "1. La gran burguesía y altos funcionarios constituyen la cúpula de la burguesía; los terratenientes, los magnates financieros, los grandes industriales, los rentistas, etc., es decir, la personificación del gran capital monopólico, ya sea porque por su posición son propietarios del gran capital o por su función constituyen el estado mayor que representa dichos intereses. Nos podemos aproximar a este grupo considerando las siguientes categorías: los directivos y gerentes de grandes empresas patrones (incluida la gran propiedad agrícola), los directivos y gerentes de grandes empresas asalariados, los funcionarios gubernamentales.

2. La pequeña burguesía se encuentra constituida por propietarios de sus condiciones materiales de existencia, que no venden su fuerza de trabajo. Este grupo se encuentra en una situación de permanente diferenciación en dos grupos:

2.1. La pequeña burguesía acomodada constituida por quienes, además de ser propietarios de sus propias condiciones materiales de existencia, son a su vez propietarios de los medios de vida y de trabajo de otros (grupo al cual nos podemos aproximar a través de la categoría de pequeños y medianos patrones), pero también quienes cumplen funciones de mando propias del capital aún bajo la forma del salario, ya sea que se encuentren insertos en la actividad económica o en el aparato estatal. Se trata de los "oficiales del ejército de la producción", a quienes nos podemos aproximar a través de las categorías de directivos y gerentes asalariados de pequeñas y medianas empresas o de establecimientos públicos. Asimismo, se encuentran en este grupo quienes cumplen funciones auxiliares como intelectuales de la burguesía, aunque una parte de ellos puede estar inmersos en procesos de proletarización y/o pauperización. Una aproximación a este grupo incluye principalmente las siguientes categorías: profesionales independientes y asalariados (abogados, contadores, médicos, etc.) y por extensión quienes desempeñan funciones de asistencia técnico-profesional (asistentes y auxiliares técnicos en diversas áreas), quienes se desempeñan en funciones intelectuales auxiliares en el campo de la educación y la cultura (docentes, artistas, deportistas, periodistas, etc) y quienes ejercen funciones superiores de apoyo administrativo, contable, jurídico y financiero (peritos, inspectores, técnicos contables, agente de bolsa, agente de seguros, agente inmobiliario, etc.).

2.2. La pequeña burguesía pobre se encuentra constituida por quienes son sólo propietarios de sus propios medios de vida y trabajo. Grupo al que nos podemos aproximar principalmente mediante las categorías de: pequeños comerciantes, pequeños propietarios de medios de transporte, trabajadores independientes de oficio y similares, etc. Atendiendo a su reclutamiento, una parte de quienes desempeñan funciones auxiliares de la burguesía puede ser asimilado a este grupo de pequeños propietarios pobres (por ej., los técnicos industriales), puesto que una parte de este grupo se encuentra también inmerso en procesos de proletarización y/o pauperización.

3. El proletariado y semiproletariado, constituido por quienes se encuentran expropiados total o parcialmente de sus condiciones de vida y de trabajo y que, en consecuencia, se ven obligados a vivir principal o parcialmente de la venta de su fuerza de trabajo, ya sea que logren venderla o no, situaciones que los constituyen como parte de la población obrera necesaria para la acumulación del capital o como parte de la población obrera sobrante para el capital bajo sus distintas formas: fluctuante, latente o estancada." 
mismo sufran mutaciones que modifiquen a su vez la posición y la función de determinados conjuntos de personas, que por esta razón deberían modificar su encuadramiento en determinados grupos sociales. Diversos elementos del proceso social generan la discusión acerca de que esta dinámica de cambio estaría desarrollándose específicamente para con los docentes, técnicos y otras profesiones. Ya retomaremos este debate.

El primer cuadro que presentamos muestra la evolución de la distribución de la población según los grupos sociales fundamentales para la provincia del Chubut desde 1960:

Cuadro № 26: Población según grupos sociales fundamentales para Chubut: gran burguesía (GB), pequeña burguesía acomodada (PBA), pequeña burguesía pobre (PBP) y proletariado y semiproletariado (PYS).

\begin{tabular}{|c|c|c|c|c|c|c|c|c|}
\hline \multirow[b]{2}{*}{ Grupo Social } & \multicolumn{2}{|c|}{1960} & \multicolumn{2}{|c|}{1980} & \multicolumn{2}{|c|}{1991} & \multicolumn{2}{|c|}{2001} \\
\hline & $\mathbf{N}^{\circ}$ & $\%$ & $\mathbf{N}^{\circ}$ & $\%$ & $\mathbf{N}^{\circ}$ & $\%$ & $\mathbf{N}^{\circ}$ & $\%$ \\
\hline Gran Burguesía & 1189 & 2,29 & 807 & 0,8 & 672 & 0,5 & 745 & 0,4 \\
\hline Peq. Burg. Acomodada & 8727 & 16,80 & 10356 & 10,60 & 26094 & 17,7 & 28240 & 16,5 \\
\hline Peq. Burg. Pobre & 3913 & 7,53 & 13980 & 14,30 & 24439 & 16,6 & 23284 & 13,5 \\
\hline Proletariado y semiproletariado & 38093 & 73,36 & 72948 & 74,40 & 96443 & 65,3 & 120197 & 69,6 \\
\hline
\end{tabular}

Fuente: Área de Estructura Social del Programa de Investigaciones sobre el Movimiento de la Sociedad Argentina (PIMSA) en base a Censos Nacionales de Población ${ }^{380}$.

El primer dato evidente es el descenso permanente de la gran burguesía como grupo social. La concentración económica y la centralización de la propiedad es tan importante que se refleja no solamente en una caída del porcentual, sino hasta en la constante caída absoluta (excepto en el período 1991-2001) del total de población agrupada en esta categoría. Este dato es evidencia de un proceso concreto de expropiación de sus condiciones materiales de existencia, en tanto grandes propietarios involucrados en la actividad productiva, de una parte del antiguo bloque dominante.

Por otro lado vemos que el proletariado y semiproletariado se mantiene creciendo en forma permanente en términos absolutos. Sin embargo su porcentual en relación al conjunto de la población muestra que tras un ascenso muy pequeño entre 1960 y 1980, registramos un descenso importante entre 1980 y 1991 y una recuperación significativa hacia 2001, que de todas maneras no recupera los porcentuales de 1960.

El primer resultado es que no hay evidencia de una "desaparición" del proletariado. Al contrario registramos un permanente ascenso de la cantidad de

\footnotetext{
${ }^{380}$ Este cuadro, y los que desarrollamos hasta el final del presente apartado, son tomados de: Donaire, Ricardo y Rosati, Germán (en prensa), "Estructuras económico sociales concretas que constituyen la formación económica de la Argentina (1980-2001)" en Nicolás Iñigo Carrera (director), "Análisis de una relación de fuerzas sociales objetiva, 1960-2001".
} 
población que debe vender su fuerza de trabajo como único mecanismo para poder reproducir su existencia ante la expropiación sufrida de sus condiciones materiales de existencia. Como ya lo hemos mostrado a partir de otros elementos, estos proletarios además deben vender su fuerza de trabajo en cada vez peores condiciones, que en muchos casos directamente dificultan la continuidad de sus posibilidades de existencia.

Marcábamos en el anterior apartado la discusión con las tan divulgadas teorías que sostenían la progresiva disminución o hasta la desaparición del proletariado, que se hicieron hegemónicas en los años ochenta y noventa en el mundo académico. El conjunto de la población que ha sido expropiada de sus condiciones materiales de existencia, y que tiene como única forma de conseguir sus medios de vida la venta de su fuerza de trabajo, ha seguido creciendo en Chubut y también a nivel nacional (según datos de Donaire y Rosati (2007a y 2007b) "mientras que en 19604.447 .935 de personas se encontraban en esta condición, en el año 2001, su número ascendía a 10.356.575").

Pero esto no significa negar algunos evidentes cambios en la composición del proletariado. Hay transformaciones cualitativas de importancia que modifican en algunos aspectos la conformación de este grupo social y por lo tanto el cómo se manifiesta parte del ciclo de rebelión. Ya veremos que la primera evidencia es el crecimiento de la población sobrante respecto a las necesidades inmediatas del capital.

Otro cambio clave es la reducción del peso relativo del proletariado y semiproletariado agrupado en la población industrial y comercial. A nivel nacional "la población ocupada en la industria manufacturera pasa de representar el 54\% de la población inserta en la producción en 1960 al 29\% en 2001" (Donaire y Rosati, 2007b). Un proceso semejante puede observarse en Chubut ${ }^{381}$.

También se destaca que, a pesar de observarse un aumento en términos absolutos de las capas que componen el proletariado y semiproletariado, en términos relativos esta población disminuye en una importante proporción entre 1980 y 1991, para luego recuperar bastante peso, aunque sin llegar al porcentual de 1980. Esta disminución en términos relativos aparece como un proceso coyuntural, donde aumenta a un ritmo llamativamente importante (específicamente entre 1980 y 1991) la proporción de población agrupada como pequeña burguesía, ya sea pobre o acomodada.

\footnotetext{
${ }^{381}$ Los datos relativos a la ocupación en la industria manufacturera para el 2001, si bien son indicativos en términos generales del proceso, deben evaluarse considerando que se estaba atravesando el momento más agudo de la crisis económica. Para nosotros se expresa allí un movimiento orgánico de la estructura económica, pero que aparece claramente sobredimensionado por la coyuntura.
} 
Tanto la pequeña burguesía pobre como la acomodada aumentan en términos absolutos y relativos de forma permanente desde 1960 hasta 1991. De 1991 hasta 2001 bajan en términos relativos ambos grupos de la pequeña burguesía, aunque la acomodada sigue aumentando en términos absolutos, mientras la pobre cae de forma importante. Aquí retomamos el debate acerca de algunos conjuntos agrupados como pequeña burguesía acomodada, y de si es posible que estén sufriendo un proceso de proletarización. Esto llevaría a un necesario cambio de la distribución de la población según grupos sociales, cambio que conduciría a un incremento muy importante de la población agrupada como pequeña burguesía pobre y como proletariado y semiproletariado.

Esta discusión ha estado planteada ya desde el trabajo que citamos de Iñigo Carrera y Podestá en 1985. Ricardo Donaire (2009 y otros) ha centrado su investigación de doctorado en esta temática, sintetizando sus resultados en "La posición social de los docentes en la actualidad. Una aproximación a partir del estudio de los docentes de la Ciudad de Buenos Aires". Allí el autor encuentra sobre la base de una muestra de docentes de la Ciudad de Buenos Aires, que los mismos están sufriendo efectivamente un proceso de proletarización, aunque todavía no puede concluirse que estemos ante un movimiento orgánico y definitivo, sino que el mismo aún pasa por un estado embrionario. Este proceso de proletarización no puede ser reducido a un proceso de pauperización, a pesar de que también se encuentran elementos de esa dinámica.

Ante la imposibilidad de extrapolar directamente estos datos a Chubut hemos decidido sostener a los docentes en la categoría de pequeña burguesía acomodada, aún a sabiendas de que esto hace que haya una sobreestimación de este grupo social.

Sostener a los docentes allí permite realizar una tarea comparativa con los datos de los anteriores censos, tarea que complementamos con una distribución de este grupo según grado de asalarización que nos permite señalar que al menos una parte de esta pequeña burguesía acomodada asalariada, está en proceso de proletarización.

Cuadro № 27: Pequeña burguesía acomodada según composición: asalariados (A), patrones (P) o independientes (I), para Chubut.

\begin{tabular}{|c|c|c|c|c|c|c|c|c|}
\hline \multicolumn{3}{|c|}{1980} & \multicolumn{3}{|c|}{1991} & \multicolumn{3}{|c|}{2001} \\
\hline$A$ & $P$ & 1 & $A$ & $P$ & I & $A$ & $P$ & $\mathrm{I}$ \\
\hline 4.753 & 4.723 & 880 & 15.987 & 7.876 & 2.231 & 18.497 & 6.521 & 3.402 \\
\hline $46 \%$ & $46 \%$ & $8 \%$ & $61 \%$ & $30 \%$ & $9 \%$ & $65 \%$ & $23 \%$ & $12 \%$ \\
\hline
\end{tabular}

Fuente: Área de Estructura Social del Programa de Investigaciones sobre el Movimiento de la Sociedad Argentina (PIMSA) en base a Censos Nacionales de Población. 
El proceso por el cual la gran mayoría de la pequeña burguesía acomodada pasa a ser asalariada muestra la progresiva expropiación de sus condiciones materiales de existencia. Lo mismo puede observarse a partir de investigaciones específicas acerca de la situación de aquellos que figuran como "independientes", encubriendo allí muchas veces procesos de proletarización bajo relaciones no formales.

Podemos aquí registrar también algunos cambios entre los asalariados a partir de los siguientes cuadros:

Cuadro № 28: Asalariados según dependencia del sector público o privado para Chubut (excluyendo servicio doméstico).

\begin{tabular}{|c|c|c|c|c|c|c|c|c|}
\hline \multicolumn{6}{|c|}{ Absolutos } & \multirow{2}{*}{\multicolumn{3}{|c|}{$\begin{array}{l}\text { Tasa Públicos * } 100 / \\
\text { Privados }\end{array}$}} \\
\hline \multicolumn{2}{|c|}{1980} & \multicolumn{2}{|c|}{1991} & \multicolumn{2}{|c|}{2001} & & & \\
\hline Público & Privado & Público & Privado & Público & Privado & 1980 & 1991 & 2001 \\
\hline 29.655 & 44.677 & 35.290 & 53.806 & 37.798 & 56.712 & 66,4 & 65,6 & 66,6 \\
\hline
\end{tabular}

Fuente: Área de Estructura Social del Programa de Investigaciones sobre el Movimiento de la Sociedad Argentina (PIMSA) en base a Censos Nacionales de Población.

Cuadro № 29: Asalariados de las ramas "explotación de minas y canteras", "industrias manufactureras", "electricidad, gas y agua", "construcción" y "transporte, almacenamiento y comunicaciones", según dependencia de sector público o privado para Chubut.

\begin{tabular}{|c|c|c|c|c|c|}
\hline \multicolumn{6}{|c|}{ Absolutos } \\
\hline \multicolumn{2}{|c|}{1980} & \multicolumn{2}{|c|}{1991} & \multicolumn{2}{|c|}{2001} \\
\hline Público & Privado & Público & Privado & Público & Privado \\
\hline 7.969 & 23.752 & 5.542 & 27.097 & 3.269 & 23.910 \\
\hline
\end{tabular}

\begin{tabular}{|c|c|c|}
\hline \multicolumn{3}{|c|}{$\begin{array}{c}\text { Tasa Públicos * } \\
\text { Privados } /\end{array}$} \\
\hline 1980 & 1991 & 2001 \\
\hline 33,6 & 20,5 & 13,7 \\
\hline
\end{tabular}

Fuente: Área de Estructura Social del Programa de Investigaciones sobre el Movimiento de la Sociedad Argentina (PIMSA) en base a Censos Nacionales de Población.

Como ya lo habíamos destacado no hay un cambio importante en los porcentuales de empleados en el sector público en comparación con los empleados en el sector privado. Sin embargo esa primera mirada se puede profundizar en el análisis a partir de los datos volcados en el último cuadro. Allí se hace observable que sí se produjo un importante cambio cualitativo en la composición del empleo estatal, reflejado en que los empleados en el Estado se centran ahora, casi con exclusividad, en las áreas de administración pública, enseñanza y salud, mientras han perdido peso en forma evidente en las ramas de minas y canteras, industrias manufactureras, electricidad, gas y agua, construcción y transporte, almacenamiento y comunicaciones.

Para el caso de Chubut es claro que esta diferencia se explica casi totalmente por la privatización de YPF (como puede observarse a partir del número de personas agrupadas en la rama de minas y canteras en el cuadro de la División Social del Trabajo). Esto demuestra, a su vez, que sí hay un aumento del nivel de empleo porcentual en las áreas de administración pública, enseñanza y salud. 
Por último exponemos los datos de la distribución de los grupos sociales fundamentales a nivel nacional, para desarrollar algunas líneas comparativas:

Cuadro № 30: Población según grupos sociales fundamentales para Argentina: gran burguesía (GB), pequeña burguesía acomodada (PBA), pequeña burguesía pobre (PBP) y proletariado y semiproletariado (PYS).

\begin{tabular}{|c|c|c|c|c|}
\hline Grupos sociales fundamentales & $\mathbf{1 9 6 0}$ & $\mathbf{1 9 8 0}$ & $\mathbf{1 9 9 1}$ & $\mathbf{2 0 0 1}$ \\
\hline Gran burguesía & $2,8 \%$ & $0,7 \%$ & $0,5 \%$ & $0,5 \%$ \\
\hline Pequeña burguesía acomodada & $17,9 \%$ & $12,9 \%$ & $18,6 \%$ & $16,5 \%$ \\
\hline Pequeña burguesía pobre & $11 \%$ & $16,2 \%$ & $19,5 \%$ & $14 \%$ \\
\hline Proletariado y semiproletariado & $68,3 \%$ & $70,2 \%$ & $61,5 \%$ & $69 \%$ \\
\hline
\end{tabular}

Fuente: Area de Estructura Social del Programa de Investigaciones sobre el Movimiento de la Sociedad Argentina (PIMSA) en base a Censos Nacionales de Población.

La comparación que nos interesa realizar aquí es la de observar las correspondencias entre ambas distribuciones en los distintos momentos históricos. La absoluta similitud de los datos de distribución de la población en grupos sociales fundamentales en 2001 contrasta con las importantes diferencias que se podían observar en 1960. Básicamente podemos concluir que hay un avance evidente hacia una mayor homogeneización de la distribución según grupos sociales fundamentales entre Argentina y Chubut. Esto es parte y demostración de la hipótesis general que sostenemos acerca de que el proceso general avanza hacia una mayor homogeneización de la estructura económica social de Chubut con la formación económica social de Argentina.

\subsection{Una mirada desde la División Social del Trabajo}

Un ejercicio que nos permitirá observar con mayor profundidad el proceso de cambios en la estructura económica social de la provincia es la evaluación del cambio que se produce en la distribución de la población según la división social del trabajo durante el último medio siglo. La división social del trabajo es un indicador del grado de desarrollo de las fuerzas productivas y del sentido que va tomando ese desarrollo. Permite hacer observable la fase por la que transita el capitalismo en cada región de la formación económica social de Argentina, posibilitando comprender las especificidades de las distintas estructuras concretas que componen la estructura nacional. La metodología parte, en términos generales y teóricos, de las indicaciones teóricas del trabajo de Vladimir Lenin, "El desarrollo del capitalismo en Rusia"(Lenin, 1981b).

Este grado de desarrollo de las fuerzas productivas nos indica las características con las cuáles los seres humanos desarrollan sus formas de 
cooperación social para producir su vida. Dicho grado está enmarcado en un determinado estadio de su desarrollo social y en una determinada instancia de la relación entre la humanidad y la naturaleza y con los medios de producción que estén a su disposición. Son esas relaciones sociales las que configuran el proceso de producción de su existencia, o sea la forma concreta de cooperación social a través de la cual se organiza la producción en ese momento.

La división social del trabajo es el elemento clave para organizar dicha cooperación. Analizar y comprender cómo se divide el trabajo social en cada momento nos permite, entonces, conocer el grado de desarrollo de las fuerzas productivas materiales de la sociedad.

¿Cómo desarrollar esta tarea? Lenin encuentra que lo fundamental para comprender la evolución del desarrollo capitalista es poder agrupar a la población según la actividad económica concreta que realiza para asegurarse la producción y reproducción de su vida material. Desde esa perspectiva comienza por agrupar a la población en los siguientes tres grandes apartados: población agrícola (PA), población industrial y comercial (PIC) y población no productiva (PNP) ${ }^{382}$.

Al igual que para la distribución según grupos sociales fundamentales, para estudiar este proceso debemos realizar el análisis sobre el total de la provincia ya que la distribución se desarrolla a partir de los datos censales y estos no permiten un mayor nivel de desagregación. Utilizamos como fuentes los censos de 1947, 1960, 1980, 1991 y 2001 (para algunos de los cuadros utilizamos únicamente los censos de 1960, 1980, 1991 y 2001, ya sea por no contarse con la información adecuada del censo de 1947, para poder comparar con los datos nacionales o por tratarse de cuadros construidos por otros investigadores).

\footnotetext{
${ }^{382}$ Como en el apartado anterior encontramos en los textos de Donaire y Rosati síntesis muy claras para exponer las características de cada uno de estos agrupamientos: "Por un lado, la población que participa en la producción de la riqueza material. Esta materialidad no debe ser entendida en términos físicos sino sociales, es decir, en tanto materialización de trabajo social, que "produce trabajo [objetivado] o produce directamente, forma, desarrolla, conserva o reproduce la fuerza de trabajo misma" (Marx, 1974: 147). En este sentido, la producción de la riqueza material comprende a toda la población vinculada a actividades de producción e intercambio, incluidas las actividades de conservación y reproducción de la fuerza de trabajo como mercancía (bajo la forma de servicios de salud y de educación). Dentro de este conjunto de población es posible distinguir entre dos grandes apartados: la Población Agrícola y la Población Industrial y Comercial.

Por otro lado, la población que no participa en la producción de la riqueza material, pero percibe un ingreso bajo alguna forma a pesar de no participar en la actividad económica en sentido estricto. Este grupo comprende entonces a: quienes desarrollan actividades relacionadas con la reproducción política e ideológica del sistema social (administración pública, defensa, religión, etc.), quienes son empleados para la prestación de servicios personales (por ej., servicio doméstico), y finalmente, quienes perciben un ingreso sin estar ocupados, ya sea bajo la forma de rentas (jubilados, pensionados, rentistas, etc.) o bajo la forma de la caridad pública y la asistencia social (como los desocupados). Este conjunto de población constituye la Población No Productiva.

La división social del trabajo se nos presenta entonces como tres grandes grupos de población: Población Agrícola, Población Industrial y Comercial y Población No Productiva."(Donaire y Rosati, 2007b).
} 
Partimos de los criterios metodológicos de distribución planteado para los censos de 1960 y 1980 por Iñigo Carrera y Podestá en "Análisis de una relación de fuerzas sociales objetiva: caracterización de los grupos sociales fundamentales en la Argentina actual',383 y para los censos de 1991 y 2001 por los trabajos ya citados de Ricardo Donaire y Germán Rosatti (2007a, 2007b, 2010).

Como ya lo destacamos la forma en que se presenta la información censal de 1970 no permite construir la distribución de la población para ese año, al menos no de un modo que garantice la fidelidad de los datos. A su vez los datos de los demás censos nos posibilitan ejecutar esta división solamente sobre la población considerada como "económicamente activa" más los jubilados y pensionados, y no sobre el total de la población.

Cuadro № 31: División social del trabajo para la provincia de Chubut. Censos Nacionales de Población y Vivienda 1947 - 1960 - 1980 - 1991 - 2001.

\begin{tabular}{|c|c|c|c|c|c|c|c|c|c|c|}
\hline & \multicolumn{2}{|c|}{1947} & \multicolumn{2}{|c|}{1960} & \multicolumn{2}{|c|}{1980} & \multicolumn{2}{|c|}{1991} & \multicolumn{2}{|c|}{2001} \\
\hline Pobl Total & \multicolumn{2}{|c|}{92456} & \multicolumn{2}{|c|}{142412} & \multicolumn{2}{|c|}{263116} & \multicolumn{2}{|c|}{357189} & \multicolumn{2}{|c|}{413237} \\
\hline $\begin{array}{c}\text { Pobl + de } \\
14\end{array}$ & \multicolumn{2}{|c|}{61356} & \multicolumn{2}{|c|}{93394} & \multicolumn{2}{|c|}{168626} & \multicolumn{2}{|c|}{238057} & \multicolumn{2}{|c|}{294563} \\
\hline $\begin{array}{c}\text { Pobl. } \\
\text { distrib. }\end{array}$ & \multicolumn{2}{|c|}{38989} & \multicolumn{2}{|c|}{59238} & \multicolumn{2}{|c|}{108440} & \multicolumn{2}{|c|}{163616} & \multicolumn{2}{|c|}{199823} \\
\hline Pob Agríc & 13811 & $35,4 \%$ & 14996 & $25,3 \%$ & 12760 & $11,8 \%$ & 14176 & $8,7 \%$ & 12336 & $6,2 \%$ \\
\hline $\begin{array}{l}\text { Pobl Ind } \\
\text { y Com }\end{array}$ & 16816 & 4 & 3 & 5 & 66097 & 60 & 4417 & $57,7 \%$ & 91586 & $45,9 \%$ \\
\hline $\begin{array}{l}\text { Minas y } \\
\text { Canteras }\end{array}$ & 5187 & $30,9 \%$ & 7758 & $23,9 \%$ & 5562 & $8,4 \%$ & 5894 & $6,2 \%$ & 5743 & $6,3 \%$ \\
\hline $\begin{array}{l}\text { Ind. } \\
\text { Manuf. }\end{array}$ & 174 & $12,9 \%$ & 7040 & $21,8 \%$ & 14002 & $21,2 \%$ & 19118 & $20,3 \%$ & 12081 & $13,2 \%$ \\
\hline $\begin{array}{l}\text { Electr, gas } \\
\text { y agua }\end{array}$ & 71 & $0,5 \%$ & 508 & $1,6 \%$ & 1592 & $2,4 \%$ & 1869 & $2 \%$ & 1535 & $1,7 \%$ \\
\hline Constr & 1449 & $8,6 \%$ & 3623 & $11,2 \%$ & 12837 & $19,4 \%$ & 11983 & $12,7 \%$ & 10645 & $11,6 \%$ \\
\hline Comercio & 3973 & $23,6 \%$ & 4729 & $14,7 \%$ & 14071 & $21,3 \%$ & 25883 & $27,4 \%$ & 24314 & $26,5 \%$ \\
\hline Transp. & 1626 & $9,6 \%$ & 4016 & $12,4 \%$ & 3745 & $5,6 \%$ & 6529 & $6,9 \%$ & 7375 & $8,1 \%$ \\
\hline Finanzas & - & - & - & - & 2547 & $3,9 \%$ & 4805 & $5,1 \%$ & 7269 & $7,9 \%$ \\
\hline Servicios & 2336 & $13,9 \%$ & 4670 & $14,4 \%$ & 11741 & $17,8 \%$ & 18336 & $19,4 \%$ & 22624 & $24,7 \%$ \\
\hline Total PIC & & $100 \%$ & & $100 \%$ & & $100 \%$ & & $100 \%$ & & $100 \%$ \\
\hline $\begin{array}{l}\text { Pobl. No } \\
\text { prod. }\end{array}$ & 8362 & $21,4 \%$ & 11898 & $20,1 \%$ & 29583 & $27,3 \%$ & 55023 & $33,6 \%$ & 95901 & $47,9 \%$ \\
\hline Servicios & 3332 & $39,8 \%$ & 6660 & $56 \%$ & 16740 & $56,6 \%$ & 29784 & $54,1 \%$ & 27383 & $28,6 \%$ \\
\hline $\begin{array}{l}\text { No bien } \\
\text { especif. }\end{array}$ & 14 & $33,6 \%$ & $3970^{*}$ & $33,4 \%$ & 5711 & $19,3 \%$ & 794 & $1,4 \%$ & 5385 & $5,6 \%$ \\
\hline $\begin{array}{l}\text { Jub y } \\
\text { Pens. }\end{array}$ & 874 & $10,5 \%$ & 1268 & $10,6 \%$ & 6829 & $23,1 \%$ & 15781 & $28,7 \%$ & 24107 & $25,1 \%$ \\
\hline
\end{tabular}

${ }^{383}$ Iñigo Carrera y Podestá, Cuadernos de CICSO № 46, 1985. No presentaremos aquí la explicación de cómo se realiza la distribución por estar contenida en el trabajo citado. Solamente aclaramos que la división entre servicios en PIC y servicios en PNP obedece a la desagregación que realizamos de esta rama de actividad censal en dos grupos, uno productivo y otro no (enseñanza, salud y servicios sociales es parte de la PIC, administración pública, servicio doméstico, órganos extraterritoriales y otros es parte de la PNP). Las características del censo de 1970 no hacen confiable la utilización de este ejercicio metodológico con esos datos. 


\begin{tabular}{|c|c|c|c|c|c|c|c|c|c|c|}
\hline Rentistas & 173 & $2,1 \%$ & - & - & - & - & - & - & - & \\
\hline Desoc. & 1169 & $14 \%$ & - & - & $303^{\circ}$ & $1 \%$ & 8664 & $15,8 \%$ & 39026 & $40,7 \%$ \\
\hline Total PNP & & $100 \%$ & & $100 \%$ & & $100 \%$ & & $100 \%$ & & $100 \%$ \\
\hline \multirow[t]{2}{*}{ Total } & 38989 & $99.9 \%$ & 59238 & $100 \%$ & 108440 & $100 \%$ & 163616 & $100 \%$ & 199823 & $100 \%$ \\
\hline & & & \multicolumn{2}{|c|}{$\begin{array}{l}\text { * incl } \\
\text { desocupados }\end{array}$} & \multicolumn{2}{|c|}{ o Nuevos trabaj. } & & & & \\
\hline
\end{tabular}

Fuente: elaboración propia sobre datos censales. Porcentaje de cada división sobre PEA más Jubilados (desocupados solo en caso en que esta relevado), porcentajes de cada rama sobre total de cada distribución. Para 1960 distribución de servicios según porcentual de 1980 como aproximación, por no presentar el censo datos desagregados.

Observaremos, además del cuadro de distribución para Chubut, la distribución de la población según la división social del trabajo para Argentina, elaborada por Cavalleri, Donaire y Rosati (2005) para 1960, 1980, 1991 y 2001. Esto nos permitirá comparar los datos y desarrollar una hipótesis explicativa de la aparente contradicción que se plantea entre una situación donde ya para los años setenta se va imponiendo el dominio del capital financiero a nivel nacional y un modelo que a nivel regional impulsa en esos años un proyecto propio de la fase de dominio del capital industrial (proyecto de polos de desarrollo)

Cuadro № 32: División social del trabajo para Argentina. Censos Nacionales de Población y Vivienda 1960 - $1980-1991-2001$.

\begin{tabular}{|c|c|c|c|c|c|c|c|c|}
\hline & \multicolumn{2}{|c|}{1960} & \multicolumn{2}{|c|}{1980} & \multicolumn{2}{|c|}{1991} & \multicolumn{2}{|c|}{2001} \\
\hline $\begin{array}{l}\text { Población } \\
\text { Agrícola }\end{array}$ & 1351869 & $16,2 \%$ & 1200992 & $10,1 \%$ & 1364870 & $8,5 \%$ & 910982 & $5 \%$ \\
\hline $\begin{array}{l}\text { Población } \\
\text { Industrial y } \\
\text { Comercial }\end{array}$ & 4639832 & $55,7 \%$ & 6884917 & $57,7 \%$ & 8486696 & $52,8 \%$ & 7885984 & $43,1 \%$ \\
\hline $\begin{array}{l}\text { Población No } \\
\text { Productiva }\end{array}$ & 2343500 & $28,1 \%$ & 3848245 & $32,2 \%$ & 6214807 & $38,7 \%$ & 9489509 & $51,9 \%$ \\
\hline Total & 8335201 & $100 \%$ & 11934154 & $100 \%$ & 16066373 & $100 \%$ & 18796966 & $100 \%$ \\
\hline
\end{tabular}

Fuente: Cavalleri, Donaire y Rosati (2005). Área de Estructura Social del Programa de Investigaciones sobre el Movimiento de la Sociedad Argentina (PIMSA) en base a Censos Nacionales de Población.

Los resultados que nos presentan estos cuadros nos permiten elaborar varias lecturas sobre el proceso de transformación de la estructura económica social. En primer lugar realizaremos el análisis de la evolución de Chubut para después compararlo con el proceso general de Argentina.

Consideramos que un primer dato del cambio en el sentido del proceso, lo marca el aumento de la población de la provincia.

Cuadro № 33: Evolución población Chubut.

\begin{tabular}{|c|c|c|c|c|c|c|}
\cline { 2 - 7 } \multicolumn{1}{c|}{} & 1947 & 1960 & 1970 & 1980 & 1991 & 2001 \\
\hline Pobl. Total & 92456 & 142412 & 189735 & 263116 & 357189 & 413237 \\
\hline \multicolumn{7}{c|}{ Fuente: elaboración propia sobre datos censales. }
\end{tabular}


Mientras entre 1947, 1960, 1970, 1980 y 1991 se denotan aumentos importantes de población, el período entre 1991 y 2001 marca un freno. Entre 1947 y 1991 la población se ha cuadruplicado, con el consiguiente aumento de la población económicamente activa y con índices de crecimiento intercensal de: 54 \% entre 1947 y $1960,33 \%$ entre 1960 y 1970, 39\% entre 1970 y 1980, 35\% entre 1980 y 1991 y de sólo el $15 \%$ entre 1991 y el 2001.

La población agrícola, para Chubut en su gran mayoría abocada a la ganadería (y más específicamente a la producción de ovejas para lana), crece en términos absolutos hasta 1960, bajando en 1980 a 12760 (11,8\% del total). El crecimiento posterior hacia 1991 (14176) nos presenta un dato contradictorio con la hipótesis de que este descenso de la población agrícola muestra el límite del desarrollo predominantemente en extensión del capitalismo en la región, aunque sigue descendiendo en términos relativos.

Creemos que este problema se debe a que los datos censales incorporan a casi toda la actividad pesquera dentro del apartado, siendo que en 1991 y 2001 la pesquera es una actividad que por su desarrollo ya es más cercana a la población industrial y comercial que a la agrícola (aunque con muy distintas características hacia su interior). Si eliminamos la pesca de la PA de 1991 y 2001, el número de personas agrupadas bajo ese apartado en 1991 pasa a 12773, un 7,8\% del total, y a 9970 en 2001, un 5\% del total. Esto nos presentaría la siguiente evolución de la población agrícola:

Cuadro № 34: Evolución PA sin sector pesca. Chubut 1947 - 2001. Porcentaje sobre PEA.

\begin{tabular}{|c|c|c|c|c|c|c|c|c|c|c|c|}
\hline \multicolumn{2}{|c|}{1947} & \multicolumn{2}{|c|}{1960} & \multicolumn{2}{|c|}{1970} & \multicolumn{2}{|c|}{1980} & \multicolumn{2}{|c|}{1991} & \multicolumn{2}{|c|}{2001} \\
\hline 13811 & $35,4 \%$ & 14996 & $25,3 \%$ & 14109 & $17,4 \%$ & 12760 & $11,7 \%$ & 12773 & $7,8 \%$ & 9970 & $5 \%$ \\
\hline
\end{tabular}

Este cuadro nos muestra más claramente que ya para 1960 hay un fuerte descenso en términos relativos de la población agrupada en esa actividad, para empezar a caer también en términos absolutos desde 1960 hasta la actualidad. El porcentaje poco superior a un $10 \%$ de 1980 ya nos muestra un alto grado de desarrollo de la división social del trabajo y, a la vez, un alto grado de desarrollo capitalista. El leve aumento de la PA en términos absolutos entre 1980 y 1991 presenta un problema en la continuidad del proceso, problema que también se presenta a nivel nacional (ver Cavalleri, Donaire y Rosati, 2006), pero que parece ser un movimiento coyuntural más que orgánico, ya que luego retoma las características anteriores al descender nuevamente entre 1991 y el 2001. De todas maneras éste es 
uno de los problemas que queda abierto en este trabajo, para intentar ser resuelto a través de la continuidad de la investigación.

Germán Rosati $(2006,2007)$ aborda directamente esta problemática, en sus trabajos ya citados acerca del análisis de la estructura económica-social concreta de la pequeña producción mercantil principalmente en el campo, y del movimiento de la estructura económica del campo chaqueño. Allí observa que el aumento de la población agrícola a nivel nacional registrado en 1991, se explica fundamentalmente por el incremento observado en la estructura económica social concreta de pequeña producción mercantil principalmente en el campo (que comprende a las provincias de Misiones, Formosa, Chaco, Corrientes, Santiago del Estero y La Pampa, tomando la distribución propuesta por Iñigo Carrera, Podestá y Cotarelo, 1999). De entre ellas casi el $30 \%$ de todo el incremento nacional se explica solamente por el cambio en la provincia de Chaco.

Destaca como principal hipótesis que este incremento estaría marcando el crecimiento de formas de superpoblación relativa (indicador del desarrollo en profundidad del capitalismo), que durante algunos años se manifestarían bajo las formas de latente y estancada (asumiendo las modalidades de superpoblación relativa expuestas por Carlos Marx en “El Capital'), para después de 1991 manifestarse como desocupación abierta.

Volviendo a nuestro análisis, observamos que en Chubut la población industrial y comercial se duplica entre 1947 y 1960 y vuelve a hacerlo entre 1960 y 1980 . Este dato es un claro indicador de una importante difusión del trabajo asalariado. La rama que más crece entre 1947 y 1960 es la industria manufacturera, comenzando allí a caer en términos relativos y absolutos la rama de minas y canteras, que agrupaba hasta 1960 a la mayoría de la PIC.

Para 1980 es más claro el nuevo perfil que adquiere la estructura económica de la provincia, con una fuerte caída de la rama minas y canteras, la consolidación de la industria manufacturera y el crecimiento de ramas que se conforman en ese momento como satélites de la industrialización, tal como la construcción y el comercio.

Este cambio en el sentido del desarrollo muestra que el enclave de Comodoro Rivadavia, centrado en la extracción minera de petróleo y gas, no crece desde 1960, desarrollándose en cambio los nuevos enclaves industriales de Trelew y Puerto Madryn. Ese proceso de creación de nuevas industrias formalmente privadas pero financiadas por aportes del Estado, genera importantes oleadas migratorias desde el norte del país, de países limítrofes y desde el interior rural de la provincia. Así durante esas décadas estamos ante una verdadera "creación" de nuevas ciudades a partir de estos proyectos orientados e impulsados por el Estado, ya que los antiguos pueblos de 
Trelew y Puerto Madryn sufren rápidas y profundas mutaciones, muchas veces sin la adecuada previsión social y aún menos con la necesaria planificación urbana.

Es interesante observar cómo el freno del proceso de crecimiento no se muestra en 1991 en la rama que impulsa este proceso (manufacturera, que para 1991 mantiene su porcentaje de 1980) sino en la construcción, que cae de representar el $19,4 \%$ de la PIC en 1980 a representar solamente el 12,7\% en 1991. Evidentemente el descenso en esta rama indicaba la caída de las inversiones y de la expectativa en que continuaría el proceso de crecimiento. En cambio crece significativamente la rama comercio y las finanzas, indicadores de la mayor importancia de la intermediación, muestras, en definitiva, del mayor peso que va adquiriendo el capital financiero sobre la estructura económica social.

El otro dato fundamental lo presenta el descenso global de la población industrial y comercial y el fuerte aumento de la población no productiva. La PNP había tenido un importante desarrollo entre 1960 y 1980, pero ahora crece significativamente en sólo once años, en lo que se constituye como un claro indicador del proceso de parasitismo y rentismo en que entra el desarrollo capitalista. Este fenómeno, como veremos, ya se hacía observable desde hacía años a nivel nacional, y ahora se mostraba como una realidad también para Chubut.

Ya para el 2001 el proceso es muy evidente, aunque debemos tener en cuenta que fue un año de profundo impacto recesivo, por lo cual si bien los datos son indicativos del proceso por el que transita el capitalismo quizás aparecen sobredimensionadas coyunturalmente algunas de sus características.

La caída en la rama manufacturera no sólo es pronunciada en términos relativos sino también en términos absolutos. La construcción también cae en términos absolutos, al igual que la rama de minas y canteras y hasta el comercio. Dentro de la PIC sólo crece en términos absolutos y relativos la rama servicios, fundamentalmente empleada en el Estado, la rama finanzas (expresión del mayor peso del capital financiero y que ya registramos que inauguraba nuevas entidades en el momento más grave del estancamiento económico) y la rama transportes.

El fuerte crecimiento de la rama de enseñanza, salud y servicios sociales nos plantea el problema de si una parte de esta población ocupada no forma en realidad parte de la población no productiva, en tanto su función en esta fase del capitalismo parece ser cada vez menos la tradicional formación y conservación de la fuerza de trabajo y se traslada cada vez más hacia las tareas de asistencia pública y contención de la superpoblación relativa (ver Cavalleri, Donaire y Rosati, 2006).

Este elemento, junto al proceso de proletarización que observamos en parte de este grupo social en el anterior apartado, se constituyen como posibles indicadores de 
un cambio en la función y posición de estos conjuntos de personas en la sociedad. Otro indicador de ese cambio es el creciente peso que estos grupos van adquiriendo en el conflicto social, generando, como ya vimos en las descripciones, una importante proporción de hechos de rebelión que toman las características propias de la clase obrera (son desarrolladas desde organizaciones sindicales, las formas más utilizadas son huelgas y marchas, etc. $)^{384}$.

Sin dudas el dato fundamental para el 2001 es el impresionante aumento de la población no productiva en relación a la estructura económica social global. Para este año la PNP agrupa a casi la mitad de la población total plausible de ser distribuida. Es un indicador muy evidente de las condiciones en que continúa la expansión capitalista en la provincia, con el incremento del rentismo y de actividades económicas dirigidas al consumo suntuario de pequeñas capas de la población local o de otros países ${ }^{385}$, formas que toma el creciente parasitismo de un sector de la población que vive del trabajo que otros realizan. El descenso en la rama servicios de la PNP se debe a la caída en "servicio doméstico", que pasa de 11922 en 1991 a 9152 en 2001 (evidencia del descenso en la capacidad adquisitiva de muchos hogares). En cambio la administración pública continúa aumentando significativamente, pasando de 15664 en 1991 a 18222 en el 2001.

Simultáneamente se incrementan los sectores pauperizados, los desplazados de la actividad económica. Se conforma una gran proporción de población sobrante ${ }^{386}$ para las necesidades del capitalismo actual, población que se estructura como desocupación estructural o se encubre como empleo estatal superfluo.

El desarrollo y crecimiento de una miseria consolidada se presenta como una nueva realidad para la región, con el surgimiento de barrios cada vez más pobres y sus consecuencias de aumento de la violencia, provocada por la patente desigualdad social. El alto índice de desocupación no se reparte en forma pareja por las ciudades,

\footnotetext{
${ }^{384}$ Sólo como otro ejemplo del rol creciente de estas fracciones en el conjunto del conflicto social, vemos que en un trabajo centrado en los hechos de rebelión sindical entre 2004 y junio de 2007, Cotarelo (2007b), destaca que "La mayor parte de los hechos son protagonizados por trabajadores estatales alrededor del 60\%-, dada la intensa movilización de los trabajadores de la administración pública nacional, provincial y municipal, los docentes y los trabajadores de los hospitales públicos."

${ }^{385}$ Específicamente el turismo, indicado como el futuro factor de desarrollo de la provincia tanto por las anteriores gestiones provinciales como por la actual de Das Neves.

${ }_{386}$ Tomamos aquí a Donaire y Rosati (2007b) "La población excedente no se reduce a la población que se presenta abiertamente desocupada o subocupada. Un análisis más exacto de la sobrepoblación debería considerar el conjunto de las formas que asume (flotante, latente, estancada), partes de las cuales se encuentran clasificadas por las estadísticas oficiales como ocupados (por ejemplo, parte del cuentapropismo) e inactivos (por ejemplo, los desocupados desalentados considerados como inactivos marginales). El conjunto de la población sobrante en Argentina ha sido estimado en alrededor de una tercera parte del proletariado y semiproletariado para mediados de la década del ochenta y cerca de dos tercios para fines de la década del noventa (Ver Iñigo Carrera, Nicolás y Podestá, Jorge (1985); Análisis de una relación de fuerzas sociales objetiva: caracterización de los grupos sociales fundamentales en la Argentina actual, Cuaderno de CICSO - Serie Estudios № 46, Buenos Aires e Iñigo Carrera, Nicolás y Podestá, Jorge (1997); Las nuevas condiciones en la disposición de fuerzas objetiva. La situación del proletariado, en Documentos y Comunicaciones, PIMSA."
} 
sino que se concentra en los barrios pobres de la región, donde habitan la mayoría de los obreros que formaban parte de las dos principales actividades en la fase de auge del parque industrial (industria y construcción).

En algunos de esos barrios, relevamientos no sistemáticos indican que la desocupación llegó a superar, en los momentos más agudos de la crisis, el 50\% de la población económicamente activa, y la subocupación otro $30 \%$ más, según encuestas realizadas por integrantes de las asociaciones vecinales del Barrio Tiro Federal en 1998 y del Barrio INTA en el año $2002^{387}$.

Las escuelas evidencian esta situación al incrementarse en forma masiva el número de alumnos que necesitan recibir la copa de leche y el refuerzo nutricional (antes era sólo para casos especiales), ante la frecuencia de desmayos por hambre. Si bien en la Universidad no hay casos tan extremos, la importancia de la lucha por bajar el precio del bono de comida en los Comedores Universitarios (que se logró en el 2004 y se mantuvo a través de la toma universitaria del 2005) tiene relación con esta problemática. Algunos Centros de Estudiantes de Trelew y Comodoro Rivadavia debieron implementar becas de comida para los estudiantes que debían decidir entre comer su almuerzo o comprar los apuntes de sus carreras.

Vemos entonces que la PNP (principalmente asociada a la administración pública del Estado y a la desocupación estructural) crece en forma ininterrumpida en términos relativos y absolutos desde 1960. Es en la rama servicios donde el crecimiento absoluto es más notorio, puesto que aumenta un 77\% entre 1980 y 1991 y un $151 \%$ entre el sesenta y el ochenta, datos que sólo se emparentan, en alguna medida, con el crecimiento de la rama de industria manufacturera, que se duplica entre el sesenta y el ochenta.

En definitiva ninguna rama de la actividad económica crece en el volumen que lo realiza la administración pública (exceptuando a los desocupados, pero no los podemos considerar una rama económica ${ }^{388}$ ). Estos datos también se presentan en Santa Cruz, donde la rama servicios de la PNP se triplica entre 1980 y 1991; así se encubría parte de la población sobrante, utilizando desde los gobiernos provinciales los fondos de regalías petroleras para intentar que no se desaten mayores conflictos sociales en sus provincias (ver Luque y otros, 2000).

El gran salto en el crecimiento de empleados públicos se da en los años ochenta, en especial a mediados de la década, justamente cuando empezaban a hacerse inocultables los límites del proyecto de polos de desarrollo. Se hacía

\footnotetext{
${ }^{387}$ Dos de los barrios más pobres de la ciudad de Trelew. El Tiro Federal es más antiguo y cercano al centro, mientras que el INTA es de los más nuevos y donde se presenta una mayor miseria consolidada.

${ }^{388}$ En términos precisos nuestra perspectiva considera que la administración pública tampoco forma parte de la actividad económica, aunque los datos censales la clasifiquen como tal.
} 
necesaria una manera de encubrir la crisis que de todas maneras llegaría. Ya señalamos anteriormente que es en 1985 cuando comienza a caer el producto bruto industrial y alrededor de 1986 cuando se estanca el PBG provincial. El Estado provincial absorbe gran parte de esta población sobrante para las necesidades del capital en esta nueva fase de su desarrollo, y los nuevos asalariados estatales son fundamentalmente población no productiva.

Completamos estas reflexiones con el siguiente cuadro, que demuestra el progresivo aumento de las ramas de educación, servicios sociales y salud, y el descenso abrupto de la industria manufacturera a partir de 1991.

Cuadro № 35: Población inserta en la producción según ocupación en industria manufacturera (IM), educación, servicios sociales y salud (EyS) o resto de las ramas para Chubut.

\begin{tabular}{|r|r|r|}
\hline \multicolumn{3}{|c|}{1980} \\
\hline \multicolumn{1}{|c|}{ IM } & \multicolumn{1}{c|}{ EyS } & Resto \\
\hline 14.002 & 7.530 & 23.736 \\
\hline $31 \%$ & $17 \%$ & $52 \%$ \\
\hline
\end{tabular}

\begin{tabular}{|r|r|r|}
\hline \multicolumn{3}{|c|}{1991} \\
\hline IM & \multicolumn{1}{|c|}{ EyS } & Resto \\
\hline 19.118 & 16.304 & 26.275 \\
\hline $31 \%$ & $26 \%$ & $43 \%$ \\
\hline
\end{tabular}

\begin{tabular}{|r|r|r|}
\hline \multicolumn{3}{|c|}{2001} \\
\hline IM & \multicolumn{1}{|c|}{ EyS } & Resto \\
\hline 12.081 & 17.007 & 25.298 \\
\hline $22 \%$ & $31 \%$ & $47 \%$ \\
\hline
\end{tabular}

Fuente: Área de Estructura Social del Programa de Investigaciones sobre el Movimiento de la Sociedad Argentina (PIMSA) en base a Censos Nacionales de Población.

El otro rasgo fundamental de transformación cualitativa en la estructura económica social es el mayor peso de la proporción de población industrial y comercial agrupada en las ramas de circulación, cayendo en forma permanente las ramas de producción:

Cuadro № 36: Población industrial y comercial según inserción en ramas de la producción (Prod.) o de la circulación (Circ.) para Chubut. 1947 - 2001.

\begin{tabular}{|l|c|c|c|c|c|}
\hline \multicolumn{1}{|c|}{ PIC } & $\mathbf{1 9 4 7}$ & $\mathbf{1 9 6 0}$ & $\mathbf{1 9 8 0}$ & $\mathbf{1 9 9 1}$ & $\mathbf{2 0 0 1}$ \\
\hline en la & $3973-$ & $4729-$ & $19475-$ & $30688-$ & $31583-$ \\
circulación & $30,9 \%$ & $19,9 \%$ & $30,1 \%$ & $33,2 \%$ & $36,7 \%$ \\
\hline en la & $8881-$ & $18929-$ & $45268-$ & $61697-$ & $54386-$ \\
producción & $69,1 \%$ & $80,1 \%$ & $69,9 \%$ & $66,8 \%$ & $63,3 \%$ \\
\hline
\end{tabular}

Nota: no se distribuye la población de la rama "otros servicios sociales, comunales y personales" ya que varía su composición según los diferentes censos. Fuente: 1947 y 1960 elaboración propia sobre datos censales. 1980 - 1991 - 2001 área de Estructura Social del Programa de Investigaciones sobre el

Movimiento de la Sociedad Argentina (PIMSA) en base a Censos Nacionales de Población.

Vemos allí como entre 1947 y 1960 se produce una profunda transformación que modifica la centralidad que hasta 1947 tenían las ramas vinculadas a la circulación en la provincia. Después de 1960 el aumento en términos relativos de la circulación es continuo, mientras los porcentuales de las ramas de producción descienden y, ya entre 1991 y 2001, caen hasta en términos absolutos. Observemos este mismo proceso entre 1960 y 2001 para el nivel nacional: 
Cuadro № 37: Población industrial y comercial según inserción en ramas de la producción (Prod.) o de la circulación (Circ.) para Argentina. 1960 - 2001.

\begin{tabular}{|l|l|l|l|l|}
\hline $\begin{array}{l}\text { Población ocupada en ramas industriales y } \\
\text { comerciales }\end{array}$ & $\mathbf{1 9 6 0}$ & $\mathbf{1 9 8 0}$ & $\mathbf{1 9 9 1}$ & $\mathbf{2 0 0 1}$ \\
\hline en la circulación & $21,2 \%$ & $35,4 \%$ & $38,6 \%$ & $42 \%$ \\
\hline en la producción & $78,8 \%$ & $64,6 \%$ & $61,4 \%$ & $58 \%$ \\
\hline
\end{tabular}

Fuente: Área de Estructura Social del Programa de Investigaciones sobre el Movimiento de la Sociedad Argentina (PIMSA) en base a Censos Nacionales de Población.

Indudablemente hay una llamativa sincronía con el proceso nacional, aunque en todo momento en la región es mayor el porcentaje de población agrupada en la producción.

Es claro que, en el caso de Chubut, los principales cambios en el sentido de la realización de la hegemonía del capital financiero al nivel de la estructura económica social, se desarrollan durante los años noventa. En ese período se conforma una gran masa de población sobrante, se desarrolla la desocupación estructural (como nunca antes había existido en la región), crece la población no productiva y caen las ramas que motorizaban el antiguo crecimiento económico asociado al dominio del capital industrial y al desarrollo en extensión del capitalismo.

La comparación con el orden nacional nos presenta otros datos de gran interés:

Cuadro № 38: Distribución social del trabajo según grandes apartados comparando Argentina Chubut de 1960 a 2001

\begin{tabular}{|l|r|r|r|r|r|r|r|c|}
\cline { 2 - 9 } \multicolumn{1}{c|}{} & \multicolumn{2}{c|}{1960} & \multicolumn{2}{c|}{1980} & \multicolumn{2}{c|}{1991} & \multicolumn{2}{c|}{2001} \\
\cline { 2 - 9 } \multicolumn{1}{c|}{} & Argent. & Chubut & Argent. & Chubut & Argent. & Chubut & Argent. & Chubut \\
\hline Pobl. Agrícola & $16,2 \%$ & $\mathbf{2 5 , 3 \%}$ & $10,1 \%$ & $\mathbf{1 1 , 8} \%$ & $8,5 \%$ & $\mathbf{8 , 7} \%$ & $5 \%$ & $\mathbf{6 , 2} \%$ \\
\hline Pobl. Ind y Com & $55,7 \%$ & $\mathbf{5 4 , 6 \%}$ & $57,7 \%$ & $\mathbf{6 0 , 9} \%$ & $52,8 \%$ & $\mathbf{5 7 , 7} \%$ & $43,1 \%$ & $\mathbf{4 5 , 9 \%}$ \\
\hline Pobl. No prod. & $28,1 \%$ & $\mathbf{2 0 , 1} \%$ & $32,2 \%$ & $\mathbf{2 7 , 3 \%}$ & $38,7 \%$ & $\mathbf{3 3 , 6} \%$ & $51,9 \%$ & $\mathbf{4 7 , 9 \%}$ \\
\hline
\end{tabular}

Vemos en esta comparación que la evolución de la división social del trabajo en la provincia y en el país, presenta diferencias que nos permiten entender el proceso en forma más profunda. Chubut para 1960 aún no tenía el grado de desarrollo capitalista que presenta la Argentina a nivel global. Esto se demuestra en que más de una cuarta parte de la población todavía se encontraba ocupada como población agrícola, dato que es indicador fundamental de un bajo desarrollo de las fuerzas productivas y una menor difusión del trabajo asalariado. Mientras a nivel nacional el capitalismo ya había alcanzado los límites de su desarrollo predominantemente en extensión, y necesitaba comenzar a desarrollarse predominantemente en profundidad, en la provincia aún no estaba agotado el desarrollo del capitalismo en extensión. 
Estos mismos rasgos también se muestran en el poco peso que tiene la población no productiva de Chubut en comparación con el alto porcentaje que ya tiene para Argentina, algo propio de la fase de dominio del capital financiero. El crecimiento acelerado que impulsa el Estado nacional durante estos años en la Patagonia se basa en la necesidad del capitalismo de incorporar a todas las regiones y a toda su población, al proceso que ya había desarrollado la parte central del país. Además de los aspectos políticos antes mencionados ésta es la base explicativa fundamental desde la cual consideramos que se resuelve esa aparente contradicción entre el modelo que las dictaduras del sesenta y el setenta impulsan para la Patagonia y el que desarrollan para la región central de Argentina.

Todavía en 1980 la provincia no había llegado a números semejantes al promedio nacional, presentando aún una mayor cantidad de población agrícola y menor de población no productiva que los datos observables a nivel país. En cambio para 1991 y 2001 esos números ya son muy semejantes. La dinámica del período que va de 1991 al 2001 muestra la continuidad de la similitud en el proceso, que impacta un poco menos en la provincia que a nivel nacional (hay un menor porcentaje de población no productiva y por lo tanto un mayor porcentual de población industrial y comercial), probablemente debido al ya analizado papel del Estado provincial como "encubridor" de una porción de la población sobrante.

La diferencia que aún se mantiene en el porcentaje de población agrícola puede deberse al hecho de incluir la pesca en ese apartado, o a que el capitalismo aún no haya agotado totalmente la forma de crecimiento en extensión para la región patagónica, algo que sí pareciera haber realizado a nivel nacional.

En definitiva el objetivo del modelo de "polos de desarrollo" fue incorporar la región patagónica al desarrollo capitalista argentino, haciéndole realizar un rápido pasaje por la fase del capital industrial para luego pasar al desarrollo del capitalismo en profundidad, en consonancia con el proceso nacional de realización hegemónica del capital financiero.

En este sentido, y de acuerdo a los distintos datos y elementos que hemos volcado en esta investigación, consideramos demostrado que la región avanza hacia una mayor homogeneización con el proceso del resto del país y justamente esa necesidad de una mayor homogeneización en su desarrollo es lo que explica, a su vez, la aparente "excepcionalidad" del proceso de desarrollo industrial subsidiado de los años sesenta, setenta y parte de los ochenta.

Este resultado se inscribe en el marco de la hipótesis general desarrollada por Nicolás Iñigo Carrera y Jorge Podestá en su clásico trabajo de 1985, donde destacan la tendencia general de la formación económica social que constituye la Argentina 
como totalidad, de avanzar hacia una mayor homogeneización de las distintas estructuras económicas sociales concretas, marcada por la dominación más directa que desarrolla el capital financiero sobre todas ellas. A su vez esa conclusión discute y desacuerda con la perspectiva que defiende Eduardo Basualdo (2000) quién sostiene que los resultados claves del proceso de cambio en la Argentina son "... no sólo la redefinición del Estado, sino también una notable "desindustrialización" que se expresa en la caída de la importancia relativa de esta actividad y en una generalizada reducción del grado de integración nacional" (43) ${ }^{389}$.

A esta altura de la exposición, creemos entonces que está consolidada la hipótesis de que el proceso que realiza la estructura económica social de la región que investigamos avanza en el mismo sentido que marcamos cuando analizábamos la situación general de Argentina, y que el proceso previo de crecimiento capitalista en el marco del proyecto de polos de desarrollo no era algo excepcional. La región está más integrada que nunca a la formación económica nacional, aún cuando esta integración sea sobre la base de una conformación regresiva para los intereses de la mayoría de los habitantes de la región y para las mayorías oprimidas del país.

Esto muestra que los cambios que se producen durante estos años en la provincia, el "crecimiento" y la "crisis", los distintos modelos que se estructuran para la región desde los gobiernos nacionales, no respondieron a la bondad o la maldad, o la eficacia o ineficacia de los gobernantes locales o nacionales, sino a las distintas fases del sistema capitalista y a sus transformaciones.

389 Vuelve a sostenerlo más adelante "La reestructuración industrial es acompañada por otra característica de singular importancia: una profunda y generalizada regresión en términos del grado de integración nacional" (Basualdo, 2000: 145). 


\section{Hacia un intento de síntesis}

Iniciamos este apartado final buscando desarrollar una síntesis de los distintos elementos que hemos ido volcando a lo largo de la investigación. En este sentido seguramente repetiremos algunas lecturas que ya fueron desarrolladas anteriormente, esperando reducir estas repeticiones al mínimo necesario.

Hemos visto cómo el capitalismo resuelve su necesidad de crecimiento en la región generando una masa de sobrepoblación relativa (o sea fuerza de trabajo que el capitalismo actual no puede hacer generadora de valor) que no sólo se expresa como desocupación abierta sino que también se encubre bajo la forma del empleo estatal. Durante los noventa la región sufrió profundos cambios a partir de la caída del proyecto de industrialización subsidiada y esto llevó a que se desarrollen como procesos generales la concentración de la propiedad y la riqueza, la proletarización y pauperización de crecientes masas de población y el incremento de la explotación de los trabajadores ocupados.

Desde mediados de 1950 la estructura económica de la región comienza a tomar las características que definimos como de "capitalismo de estado en enclaves". Este modelo se desarrolla centralmente entre 1960 y 1980, entra en crisis a mediados de los ochenta y allí se realizan profundas transformaciones durante la década del noventa, a partir de la realización hegemónica del capital financiero.

Durante el período que va de 1960 a mediados de los ochenta se logran índices de crecimiento muy altos desde la puesta en marcha de los proyectos de "polos de desarrollo", presentando una tasa casi nula de desempleo y constante demanda de nuevos trabajadores. Esto queda cancelado, pasando a una configuración donde aumenta la pobreza, se desarrolla una importante desocupación estructural y, en lugar de crearse puestos de trabajo y aumentar la producción, lo que aumenta es la destrucción de puestos laborales y el parasitismo.

El Estado pasa a realizar otra planificación y otra regulación de la economía, en función de los intereses de la nueva alianza de clases que ocupa el poder, expresión política de la nueva fase del capitalismo. Esto se muestra en la finalización de las políticas de promoción industrial y en la privatización de aquellas empresas donde funcionaba como capitalista directo.

La economía de la región pasa a estar directamente en manos del capital financiero transnacional que controla los enclaves de gran capital (extracción y depredación de recursos naturales como petróleo, pesca, etc.). Los enclaves generados por el papel del Estado como planificador (polos de desarrollo, 
promociones industriales) son en gran medida abandonados ya que no resultan rentables para las grandes empresas privadas.

Para la zona analizada en este trabajo esa decisión implicó el final de las políticas de promoción industrial que se realizaban en el marco del proyecto de polos de desarrollo. Políticas que garantizaban la continuidad de las fábricas textiles en Trelew, Rawson y Puerto Madryn y sin las cuales esas fábricas no podían competir con la producción del área central del país y menos aún con las importaciones. También las plantas pesqueras atravesaron una profunda crisis que llevó a continuos cierres, despidos y suspensiones, y a una mayor explotación del personal que seguía ocupado.

En el sector pesquero el Estado, en especial el nacional pero con el visto bueno (o al menos la pasividad) del provincial, realizó una planificación que privilegió la explotación del recurso por parte de las grandes empresas multinacionales del sector, en especial a través de los llamados buques factorías que realizan todo el procesamiento a bordo sin ocupar personal en tierra (siendo el personal a bordo en su gran mayoría de origen extranjero). Así se otorgaron permisos de pesca, se dieron exenciones impositivas, se entregaron créditos, que aseguraron a estas grandes empresas la depredación casi sin control de un recurso frágil como es el pesquero (especialmente frágil porque se concentra la captura en pocas especies, por ser las de mayor valor comercial).

De los proyectos nacidos en el marco del modelo de polos de desarrollo ALUAR es la única empresa que continúa creciendo y que en los últimos años ha duplicado su capacidad productiva. Hemos destacado que estamos ante un caso clave, ya que ALUAR es una gran empresa de capital concentrado que logra mantener y profundizar su capacidad para recibir subsidios y privilegios por parte del Estado. Su situación monopólica en Argentina como productora de aluminio primario le permite ser formadora de precios en el sector y, a partir de esa condición, sostiene esa relación privilegiada con el Estado provincial y nacional. Un ejemplo reciente es la última ampliación de ALUAR, que recibió subsidios por 690 millones de pesos ${ }^{390}$. También en esta empresa se desarrolla en profundidad la explotación de los trabajadores, hecho que quedó evidenciado en la tragedia del $2007^{391}$.

\footnotetext{
390 Según datos publicados en el 2005 en "Página/12" y "Clarín”, los subsidios aprobados por el Gobierno incorporaban la devolución anticipada del IVA (\$279,1 millones) y la amortización acelerada en el Impuesto a las Ganancias (\$410,6 millones), beneficios fiscales que el Estado aprobó a la compañía por 690 millones de pesos.

${ }^{391}$ El 20 de junio de 2007 diez obreros de la construcción murieron tras derrumbarse la construcción de uno de los silos de Aluar. Las muertes fueron producto de la falta de medidas de seguridad en aspectos tan básicos para la región como tener en cuenta la velocidad del viento. La mayoría de estos trabajadores estaban indocumentados y eran de origen boliviano, un mecanismo que usa esta empresa, a través de sus contratistas, para abaratar costos.
} 
Observamos aquí datos que hacen visible que no estamos ante un proceso de "desindustrialización" o de "reprimarización" de la economía. La producción industrial crece en términos absolutos (como ya lo vimos), en base a un creciente aumento de la tasa de explotación de los trabajadores ocupados. Menos obreros en menos fábricas con mayores niveles de tecnificación, maquinización y control del proceso de trabajo, producen mucho más que una cantidad mayor de obreros en mayor número de fábricas, como se registraba en la década del ochenta en la región.

Para la mirada más directa esto aparece como caída de las industrias, porque hay menos empresas funcionando, con menor cantidad de empleos industriales. Desde lo que consideramos una evaluación más profunda del proceso de desarrollo capitalista, observamos que asistimos a la consolidación del régimen de gran industria, a la superación del régimen de manufactura que aún imperaba en gran parte de las textiles y pequeñas y medianas metalúrgicas, que fueron cerrando o siendo absorbidas por empresas transnacionales durante los años noventa y los transcurridos en el nuevo siglo.

Sólo podríamos hablar de desindustrialización si cerráramos los ojos ante el crecimiento de ALUAR o si pensáramos que al conceptualizarla como enclave supusiéramos que no tiene importancia para comprender la estructura económica social de la región y sus transformaciones. Al contrario, para nosotros ALUAR funciona como un indicador acerca del proceso general de cambio de la estructura económica social de la región: las pequeñas y medianas industrias son desplazadas y dejan de recibir apoyo estatal, mientras las grandes de capital concentrado, crecen e incrementan su capacidad para apropiarse de subsidios estatales.

El ya trabajado artículo de Azpiazu y Schorr (2010) presenta datos claves para demostrar este proceso. Allí destacan que entre los cinco sectores industriales que explican más de las dos terceras partes de la producción hacia el 2007, una de ellas es la producción de aluminio primario (junto a la industrialización de recursos naturales, los productos químicos, la siderurgia y el sector automotor, con la particularidad ya citada del carácter monopólico de la producción de aluminio primario en Argentina). Además esas industrias oligopólicas o monopólicas consiguieron un gran aumento en sus precios relativos. En el caso de ALUAR registró un fabuloso incremento del 241,8\% entre 2001 y 2007 (Azpiazu y Schorr, 2010: 35).

El papel del Estado es clave en este proceso, demostrando también que estamos ante una nueva planificación y regulación de la economía. El régimen promocional puesto en marcha tras la convertibilidad se puso en beneficio directo de las empresas de capital más concentrado: "apenas quince proyectos explican más de las tres cuartas partes de la inversión, poco más del 82\% de los beneficios y el 83,2\% 
de las exportaciones incrementales derivadas de la concreción de los respectivos emprendimientos" (Azpiazu y Schorr, 2010: 67). Entre ellas la más favorecida fue ALUAR. Citamos dos extractos de cuadros desarrollados en dicho trabajo:

Cuadro № 39: Proyectos de Inversión aprobados a Aluar bajo la Ley № 25.924 (en valores absolutos). Cuadro № VI.1. Principales proyectos de inversión aprobados bajo la Ley № 25.924 (en valores absolutos)

\begin{tabular}{|c|c|c|c|c|c|c|c|}
\hline \multirow[t]{2}{*}{$\begin{array}{l}\text { Razón } \\
\text { Social }\end{array}$} & \multirow[t]{2}{*}{$\begin{array}{l}\text { Descripción del } \\
\text { proyecto }\end{array}$} & \multicolumn{2}{|c|}{$\begin{array}{l}\text { Beneficio otorgado } \\
\text { (miles de pesos) }\end{array}$} & \multirow{2}{*}{$\begin{array}{c}\text { Monto de la } \\
\text { inversión sin } \\
\text { IVA (en miles } \\
\text { de pesos) }\end{array}$} & \multirow[t]{2}{*}{$\begin{array}{c}\% \\
\text { Total }\end{array}$} & \multirow{2}{*}{$\begin{array}{c}\text { Generac } \\
\text { ión de } \\
\text { empleo }\end{array}$} & \multirow{2}{*}{$\begin{array}{c}\text { Exportacion } \\
\text { es netas } \\
\text { (miles de } \\
\text { U\$S) }\end{array}$} \\
\hline & & IVA & A. A. & & & & \\
\hline Aluar SAIC & $\begin{array}{lcr}\begin{array}{l}\text { Ampliación } \\
\text { productora } \\
\text { primario }\end{array} & \text { de } & \text { planta } \\
\text { aluminio }\end{array}$ & 279.149 & 410.567 & $1.947 .863,8$ & 19,8 & 204 & $154.922,5$ \\
\hline Aluar SAIC & Ampliación de planta & $121.125,8$ & $117.424,2$ & $968.831,1$ & 9,8 & 115 & $72.169,9$ \\
\hline
\end{tabular}

Fuente: Azpiazu y Schorr, 2010: 69.

Cuadro № 40: Indicadores de performance de Aluar. Cuadro № VI.2. Indicadores de performance de las principales empresas patrocinantes de los proyectos de inversión presentados al amparo de la Ley № 25.924, 2001 y 2005 (en porcentajes y millones de dólares)

\begin{tabular}{|l|c|c|c|c|c|c|}
\hline & \multicolumn{2}{|c|}{$\begin{array}{c}\text { Utilidades sobre } \\
\text { ventas \% }\end{array}$} & \multicolumn{2}{c|}{$\begin{array}{c}\text { Exportaciones } \\
\text { (millones de U\$) }\end{array}$} & $\begin{array}{c}\text { Coeficiente exportación } \\
\text { (\%) }\end{array}$ \\
\hline & $\mathbf{2 0 0 1}$ & $\mathbf{2 0 0 5}$ & $\mathbf{2 0 0 1}$ & $\mathbf{2 0 0 5}$ & $\mathbf{2 0 0 1}$ & $\mathbf{2 0 0 5}$ \\
\hline Aluar SAIC & 16,1 & 20,6 & 338,5 & 408,0 & 53,8 & 68,8 \\
\hline
\end{tabular}

Fuente: Azpiazu y Schorr, 2010: 70.

En definitiva, sostenemos que durante la década del noventa se desarrolló un nuevo modelo de articulación del Estado con las empresas privadas, modelo que parte de las necesidades de un capitalismo que ya había encontrado sus límites de desarrollo predominantemente en extensión alrededor de mediados de la década del ochenta y que necesita ahora desarrollarse en profundidad. Las empresas industriales que no son de capital concentrado dejan de recibir el apoyo estatal, realizándose durante estos años un fuerte proceso de concentración de la propiedad y la riqueza que se expresa en el cierre de la mayoría de las pequeñas y medianas empresas, la venta a capitales extranjeros de otras y la caída de la producción de las que quedaron en pie.

El Estado realiza una planificación a favor de las grandes empresas de capital concentrado, que son las que subsisten y crecen en el marco de la fase de dominio del capital financiero. Retomamos aquí el clásico trabajo de Basualdo y Azpiazu sobre la promoción industrial en Argentina (1981). Allí los autores sostienen que "La promoción industrial no resulta contradictoria con el proceso de oligopolización de estas industrias sino que, por el contrario, desempeña un papel decisivo en la concentración y 
centralización del poder económico" (Basualdo y Azpiazu, 1981: 29). Demostrando que el Estado nacional abona este proceso de concentración y centralización económica a partir de su papel como promotor e impulsor de nuevos proyectos industriales: "En síntesis, el análisis de los cincuenta mayores proyectos promocionados permite comprobar que, más allá de las fenomenologías que adopta en los distintos sectores de actividad, el proceso de centralización del capital se ha visto fortalecido y subsidiado por la política desarrollada en el campo de la promoción industrial" (Basualdo y Azpiazu, 1981: 166)

Como nos suele pasar con los trabajos de esta perspectiva encontramos acuerdos importantes en los resultados pero desacuerdos claves en las evaluaciones de los mismos. Para Basualdo y Azpiazu esto determina que "...la política implementada en el ámbito de la promoción no se vio inscripta en una determinada estrategia de desarrollo industrial sino que, por el contrario, denota una clara subordinación respecto a la estrategia empresarial de los grandes capitales privados" (Basualdo y Azpiazu, 1981: 180).

Según esto el Estado pierde su papel de impulsor de una política, y por lo tanto deja de ser el impulsor y planificador de la economía. Para nosotros, al contrario, los datos expuestos demuestran que el Estado sigue siendo el impulsor y promotor de las políticas económicas a nivel nacional, hecho que queda en clara evidencia en el rol que juega como "promotor industrial" (discutiendo también con la idea de un Estado que deja de prestar atención a la industria, en todo caso la distinción operada sería el tipo de industria a la que presta apoyo en cada momento histórico).

Se configura un nuevo tipo de estructura que ya no se organiza como un capitalismo de estado en enclaves, sino que ahora toma la forma de un capitalismo de estado en enclave de grandes empresas privadas de capital concentrado, en condiciones oligopólicas o directamente monopólicas. Si bien el capitalismo de estado es por definición de capital monopólico, en estos años se desarrolla una profundización del dominio de los monopolios privados sobre los recursos naturales y el trabajo asalariado en la región.

Creemos que esta nueva articulación de la estructura económica que señalamos para la región estudiada también se observa en el sur de la provincia, donde durante el año 2007, por ejemplo, el Estado provincial les aseguró a las grandes empresas petroleras la renegociación de los contratos petroleros hasta el $2047^{392}$

\footnotetext{
392 Para evaluar la importancia central de estas renegociaciones, ver, entre otros artículos que trabajan la problemática de los hidrocarburos en Argentina, los trabajos de Marcelo García (2005) "Kirchner y las
} 
Este proceso de transformación se desarrolla en un marco nacional, donde la región investigada avanza hacia una mayor homogeneización con el conjunto de la formación económica social de Argentina. Ya marcamos que consideramos demostrada esta hipótesis y que este proceso explica, a su vez, la aparente "excepcionalidad" del proceso de desarrollo industrial subsidiado de los años sesenta, setenta y parte de los ochenta. La región está hoy más integrada que nunca a la formación económica nacional, aún cuando esta integración sea sobre la base de una conformación regresiva para los intereses de la mayoría de los habitantes de la región y para las mayorías oprimidas del país.

Ahora bien, este mapa de transformaciones debe ser completado con la observación y análisis del ciclo de rebelión y de los diversos hechos que se van desarrollando. Presentaremos en primer término una lectura cuantitativa de la totalidad de los hechos de rebelión relevados en el período investigado, buscando precisar la periodización propuesta oportunamente. Luego avanzaremos con una perspectiva de conjunto y una evaluación cualitativa sobre el ciclo de rebelión, acercándonos a algunas especificidades de las fracciones fundamentales de la clase obrera en la región.

La información cuantitativa sobre los hechos de rebelión nos dará elementos importantes de análisis, aunque desde nuestra perspectiva las herramientas claves las encontramos en la evaluación cualitativa del proceso. Como ya lo hemos marcado no evaluamos los momentos de ascenso y descenso a partir de la simple cantidad de hechos relevados, sino desde la utilización de otros indicadores, especialmente el grado de unidad o división de la clase y el grado de alianza o aislamiento que ella expresa. Basarse únicamente en el número de hechos relevados da una visión distorsionada, ya que muchas veces una mayor cantidad de conflictos no es expresión de mayor organización sino de la dificultad para conseguir lo reclamado a partir de atravesar una situación de debilidad de la clase o de alguna fracción particular.

Pero la evaluación cuantitativa sí nos permitirá encontrar resultados sobre algunas de las hipótesis planteadas acerca de cuál es el sujeto que protagoniza centralmente la rebelión, qué tipo de organización es la convocante de los hechos y qué formas o instrumentos se desarrollan. En primer término buscaremos observar cuál es el sujeto fundamental que protagoniza la rebelión en nuestra región:

petroleras", en Anuario EDI № 1, pp. 74-83 y Claudio Katz (2005) "Quebrantos públicos, negocios privados", en Anuario EDI № 1, pp. 84-91 
Cuadro № 41: Hechos de rebelión entre 1990 y 2005 en el Noreste de Chubut según sujeto ${ }^{393}$ que lo protagoniza.

\begin{tabular}{|l|c|c|c|c|c|c|c|c|c|c|}
\hline Año/suj & Asal & $\begin{array}{l}\text { Asal + } \\
\text { otros }\end{array}$ & Est & $\begin{array}{l}\text { Peq } \\
\text { burg }\end{array}$ & $\begin{array}{l}\text { Vec y } \\
\text { pobl }\end{array}$ & Des & $\begin{array}{l}\text { Pobr, } \\
\text { viller, }\end{array}$ & $\begin{array}{l}\text { Milit, } \\
\text { dirig, }\end{array}$ & $\begin{array}{l}\text { Otro } \\
\text { s }\end{array}$ & Total \\
\hline $\mathbf{1 9 9 0}$ & 74 & 12 & 11 & 2 & 0 & 3 & & 1 & 2 & $\mathbf{1 0 5}$ \\
\hline $\mathbf{1 9 9 1}$ & 30 & & 2 & 2 & & & & & & $\mathbf{3 4}$ \\
\hline $\mathbf{1 9 9 2}$ & 44 & 2 & 1 & 2 & 1 & & 4 & & 1 & $\mathbf{5 5}$ \\
\hline $\mathbf{1 9 9 3}$ & 54 & 3 & 6 & 1 & & & 2 & & 1 & $\mathbf{6 7}$ \\
\hline $\mathbf{1 9 9 4}$ & 28 & 1 & 2 & 2 & 4 & 8 & 4 & 1 & 1 & $\mathbf{5 1}$ \\
\hline $\mathbf{1 9 9 5}$ & 38 & 1 & 7 & & & 4 & & 1 & & $\mathbf{5 1}$ \\
\hline $\mathbf{1 9 9 6}$ & 48 & 4 & 6 & 1 & 2 & 6 & 1 & & 10 & $\mathbf{7 8}$ \\
\hline $\mathbf{1 9 9 7}$ & 53 & 6 & 2 & 3 & 5 & 13 & 5 & 1 & & $\mathbf{8 8}$ \\
\hline $\mathbf{1 9 9 8}$ & 84 & 5 & 5 & 2 & 6 & & & & 5 & $\mathbf{1 0 7}$ \\
\hline $\mathbf{1 9 9 9}$ & 86 & 11 & 8 & 6 & & 7 & 2 & 6 & 3 & $\mathbf{1 2 9}$ \\
\hline $\mathbf{2 0 0 0}$ & 58 & 11 & 6 & 3 & 6 & 12 & 1 & 1 & 1 & $\mathbf{9 9}$ \\
\hline $\mathbf{2 0 0 1}$ & 105 & 13 & 16 & 10 & 3 & 23 & 1 & 1 & 7 & $\mathbf{1 7 9}$ \\
\hline $\mathbf{2 0 0 2 a} \mathbf{a}^{394}$ & 70 & 11 & 1 & 2 & 1 & 32 & 3 & 3 & 23 & $\mathbf{1 4 6}$ \\
\hline $\mathbf{2 0 0 2 b}$ & 34 & 6 & 1 & 6 & 3 & 14 & 2 & & 2 & $\mathbf{6 8}$ \\
\hline $\mathbf{2 0 0 3}$ & 46 & 2 & 2 & 1 & 2 & 33 & 12 & 1 & 3 & $\mathbf{1 0 2}$ \\
\hline $\mathbf{2 0 0 4}$ & 55 & 3 & 1 & 9 & 2 & 33 & 1 & 2 & 18 & $\mathbf{1 2 4}$ \\
\hline $\mathbf{2 0 0 5}$ & 120 & 8 & 14 & 6 & 1 & 26 & 3 & 3 & 5 & $\mathbf{1 8 6}$ \\
\hline Total & $\mathbf{1 0 2 7}$ & $\mathbf{9 9}$ & $\mathbf{9 1}$ & $\mathbf{5 8}$ & $\mathbf{3 6}$ & $\mathbf{2 1 4}$ & $\mathbf{4 1}$ & $\mathbf{2 1}$ & $\mathbf{8 2}$ & $\mathbf{1 6 6 9}$ \\
\hline$\%$ & $\mathbf{6 1 , 5}$ & $\mathbf{5 , 9}$ & $\mathbf{5 , 4}$ & $\mathbf{3 , 4}$ & $\mathbf{2 , 2}$ & $\mathbf{1 2 , 8}$ & $\mathbf{2 , 5}$ & $\mathbf{1 , 3}$ & $\mathbf{4 , 9}$ & \\
\hline
\end{tabular}

Vemos que, a contramano de las expresiones más difundidas en la academia (especialmente desarrolladas durante los años noventa), que sostenían una caída de los hechos protagonizados por los asalariados, estos siguen siendo el sujeto fundamental de la rebelión, expresión del conflicto de clase permanente en una sociedad articulada alrededor de la explotación de la fuerza de trabajo asalariada. El $61,5 \%$ de los hechos fueron desarrollados por asalariados, subiendo esta proporción a $67,4 \%$ si le sumamos los hechos protagonizados por asalariados y otros.

Otro sujeto relevante para explicar la conflictividad social son los desocupados, que concentran las acciones que realizan en los últimos años de nuestra investigación. Si bien para algunas perspectivas teóricas este sujeto estaría expresando a un "nuevo movimiento social", nosotros ya hemos sostenido que lo consideramos una parte de la

\footnotetext{
${ }^{393}$ Los sujetos incluidos en el cuadro son, por orden:

Asalariado: además incluye jubilados, profesionales asalariados y familiares de trabajadores.

Asalariado y otros: asalariados más pequeña burguesía, estudiantes, patrones, propietarios, militantes, vecinos, usuarios, pobres, etc.

Estudiantil y comunidad educativa

Pequeña burguesía: comerciantes, empresarios, propietarios de medios de transporte, vendedores ambulantes, productores agropecuarios, profesionales, ahorristas.

Vecinos y Pobladores.

Desocupados.

Pobres, villeros, sin techo, sin tierra.

Militantes, dirigentes, funcionarios

Otros: familiares de víctimas, familiares de detenidos, ecologistas, autoconvocados por médico condenado por mala praxis, madres de un barrio, hinchas de club de fútbol, presos, veteranos de Malvinas, evangélicos, motociclistas, pueblo

${ }^{394}$ Para facilitar la interpretación de la información, y adecuar la presentación a la periodización propuesta en la descripción, presentamos los datos del 2002 separados entre el período enero-junio (2002a) y el período julio-diciembre (2002b).
} 
clase obrera, excluida de la relación asalariada por el desarrollo del capitalismo que va generando una masa cada vez mayor de población sobrante. Volveremos sobre esto más adelante.

Luego solamente presenta una proporción importante el sujeto estudiantil, que es otra expresión tradicional del conflicto social y no destaca tampoco un surgimiento de nuevos sujetos. Esos nuevos sujetos sí aparecen bajo la categoría de "otros" y suman una proporción de 4,9\%. Obviamente no son un factor explicativo clave, excepto en algunos pocos años.

El primero es 1996. Hay allí una proporción importante de hechos protagonizados por "ecologistas", alrededor del proceso de movilizaciones contra la instalación de un basurero nuclear en Gastre, en la meseta central de Chubut. En la mayoría de los otros años aparecen pocos hechos, explicados centralmente por familiares de víctimas.

Sí creemos fundamental observar lo sucedido a partir de 2001. En 2001 y durante los primeros seis meses del 2002 se destaca la presencia de 30 hechos agrupados en la categoría "otros", siendo casi la totalidad realizados desde el sujeto "pueblo". Distintas fracciones sociales se manifiestan unificadas como campo popular, sin presentar los reclamos sectoriales como centrales, sino exigiendo distintos cambios en tanto conjunto de expropiados del poder político en la sociedad. Es un momento clave que ya para el segundo semestre del 2002 ha pasado. Los conflictos vuelven a fraccionarse y la reaparición de altos niveles en esta categoría (en 2004) se explica en su totalidad por un gran aumento de los hechos desarrollados por "familiares de víctimas", quienes reclaman "justicia y seguridad", con un discurso centralmente reaccionario que hace foco en la problemática de los delincuentes pobres y jóvenes.

Otro rasgo importante son la cantidad de hechos relevados por año. Vemos allí un período de bajo número de hechos entre 1991 y 1997, un salto a partir de allí que pone un nuevo piso de alrededor de 100 hechos por año (casi el doble del promedio de los años anteriores) y ya para el 2001 y 2002 un considerable incremento, que cae en los dos años siguientes y se recupera en 2005. Como ya lo marcamos anteriormente, 1990 aparece como parte de un ciclo anterior, con números de hechos muy superiores a los otros años que agrupamos como parte del mismo período. Consideramos que esta característica de 1990 nos plantea la necesidad de repensar a los hechos conocidos como "chubutazo" a la luz de un estudio más detallado del proceso anterior, tarea de investigación que intentaremos desarrollar en una próxima etapa. 
Observaremos a continuación qué sucede cuando centramos la observación en los hechos protagonizados únicamente por asalariados, dividiendo los protagonizados por estatales, privados o por ambos:

Cuadro № 42: Hechos de rebelión protagonizados por asalariados según estos sean realizados por estatales, privados o por ambos, entre 1990 y 2005 en el Noreste de Chubut.

\begin{tabular}{|l|c|c|c|c|}
\hline & Estatales & Privados & Juntos & Total \\
\hline $\mathbf{1 9 9 0}$ & 56 & 18 & & 74 \\
\hline $\mathbf{1 9 9 1}$ & 14 & 16 & & 30 \\
\hline $\mathbf{1 9 9 2}$ & 17 & 26 & 1 & 44 \\
\hline $\mathbf{1 9 9 3}$ & 18 & 36 & & 54 \\
\hline $\mathbf{1 9 9 4}$ & 6 & 22 & & 28 \\
\hline $\mathbf{1 9 9 5}$ & 7 & 29 & 2 & 38 \\
\hline $\mathbf{1 9 9 6}$ & 14 & 30 & 4 & 48 \\
\hline $\mathbf{1 9 9 7}$ & 16 & 36 & 1 & 53 \\
\hline $\mathbf{1 9 9 8}$ & 26 & 58 & & 84 \\
\hline $\mathbf{1 9 9 9}$ & 41 & 45 & & 86 \\
\hline $\mathbf{2 0 0 0}$ & 17 & 38 & 3 & 58 \\
\hline $\mathbf{2 0 0 1}$ & 40 & 59 & 6 & 105 \\
\hline $\mathbf{2 0 0 2}$ a & 55 & 15 & & 70 \\
\hline $\mathbf{2 0 0 2 b}$ & 27 & 7 & & 34 \\
\hline $\mathbf{2 0 0 3}$ & 11 & 35 & & 46 \\
\hline $\mathbf{2 0 0 4}$ & 23 & 32 & & 55 \\
\hline $\mathbf{2 0 0 5}$ & 41 & 77 & 2 & 120 \\
\hline Total & $\mathbf{4 2 9}$ & $\mathbf{5 7 9}$ & $\mathbf{1 9}$ & $\mathbf{1 0 2 7}$ \\
\hline$\%$ & $\mathbf{4 1 , 8}$ & $\mathbf{5 6 , 4}$ & $\mathbf{1 , 8}$ & \\
\hline
\end{tabular}

Hay dos datos centrales: el primero es la muy escasa cantidad de hechos protagonizados por el conjunto de los asalariados. La división entre trabajadores estatales y trabajadores privados es algo que atraviesa a todo el país pero que en nuestra región se hace especialmente relevante por el rol que tuvo el Estado como personificación central del desarrollo capitalista, tanto en el ámbito formalmente estatal como en el formalmente privado. El reclamo muchas veces planteado por los trabajadores privados es que el Estado provincial ocupe el rol que antiguamente tenía el Estado nacional, garantizando promociones industriales y planes de obras públicas. Esos fondos son disputados, en varias ocasiones explícitamente, por los estatales, quienes reclaman que se destinen al pago de sus salarios.

Casi siempre los hechos son desarrollados en forma fracturada. Esto sucede aún cuando hay huelgas generales, donde muchas veces cada grupo de trabajadores desarrolla sus propias acciones. Creemos que esta división se vio reforzada por el agrupamiento de gran parte de los estatales de la región en la CTA, mientras los trabajadores privados siguieron agrupados en la CGT.

Es evidente el bajo grado de conflictividad entre los estatales desde 1991 hasta 1998. Es el período que nosotros planteamos como una suerte de acuerdo tácito entre estatales y gobierno, tras el cierre del chubutazo. Los estatales sostuvieron su 
estabilidad laboral a cambio de no oponerse en forma decidida a la quita de derechos laborales y a la baja de sus salarios. Esto profundiza la división con los trabajadores privados, que sufrieron durante esos años continuos despidos y suspensiones y que en varios casos se refieren a los estatales como "privilegiados".

Aquí debemos destacar, sin profundizar la reflexión, la necesidad de pensar en mayor profundidad teórica esta distinción entre trabajadores estatales y privados. Creemos que en el caso de los estatales, los procesos de desarrollo de conciencia como expropiados de sus condiciones materiales de existencia y de ruptura de la hegemonía del Estado capitalista, generan elementos de suma complejidad. Hay una identificación de sus intereses con los del Estado que hace muy difícil la negación del mismo en tanto Estado capitalista y, por tanto, complejiza la posibilidad de enfrentar su dominación. Intentaremos pensar esta distinción en otros trabajos.

El otro rasgo fundamental que nos ofrece este cuadro es que, contrariamente a los planteos más difundidos acerca de la protesta social en los noventa y en este nuevo siglo, los asalariados privados son el sujeto fundamental de la rebelión en términos cuantitativos. La diferencia entre los hechos protagonizados por privados y estatales es aún más importante si tenemos en cuenta que gran parte de los hechos protagonizados por estatales se producen como protestas de poca duración y bajo acatamiento, en muchos casos por atrasos coyunturales en los pagos de salarios por parte del Estado provincial.

Si son los asalariados, y dentro de ellos los asalariados privados, los sujetos fundamentales de la rebelión ¿cuáles son las formas organizativas fundamentales desde las que se convoca el conjunto de estos hechos? Poder conocer estos datos es clave para evaluar si realmente estamos ante la caída de las formas tradicionales de organización de la clase obrera:

Cuadro № 43: Hechos de rebelión entre 1990 y 2005 en el Noreste de Chubut según organización ${ }^{395}$ convocante.

\begin{tabular}{|c|c|c|c|c|c|c|c|r|r|}
\hline $\begin{array}{c}\text { año/or } \\
\mathbf{g}\end{array}$ & $\begin{array}{c}\text { Sindi } \\
\text { cal }\end{array}$ & $\begin{array}{c}\text { Sind y } \\
\text { otro }\end{array}$ & Multis & Empr & Est & Desoc & $\begin{array}{l}\text { Part } \\
\text { y org }\end{array}$ & $\begin{array}{l}\text { Otro } \\
\text { s }\end{array}$ & Total \\
\hline $\mathbf{1 9 9 0}$ & 74 & 3 & 8 & 2 & 4 & 3 & 1 & 10 & $\mathbf{1 0 5}$ \\
\hline $\mathbf{1 9 9 1}$ & 29 & & & 2 & 2 & & & 1 & $\mathbf{3 4}$ \\
\hline $\mathbf{1 9 9 2}$ & 46 & 1 & & 1 & 1 & & & 6 & $\mathbf{5 5}$ \\
\hline
\end{tabular}

395 Sindical: incluye jubilados y profesionales asalariados y todas las instancias de organización sindical, sea nacional, seccional, comisiones internas, delegados, etc.

Sindical y otros: sindical y partidos políticos, y grupos de DDHH, y vecinales, pequeños propietarios, empresarios, estudiantes, multisectoriales, desocupados, empresarios.

Multisectorial

Empresaria: empresarios, profesionales y gubernamental

Estudiantil: incluye estudiantes y comunidad educativa y estudiantes y grupos políticos

Desocupados

Partidos y organizaciones políticas

Otros: espontánea, vecinal, autoconvocado, religiosa, de $\mathrm{DDHH}$, de pequeños propietarios, familiares de víctimas, ecologistas, usuarios o consumidores, iglesias, clubes de fútbol, ecologistas, ocupas, pueblos originarios, etc. 


\begin{tabular}{|l|c|c|c|c|c|c|c|r|r|}
\hline $\mathbf{1 9 9 3}$ & 53 & 4 & & 1 & 4 & & & 5 & $\mathbf{6 7}$ \\
\hline $\mathbf{1 9 9 4}$ & 27 & 1 & 3 & 2 & 2 & 8 & 1 & 7 & $\mathbf{5 1}$ \\
\hline $\mathbf{1 9 9 5}$ & 36 & 1 & & & 6 & 5 & 1 & 2 & $\mathbf{5 1}$ \\
\hline $\mathbf{1 9 9 6}$ & 46 & & 9 & 1 & 7 & 6 & 1 & 8 & $\mathbf{7 8}$ \\
\hline $\mathbf{1 9 9 7}$ & 54 & 3 & 2 & 3 & 2 & 13 & & 11 & $\mathbf{8 8}$ \\
\hline $\mathbf{1 9 9 8}$ & 64 & 1 & & 3 & 4 & & & 35 & $\mathbf{1 0 7}$ \\
\hline $\mathbf{1 9 9 9}$ & 81 & 7 & 8 & 6 & 8 & 7 & & 12 & $\mathbf{1 2 9}$ \\
\hline $\mathbf{2 0 0 0}$ & 58 & 5 & 5 & 3 & 6 & 12 & & 10 & $\mathbf{9 9}$ \\
\hline $\mathbf{2 0 0 1}$ & 110 & 3 & 5 & 3 & 17 & 23 & 3 & 15 & $\mathbf{1 7 9}$ \\
\hline $\mathbf{2 0 0 2 a}$ & 63 & 3 & 13 & 2 & 1 & 33 & 2 & 29 & $\mathbf{1 4 6}$ \\
\hline $\mathbf{2 0 0 2 b}$ & 33 & 1 & 3 & 7 & 1 & 14 & & 9 & $\mathbf{6 8}$ \\
\hline $\mathbf{2 0 0 3}$ & 46 & & 3 & & 2 & 34 & 1 & 16 & $\mathbf{1 0 2}$ \\
\hline $\mathbf{2 0 0 4}$ & 55 & 11 & 3 & 1 & 1 & 32 & & 21 & $\mathbf{1 2 4}$ \\
\hline $\mathbf{2 0 0 5}$ & 121 & 9 & 4 & & 15 & 26 & 4 & 7 & $\mathbf{1 8 6}$ \\
\hline Total & $\mathbf{9 9 6}$ & $\mathbf{5 3}$ & $\mathbf{6 6}$ & $\mathbf{3 7}$ & $\mathbf{8 3}$ & $\mathbf{2 1 6}$ & $\mathbf{1 4}$ & $\mathbf{2 0 4}$ & $\mathbf{1 6 6 9}$ \\
\hline$\%$ & $\mathbf{5 9 , 7}$ & $\mathbf{3 , 2}$ & $\mathbf{4 , 0}$ & $\mathbf{2 , 2}$ & $\mathbf{5 , 0}$ & $\mathbf{1 2 , 9}$ & $\mathbf{0 , 8}$ & $\mathbf{1 2 , 2}$ & \\
\hline
\end{tabular}

Evidentemente el primer dato fundamental es la sostenida importancia de la organización sindical. En todos los años es la organización más convocante, con una amplia diferencia sobre toda otra forma organizativa. Lo siguen las organizaciones de desocupados. Destacamos, como un rasgo fundamental, que es alrededor de los hechos convocados por las organizaciones sindicales cuando se articulan las protestas de otras organizaciones. Esto sucede especialmente durante las huelgas generales, donde también convocan a diversos hechos organizaciones de desocupados, estudiantiles, empresariales y de autoconvocados. En algunos pocos casos los grupos de desocupados también logran generar estas articulaciones con otras fracciones sociales, en especial de estudiantes y docentes. Pero esto sucede solamente en el momento de mayor auge de la movilización popular, entre el 2001 y el 2003.

El importante porcentaje de la categoría "otros" (especialmente si lo comparamos con la distribución según "sujeto") se explica en su mayoría por el surgimiento de grupos de "autoconvocados". Son grupos de asalariados, especialmente relevantes entre los docentes y los pesqueros, que se organizan por fuera de las estructuras sindicales, con un discurso de fuerte oposición a sus conducciones. Esta figura es relevante a partir de 1998 y tiene incidencia en los siguientes años, aunque ya desde el 2003 la categoría "otros" se explica centralmente por los familiares de víctimas.

Estos asalariados "autoconvocados" no se oponen a la organización sindical como tal, sino a las conducciones de sus respectivos sindicatos, y denuncian que por mecanismos burocráticos se les impide dar la pelea por una conducción alternativa. Este caso es especialmente claro entre los docentes, donde se registraron varias denuncias de fraude en elecciones durante los años noventa. En los hechos van conformando embriones de organizaciones sindicales paralelas, que reproducen el 
funcionamiento en base a delegados y asambleas, y que van consolidando direcciones estables. Ya hacia el 2003 y 2004 los antiguos grupos autoconvocados de docentes actúan como sindicatos alternativos, teniendo en algunos casos hasta acceso a licencias gremiales por parte del Estado provincial.

De todas maneras es claro que el surgimiento de estos grupos, si bien no expresa el abandono de la forma sindical (de hecho vuelven a actualizar la fuerte tradición de organización sindical presente en los trabajadores argentinos), sí muestran la perdida de poderío de algunas conducciones y el cuestionamiento creciente hacia prácticas de tipo burocrático que impiden la participación del conjunto de los trabajadores. Este rasgo también se hace evidente durante el 2004 y 2005, cuando es importante el porcentual de conflictos protagonizados por formas organizativas del sindicato que se oponen a la conducción formal. Así se convocan distintas medidas desde cuerpos de delegados, asambleas sindicales y comisiones internas, aún contra la opinión de las direcciones locales o nacionales. Este rasgo, presente en la última etapa del período que investigamos, también lo registra María Celia Cotarelo (2009 y 2007) en sus más recientes investigaciones sobre el proceso de rebelión a nivel nacional.

Pretendemos también observar cuáles son las formas o instrumentos utilizados centralmente en la rebelión social. Durante muchos años se hizo hincapié en la supuesta pérdida de centralidad de la protesta callejera y luego (cuando se había hecho evidente que la protesta callejera seguía siendo parte central de la realidad) se afirmó repetidamente que estábamos ante un "cambio de repertorio" en las formas de protesta, donde centralmente perdería peso la huelga (como forma de protesta que solamente puede ser desarrollada por los asalariados ocupados) y las formas tradicionales utilizadas por la clase obrera:

Cuadro № 44: Hechos de rebelión entre 1990 y 2005 en el Noreste de Chubut según forma o instrumento ${ }^{396}$ utilizado.

\begin{tabular}{|l|c|c|c|c|c|c|c|c|c|}
\hline año/forma & Manif & Cortes & Huelga & Ocup & Saqueo & Ataq & $\begin{array}{l}\text { Lock- } \\
\text { out }\end{array}$ & Otros & Total \\
\hline $\mathbf{1 9 9 0}$ & 47 & 1 & 36 & 9 & & 6 & & 6 & $\mathbf{1 0 5}$ \\
\hline $\mathbf{1 9 9 1}$ & 17 & & 12 & 2 & & & & 3 & $\mathbf{3 4}$ \\
\hline $\mathbf{1 9 9 2}$ & 26 & 2 & 15 & 7 & & 2 & & 3 & $\mathbf{5 5}$ \\
\hline
\end{tabular}

\footnotetext{
${ }^{396}$ Manifestación: incluye marcha, concentraciones, carpas, escraches, radios abiertas, ollas populares, exhibición artística y festivales, abrazo a edificio, misas, asambleas públicas, caravanas de vehículos, clases públicas, batucada, cacerolazo, tractorazo, ayuno colectivo, junta de firmas en la calle, vigilia. Cortes: incluye corte de ruta y corte de calle

Ocupaciones: de lugares de trabajo, facultades, escuelas, edificio público, bancos, viviendas, terrenos, edificios abandonados, empresa privatizada, local sindical, plaza, etc.

Ataques: apedreos e incendios de edificios públicos, bancos, sedes de empresas, medios de transporte, locales partidarios o sindicales.

Otros: huelga de hambre, motín carcelario, resistencia a desalojo de vivienda o terreno, jornada de luto o de protesta, encadenamiento, toma de rehenes, trabajo a desgano, apagón, cerco a supermercado, cerco a legislatura, etc.
} 


\begin{tabular}{|l|r|c|c|c|c|c|c|r|r|}
\hline $\mathbf{1 9 9 3}$ & 26 & 1 & 21 & 12 & & 1 & & 6 & $\mathbf{6 7}$ \\
\hline $\mathbf{1 9 9 4}$ & 28 & 3 & 12 & 4 & & 1 & & 3 & $\mathbf{5 1}$ \\
\hline $\mathbf{1 9 9 5}$ & 23 & 3 & 18 & 6 & & 1 & & & $\mathbf{5 1}$ \\
\hline $\mathbf{1 9 9 6}$ & 41 & 7 & 15 & 11 & & & & 4 & $\mathbf{7 8}$ \\
\hline $\mathbf{1 9 9 7}$ & 51 & 7 & 9 & 15 & & & 1 & 5 & $\mathbf{8 8}$ \\
\hline $\mathbf{1 9 9 8}$ & 68 & 3 & 23 & 8 & & & 1 & 4 & $\mathbf{1 0 7}$ \\
\hline $\mathbf{1 9 9 9}$ & 85 & 5 & 24 & 11 & & 1 & & 3 & $\mathbf{1 2 9}$ \\
\hline $\mathbf{2 0 0 0}$ & 61 & 6 & 24 & 6 & & 2 & & & $\mathbf{9 9}$ \\
\hline $\mathbf{2 0 0 1}$ & 93 & 23 & 27 & 27 & 1 & 3 & 1 & 4 & $\mathbf{1 7 9}$ \\
\hline $\mathbf{2 0 0 2 a}$ & 94 & 15 & 12 & 18 & & 3 & 1 & 3 & $\mathbf{1 4 6}$ \\
\hline $\mathbf{2 0 0 2 b}$ & 50 & 4 & 9 & 3 & & & & 2 & $\mathbf{6 8}$ \\
\hline $\mathbf{2 0 0 3}$ & 56 & 18 & 13 & 12 & & & & 3 & $\mathbf{1 0 2}$ \\
\hline $\mathbf{2 0 0 4}$ & 77 & 15 & 24 & 7 & & 1 & & & $\mathbf{1 2 4}$ \\
\hline $\mathbf{2 0 0 5}$ & 101 & 28 & 44 & 12 & & & & 1 & $\mathbf{1 8 6}$ \\
\hline Total & $\mathbf{9 4 4}$ & $\mathbf{1 4 1}$ & $\mathbf{3 3 8}$ & $\mathbf{1 7 0}$ & $\mathbf{1}$ & $\mathbf{2 1}$ & $\mathbf{4}$ & $\mathbf{5 0}$ & $\mathbf{1 6 6 9}$ \\
\hline$\%$ & $\mathbf{5 6 , 6}$ & $\mathbf{8 , 4}$ & $\mathbf{2 0 , 3}$ & $\mathbf{1 0 , 2}$ & $\mathbf{0 , 1}$ & $\mathbf{1 , 2}$ & $\mathbf{0 , 2}$ & $\mathbf{3}$ & \\
\hline
\end{tabular}

La protesta callejera explica el $65 \%$ de los hechos (sumando manifestaciones y cortes de calles y rutas) y las huelgas mantienen una centralidad indiscutible, explicando más del $20 \%$ del total de hechos de rebelión. Sumando las ocupaciones, estas formas tradicionales de la protesta social (herramientas históricas en la lucha de la clase obrera argentina y mundial) explican más del 95\% de la rebelión en la región durante los años relevados.

Vimos además en la descripción que los cortes de calles y rutas no son un instrumento que solamente desarrollan los desocupados, sino que también lo toman ( $y$ son los primeros que lo realizan en la región) distintos grupos de trabajadores ocupados, ya sean privados o estatales. Hacia el final del período también empieza a ser utilizado como forma de protesta por los pobres y vecinos.

Por último intentaremos observar qué sucede cuando estos mismos cuadros los dividimos de acuerdo a la periodización que realizamos. En primer lugar tomamos a los sujetos de la rebelión:

Cuadro № 45: Hechos de rebelión entre 1990 y 2005 en el Noreste de Chubut según sujeto que lo protagoniza, divididos según la periodización desarrollada

\begin{tabular}{|l|c|c|c|c|c|c|c|c|c|c|}
\hline $\begin{array}{l}\text { per/s } \\
\text { uj }\end{array}$ & $\begin{array}{l}\text { Asalari } \\
\text { ados }\end{array}$ & $\begin{array}{l}\text { Asal } \\
\text { +otr }\end{array}$ & $\begin{array}{l}\text { Estu } \\
\text { d }\end{array}$ & $\begin{array}{l}\text { Peq } \\
\text { burg }\end{array}$ & $\begin{array}{l}\text { Vec y } \\
\text { pobl }\end{array}$ & $\begin{array}{l}\text { Deso } \\
\text { c }\end{array}$ & $\begin{array}{l}\text { Pob, } \\
\text { vill, }\end{array}$ & $\begin{array}{l}\text { Milit, } \\
\text { dirig, }\end{array}$ & $\begin{array}{l}\text { Otro } \\
\text { s }\end{array}$ & Total \\
\hline $\begin{array}{l}\mathbf{1 9 9 0 -} \\
\mathbf{1 9 9 3}\end{array}$ & 202 & 17 & 20 & 7 & 1 & 3 & 6 & 1 & 4 & $\mathbf{2 6 1}$ \\
\hline$\%$ & $\mathbf{7 7 , 4}$ & $\mathbf{6 , 5}$ & $\mathbf{7 , 6}$ & $\mathbf{2 , 7}$ & $\mathbf{0 , 4}$ & $\mathbf{1 , 1}$ & $\mathbf{2 , 3}$ & $\mathbf{0 , 4}$ & $\mathbf{1 , 5}$ & \\
\hline $\begin{array}{c}\mathbf{1 9 9 4 -} \\
\mathbf{1 9 9 6}\end{array}$ & 114 & 6 & 15 & 3 & 6 & 18 & 5 & 2 & 11 & $\mathbf{1 8 0}$ \\
\hline$\%$ & $\mathbf{6 3 , 3}$ & $\mathbf{3 , 3}$ & $\mathbf{8 , 3}$ & $\mathbf{1 , 7}$ & $\mathbf{3 , 3}$ & $\mathbf{1 0}$ & $\mathbf{2 , 8}$ & $\mathbf{1 , 1}$ & $\mathbf{6 , 1}$ & \\
\hline $\begin{array}{l}\mathbf{1 9 9 7 -} \\
\mathbf{1 9 9 9}\end{array}$ & 223 & 22 & 15 & 11 & 11 & 20 & 7 & 7 & 8 & $\mathbf{3 2 4}$ \\
\hline$\%$ & $\mathbf{6 8 , 8}$ & $\mathbf{6 , 8}$ & $\mathbf{4 , 6}$ & $\mathbf{3 , 4}$ & $\mathbf{3 , 4}$ & $\mathbf{6 , 2}$ & $\mathbf{2 , 2}$ & $\mathbf{2 , 2}$ & $\mathbf{2 , 5}$ & \\
\hline $\begin{array}{l}\mathbf{2 0 0 0 -} \\
\mathbf{2 0 0 2 a}\end{array}$ & 233 & 35 & 23 & 15 & 10 & 67 & 5 & 5 & 31 & $\mathbf{4 2 4}$ \\
\hline$\%$ & $\mathbf{5 4 , 9}$ & $\mathbf{8 , 3}$ & $\mathbf{5 , 4}$ & $\mathbf{3 , 5}$ & $\mathbf{2 , 4}$ & $\mathbf{1 5 , 8}$ & $\mathbf{1 , 2}$ & $\mathbf{1 , 2}$ & $\mathbf{7 , 3}$ & \\
\hline $\begin{array}{l}\mathbf{2 0 0 2 b} \\
\mathbf{2} \mathbf{2 0 0 5}\end{array}$ & 255 & 19 & 18 & 22 & $\mathbf{8}$ & 106 & 18 & 6 & 28 & $\mathbf{4 8 0}$ \\
\hline$\%$ & $\mathbf{5 3 , 1}$ & $\mathbf{4 , 0}$ & $\mathbf{3 , 8}$ & $\mathbf{4 , 6}$ & $\mathbf{1 , 6}$ & $\mathbf{2 2}$ & $\mathbf{3 , 8}$ & $\mathbf{1 , 2}$ & $\mathbf{5 , 8}$ & \\
\hline
\end{tabular}


Una primera lectura podría observar un constante descenso relativo en el porcentaje de participación de los asalariados. Sin embargo vemos que hay un constante aumento absoluto de los hechos que protagonizan y que el descenso porcentual se debe fundamentalmente al aumento de los hechos desarrollados por desocupados (o sea fundamentalmente por asalariados sin trabajo).

Otro rasgo importante es el alto peso de la categoría de "asalariados y otros" en el momento de mayor ascenso de la conflictividad (2000 - 2000a) para luego caer al corporativizarse nuevamente la protesta. Por otro lado queda en evidencia el aumento permanente de la cantidad de hechos de rebelión en cada período, a excepción de la diferencia entre el primero y el segundo, donde sigue operando como factor de distorsión la inclusión allí de 1990.

Algunos datos semejantes encontramos al comparar la distribución de los hechos protagonizados por asalariados, según estos sean estatales o privados, y por período:

Cuadro № 46: Hechos de rebelión protagonizados por asalariados según estos sean realizados por estatales, privados o por ambos, entre 1990 y 2005 en el Noreste de Chubut, divididos según la periodización desarrollada

\begin{tabular}{|c|c|c|c|}
\hline & Estatales & Privados & Juntos \\
\hline $\mathbf{1 9 9 0 - 1 9 9 3}$ & 105 & 96 & 1 \\
\hline$\%$ & $\mathbf{5 2 , 0}$ & $\mathbf{4 7 , 5 2}$ & $\mathbf{0 , 5}$ \\
\hline $\mathbf{1 9 9 4 - 1 9 9 6}$ & 27 & 81 & 6 \\
\hline$\%$ & $\mathbf{2 3 , 7}$ & $\mathbf{7 1 , 1}$ & $\mathbf{5 , 2}$ \\
\hline $\mathbf{1 9 9 7 - 1 9 9 9}$ & 83 & 139 & 1 \\
\hline$\%$ & $\mathbf{3 7 , 2}$ & $\mathbf{6 2 , 3}$ & $\mathbf{0 , 5}$ \\
\hline $\mathbf{2 0 0 0 - \mathbf { 2 0 0 2 a }}$ & 112 & 112 & 9 \\
\hline$\%$ & $\mathbf{4 8 , 1}$ & $\mathbf{4 8 , 1}$ & $\mathbf{3 , 8}$ \\
\hline $\mathbf{2 0 0 2} \mathbf{b}-\mathbf{2 0 0 5}$ & 102 & 151 & 2 \\
\hline$\%$ & $\mathbf{4 0}$ & $\mathbf{5 9 , 2}$ & $\mathbf{0 , 8}$ \\
\hline
\end{tabular}

Vemos que solamente en el primer período los estatales protagonizan más hechos que los privados, dato que nuevamente se plantea por la inclusión de 1990. Luego es durante el período 2000 - 2002a cuando se iguala la distribución y donde también aparece la mayor cantidad de hechos protagonizados en forma conjunta.

La evaluación de los hechos según organización convocante muestra una distribución por períodos que coincide centralmente con los rasgos ya descriptos:

Cuadro № 47: Hechos de rebelión entre 1990 y 2005 en el Noreste de Chubut según organización convocante, divididos según la periodización desarrollada

\begin{tabular}{|c|c|c|c|c|c|c|c|c|c|}
\hline per/org & Sindical & $\begin{array}{l}\text { Sind y } \\
\text { otro }\end{array}$ & Multis & Empres & Estud & Desoc & $\begin{array}{l}\text { Part } \\
\text { y org }\end{array}$ & Otros & Total \\
\hline $\begin{array}{l}\mathbf{1 9 9 0 -} \\
\mathbf{1 9 9 3}\end{array}$ & 202 & 8 & 8 & 6 & 11 & 3 & 1 & 22 & $\mathbf{2 6 1}$ \\
\hline$\%$ & $\mathbf{7 7 , 3}$ & $\mathbf{3 , 1}$ & $\mathbf{3 , 1}$ & $\mathbf{2 , 3}$ & $\mathbf{4 , 2}$ & $\mathbf{1 , 2}$ & $\mathbf{0 , 4}$ & $\mathbf{8 , 4}$ & \\
\hline
\end{tabular}




\begin{tabular}{|c|c|c|c|c|c|c|c|c|c|}
\hline $\begin{array}{l}1994- \\
1996\end{array}$ & 109 & 2 & 12 & 3 & 15 & 19 & 3 & 17 & 180 \\
\hline$\%$ & 60,5 & 1,1 & 6,7 & 1,7 & 8,3 & 10,6 & 1,6 & 9,4 & \\
\hline $\begin{array}{l}1997- \\
1999\end{array}$ & 199 & 11 & 10 & 12 & 14 & 20 & & 58 & 324 \\
\hline$\%$ & 61,4 & 3,4 & 3,1 & 3,7 & 4,3 & 6,2 & & 17,9 & \\
\hline $\begin{array}{l}2000- \\
2002^{\mathrm{a}}\end{array}$ & 231 & 11 & 23 & 8 & 24 & 68 & 5 & 54 & 424 \\
\hline$\%$ & 54,5 & 2,6 & 5,4 & 1,9 & 5,7 & 16,0 & 1,2 & 12,7 & \\
\hline $\begin{array}{l}2002 b \\
-2005\end{array}$ & 255 & 21 & 13 & 8 & 19 & 106 & 5 & 53 & 480 \\
\hline$\%$ & 53,1 & 4,4 & 2,7 & 1,6 & 4,0 & 22,1 & 1,0 & 11,0 & \\
\hline
\end{tabular}

Hay una caída relativa de los hechos convocados por los sindicatos, aunque esto se explica fundamentalmente por el aumento porcentual de los hechos convocados por organizaciones de desocupados.

Finalmente en la distribución por períodos de las formas de rebelión utilizadas sí podemos encontrar algún elemento novedoso, que puede entrar en discusión con nuestra mirada:

Cuadro № 48: Hechos de rebelión entre 1990 y 2005 en el Noreste de Chubut según instrumento o forma utilizada, divididos según la periodización desarrollada

\begin{tabular}{|l|c|c|c|c|c|c|c|c|c|}
\hline per/forma & Manif & Cortes & Huelg & Ocup & Saq & Ataq & $\begin{array}{l}\text { Lock- } \\
\text { out }\end{array}$ & Otros & Total \\
\hline $\begin{array}{l}\mathbf{1 9 9 0 -} \\
\mathbf{1 9 9 3}\end{array}$ & 116 & 4 & 84 & 30 & & 9 & & 18 & $\mathbf{2 6 1}$ \\
\hline $\begin{array}{l}\mathbf{\%} \\
\mathbf{1 9 9 4 -}-\end{array}$ & 92 & 13 & 45 & 21 & & 2 & & 7 & $\mathbf{1 8 0}$ \\
\hline $\mathbf{1 9 9 6}$ & $\mathbf{1 , 5}$ & $\mathbf{3 2 , 2}$ & $\mathbf{1 1 , 5}$ & & $\mathbf{3 , 4}$ & & $\mathbf{6 , 9}$ & \\
\hline $\begin{array}{l}\mathbf{1 9 9 7 -} \\
\mathbf{1 9 9 9}\end{array}$ & $\mathbf{5 1 , 1}$ & $\mathbf{7 , 2}$ & $\mathbf{2 5}$ & $\mathbf{1 1 , 6}$ & & $\mathbf{1 , 1}$ & & $\mathbf{3 , 9}$ & \\
\hline$\%$ & 204 & 15 & 56 & 34 & & 1 & 2 & 12 & $\mathbf{3 2 4}$ \\
\hline $\begin{array}{l}\mathbf{2 0 0 0 -} \\
\mathbf{2 0 0 2 a}\end{array}$ & 248 & 44 & 63 & 51 & 1 & 8 & 2 & 7 & $\mathbf{4 2 4}$ \\
\hline$\%$ & $\mathbf{5 8 , 5}$ & $\mathbf{1 0 , 4}$ & $\mathbf{1 4 , 9}$ & $\mathbf{1 2 , 0}$ & $\mathbf{0 , 2}$ & $\mathbf{1 , 9}$ & $\mathbf{0 , 5}$ & $\mathbf{1 , 6}$ & \\
\hline $\begin{array}{l}\mathbf{2 0 0 2 b}- \\
\mathbf{2 0 0 5}\end{array}$ & 284 & 65 & 90 & 34 & & 1 & & 6 & $\mathbf{4 8 0}$ \\
\hline$\%$ & $\mathbf{5 9 , 2}$ & $\mathbf{1 3 , 5}$ & $\mathbf{1 8 , 7}$ & $\mathbf{7 , 1}$ & & $\mathbf{0 , 2}$ & & $\mathbf{1 , 2}$ & \\
\hline
\end{tabular}

Se destaca la permanente relevancia de los hechos desarrollados en la calle (manifestaciones más cortes). Sin embargo dentro de estos relevamos un aumento significativo de la importancia de los cortes como instrumento de rebelión. Al mismo tiempo observamos una caída relativa del número de huelgas, aunque asciende en términos absolutos (excepto entre el primer y el segundo período). El descenso en términos relativos de las huelgas y el aumento en términos relativos y absolutos de los cortes, puede estar planteando un cambio en la modalidad de las luchas. Especialmente creemos importante que aparecen con fuerza hacia el 2005 las huelgas 
con cortes de rutas y calles, tal como sucede en la huelga pesquera (fenómenos semejantes ocurren en 2005 en la región sur de Chubut, alrededor de la huelga petrolera y la huelga docente).

Está claro que este análisis no ha sido solamente cuantitativo, sino que involucró muchos elementos de evaluación cualitativa del proceso. Para cerrar el trabajo profundizaremos en estos aspectos.

Hemos destacado ya que la experiencia de los trabajadores, y por lo tanto de sus organizaciones, no les daba elementos claves para afrontar la nueva situación que se les planteaba en los noventa. No había tradiciones acerca de cómo organizarse para luchar contra los cierres y despidos. Su historia de luchas pasaba por el reclamo de mejores condiciones laborales y de vender su fuerza de trabajo a un precio mejor. Pero ahora ya no se trataba de pelear por mejoras en el marco del mismo proyecto de los sectores dominantes: se trataba de la necesidad de disputar con el proyecto que se les imponía.

Consideramos que para poder entender este desarrollo debemos recuperar algunos rasgos claves de la conformación de este grupo social que constituye a la clase obrera de nuestra región. Como ya lo planteamos desde los años setenta el discurso sobre la paz social y la supuesta comunidad de intereses entre empresarios y trabajadores para "que crezca la Patagonia" ante el "olvido" del poder central, funcionó como un elemento clave para impedir la conformación de una clase obrera consciente de sus intereses en tanto expropiados de sus condiciones materiales de existencia.

La propaganda tendía a buscar construir la convicción de que era necesaria la unidad de todos los que estaban "haciendo patria" en la Patagonia, y eso se reflejaba centralmente en la supuesta necesidad de defender a aquellos que "invertían en la región". Así se sostenía que era fundamental defender los intereses de la burguesía con intereses en la región, como única forma de asegurar las fuentes de trabajo y el desarrollo. Esta es la matriz ideológica que operaba, casi a modo de un sentido común regional, en la conformación de esas alianzas que reclamaban determinadas políticas del Estado en defensa de la región, la ciudad o la rama económica, en tanto "corporación económica".

Son trabajadores que comienzan a desarrollar sus primeras experiencias de organización y lucha a partir de una escasa experiencia de vida urbana y menos de trabajo fabril o de organización sindical o política. No era un grupo homogéneo, con historia y experiencias en común. Durante el período que va de 1970 a mediados de 1980 estos obreros viven un período sin desempleo, con poca miseria estructural y constante demanda de nuevos trabajadores. Estaban acostumbrados a un trabajo estable y a la posibilidad de ir mejorando sus condiciones de vida sin dar grandes 
luchas. Sus sindicatos eran organizaciones poderosas, que incidían fuertemente en la política de las ciudades de la región, y que garantizaban buenas condiciones de trabajo.

La dificultad para afrontar la nueva situación se evidencia en los paros por aumento salarial a principios de los noventa, mientras se producían despidos masivos y cierres de fábricas sin que se desarrollaran mayores protestas. Se expresa así, al mismo tiempo, la fortaleza de la conciencia de su situación de vendedores de fuerza de trabajo y la dificultad para reaccionar cuando no les quieren comprar esa fuerza de trabajo. Su historia les permitía saber cómo articular la defensa de sus intereses en tanto asalariados de una fracción o capa particular del proletariado (lo que Marín denomina "reformismo burgués"), sin poder articular una defensa colectiva a largo plazo de sus intereses comunes en tanto conjunto de los asalariados (lo que Marín conceptualiza como un "reformismo obrero") y menos aún consiguiendo unificar su lucha en tanto expropiados de sus condiciones materiales de existencia.

Al intentar periodizar el proceso encontramos un quiebre entre 1990 y 1991, cuando se derrota la lucha de Modecraft, se desarticula el intento de conformar una agrupación de obreros desocupados y se despide a la mayoría de los delegados combativos del parque industrial textil. Estas acciones lograron quebrar el intento de algunos sectores obreros de luchar en forma decidida contra la caída del antiguo modelo de desarrollo industrial. Se derrotaba la estrategia de resistir el cambio de estructura económica social (expresado en términos concretos en el cierre de fábricas y la pérdida de puestos de trabajo) con la lucha en las calles. A esto lo denominamos una estrategia de resistencia obrera.

Luego observamos otro período hasta fines de 1993. Se impone la estrategia de la dirigencia sindical, que busca una alianza con la burguesía con intereses en la región como forma de oponerse al avance del capital financiero. Es lo que llamamos una estrategia de resistencia burguesa, donde la lucha obrera se subordinaba a la lucha interburguesa (actuando como masa de maniobra de sus patrones y negando la posibilidad de que la clase pudiera formular una alternativa propia).

Esa estrategia es la que lleva adelante la mayoría de las direcciones sindicales. Aquí debemos superar la "acusación" de burocracia o traición. Si bien pueden existir prácticas de este tipo, ello no explica lo central: que en verdad esas direcciones sindicales expresan el nivel de conciencia acerca de sus intereses del sector mayoritario de los trabajadores ${ }^{397}$. Dicha estrategia se impone allí como hegemónica

\footnotetext{
397 Lejos de suponer que estos hechos puedan explicarse con "acusaciones", creemos que debemos buscar las causas profundas de los mismos.
} 
pero ya era la dirección del movimiento desde antes. Lo que logra en estos años es derrotar a los que en el anterior período planteaban la otra estrategia.

Los trabajadores textiles de la región realizaron cientos de hechos de rebelión, pero no lograron frenar lo central del proceso. Las fuerzas con las que se enfrentaban eran muy poderosas para combatirlas con las armas que su experiencia había forjado. La mayoría de las luchas textiles apoyaron los pedidos de subsidios de empresarios con los que día a día se enfrentaban dentro de la fábrica. Desde estos trabajadores no se logró construir un proyecto alternativo al de "su" burguesía, y por eso se terminaba apoyando a la fracción burguesa que les compraba su fuerza de trabajo. Era lo que se veía como posible ante la carencia de otras alternativas.

Desde fines de 1993 aparecen mayores inconvenientes para el desarrollo del proyecto del capital financiero a nivel nacional. En la región la alianza de un sector de los obreros con los empresarios del parque se disuelve en gran medida, en parte porque los sectores de la burguesía que al principio manifestaban cierta oposición ahora se subordinan al proyecto del capital financiero.

Centrando nuestra mirada en los trabajadores desocupados vemos que hasta 1994-1995 no surgen nuevos intentos de agrupar a estos obreros sin trabajo para luchar por sus condiciones de vida. Durante este período la desocupación se asume por la mayoría como un problema transitorio e individual. Recién para mediados de 1992 hay expresiones que muestran una mayor conciencia de que la desocupación es una realidad que llegó para quedarse.

Los trabajadores comienzan a tomar conciencia de la nueva situación y a buscar los medios para resistir. Poco a poco construyen esa experiencia. En los siguientes años, y en clara sintonía con el ciclo nacional, en la región se comienzan a organizar algunos grupos de desocupados y realizan diversas acciones, aunque no logran consolidar sus organizaciones más allá de hechos y protestas aisladas. Mientras tanto el parque textil había quedado tan debilitado que parecía muy complejo articular desde allí respuestas contundentes, aunque sigue siendo importante la oposición a los intentos de aumento en la explotación laboral.

Ya para 1997 aparecen los primeros cortes de ruta desarrollados por grupos de desocupados en Chubut, en fechas muy cercanas entre sí en las tres principales ciudades. Tras estos cortes los desocupados avanzan en formas más sistemáticas de organización, donde la asamblea y la conformación de cuerpos de "delegados" o "coordinadores" por barrio, juegan un papel central. Pero este proceso no surge de la nada ni es solamente desarrollado por los desocupados. Los trabajadores ocupados ya venían dando muestras de una voluntad cada vez mayor de resistir los avances del capital financiero y articular de forma más contundente la lucha por sus intereses. 
Es así que también los trabajadores ocupados comienzan a reapropiarse de elementos de organización y formas de lucha históricas de la clase, como la asamblea, la democracia directa y la voluntad de enfrentamiento a las fuerzas represivas. Son elementos tradicionales, pero que en el ciclo que investigamos se hacen especialmente evidentes cuando los retoman los primeros grupos de trabajadores desocupados en sus acciones de lucha. Se observa en el proceso el desarrollo de una acumulación de fuerza y de experiencia que arma de mejor manera a los trabajadores (tanto ocupados como desocupados) para enfrentar las nuevas condiciones que imponía el neoliberalismo.

Esos rasgos aparecen en la región desde 1997 y se hacen más frecuentes en el 2000 y el 2001: la decisión en asamblea, la práctica de la democracia directa, la voluntad de confrontación con la fuerza represiva del Estado, la aparición de la personificación social del piquetero y la construcción de una alianza entre sectores de la clase obrera y de la pequeña burguesía (representada especialmente por los estudiantes). Elementos que expresan indicios, aunque no sea más que en forma embrionaria, de una ruptura con la hegemonía del capital financiero y con una estrategia reformista burguesa, y que aparecen con fuertes lazos con la experiencia de la estrategia de resistencia obrera.

Esa experiencia de resistencia obrera que los textiles y otros sectores de trabajadores habían ido forjando en todos estos años, no la observamos expresada en primer término en las fábricas sino centralmente en los barrios, en gran medida porque los militantes que personificaban esa resistencia habían sido barridos de las fábricas. Los trabajadores despedidos vuelcan su experiencia a la organización de los trabajadores por fuera de las fábricas, conformando asociaciones vecinales, comedores y grupos de desocupados. La experiencia obrera alimentó el proceso de rebelión social, fue parte fundamental de ese proceso que se gestó en la década del noventa y que generó la fuerza social expresada en diciembre del 2001.

Como vimos la mayoría de los sindicatos no lograban hacer frente al proceso de despidos masivos. Creemos que esta dificultad parte de su experiencia previa y de la incapacidad para impugnar lo que se entendía como un derecho de los patrones a decidir sobre los trabajadores que ocupaban. La conciencia limitada a la defensa de los intereses en tanto vendedores de fuerza de trabajo, impide cuestionar la dictadura del capital y la legalidad burguesa. Por eso la mayoría de las dirigencias gremiales restringen el reclamo a la exigencia de la indemnización, o sea a que se respete la legalidad.

La gran burguesía ponía al conjunto de la clase ante la realidad de su situación concreta: que son expropiados de sus condiciones materiales de existencia. Eso se 
vivenciaba en forma dramática en la desocupación. Para luchar realmente contra esto era necesario otro nivel de conciencia, uno que permitiera formular, desde el enfrentamiento, un proyecto alternativo al del poder, que cuestionara su legalidad. $Y$ para eso ya no servía una conciencia limitada a lo corporativo. Eso es lo que llegan a poner en cuestión los desocupados en el 2001-2002. Es lo que se evidencia al negarle al Estado su "legítimo" derecho a decidir donde trabajarían los desocupados tras el corte de ruta del 2002.

Pero esta ruptura de la legitimidad del dominio burgués se dio durante el enfrentamiento y no había sedimentado en la conciencia de amplios sectores, ni siquiera en la mayoría de la dirigencia de estos grupos. Cuando la economía entró en un ciclo de recuperación que les permitió obtener mejoras en sus condiciones de vida sin impugnar aspectos del sistema sino adaptándose al mismo, avanzaron en esa dirección, haciendo sus reclamos cada vez más corporativos y dejando de ser un elemento rupturista de la lógica capitalista.

Los grupos de desocupados habían surgido como una impugnación de hecho al modelo sindical impuesto en Argentina, a ese modelo que deja a la clase obrera encerrada en los límites de lo corporativo. Los desocupados se habían quedado sin organización, justamente porque no había forma de defenderlos desde organizaciones que no cuestionaban el derecho del empresario a decidir sobre "su" fuerza de trabajo. Desde la necesidad de impugnar esa situación es que surgen estos grupos. Pero esa impugnación fáctica a la legalidad capitalista que implicaba la organización de los desocupados, no se tradujo en conciencia explicita, ni en un programa alternativo.

Fueron una alternativa en la calle durante un breve período pero no pudieron traducir eso hacia convertirse en una alternativa en la conciencia. Los desocupados solos no podían hacerlo, necesitaban del acompañamiento de los trabajadores ocupados y de otros sectores sociales. En los últimos años estos grupos que habían surgido cuestionando el corporativismo de los sindicatos fueron repitiendo esa experiencia. Sus exigencias pasaron a ser unicámente los reclamos de mejoras para los desocupados, y de allí a reclamar solamente para su grupo particular de desocupados.

Esto se refleja claramente en el cambio de las herramientas de lucha y de decisión: pierden importancia las asambleas como espacio de resolución, en especial durante el desarrollo de los conflictos, quedando esto cada vez más reducido a la decisión de la dirigencia. A su vez las herramientas de lucha se van institucionalizando, pierden su carácter disruptivo y de impugnación social para hacerse parte del paisaje cotidiano. La acción de los desocupados ya no interrumpe la normalidad capitalista sino que pasa a ser parte de esa normalidad, justamente como 
consecuencia de que sus reclamos tienen cada vez menos elementos que cuestionan la legitimidad del sistema.

Creemos demostrado que el surgimiento de los movimientos de trabajadores desocupados en Argentina expresan la organización de un sector de la clase obrera y no la aparición de "nuevos sujetos" o "nuevos movimientos sociales". De hecho estos grupos expresan las potencialidades y los límites tradicionales de la clase obrera de la región, la importancia histórica de su organización a nivel corporativo y las dificultades para poder plantearse la necesidad de un nuevo orden social. El tipo de acciones que realizan también se entroncan con las tradiciones del movimiento obrero, así como sus estructuras internas en base a delegados o coordinadores, a la asamblea y a una progresiva burocratización de las instancias de resolución.

Entre los trabajadores de ALUAR hemos observado que la debilidad fundamental que nunca lograron quebrar fue el aislamiento en el que dieron sus luchas. Por las características de la empresa (una fábrica de alta tecnología con características de gran industria, en una región caracterizada por otro tipo de estructura industrial menos maquinizada) y por el tipo de relación que estableció durante años con sus obreros, las luchas en ALUAR se producían como por fuera del proceso social de la región. De igual manera cuando en la región se producen importantes procesos de confrontación social es muy poco el impacto que se genera hacia adentro de la planta.

Entre los operarios de ALUAR se crea una suerte de "comunidad ocupacional”398 que impide la articulación con otros grupos y que además los presenta como supuestos "privilegiados" por su estabilidad laboral y por los mejores sueldos que recibían. Similar a lo que les sucede a los trabajadores de YPF ${ }^{399}$, son vistos por los otros obreros de la región como un grupo aparte, que no compartía sus intereses y, sobre todo, que no sufría sus mismas penurias.

El conflicto de 1993-1994 es indicador del proceso de transformaciones que hacían a la instalación de la hegemonía del capital financiero sobre la región, caracterizado por el desarrollo predominantemente en profundidad del capitalismo. Se hacía necesario acentuar los niveles de explotación de los obreros ocupados y

\footnotetext{
398 Tomando el concepto que aplica Joel Horowitz (1985), a los trabajadores ferroviarios, en "Los trabajadores ferroviarios en la Argentina (1920-1943). La formación de una élite obrera”, en Desarrollo Económico. Revista de Ciencias Sociales IDES, vol. 25, № 99.

399 "Esta "comunidad ocupacional", al decir de Horowitz, los lleva a tener una conciencia de sus intereses limitados a su experiencia en YPF. De alguna manera esta situación limitaba la posibilidad de la solidaridad y la comunidad de intereses con los otros trabajadores y con la comunidad en general donde vivían. Esta característica les generaría a los trabajadores de YPF una gran debilidad al momento de la lucha contra la privatización", en López, Gatica y Pérez Álvarez (2008) "Son errores que tuvimos que pasar para después en un futuro no volverlos a hacer" La experiencia de Jaime, un ex trabajador de YPF, en Pasquali, Laura (comp.) Historia Social e Historia Oral. Experiencias en la Historia Reciente de Argentina y América Latina, Edic. Homo Sapiens, Rosario. pp. 145 a 170. pág. 162.
} 
reestructurar el proceso productivo a fin de lograr que menos obreros produzcan más. Los obreros de ALUAR venían de años de otro tipo de relación con la empresa. Por eso decimos que su experiencia previa no los había preparado para un proceso de este tipo.

Este conflicto se desarrolla justamente en un momento de inflexión en el ciclo de rebelión de la clase obrera argentina, donde ya hay sectores de la clase que expresan mayor conciencia sobre la necesidad de organizarse contra los cambios que se imponían desde el poder. La transformación que se desarrolla a nivel general se expresa en este hecho, que funciona como una bisagra (por eso lo caracterizamos como un hito). A partir de allí se desata la ofensiva de la patronal, consiguiendo reconvertir el proceso productivo, asegurándose un ciclo de expansión y altas ganancias, mientras se acentúa la precarización e intensificación del trabajo.

$Y$ así el balance del proceso es contradictorio, ya que si bien se logra frenar lo que hubiera sido un caso testigo para los trabajadores de todo el país (un fuerte descuento salarial en una empresa de punta), esto se consigue a costa de un importante número de despidos, que se concentran en aquellos trabajadores más combativos, opositores a la dirigencia de la UOM.

A partir de allí los años siguientes son de constante ofensiva de la patronal hacia adentro de la planta, consiguiendo reconvertir el proceso productivo sin mayores resistencias, asegurándose un largo ciclo de expansión y altas ganancias para los empresarios, mientras se acentuaba la precarización e intensificación del trabajo de los obreros.

El cambio sufrido en 1994, y la sucesión de golpes que reciben en los años siguientes, les impide a los obreros de ALUAR resistir los proyectos de la patronal. Sin embargo poco a poco van desarrollando una nueva experiencia que se expresa en las huelgas del 2005 y 2007. Se hace observable allí el impacto del ciclo de rebelión desarrollado durante los noventa y que tuvo su punto más alto en los hechos de diciembre del 2001. Ese impacto se personifica en esos jóvenes que son los más decididos al momento de la lucha, pero que aún no consiguen construir una estrategia alternativa que logre organizar a los trabajadores más allá de los momentos más álgidos de algunos conflictos.

Para el caso de los trabajadores pesqueros se observa el aumento en paralelo de la explotación del recurso natural y de la fuerza de trabajo, durante los años estudiados. Como sintetiza el comunicado del Stia del 2005 (previo a la gran huelga) esto lleva a un aumento de la productividad que eleva las ganancias de las grandes empresas de capital concentrado y actividades diversificadas. El crecimiento de la flota congeladora, el mayor papel del capital transnacional y la caída de las pequeñas y 
medianas empresas, demuestra cómo se desarrolla el proceso general de imposición del dominio del capital financiero en una rama particular de la actividad económica.

En términos de la periodización vemos que durante la década del noventa los ciclos de lucha en el sector no siguen el sentido del proceso general. No vemos una recuperación de la lucha a partir de 1994 (como sí lo marcamos en otros sectores) sino en 1997-1998 a partir de la crisis del recurso merluza. El ciclo aparece muy relacionado con la situación particular de la rama.

En cambio sí destacamos una significativa participación de ex trabajadores de la pesca (como también de ex trabajadores y delegados textiles) en la conformación de los grupos piqueteros y en los primeros cortes de ruta de desocupados en Trelew y Puerto Madryn. Pero esto no se realiza en tanto obreros de la pesca, sino en tanto trabajadores desocupados, junto a desocupados de otros sectores.

Pero también en esta fracción de la clase finalmente aparece el impacto del ciclo general. Ya para el 2001 la periodización particular sí se entronca con el proceso general. Durante el 2001 los conflictos en la pesca aumentan. Se hacen presentes los rasgos claves del ciclo de rebelión que destacamos a nivel general: la decisión en asamblea, la voluntad de resistir ante las fuerzas represivas, el piquete como medio de exponer públicamente la situación y de garantizar la medida.

Ese proceso de acumulación de fuerza social se refleja en la huelga del 2005. Las alianzas con los empresarios son dejadas atrás y se construye un programa propio de la clase, aunque limitado al nivel de conciencia como vendedores de fuerza de trabajo. Pero es en el proceso de lucha cuando esos límites pueden ser superados. Los enfrentamientos van cambiando las condiciones y la decisión en asamblea y la descorporativización del proceso lleva a que la lucha tome un carácter político. El primero en leer esta situación es el gobierno de la provincia, quién cambia su alineación y se coloca contra la huelga.

A lo largo de los años estudiados consideramos que es posible observar una estrategia mayoritaria entre los obreros de la región. Esa estrategia es reformista, expresando los intereses de los obreros en tanto asalariados de la región noreste del Chubut. Por ello esa estrategia suele avanzar hacia la conformación de alianzas con "sus" respectivos empresarios. Así se conforman estas alianzas que entre los pesqueros toman un distinto carácter en Rawson y en Puerto Madryn: en el primer caso es con los empresarios fresqueros y en el segundo centralmente con los congeladores. Cuando se encolumnan en esta estrategia los trabajadores se dividen de acuerdo a los intereses de las respectivas fracciones burguesas.

Al mismo tiempo se va perfilando otra estrategia, que es la que consideramos que impulsa los momentos de auge del conflicto, en especial la huelga pesquera del 
2005. Es una estrategia que definimos como un reformismo obrero, en oposición a la anterior a la que denominamos reformismo burgués. Allí se quiebran las alianzas con el empresariado y se postula un programa que hace a los problemas de la clase. Además se busca la unidad con los demás sectores obreros. Esta segunda estrategia se hace observable en el primer ciclo de la huelga del 2005, pero creemos que es una estrategia que no logra hegemonizar el movimiento ya que no tiene una propuesta clara de cómo resolver el conflicto. Se busca quebrar lo corporativo pero no se tiene la fuerza material y moral para construir un programa alternativo.

Por eso en el segundo período de la huelga (tras el acuerdo en Comodoro Rivadavia) es el reformismo burgués el que logra dirigir el proceso. No se articulan los reclamos con los otros sectores en lucha y se permite que en la negociación no se reconozca el pago de los días en huelga. Esa estrategia es la que lleva adelante la dirección del sindicato. Repetimos que esto no puede pretender explicarse por la simple recurrencia a la "acusación" de burócratas o traidores. La cuestión clave es que ese tipo de prácticas expresan el nivel de conciencia acerca de sus intereses del sector mayoritario de los obreros. No debemos olvidar que el sindicato que durante la huelga pesquera se muestra tan cercano al gobierno es el mismo que había tratado de desafiarlo durante el 2004, sin obtener allí el apoyo de la mayoría de los obreros, ni de su fracción particular, ni del resto de la clase obrera de la región (recordemos que dicha huelga fue impulsada como CGT).

Los trabajadores que a través de sus prácticas proponían un reformismo obrero no logran plasmarlo en una propuesta teórica distinta. Cuando la lucha supera lo económico y entra en el terreno político-ideológico se quedan sin herramientas para seguir adelante. Ese reformismo obrero funciona más como una idea inherente, que como una propuesta política alternativa a la del capital financiero. Hasta que eso no sea conseguido la lucha no logrará superar el plano corporativo excepto en breves momentos, y por ello no podrá cambiar las cosas de fondo.

En el marco de transformación socio-económica analizado, las luchas de los trabajadores no lograron estructurar y materializar posibles proyectos alternativos, más allá de los momentos de auge de algunos enfrentamientos sociales. Durante el desarrollo general de los conflictos la clase obrera no logra construir una propuesta alternativa a la que impulsa el capital financiero, y en su mayoría expresa una estrategia que busca resistir los aspectos más regresivos del cambio, intentando insertarse en las mejores condiciones posibles en el nuevo marco social. La estrategia central de la clase hace a su interés corporativo y por ello se centran en buscar vender su fuerza de trabajo en las mejores condiciones posibles. 
Las dos estrategias que reseñamos para el inicio de la década hacen al interés corporativo de la clase social (Gramsci, 1997) aunque una reduce la corporación al grupo profesional y la otra toma como corporación al conjunto de la clase (por eso expresan un posible distinto desenlace según cuál se estableciera como dirección). Esas estrategias son derrotadas ambas, la resistencia obrera primera y la resistencia burguesa después por el abandono de los empresarios de la región de la antigua alianza con parte de la clase obrera.

Pero la resistencia no queda en la nada sino que se encadena con el ciclo de rebelión posterior. Proceso que ahora sí (una vez derrotado el intento de resistir la ruptura de su territorio social) podemos pensar en el marco de una estrategia reformista, que es la que también se expresa como mayoritaria en el ciclo que se desarrolla a nivel país.

La experiencia obrera alimentó el proceso de rebelión social, siendo parte de esa construcción que se fue gestando a lo largo de la década del noventa y que generó la fuerza social que se expresó en las jornadas de diciembre del 2001.

Tras este hecho puede observarse un aumento de la conflictividad y el nuevo surgimiento de formas de conciencia que recuperan la perspectiva de una posible superación de los límites del reformismo burgués. Esa perspectiva se hace observable en el corte de ruta de los desocupados en 2002 y en el crecimiento de la solidaridad que hemos registrado entre diversas fracciones sociales ante el surgimiento de conflictos de distinta índole.

Sin embargo en este nuevo ciclo nuevamente no parece que consiga emerger una expresión política popular que pueda tomar la iniciativa en las luchas más allá de breves momentos. La acción desde el poder del Estado va consiguiendo retomar la corporativización de los reclamos, fracturando el movimiento social e impidiendo la posibilidad de que se desarrollen otros niveles de conciencia en el proceso de lucha.

Las acciones de la entrada a la Legislatura provincial y del corte de ruta de junio, operan en un sentido semejante para la región a la masacre del Puente Pueyrredón a nivel nacional. Allí se expresa la incapacidad desde el campo del pueblo para articular un proyecto que integre a sus diversas fracciones y que confronte con el proyecto de rearticulación de la hegemonía burguesa. Por su parte el capital financiero tomó nota rápidamente del cambio en la relación de fuerzas sociales operado por el ciclo de rebelión y que se expresó en forma evidente en los días de diciembre de 2001, donde el poder dominante no logra durante un importante lapso de tiempo controlar la situación social.

A partir de allí se lanza a reconstruir su legitimidad, buscando cerrar la más aguda crisis de dominación social. Y lo hace fundamentalmente dividiendo los 
reclamos y construyendo expresiones reaccionarias que también apuntan a fragmentar el campo de los expropiados del poder político. Esta claro que el reclamo circunscrito a lo corporativo, es el reaseguro fundamental de la continuidad de la actual estructura económica social. Por más fuerte y combativo que pueda ser la expresión, mientras se quede en esos límites no cuestionará nunca el hecho constitutivo de la sociedad capitalista: que unos sean propietarios de los medios de existencia y el resto esté expropiado de ellos y sólo pueda sobrevivir vendiendo su fuerza de trabajo.

Así el sujeto "pueblo", que había surgido en diciembre del 2001 y que siguió apareciendo en varios hechos de rebelión durante el 2002, ya había sido desarticulado hacia el 2003. Vuelve a "normalizarse" la fragmentación de los hechos, aunque estos parten ya de un nuevo piso. Las protestas tienen otra contundencia y esto se refleja especialmente en los hechos relevados en 2005 y 2007. Reaparecen expresiones fuertes de reformismo obrero y vuelven a hacerse presentes en la conflictividad social distintos sectores de izquierda, que impulsan formas de organización obrera que busquen superar los límites de la forma sindical. Muchas de las protestas empiezan a tener como impulsoras a sectores disconformes con las conducciones sindicales, aunque esto no implica que se realicen por fuera o repudiando al sindicato: se organizan cuerpos de delegados, comisiones internas y asambleas que intentan disputar la conducción de los conflictos, y que en varios casos lo consiguen, especialmente durante los momentos de auge.

Pero aún esos conflictos de gran contundencia se dan sin importantes articulaciones entre sí. La acumulación de experiencia y de fuerza social no ha sedimentado, aún, en términos de un cambio de la conciencia mayoritaria en la clase. El programa de la mayoría de los trabajadores (y de sus dirigencias) dejaba la lucha circunscripta a cada fracción obrera, al grupo económico corporativo, y en ese estrecho círculo sus intereses tarde o temprano tenían puntos de contacto con los de sus patrones.

Para aquellos que consideramos que la sociedad actual es injusta y que debemos intentar construir otros modelos de organización social, se trata de conformar las herramientas organizativas que desarrollen la lucha por superar esa conciencia limitada a los intereses en tanto vendedores de fuerza de trabajo y transformar en fuerza material una conciencia que exprese los intereses de esa parte cada vez mayor de la sociedad argentina que esta expropiada de sus condiciones materiales de existencia.

Nuestra investigación muestra que aún tenemos grandes límites y dificultades para realizar, y hasta para pensar, esta tarea. Pero al mismo tiempo nos plantea que estamos en mejores condiciones para realizarla que durante los años noventa. Se 
tratará de seguir profundizando la investigación y la reflexión científica para hacer de ese conocimiento acumulado fuerza material y moral que contribuya a la construcción de un proyecto alternativo de organización social. 


\section{Bibliografía}

Acha, Omar (2009) "Intelectuales en el ocaso de la ciudad letrada: los albores de una nueva generación crítica en América Latina", en Nuevo Topo, ํㅡ 6, Buenos Aires.

Acha, Omar (2008) La nueva generación intelectual. Incitaciones y ensayos, Herramientas, Buenos Aires.

Acha, Omar y Quiroga, Nicolás (2009) "Pliegues de la normalización de los estudios sobre el primer peronismo: complementos y aclaraciones", en Rein, Barry, Acha y Quiroga Los estudios sobre el primer peronismo. Aportaciones desde el siglo XXI, La Plata, Instituto Cultural de la Provincia de Buenos Aires.

Agamben, Giorgio (1998) Homo sacer. El poder soberano y la nula vida, Ed. Pretextos, Valencia.

Aguado, Alejandro (2000) El viejo oeste de la Patagonia. Lago Blanco, Valle Huemules, El Chalía - Chubut, Dirección de Impresiones Oficiales de la provincia de Chubut, Rawson.

Aiziczon, Fernando (2009) Construyendo tradiciones en tiempos de transición: activistas en las luchas de los obreros de la construcción de Neuquén a fines de los años '80, en el Primer Congreso Nacional Sobre Protesta Social, Acción Colectiva y Movimientos Sociales, Marzo de 2009, en CD, ISBN 978-987-24976-2-0.

Aiziczon, Fernando (2007a) "El clasismo revisitado. La impronta del trotskismo en la politización del sindicato ceramista: Zanón Bajo Control Obrero, Neuquén 1998-2006", en Labour Again Publications, http://www.iisg.nl/labouragain/documents/aiziczon.pdf.

Aiziczon, Fernando (2007b) "Sindicatos y conflictividad social. ATEN durante la primer década de los '90" en Actas IV Jornadas de Historia Reciente.

Albuquerque, F. (1999) "Cambio estructural, globalización y desarrollo económico local", Comercio exterior, Banco Nacional de Comercio Exterior, México, Vol. 49, Num. 8.

Almeyra, Guillermo (2004) La protesta social en la Argentina: 1990 - 2004, Ediciones Continente, Bs. As.

Altimir, Oscar (1970) Análisis de la economía del Chubut y de sus perspectivas de desarrollo, tomo III. Provincia del Chubut - Asesoría de Desarrollo, Rawson.

Ambruso, Marcos; Campos, Julia; Campos, Luís y Castello, Felipe (2009) "La negociación colectiva 2003 - 2008: un estudio comparativo con el período 1991 1999, en particular sobre la regulación de jornada y organización del trabajo" en Actas XII Jornadas Interescuelas Departamentos de Historia, Bariloche, Universidad Nacional de Comahue, 28 al 31 de Octubre de 2009, publicada en CD ISBN 978-987604-153-9.

Amin, Samir (1999) El capitalismo en la era de la globalización, Ediciones Paidos Ibérica, Barcelona.

Anderson, Perry (1995) Balance del neoliberalismo: lecciones para la izquierda. Conferencia sept. 1995 Fac. de Ciencias Sociales (UBA) Traducción de la revista argentina EL Rodaballo nro.3, año II.

Anderson, Perry (1997) Neoliberalismo: balance provisorio en Sader, E. y otro, La trama del neoliberalismo. Mercado, crisis y exclusión social. Oficina de Publicaciones del CBC. UBA.

Ansaldi, Waldo (1994) "Mediaciones políticas y construcción de la democracia argentina". ESTUDIOS 3. Revista del Centro de estudios avanzados. №3. Universidad Nacional de Córdoba. 
Ansaldi, Waldo (1994) "La interferencia está en el canal. Mediaciones políticas (partidarias y corporativas) en la construcción de la democracia en la Argentina", en BOLETIN AMERICANISTA, n44, Barcelona.

Antognazzi, Irma (1997) "Argentina de los 60 a los 80: buscando criterios de periodización", en Antognazzi y Ferrer (comp.), Argentina, raíces históricas del presente, UNR, Rosario.

Anuario CEICS (2007) Centro de Estudios e Investigaciones en Cs. Sociales, Año 1, №1, Bs. As.

Anuario CEICS (2008) Centro de Estudios e Investigaciones en Cs. Sociales, Año 2, №2, Bs. As.

Anuario EDI 1 (2005) Economistas de Izquierda, № 1, Bs. As.

Anuario EDI 2 (2006) Economistas de Izquierda, № 2, Bs. As.

Anuario EDI 3 (2007) Economistas de Izquierda, № 3, Bs. As.

Arfuch, Leonor (comp. 2002) Identidades, sujetos y subjetividades, Prometeo Libros, Bs. As.

Arias Bucciarelli, Mario, "Tendencias en el proceso de conversión de territorios nacionales a provincias. La pervivencia de un horizonte referencial", s.d.e.

Astarita, Rolando (2007) "Tendencias en la economía mundial y los cambios en Argentina", en Anuario EDI № 3, Bs. As. pp. 7-17.

Astarita, Rolando (2004) Valor, mercado mundial y globalización, Edic Cooperativas, Bs. As.

Astarita-Giarracca-Izaguirre-Pérez (2003) Conversaciones: Protesta Social $\begin{array}{llll}\text { Argumentos, } & 1 & \text { (2), 2003, }\end{array}$ http://www.revistaargumentos.com.ar/index.php/argumentos/article/viewFile/23/20

Auyero, Javier (2002) La protesta: retratos de la beligerancia popular en la Argentina democrática, Libros del Rojas, UBA, Buenos Aires.

Auyero, Javier (2000) "El juez, la reina y el policía. Etnografía, narrativa y los sentidos de la protesta", en Apuntes de Investigación, año IV $n^{\circ} 6$, Centro de Estudios de Cultura y Política, Fundación del Sur; Bs. As.

Auyero, Javier (1997) "Evita como perfomance. Mediación y resolución de problemas entre los pobres urbanos del Gran Buenos Aires" en Auyero, Javier (comp.) ¿Favores por votos? Estudios sobre clientelismo político contemporáneo, Losada, Bs. As. pp. 167 a 232.

Auzoberría, M.; Luque, E.; Martínez, S. (2007) Los 70’ y la crisis política en Santa Cruz, Edit. Dunken, Bs. As.

Azpiazu, Daniel; Schorr, Martín; Basualdo, Victoria (2010) La industria y el sindicalismo de base en la Argentina, Edit. Cara o Ceca, Bs. As.

Azpiazu, Daniel y Schorr, Martín (2010) "La industria argentina en la posconvertibilidad", en Azpiazu, Daniel; Schorr, Martín; Basualdo, Victoria; La industria y el sindicalismo de base en la Argentina, Edit. Cara o Ceca, Bs. As.

Azpiazu, Daniel; Basualdo, Eduardo y Khavisse, Miguel (2004) El nuevo poder económico en la Argentina de los años 80, Siglo XXI Editores, Bs. As.

Azpiazu, Daniel y Basualdo, Eduardo (2004) Las privatizaciones en la Argentina. Génesis, desarrollo y los impactos estructurales, en Petras, J. y Veltmeyer, (comp.), Las privatizaciones y la desnacionalización de América Latina, Prometeo, Bs. As. pp $55-112$. 
Azpiazu, Daniel (2003) Las privatizaciones en la Argentina. Diagnósticos y propuestas para una mayor competitividad y equidad social, OSDE-CIEPP-Miño y Dñavila, Bs. As.

Badenas, Ester y Rotstein, Telma (1999a) Caracterización del sector comercio de la provincia del Chubut, en Anuario 1999, FCE, UNPSJB, Trelew.

Badenas, Ester y Rotstein, Telma (1999b) Caracterización del sector servicios de la provincia del Chubut, en Anuario 1999, FCE, UNPSJB, Trelew.

Badenas, Ester y Rotstein, Telma (1998) Caracterización de la industria manufacturera de la provincia del Chubut, en Anuario 1998, FCE, UNPSJB, Trelew.

Badiou, Alain (1999) El ser y el acontecimiento, Manantial, Bs. As.

Bagnasco, A. (2003), Societa' fuori squadra. Come cambia la organizzazione sociale, II Mulino.

Balvé, Beatriz y Guerrero, Claudia (2006) "De lucha política a guerra social abierta. El Alto Valle de Río Negro 2001 y 1969", en Historia Regional №24, Setiembre 2006, pp. 29 a 46.

Balvé Beba y Balvé, Beatriz (2005a) El 69 Huelga política de masas, RyR, CICSO, Buenos Aires.

Balvé, Beba et al (2005b) Lucha de calles, lucha de clases (Córdoba 1971 - 1969), RyR, CICSO, Buenos Aires.

Balvé, Beba y Balvé, Beatriz (1991) Acerca de los movimientos sociales y la lucha de clases, CICSO, Buenos Aires.

Balvé, Beba y Balvé, Beatriz (1989) Algunas consideraciones acerca de la temática de los movimientos sociales, CICSO, Buenos Aires.

Bandieri, Susana (2005) Historia de la Patagonia, Edit. Sudamericana, Buenos Aires.

Bandieri, Susana, Graciela Blanco y Gladys Varela (directoras, 2006), Hecho en Patagonia. La historia en perspectiva regional, Editorial de la Universidad Nacional del Comahue, Neuquén.

Bandieri, S., Favaro, O., Morinelli, M. (comp. 1993) Historia del Neuquén, Plus Ultra, Bs. As.

Barberena, Daniel (2009) "Los Barrios Populares de Trelew en la década del 70: El Barrio La Laguna", Ediciones TER, Trelew.

Barbería, Elsa (1995) Los dueños de la tierra en la Patagonia Austral. 1880-1920, Universidad Federal de la Patagonia Austral.

Baschetti, Roberto (comp. 2004) Documentos de la Resistencia peronista 1970-1973, De la Campana, Bs. As.

Basualdo, Eduardo (2002a) Sistema político y modelo de acumulación en la Argentina, Univ. Nac. de Quilmes. Ediciones, Buenos Aires.

Basualdo, Eduardo (2002b)"La crisis actual en Argentina: entre la dolarización, la devaluación y la redistribución del ingreso", en Chiapas, UNAM, México.

Basualdo, Eduardo (2000) Concentración y centralización del capital en la Argentina durante la década del noventa, UNQ - FLACSO - IDEP, Bs. As.

Basualdo E. y Lozano, Claudio (2000) Entre la dolarización y la devaluación: la crisis de la convertibilidad en la Argentina, IDEP - ATE - CTA, Bs. As.

Basualdo, Eduardo y Daniel Azpiazu (1981) Cara y contracara de los grupos económicos. Estado y promoción industrial en la Argentina. Ed. Cántaro, Bs. As. 
Basualdo, Victoria (2010) "Los delegados y las comisiones internas en la historia Argentina 1943-2007", en Azpiazu, Daniel; Schorr, Martín; Basualdo, Victoria: La industria y el sindicalismo de base en la Argentina, Edit. Cara o Ceca, Bs. As.

Basualdo, Victoria (2009) "El debate historiográfico sobre la "posición estratégica" y la "fuerza obrera" y la definición de una nueva agenda de investigación en la historia de la clase trabajadora en América Latina: aportes metodológicos y de fuentes para el desarrollo de estudios centrados en el lugar de trabajo" en Actas XII Jornadas Interescuelas Departamentos de Historia, Bariloche, Universidad Nacional de Comahue, 28 al 31 de Octubre de 2009, publicada en CD ISBN 978-987-604-153-9.

Battistini, Osvaldo (comp. 2002) La atmósfera incandescente, Asoc. Trabajo y Sociedad, B.A.

Bauman, Zygmunt (2000) Modernidad líquida, F.C.E., Buenos Aires.

Bayer, Osvaldo (1974) Los vengadores de la Patagonia trágica Tomo I, Editorial Galerna, Bs. As.

Beck, Ulrico (1998) ¿Qué es la globalización? Falacias del globalismo respuestas a la globalización, Paidós, Barcelona.

Beinstein, Jorge (2000) La larga crisis de la economía global, Edic. Corregidor, Bs. As.

Beinstein, Jorge (1993) Dinámica global de la economía patagónica, LUDEPA-SME / INTA-GTZ.

Benjamín, Walter (2007) Conceptos de filosofía de la historia, Caronte, Bs. As.

Benko, G. y Lipietz, A. (1994) Las regiones que ganan. Distritos y redes. Los nuevos paradigmas de la geografía económica, Valencia, Edicions Alfons El Magnanim, Generalitat Valenciana, Cap 1.

Bercovich, Alejandro y Gigliani, Guillermo (2006) "Productividad y salarios industriales en la "era Kirchner", en Anuario EDI № 2, Bs. As. pp. 86-101.

Bergel, Pablo (2002) "Nuevas formas asociativas: asambleas vecinales y movimientos de trabajadores desocupados", en González Bombal, Inés (comp) Nuevos movimientos sociales y ONGs en la Argentina de la crisis, CEDES, Bs. As.

Bertaux, Daniel (1989) Los relatos de vida en el análisis social; en Historia y Fuente Oral 1, Barcelona.

Bilder, Ernesto y Giuliani, Adriana (2009) "Petróleo y gas en la política neuquina" en Realidad Económica № 248, IADE, Bs. As.

Bilder, Ernesto y Zambon, Humberto, "La matriz productiva del Neuquén: evolución y perspectiva", Opinión y Conocimiento. Apuntes sobre la realidad neuquina, no 1, Vol. 1, Año 1, p. 68.

Bohoslavsky, Ernesto (2008) La Patagonia: de la guerra de Malvinas al final de la familia ypefiana; UNGS - Biblioteca Nacional; Bs. As.

Bohoslavsky, Ernesto y Harambour, Alberto (2007) "El miedo rojo más austral del mundo. Clase dominante local y Estado nacional frente a los trabajadores en la Patagonia argentino-chilena (1917-1922)", en Mases y Galucci (edit.) Historia de los trabajadores en la Patagonia, Educo, UNCo, Neuquén.

Boisier, S., Lira, L. Quiroga B., Rojas, C. y Zurita, G. (1995), "Sociedad civil, actores sociales y desarrollo regional, Dirección de políticas y planificación regionales", Documento 95/14, Serie Investigación, Chile, Instituto Latinoamericano y del Caribe de Planificación Económica y Social (ILPES). 
Boisier, S. (1997) "Sociedad civil, participación, conocimiento y gestión territorial", Documento 97/39, Serie Ensayos, Chile, Instituto Latinoamericano y del Caribe de Planificación Económica y Social (ILPES).

Bona, Aixa y Vilaboa, Juan (2008) "La transición política de los territorios nacionales y la caída del peronismo: el caso de Santa Cruz", en Actas Terceras Jornadas de Historia de la Patagonia -San Carlos de Bariloche, 6-8 de noviembre de 2008 -, publicada en CD, ISBN: 978-987-604-107-2.

Bona, Aixa y Vilaboa, Juan (comp. 2007) "Las formas de la política en la Patagonia. El primer peronismo en los territorios nacionales", Edit. Biblos, Bs. As.

Bona, Aixa y Vilaboa, Juan (2007) "Trabajadores y peronismo en Santa Cruz", en Mases y Galucci (edit.) Historia de los trabajadores en la Patagonia, Educo, UNCo, Neuquén.

Bonifacio, José Luís (2007) "La organización de los trabajadores desocupados en Neuquén Capital durante los años noventa..." en Actas II Jornadas de Historia Social de la Patagonia.

Bonnet, A. y Piva A. (comp. 2009) "Argentina en pedazos. Luchas sociales y conflictos interburgueses en la crisis de la convertibilidad", Peña Lillo - Edic. Continente, Bs. As.

Bonnet, Alberto (2009) Las relaciones con el estado en las luchas sociales recientes...; en Bonnet, A. y Piva A. (comp. 2009) "Argentina en pedazos. Luchas sociales y conflictos interburgueses en la crisis de la convertibilidad", Peña Lillo - Edic. Continente, Bs. As. Pág. 71 a 114.

Bonnet, Alberto (2008) "La hegemonía menemista”, Prometeo, Bs. As.

Bonnet, Alberto (2007a) "Una aproximación a la metamorfosis en el modo de desenvolvimiento de la lucha de clases en la Argentina de los 90", en Actas XI Jornadas Interescuelas, en CD, ISBN 978-950-554-540-7.

Bonnet, Alberto (2007b) "Argentina: ¿un nuevo modelo de acumulación?", en Anuario EDI No 3, Bs. As. pp. 82-92.

Bonnet, Alberto (2005) "Luchas sociales y neoconservadurismo: a propósito de La protesta social en la Argentina (1990-2004) de Guillermo Almeyra", en Cuadernos del Sur № 38/39, Bs. As.

Bonnet, Alberto (2002) "Crisis e insurrección en Argentina 2001", en Bajo el Volcán, Revista de la Univ. De Puebla, Año 2 N5, Puebla, M éxico.

Bonnet, Alberto (1995) "Argentina 1995: ¿Una nueva hegemonía?”, en Cuadernos del Sur № 19, Junio de 1995, Bs. As.

Borón, Atilio (2007) "Movimientos sociales y luchas democráticas: algunas lecciones de la experiencia reciente en América Latina", en Villanueva, E. y Massetti, A. (comp.) Movimientos sociales y acción colectiva en la Argentina de hoy, Prometeo, Bs. As.

Boron, A.; Amadeo, J. y González, S. (comp. 2006) La teoría marxista hoy. Problemas y perspectivas, Clacso, Bs. As.

Borón, Atilio (2002) Imperio \& Imperialismo, Edic. CLACSO, Bs. As.

Borón, Atilio (2000) "Tras el búho de Minerva. Mercado contra democracia en el capitalismo de fin de siglo, Edic. CLACSO, Bs. As.

Borón, Atilio (1997) "La sociedad civil después del diluvio neoliberal", en Sader, E. y otro, La trama del neoliberalismo. Mercado, crisis y exclusión social. Oficina de Publicaciones del CBC. UBA. 
Borón, Atilio (1991) Estado, Capitalismo y Democracia en América Latina. Imago Mundi, Buenos Aires.

Boron, Atilio y Thwaites Rey, Mabel (2004) La expropiación neoliberal: el experimento privatista en la Argentina, en Petras, J. y Veltmeyer, (comp.), Las privatizaciones y la desnacionalización de América latina, Prometeo, Bs. As. pp. 113 - 182.

Borquez Daniel (2007) Luchas Político-Gremiales y la puja por la Identidad Nacional Comodoro Rivadavia 1943-1955, en Actas I Jornadas de Investigación en Cs Soc. Fac. de Humanidades y Cs. Soc. UNPSJB.

Bourdieu y Wacquant (2005) Una invitación a la sociología reflexiva, Siglo XXI, Bs. As.

Bourdieu, Pierre (direcc. 2002) La miseria del mundo, F.C.E., Bs. As.

Bourdieu, Pierre (2000) Poder, derecho y clases sociales, Editorial Desclée de Brower, Bilbao.

Bourdieu, Pierre (1999) Meditaciones Pascalianas, Anagrama, Barcelona

Briones, Claudia (edit. 2005) Cartografías argentinas. Políticas indigenistas y formaciones provinciales de la alteridad, Geaprona, Bs. As.

Cabrera, David (1997) Los distintos momentos y grados de organización en el caso de la lucha popular en Santiago del Estero, en Antognazzi y Ferrer (comps.) "Argentina, raíces históricas del presente", UNR, Rosario.

Caetano, Gerardo (comp. 2006), Sujetos sociales y nuevas formas de protesta en la historia reciente de América Latina, CLACSO, Bs. As.

Calcagno, Alfredo y Calcagno, Eric (2001) Un gran país devenido en casino, en Le Monde Diplomatique, marzo de 2001.

Calderón, Fernando y Szmukler, Alicia (1997) "La pobreza y las nuevas condiciones de desigualdad social" en Nueva sociedad, Nro. 149.

Calveiro, Pilar (1998) Poder y desaparición. Los campos de concentración en la Argentina, Buenos Aires, Colihue.

Camarero, Hernán (2008) "Reflexiones acerca de dos luchas obreras impulsadas por los comunistas: la huelga petrolera en Comodoro Rivadavia y la huelga de la carne en Avellaneda (1932)", en Historia Regional № 26, Año XXI, Revista del ISP №3, Villa Constitución - Argentina. ISSN 0329-8213.

Camarero, Hernán (2007) A la conquista de la clase obrera. Los comunistas y el mundo del trabajo en la Argentina, 1920-1935, Siglo XXI, Bs. As.

Camarero, Hernán; Pozzi, Pablo y Schneider, Alejandro (2001) "Eppur si muove. De la realidad a la conceptualización en el estudio de la clase obrera argentina"; en Taller. Revista de Sociedad, Cultura y Política, v.6, №16, (Buenos Aires: julio de 2001).

Camarero, Hernán; Pozzi, Pablo y Schneider, Alejandro (2000) De la Revolución Libertadora al menemismo. Historia social y política argentina. Imago Mundi, Bs. As.

Campione, Daniel (2002) Estado, dirigencia sindical y clase obrera, en http://fisyp.rcc.com.ar/Dirigencia\%20sindical\%20y\%20clase\%20obrera.pdf.

Campos, Julia y Frankel, Jimena (2010) Obstáculos y estrategias organizativas de los trabajadores en su lugar de trabajo: un análisis de casos. 2003-2009, en II Encuentro Internacional Teoría y práctica política en América Latina. Nuevas derechas e izquierdas en el escenario regional; Universidad Nacional de Mar del Plata - 3 al 5 de marzo de 2010, publicada en CD ISBN 978-987-1314-96-6.

Campos, Julia y Kan, Julián (2005),"Aproximación a la lucha interburguesa: configuración de alineamientos en la antesala de la hiperinflación de febrero de 1989". 
Ponencia presentada en las $\mathrm{X}$ Jornadas Interescuelas de Historia realizadas el año 2005 en la ciudad de Rosario

Cangiano, María Cecilia (2006) "Revisión del pasado y construcción del presente. Los obreros metalúrgicos de Villa Constitución y el menemismo, 1989-1992", en Historia Regional № 24. ISP №3. Villa Constitución. Pág: 175 a 195.

Caprano, Celia Raquel y Palacios, Dora Liliana (2009) "Economías de enclave y estrategias empresariales. El Caso Aluar" ponencia en XII Jornadas Interescuelas Departamentos de Historia, Bariloche, Universidad Nacional de Comahue, 28 al 31 de Octubre de 2009, inédita.

Caprano, R., Lopez, L., Palacios, D., (2004) ALUAR ¿Privado o Estatal?, Avance de Tesis de Licenciatura, Depto de Historia, UNP, Sede Trelew

Cardoso, F. y Faletto, E. (1987) Dependencia y desarrollo en América Latina. Edit. Siglo XXI, México.

Carrizo, Gabriel (2007) "Entre Ongaro y Vandor. Una mirada al sindicalismo comodorense: la huelga de SUPE en 1968", en Mases y Galucci (edit.) Historia de los trabajadores en la Patagonia, Educo, UNCo, Neuquén.

Castel, Robert (2005) Estado e Inseguridad social, Exposición en la Subsecretaría de la Gestión Pública, República Argentina, 3 de agosto de 2005.

Castel, Robert (1997) Las metamorfosis de la cuestión social. Una crónica del salariado, Paidós, Barcelona.

Castellani, Ana Gabriela y Szkolnik, Mariano (2005) "'Devaluacionistas' y 'dolarizadores'. La construcción social de las alternativas propuestas por los sectores dominantes ante la crisis de la Convertibilidad. Argentina 1999-2001". Ponencia presentada en las X Jornadas Interescuelas de Historia realizadas el año 2005 en la ciudad de Rosario.

Castillo, Christian (2005) "Transformaciones sociales y políticas bajo el gobierno de Kirchner". Ponencia presentada en las X Jornadas Interescuelas de Historia realizadas el año 2005 en la ciudad de Rosario.

Castillo, José (2007) "La economía argentina desde mediados del 2002", en Anuario EDI № 3, Bs. As. pp. 127-139.

Cavalleri, Donaire y Rosati (2005) "Evolución de la distribución de la población según la división del trabajo social Argentina, 1960-2001”, en PIMSA DT № 51, Bs. As.

Ceballos, Ester Elizabeth (2009) "Conmemoración del 1ํ de Mayo entre 1955 y 2002, en Comodoro Rivadavia, según la prensa local" en Actas XII Jornadas Interescuelas Departamentos de Historia, Bariloche, Universidad Nacional de Comahue, 28 al 31 de Octubre de 2009, publicada en CD ISBN 978-987-604-153-9.

Centro de Estudios Nueva Mayoría. Base de datos en la web.

Cerio Débora (2010) "Entre la explotación y la experiencia. Debates sobre condición obrera y subjetividad", en II Encuentro Internacional Teoría y práctica política en América Latina. Nuevas derechas e izquierdas en el escenario regional; Universidad Nacional de Mar del Plata - 3 al 5 de marzo de 2010, publicada en CD ISBN 978-9871314-96-6.

Chakrabarty, Dipesh (2008) Al margen de Europa. ¿Estamos ante el final del predominio cultural europeo?, Tusquets, Barcelona.

Chiappe, Lucas (2007): Bosques del Sur, reflexiones sobre las amenazas ambientales que enfrentan, Proyecto Lemu, Epuyén. 
Chiappe, Lucas (coord. 2004) La Patagonia de pie. Ecología versus negociados, Edit. Edgardo Suárez, El Bolsón.

Cicciari, M. Rosa (2007) "Prácticas sociales organizativas y desarrollo local en una comunidad petrolera. Estudio de caso: los ex agentes de YPF de Caleta Olivia", en Mases y Galucci (edit.) Historia de los trabajadores en la Patagonia, Educo, UNCo, Neuquén.

Cicciari María Rosa (2001) "Trayectorias laborales en espacios sociales urbanos afectados por el proceso de reestructuración productiva. Estudio de caso: Comodoro Rivadavia en los años '90", ponencia presentada en el 50 Congreso de la ASET, http://www.aset.org.ar/congresos/5/aset/PDF/CICCIARI.PDF.

Cicciari, M.R., Prado, M y Romero, J.C. (1997) "Cambios en las oportunidades de empleo y nuevos emprendimientos en el complejo petrolero de Santa Cruz Norte (1993-1995)"en La Patagonia privatizada. Crisis, cambios estructurales en el sistema regional y sus impactos en los mercados de trabajo; Salvia, A. y Panaia, M. (Compiladores); CEA, Ofic. de Publicaciones CBC. Buenos Aires.

CICSO Centro de Investigaciones en Ciencias Sociales (2000) El desarrollo del capitalismo en la Argentina. Circunstancias y Contradicciones. En Razón y Revolución № 6, Bs. As.

CIFSML Centro de Investigación y Formación de los Movimientos Sociales Latinoamericanos (2008) Patagonia: resistencias populares a la recolonización del continente, Edic. América Libre, Bs. As.

Ciselli, Graciela (2005) Género, migración y mercado laboral en el sureste del Chubut.

Ciselli, Graciela (2004) Pioneras astrenses. Dunken, Buenos Aires.

Ciselli, Graciela y Duplatt, Adrián (2005) Km 5 Barrios patagónicos con memoria petrolera y ferroviaria, v.1.

Ciselli, Graciela; Torres, Susana y Duplatt, Adrián (2004) Historia de un ferrocarril patagónico. Dunken, Buenos Aires.

Claps, Luis (2007) Navidad, minería y saqueo en la meseta de Chubut. Revista Theomai, $\mathrm{n}^{\circ}$ 15, 1er semestre de 2007. http://www.revistatheomai.unq.edu.ar/NUMERO15/ArtClaps_15.pdf

Colectivo Redes (1998) "Desocupación y Trabajo. Percepciones de la situación..." en PIMSA 1998, Bs. As.

Colectivo Situaciones (2002) 19 y 20. Apuntes para el nuevo protagonismo social; Ediciones de Mano en Mano, Bs. As.

Colectivo Situaciones y MTD Solano (2002) La hipótesis 891. Más allá de los piquetes, Edic. de Mano en Mano, Bs. As.

Colombo, Guillermo (2009a) “'Los burócratas son ellos'. Una aproximación a la contienda gremial en el Sindicato de Obreros de la Industria del Pescado, Mar del Plata (1997-2007)" en Actas XII Jornadas Interescuelas Departamentos de Historia, Bariloche, Universidad Nacional de Comahue, 28 al 31 de Octubre de 2009, publicada en CD ISBN 978-987-604-153-9.

Colombo, Guillermo (2009b) "Cuando los trabajadores se vuelven 'vándalos'. Descripción y análisis de un 'estallido social' en el puerto de Mar del Plata (año 2000)", en Actas del Primer Congreso Nacional Sobre Protesta Social, Acción Colectiva y Movimientos Sociales.

Colombo, Guillermo (2005) "Conflicto social en el puerto de Mar del Plata. Los medios y sus fines. Una aproximación crítica en torno a la cobertura mediática de la protesta 
social". Ponencia presentada en las X Jornadas Interescuelas de Historia realizadas en la ciudad de Rosario.

Colombo y Nieto (2008) "Aproximación a las formas de la lucha obrera en la industria de la pesca, Mar del Plata 1997-2007", LabourAgain Publications (online) http://www.iisg.nl/labouragain/documents/colombo-nieto.pdf, 2008.

Cominiello Sebastián (2007) "Tres semanas de cortes que iniciaron el argentinazo" en Anuario CEICS Centro de Estudios e Investigaciones en Cs. Sociales, Año 1, №1, Bs. As.

Comisión Bicameral Investigadora Especial de Estudio Contrato ALUAR-Estado Nacional informe, debates y antecedentes

Comité de Acción Jurídica (1999) Informe anual 1998, CTA, Bs. As.

Comité de Acción Jurídica (1997) Informe anual, situación de los derechos humanos en el movimiento obrero de la Argentina, CTA, Bs. As.

Contraviento (2000) Primera Revista - Libro sobre Historia económica y social de Santa Cruz, Editorial LaMadrid, Río Gallegos.

Contreras, Gustavo (2008) "En río revuelto ganancia de Pescador. El gremio marítimo y el peronismo", en el №1 de la Revista de Estudios Marítimos y Sociales.

Contreras, Gustavo (2006) "El peronismo obrero. La estrategia laborista de la clase obrera durante el gobierno peronista. Un análisis de la huelga de los trabajadores frigoríficos de 1950", DT №60 en PIMSA 2006, Bs. As.

Cooke, John William, Aportes para una crítica del reformismo en la Argentina, escrito entre mediados y fines de 1961, Edición Digital, sin más datos.

Correa, Mauricio (2006) El fracaso de la concepción sindical vandorista de la UOM San Nicolás en el conflicto por la privatización de SOMISA, en Historia Regional № 24. ISP №3. Villa Constitución. Pág: 65 a 86.

Cortese, Carmelo (2005) "Luchas sociales y nuevas organizaciones como respuestas a la crisis en Mendoza", en Nuevos escenarios del trabajo: rupturas y continuidades, $7^{\circ}$ Congreso ASET.

Costa, G. y Ratti, C. (1995) Crisis y conflicto social: asentamiento en Primera Junta, Tesis de Licenciatura en Historia, UNPSJB.

Cotarelo, María Celia (2009) "Conflicto social en Argentina entre 2002 y 2008", en Actas XII Jornadas Interescuelas Departamentos de Historia, Bariloche, Universidad Nacional de Comahue, 28 al 31 de Octubre de 2009, publicada en CD ISBN 978-987604-153-9.

Cotarelo, Maria Celia (2007a) "La rebelión en la América Latina actual. Un ejercicio cuantitativo”, en PIMSA 2007, Bs. As. pp. 199-226.

Cotarelo, Maria Celia (2007b) "Movimiento sindical en Argentina 2004-2007: ¿anarquía sindical?", en Actas XI Jornadas Interescuelas/ De partamentos de Historia, en CD, ISBN 978-950-554-540-7.

Cotarelo, María Celia (2005) "Aproximación al análisis de los "sujetos" emergentes en la crisis de 2001-2002 en Argentina". Ponencia presentada en las X Jornadas Interescuelas de Historia realizadas el año 2005 en al ciudad de Rosario.

Cotarelo, María Celia (2004) "Crisis política en Argentina (2002)", PIMSA, Bs. As.

Cotarelo, María Celia (2000) "La protesta en la Argentina de los 90", en Herramienta No12, Bs. As. 
Cotarelo, María Celia (1999) "El motín de Santiago del Estero. Argentina, diciembre de 1993"; PIMSA DT № 19, Bs. As.

Cotarelo, M. C. y Fernández, F. (1998) "Huelga general con movilización de masas. Argentina junio y julio de 1975"; PIMSA DT № 13, Buenos Aires.

Cotarelo, María Celia e Iñigo Carrera, Nicolás (2004) De la insurrección espontánea a la tregua (Argentina 2001 - 2003), Edición Digital, s/d.

Crespo, Edda y González, Myriam (comp. 2009) Mujeres en palabras de mujeres, Fondo Editorial Provincial Secretaría de Cultura del Chubut.

Crespo, Edda (2009) Más allá del ritual de belleza. Las reinas del petróleo en sus imágenes y palabras, en Crespo, Edda y González, Myriam (comp.) Mujeres en palabras de mujeres, Fondo Editorial Provincial Secretaría de Cultura del Chubut.

Crespo, Edda (2007) "El fantasma de Rodó. Ariel, públicos lectores y nacionalismo petrolero en Comodoro Rivadavia", en Mases y Galucci (edit.) Historia de los trabajadores en la Patagonia, Educo, UNCo, Neuquén.

Crespo, Edda (2000) "Cien años no es nada... Patrimonio, imaginarios urbanos y políticas sociales de conmemoración. Caleta Olivia 1995-1999", Informe de Avance, UNPA.

Cross, Cecilia y Montes Cató, Juan (2002) "Crisis de representación e identidades colectivas en los sectores populares. Acerca de las experiencias de las organizaciones piqueteras", en Battistini, Osvaldo (comp. 2002) "La atmósfera incandescente", Asoc. Trabajo y Sociedad, Buenos Aires.

Cross, Celia; Lenguita, Paula y Wilkins, Ariel (2002) "Piqueteros: de la exclusión a la revitalización del conflicto social. Apuntes para comprender la emergencia del movimiento piquetero como un nuevo sujeto político en los conflictos de trabajo", en Battistini, Osvaldo (comp. 2002) "La atmósfera incandescente", Asoc. Trabajo y Sociedad, Buenos Aires.

Cuesta Bustillo, Josefina (2007) La odisea de la memoria, curso de Doctorado, Universidad Nacional de La Plata.

Cuesta Bustillo, Josefina. (ed. 1998) Memoria e historia. Marcial Pons, Madrid.

Cuesta Bustillo, Josefina (1993) Historia del presente. Eudema, Madrid.

D'Amelio, M. E., Galaretto, M. y Prado, M. (1997) "El lado oscuro de la reestructuración. Empleo, desempleo y precariedad laboral en Caleta Olivia, 19931995" en Salvia,A. y Panaia, M. (comps.); La patagonia privatizada, CEA -CBCUNPA, Buenos Aires.

Dargoltz, Raúl (1997) "El Santiagueñazo. El estallido social de una provincia empobrecida", en Argentina, raíces históricas del presente, en Antognazzi y Ferrer (comps.) "Argentina, raíces históricas del presente", UNR, Rosario.

De Mattos, C. (2001), Reestructuración del mercado metropolitano de trabajo y desigualdades sociales Gran Santiago: ¿hacia una ciudad dual?, en: http://www.mundourbano.unq.edu.ar/index.php?option= content\&task=view\&id $=98 \&$ temid $=43$

Delamata, Gabriela (2004) Los barrios desbordados. Las organizaciones de desocupados del Gran Buenos Aires, EUDEBA-Libros del Rojas, Bs. As.

De Santis, Daniel (comp. 2000) A vencer o morir. Documentos del PRT-ERP, Tomo II, Eudeba, Bs. As.

De Santis, Daniel (comp. 1998) A vencer o morir. Documentos del PRT-ERP, Tomo I, Eudeba, Bs. As. 
Di Marco y Palomino (comp. 2004) Reflexiones sobre los movimientos sociales en la Argentina, Jorge Baudino Edit. Bs. As.

Di Santo, Martín (2008) Derecha, nacionalismo y fascismo en el Valle Inferior del río Chubut. Discursos y representaciones de la prensa escrita en la década de 1930. Tesis de Licenciatura, Depto. de Historia Sede Trelew - UNPSJB.

Diario Jornada y Diario El Chubut, Enero 1990 a Diciembre 2005, Chubut.

Díaz, Alejandra y Carreño, Nadine (2003), "La Sierra y su mina de hierro", en http://www.labardarevista.com.ar.

Díaz Alejandro, C. (1983) Ensayos sobre la historia económica argentina, Amorrortu, Bs. As.

Díaz, Chele (2003) 1937: el desalojo de la tribu Nahuelpan, Editorial Musiquel, El Bolsón.

Díaz, Martha Susana (2007) Movimientos Sociales en Patagonia y el papel de la mujer: Significaciones e ideas fuerzas, en Actas I Jornadas de Investigación en Cs Soc. - Fac. de Humanidades y Cs. Soc. UNPSJB.

Dinerstein, Ana Cecilia (2002) "¡Que se vayan todos! Crisis, insurrección y la reinvención de lo político en Argentina", en Bajo el Volcán, Revista de la Univ. De Puebla, Año 2 N5, Puebla, México.

Dinerstein, Ana Cecilia (2001) "El poder de lo irrealizado en Argentina y el potencial subversivo de la mundialización", OSAL № 5, CLACSO.

Documentos Unión Industrial Patagónica: Algunos aspectos de los cambios demográficos en la Argentina; algunos comentarios sobre la política arancelaria y la situación industrial: el caso de los Textiles; análisis de la distribución espacial de la industria. S/d. Edit.

Donaire, Ricardo y Rosati, Germán (2010 en prensa), "Estructuras económico sociales concretas que constituyen la formación económica de la Argentina (1980-2001)" en Nicolás Iñigo Carrera (director), "Análisis de una relación de fuerzas sociales objetiva, 1960-2001".

Donaire y Rosati (2007a) Aproximación a la evolución de la distribución de la población según grupos sociales fundamentales. Argentina, 1960-2001, VIII Congreso Nacional de Estudios del Trabajo Buenos Aires.

Donaire y Rosati, (2007b), Aproximación a los cambios en la distribución de la población según división del trabajo social y según grupos sociales fundamentales. Argentina, 1960- 2001, VII Jornadas de Sociología. Pasado, presente y futuro, 19572007. Universidad de Buenos Aires.

Donaire, R. y Lascano, V. (2002) "Movimiento obrero e hiperinflación"; PIMSA DT № 36, Buenos Aires.

Donaire, Ricardo (2009) "La posición social de los docentes en la actualidad. Una aproximación a partir del estudio de los docentes de la Ciudad de Buenos Aires", Tesis para optar al titulo de Doctor en Ciencias Sociales - Facultad de Ciencias Sociales Universidad de Buenos Aires.

Donaire, Ricardo (2006) "Sobre la existencia de una masa de reserva para las funciones intelectuales en Argentina"; en PIMSA 2006, Bs. As. pp. 8-20.

Donaire, Ricardo (2004) "Diferentes fracciones sociales encubiertas bajo la categoría ocupacional 'trabajadores por cuenta propia' “; PIMSA DT № 44, Bs. As.

Donaire, Ricardo (2002) "Aproximación a la situación de los profesionales y los técnicos"; PIMSA DT № 34, Buenos Aires. 
Donaire, Ricardo (2001) "Acercamiento empírico al reclutamiento de los docentes"; PIMSA DT № 28, Buenos Aires.

Dorfman, Adolfo (1983) Cincuenta años de industrialización en la Argentina. 19301980, Ed. Solar, Buenos Aires.

Draguicevich, Juan Manuel (2000) "Desarrollo fabril en el Valle inferior del Río Chubut y su competencia con los grupos fabriles nacionales: compañía cervecera chubutense un caso testigo", Avance de Tesis de Licenciatura, Depto de Historia, UNP, Sede Trelew

Dube, Saurabh (2001) Sujetos subalternos, El Colegio de México, México DF.

Duek, María Celia e Inda, Graciela (2009) “¿Desembarazarse de Marx?”, en Conflicto Social, Año 2, N¹, Revista del Programa de Invest igaciones sobre Conflicto Social ISSN 1852-2262 Instituto Gino Germani - Facultad de Ciencias Sociales - UBA http://www.iigg.fsoc.uba.ar/conflictosocial/revista

Dumrauf, Clemente I. (1996) Historia de Chubut, Plus Ultra, Buenos Aires.

Eder, K. (1998) "La institucionalización de la acción colectiva. Hacia una nueva problemática teórica en el análisis de los movimientos sociales", en Ibarra, Pedro y Tejerina, Benjamín (editores) Los Movimientos Sociales. Transformaciones políticas y cambio cultural. Editorial Trotta. Madrid. Págs. 337 a 359.

Elster, Jon (1992) Una introducción a Karl Marx, Siglo XXI, México.

Engels, Federico (1974a) La situación de la clase obrera en Inglaterra; Ediciones Diáspora. Buenos Aires.

Engels, Federico (1974b) Economía Política, Edic. Roca, México D.F.

Engels, Federico (1972) Filosofía, Edic. Roca, México D.F.

Escobar, Paz (2007a) "La Patagonia Rebelde: representaciones cinematográficas de las formas de lucha de la clase obrera" en Actas II Jornadas de Historia Social de la Patagonia.

Escobar, Paz (2007b) "Cine e Historia: la Patagonia en imágenes (1936-1976)", en Actas $\mathrm{XI}^{\circ}$ Jornadas Interescuelas/ Departamentos de Historia, en CD, ISBN 978-950554-540-7.

Escobedo, Martín y Prospitti, Agustín (2006) Estudio de las prácticas sindicales de los trabajadores petroquímicos y metalúrgicos en sur santafesino, en Historia Regional № 24. ISP №3. Villa Constitución. Pág: 47 a 64.

Eskenazi, Matías (2009) El espectro de la dolarización. Discutiendo las interpretaciones sobre la disputa interburguesa en el origen de la crisis de la convertibilidad; en Bonnet, A. y Piva A. (comp.) "Argentina en pedazos. Luchas sociales y conflictos interburgueses en la crisis de la convertibilidad", Peña Lillo - Edic. Continente, Bs. As. Pág. 147 a 188.

España, Gonzalo (s/f) El movimiento anarquista en Trelew a principios del siglo XX. El caso del Centro Obrero Tierra y Libertad. (Mimeo).

Espinoza, Carlos Gustavo (2004) ¿Más valor que el oro? Los movimientos populares en oposición a la minería con cianuro. Revista Theomai no 9, primer semestre de 2004; http://www.revista-theomai.unq.edu.ar/numero9/artespinoza9.htm

Expedientes Judiciales, casos de corte de ruta en Trelew y Madryn, Poder Judicial de la Nación.

Fanon, Frantz (1963) "Los condenados de la tierra", FCE, México.

Farinetti, María (2000a) El estallido. Formas de la protesta, Buenos Aires. 
Farinetti, Marina; (2000b) Violencia y risa contra la política en el Santiagueñazo. Indagación sobre el significado de una rebelión popular; Apuntes de Investigación; CECYP, N6, Buenos Aires.

Farinetti, Marina (1999) "¿Qué queda del "movimiento obrero"? Las formas del reclamo laboral en la nueva democracia argentina", en Trabajo y Sociedad 1, julioseptiembre, 1999, http://habitantes.elsitio.com/proit/zmarina.htm.

Favaro, Orietta (2006) Una puesta en cuestión sobre el tema de los movimientos sociales. Problemas, tendencias y desafíos Anuario Rosario.

Favaro, Orietta; (2002) "Neuquén. La sociedad y el conflicto. ¿Viejos actores y nuevas prácticas sociales?", Realidad Económica 185, Bs. As.

Favaro, Orietta e luorno, Graciela (2008) "Nuevas formas organizativas en la Argentina de los últimos años. El caso de las cooperativas Ados y Fricader (Neuquén y Río Negro), 1990-2006", en Pasquali, Laura (comp. 2008) Historia Social e Historia Oral. Experiencias en la Historia Reciente de Argentina y América Latina, Edic. Homo Sapiens, Rosario, Argentina. ISBN 978-950-808-545-0. Pág. 171 a 198.

Favaro, Orietta e luorno, Graciela (2006) "La Patagonia protesta", Realidad Económica 217, Bs. As.

Favaro, Orietta, luorno, Graciela y Cao Horacio; (2006) "Política y protesta social en las provincias argentinas", en Caetano, Gerardo (comp.), Sujetos sociales y nuevas formas de protesta en la historia reciente de América Latina, CLACSO, Bs. As.

Favaro, Orietta y Cao, Horacio (2005) "Los estados provinciales. Una conceptualización provisoria", en Orietta Favaro (coord.) Sujetos sociales y política. Historia reciente de la Norpatagonia argentina, Editorial La Colmena, CEHEPYC, Universidad Nacional del Comahue, Bs. As.

Favaro, Orietta y Scuri, María Carolina (2005) "La trastienda de la Historia Regional", en Orietta Favaro (coord.) Sujetos sociales y política. Historia reciente de la Norpatagonia argentina, Editorial La Colmena, CEHEPYC, Universidad Nacional del Comahue, Bs. As.

Favaro, Orietta y Aiziczon, Fernando (2004) Al filo de la cornisa - La resistencia obrera en la fábrica Zanón, Neuquén, Realidad Económica 197.

Favaro, Orietta; Arias Bucciarelli, Mario; luorno, Graciela (1997) La conflictividad social en Neuquén: el movimiento cutralquense y los nuevos sujetos sociales, Realidad Económica 148.

Fernández, Fabián (2001) Las transformaciones en los procesos de trabajo en la industria argentina actual: algunas hipótesis e interrogantes, en PIMSA 2001, Bs. As.

Fernández Albouy y Vicini (2003) Disciplinamiento de la mano de obra y Estrategia obrera: La experiencia de los trabajadores ceramistas de la Fábrica Zanon y los trabajadores desocupados del M.T.D. Neuquen, 2000-2003, en Actas IX Jornadas Interescuelas/Departamentos de Historia.

Fernández Chein, Guadalupe (2010) "Viva la Burguesía, Mueran los obreros" La construcción de hegemonía. Un período bisagra: entre la coerción y el consenso - Las Jornadas del 13, 14 y 15 de mayo de 1910 en la ciudad de Buenos Aires - Proyecto de Tesis de Licenciatura en Historia - Facultad de Humanidades y Ciencias Sociales Sede Trelew - UNPSJB

Fernández Miranda, M.C. (1975) Situación industria textil en la provincia del Chubut.

Fernández Picolo, Mauricio y Rivera Guerrero, Rene (2009) "Sindicatos participacionistas y terrorismo de estado. Las huelgas de Guilford en Comodoro Rivadavia 1975-1976", ponencia en XII Jornadas Interescuelas Departamentos de 
Historia, Bariloche, Universidad Nacional de Comahue, 28 al 31 de Octubre de 2009, inédita.

Fernández Picolo, M. (2005) Avance de Investigación sobre el conflicto social en Sierra Grande, UNPSJB - Sede Trelew (inédito).

Fernández Picolo, M., Western, W., y De Oto, A., (1990) Autoritarismo y participación popular: Trelew, Octubre de 1972. Tesis de Licenciatura, Departamento de Historia, FHCS, UNP, Trelew.

Ferrara, Francisco (2003) "Más allá del corte de rutas. La lucha por una nueva subjetividad" La Rosa Blindada, Buenos Aires.

Ferrer, Aldo y otros (1974) Los planes de estabilización en la Argentina, Paidós, Buenos Aires.

Figueroa Ibarra, Carlos y Iñigo Carrera, Nicolás (2010) "Algunas reflexiones sobre Historia Reciente", en Margarita López Maya, Carlos Figueroa y Beatriz Rajland (editores) "Temas y procesos de la historia reciente de América Latina"; Arcis CLACSO, Santiago de Chile.

Fiori, Jorge y Gustavo De Vera (2006) 1902. El protagonismo de los colonos galeses en la frontera argentino-chilena, Municipalidad de Trevelin, Trevelin.

Fiori, Jorge y Gustavo De Vera (2004) Trevelin. Un pueblo en los tiempos del Molino, Municipalidad de Trevelin, Trevelin.

Flores, Toty (comp. 2003) "De la culpa a la autogestión. Un recorrido del Movimiento de Trabajadores Desocupados de La Matanza", Edit. MTD, Buenos Aires.

Flores Torres, Mariela (2009) "Palestinos en Argentina y Chile. Representación y construcción del conocimiento histórico", Proyecto de Tesis Doctoral. Universidad de Quilmes.

Fontana, Josef (1982) Historia. Análisis del pasado y proyecto social, Editorial Crítica, Barcelona.

Forster, Ricardo (2002) La memoria como campo de batalla, en Puentes, año 2, número 8.

Fradkin, Raúl (2002) Cosecharas tu siembra. Notas sobre la rebelión popular argentina de diciembre de 2001, Prometeo Libros, Buenos Aires.

Fressoli, Mariano (2000) "La ciudad y el recorrido del secreto", en Vernik, Esteban (comp.) Escritos contra la cosificación. Acerca de Georg Simmel, Altamira, Bs. As.

Freytes Frey, Carlos (2000) "La ciudad y la moda", en Vernik, Esteban (comp.): Escritos contra la cosificación. Acerca de Georg Simmel, Altamira, Bs. As.

Frondizi, Silvio (1957) La realidad argentina, Praxis, Buenos Aires

Frondizi, Silvio (1945) El estado moderno, Losada, Buenos Aires.

Fuchs, Jaime (1994) "Las transnacionales ..." , Edic. Letra Buena, Argentina.

Fuchs, Jaime (1981) Argentina: actual estructura económico social, Ediciones Estudio, Bs. As.

Galafassi, Guido (2008) Minería de oro y plata y conflictos sociales. Un proceso de historia reciente en Patagonia, Ponencia presentada en las XXI Jornadas de Historia Económica, 23-26 septiembre 2008, Universidad Nacional de Tres de Febrero http://www.untref.edu.ar/historia_economica.htm.

Galafassi, Guido (2005) Un nuevo despojo en la Patagonia Andina. La lucha de la comunidad mapuche Pillan Mahuiza y de decenas de campesinos por sus tierras, en 
Theomai número $11 \quad$ (primer semestre), http://revistatheomai.unq.edu.ar/numero11/artcorcovado11.htm

Galafassi, Guido (2004) "Movilización social contra la devastación minera en la Patagonia". Herramienta no 26, pp. 83-90, Buenos Aires.

Galafassi, Guido y Dimitriu, Andrés (2007) El Plan "B" de los Capitales Mineros A propósito de las notas sobre "Inversiones mineras en Argentina" en Le Monde Diplomatique de mayo 2007, en Revista Theomai número 15 (primer semestre)

Gambina, Julio (2007) "Las tendencias globales y la economía Argentina", en Anuario EDI № 3, Bs. As. pp. 18-31.

Gambina, Julio y Campione, Daniel (2003) Los años de Menem. Cirugía mayor, Centro Cultural de la Cooperación, Buenos Aires.

García, Marcelo (2005) "Kirchner y las petroleras", en Anuario EDI № 1, Bs. As. pp. 74-83

García, Norma y Mases, Enrique (2007) "De la perspectiva desde abajo a la perspectiva desde afuera: ¿una nueva mirada para el análisis de la protesta social?", en Mases y Galucci (edit.) Historia de los trabajadores en la Patagonia, Educo, UNCo, Neuquén.

Gatica, Mónica y Pérez Álvarez, Gonzalo (2009) "El surgimiento del movimiento obrero en el noreste del Chubut", en Actas III Jornadas de Historia Social: Los trabajadores y el mundo del trabajo en la Patagonia, Comodoro Rivadavia, 15 y 16 de mayo de 2009, publicada en CD ISBN 978-950-763-090-3.

Gatica, Mónica (2007) Los hacedores de caminos, Imago Mundi, Bs. As.

Gatica, Mónica y Debattista, Susana (2006) La Masacre de Trelew: Reflexiones en torno a la problemática de las memorias Actas VII Jornadas Nacionales Hacer la Historia. Facultad de Ciencias Humanas Universidad Nacional de La Pampa.

Gatica, Mónica; López, Susana; Monedero, María Laura; Pérez Álvarez, Gonzalo (2005) Patagonia desarrollo y neoliberalismo, Imago Mundi, Buenos Aires.

Gatica, Mónica y López, Susana (2002) "Patagonia: identidades múltiples y fragmentadas. Una aproximación" en Actas III Congreso de Historia Social y Política de la Patagonia Argentino Chilena, Subsecretaría de Cultura de la Pcia. del Chubut, Rawson.

Gatica, Mónica y López, Susana (2001) "Los desvelos de Clío. El oficio del historiador en Patagonia. Límites y posibilidades", Revista Sociohistórica $N^{\circ} 8$. Cuadernos del $\mathrm{CISH}$, Centro de Investigaciones Sociohistóricas, Facultad de Humanidades y Ciencias de la Educación, Universidad Nacional de La Plata y Ediciones Al Márgen.

Gatica, M. (2000a) "Identidades conflictivas o víctimas de una experiencia de desarrollo en Patagonia. Las trabajadoras de INTECO S.A.", en Boletín Realidad y Palabra N5, UDIHAYA, Departamento de Historia, Tr elew, Universidad Nacional de la Patagonia.

Gatica, Mónica (2000b) Industrialización, Proletarización y Subproletarización. ¿Una nueva identidad para la mujer en Trelew? Informe Final- SCyT.UNPSJB.

Gatica, Mónica y López, Susana (2000c) De efemérides, conmemoraciones y memorias múltiples en Patagonia. Una aproximación. Ponencia en I Jornadas de Investigación La relación historia memoria. Universidad Nacional del Comahue.

Gatica, Mónica (1998) "Trelew, ¿un polo de desarrollo y modernización?, Ponencia en IV Jornadas de Historia, UNPA, Caleta Olivia. 
Gatica, Mónica (1993) El Sindicato de Trabajadores Viales del Chubut -. De su creación a su burocratización (1972 - 1976). Tesis de Licenciatura. Depto. Historia. FHCS, Sede Trelew. Universidad Nacional de la Patagonia "San Juan Bosco".

Ghigliani, Pablo (2008a) "La noción de derrota en la historia reciente del movimiento obrero argentino", en las V Jornadas de Sociología de la UNLP y I Encuentro Latinoamericano de Metodología de las Ciencias Sociales - Universidad Nacional de La Plata, 10, 11 y 12 de diciembre de 2008 - publicada en CD, ISBN: 978-950-340514-7.

Ghigliani, Pablo (2008b) "Dilemas de la democracia sindical: la Federación Gráfica Bonaerense (1966-1975)", en Alejandro Belkin (comp.) Relatos de Luchas. Desde el Subte Editorial; Buenos Aires.

Giarracca, Norma (2002) Argentina 1991-2001: Una década de protesta que finaliza en un comienzo. La mirada desde el país interior, Argumentos, 1 (1), diciembre 2002, http://www.revistaargumentos.com.ar/index.php/argumentos/article/viewFile/23/20

Giarracca, N. y Teubal, M. (1997) "El Movimiento de Mujeres Agropecuarias en Lucha. Las mujeres en la protesta rural en la Argentina", en Realidad Económica № 150, Buenos Aires.

Giarraca, Norma et al (1993) La protesta social en Argentina, Alianza, Buenos Aires.

Giddens, Anthony (1997) Consecuencias de la modernidad, Alianza Universidad, Madrid.

Gigliani, Guillermo (2005) "Argentina después del canje: se redujo la deuda pero crecieron los pagos", en Anuario EDI № 1, Bs. As. pp. 37-48.

Gilly, Adolfo (2006) Historia a contrapelo. Una constelación, Ediciones ERA, México D.F.

Gilly, Adolfo, Subcomandante Marcos, Guinzburg, Carlo (1995) "Discusión sobre la historia", Edit Aguilar, México.

Gilly, Adolfo. "Paisaje después de una derrota" en Movimientos sociales en A.L. s.d.e.

Gilly, Adolfo (1990) La anomalía Argentina. Estado, corporaciones y trabajadores en El Estado en América Latina: teoría y práctica. Siglo Veintiuno. México, D.F.

Gilly, Adolfo (1978) "Los consejos de fábrica: Argentina, Bolivia, Italia"; en Coyoacan Revista Marxista Latinoamericana № 5; Edic. El Caballito. México, D.F.

Giuliani, Adriana y Bilder, Ernesto (2009) "La Economía Política de la Provincia de Neuquén (1983-2008)", en Actas XII Jornadas Interescuelas Departamentos de Historia, Bariloche, Universidad Nacional de Comahue, 28 al 31 de Octubre de 2009, publicada en CD ISBN 978-987-604-153-9.

Goffman, Irving (1997) La presentación de la persona en la vida cotidiana, Amorrourtu, Bs. As.

Goffman, Irving (1995) Estigma. La identidad social deteriorada, Amorrourtu, Bs. As.

Gómez, Elizabeth y Kindgard, Federico (1998) "Los cortes de ruta en la provincia de Jujuy. Mayo/Junio de 1997" en PIMSA, Buenos Aires.

Gómez, Marcelo (2007) "Origen y desarrollo de los patrones de acción y organización colectiva desafiante de los movimientos de desocupados en la Argentina", en Villanueva, E. y Massetti, A. (comp.) Movimientos sociales y acción colectiva en la Argentina de hoy, Prometeo, Bs. As.

Gómez, Marcelo (2003) La conflictividad laboral después del 19/12/01: cambios en la acción reivindicativa y nuevo marco político, Edición digital, s/d. 
González, Myriam (2009) Trayectorias laborales y prácticas espaciales de mujeres de sectores populares. El caso del barrio San Martín en Comodoro Rivadavia, en Crespo, Edda y González, Myriam (comp.) Mujeres en palabras de mujeres, Fondo Editorial Provincial Secretaría de Cultura del Chubut.

González Casanova, Pablo (1997) "La trama del neoliberalismo: una introducción" en Sader, E. y otro. La trama del neoliberalismo. Mercado, crisis y exclusión social. Oficina de Publicaciones del CBC. UBA.

Gramsci, Antonio (1997) Notas sobre Maquiavelo, sobre la política y sobre el estado moderno; Nueva Visión, Buenos Aires.

Gramsci, Antonio (1977) Pensamiento político (el partido), Edic. Roca. México DF.

Gramsci, Antonio (1975) Cuadernos de la cárcel: los intelectuales y la organización de la cultura, Juan Pablo Editor, México.

Gramsci, Antonio (1973) Contra el pesimismo, Edit. Roca. México DF.

Gramsci, Antonio (1973) Consejos de fábrica y estado de la clase obrera, Edit. Roca, México DF.

Graña, Juan M. y Kennedy, Damián (2005) Mercado de trabajo en el período 1998 2004: Asalariados y extensión de la jornada de trabajo Revista de Estudios Sobre Cambio Social, año VI. Número17-18. Otoño/Invierno 2005, Buenos Aires

Grigera, Juan (2007) "Debates en torno a la industrialización en Argentina hasta los años '70: una reconsideración a la luz de la 'desindustrialización'.", en Actas $\mathrm{XI}^{\circ}$ Jornadas Interescuelas, en CD, ISBN 978-950-554-540-7.

Groppo, Bruno y Flier, Patricia (2001) Recorridos de la memoria en Argentina, Chile y Uruguay, Ediciones al margen, Bs. As.

Grüner Eduardo (2006) "Lecturas culpables: Marx(ismos) y la praxis del conocimiento", en Boron, Amadeo y González (comp.) La teoría marxista hoy. Problemas y perspectivas, Clacso, Bs. As.

Guevara, Ernesto (2002) "Mensaje a los pueblos del mundo a través de la Tricontinental", Abril 1967, Edición Digital, CÁTEDRA LIBRE ERNESTO CHE GUEVARA, Universidad Popular Madres de Plaza de Mayo, Bs. As.

Guevara, Ernesto (2002) "El socialismo y el hombre en Cuba", Edición Digital, CÁTEDRA LIBRE ERNESTO CHE GUEVARA, Universidad Popular Madres de Plaza de Mayo, Buenos. Aires.

Guha, Ranajit (2002) Las voces de la historia y otros estudios subalternos, Crítica, Barcelona.

Hardt, Michael y Negri, Toni (2004) Multitud, Debate, Buenos Aires.

Hardt, Michael y Negri, Toni (2002) Imperio, Paidós, Bs. As.

Harvey, D. (2004), El Nuevo Imperialismo, Madrid, Ediciones Akal S.A.

Hernández, Carlos A. (1999), Capital comercial y elite local. Trelew y su hinterland: 1889-1930. Licenciatura en Historia, Trelew, UNPSJB.

Hobsbawm, Eric (1987) El mundo del trabajo, Crítica, Barcelona.

Hobsbawm, Eric (1968) Rebeldes Primitivos, Ariel, Barcelona.

Holloway, John (2000) Cambiar el mundo sin tomar el poder, Herramienta, Buenos Aires. 
Hopstein, Graciela (2004) "Piqueteros: Dilemas e potencialidades de um movimiento que emergiu a pesar do estado e a margen do mercado", en Multitudes, Revista electrónica 14, http://multitudes.samizdat.net/Piqueteros-Dilemas-e.

Horowicz, Alejandro (2007) Los cuatro peronismos, Edhasa. Buenos Aires.

Horowitz, Joel (1985) "Los trabajadores ferroviarios en la Argentina (1920-1943). La formación de una élite obrera", en Desarrollo Económico. Revista de Ciencias Sociales IDES, vol. 25, № 99.

Hualpa, Eduardo Raúl (2003) Sin despojos. Derecho a la participación mapuchetehuelche, Cuadernos de ENDEPA.

Ibarra, H. y Hernández, C. (2005) "Estado, Economía y Sociedad. Trelew y su hinterland: 1989-1999", Informe de Investigación, UNPSJB.

Ibarra, Horacio (1997) "Patagonia Sur. La construcción interrumpida de un proceso de desarrollo regional”. Depto. Historia, FHCS, UNPSJB, Trelew, mimeo.

INTA, Trelew (2003) "Diagnostico y selección de participantes para la implementación de sistemas de gestión de calidad en producción y empaque de cerezas en el Valle Inferior del Río Chubut".

INTA, Trelew (2000) Proyecto Regional de Cerezas: Cerezas del VIRCH.

Iñigo Carrera, Nicolás (2010) "El movimiento orgánico de la estructura de la sociedad argentina 1975 - 2007", en Margarita López Maya, Carlos Figueroa y Beatriz Rajland (editores) "Temas y procesos de la historia reciente de América Latina"; Arcis CLACSO, Santiago de Chile.

Iñigo Carrera, Nicolás (2009) "La huelga general como indicador de momentos de ascenso y descenso en la lucha de la clase obrera. Argentina 1984 - 2002", en Actas XII Jornadas Interescuelas Departamentos de Historia, Bariloche, Universidad Nacional de Comahue, 28 al 31 de Octubre de 2009, publicada en CD ISBN 978-987604-153-9.

Iñigo Carrera, Nicolás (2008a) "Instrumentos teórico metodológicos para la investigación de la historia de la clase obrera", en Revista de Estudios Sociales y Marítimos №1 (2008), Pág. 7 a 12

Iñigo Carrera, Nicolás (2008b) "Algunos instrumentos para el analisis de las luchas populares en la llamada historia reciente", en López Maya, Iñigo Carrera y Calveiro (edit.) Luchas contrahegemónicas y cambios políticos recientes de América Latina, CLACSO Libros, Bs. As. pág 77 a 94.

Iñigo Carrera, Nicolás (2003) El concepto de clase obrera, Conicet, FCH- UNPCBA, Pimsa.

Iñigo Carrera, Nicolás (2002) De la revuelta del hambre a la insurrección espontánea, Revista América Libre, Edición digital.

Iñigo Carrera, Nicolás (2001a) "Las huelgas generales, Argentina 1983-2001: un ejercicio de periodización", PIMSA DT № 33, Bs. As.

Iñigo Carrera, Nicolás (2001b) La huelga general política de 1932: descripción de los inicios de un ciclo en la historia de la clase obrera argentina, en PIMSA, Buenos Aires.

Iñigo Carrera, Nicolás, (2000a), La estrategia de la clase obrera. 1936, PIMSA y La Rosa Blindada, Buenos Aires.

Iñigo Carrera, Nicolás (2000b) La investigación en historia: ¿disciplina científica o corporación profesional?, en Contraviento, Editorial LaMadrid, Río Gallegos. 
Iñigo Carrera, Nicolás (1999) Fisonomía de las Huelgas generales de la década de 1990 (1992-1999), en PIMSA, Buenos Aires.

Iñigo Carrera, Nicolás (1988) La violencia como potencia económica: Chaco, 1870 1940, CEAL, vol. 11, Buenos Aires.

Iñigo Carrera, Nicolás (1984) Campañas militares y clase obrera. Chaco, 1870 1930, CEAL, Historia Testimonial Argentina, N25, Buenos Aires.

Iñigo Carrera, Nicolás (1983) La colonización del Chaco, CEAL, Historia Testimonial Argentina, $\mathrm{N}^{\circ} 3$, Bs. As.

Iñigo Carrera, Nicolás y Fernández, Fabián (2007) "El movimiento obrero ante la organización y formas de rebelión de los desocupados: 1930 - 1935"; en Revista Ciclos, Año XVII, Volumen XVI, № 31/32; pág. 125 -152.

Iñigo Carrera, Nicolás y Cotarelo, María Celia (2004) "Algunos rasgos de la rebelión en Argentina 1993-2001", en PIMSA DT № 49, Buenos Aires.

Iñigo Carrera, Nicolás y Cotarelo, María Celia (2003a) "La insurrección espontánea. Argentina diciembre 2001. Descripción, periodización, conceptualización", en PIMSA DT № 43, Buenos Aires.

Iñigo Carrera, Nicolás y Cotarelo, María Celia (2003b) ¿Quién es el sujeto?, en Razón y Revolución № 11, Buenos Aires.

Iñigo Carrera, Nicolás y Cotarelo, María Celia (2002) "Luchas sociales en la Argentina actual (1993-2001)", en Bajo el Volcán, Revista de la Univ. De Puebla, Año 2 N5, Puebla, México.

Iñigo Carrera, Nicolás y Cotarelo, María Celia (2000) "La protesta social en los 90. Aproximación a una periodización", en Herramienta, N12, Buenos Aires.

Iñigo Carrera, Podestá y Cotarelo (1999) "Las estructuras económico sociales concretas que constituyen la formación económica de la Argentina", en PIMSA DT № 18, Bs. As.

Iñigo Carrera, Nicolás y Cotarelo, María Celia (1998) "Los llamados "cortes de ruta". Argentina 1993 1997", en PIMSA, Buenos Aires.

Iñigo Carrera, Nicolás y Podestá, Jorge (1997a) Elementos para el análisis de una relación de fuerzas sociales objetiva. Argentina 1991, en PIMSA, Buenos Aires.

Iñigo Carrera y Podestá (1997b) Las nuevas condiciones en la disposición de fuerzas objetivas. La situación del proletariado, en PIMSA DT № 5, Bs. As.

Iñigo Carrera, Nicolás, Cotarelo, María Celia y Podestá (1996) Situación de los grupos sociales fundamentales en Argentina: el proletariado, en Razón y Revolución № 2, Buenos Aires.

Iñigo Carrera, Nicolás, Cotarelo, María Celia, Gómez, Elizabeth y Kindgard, Federico (1995) La revuelta. Argentina 1989/90; en PIMSA DT № 4, Bs. As.

Iñigo Carrera y Podestá (1985) Análisis de una relación de fuerzas sociales objetiva: caracterización de los grupos sociales fundamentales en la Argentina actual; Cuadernos de Cicso - serie estudios № 46, Bs. As.

Irusta, Delia y Rodríguez, Lidia (1993) Aportes para el estudio del desarrollo urbano de Trelew, Informe final de proyecto PID-CONICET.

Iuliano, R. Pinedo, J. y Viguera, A. (2007). "El campo de estudios sobre la protesta social en la nueva etapa democrática". En Camou, Antonio, Cristina Tortti y Aníbal Viguera (coord.). La Argentina democrática: los años y los libros. Buenos Aires: Prometeo. 
Izaguirre, Inés (2006) Movimientos sociales y lucha de clases. Sociogénesis de una sustitución conceptual en el discurso académico. Crítica de nuestro tiempo 4, p. 4. Buenos Aires.

Izaguirre, Inés (2002) Algunos ejes teórico-metodológicos en el estudio del conflicto social, Argumentos, 1 (1), diciembre 2002, http://www.revistaargumentos.com.ar/index.php/argumentos/article/viewFile/23/20

Izaguirre, M. I. (1994a) "Problemas metodológicos y construcción de observables en una investigación sobre luchas obreras", en Daniel Campione compilador, La Clase Obrera De Alfonsín A Menem, CEAL, Buenos Aires.

Izaguirre, Inés (1994b) Los desaparecidos: recuperación de una identidad expropiada. Centro Editor de América Latina, Buenos Aires.

Izaguirre, Inés y Aristizábal, Zulema (2002) Las luchas obreras 1973-1976 Los alineamientos de la clase obrera durante el gobierno peronista. Nuevas consideraciones teórico-metodológicas para el estudio de los conflictos obreros. Instituto de Investigaciones Gino Germani - Facultad de Ciencias Sociales - UBA.

Jacoby, Roberto (1986) El asalto al cielo. Formación de la teoría revolucionaria desde la Comuna de 1871 a octubre de 1917. Mimeo, investigación inédita.

Jacoby, Roberto (1978) Conciencia de clase y enfrentamientos sociales. Argentina 1969., Buenos Aires, Cuadernos de CICSO, Serie estudios No. 32.

Jelín, Elizabeth (2002) Los trabajos de la Memoria. Memorias de la represión. Siglo XXI de Argentina Editores- Siglo XXI de España editores, Bs. As.

Jones, Lewis (1983) La colonia galesa. Historia de una Nueva Gales en el Territorio del Chubut en la República Argentina. Sudamérica. El Regional. Rawson.

Jones, Matthew Henry (1981) Trelew, un desafío patagónico. Impresora Golfo Nuevo, Puerto Madryn.

Kan, Julián (2009) Vuelta previa al 2001... La devaluación del real de 1999 y algunas implicancias en la burguesía argentina; en Bonnet, A. y Piva A. (comp. 2009) "Argentina en pedazos. Luchas sociales y conflictos interburgueses en la crisis de la convertibilidad", Peña Lillo - Edic. Continente, Bs. As. Pág. 223 a 251.

Katz, Claudio (2007) "El giro en la economía”, en Anuario EDI № 3, Bs. As. pp. 93-107. Katz, Claudio (2006) "Coyuntura, modelo y distribución”, en Anuario EDI № 2, Bs. As. pp. 50-72.

Katz, Claudio (2005a) “¿Quién gana con el canje?”, en Anuario EDI № 1, Bs. As. pp. 11-23.

Katz, Claudio (2005b) "Quebrantos públicos, negocios privados", en Anuario EDI № 1, Bs. As. pp. 84-91

Kicillof, Axel y Nahón, Cacilia (2007) "El retorno de la inflación a la Argentina: un problema de salarios y ganancias", en Anuario EDI № 3, Bs. As. pp. 156-171.

Klachko, Paula (2006) La forma de organización emergente del ciclo de la rebelión popular de los '90 en Argentina, Tesis de Doctorado en Historia, Facultad de Humanidades y Ciencias de la Educación, Universidad Nacional de La Plata.

Klachko, Paula (2003) "El proceso de lucha social en Corrientes, marzo a diciembre de 1999. Los “Autoconvocados"; en PIMSA 2003 DT № 42, Buenos Aires.

Klachko, Paula (2002) "La conflictividad social en la Argentina de los '90: el caso de las localidades petroleras de Cutral Có y Plaza Huincul (1996-1997)"; en Bettina Levy 
(comp.)Crisis y conflicto en el capitalismo latinoamericano: lecturas políticas; CLACSO, Bs. As.

Klachko, Paula (1999) "Cutral Có y Plaza Huincul El primer corte de ruta (del 20 al 26 de Junio de 1996) Cronología e hipótesis"; en PIMSA 1999 DT № 20, Buenos Aires.

Kloster, Elba E. (2001) "Región Patagónica”; en Velázquez, G. Geografía, calidad de vida y fragmentación en la Argentina de los noventa. Tandil, CIG. UNICEN.

Kohan, Néstor (2002) "El humanismo guevarista y el posmodernismo - El sujeto y el poder" CÁTEDRA LIBRE ERNESTO CHE GUEVARA, Universidad Popular Madres de Plaza de Mayo, Bs. As.

Kohan, Néstor (2002) "El marxismo y el trabajo enajenado", CÁTEDRA LIBRE ERNESTO CHE GUEVARA, Universidad Popular Madres de Plaza de Mayo, Bs. As.

Korol, Claudia (2002) "Las palabras nuevas de los piqueteros", Chiapas, UNAM, México.

Lagos, Marcelo; Fleitas, María Silvia y Bovi, María Teresa (comps. 2004) A cien años del informe Bialet Massé. El trabajo en la Argentina del siglo XX y albores del XXI. Tomo 1; EdiUnju - Universidad Nacional de Jujuy, San Salvador de Jujuy.

Lagos, Marcelo; Fleitas, María Silvia y Bovi, María Teresa (comps. 2007) A cien años del informe Bialet Massé. El trabajo en la Argentina del siglo XX y albores del XXI. Tomo 2; EdiUnju - Universidad Nacional de Jujuy, San Salvador de Jujuy.

Lash, Scott (1997) Sociología del posmodernismo, Amorrourtu editores, Buenos Aires.

Lash S. y Urry, J. (1994) Economías de signos y espacio, Buenos Aires, Amorrortu.

Laveglia, Fernando (2004) Apuntes de la economía del Chubut, Edit. Dunken, Bs. As.

Lenguita, Paula (2002) "El poder del desempleo. Reflexiones críticas sobre la relevancia del movimiento piquetero", en Battistini, Osvaldo (comp. 2002) "La atmósfera incandescente", Asoc. Trabajo y Sociedad, Buenos Aires.

Lenin, Vladimir (1981a) Obras Escogidas, Edit. Progreso, Moscú.

Lenin, Vladimir (1981b) El desarrollo del capitalismo en Rusia, Edit. Progreso, Moscú.

Lenin, Vladimir (1972) Cuadernos Filosóficos, Edic. Estudio, Bs. As.

Lewkowicz, Ignacio (2002) Sucesos argentinos. Cacerolazo y subjetividad postestatal; Paidós; Bs. As.

Ley Provincial de Pesca Artesanal de Chubut, Legislatura del Chubut, Ley 4725, 2001.

Lindemboin, Javier; Kennedy, Damián y Graña, Juan (2006) "Distribución, consumo e inversión en la Argentina a comienzos del siglo XXI", en Realidad Económica № 218, IADE, Bs. As. pp 65-92.

Lipietz, A. (1994) "El posfordismo y sus espacios. Las relaciones capital-trabajo en el mundo", Documento de trabajo № 4, Serie de Seminarios intensivos de investigación, Buenos Aires, PIETTE del CONICET.

Livigni, Ester y Sendín, María (1998) Composición del desempleo en Chubut. Período 1984-1997, en Anuario 1998, FCE, UNPSJB, Trelew.

Lobato, Mirta y Suriano, Juan (2003) La protesta social en la Argentina, Fondo de Cultura Económica, Buenos Aires

López, Susana; Gatica, Mónica y Pérez Álvarez, Gonzalo (2008) "Son errores que tuvimos que pasar para después en un futuro no volverlos a hacer" La experiencia de Jaime, un ex trabajador de YPF, en Pasquali, Laura (comp. 2008) Historia Social e Historia Oral. Experiencias en la Historia Reciente de Argentina y América Latina, Edic. 
Homo Sapiens, Rosario, Argentina. ISBN 978-950-808-545-0. Pág. 145 a 170. Pág. Totales: 286.

López, Susana; Gatica, Mónica y Pérez Álvarez, Gonzalo (2007) "Argentina: implicaciones del Neoliberalismo en el Noreste del Chubut" en la revista "Marxismo Vivo № 15" Revista de Teoría y Política Internacional, ISSN: 1806-1591, San Pablo, Brasil. Pág. 85 a 96.

López, Susana; Gatica, Mónica y otros (2004) Patagonia, la construcción hegemónica del desierto. Su resignificación desde estrategias contrahegemónicas, Mimeo. Trelew.

López, Susana (2003a) Representaciones de la Patagonia. Colonos Científicos y Políticos (1870-1914), Ediciones Al Margen, La Plata.

López, Susana; Gatica, Mónica y otros (2003b) Una aproximación a los diseños políticos para Patagonia, Informe final de investigación, UNP.

López, Susana (1998) "La Historiografía sobre Patagonia. Un comentario" en Boletín Realidad y Palabra N 4, UDIHAYA, Dpto. de Historia, Trelew, Universidad Nacional de la Patagonia.

López, Susana (1997) "Patagonia y la mirada de los colonos galeses del Chubut. Dos proyectos y una nación”, en Boletín Realidad y Palabra N3․ Dpto. de Historia, Trelew, Universidad Nacional de la Patagonia.

Lo Presti, Pablo (2010) Fraternidad, romerías y disputas. La Asociación Española de Socorros Mutuos de Trelew. 1908-2008 Asociación Española de Socorros Mutuos. Trelew.

Löwy, Michael (2001) "Ni calco ni copia: Che Guevara en búsqueda de un nuevo socialismo", Ponencia presentada a la Conferencia anual de la Fundación Ernesto Che Guevara, Italia.

Lozano, Claudio (2001) "Contexto económico y político en la protesta social de la Argentina contemporánea", OSAL № 5, CLACSO.

Lucita, Eduardo (2007) "Nueva etapa de acumulación, ¿qué perspectivas?”, en Anuario EDI № 3, Bs. As. pp. 32-44.

Lucita, Eduardo (2006a) "Economía mundial: Tendencias y tensiones", en Anuario EDI № 2, Bs. As. pp. 9-21.

Lucita, Eduardo (2006b) "Economía Argentina: ciclo expansivo y desequilibrios estructurales", en Anuario EDI № 2, pp. 73-85.

Lucita, Eduardo (2005) "Argentina: nueva reestructuración de la deuda", en Anuario EDI № 1, Bs. As. pp. 24-29.

Luhmann, Niklas (1997) Observaciones de la modernidad, Racionalidad y contingencia en la sociedad moderna. Paidós Studio, Barcelona.

Luque, Elida y Martínez, Susana (2006) "La situación de los trabajadores desocupados del petróleo en la zona norte de la provincia de Santa Cruz" en Actas VII Jornadas Grupo Hacer la Historia.

Luque, Elida I. y Martínez, Susana (2005) "Los conflictos sociales producidos en las primeras décadas del siglo XX en Santa Cruz. La constitución de un territorio social." Ponencia presentada en las $X$ Jornadas Interescuelas de Historia realizadas el año 2005 en la ciudad de Rosario.

Luque, Elida, Martínez, Susana y otros (2003a) Conflictos sociales en la provincia de Santa Cruz. Los años noventa, PIMSA, Bs. As. 
Luque (co-director), Martínez, Avalos, Auzoberría, (2003b) Nueva articulación del capitalismo de estado en Santa Cruz: sus efectos en los grupos sociales, las alianzas políticas y la ideología. Los años noventa, Informe Final de Proyecto de Investigación dirigido por Iñigo Carrera, SECyT, UNPA.

Luque, Martínez, Avalos y Auzoberría (2000) De la génesis a la crisis de una estructura económica (Santa Cruz entre 1940 y los 90), en Contraviento, Edit. LaMadrid, Río Gallegos.

Maceira, Verónica y Spaltenberg, Ricardo (2001) "Una aproximación al movimiento de desocupados en el marco de las transformaciones de la clase obrera en Argentina", OSAL № 5, CLACSO.

Marín, Juan Carlos (2000) "La noción de polaridad en los procesos de formación y realización de poder. Selección", en Razón y Revolución, número 6, pp 21-33.

Marín, Juan Carlos (1995) Conversaciones sobre el poder, Edit. CBC/Instituto Gino Germani, UBA.

Marín, Juan Carlos (1984a), Los hechos armados. Un ejercicio posible. Cicso. Buenos Aires.

Marín, Juan Carlos (1984b) Acerca del origen del poder. Ruptura y propiedad. Buenos Aires, Cuadernos del CICSO, Serie Teoría, No 10.

Marín, Juan Carlos (1981) La noción de polaridad en los procesos de formación y realización del poder, Cuadernos del CICSO, Serie Teoría No. 8, Buenos Aires.

Marqués, Daniel (2007a) "Del pozo al socavón. Trabajadores petroleros y mineros estatales en la Patagonia Austral: un estudio comparativo", en Mases y Galucci (edit.) Historia de los trabajadores en la Patagonia, Educo, UNCo, Neuquén.

Marques, Daniel (2007b) "El peronismo y los trabajadores petrolíferos estatales en la Patagonia Austral: Entre la madurez de una racionalidad socialmente inclusiva y la emergencia de un nuevo formato sindical (1945-1955)" en Actas II Jornadas de Historia Social de la Patagonia.

Marques, Daniel (1999) "Entre la crisis del valor social del trabajo y la fragilidad de la identidad del trabajador: cuenca del Golfo San Jorge”, en Salvia, Agustín (comp. 1999) La Patagonia de los noventa: sectores que ganan, sociedades que pierden, Edit. La Colmena, Bs. As.

Marques, Daniel y Mario Palma Godoy (1993) Comodoro Rivadavia en tiempos de cambio. Una propuesta para la revalorización de nuestras identidades culturales. Ediciones Proyección Patagónica, Comodoro Rivadavia.

Martínez, Susana (2003) "Yacimientos Carboníferos Fiscales y el paternalismo como estrategia empresarial", en Actas IX Jornadas Interescuelas U.N.Córdoba, en CD.

Martínez, Tomás Eloy (1973) La pasión según Trelew, Ed. Planeta, Buenos Aires.

Martuccelli, Danilo, 2007, Gramática del individuo, Losada, Bs. As.

Marx, Carlos (2008) Introducción general a la crítica de la economía política/1857, Edic. Luxemburg, Bs. As.

Marx, Carlos (2006) El dieciocho brumario de Luis Bonaparte, Edición electrónica en Internet.

Marx, Carlos (1997) Introducción general a la crítica de la economía política/1857, S XXI, México.

Marx, Carlos (1987) Miseria de la filosofía, Editorial Cartago, Bs. As.

Marx, Carlos (1983) El Capital, Editorial Cartago, Bs. As. 
Marx, Carlos (1975) Teorías sobre la plusvalía, Editorial Cartago, Bs. As.

Marx, Carlos (1946) Las luchas de clases en Francia, Edic. Lautaro, B.s A.s

Marx, Carlos y Engels, Federico (1985) La ideología alemana, Edic. Pueblos Unidos, Bs. As.

Marx, Carlos y Engels, Federico (1973) Correspondencia, Edit. Cartago, Bs. As.

Mases y Galucci (2007) "La historiografía sobre los trabajadores en la Patagonia. Un estudio preliminar", en Mases y Galucci (edit.) Historia de los trabajadores en la Patagonia, Educo, UNCo, Neuquén.

Mases y Galucci (edit.) (2007) Historia de los trabajadores en la Patagonia, Educo, UNCo, Neuquén.

Masid, Mirta y Mateo, José (2008) "De la sustitución a la exportación. El sector pesquero argentino entre 1930 y 1965", en el №1 de la Revista de Estudios Marítimos y Sociales, Mar del Plata.

Massetti, Astor (2004) Piqueteros. Protesta social e identidad colectiva; FLACSO, Bs. As.

Mattini, Luís (2003) "Autogestión productiva y asambleismo", en Cuadernos del Sur № 36, Año 19, Bs. As.

Mazzeo, Miguel (2004) Piqueteros. Notas para una tipología, Manuel Suárez Editor, FISyP; Bs. As.

Melucci, Alberto (1999) Acción colectiva, vida cotidiana y democracia, El Colegio de México, México D.F.

Melucci, Alberto (1994) "Asumir un compromiso: identidad y movilización en los movimientos sociales", en Zona Abierta 69.

Melucci, Alberto, "La experiencia individual y los temas globales en una sociedad planetaria", fotoduplicado, s/d.

Menni, Ana María (2004) El trabajo masculino en el Alto Valle de Río Negro en 1993 y 2003, en Actas Historia Económica.

Merklen, Denis (1991) Asentamientos en La Matanza. La terquedad de lo nuestro, Catálogos; Bs. As.

Miralles, Glenda (2007) "El sindicato, el galpón y la casa: las mujeres en el Sindicato de la Fruta (1953-1996)", en Mases y Galucci (edit.) Historia de los trabajadores en la Patagonia, Educo, UNCo, Neuquén.

Monedero, María Laura (2001) Brazo y Cerebro, periódico anarquista de Bahía Blanca. Una importante experiencia libertaria en una década crítica. 1925 - 1930, Tesis de Licenciatura en Historia, FHCS, Sede Trelew, UNPSJB (mimeo).

Moreno, Omar (1993) "La última oportunidad del sindicalismo argentino", en HolmDetlv Kohler and Mandred Wannoffel (edit.) Modelo Neoliberal y Sindicatos en América Latina, Fundación Friedrich Ebert, México, pp. 53-56.

Narodowski, Patricio (2008) La Argentina pasiva. Desarrollo, subjetividad, instituciones, más allá de la modernidad. Edit. Prometeo, Bs. As.

Narodowski, Patricio (2004) "La informalidad en la cadena de valor, en el municipio de Quilmes", Proyecto UNLP-FCE-UIQ

Nieto, Agustín (2010) Notas críticas en torno al sentido común historiográfico sobre 'el anarquismo argentino' en II Encuentro Internacional Teoría y práctica política en América Latina. Nuevas derechas e izquierdas en el escenario regional; Universidad 
Nacional de Mar del Plata - 3 al 5 de marzo de 2010, publicada en CD ISBN 978-9871314-96-6.

Nieto, Agustín (2009) "Conflictividad obrera en la industria de la pesca, 1997-2008" en Actas del Primer Congreso Nacional Sobre Protesta Social, Acción Colectiva y Movimientos Sociales.

Nieto, Agustín (2008) "Conflictividad obrera en el puerto de Mar del Plata: del anarquismo al peronismo..."; №1 de la Revista de Estudios Marítimos y Sociales, Mar del Plata.

Nieto, Agustín (2005a) "El Argentinazo: entre lo consciente y lo espontáneo". Ponencia presentada en las X Jornadas Interescuelas de Historia realizadas el año 2005 en la ciudad de Rosario.

Nieto, Agustín (2005b) "Lucha de calles en el puerto de Mar del Plata. 28 y 29 de Junio de 2000" Ponencia presentada en las X Jornadas Interescuelas de Historia realizadas el año 2005 en la ciudad de Rosario.

Nievas, Flabián (2002) "La crisis en Argentina", en Bajo el Volcán, Revista de la Univ. De Puebla, Año 2 N5, Puebla, México.

Nora, Pierre (1984) Entre memoria e historia. La problemática de los lugares, en Lieux de Mémoire I: La République; Gallimard, París (traducción al castellano en mímeo)

Novack, George (1974) La ley del desarrollo desigual y combinado, Edic. Pluma, Bs. As.

Offe, Claus (1992) Partidos políticos y nuevos movimientos sociales, Editorial Sistema, Madrid.

Oriola, Jorge (2004) Esquel... del telégrafo al pavimento, Honorable Senado de la Nación, Buenos Aires.

Oriola, Jorge (2003) El Trocha y los ferrocarriles patagónicos, Editorial UHF Patagonia, Esquel.

Oriola, Jorge (2006) Esquel... del sismo al no a la mina, edición del autor, Esquel

Oroquieta, Pedro (2004) "Pesca artesanal en Chubut, Argentina: Problemáticas afines a la actividad", APA Madryn.

Ortiz, Renato (1996) Otro territorio. Ensayos sobre el mundo contemporáneo. UNQ, Bs. As.

Ortiz, Sebastián; Tavormina, Diego; Viegas, Alejandro (2005) De Remes Lenicov a Lavagna: un enfrentamiento particular de la lucha interburguesa reciente. En Actas $X$ Jornadas Interescuelas de Historia.

Oszlak, Oscar (1982) La formación del estado argentino, Editorial de Belgrano, Bs. As.

Ouviña, Hernán (2009) La autonomía urbana en territorio argentino. Apuntes en torno a la experiencia ...; en Bonnet, A. y Piva A. (comp. 2009) "Argentina en pedazos. Luchas sociales y conflictos interburgueses en la crisis de la convertibilidad", Peña Lillo - Edic. Continente, Bs. As. Pág. 115 a 145.

Ouviña, Hernán (2002) "Las asamblea barriales: apuntes a modo de hipótesis de trabajo", en Bajo el Volcán, Revista de la Univ. De Puebla, Año 2 N5, Puebla, México.

Oviedo, Luís (2001) De las primeras coordinadoras a las Asambleas Nacionales. Una Historia del movimiento piquetero, Edic. Rumbos, Buenos Aires,

Palomino, Héctor (1986) Cambios ocupacionales y sociales en Argentina (1974-1985); CISEA, Bs. As. 
Panettieri, José (1983) Proteccionismo, liberalismo y desarrollo industrial, Biblioteca Política Argentina, CEAL, Buenos Aires.

Paniquelli, María y Sancci, Bruno (2006) El Chubutazo: octubre de 1990, De los cuatro vientos, Bs. As.

Paniquelli, María y Sancci, Bruno (1993) Conflicto político y protesta urbana. Chubut, octubre de 1990. Tesis de Licenciatura en Historia, Trelew, UNPSJB.

Pascucci, Silvina (2009) "El trabajo a domicilio en la industria de la confección de indumentaria. Buenos Aires 1970-2007", Ponencia presentada en XII Jornadas Interescuelas y/o Departamentos de Historia.

Pasquali, Laura (comp. 2008) Historia Social e Historia Oral. Experiencias en la Historia Reciente de Argentina y América Latina, Edic. Homo Sapiens, Rosario, Argentina.

Passerini, Luisa (1984) Torino Operaria e Fascismo; una storia orale. Laterza. Roma.

Pelosi, Martha y otros (1977) El Parque Industrial de Trelew. Su importancia socioeconómica.

Peña, Milcíades (1973), La clase dirigente argentina frente al imperialismo, Edic. Fichas, Buenos Aires.

Peña, Milcíades (1973), Industria, burguesía industrial y liberación nacional, Edic. Fichas, Buenos Aires.

Peralta Ramos, Mónica (1997) Acumulación del capital y crisis política en Argentina (1930-1974), Siglo Veintiuno editores, México.

Pereyra, Sebastián (2008) ¿La lucha es una sola? La movilización social entre la democratización y el neoliberalismo; UNGS - Biblioteca Nacional; Bs. As.

Pereyra, Daniel (2003) Argentina rebelde. Crónicas y enseñanzas de la revuelta social; El viejo Topo; Bs. As.

Pérez, Germán (2002) Modelo para armar: complejidad y perspectivas de la protesta social en la Argentina reciente, Argumentos, 1 (1), diciembre 2002, http://www.revistaargumentos.com.ar/index.php/argumentos/article/viewFile/23/20

Pérez Álvarez, Gonzalo (2010a) "Transformaciones económico-sociales en la Patagonia durante los noventa: el caso del noreste del Chubut", en "Realidad Económica" № 251, Revista del IADE, Instituto Argentino para el Desarrollo Económico. Bs. As. Pág. 70 a 96

Pérez Álvarez, Gonzalo (2010b) "Un acercamiento a la discusión sobre bases, direcciones, sindicatos, proyectos políticos y estrategias obreras" en II Encuentro Internacional Teoría y práctica política en América Latina. Nuevas derechas e izquierdas en el escenario regional; Universidad Nacional de Mar del Plata - 3 al 5 de marzo de 2010, publicada en CD ISBN 978-987-1314-96-6.

Pérez Álvarez, Gonzalo (2009a) "Los trabajadores desocupados: el caso del noreste de Chubut, continuidad, ruptura y estrategias" en Revista "Razón y Revolución", № 19, Buenos Aires, Ediciones ryr, ISSN 1515-1913 (53 a 68).

Pérez Álvarez, Gonzalo (2009b) "Aunque parezca, la red no está vacía. Luchas de los obreros pesqueros del noreste de Chubut, 1990-2005" en Revista de Estudios Marítimos y Sociales, № 2, Mar del Plata, ISSN 1852-0669. Pág. 171 a 183.

Pérez Álvarez, Gonzalo (2009c) "Lucha y memoria obrera en el noreste del Chubut. Una aproximación desde la fábrica Modecraft 1990-1991" en Historia Antropología y Fuentes Orales, № 41, Barcelona, España. ISSN 1136-1700. Pág. 25 a 48. 
Pérez Álvarez, Gonzalo (2009d) "Los movimientos de trabajadores desocupados en el noreste del Chubut de 1990 al 2005: continuidad, ruptura y estrategias", en el Primer Congreso Nacional Sobre Protesta Social, Acción Colectiva y Movimientos Sociales, Marzo de 2009, en CD, ISBN 978-987-24976-2-0.

Pérez Álvarez, Gonzalo (2009e) "Bases, direcciones y estrategias obreras: un acercamiento desde la historia oral" en Actas IX Encuentro Nacional y III Congreso Internacional de Historia Oral, "Los usos de la memoria y la historia oral", Buenos Aires, 7, 8 y 9 de Octubre, publicada en CD ISBN 978-987-1642-02-1.

Pérez Álvarez, Gonzalo (2009f) "Una aproximación a la lucha de los trabajadores de la pesca" en Actas III Jornadas de Historia Social: Los trabajadores y el mundo del trabajo en la Patagonia, Comodoro Rivadavia, 15 y 16 de mayo de 2009, publicada en CD ISBN 978-950-763-090-3.

Pérez Álvarez, Gonzalo (2009g) "La clase obrera en el noreste del Chubut entre 1990 y el 2005: una expresión local del proceso general (periodización, ciclos y conciencia)" en Actas XII Jornadas Interescuelas Departamentos de Historia, Bariloche, Universidad Nacional de Comahue, 28 al 31 de Octubre de 2009, publicada en CD ISBN 978-987-604-153-9.

Pérez Álvarez, Gonzalo (2008a) "El período 1989 -2005 en el noreste del Chubut: la formulación de un sistema de problemas", trabajo final Seminario de Postgrado: "Los movimientos de rebelión social en el capitalismo....", dictado por Nicolás Iñigo Carrera y María Celia Cotarelo.

Pérez Álvarez, Gonzalo (2008b) "La experiencia obrera en el noreste del Chubut" Una aproximación desde los conflictos en las fábricas Modecraft y Aluar", en Actas Terceras Jornadas de Historia de la Patagonia -San Carlos de Bariloche, 6-8 de noviembre de 2008 -, publicada en CD, ISBN: 978-987-604-107-2.

Pérez Álvarez, Gonzalo (2008c) "Cambios en la estructura económica social y protestas sociales en el noreste de Chubut 1990 - 2003", en actas XXI Jornadas de Historia Económica - Universidad Nacional de Tres de Febrero, 23 al 26 de Septiembre de 2008, en http://xxijhe.fahce.unlp.edu.ar

Pérez Álvarez, Gonzalo (2008d) "Tejiendo otra historia. Las luchas obreras en el parque textil de Trelew 1990 - 2000", en Actas IV Jornadas de Trabajo sobre Historia Reciente - Universidad Nacional de Rosario, 14, 15 y 16 de Mayo de 2008, publicada en CD, ISBN: 978-950-673-669-9.

Pérez Álvarez, Gonzalo (2008e) "La lucha obrera en el noreste del Chubut. Un ejercicio de periodización 1990 - 1997", en Historia Regional № 26, Año XXI, Revista del ISP №3, Villa Constitución - Argentina. ISSN 0329-8213. Pág. 13 a 36.

Pérez Álvarez, Gonzalo (2008f) "Protestas obreras en el noreste de Chubut: los textiles y los metalúrgicos en la década del 90'.”, en e-l@tina, Vol. 6, núm. 24, Buenos Aires, julio-septiembre de 2008 - http://www.iigg.fsoc.uba.ar/elatina.htm - Revista electrónica de estudios latinoamericanos Facultad de Ciencias Sociales, Universidad de Buenos Aires. ISSN 1666-9606. Pág. 41 a 60.

Pérez Álvarez, Gonzalo (2008g) "Transformaciones económicas y luchas de los trabajadores: el caso de ALUAR en Puerto Madryn", en Actas VIII Jornadas Nacionales y V Latinoamericanas Grupo de trabajo Hacer la Historia - 16, 17 y 18 de octubre de 2008 - Ciudad de Córdoba, Argentina, publicada en CD.

Pérez Álvarez, Gonzalo (2008h) "Una discusión acerca de cómo se explica el movimiento de la sociedad en la Argentina actual", en las II Jornadas Nacionales de Investigación en Ciencias Sociales - Facultad de Humanidades y Ciencias Sociales Sede Trelew - U.N.P.S.J.B. - 13 al 15 de Noviembre de 2008 - publicada en CD, ISSN: 1812-1215. 
Pérez Álvarez, Gonzalo (2008i) "Transformaciones en el noreste del Chubut entre 1989 y el 2005: hipótesis y sistema de problemas", en las V Jornadas de Sociología de la UNLP y I Encuentro Latinoamericano de Metodología de las Ciencias Sociales Universidad Nacional de La Plata, 10, 11 y 12 de diciembre de 2008 - publicada en CD, ISBN: 978-950-34-0514-7.

Pérez Álvarez, Gonzalo (2008j) "La lucha de clases en el noreste del Chubut 19902001", en Revista Teórica "Qué hacer: por el rearme teórico de la clase trabajadora" № 3 primavera 2008 - Editorial "A Vencer" - Bs. As. Pág. 169 a 202.

Pérez Álvarez, Gonzalo (2007a) "Las luchas obreras en el noreste del Chubut durante los años noventa", en Actas $\mathrm{XI}^{\circ}$ Jornadas Interescue las/ Departamentos de Historia, en CD, ISBN 978-950-554-540-7.

Pérez Álvarez, Gonzalo (2007b) "Cambios en la estructura económica social en el noreste de Chubut durante los años noventa", en Actas XI Jornadas Interescuelas/ Departamentos de Historia, en CD, ISBN 978-950-554-540-7.

Pérez Álvarez, Gonzalo (2007c) Calidad de Vida y desigualdad en Chubut, Trabajo final del seminario de Postgrado "Geografía y bienestar. Argentina, S XXI", dictado por el Dr. Guillermo Velásquez.

Pérez Álvarez, Gonzalo (2007d) "Memorias obreras en el noreste del Chubut: Una aproximación desde el conflicto en la fábrica Modecraft en los primeros años de la década del noventa" trabajo final Seminario de Postgrado: "De la Memoria a la Historia" dictado por la Dra. Josefina Cuesta Bustillo.

Pérez Álvarez, Gonzalo (2007e) "La resistencia obrera en el noreste del Chubut 19901995. Un ejercicio de periodización", en Actas I Jornadas de Historia Social de la Patagonia y II Jornadas de Historia de los Trabajadores de la Patagonia en Neuquén, 26 y 27 de abril de 2007, publicada en CD.

Pérez Álvarez, Gonzalo (2007f) "Algunas reflexiones sobre las formas de representación de la protesta social desde el estudio en el noreste de Chubut de 1990 al 2003" en Actas de las I Jornadas Nacionales de Filosofía y Epistemología de la Historia 7 al 9 de junio de 2007, Editorial Educo, Neuquén, Argentina, Universidad Nacional del Comahue, Facultad de Humanidades, en CD, ISBN 978-987-604-057-0.

Pérez Álvarez, Gonzalo (2007g) "Luchas obreras y experiencia en el noreste del Chubut 1990 - 2000", en Actas I Jornadas de Investigación en Ciencias Sociales Facultad de Humanidades y Ciencias Sociales U.N.P.S.J.B.- 26 al 29 de Noviembre de 2007, publicada en CD. ISBN 978-950-763-081-1

Pérez Álvarez, Gonzalo (2007h) "La lucha obrera en el noreste del Chubut de 1990 a 1999" en Revista "Pasado por-venir" № 2, Depto. De Historia, F.H.C.So. - UNPSJB, Trelew, Chubut, Argentina. ISSN 1669-9599. Pág. 15 a 42.

Pérez Álvarez, Gonzalo (2006) "Organizaciones y propuestas políticas en el conflicto social del noreste de Chubut 1990 - 1991", Actas de las VII Jornadas Nacionales IV Jornadas Latinoamericanas "Conocer para poder hacer una nueva sociedad" Hacer La Historia - U. N. La Pampa, publicada en CD, ISBN 978-987-23666-0-5.

Pérez Álvarez, Gonzalo (2005) "Cambios en la estructura económica social y luchas en Trelew: una aproximación desde el estudio de los movimientos de desocupados y los cortes de ruta en la ciudad de Trelew. Marzo de 2002- Diciembre de 2003". Tesis de Licenciatura en Historia, UNP, Sede Trelew.

Pérez Artica, Rodrigo (2009) "Un enfoque micro del ciclo Posconvertibilidad. Los casos de Acindar, Aluar y Siderar", en Realidad Económica № 246, Revista del IADE, Bs. As. Pág. 105-126 
Perren, Joaquín y Pérez Álvarez, Gonzalo (2009) "Las "nuevas" provincias como problema historiográfico. Una primera aproximación a los casos patagónicos" en Actas XII Jornadas Interescuelas Departamentos de Historia, Bariloche, Universidad Nacional de Comahue, 28 al 31 de Octubre de 2009, publicada en CD ISBN 978-987604-153-9.

Perren, Joaquín (2007a) "Un desarrollismo genérico en la Patagonia. Pragmatismo y dependencia financiera en la economía neuquina (1960-1991)", en Actas XI Jornadas Interescuelas/Departamentos de Historia.

Perren, Joaquín (2007b) "Hacer la América en la Patagonia. Los migrantes bajo la lupa de la comparación (Neuquén: 1980-1991)", en Mases y Galucci (edit.) Historia de los trabajadores en la Patagonia, Educo, UNCo, Neuquén.

Perren, Joaquín (2007c) "Érase una vez en la Patagonia - Luces y sombras de la economía neuquina (1958-1991)" en Observatorio de la Economía de la Patagonia. En http://www.eumed.net/oe-pat/.

Petras, J. y Veltmeyer, (comp. 2004), Las privatizaciones y la desnacionalización de América Latina, Prometeo, Bs. As.

Petras, James y Veltmeyer, Henry (2004) Argentina: entre la desintegración y la revolución, en Petras, J. y Veltmeyer, (comp.), Las privatizaciones y la desnacionalización de América Latina, Prometeo, Bs. As. pp. 5 - 54

Petras, James (1999) "América Latina. De la globalización a la revolución", Homo Sapiens, Rosario.

Petruccelli, A. (2005) Docentes y piqueteros. De la huelga de Aten a la pueblada de Cutral Co. El Cielo por Asalto. Bs. As.

PIMSA (2007) “Los hechos de rebelión en Argentina 2002-2007”, en PIMSA 2007, Bs. As. pp. 228-237.

PIMSA (2000) Taller: "Estructura social de la Argentina", en PIMSA 2000, Bs. As. pp. 59 a 75

Piva, Adrián (2009a) Vecinos, piqueteros y sindicatos disidentes. La dinámica del conflicto social entre 1989 y 2001; en Bonnet, A. y Piva A. (comp. 2009) "Argentina en pedazos. Luchas sociales y conflictos interburgueses en la crisis de la convertibilidad", Peña Lillo - Edic. Continente, Bs. As. Pág. 19 a 70.

Piva, Adrián (2009b) "El desacople entre los ciclos del conflicto obrero y la acción de las cúpulas sindicales en Argentina (1989 - 2001)", en Actas XII Jornadas Interescuelas Departamentos de Historia, Bariloche, Universidad Nacional de Comahue, 28 al 31 de Octubre de 2009, publicada en CD ISBN 978-987-604-153-9.

Piva, Adrián (2007a) "Algunas hipótesis sobre la relación entre modo de acumulación y hegemonía débil en Argentina (1989-2001)", en Villanueva, E. y Massetti, A. (comp.) Movimientos sociales y acción colectiva en la Argentina de hoy, Prometeo, Bs. As.

Piva, Adrián (2007b) "Notas sobre la noción marxista de clase", en Actas XI Jornadas Interescuelas, en CD, ISBN 978-950-554-540-7.

Piva, Adrián (2007c) "Modo de acumulación y hegemonía en Argentina", en Anuario EDI № 3, Bs. As. pp. 51-67.

Piva Adrián (2006) "El desacople entre los ciclos del conflicto obrero y la acción de las cúpulas sindicales en Argentina (1989-2001)", Estudios del Trabajo, 31.

Piva, Adrián (2005) "Acumulación de capital, desempleo y sobreocupación en Argentina", en Cuadernos del Sur № 38/39, Bs. As. 
Piva, Adrián (2001) "La década 'perdida'. Tendencias de la conflictividad obrera frente a la ofensiva del capital (1989/2001)", Cuadernos del Sur, 17(32), Noviembre, Buenos Aires.

Pla, Alberto J. (2005) "Una discusión sobre la realidad y la teoría del capitalismo hoy: América Latina, señal de advertencia". Ponencia presentada en las X Jornadas Interescuelas de Historia realizadas en la ciudad de Rosario.

Pla, Alberto (1997a) "La inestablidad incurable del sistema: de la crisis al ajuste y del ajuste a la crisis", serie Papeles de Trabajo N2, CEHO, UNR.

Pla, Alberto (1997b) "Capitalismo, trabajo y rebeldía social a fines del siglo XX" en Cuadernos Americanos, Nueva época. Nro. 69, UNAM, Mayo.

Pla, Alberto (1994) "Los intelectuales y el estado" en Anuario 16 Segunda época, Escuela de Historia, Facultad de Humanidades y Artes, Universidad Nacional de Rosario.

Pla, Alberto (1992a) "Del estado nacional (centralizado) al estado del ajuste neoliberal (posfordista) en América Latina" en América Latina: planteos, problemas, preguntas, Manuel Suárez Editor, Buenos Aires.

Pla, Alberto (1992b) "Estado, democracia y socialismo" en Temas y Debates Nro.2 Segunda época, Escuela de Historia, Facultad de Humanidades y Artes, Universidad Nacional de Rosario.

Pla, Alberto (1990) "Apuntes para una discusión metodológica. Clases sociales o sectores populares. Pertinencia de las categorías analíticas de "clase social" y "clase obrera" en Anuario 14, Segunda época, Escuela de Historia, Facultad de Humanidades y Artes, Universidad Nacional de Rosario.

Pla, Alberto (1987) "La mundialización de la crisis del sistema: más allá de los límites del capital" en Anuario 13 Segunda época, Escuela de Historia, Facultad de Humanidades y Artes, Universidad Nacional de Rosario.

Pla, Alberto (1985a) Introducción a la historia general del movimiento obrero, Tierra del Fuego, Bs. As.

Pla, Alberto (1985b) "Trabajo productivo y trabajo improductivo. Clases sociales y capitalismo" en Anuario 11 Segunda época, Escuela de Historia, Facultad de Humanidades y Artes, Universidad Nacional de Rosario.

Pla, Alberto (1982) La historia y su método, Fontamara, Barcelona.

Pla, Alberto (1980) Ideología y método en la historiografía argentina. Ediciones Nueva Visión, Bs. As.

Plejanov, Jorge (1979) El socialismo y la lucha política, Edic. Roca, México D.F.

Plejanov, Jorge (1977) La concepción histórica del materialismo histórico, Edic. Roca, México D.F.

Plejanov, Jorge (1959) El papel del individuo en la historia, Edic. Intermundo, Bs. As.

Podestá, Jorge (1999) "La "crisis" de desocupación en la Argentina (1993/1998)" en PIMSA DT № 17, Buenos Aires.

Podestá, Jorge y Tarditi, Roberto (1998) "Apuntes teórico metodológicos para el estudio de las crisis: el aporte de Antonio Gramsci", en PIMSA DT № 10, Buenos Aires.

Podestá, Jorge y Tarditi, Roberto (1997) Crisis y movimiento social: De la posibilidad de la crisis a la crisis real. Observaciones sobre la crisis de los setenta y los ochenta, en PIMSA, Buenos Aires. 
Portelli, Alessandro (1989) "Historia y Memoria. La muerte de Luiggi Trastulli", en Revista Historia y Fuente Oral № 4, Universidad de Barcelona, Barcelona.

Portelli, Alessandro (1987) "Las peculiaridades de la historia oral" en Bravo, Jorge (ed.) Memoria histórica y sujeto popular, Educo №16, Sa ntiago de Chile.

Poy Piñeyro, Lucas y Rabey, Pablo (2005) "¿Lucha piquetera? La lucha obrera en la Argentina actual"; Ponencia presentada en las X Jornadas Interescuelas de Historia realizadas en la ciudad de Rosario.

Pozzi, Pablo (2008) La oposición obrera a la dictadura (1976-1982), Imago Mundi, Bs. As.

Pozzi, Pablo (1998) "Hacia una alternativa intelectual" en Taller. Revista de Sociedad, Cultura y Política, Vol. 3. Nro.6.

Pozzi, Pablo y Schneider, Alejandro (1994) Combatiendo el capital: Crisis y Recomposición de la clase obrera argentina (1985-1993), Bs. As., El Bloque Editorial.

Pradas, Eduardo Maro (2006) Un acercamiento a la problemática pesquera marplatense. El Mensajero; Buenos Aires.

Pucciarelli, Alfredo (coord. 2006) Los años de Alfonsín ¿El poder de la democracia o la democracia del poder, Siglo XXI Edit. Bs. As.

Pugh, Eduardo (2002) Proyecto: "Cerezas de la Patagonia Sur" Convenio INTA - Ctifl.

Rajchemberg, Enrique (2002) La rebelión de la memoria, entrevista a Mauricio Fernández Picolo , en Chiapas 13, UNAM, México.

Rebón, Julián (2007) La empresa de la autonomía. Trabajadores recuperando la producción, Colectivo Ediciones - PICASO, Bs. As.

Rebón J. y Saavedra, I. (2006) Las empresas recuperadas. La autogestión de los trabajadores; Claves para todos, Capital Intelectual, Bs. As.

Robles, Fernando (2000) Individualización e individuación, inclusión/exclusión y construcción de identidad en las sociedades periféricas de riesgo. Lineamientos preparatorios para una sociología de la exclusión. Departamento de Sociología, Universidad de Concepción. Chile.

Rodríguez, Gloria (2001) Un "Rosario" de conflictos. La conflictividad social en clave local, OSAL № 5, CLACSO.

Rofman, Alejandro (1999) Las economías regionales a fines del siglo XX, Bs. As., Edic. Ariel.

Rofman, Alejandro B. y Romero, Luís A. (1997), Sistema socioeconómico y estructura regional en la Argentina, Amorrortu, Buenos Aires.

Roldán, Martha (1999) ¿Globalización o mundialización? Teoría y práctica de procesos productivos y asimetrías de género, EUDEBA, FLACSO, UNPSJB.

Romero, Luís y Gutiérrez, Leandro (2007) Sectores populares, cultura y política; Siglo $\mathrm{XXI}$, Bs. As.

Romero Luís (1990) Los sectores populares urbanos como sujetos históricos, publicado originalmente en Proposiciones N19: “Chile, historia y 'bajo pueblo'». Ediciones SUR, Santiago, 1990, pp. 268-278. Se encuentra en http://www.cidpa.cl/txt/7artic02.pdf

Rosanvallón, Pierre (1995) La nueva cuestión social. Repensar el Estado providencia, Manantial, Bs. As. 
Rosanvallón, Pierre (1992) La consagración del ciudadano. Historia del sufragio universal en Francia, Ed. Gallimard. Traducción Carolina Zapiola, París.

Rosati, Germán (2007) "Un caso de crisis de la pequeña propiedad agrícola. Acercamiento empírico al movimiento de la estructura económica del campo chaqueño", en PIMSA 2007, Bs. As. pp. 8-27.

Rosati, Germán (2006) "Aproximación al análisis de una estructura económica-social concreta: pequeña producción mercantil, principalmente en el campo (1980-2001)", en PIMSA 2006, Bs. As., pp. 21-47.

Roze, Jorge Próspero (2007) Lucha de clases en el Chaco Contemporáneo, Resistencia. Librería de la Paz.

Roze, Jorge Próspero (2003) Inundaciones recurrentes: ríos que crecen, identidades que emergen. Ediciones Al Margen. Colección Entasis. La Plata.

Roze, Jorge y Vacarezza, Leonardo (1995) Fracciones agrarias y vivienda rural en Misiones. Editorial Universitaria. Universidad Nacional de Misiones (UNaM).

Rozitchner, León (1996) Los desfiladeros de la memoria, en Fin de Siglo, Bs. As.

Rudé, George (1981) La ideología de la protesta popular; en Revuelta popular y conciencia de clase; Crítica de Grijalbo, Barcelona.

Sábato, Jorge (1988) La clase dominante en la Argentina Moderna. Formación y características, CISEA, Buenos Aires.

Salgado Leticia (2005) Avance de Investigación sobre el surgimiento de Sierra Grande, UNPSJB - Sede Trelew (inédito).

Salvia, Agustín (comp. 1999) La Patagonia de los noventa: sectores que ganan, sociedades que pierden, Edit. La Colmena, Bs. As.

Salvia, Agustín (1997) "Crisis y reestructuración de complejos mineros: estudio de dos sistemas regionales patagónicos" en La Patagonia privatizada; Salvia, A. y Panaia, M. (comps.); CEA -CBCUNPA, Buenos Aires.

Salvia, Agustín y Panaia, Marta (comp. 1997) La Patagonia privatizada. Crisis, cambios estructurales en el sistema regional patagónico y sus impactos en los mercados de trabajo. Colección CEA - CBC, Buenos Aires.

Salvia, Sebastián (2009) "Estado y conflicto interburgués en Argentina. La crisis de la convertibilidad (1999-2001)"; en Bonnet, A. y Piva A. (comp. 2009) "Argentina en pedazos. Luchas sociales y conflictos interburgueses en la crisis de la convertibilidad", Peña Lillo - Edic. Continente, Bs. As. Pág. 189 a 222.

Santella, Agustín (2009) "Ciclos de protestas laborales sin situaciones revolucionarias, Argentina 1958-2002" en Actas XII Jornadas Interescuelas Departamentos de Historia, Bariloche, Universidad Nacional de Comahue, 28 al 31 de Octubre de 2009, publicada en CD ISBN 978-987-604-153-9.

Santella, Agustín (2008) "Ciclos de lucha en perspectiva (notas para la discusión)", Contribución a la Crítica, 2/3.

Santella, Agustín (2006) "Conflictos obreros en el sector automotriz. 1994-2006", DT №62 en PIMSA 2006, Bs. As.

Sartelli, Eduardo (2007) ¿Cómo se estudia la historia de la industria?, en Anuario CEICS (2007) Centro de Estudios e Investigaciones en Cs. Sociales, Año 1, №1, Bs. As.

Schneider, Alejandro (2006) Los compañeros. Trabajadores, izquierda y peronismo (1955-1973). Imago Mundi, Bs. As. 
Schorr, Martín (2001) ¿Atrapados sin salida? La crisis de la convertibilidad y las contradicciones en el bloque de poder económico, FLACSO, Bs. As.

Schuster, Federico (2007) "Universidad de Buenos Aires: crisis de representación y movimientos sociales", en Villanueva, E. y Massetti, A. (comp.) Movimientos sociales y acción colectiva en la Argentina de hoy, Prometeo, Bs. As.

Schuster, Pérez, Pereyra y otros (2006) Transformaciones de la protesta social en Argentina 1989-2003, GEPSAC, (Grupo de Estudios Sobre Protesta Social y Acción Colectiva), Instituto Germani, UBA.

Schuster, Federico; Naishtat, Francisco; Nardacchione, Gabriel y Pereyra, Sebastián (comp. 2005) Tomar la palabra, Prometeo Libros, Bs. As.

Schuster, Federico (2004) "Algunas reflexiones sobre la sociedad y la política en la Argentina contemporánea", en Di Marco y Palomino (comp.) Reflexiones sobre los movimientos sociales en la Argentina, Jorge Baudino Edit. Bs. As.

Schuster, F. y Pereyra, S. (2001) La protesta social en la Argentina democrática: balance y perspectiva de una forma de acción política, en Giarraca, Norma (comp.) La protesta social en Argentina. Transformaciones económicas y crisis social en el interior, Alianza Edit., Buenos Aires.

Schvarzer, Jorge (1996) La industria que supimos conseguir. Una historia político social de la industria argentina, Ed. Planeta, Bs. As.

Schvarzer, Jorge (1986) "Promoción industrial en Argentina. Características, evolución y resultados." Documentos del CISEA, Buenos Aires

Schwarzstein, Dora (comp. 1991) La historia oral. Centro Editor de América Latina, Buenos Aires.

Scodeller, Gabriela (2009) Conflictos gremiales en la historia reciente argentina: una mirada, en A Contra Corriente, Vol. 6, No. 3, Spring 2009, 108-136 www.ncsu.edu/project/acontracorriente

Scott, James (2000) Los dominados y el arte de la resistencia. Discursos ocultos, ERA, México D.F.

Scribano, Adrián (2009) "Acciones colectivas, movimientos y protesta social: preguntas y desafíos", en Conflicto Social, Año 2, №1, Revi sta del Programa de Investigaciones sobre Conflicto Social - ISSN 1852-2262 Instituto de Investigaciones Gino Germani Facultad de Ciencias Sociales - UBA http://www.iigg.fsoc.uba.ar/conflictosocial/revista

Scribano, Adrián (2008) Fantasmas y fantasías sociales: notas para un homenaje a T. W. Adorno desde Argentina. En Intersticios: Revista Sociológica de Pensamiento Crítico. Vol 2 № 2. http://www.intersticios.es/issue/view/176 ISSN 1887-3998 España.

Scribano, Adrián (2005a) Geometría del Conflicto: Estudios sobre Acción Colectiva y Conflicto Social (Comp.) CEA- Universidad Nacional de Córdoba: Editorial Universitas.

Scribano, Adrián (2005b). Itinerarios de la Protesta y del Conflicto Social. CEAUniversidad Nacional de Córdoba- Instituto Académico Pedagógico de Ciencias Sociales. Universidad Nacional de Villa Maria: Editorial Copiar.

Scribano, A. y Schuster, F. (2001) Protesta social en la Argentina de 2001: entre la continuidad y la ruptura, OSAL № 5, CLACSO.

Sendín, María y García, Silvia (1998) Medición de la desigualdad de la distribución geográfica de las ramas de la industria manufacturera entre los departamentos de la provincia del Chubut usando el índice de Gini, en Anuario 1998, FCE, UNPSJB, Trelew.

Senett, Richard (2000) La corrosión del carácter. Las consecuencias personales del 
trabajo en el nuevo capitalismo, Anagrama, Barcelona.

Seoane, José (comp. 2003) Movimientos Sociales y conflicto en América Latina, CLACSO, Buenos Aires

Seoane, José (2002) Crisis de régimen y protesta social en Argentina, en Chiapas 13, UNAM, México.

Seoane, José y Taddei Emilio (comps. 2001a), Las resistencias mundiales. De Seattle a Porto Alegre, CLACSO, Buenos Aires.

Seoane, José y Taddei, Emilio (2001b) Protesta social, ajuste y democracia: la encrucijada latinoamericana, OSAL № 4, CLACSO.

Seoane, José; Taddei, Emilio y Algranati, Clara (2001) Neoliberalismo, crisis y resistencias sociales en América Latina: las configuraciones de la protesta, OSAL № 5, CLACSO.

Silvestre, G. (1989) La construcción de la memoria, en Punto de Vista, № 64, Junio de 1998.

Simonassi Silvia (2007) "A trabajar y muzzarella" Prácticas y políticas de disciplinamiento laboral en la industria metalúrgica de Rosario 1974 - 1983, en Historia Regional № 25. ISP №3. Villa Constitución. Pág: 57 a 82.

Solari Irigoyen, Hipólito (1976) El escándalo ALUAR, Rafael Cerdeño Editor.

Solberg, Carl (1982) Petróleo y nacionalismo en la Argentina. Buenos Aires. EMECÉ

Sorrouille, Marcos (2008) "La incorporación del territorio del noroeste cordillerano de la actual provincia de Chubut al modo de producción capitalista", Actas III Jornadas de Historia de la Patagonia, Universidad Nacional del Comahue, San Carlos de Bariloche, 6, 7 y 8 de Noviembre de 2008. CD-rom ISBN 978-987-604-107-2.

Soul, Julia (2010) Espacios de trabajo, cotidianeidad laboral y conflictividad obrera. Aportes socioantropológicos para la construcción de una agenda de investigación, en II Encuentro Internacional Teoría y práctica política en América Latina. Nuevas derechas e izquierdas en el escenario regional; Universidad Nacional de Mar del Plata - 3 al 5 de marzo de 2010, publicada en CD ISBN 978-987-1314-96-6.

Soul, Julia (2009) "Cotidianeidad laboral y estrategias sindicales. Reflexiones en torno al caso SOMISA" en Actas XII Jornadas Interescuelas Departamentos de Historia, Bariloche, Universidad Nacional de Comahue, 28 al 31 de Octubre de 2009, publicada en CD ISBN 978-987-604-153-9.

Soul, Julia (2007) "Los unos y los otros. La fractura que persiste." Aproximación antropológica al proceso de privatización y reconversión productiva en la ex - SOMISA, en Historia Regional № 25. ISP №3. Villa Constitución. Pág: 33 a 56.

Spivak, Gayatri Chakravorty (2003) “¿Puede hablar el subalterno?”, en Revista Colombiana de Antropología, Vol. 39, enero-diciembre 2003, pp. 297-365.

Stolze, Brenda; Álamo, Matías y Romero, Fernando (2005) "La protesta rural en Stroeder", en Actas X Jornadas Interescuelas de Historia, realizadas en la ciudad de Rosario.

Stratta, Fernando y Barrera, Marcelo (2009) ¿Movimientos sin clases o clases sin movimiento?, en Conflicto Social, Año 2, $\mathrm{N}^{\circ}$ 1. Revi sta del Programa de Investigaciones sobre Conflicto Social - ISSN 1852-2262 Instituto Gino Germani Facultad de Ciencias Sociales - UBA http://www.iigg.fsoc.uba.ar/conflictosocial/revista

Subcomandante Marcos, Las siete piezas rotas del rompecabezas mundial, en www.ezln.org, Edición Digital, s/d. 
Subsecretaría de Trabajo de la Provincia del Chubut, Expedientes sobre ALUAR, Modecraft y otras empresas textiles.

Svampa, M (2008) Cambio de época. Movimientos sociales y poder político; Siglo $\mathrm{XXI/CLACSO}$; Bs. As.

Svampa, M. (2005). La sociedad excluyente. La Argentina bajo el signo del neoliberalismo. Taurus, Bs. As.

Svampa, Maristella (2002a) "El análisis de la dinámica asamblearia", en González Bombal, Inés (comp) Nuevos movimientos sociales y ONGs en la Argentina de la crisis, CEDES, Bs. As.

Svampa, Maristella (2002b) "Organizaciones de trabajadores desocupados. El modelo General Mosconi”, en González Bombal, Inés (comp) Nuevos movimientos sociales y ONGs en la Argentina de la crisis, CEDES, Bs. As.

Svampa, Maristella (2001) Los que ganaron. La vida en los countries y barrios privados, Biblos, Bs. As.

Svampa, Maristella (2000) "Identidades astilladas. De la patria metalúrgica al heavy metal", en: Svampa, M. (ed.) Desde abajo. La transformación de las identidades, UNGS/Biblos, Bs. As.

Svampa, Maristella y Pereyra, Sebastián (2003) Entre la ruta y el barrio. La experiencia de las organizaciones piqueteras; Biblos, Buenos Aires.

Sztulwark, Diego (2002) "Doce hipótesis sobre el contrapoder elaboradas desde la Argentina convulsionada", en Bajo el Volcán, Revista de la Univ. De Puebla, Año 2 N5, Puebla, México.

Taranda, Demetrio; Perren, Joaquín; Mases, Enrique; Galucci Lisandro y Casullo, Fernando (2009) "Silencio Hospital. Una historia de la salud pública en Neuquén", Neuquén, Educo.

Taranda, Demetrio; Matus, Ana y Maqueda, Guillermo (2005) "Movimiento de los Trabajadores Desocupados (MTD): de la emergencia a la cotidianeidad. Un estudio de caso en la zona oeste de Neuquén capital" en Actas X Jornadas Interescuelas de Historia.

Taranda et al (2003) "Procesos de constitución de movimientos piqueteros en la provincia de Neuquén" en Actas IX Jornadas Interescuelas de Historia.

Tarrow, Sydney (2003) "Agitaciones sociales y cambios electorales” en Página Abierta, № 139.

Tarrow, Sydney (1997) El poder en movimiento. Los movimientos sociales, la acción colectiva y la política, Alianza Universidad, Madrid.

Tarrow, Sydney (1991) "Ciclos de protesta”, en Zona Abierta №56.

Thwaites Rey, Mabel (2003) "La autonomía como mito y como posibilidad", en Cuadernos del Sur № 36, Año 19, Bs. As.

Therborn, Goran (1997) "La crisis y el futuro del capitalismo" en Sader, E. y otro. La trama del neoliberalismo. Mercado, crisis y exclusión social. Oficina de Publicaciones del CBC. UBA.

Thompson, E.P. y otros (1994) Agendas para una historia alternativa. El cielo por asalto. Año III - Nro.6. Verano 1993/94.

Thompson, Edward P. (1989) La formación de la clase obrera en Inglaterra, Crítica, Barcelona. 
Thompson, E. P. (1982) Tradición, revuelta y conciencia de clase. Estudio sobre la crisis de la sociedad preindustrial, Crítica, Barcelona.

Thwaites Rey, Mabel (2001) Ajuste estructural y privatizaciones en la Argentina de los noventa (o cómo achicar el Estado no es agrandar la Nación)", Tesis doctoral, Facultad de Derecho, UBA.

Tilly, Charles (2000) "Acción colectiva", en Apuntes de Investigación, año IV n 6, Centro de Estudios de Cultura y Política, Fundación del Sur, Bs. As.

Tilly, Charles (1995) Las revoluciones europeas (1492-1992), Crítica, Barcelona.

Tomas, Rubén (2008) El desequilibrio de la clase media en Trelew. La crisis de hiperinflación y la discusión neoliberal. 1989-1993, Tesis de Licenciatura, Depto. de Historia, UNP, Trelew.

Torrado, Susana (1992) Estructura social de la Argentina: 1945-1983, Ediciones de la Flor, Bs. As.

Torre, Juan Carlos (1983) Los sindicatos en el gobierno 1973-1976, CEAL, Bs. As.

Torres, Susana (2007) "Una primera aproximación a las relaciones laborales en Y.P.F., Comodoro Rivadavia, entre 1930 y 1943", en Actas XI Jornadas Interescuelas/Departamentos de Historia.

Touraine, Alain (2006) Un Nuevo Paradigma para comprender el mundo de hoy, Paidós, Bs. As.

Touraine, Alain (1997) ¿Podremos vivir juntos?, FCE, Bs. As.

Touraine, Alain (1991) Los movimientos sociales, Edit. Almagesto, Bs. As.

Touraine, Alain (1979) "La voz y la mirada", en Revista Mexicana de Sociología, año XLI, №4.

Troiano, Marcelo (2003) Y nació Esquel..., edición del autor, Esquel.

Trotski, León (1972) En defensa del marxismo, Pluma, Bs. As.

Trpin, Verónica (2007a) "Sindicalismo rural en el Alto Valle de Río Negro. La presencia de las mujeres en UATRE" en Actas II Jornadas de Historia Social de la Patagonia.

Trpin, Verónica (2007b) "Migrantes chilenos que trabajan en las chacras: la etnicidad ante una nueva ruralidad", en Mases y Galucci (edit.) Historia de los trabajadores en la Patagonia, Educo, UNCo, Neuquén.

Van der Lienden Marcel (2008) "Globalizando el concepto de clase obrera" en la Revista de Estudios Sociales y Marítimos №1, Universidad Nacional de Mar del Plata.

Velásquez, Guillermo (2007) Geografía y bienestar. Argentina, S XXI, edición Digital, Seminario de Postgrado, Universidad de La Plata, Agosto 2007.

Vergara, P. (2004) "¿Es posible el desarrollo endógeno en territorios pobres y socialmente desiguales?", Desarrollo en Ciencias Sociales Online, Vol. I, No 1, Universidad de Viña del Mar, Chile, en: http://www.uvm.cl/csonline/pdf/Patricio\%20Vergara\%20es\%20posible\%20el\%20.pdf.

Vezzetti, Hugo (2002) Variaciones sobre la memoria social, en Punto de Vista.

Viano, María Cristina (2004) Movimientos Sociales: en plural y sin adjetivos. Revisando teoría(s) desde América Latina, Rosario, Papeles de Trabajo del CEHO, Facultad de Humanidades y Artes, UNR.

Videla, Oscar (2010) "Una mirada a las tradiciones y prácticas obreras en el sudeste santafesino de los treinta para reflexionar sobre las continuidades históricas y las interpretaciones de la historia del movimiento obrero", en II Encuentro Internacional 
Teoría y práctica política en América Latina. Nuevas derechas e izquierdas en el escenario regional; Universidad Nacional de Mar del Plata - 3 al 5 de marzo de 2010, publicada en CD ISBN 978-987-1314-96-6.

Videla, Oscar R. (2009) "Algunas reflexiones sobre tradiciones obreras e interpretaciones de la historia del movimiento obrero a través del análisis de la historia local. Conflictos intersindicales, movimiento obrero y política en el sudeste santafesino en los treinta", en Actas XII Jornadas Interescuelas Departamentos de Historia, Bariloche, Universidad Nacional de Comahue, 28 al 31 de Octubre de 2009, publicada en CD ISBN 978-987-604-153-9.

Viguera, Aníbal (2009) "Movimientos sociales y lucha de clases" en Conflicto Social №1 Año 2 - ISSN 1852-2262 Instituto de Investigaciones Gino Germani - Facultad de Ciencias Sociales - UBA http://www.iigg.fsoc.uba.ar/conflictosocial/revista.

Viguera, Aníbal (1998) La política de la apertura comercial en la Argentina, 1987-1996, Departamento de Sociología, Facultad de Humanidades y Ciencias de la Educación, Universidad Nacional de La Plata

Villanova, Nicolás et. al. (2008) "Los cartoneros y la explotación capitalista", en Anuario CEICS 2008; Ediciones ryr, Buenos Aires.

Villanueva, E. y Massetti, A. (comp. 2007) Movimientos sociales y acción colectiva en la Argentina de hoy, Prometeo, Bs. As.

Villanueva, Ernesto (coord. 1994) Conflicto obrero. Transición política, conflictividad obrera y comportamiento sindical en la Argentina 1984-1989, UNQ, Bs. As.

Vommaro, Pablo (2005) "Las organizaciones sociales en la Argentina reciente: una aproximación hacia los procesos de trabajo y las subjetividades contemporáneas". Ponencia presentada en las $\mathrm{X}$ Jornadas Interescuelas de Historia realizadas en la ciudad de Rosario.

Williams, Raymond (1980) Marxismo y literatura. Ediciones Península. Barcelona.

Womack, John (2007) Posición estratégica y fuerza obrera. Hacia una nueva historia de los movimientos obreros. FCE, México.

Zamora, Víctor y Ramírez, Gladys (1995) Porque cierran los negocios en Trelew, en Anuario 1995, FCE, UNPSJB, Trelew.

Zibechi, Raúl (2003) Genealogía de la Revuelta. Argentina: la sociedad en movimiento, Editorial Letra Libre, Bs. As. 